\title{
URANIUM MINERALIZATION IN FLUORINE-ENRICHED VOLCANIC ROCKS
}

By Donald M. Burt

Michael F. Sheridan

Department of Geology

Arizona State University

Tempe, Arizona 85281

September, 1980

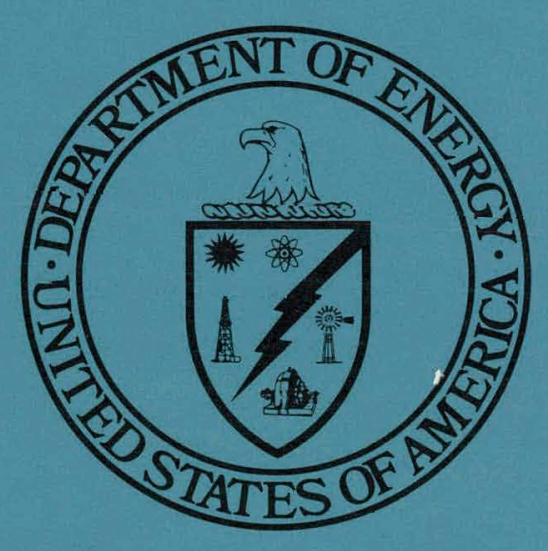

Prepared for the U.S. Department of Energy

Assistant Secretary for Resource Applications

Grand Junction Office, Colorado 


\section{DISCLAIMER}

This report was prepared as an account of work sponsored by an agency of the United States Government. Neither the United States Government nor any agency Thereof, nor any of their employees, makes any warranty, express or implied, or assumes any legal liability or responsibility for the accuracy, completeness, or usefulness of any information, apparatus, product, or process disclosed, or represents that its use would not infringe privately owned rights. Reference herein to any specific commercial product, process, or service by trade name, trademark, manufacturer, or otherwise does not necessarily constitute or imply its endorsement, recommendation, or favoring by the United States Government or any agency thereof. The views and opinions of authors expressed herein do not necessarily state or reflect those of the United States Government or any agency thereof. 


\section{DISCLAIMER}

Portions of this document may be illegible in electronic image products. Images are produced from the best available original document. 
This report is a result of work performed by Arizona State University through a Bendix Field Engineering Corporation Subcontract, as part of the National Uranium Resource Evaluation. NURE is a program of the U.S. Department of Energy's Grand Junction, Colorado, Office to aquire and compile geologic and other information with which to assess the magnitude and distribtuion of uranium resources and to determine areas favorable for the occurrence of uranium in the United States.

This report was prepared as an account of work sponsored by an agency of the United States Government. Neither the United States Government nor any agency thereof, nor any of their employees, makes any warranty, express or implied, or assumes any legal liability or responsibility for the accuracy, completeness, or usefulness of any information, apparatus, product, or process disclosed, or represents that its use would not infringe privately owned rights. Reference herein to any specific commercial product, process, or service by trade name, trademark, manufacturer, or otherwise, does not necessarily constitute or imply its endorsement, recommendation, or favoring by the United States Government or any agency thereof. The views and opinions of authors expressed herein do not necessarily state or reflect those of the United States Government or any agency thereof. 
URANIUM MINERALIZATION IN

FLUORINE-ENRICHED VOLCANIC ROCKS

FINAL REPORT

D. M. Burt

M. F. Sheridan

J. Bikun

E. Christiansen

B. Correa

B. Murphy

S. Self

\begin{abstract}
Department of Geology
Arizona State University

Tempe, Arizona 85281
\end{abstract}

September, 1980

Prepared for the U.S. Department of Energy

Assistant Secretary for Resource Applications

Grand Junction Office, Colorado

Under Bendix Field Engineering Corporation Subcontract No. 79-270-E

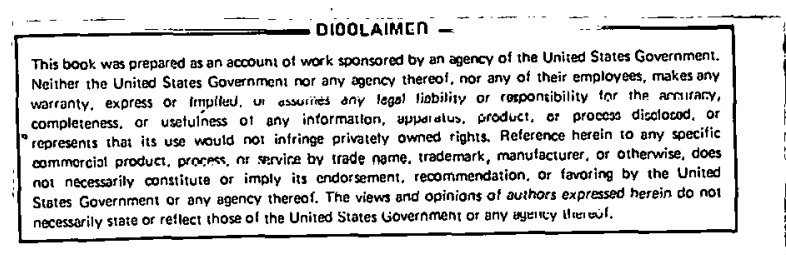




\section{TABLE OF CONTENTS}

Page

Chapter I. A model for the formation of uranium/lithophile element deposits in fluorine-enriched volcanic rocks.

D. M. Burt and M. F. Sheridan.

Chapter II. Petrology and geochemistry. of topaz rhyolites, Western United States.

E. H. Christiansen, J. V. Bikun, and D. M. Burt.

Chapter III. Eruption and emplacement of rhyolitic pyroclastic deposits and lavas.

S. Self, D. M. Burt, and M. F. Sheridan.

Chapter IV. Fluorine and lithophile element mineralization at Spor Mountain, Utah.

$$
\text { J. V. Bikun. }
$$

Chapter V. Studies of mineralization at Spor Mountain, Utah, and a comprehensive Spor Mountain bib1iography.

B. A. Murphy.

378

Chapter VI. Uranium mineralization associated with fluorine-rich rhyolites in southwestern Utah.

E. H. Christiansen.

Chapter VII. Fiuorine and lithophile element mineralization in the Black Rangc and Sierra Cuchillo, New Mexico.

B. I'. Correa. 
Chapter I

\begin{abstract}
A MODEL FOR THE FORMATION OF
URANIUM/LITHOPHILE ELEMENT DEPOŚSITS

IN FLUORINE-ENRICHED VOLCANIC ROCKS
\end{abstract}

by

Donald M. Burt

and

Michael F. Sheridan 


\section{Abstract}

Several uranium and other lithophile element deposits are located within or adjacent to small middle to late Cenozoic, fluorine-rich rhyolitic dome complexes. Examples studied include Spor Mountain, Utah (Be-U-F), the Honeycomb Hills, Utah (Be-U), the Wah Wah Mountains, Utah (U-F), and the Black Range-Sierra Cuchil1o, New Mexico (Sn-Be-W-F). The formation of these and similar deposits begins with the emplacement of a rhyolitic magma, enriched in lithophile metals and complexing fluorine, that rises to a shallow crustal level, where its roof zone may become further enriched in volatiles and the ore elements. During initial explosive volcanic activity, aprons of lithicrich tuffs are erupted around the vents. These early pyroclastic deposits commonly host the mineralization, due to their initial enrichment in the lithophile elements, their permeability, and the reactivity of their foreign lithic inclusions (particularly carbonate rocks). The pyroclastics are capped and preserved by thick topaz rhyolite domes and flows that can serve as a sourcc of heat and of additional quantities of ore elements. Devitrification, vaporphase crystallization, or fumarolic alteration may free the ore elements from the glassy matrix and place them in a form readily leached by percolating meteoric waters. Heat from the rhyolicic slieels drives such waters through the system, generally into and up the vents and out through the early tuffs. Secondary alteration zones (K-feldspar, sericite, silica, clays, fluorite, carbonate, and zeolites) and economic minter cuncentrations may form in response to this low temperature (less than $200^{\circ} \mathrm{C}$ ) circulation. After cooling, meteoric water continues to migrate through the system, modifying the distribution and concentration of the ore elentents (especially uranium). In this model, the ore elements are derived essentially from the vulcanic vent complex itself, although contributions from the underlying magma chamber are not excluded. In fact, plutons and country rocks beneath such vent complexes may themselves contain disseminated, vein, or replacement deposits of $U$, Th, Be, $\mathrm{Sn}, \mathrm{Mo}, \mathrm{W}, \mathrm{Nb}, \mathrm{Ta}$, or associated elements. 


\section{Introduction}

Important deposits of fluorite, uranium, and other lithophile elements (Be, Sn, Li, etc.) may be located within or adjacent to small fluorine-rich rhyolitic dome complexes. The alkaline (but no peralkaline) silicic lavas that cap these complexes are commonly characterized by the presence of the gemstone topaz, $\mathrm{Al}_{2} \mathrm{SiO}_{4} \mathrm{~F}_{2}$, especially in miarolitic and 1ithophysal cavities, leading to the designation "topaz rhyolites". Dated examples are middle to late Cenozoic in age, typically occur in the Basin and Range province, U.S.A., and have high contents of fluorine and lithophile elements such as $U, B e$, $\mathrm{Sn}, \mathrm{Nb}$, and $\mathrm{Rb}$ (Nash et ai., 1978; Turley et al., 1979), especially in obsidians. This enrichment leads to the alternate term "rare metal rhyolites" (Robert Wilson, personal communication, 1980). They belong to the more general class of Cenozoic bimodal high silica or alkalai rhyolites (Christiansen and Lipman, 1972; Lipman et al., 1972; E1ston and Bornhorst, 1979).

Our "type example" for topaz rhyolite mineralization occurs at Spor Mountain, Utah, a district characterized by economic deposits beryllium (as bertrandite) with uraniferous fluorite and opal and lithium clays in tuff, economic deposits of oxidized uranium in underlying sandstones and conglomerates, and uraniferous fluorite in vent complexes and breccia pipes in Paleozoic carbonates (Staatz and Carr, 1964; Shawe, 1968; Lindsey, 1977; 1978; 1979; and this volume). In addition, we have briefly studied similar mineralization at the Honeycomb Hills, Utah (Be-U-Li-F: McAnulty and Levinson, 1964; Montoya et al., 1974; Lindsey, 1977), the Staats Mine and Holly Claim area, Wah Wah Mountains (U-F: Whelan, 1965; Lindsey and Osmonson, 1978), the Black Range and Sierra Cuchi110, New Mexico (Sn-Be-W-F: Fries, 1940; Jahns, 1944 ; Hillard, 1969; Ericksen et al., 1970; Lufkin, 1976; 1977), and Izenhood Ranch, Nevada (Sn-F: Fries, 1942). We also looked at unmineralized topaz rhyolites 
at E. Grants Ridge, New Mexico (Kerr and Wilcox, 1963), Nathrop, Colorado (Van Alstine, 1969), and Burro Creek, Arizona. The above-named localities are located on Figure 1.

We visited for comparative purposes a number of peralkaline, generally caldera-related uranium districts, including McDermitt, Nevada (Rytuba and Glanzman, 1979; Rytuba, in press ; Wallace and Roper, in press); Peña Blanca, Chihuahua, Mexico (Goode11 et al., 1978; Goode11 and Carraway, this volume), and the Chinati Mountains, Trans Pecos Texas (Walton and Henry, 1979). These peralkaline complexes appear to be of much larger volume and are petrologically distinct from those that we have studied. Many are discussed in a special volume to be published by the AAPG (references in press above).

Perhaps more deposits of the topaz rhyolite type would be discovered if more geologists learned to recognize microcrystalline topaz. With a hand lens, transparent elongate topaz prisms can be distinguished from similar-appearing quartz crystals by their orthorhombic symmetry and perfect basal cleavage. This basal cleavage, coupled with topaz's high refractive index, gives topazrich sands an unusual sparkling appearance in bright sunlight. In freshlybroken specimens of topaz rhyolite the topaz commonly has a yellowish to reddish brown coloration which fades on exposure to sunlight.

From a distance, the honeycomb-1ike weathering (from which the name Honeycomb Hills is derived in Utah) of some topaz rhyolites may be distinctive. Unfortunately, at Spor Mountain itself the grayish porphyritic topaz rhyolite generally lacks abundant gas cavities filled with topaz and does not exhibit "honeycomb" weathering. Topaz is, however, abundant in thin section and purple fluorite occurs along microfractures.

The main purpose of the present investigation has been to develop an exploration model for deposits of the Spor Mountain type, as a guide to the evaluation of areas where topaz rhyolites may be found. 


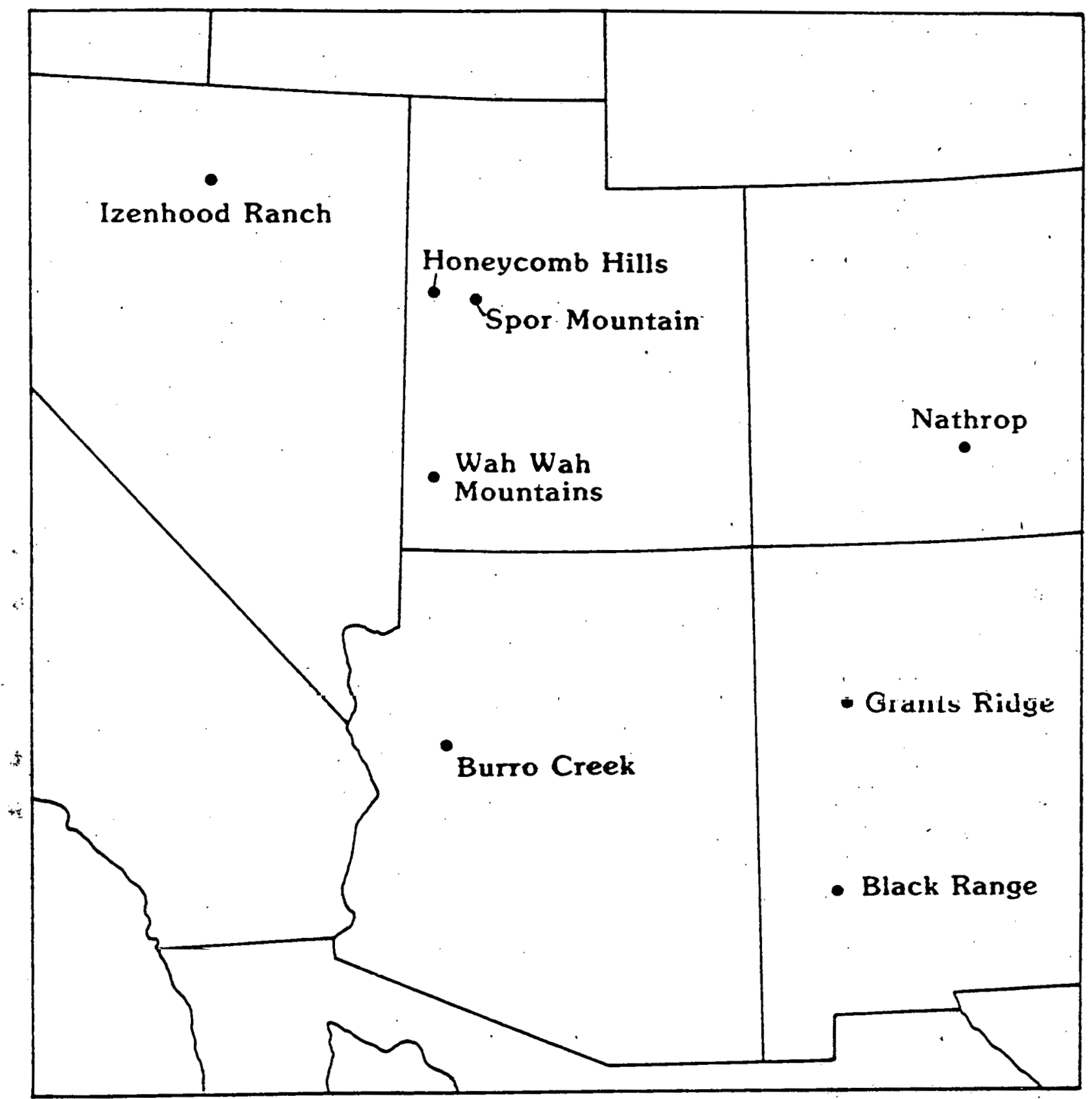

Figure 1. Location map of the Western United States showing topaz rhyolite distrir.t.s studied. 
Occurrence and Origin

Small dome and flow complexes of 0ligocene and younger topaz rhyolites are widespread in the Western United States (Figure 2, modified from Shawe, 1976) and perhaps many others have not been identified. Available radiometric data suggest that the oldest identified topaz rhyolites ( $36 \mathrm{m.y.}$ ) may occur in the Elkhorn Mts., Montana (Smedes, 1966; Chadwick, 1977); in the Great Basin of Utah they range in age from about $21 \mathrm{m.y}$. at Spor Mountain (Lindsey, 1979) and $20 \mathrm{~m} . \mathrm{y}$. at the Staats Mine (Rowley et al., 1978; Lindsey and Osmonson, 1978) to $6.3 \mathrm{~m} . \mathrm{y}$. in the Thomas Range (Lindsey, 1979); $4.7 \mathrm{m.y}$. in the Honeycomb Hills (Turley et al., 1979), and $0.5 \mathrm{m.y}$. in the Mineral Mountains, Utah (Lipman et al., 1978; Ward et a1., 1978).

Spatially, the topaz rhyolites lie in a well-defined belt that generally coincides with the Rio Grande rift in New Mexico and Colorado, and in a more diffuse zone along the eastern margin of the Basin and Range province from Arizona to Idaho and Montana. Another description would be that most known occurrences of topaz rhyolite occur around the edge of the Colorado Plateau. Great Basin occurrencès in Utah lie in the east-west rrending Deep-CreekTintic. and Wah Wah-Tushar mineral belts (Hilpert and Roberts, 1964; Stewart e.t $a 1$, 1.977).

Not surprisingly, topaz rhyolites roughly coincide in their distribution with areas of abundant fluorite occurrences and deposits (Worl et al., 1974; Shawe, 1976; Van Alstine, 1976; Van Alstine and Tooker, 1979) and, as shown on. Figure 2, with mid-Tertiary topaz-bearing porphyry molybdenum deposits in Colorado and New Mexico (Shawe, 1976; Woodcock and Hollister, 1978).

Similar middle to late Tertiary topaz rhyolites are widespread in central Mexico (Sinkankas, 1959; 1976). Some have been sources of alluvial tin (Foshag and Fries, 1942; Pan, 1974), but few details are available as to their ages, occurrence, or geochemistry. 


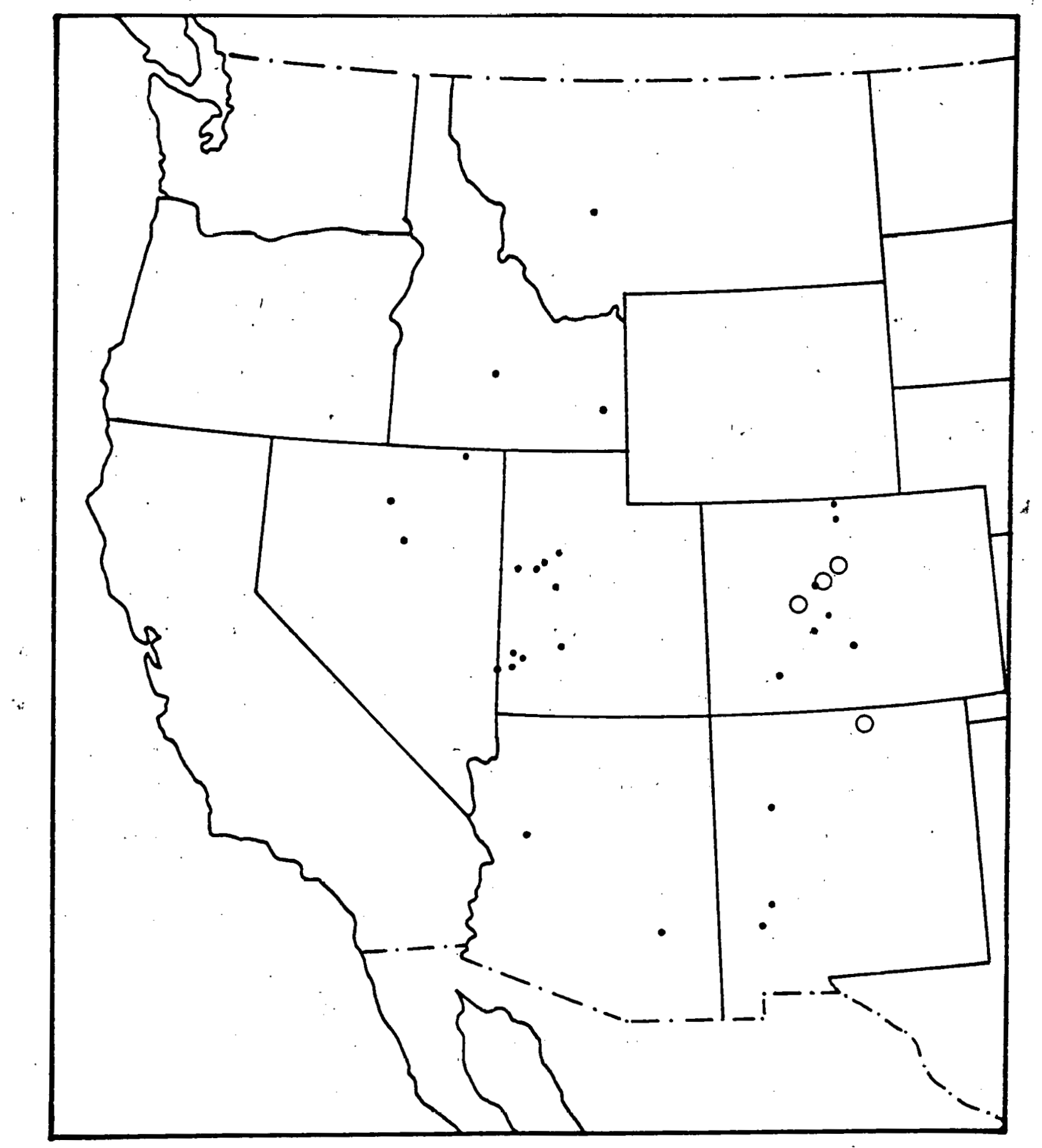

Figure 2. Topaz-bearing rhyolite localities ( $\bullet$ ) with topaz-bearing porphyry molybdenite deposits (o), Western United States (modified from Shawe, 1976, Figure 10, p. 20). 
In Mongolia and the Soviet Union occur several smal1, near-surface, topazbearing intrusives with glassy margins; the Soviets have named the rock type "ongonite" (Kovalenko et al., 1971; 1975; Kovalenko and Kovalenko, 1976). Ongonites are alkali rhyolites enriched in rare elements and fluorine, with fluorine contents in glass ranging from 0.8 to $3.2 \%$, or as much as twice those reported here in vitrophyre from Spor Mountain. Ongonites appear to be nearsurface analogs to the topaz rhyolites we have studied and to Li-F granites at depth (Kovalenko, 1978). Their higher fluorine contents, compared to Spor Mountain vitrophyres, are possibly explained by the fact that no fluorine has been lost on venting (i.e., they are intrusive). Allman and Koritnig (1972) and Shawe (1976) have noted a general tendency for volcanic rocks to be depleted in fluorine in comparison with compositionally similar intrusives.

We11-documented occurrences of topaz rhyolites on other continents appear to be lacking, although a topaz-bearing "tuffisite" (intrusive tuff) has been described from the U-Sn-Be-Nb-F-rich younger granite province of Nigeria (Wright, 1974). Topaz rhyolites are probably to be expected in young volcanogenic tin provinces such as those in Bolivia and Argentina described by Sillitoe (1977). In older fluorine-rich provinces, such as the St. Francois Mountains, Missouri (Kisvarsanyi, 1980) and the British Isles (Simpson et al., 1979), intrusive porphyry or greisen-type $\mathrm{Sn}-\mathrm{Be}-\mathrm{W}-\mathrm{Mo}-\mathrm{Nb}-\mathrm{U}-\mathrm{Th}$ deposits may once have been overlain by topaz rhyolites.

In contrast to the large eruptive volumes of caldera-related calcalkaline and peralkaline silicic volcanlcs (up to $10,000 \mathrm{~km}^{3}$ : Smilli, 1979), the eruptive volumes of topaz rhyolites are generally small, with the $50 \mathrm{~km}^{3}$ volume of the Thomas Range, Utah (Turley et al., 1979) apparently being a maximum for the Great Basin. (This figure excludes more voluminous U+F-mineralized rhyolitic volcanic rocks at Marysvale, Utah, where no topaz has yet been found: C. G. Cunningham, personal communication, 1980.) The vent complexes 
usually show no obvious relation to caldera structures or they formed after caldera-related:volcanism. This may imply that fluorine-rich magmas seldom reach the surface (i.e., they overlie large batholiths at depth). Rhodes (1976) and Elston (1978) proposed that such a batholith underlies the voluminous $\left(130 \mathrm{~km}^{3}\right)$ tin rhyolites of the Black Range, N.M.

Fluorine-rich rhyolitic magma seems to share with peralkaline magma a low viscosity - it flows readily unless relatively cool and rich in phenocrysts. Fluorine, like water, tends to lower solidus temperatures and melt viscosities of granitic magma (Wyllie, 1979); the difference is that fluorine has much less of a tendency to escape explosively with release of pressure. It also has a tendency to form stable complexes with and be associated geochemically with the lithophile elements, including $\mathrm{U}, \mathrm{Be}, \mathrm{Li}, \mathrm{Mn}, \mathrm{Nb}, \mathrm{Sn}, \mathrm{W}$, and $\mathrm{Y}$ (Shawe, 1976, p. 15; Bailey, 1977). Some alkali and fluorine-rich magmas exhibit liquid . immiscibility (Kogarko et al., 1974); the fluorine-rich separates may evolve continuously into hydrothermal fluids.

Whether fluorine-rich magmas and associated fluorite deposits are developed at the end stages of shallow subduction or the initial stages of extension has been debated (Lamarre and Hodder, 1978; Shawe, 1979). Topaz rhyolite volcanism in the U.S. extended to less than a million years ago (Ward et a1., 1978), and thus may still be continuing. This interpretation supports Shawe's "extens1onal" hypothesis. The problem then becomes one of the origin of the extension itself. Although opinions are not unanimous (Christiansen and McKee, 1978), most recent reviews (Thompson and Burke, 1974; Stewart, 1978; Eaton, 1979; E1ston and Burnhurst, 1979) have tended to favor the initiation of Basin and Range extension by back-arc spreading from the subducting slab that is also responsible for calc-alkaline volcanism (Karig, 1971; Scholz et a1., 1971). The occurrence of 28-29 m.y. old topaz rhyolite at Nathrop, Colorado (Van Alstine, 1969), together with other features, led Tweto (1979) to suggest that extension 
related to the Rio Grande rift began as much as $28 \mathrm{~m} . y$. ago in Colorado.

Whatever the origin of the extension, their extensional setting, as well as geochemical features, suggest that topaz rhyolites might be the extrusive equivalents of "A-type" or "anorogenic" granites (Loiselle and Wones, 1979; Wones, 1979; Petro et al., 1979). These have also been called residual or R-type granites (White, 1979).

In any case, topaz rhyolite petrogenesis presumably involves partial melting of fluorine-bearing Precambrian crust in the presence of high heat flow (which would tent to drive off water, enriching residual fluorine), with mafic magmas possibly providing a heat source (Christiansen and Lipman, 1972). In support of this conjecture, available evidence suggests that the crust is thinner $(25-30 \mathrm{~km})$ and uppermost mantle seismic velocities lower $(<7.4 \mathrm{~km} / \mathrm{sec})$ in west central Utah, where younger $(<7$ m.y.) topaz rhyolites occur, then elsewhere in the eastern Basin and Range province (Prodeh1, 1979, p. 47). In fact, as compared with the main part of the Basin and Range province, the eastern transition to the Colorado Plateau is a remarkable north-south zone of increased seismicity, volcanism, heat flux (Blackwell, 1978), crustal thinning, and lowering of upper mantle seismic velocities. Furthermore, there appears to be a low velocity zone in the crust that may indicate partial melting (Smith, 1978).

We have been impressed with the abundance of fluorite and beryl-bearing Precambrian granites near the two identified topaz rhyolite occurrences in Arizona; similar relations hold in lolorado and may hold in Utah (ct. Silver, 1976; Moore and Sorensen, 1978). We also note the apparent absence of topaz rhyolite volcanism in the high heat flux volcanic zone on the western margin of the Basin and Range province (Blackwe11, 1978), where Precambrian crust is lacking. Although we would prefer to derive fluorine from the crust, some writers (e.g. Van Alstine, 1976; Bailey, 1978) prefer to derive fluorine by 
"leakage" from the upper mantle.

Unfortunately, most topaz rhyolites, especially the younger ones, are not known to be associated with economic mineralization, although the presence of topaz, bixbyite, specular hematite, pseudobrookite, red beryl, and Mn-Fe garnet in lithophysae may make them well-known to mineral collectors (Ream, 1979). A major question that any model for Spor Mountain-type mineralization must answer, then, is why it is not more common. For example, why is Be-U-F mineralization not developed in association with the abundant 6-7 m.y. old topaz rhyolites of the Thomas Range only a few kilometers to the east of. Spor Mountain?

\section{Mineralization: A Model}

Magma Intrusion

We infer that the formation of Spor Mountain-type deposits associated with topdz ihyolitc lava flows involves four stages: (1) magma intrusion, (2) eruption of pyroclastics and capping lavas, (3) vapor phase and hydrothermal alteration and element redistribution, and (4) ground water diagenesis and element redistribution. The process begins with the intrusion of waterdepleted rhyolitic magma, enriched in lithophile metals and complexing fluorine, to shaliow levels in the Earth's crust (Figure 3). It's enrichment may involve small degrees of partial melting and/or large degrees of fractional crystallization (Groves and McCarthy, 1978); dehydration or zone refining (Barker et a1., 1975) during its rise through the crust; or dehydration and crystallization due to earlier cauldron-forming pyroclastic volcanism (Rhodes, 1976).

The top portions of the magma chamber becomes further enriched in volatiles and the ore elements, following a trent that has long been recognized (Emmons, 1933). The cause of this apical enrichment may be roofward streaming of volatiles escaping from the magma, or a recent variation on this concept called 


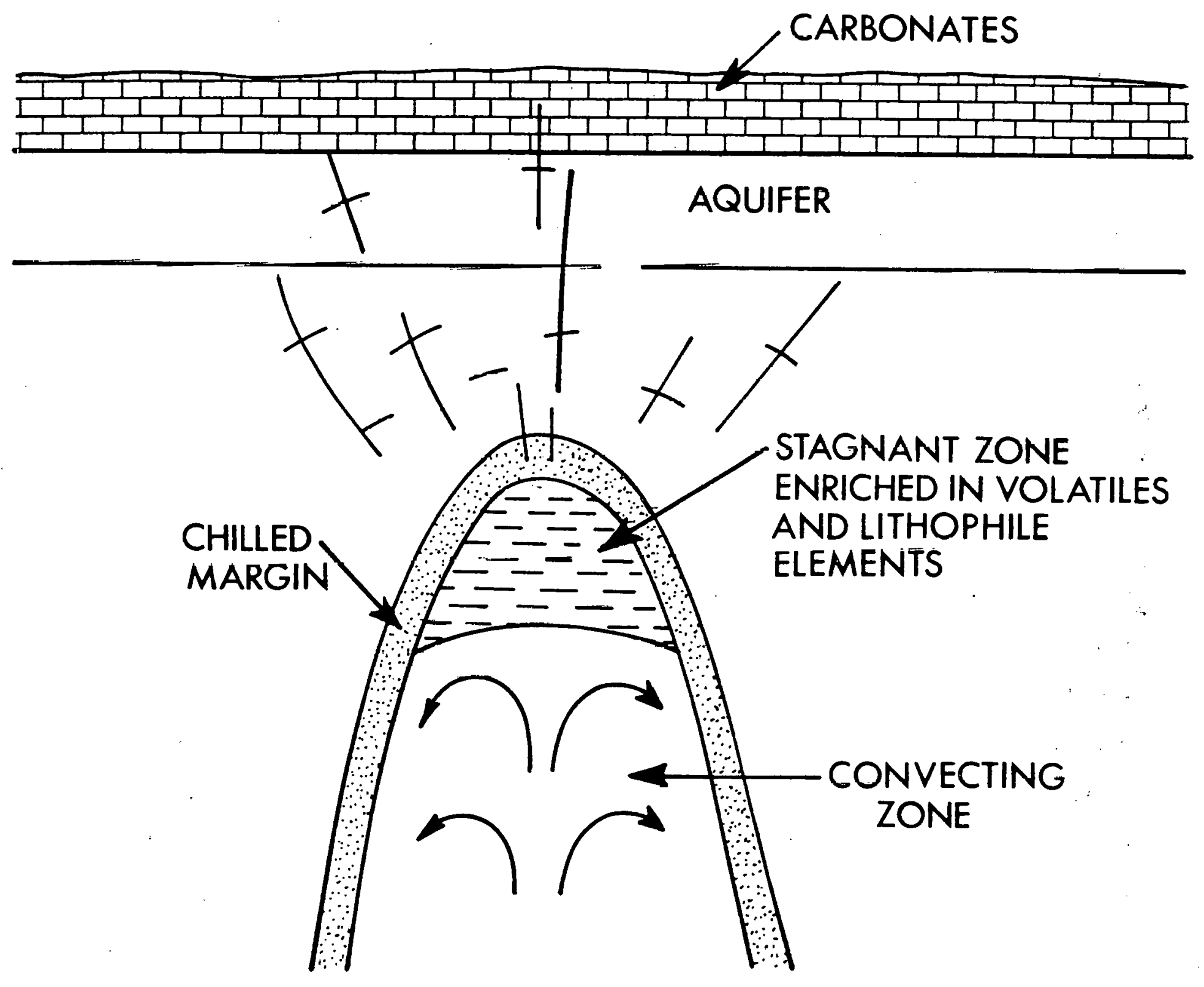

Figure 3. Model Stage1-Magma intrusion. 
thermogravitational diffusion (Shaw et al., 1976; Hildreth, 1979) that also involves magma convection. The result is the creation of an upper "stagnant" zone enriched in $\mathrm{H}_{2} \mathrm{O}, \mathrm{F}, \mathrm{Cl}$, and the lithophile metals, including, for the Bishop tuff, Be, Mn, Y, Sc, Nb, l'a, Mo, W., Sn, Cs, Rb, Li, U, and Th. This zone is depleted in $\mathrm{Mg}, \mathrm{P}, \mathrm{Ca}, \mathrm{Ti}, \mathrm{Fe}, \mathrm{Co}, \mathrm{Cu}, \mathrm{Sr}, \mathrm{Ba}, \mathrm{La}, \mathrm{Ce}, \mathrm{Eu}$, and $\mathrm{Au}$ (Hildreth, 1979, p. 61).

Eruption

The build-up of volatiles, or magma interactions with ground water, or even influxes of mafic magma into the silicic magma chamber next cause an explosive volcanic eruption (Figure 4). This results in the emplacement of a mantle of lithic-rich pyroclastic deposits around the vent. These pyroclastics ideally may be classified as (1) massive appearing, poorly sorted pyroclastic flows, or "ignimbrites" (Sheridan, 1979); (2) thin overlying beds of finegrained, well-sorted coignimbrite air falls or "tephra", and/or thick adjacent lithic-rich, coarse-grained, near-vent coignimbrite lag-falls (Wright and Walker, 1977) and (3) basal stratified or cross-bedded pyroclastic surges (Wohletz and Sheridan, 1979). This "standard ignimbrite flow unit" (Sparks, 1976) can in turn be underlain by inversely graded Plinian air fall or avalanche deposits. Field identification of lithic-rich tuffs on the basis of the above classification is complicated in actual situations by the effects of multiple vents and/or multiple eruption episodes, by the influence of preexisting topography, by volcanic mudslides or lahars, and by various alteration processes discussed below. The important fact is that a wide variety of pyroclastic deposits can result from the same eruption episode.

The stratified, cross-bedded, and well-sorted nature of some of the tuffs in the Spor Mountain district and elsewhere has earlier led to their classification as "water-laid tuffs" in the literature. The uranium-mineralized 
sandstones and conglomerates that occur locally in the vicinity of the Yellow. Chief mine are the only deposits we have found near Spor Mountain that show direct evidence of aqueous deposition.

The pyroclastic deposits commonly host subsequent ore mineralization, due to their initial enrichment in lithophile elements, their fine-grained and glassy nature (susceptibility to alteration), their permeability, and their content of foreign lithics (pieces of country rock ejected during clearing of the volcanic vents). The chemical dissimilarity of the foreign lithics to the tuffs around them tends to localize ore precipitation, especially if the foreign lithics are reactive carbonate rocks, as at Spor Mountain, although. mafic volcanics (cf. Roper and Wallace, in press) or carbonaceous schists might play a similar role elsewhere.

Thick volatile-depleted rhyolite domes and lava flows next are deposited on top of the pyroclastics (Figure 5). These can serve as a source of convection-driving heat and, during crystallization, of additional quantities of ore elements. Once crystallized, the flows serve as an impermeable barrier (or "screen", in translated Soviet terminology) to convecting aqueous fluids; they also protect the ore deposit from later erosion (and discovery?). Thick welded tuff layers in peralkaline rhyolite complexes might serve the same funcrions.

During and shortly after the initial eruption, unknown amounts of uranium and other lithophile elements may be lost in the gas cloud as volatile halides and hydroxylhalides (Zielinski et al., 1977). These losses are virtua1ly undetectable by later observations, inasmuch as they are reflected even in obsidian compositions (that is, even the obsidians have lost volatiles). Such losses may explain why we have found no extrusive vitrophyres with more than about $1.5 \%$ fluorine, although intrusive ongonites in Mongolia and the U.S.S.R. 


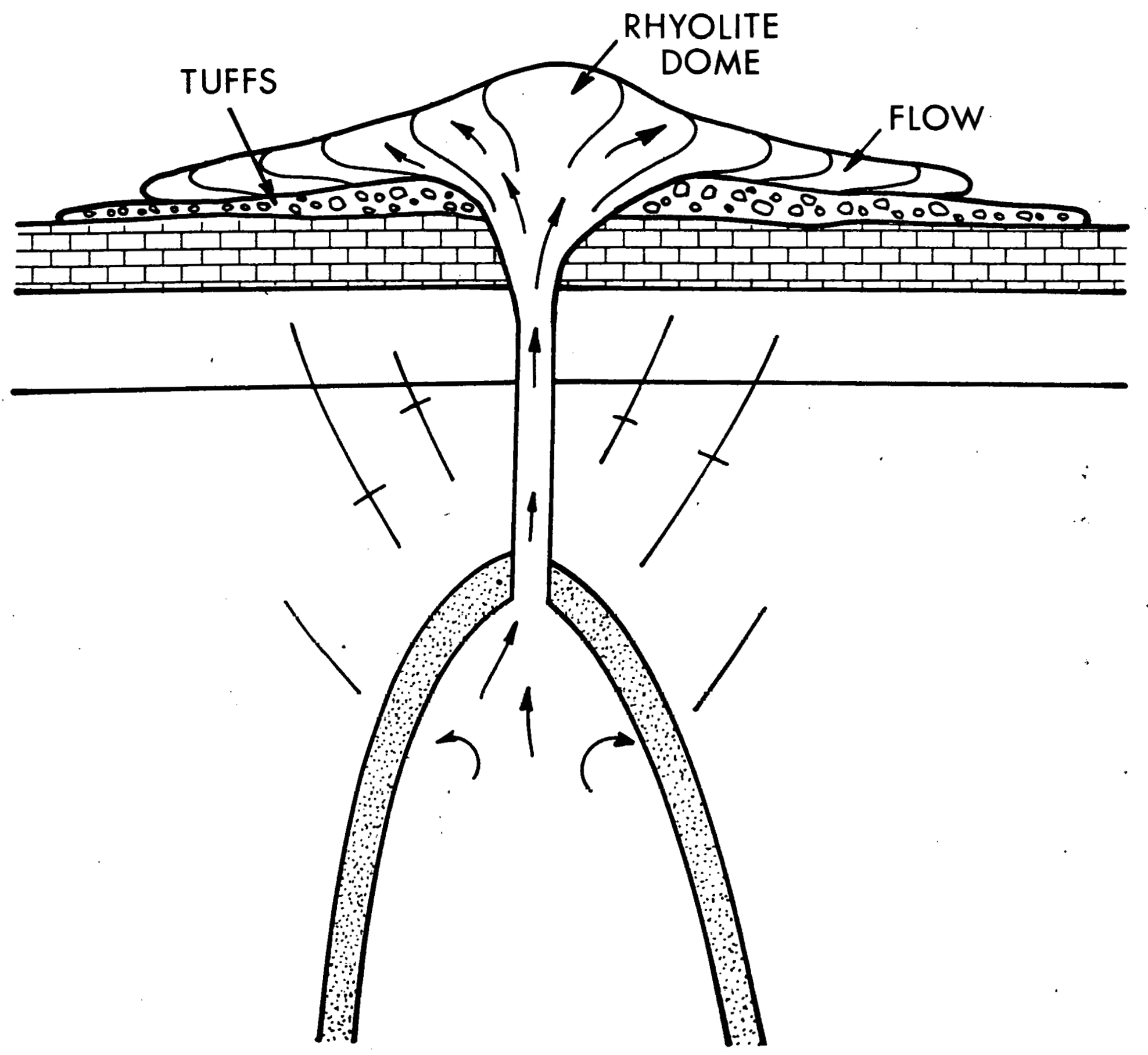

Figure 5. Model Stage $2 b$ - Eruption of dome-flow complex. 
contain up to $3.2 \%$ fluorine in glass, as mentioned above. Chlorides are generally more volatile than fluorides (Fuge, 1977), but $\mathrm{UF}_{6}$ is an exception (Krauskopf, 1969). Some of the volatile halides so lost may be "recaptured" by condensation and adsorption on volcanic ash (Taylor and Stoiber, 1973) and thus be subject to later leaching and redeposition.

\section{Vapor Phase and Hydrothermal Mineralization}

Crystallization and the formation of gas cavities in the rhyolite lava flows, plus welding, spherulitic devitrification, granophyric crystallization and vapor phase alteration in the tuffs (Smith, 1960), plus fumarolic alteration in tuffs and flows above where these processes are occurring (Sheridan, 1970), are probably the main high temperature processes by which the ore elements are redistributed in the erupted rhyolites and perhaps lost to the atmosphere. 'The very distinct compositions of glassy and crystalline rhyolites (see review by Zielinski et al., 1977; Zielinski, 1978) indicate that large quantities of ore elements can be liberated by these processes.

At Spor Mountain, for example, our analyses show that a fresh vitrophyre layer locally present near the top of the tuff contains about $1.0-1.5 \% \mathrm{~F}, 50-85$ ppm Be, and 25-50 ppm U (based on several samples), whereas granophyrically crystallized rhyolite from overlying lava flows contains an average of $0.5-$ $0.7 \% \mathrm{~F}, 7-15 \mathrm{ppm} \mathrm{Be}$, and 10-18 ppm U. Simple-minded calculations show that the implied loss of Be on crystallization of the capping rhyolite flows, neglecting additional rhyolite that has been lost by erosion, Be initially present in the tuffs, or lateral migration of Be, is more than adequate to account for the Be orebodies just underneath the flows (not that we believe that the overlying flows were necessarily the source of all of the beryllium being mined).

A possiblc problom with high temperature crystallization as an oregenerating mechanism is that it could just as easily disperse some of the metals 
to the atmosphere as concentrate them or place them in a readily leachable form. Another problem is that most of the pyroclastic deposits near topaz rhyolite vents are too thin to have undergone much welding, high temperature devitrification, or vapor phase alteration. A final problem is that high temperature processes should affect all erupted topaz rhyolite flows and underlying tuffs more-or-1ess equally, yet few are economically mineralized. In genera1, then, one or more episodes of lower temperature alteration-mineralization seem necessary for the creation of an economic orebody.

As an example, cassiterite deposited in miarolitic cavities and tension fractures at the top of topaz rhyolite flows may, in part, have formed at temperatures above $500^{\circ} \mathrm{C}$ (Lufkin, 1976), but most wood-tin (and associated chalcedony and opal) in "tin rhyolites" appears to have formed at temperatures of $150^{\circ}$ or below (Pan, 1974; Lufkin, 1977).

The hydrothermal (or "geothermal", to use the terminology of Henry, 1978) fluids responsible for low temperature beryllium and uranium transport (presumably as fluoride, hydroxyl, or carbonate complexes: Langmuir, 1978; Romberger, 1978) and deposition might be the products of crystallization of and/or convective meteoric water circulation by a hidden pluton at shallow depths, as most previous workers at Spor Mountain (following Staatz and Osterwald, 1959, p. 59-61) have assumed. While we cannot exclude this possibility, there is no direct evidence such as pervasive microfracturing, contact metamorphism, or high temperature mineralization (e.g. skarm in carbonate rocks: Burt, 1977) to suggest thc presence of a near-surface pluton. We therefore suggest the possibility that an aqueous circulation cell and especially the ore elements contained within it could be derived directly from the rhyolite vent complex itself.

Heat from the rhyolite domes and flows (and/or from the hypothetical pluton or regional high heat flow) circulates low temperature (less than $200^{\circ}$ ) 
meteoric fluids into and up the vents and related fractures and out through the underlying tuffs (Figure 6). Flow is concentrated just beneath the capping flows, causing most ore deposition to take place there (see element profiles in Bikun, 1980 and Lindsey, in press ). Low temperature alteration zones containing K-feldspar, sericite, Mn-oxides, chalcedony, uraniferous opal, clays, fluorite, calcite, and zeolites form in response to this circulation, and reactive foreign lithics and/or evaporation due to the heat of the overlying lava localize ore deposition. Low temperature leaching of vitric tuff and lava is a possible source of some of the ore elements (Zielinski, 1979 and in press).

Preliminary fluid inclusion studies on atypical vuggy vein material from the Fluoro Pit (studies performed by Barbara Murphy using facilities at the University of Arizona, Tucson) yielded quartz and fluorite homogenization temperatures in the range $143-165^{\circ}$, consistent with the low temperature mineralogy and fine grain size of the Spor Mountain mineralization, but nevertheless suggesting the existence of a thermal "event" in its formation. Most of the mineralization is too fine-grained to permit the aquisition of fluid inclusion data.

The above-suggested thermally-driven circulation pattern is perhaps also supported by the observation that at fluorite-mineralized volcanic vents at Spor Mountain and at the brecciated rhyolite/carbonate contact at the Staats Mine, Wah Wah Mountains, fine-grained purple fluorite mineralization rarely extends into the carbonate rocks. This suggests that Ca-saturated waters from the carbonate aquifer were flowing into the vent complexes where they deposited fluorite on encountering fluorine from the rhyolite. It further suggests that the convection cells were shallow, as shown by the upper arrows on Figure 6 .

Ground Water Mineralization

After the complex cools, ground water continues to migrate through the 


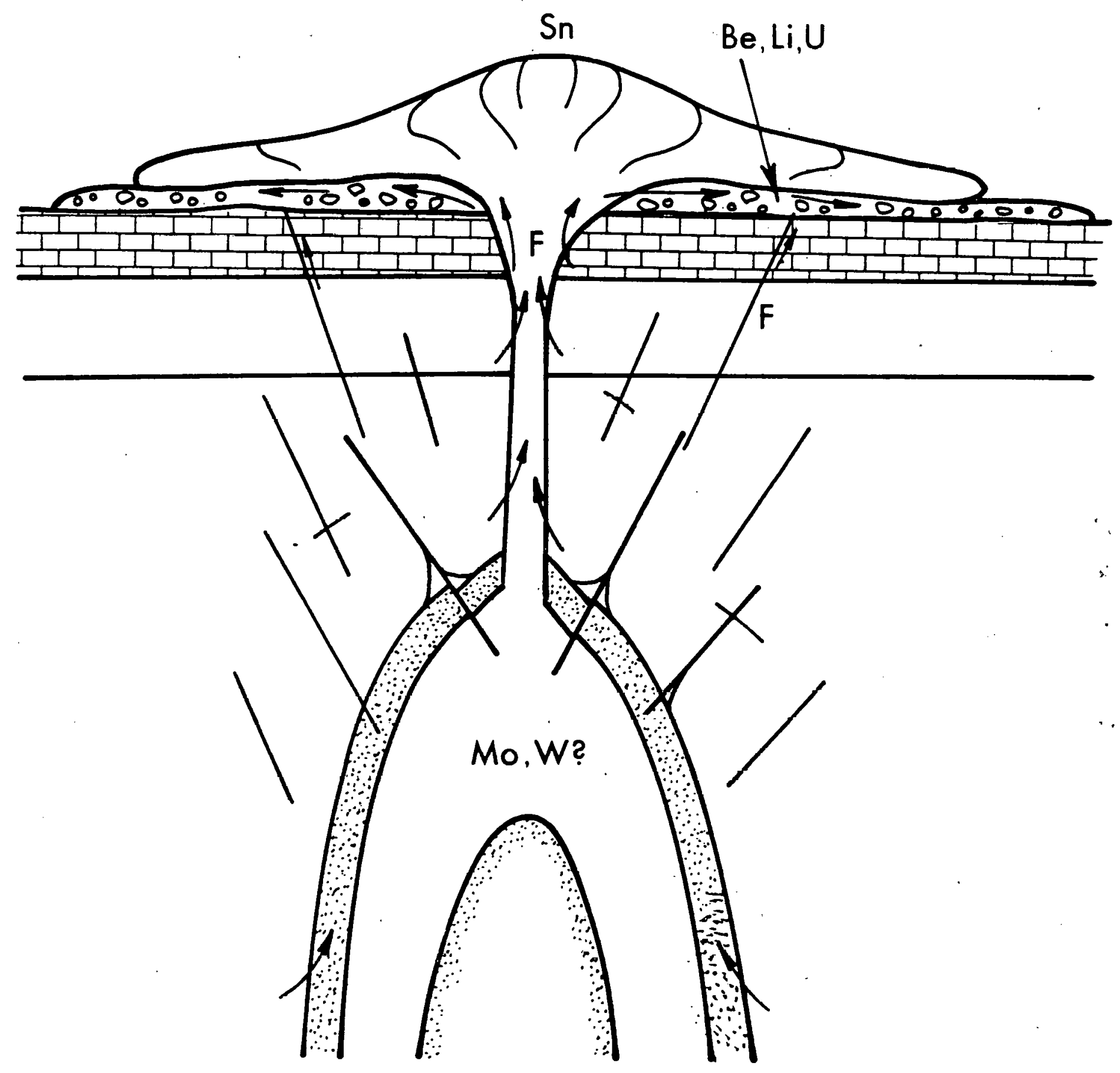

Figure 6. Model Stage 3 - Low temperature mineralization due to near-surface convection. 
system, further modifying the distribution of the ore elements. Uranium and silica are particularly susceptible, and nodules of uraniferous opal from the tuffs at Spor Mountain yield $\mathrm{U}-\mathrm{Pb}$ ages ranging from about $21 \mathrm{m.y}$. (the age of the volcanics) at the core to $3-5 \mathrm{~m} . \mathrm{y}$. in cross-cutting veinlets (Ludwig et al., 1980). The authors interpret this range of ages as probably indicating intermittent or extended hydrothermal activity, but we would prefer to ascribe most of it to low temperature ground water migration. 'The Yellow Chief uranıum mine in clastics beneath tuff near Spor Mountain may owe its existence entirely to this type of oxidizing transport and redeposition (Lindsey, 1979 and in press).

Karst-like oxidized uranium deposits in Paleozoic carbonates, similar to those at Sierra Gomez, Chihuahua, Mexico (Mitchell and Goode1l, in press). may also occur under the tuff at Spor Mountain. However, none of any size have yet been identified, unless some of the very fine-grained uraniferous fluoriteclay mineralization in pipes and veins has this "descending" origin. Many pipes seem to coincide with former volcanic vents, but this configuration does not exclude some later mineralization by descending fluids. U-Pb dating of opal or chalcedony associated with the fluorite in the pipes might resolve the question.

\section{Barren and Productive Topaz Rhyolites}

Failure to attain ore grade mineralization in most topaz rhyolite vent complexes may be due to a variety of factors. First, the initial fluorine activity and metal content of the magma may be too low. Our preliminary study of vitrophyres has shown that few topaz rhyolite glasses, save possibly those from the Honeycomb Hills, Utah, are as enriched in F, Be, and $U$ as those from Spor Mountain. A puzzling observation is that tin-rich topaz rhyolites in Nevada and New Mexico are not known to be associated with significant uranium mineralization. 
The high fluorine activity in Spor Mountain and Honeycomb Hills rhyolite is perhaps indicated by the fact (our analyses; also Turley et a1., 1979) that plagioclase from there has roughly half the anorthite content $(6-10$ mole $\%)$ as that from the "barren" topaz rhyolites of the nearby Thomas Range (13-20 mole \%), although total calcium contents in the rocks are comparable. Titanite (sphene) is rare or absent in topaz rhyolites, and even in the Thomas Range occurs only in lithic inclusions of older rocks (David Lindsey, personal communication, 1980). The calcium in high-fluorine rhyolites is presumably "remover" as fluorite, by relations such as the following:

$$
\begin{aligned}
& \text { (1) } \left.\mathrm{CaAl}_{2} \mathrm{Si}_{2} \mathrm{O}_{8}\right]+2 \mathrm{~F}_{2} \mathrm{O}_{-1}=\mathrm{CaF}_{2}+\mathrm{Al}_{2} \mathrm{SiO}_{4} \mathrm{~F}_{2}+\mathrm{SiO}_{2} \\
& \text { Anorthite }+2 \mathrm{~F}_{2} \mathrm{O}_{-1}=\mathrm{Fluorite}+\mathrm{Topaz}+\text { Quartz } \\
& \text { (in plagioclase) } \\
& \text { (2) } \text { CaTiSiO }_{5}+\mathrm{F}_{2} \mathrm{O}_{-1}=\mathrm{CaF}_{2}+\mathrm{IiO}_{2}+\mathrm{SiO}_{2} \\
& \text { Titanite }+\mathrm{F}_{2} \mathrm{O}_{-1}=\mathrm{Fluorite}+\text { Rutile + Quartz } \\
& \text { (or other Ti mineral) }
\end{aligned}
$$

In the above equations, $\mathrm{F}_{2} \mathrm{O}_{-1}$ is an "exchange operator", the "acid anhydride" of $\mathrm{HF}$ (Burt, 19\%4) whose chemical potential gives a measure of the tendency for fluorine to replace oxygen in the melt.

closely-related factors are the water content and eruption temperature of the magma. "Productive" topaz rhyolites from the Black Range, N.M., Spor Mountain, Utah, and the Staats Mine-Holly claim area, Wah Wah Mts., Utah tend to be phenocryst-rich, blocky or massive, poor or lacking in gas cavities, and granophyrically crystallized, suggesting relatively low eruption temperatures and water contents or fugacities and slow cooling rates. "Barren" topaz rhyolites from the Thomas Range, Utah, Four Mile Wash area, Wah Wah Mountains, Utah and numerous other areas are phenocryst-poor, remarkably flow-banded, lithophysae-rich, and spherulitically crystallized, suggesting 
the opposite.

Two similar classes of fluorine-rich Quaternary rhyolites have been recognized in the Mineral Mountains, Utah (Nash and Evans, 1977; Evans and Nash, 1978; Lipman et al., 1978; Ward et al., 1978), older (0.8 m.y.) phenocryst-poor flows and younger $\left(0.5 \mathrm{~m} . \mathrm{y}_{.}\right)$phenocryst-rich domes. Geothermometry involving iron-titanium oxides and two feldspars yields magma temperatures as diverse as $785^{\circ}$ and $650^{\circ}$, and geobarometry water fugacities as diverse as $3.0 \mathrm{~kb}$ and $0.4 \mathrm{~kb}$, respectively, for the two groups of rocks (Nash and Evans, 1977). Obsidians of the older group have less than half the fluorine content of the younger (about 0.16 vs. 0.44\%: Lipman et a1., 1978); the younger rhyolites have some topaz in gas cavities. They are also enriched in $\mathrm{Na}, \mathrm{Rb}$, $\mathrm{Nb}$, and $\mathrm{Mn}$ and depleted in $\mathrm{K}, \mathrm{Ba}, \mathrm{Sr}, \mathrm{Ca}, \mathrm{Ti}$, and $\mathrm{Fe}$, Based on europium anomalies in younger feldspars, these differences are tentatively ascribed to feldspar fractionation. Uranium contents are not given, but the data given above would suggest that rhyolites of the older group are more likely to be "barren" than those of the younger.

Possibly much of the uranium escaped from the barren rhyolites during or shortly after eruption in the vapor phase, or was fixed in the spherulitically-crystallized groundmass by rapid crystallization. Vapor phase losses have previously been used to explain lower uranium contents in miarolitic, as opposed to massive, near-surface intrusives (Bohse et al., 1974). Another possibility is that the uranium wasn't there in the first place (i.e., that the water-rich magmas were less enriched in uranium and fluorine).

A major factor at most topaz rhyolite localities is undoubtedly the content and reactivity of foreign lithics in the pyroclastics. These in turn reflect the country rock penetrated at the vent $(s)$. Carbonate lithics are abundant at Spor Mountain and common at the Holly Claims, Wah Wah Mountains, Utah, but are virtually lacking in the other areas studied. The above two districts 
both have significant uranium-fluorite mineralization also lacking in the other districts.

An equally important factor may be the level of the water table and the availability of an aquifer at the time of eruption. If ground water is too. deep or lacking, its convective circulation through the tuffs will be impossible. None of the other districts studied show the degree of pervasive alteration of tuff seen at Spor Mountain and presumably indicative of a low temperature hydrothermal event.

$\Lambda$ general feature shared by must topaz rhyolites is their relatively small eruption volume. Without considerable initial magmatic enrichment in $F$, $U$, and Be, the formation of significant tonnages of ore due to leaching would be difficult, if not impossible. Also, the small size minimizes the time available for high temperature devitrification in the lavas and tuffs and the time available for thermally-driven meteoric water circulation (unless there is a shallow pluton or other heat source to drive convection after surfacc cooling has occurred).

A related general problem is the radial drainage pattern idcally cxhibited by small rhyolitic dome complexes, which would tend to disperse, rather than concentrate, uranium transported in low temperature ground water. The central drainage basin typical of calderas is much more favorable in this respect (Henry, 1978) and it is interesting that the Yellow Chief uranium mine in clastics under the beryllium tuff near Spor Mountain lies inside what has been interpreted as a former caldera (Lindsey, 1979 and this volume). It is also interesting that the Spor Mountain topaz rhyolite is the oldest yet identified in the Great Basin, implying a maximum amount of time for ground water leaching to have been effective.

We conclude that the magma composition and temperature, type of country rock exposed at the surface, level of water table, and even drainage pattern 
and age were more favorable for mineralization at Spor Mountain than at any of the other areas studied. Similar mineralization at the Honeycomb Hills and (so far as is known) at the Staats Mine-Holly claims area appears much less economic.

In the next section we attempt to indicate the possible significance of topaz rhyolites in prospecting for types of ore deposits other than those found at Spor Mountain (i.e., subsurface deposits).

\section{Related Mineral Deposits}

The exploration significance of topaz rhyolites probably does not end at the Earth's surface, although so far we have discussed only surface and near-surface processes. Obvious variations on the model presented above are cases where the magma chamber does not vent or where its venting only involves the deposition of easily-eroded pyroclastics. These cases are unfavorable for the formation of surficial deposits such as those discussed here, but are very favorable for the formation of disseminated (porphyry), vein (greisen), or replacement (skarn) deposits at depth.

These deposits might also form under topaz rhyolite dome complexes where a significant fraction of the magma has been vented, especially if a second post-volcanic magma body finds its way upwards (as indicated by the "Mo-W?" on Figure 6). Multiple episodes of intrusion and mineralization seem to be characteristic of fluorine-rich porphyry Mo-W systems such as those at Climax (Wallace et al., 1968) and Urad-Henderson (Wallace et al., 1978), Colorado. The close spatial and age correlation of these deposits with identified topaz rhyolite flows is also notable in this regard (Figure 2).

Similar considerations have led to the hypothesis that a porphyry molybdenum system underlies the fluorite and uranium-rich veins and volcanic breccias of the Central Mining area, Marysvale, Utah (Cunningham and Steven, 1979; Steven 
et a1., in press), but this hypothesis awaits confirmation. A more direct result is the correlation by Keith (1979) of $\mathrm{Mn}$-Fe garnet-bearing Miocene ash-flow tuffs in the Wah Wah Mountains, Utah with the venting of the nearby Pine Grove porphyry molybdenum system, which contains identical garnets. Molybdenum and tungsten need not be the only lithophile metals deposited in or near intrusives under topaz rhyolites. Rosettes of beryl disseminated in Miocene granite in the Sheeprock Mountains, Utah were extensively prospected before the nearby discovery of Spor Mountain; minor $U$ and $W$ (wolframite) occur in associated veins and greisens (Cohenour, 1963). Deposit.s of other lithophile elements such as 'l'h, $\mathrm{Sn}, \mathrm{Nb}, \mathrm{Ta}, \mathrm{Y}$, and the rare earths might also be expected in intrusive environments.

In carbonate host rocks, replacement deposits of "ribbon-rock" or laminar fluorite-rich skarn enriched in $\mathrm{Be}, W$, and $\mathrm{Sn}$ might be expected, by analogy with Iron Mountain, New Mexico (Jahns, 1944) and the Seward Peninsula, Alaska (Sainsbury, 1969). Similar economically-important deposits have recently been found in Australia (Teunis A. P. Kwak, personal communication, 1979). A vertical sequence for types of lithophile element mineralization in fluorine-rich silicic systems might be as follows:

1. Wood-Sn in topaz rhyolite lava flows

2. $U-B e-F$ in underlying tuffs and sediments

3. U-F-Be-Sn-W-Mo in subvolcanic breccias, veins, and replacements

4. Mo-W-Sn (Nb-Ta-Be-U-Th) in "porphyry" deposits

5. Sil-W-B $\operatorname{Mo}$ in greiscns

6. $\mathrm{Li}-\mathrm{Nb}-\mathrm{Ta}-\mathrm{Be}-\mathrm{Sn}-\mathrm{U}$ in pegmatites.

It is unknown how many of these types of mineralization might occur in the same district.

Perhaps, however, that is "drilling too deeply". Going back to the surface, we should not forget the economic importance of leached Li and B in 
brines and evaporites, respectively (Glanzman et al., 1979) not the significance of younger topaz rhyolite vent systems, such as those near Roosevelt Hot Springs, Utah, as indicating possible sources of geothermal energy (Ward et $a 1 ., 1978)$.

\section{Summary}

The combination of fluorine and uranium-enriched magma, reactive carbonate rocks exposed in the volcanic vent area, (presumably) elevated water table, and clastics underlying tuffs was uniquely favorable for beryl1ium and/or uranium mineralization at Spor Mountain. This complete combination apparently was not present at the other areas studies, although it might not always be necessary. For example, reactive carbonate rocks are not needed for ground water mineralization of the Yellow Chief type, and mafic-rich vent breccias might prove almost as reactive as carbonate-rich ones. Finally, subvolcanic and prophyry-type mineralization related to topaz rhyolite volcanism might prove more significant than the near-surface types of mineralization emphasized here.

\section{Acknowledgements}

We owe much to discussions with and readings from Rex Cole, Saleh AbouZied, Dave Lindsey, Skip Cunningham, Bill Nash, Phil Goodel1, Chris Henry, and Tony Wa1ton, and to perceptive reviews by Dave Lindsey, Aaron Waters, Phil Goode11 and Robert Wilson. We are also grateful to the Bendix Field Engineering Corporation and the U.S. Department of Energy for their support of this research under subcontract \#79-270-E. Four of our graduate students, Jim Bikun, Eric Christiansen, Brian Correa and Barbara Murphy, performed much of the work here summarized, and were always generous with their time, ideas, and effort. Finally, we are grateful to Terry Sprowl for typing the manuscript and to Sue Selkirk for drafting the figures. 


\section{References Cited}

Allman, R. and Koritnig, S., 1972, Fluorine, in Handbook of Geochemistry, v. II-1, chapter 9: New York, Springer-Verlag.

Bailey, D. K., 1978, Continental rifting and mantle degassing, in Newmann, E. R. and Ramberg, I. B., eds., Petrology and geochemistry of continental rifts: Dordrecht, The Netherlands, D. Reidel Publishing Co., p. 1-13.

Bailey, J. C., 1977, Fluorine in granitic rocks and melts: a review: Chemical Geology, v. 19, no. 1, p. 1-42.

Barker, F., Wones, D. R., Sharp, W. N., and Desborough, G. A., 1975, The Pikes Peak batholith, Colorado Front Range, and a model for the origin of the gabbro-anorthosite-syenite-potassic granite suite: Precambrian Research, v. 2 , no. 2 , p. 97-160.

Bikun, J. V., 1980, Fluorine and 1ithophile element mineralization at Spor Mountain, Utah: Unpublished M.S. thesis, Arizona State University, Tempe, Arizona, $195 \mathrm{p}$. (Chapter IV, this report).

Blackwe11, D. D., 1978, Heat flow and energy loss in the western United States: Geological Society of America Memoir 152, p. 175-208.

Bohse, H., Rose-Hansen, J., Sorensen, H., Steenfelt, A., Lovborg, L., and Kunzendorf, H., 1974, On the behavior of uranium during crystallization of magmas - with special emphasis on alkaline magmas, in Formation of Uranium Ore Deposits: Vienna, Austria, International Atomic Energy Agency, p. 49-60.

Burt, D. M., 1974, Concepts of acidity and basicity in petrology - the exchange operator approach: Geological Society of America, Abstracts with Programs, v. 6 , no. 7, p. 674-676.

Burt, D. M., 1977, Mineralogy and petrology of skarn deposits: Rendiconti della Societa Italiani di Mineralogia e Petrologia, v. 33, p. 859-873.

Chadwick, R. A., 1977, An overview of early Tertiary volcanism in the Northern kockies region (abstr.): Geological Society of America, Abstracts with Programs, v. 9, no. 6, p. 715-716.

Christiansen, R. L. and Lipman, P. W., 1972, Cenozoic volcanism and platetcctonic evolution of the western United States II. Late Cenozoic: Royal Society of London Philosophical Transactions, v. 271, p. 249-284.

Christiansen, R. L. and McKee, E. H., 1978, Late Cenozoic and tectonic evolution of the Great Basin and Columbia Intermontane regions: Geological Society of America Memoir 152, p. 283-311.

Cohenour, R. E., 1963, Beryl1ium and associated mineralization in the Sheeprock Mountains, in Sharp, B. J. and Williams, N. C., eds., Beryllium and uranium mineralization in western Juab County, Utah: Utah Geological. Society, Guidebook no. 17, p. 8-13. 
Cunningham, C. G. and Steven, T. A., 1979, Uranium in the Central mining area, Marysvale, west central Utah: U.S. Geological Survey Miscellaneous Investigations Map I-1117.

Eaton, G. P., 1979, A plate tectonic model for Late Cenozoic crustal spreading in the western United States, in Riecker, R. E., ed., Rio Grande rift: tectonics and magmatism: Washington, D.C., American Geophysical Union, p. 7-32.

Elston, W. E., 1978, Mid-Tertiary cauldrons and their relation to mineral resources: a brief review: New Mexico Geological Society Special Publication 7, p. 103-113.

Elston, W. E., and Bornhorst, T. J., 1979, The Rio Grande rift in context of regional post-40 m.y. volcanic and tectonic events, in Riecker, R. E., ed., Rio Grande rift: tectonics and magmatism: Washington, D.C., American Geophysical Union, p. 416-438.

Emmons, W. H., 1933, On the mechanism of the deposition of certain metalliferous lode systems associated with granitic batholiths, in Ore Deposits of the Western States - Lindgren Volume: New York, American Institute of Mining Engineers, p. 327-349.

Ericksen, G. E., Wedow, H., Jr., Eaton, G. P., and Leland, G. R., 1970, Mineral resources of the Black Range Primitive Area, Grant, Sierra and Catron Counties, New Mexico: U.S. Geological Survey Bulletin 1319-E, 162 p.

Evans, S. H., Jr. and Nash, W. P., 1978, Quaternary rhyolite from the Mineral Mountains, Utah: U.S. Dept. of Energy, Division of Geothermal Energy, Contract EY-76-S-07-1601, Final Report, v. 77-10, 59 p.

Foshag, W. F. and Fries, C., Jr., 1942, Tin deposits of the Republic of Mexico: U.S. Geological Survey Bulletin 935-C, p. 99-176.

Fries, Carl, Jr., 1940, Tin deposits of the Black Range, Catron and Sierra Counties, New Mexico: U.S. Geological Survey Bulletin 992-M, p. 355-370.

Fries, Carl, Jr., 1942, Tin deposits of northern Lander County, Nevada: U.S. Geological Survey Bulletin 931-L, p. 279-294.

Fuge, R., 1977, On the behavior of fluorine and chlorine during magmatic differentiation: Contributions to Mineralogy and Petrology, v. 61, p. 245-249.

Glanzman, R. K., Rytuba, J. J., and Otton, J. K., 1979, Lithium and boron association with uranium mineralization (abstr.): Geological Society of America, Abstracts with Programs, v. 11, no. 7, p. 433.

Goodel1, P., and Carraway, K., 1980, Geology of the Sierra Peña Blanca region, Chihuahua, Mexico: AAPG Special Volume (in press).

Goode11, P. C., Trentham, R. C., and Carraway, K., 1.978, Geologic setting of the Pena Blanca uranium deposits, Chihuahua, Mexico: U.S. Dept. of tnergy Open-F1le Repür GJBX-22(79), Chapter 9. 
Groves, D. I., and McCarthy, T. S., 1978, Fractional crystallization and the origin of tin deposits in granitoids: Mineralium Deposita, v. 13, p. 11-26.

Henry, C. D., 1978, Origin of uraniferous opal: U.S. Dept. of Energy OpenFile Report GJBX-22 (79), Chapter 10.

Hildreth, W., 1979, The Bishop tuff: evidence for the origin of compositional origin in silicic magma chambers: Geological Society of America, Special Paper 180 , p. 43-75.

Hillard, P. D., 1969, Geology and beryllium mineralization near Apache Warm Springs, Socorro County, New Mexico: New Mexico Bureau of Mines and Mineral Resources Circular 103, 16 p.

Hilpert, L. S., and Roberts, R. J., 1964, Geology-Economic geology, in II.S. Geological Survey, Mineral and water resources of Utah: Utah Geological and Mineral Survey, Bulletin 73, p. 28-38.

Jahns, R. H., 1944, Beryllium and tungsten deposits of the Iron Mountain district, Sierra and Socorro Counties, New Mexi nn: U.S. Geological Survey Bulletin 945-C, p. 45-79.

Karig, D. E., 1971, Origin and development of marginal basins in the western Pacific: Journa1 of Geophysical Research, v. 76, p. 2542-2561.

Keigh, Jeffery D., 1979, Miocene volcanic centers hosting porphyry-molybdenum and epithermal vein mineralization, Southwestern Utah and Nevada (abstr.): Geological Society of America, Abstracts with Programs, v. 11, no. 7, p. 455 .

Kerr, P. F., and Wilcox, J. T., 1963, Structure and volcanism, Grants Ridge area: New Mexico Bureau of Mines and Mineral Resources Memoir 15, p. 205-213.

Kisvaršanyi, E. B., 1980, Granitíc ring complexes and Precambrian hot-spot activity in the St. Francois terrane, Midcontinent region, United States: Geology, v. 8, p. 43-47.

Kogarko, L. N., Ryabchikov, I. D., and Sorensen, H., 1974, Liquid fractionation, in Sorensen, H., ed., The alkaline rocks: London, John Willey and Sons, p. 188.500.

Kovalenko, V. 1., and Kovalenko, N. I., 1976, Ongonites - (topaz-bearing quartz keratophyre) - subvolcanic analogue of rare metal Li-F granites (in Russian): Muscuw, "Nauka" Press, $128 \ddot{8}$.

Kovalenko, V. I., Grebennikov, A. M., and Antipin, V. S., 1975, Ongonite of the Arybulak stock, Transbaikal: the first find of a subvolcanic analog of rare metal-bearing lithium-fluorine granite (apogranite) in the U.S.S.R.: Doklady of the Academy of Sciences, U.S.S.R., Earth Science Sections, v. 220 , p. $158-160$.

Kovalenko, V. I., Kuz'min, M. I., Antipin, V. S., and Petrov, L. L., 1971, Topaz-bearing quartz keratophyre (ongonite), a new variety of subvolcanic igneous vein rock: Doklady of the Academy of Sciences, U.S.S.R., Earth Science Sections, v. 199, p. 132-144. 
Krauskopf, K. B., 1969, Relative volatilities of fluorides of ore forming metals in magmatic gases, in Khitarov, N. I., ed., Problems in geochemistry: Jerusalem, Israel Program for Scientific Translations, p. $155-165$.

Lamarre, A. L., and Hodder, R. W., 1978, Distribution and genesis of fluorite deposits in the western United States and their significance to metallogeny: Geology, v. 6, p. 236-238.

Langmuir, Donald, 1978, Uranium solution-mineral equilibria at low temperatures with applications to sedimentary ore deposits: Geochimica et Cosmochimica Acta, v. 42, p. 547-569.

Lindsey, D. A., 1977, Epithermal beryllium deposits in water-laid tuff, western Utah: Economic Geology, v. 72, p. 219-232.

Lindsey, D. A., 1978, Geology of volcanic rocks and mineral deposits in the southern Thomas Range, Utah: A brief summary: Brigham Young University Geology Studies, v. 25, pt. 1, p. 25-31.

Lindsey, D. A., 1979, Preliminary report on Tertiary volcanism and uranium mineralization in the Thomas Range and Drum Mountains, Juab County, Utah: U.S. Geological Survey Open-File Report 79-1076, 101 p.

Lindsey, D. A., 1980, Volcanism and uranium mineralization at Spor Mountain, Utah: AAPG Special Volume (in press):

Lindsey, D. A. and Osmonson, L. M., 1978, Mineral potential of altered rocks near Blawn Mountain, Wah Wah Range, Utah: U.S. Geological Survey, OpenFile Report 78-114, $18 \mathrm{p}$.

Lipman, P. W., Prostka, H. J., and Christiansen, R. L., 1972, Cenozoic volcanism and plate-tectonic evolution of the western United States. I. Early and Middle Cenozoic: Royal Society of London Philosophical Transactions, v. 271 , p. 217-248.

Lipman, P. W., Rowley, p. D., Mehnert, H., Evans, S. H., Nash, W. P., and Brown, F. H., 1978, P1eistocene rhyolite of the Mineral Mountains, Utah: geothermal and archeological significance: U.S. Geulugical Survey, Journal of Research, v. 6, p. 133-147.

Loiselle, M. C. and Wones, D. R., 1979, Characteristics and origin of anorogenic granites (abstr.): Geological Society of America, Abstracts with Programs, v. 11 , no. 7, p. 468 .

Ludwig, K. R., Lindsey, D. A., Zielinski, R. A., and Simmons, K. R., 1980, $\mathrm{U}-\mathrm{Pb}$ ages of uraniferous opals and implications for the history of beryllium, fluorine, and uranium mineralization at Spor Mountain, Utah: Earth and Planetary Science Letters, v, 46, p. 221-232.

Lufkin, J. L., 1976, Oxide minerals in miarolitic rhyolite, Black Range, New Mexico: American Mineralogist, v. 61, p. 221-232.

Lufkin, J. L., 1977, Chemistry ānd mlneralogy uf wơud-tin, Black Rangc, New Mexico: American Mineralogist, v. 62, p. 100-106. 
McAnulty, W. N., and Levinson, A. A., 1964, Rare alkali and beryllium mineralization in volcanic tuffs, Honey Comb Hills, Juab County, Utah: Economic Geology, v. 59, p. 768-774.

Mitche11, S. and Goode11, P. C., 1980, The geology of Sierra Gomez, Chihuahua, Mexico: AAPG Special Volume (in press).

Montoya, J. W., Baur, G. S., and Wilson, S. R., 1964, Mineralogical investigations of beryllium-bearing tuff, Honeycomb Hills, Juab County, Utah:

U.S. Bureau of Mines Report of Investigations $6408,11 \mathrm{p}$.

Moore, W. J., and Sorensen, M. L., 1978, Metamorphic rocks of the Granite Peak area, Tooele County, Utah (abstr.): Geological Society of America, Abstracts with Programs, v. 10, no. 5, p. 234.

Nash, W. P., and Evans, S. H., Jr., 1977, Natural silicic liquids: fugacities and flow (abstr.): Geological Society of America, Abstracts with Prngrams, v. 9, no. 7, p. $111 n$,

Pan, Y.-S., 1974, The genesis of the Mexican type tin deposits in acidic volcanics: Unpublished Ph.D. thesis, New York, N.Y., Columbia University, $286 \mathrm{p}$.

Petro, W. L., Vogel, T. A., and Wilband, J. T., 1979, Major element geochemistry of plutonic rock suites from compressional and extensional plate boundaries: Chemical Geology, v. 26, p. 217-235.

Prodeh1, C., 1979, Crustal stmucture of the western United States: U.S. Geological Survey Professional Paper 1034, $74 \mathrm{p}$.

Ream, L. K., 19\%, 'l'he Thomas Range, Wah Wah Mountains, and vicinity, western Utah: Mineralogica1 Record, v. 10, p. 261-278.

Rhodes, R. C., 1976, Petrologic framework of the Mogollon Plateau volcanic ring complex, Ncw Mexico - surface expression of a major batholith: New Mexico Geological Society Special Publication No. 5, p. 103-112.

Romberger, S. B., 1978, Hydrothermal transport and deposition, and the origin of vein uranium deposits (abstr.): Geological Society of America, Abstracts with Programi, v. 10 , no. 7, p. 480.

Roper, M. W., and Wallace, A. B., 1980, Geology of the Aurora uranium prospect, Malheur County, Oregon: AAPG Special Volume (in press).

Rowley, P. D., Lipman, F. W., Melunerl, H. H., Lindsey, D. A., and Anderson, J. J., 1978, Blue Ribbon Lineament, an east-trending structural zone within the Pioche mineral belt of southwestern Utah and eastern Nevada: U.S. Geological Survey, Journal of Research, v. 6, no. 2, p. 175-192.

Rytuba, J. J., 1980, Petrochemical characteristics of volcanic rocks associated with uranium deposits in the McDermitt Caldera: AAPG Special Volume (in press).

Rytuba, J. J., and Glanzman, R. K., 1979, Relation of mercury, uranium and lithium deposits to the McDermitt caldera complex, Nevada-Oregon: Nevada Bureau of Mines and Geology, Report 33, p. 109-117. 
Sainsbury, C. L., 1969, Geology and ore deposits of the central York Mountains, western Seward Peninsula, Alaska: U.S. Geological Survey Bulletin 1287 , $101 \mathrm{p}$.

Scholz, C. H., Barazangi, M., and Sbar, M. C., 1971, Late Cenozoic evolution of the Great Basin, western United States, as an ensialic interarc basin: Geological Society of America Bulletin, v, 82, p. 2979-2990.

Shaw, H. R., Smith, R. L., and Hildreth, W., 1976, Thermogravitational mechanisms for chemical variations in zoned magma chambers (abstr.): Geological Society of America, Abstracts with Programs, v. 8, p. 1102.

Shawe, D. R., 1968, Geology of the Spor Mountain beryllium district, Utah, in Ridge, J. D., ed., Ore deposits in the United States, 1933-1967 (GratonSales Volume): New York, American Institute of Mining, Metallurgical and Petroleum Engineers, v. 2, p. 1148-1161.

Shawe, D. R., ed., 1976, Geology and resources of fluorine in the United States: U.S. Geological Survey Professional Paper 933, 99 p.

Shawe, D. R., 1979, Distribution and genesis of fluorite deposits in the western United States and their significance to metallogeny. Comments: Geology, v. $7, \mathrm{p} .115-117$.

Sheridan, M. F., 1970, Fumarolic mounds and ridges of the Bishop tuff, California: Geological Society of America Bulletin, v. 81, p. 851-868.

Sheridan, M. F., 1979, Emplacement of pyroclastic flows: a review: Geological Society of America, Specia.1. Paper 180, p. 125-136.

Silver, L. T., 1976, A regional uranium anomaly in the Precambrian basement of the Colorado Plateau (abstr.): Geological Society of America, Abstracts with Programs, v. 8, no. 6, p. 1107-1108.

Sillitoe, R. H., 1977, Metallic mineralization affiliated to subaerial volcanism: a review, in Volcanic processes in ore genesis: London, Institution of Mining and Metallurgy, p. 99-116.

Simpson, P. R., Brown, G. C., Plant, J., and Ostle, D., 1979, Uranium mineralization and granite magmatism in the British Isles: Royal Society of London, Philosophical Transactions, Sec. A, v. 291, p. 385-412.

Sinkankas, J., 1959, Gemstones of North America, Vol. 1: New York, Van Nostrand Reinhold Co., 675 p.

Slnkarkas, J., 1976, Gemstones of North America, Vol. 2: New York, Van Nostrand Reinhold Co., 494 p.

Smedes, H. W., 1966, Geology and igneous petrology of the northern Elkhorn Mountains, Jefferson and Broadwater Counties, Montana: U.S. Geological Survey Frofessional Paper 510; $116 \mathrm{p}$.

Smith, R. B., 1978, Seismicity, crustal structure, and intraplate tectonics of the interior of the Western Cordillera: Genlngical Society of America Memoir 152, p. 111-144. 
Smith, R. L., 1960, Zones and zonal variations in welded ash flows: U.S. Geological Survey Professional Paper 354-F, p. 149-159.

Smith, R. L., 1979, Ash flow magmatism: Geological Society of America, Special Paper 180, p. 5-27.

Sparks, R. S. J., 1976, Grain size variations in ignimbrites and implications for the transport of pyroclastic flows: Sedimentology, v. 23, p. 147-188.

Staatz, M. H., and Carr, W. J., 1964, Geology and mineral deposits of the Thomas and Dugway Ranges, Juab and Tooe le Counties, Utah: U.S. Geological Survey Professional Paper 415, $188 \mathrm{p}$.

Staatz, M. H., and Osterwald, F. W., 1959, Geology of the Thomas Range fluorospar district, Juab County, Utah: U.S. Geological Survey Bulletin 1069, $97 \mathrm{p}$.

Steven, T. A., Cunningham, C. G., and Rasmussen, J. D., 1980, Volcanogenic uranium deposits associated with the Mount Belknap volcanics, Marysvale volcanic field, West-Central Utah: AAPG Special Volume (in press).

Stewart, J. H., 1978, Basin-range structure in western North America: a review: Geological Society of America Memoir 152, p. 1-31.

Stewart, J. H., Moore, W. J., and Zietz, I., 1977, East-west patterns of Cenozoic igneous rocks, aeromagnetic anomalies, and mineral deposits: Geological Society of America Bulletin, v. 88, p. 67-77.

Taylor, P. S., and Stoiber, R. E, 1973, Soluble material on ash frnm artive. Central American volcanoes: Geological Society of America Bulletin. v. 84, p. 1031-1042.

'Ihompson, G. A., and Burke, D. B., 1974, Regional geophysics of the Basin and Rangc: Annual Review of Earth and P1 anetary Sciences, v. 2, p. 213-238.

Turley, C. P., Nash, W. P., and Brown, W. P., 1979, Petrology and geochronology of late Tertiary and Quaternary volcanic rocks in the eastern margin of the Basin and Range Province, Utah: U,S, Dept. of Energy, Contract. EY-76-S-07-1601, Fina1 Rept., University of Utah, v. 1, $78 \mathrm{p}$.

Tweto, O., 1979, The Rio Grande rift system in Colorado, in Riecker, R. E., ed., Rio Grande rift: tectonics and magmatism: Washington, D.C., American Geophysical Union, p. 33-56.

Viwi Alslint, R. B., 1969, Ccology and mineral deposits of the foricha springs NE quadrangle, Chaffee County, Colorado: U.S. Geological Survey Professional Paper 626, $52 \mathrm{p}$.

Van Alstine, R. E., 1976, Continental rifts and lineaments associated with major fluorospar districts: Economic Geology, v. 71, p. 977-987.

Van Alstine, R. E., and Tooker, E. W., 1979, Preliminary map of fluorine provinces in the conterminous United States: U.S. Geological Survey Open-File Report 79-576G. 
Wallace, A. B., and Roper, M. W., 1980, Geology and uranium deposits along the northeastern margin of the McDermitt caldera complex, southern Malheur County, Oregon: AAPG Special Volume (in press).

Walace, S. R., Muncaster, N. K., Jonsen, D. C., MacKenzie, W. B., Bookstrom, A. A., and Surface, V. E., 1968, Multipleintrusion and mineralization at Climax, Colorado in Ridge, J. D., ed., Ore Deposits of the United States, 1933-1967 (Graton-Sales Volume): New York, American Institute of Mining, Metallurgica1, and Petroleum Engineers, p. 605-640.

Wallace, S. R., MacKenzie, W. B., Blair, R. G., and Muncaster, N. K., 1978, Geology of the Urad and Henderson molybdenite deposits, Clear Creek County, Colorado, with a section on a comparison of these deposits with those at Climax, Colorado: Economic Geology, v. 73, p. 325-368.

Walton, A. W., and Henry, C. D., eds., 1979, Cenozoic geology of the TransPecos volcanic field of Texas: Texas Bureau of Economic Geology, Guidebook 19, $202 \mathrm{p}$.

Ward, S. H., Parry, W. T., Nash, W. P., Sill, W. R., Cook, K. L., Smith, R. B., Chapman, D. S., Brown, F. H., Whelan, J. A., and Bowman, J. R., 1978, A summary of the geology, geochemistry, and geophysics of the Roosevelt Hot Springs thermal area, Utah: Geophysics, v. 43, p. 1515-1542.

Whelan, J. A., 1965, Hydrothermal alteration and mineralization, Staats mine and Blawn Mountain areas, central Wah Wah Range, Beaver County, Utah: Utah Geological and Mineral Survey, Special Studies, No. 12, 35 p.

White, A. J. R., 1979, Sources of granite magmas (abstr.): Geological Society of America, Abstracts with Programs, v. 11, no. 7, p. 539.

Wohletz, K. H., and Sheridan, M. F., 1979, A model of pyroclastic surge: Geological Soclety of America Special Paper 180, p. 177-194.

Womes, D. R., 1979, Intensive parameters during the crystallization of granitic plutons (abstr.): Geological Society of America, Abstracts with Programs, v. 11, no. 7, p. 543 .

Woodcock, J. R., and Hollister, V. F., 1978, Porphyry molybdenite deposits of the North American Cordillera: Minerals Science and Engineering, v. 10, p. 3-18.

Worl, R. G., Van Alstine, R. E., and Hey1, A. V., 1974, Fluorite in the United States (Exclusive of Hawaii): U.S. Geological Survey Mineral Investigations Resources Map MR-60.

Wright, J. B., 1974, Tuffisite with topaz from the Nigerian younger granite province-the Balfour Hills 'sediments': Geological Magazine, v. 1.1.1, p. $337-342$.

Wright, J. V., and Walker, G. P. L., 1977, The Ignimbrite source problem: significance of a co-ignimbrite lag-fall deposit: Geology, v. 5, p. 792-732.

Wyllie, P. J., 1979, Magmae and volatile components: American Mineralogist, v. 64, p. 469-500. 
Zielinski, R. A., 1978, Uranium abundances and distribution in associated glassy and crystalline rhyolites of the western United States: Geological Society of America Bulletin, v. 89, p. 409-414.

Zielinski, R. A., 1979, Uranium mobility during interaction of rhyolitic obsidian, perlite, and felsite with alkaline carbonate solution: $\mathrm{T}=$ $120^{\circ} \mathrm{C}, \mathrm{P}=210 \mathrm{~kg} / \mathrm{cm}^{2}$ : Chemical Geology, v. 27, p. 47-63.

Zielinski, R. A., 1980, Experimental leaching of volcanic glass: AAPG Special Volume (in press).

Zielinski, R. A., Lipman, P. A., and Millard, H. T., Jr., 1977, Minor-element abundances in obsidian, perlite, and felsite of calc-alkaline rhyolites: American Mineralogist, v. 62, p. 426-437. 
Chapter II

PETROLOGY AND GEOCHEMISTRY OF

TOPAZ RHYOLITES, WESTERN U.S.A.:

by

Eric H. Christiansen

James V: Bik.un.

Donald M. Burt 
A distinctive suite of high silica rhyolites enriched in fluorine and lithophile elements is widely distributed across the western United States. Their ages range from mid- to late-Cenozoic ( $36 \mathrm{~m} . \mathrm{y}$. to present). These rhyolites contain topaz (along with garnet, bixbyite, pseudobrookite, hematite and quartz) in lithophysae or in the groundmass, and are associated with U, F, Be and Sn mineralization. Topaz rhyolites are generally emplaced as small domes or lava flows and follow or are contemporaneous with calc-alkalic and basaltic volcanism in the Basin and Range province and along the Rio Grande Rift. The major phenocrysts in topaz rhyolites are sanidine ( 0 r $_{0}$ ), quartz, oligoclase and biotite, in crystal-rich varieties; garnet and hornblende are rare. Two-feldspar and Fe-Ti oxide geothermometry indicates that these F-rich lavas equilibrated at low temperatures $\left(630-800^{\circ} \mathrm{C}\right)$. The Fe-rich biotites and Fe-Mn garnets, that crystalized within the magmas are similar to those in greisens and pegmatites and suggest that crystallization may have occurred under vapor-saturated conditions and low oxygen fugacities.

Topaz rhyolite vitrophyres are typically high in silica $(>74 \%)$ and fluorine $(0.3-1.5 \%)$ and are depleted in $\mathrm{Ca}, \mathrm{Mg}$, and Ti--features typical of rhyolites from bimodal associations. Corundum appears in the normative mineralogy of many and along with the presence of topaz and garnet suggests that the magmas were peraluminous. Concentrations of incompatible elements are high: U 5-40, Th 40-70, Rb 200-1000, Ta 2-25, Li 20-80, Sn 5-30 and Be 2-70 ppm. The REE patterns of vitrophyres enriched in these elements are almost flat $\left(\mathrm{La} / \mathrm{Yb}_{\mathrm{N}}=1-3\right)$ and have deep Eu anomalies $\left(\mathrm{Eu} / \mathrm{Eu}^{*}=0.01-0.02\right)$.

Topaz rhyolites are contemporaneous with rhyolites of peralkaline and calc-alkalic lineages. They are distinct from the former (typified by those at McDermitt Caldera) by their mineralogy, their mode of emplacement and their lower content of $\mathrm{Fe}, \mathrm{Mg}, \mathrm{Ti}$ and higher $\mathrm{Ca}, \Lambda 1, \mathrm{Rb}$ and usually $\mathrm{U}$ and Th. Topaz rhyolites are distinguishable from calc-alkalic rhyolites (typified by rhyolites from western Utah and Colorado) by their trace element contents (lower $\mathrm{Ti}, \mathrm{Ba}, \mathrm{Sr}$ and higher $\mathrm{Rb}, \mathrm{U}, \mathrm{Th}$ and other lithophile elements). The usually low $\mathrm{La} / \mathrm{Yb}_{\mathrm{N}}$ ratio. $(\sim 1-3)$ ) of topaz rhyolites distinguishes them from both rhyolite suites. 
The distribution of topaz rhyolites, their association with generally more mafic volcanism (andesitic or basaltic) and their similarity to anorogenic granites suggest that they are the result of partial melting of the Precambrian crust which is enriched in $\mathrm{F}, \mathrm{U}, \mathrm{Th}$ and $\mathrm{Be}$ throughout this region. Trace element variation patterns are consistent with magmatic evolution by thermogravitational diffusion possibly associated with the separation of an F-rich fluid that migrated to the upper, cooler parts of evolving magma chambers. The high F content probably caused the low equilibration temperatures and may have extended the duration of early magmatic evolution. The extreme magmatic enrichments typical of topaz rhyolites suggests that their subvolcanic analogs may be the hosts for U, Th, Be, F, Sn or associated ore depostts. 


\section{INTRODUCTION}

Topaz rhyolites are widely distributed in the western United States (Fig. 1). These fluorine-rich rhyolites are distinctive because of their dramatic enrichments in lithophile (or "fluorophile") elements such as uranium, thorium, beryllium, rubidium, lithium, molybdenum and niobium. Their mineralogy is distinctive as well since, in addition to topaz, they commonly contain Fe-Mn garnet, bixbyite, beryl, pseudobrookite and fluorite in cavities or within the groundmass. The only producing beryllium deposit in the United States occurs within tuffs beneath a topaz rhyolite lava at Spor Mountain, Utah, and other deposits of uranium, fluorite and tin are associated with them in Utah and elsewhere.

Petrologic studies of topaz rhyolites began with the rlassic descriptions by Cross (1086, 1896). of occurrences at Nathrop and Rosita Hills - Silver Cliff, Colorado. Topaz rhyolites in Utah's Thomas Range were described by many (e.g., Alling, 1887; Hillebrand, 1905; Patton, 1908; Penfield and Foote, 1897). More recently Turley et al. (1979) re-examined some of the topazbearing lavas from western Utah, while Nash (1976), Evans and Nash (1978) and Lipman et al. (1978b) studied the young rhyolites from the Mineral Mountains, Utah, that occasionally bear topaz in lithophysae (Ward et al., 1978). Studies of other topaz rhyolites have been related to their aconomic potential or to regional geologic investigations. The major features of 20 topaz rhyolite localities in the western United States are tabulated in Table 1.

The purpose of this study was to survey the gcochcmistry and pelsulugy of topaz rhyolites from the western United States in order to determine their mode of origin and the processes which controlled their evn 1,ntion. This is a continuing project and the interpretatinns are preliminary.

\section{SAMPLING AND ANALYTICAL METHODS}

Topaz rhyolites from three areas were investigated in detail: (1) west-cenlral Utah, where we examined four areas with topaz rhyolites (Spor Mountain - $21 \mathrm{~m} \cdot \mathrm{y}$. , the Thomas Range - $6 \mathrm{~m} . \mathrm{y}$. , the Honeycomb Hills $-5 \mathrm{~m} \cdot \mathrm{y}$. , and Smelter Knolls - $3.4 \mathrm{~m} . \mathrm{y}$.$) ; (2) the Wah Wah Mountains, Utah (22-20 m.y.);$ and (3). the Black Range, New Mexico (24 m.y.). In addition, topaz rhyolites from Izenhood Ranch, Sheep Creek Range, Nevada (14 m.y.). East Grants Ridge, New Mexico (3.3 m.y.), Nathrop, Colorado (28-29 m.y.) and Burro Creek, Arizona (Miocene?) were collected and analyzed. Since a principal concern of this study was the relationship of petrogenesis to uranium mineralization, 


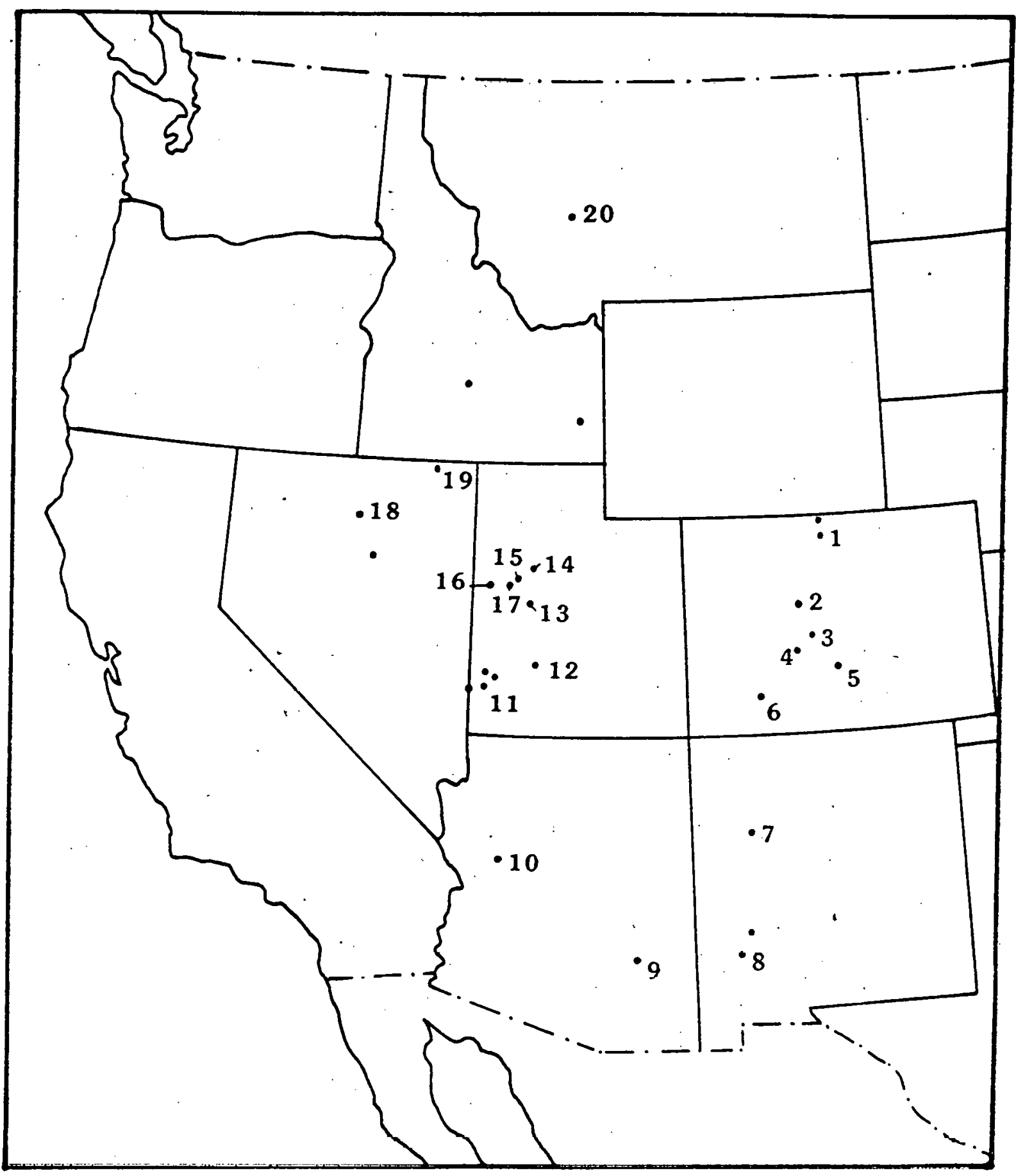

Fig. 1. Locations of Cenozoic topaz rhyolites in the western United States. The numbers refer to the descriptions in Table 1. Unlabeled localities are from Shawe (1976). 
Table 1. Locations and descriptiors of topaz rhyolites from the western United States

\section{location}

1. Specimen Mountain, north-central Colorado

$\left(4 \mathrm{~km}^{2}\right)$

2. Chalk Mountain, central Colorado

$\left(4 \mathrm{~km}^{2}\right)$

3. Nathrop, central Colorado

\section{Description}

- Lithophysal rhvolite flow with underlying, partly silicified, tuff.

- Overlies p6 gneisses, granites and pegmatites.

- Contemporaneous with basaltic and andesitic magmatism.

- 27 - 28 m.y. (?).

- Topaz-bearing "rhyolite porphyry".

- Pennylvanian sediments.

- San, Q, biot.

- $\mathrm{SiO}_{i}>74 \%$.

- adjecent to porphyry Bo deposit at Climax .

- mid-Tertiary.

- Dome and flow complex overlyling partially argillized tu=f.

- Overlies pt-gneiss and quartz monzonite.

- San, Q, plag, biot, Fe-Mn oxides.

- Topaz, garnet, san, Q, Fe-oxides, opal, calcite.

- On margin of Thirtynine Mile volcanic field; calc-alkalic $(40-34$ \& $19 \mathrm{m.y}$.$) .$

- 28-29 m.y.

- $\mathrm{SiO}_{2}>76 \%$, F $0.17-0.55 \%$, U 16 , Th 34 , Be 10, Li $95, \mathrm{Nb} 83$, Mo 5 ppm.

\section{References}

Conn, 1939

Wahlstrom, 1941, 1944

Corbett, 1968

Pear1, 1939

Cross, 1885

Cross, 1886

Epis and Chapin, 1968

Van Alstine, 1969

Zielinski: et.a1., 1977

this report 
4. Tomichi Dome, central Colorado

$\left(6 \mathrm{~km}^{2}\right)$

5. Rosita Hills and Silver Cliff, southcentral Colorado

$\left(\sim 30 \mathrm{~km}^{2}\right.$ each)

6. Lake City, southeastern Colorado
- Dome and flow overlying tuff, small sill intrudes country rocks.

- pE gneiss overlain by Cretaceous sediments.

- San, plag, Q, biot (ap, hb, sphene, Fe-Ti oxides).

- Topaz, garnet, magnetite.

- Domes with flows overlying tuff, erupted along ring-fracture of sma11 subsidence feature.

- p€ gneisses, granites and older Tertiary volcanic rocks.

- San, Q, plag (<10\%).

- Topaz, garnet, quartz.

- contemporaneous with calc-alkalic volcanics in San Juan Mtns., emplaced with trachyte and andesite.

- $\mathrm{SiO}_{2}>73 \%$.

- $\mathrm{Ag}, \mathrm{Au}, \mathrm{Pb}, \mathrm{Zn}$ and $\mathrm{Cu}$ mineralization in fissure veins and along faults.

- 26 m.y.

- Plugs, dikes, st1ls and laccoliths near margin of $28 \mathrm{~m} . \mathrm{y}$. caldera.

- Oligocene ash-flow tuffs of San Juan volcanic field.

- Q, san, biot.

- Topaz, fluorite, quartz.

- Contemporaneous with basaltic andesite $\left(57 \% \mathrm{SiO}_{2}\right)$ volcanism.

- $\mathrm{SiO}_{2}>76 \%$, F $0.13 \%$, U 40, Th 63, Be 20, Nb 80 , Mo $15 \mathrm{ppm}$.

- Secondary U-minerals occur on fractures, minor $\mathrm{U}$-ore removed.

-18.5 m.y.
Stark, 1934

Stark and Behre, 1936
Cross, 1896

Siems, 1968

Sharp, 1978
Steven et al., 1977

Lipman et al., 1978a 
7. Grants Ricige, westcentral, New Mexico

8. Black Range, southwestern New Mexico

$\left(\sim 130 \mathrm{~km}^{3}\right)$

9. Saddle Mountain, southeastern Arizora

10. Burro Creek, west-central Arizona
- Dome and -ava flow orerlying tufí.

- Emplaced through Cretaceous sediments.

- Q, san, plag ( $10 \%$ ).

- Topaz, garnet, beryl.

- Contemporaneous with basaltic volcanism, part of Mt. Taylor volcanic fleld.

- $3.3 \mathrm{~m}$. y.

- Domes occassionally with underlying tuffs.

- Emplaced inrough older rhyolitic lavas and tuf

- San, Q, blot, amph, plag (25\%).

- Topaz, bixbyite, pseudobraokite, cassiterite, garnet.

- Contemporaneous with basaltic andesite lavas.

- $\mathrm{SiO}_{2}>75 \%$, F $0.38 \%$, U 13, Th 32 , Be 12 , Li 50, Sn $25 \mathrm{ppm}$.

- Sn (cassi=erite and rood tin) mineralization

- $24 \mathrm{~m} \cdot \mathrm{y}$.

- Rhyolite iith topaz, pseudobrookite, bixbyite and garnet in lithophysae.

- Domes, plugs and flows, some with underlylng tuffs.

- Emplaced through PC gneisses, granites and pegnatites.

- San, Q, plag ( $10 \%)$.

- Topaz, garnet, quarta.

- Contemporaneous (?) with basaltic volcanism.
Zerr and Wilcox, 1963

Bassett, 1963

Lipman and Mehnert, 1979

Fries et a1., 1942

Elston et al., 1976

Lufkin, 1976, 1977

Sorrea, this report

Anthony et al., 1977

This report. 
11. Wah Wah Mountains, southwestern Utah

$\left(\sim 75 \mathrm{~km}^{2}\right)$

12. Minera1 Mountains, southwestern Utah

$\left(\sim 10 \mathrm{~km}^{2}\right)$

13. Smelter Knol1s, west-central Utah

$\left(2.2 \mathrm{~km}^{3}\right)$
- Domes and lava flows with underlying tuffs; plugs and dikes.

- Emplaced through 0ligocene volcanic rocks and locally through Paleozoic carbonates.

- San, Q, plag, Fe-Ti oxides \pm biot. \pm hb \pm gt. $(2-20 \%)$.

- Topaz, garnet, beryl, fluorite, Fe oxides, $Q$, san, opal.

- Contemporaneous with trachyandesite lavas $\left(60 \% \mathrm{SiO}_{2}\right)$.

- $\mathrm{S}_{10}>76 \%$, F $0.5 \%$, U 15-21, Th 50-65, Be 9, Li 65 , Nb 100-150, Mo 10-70, Sn 12 .

- $U$ and $F$ mineralization along margins of intrusions and in altered tuffs, possibly associated with Mo-mineralization.

- 22-21 m.y.

- Domes and lava flows with associated tuffs.

- Emplaced through Tertiary pluton of granitic composition.

- San, Q, plag, biot, Fe-Ti oxides (allanite, sphene, apatite) (3-15\%).

- Topaz, pseudobrookite, hematite.

- Contemporaneous with basaltic volcanism.

- $\mathrm{SiO}_{2}>75 \%$, F 0.15-0.44\%, Th 10-40, Nb 5-35 ppm.

$-<1 \mathrm{~m} \cdot \mathrm{y}$.

- Rhyolite domes and lava flows.

- Emplaced through Quaternary alluvium and older volcanic rocks.

- San, Q, plag, biot, Fe-Ti oxides (10-20\%).

- Topaz, hematite.

- Contemporaneous with basalt $\left(48 \% \mathrm{SiO}_{2}\right)$ and basaltic andesite $\left(57 \% \mathrm{SiO}_{2}\right)$.

- $\mathrm{SiO}_{2}>74 \%$, $\mathrm{F} 0.45-0.78 \%$, U 9-15, Th 55, Be 13, Li 120, Nb 50, Mo 2-6 ppm.

$-3.4 \mathrm{m.y}$.
Lindsey and Osmonson, 1978

Rowley et a1., 1978b

Keith, 1980

Best et al., unpub. ms.

Christiansen, this report

Nash, 1976

Evans and Nash, 1978

Ward et al., 1978

Lipman et al., $1978 b$

Turley, et .a1., 1979 
14. Keg Mountain, west-central Uta:

$\left(20 \mathrm{~km}^{3}\right)$

\section{Thomas Range,} west-central Utah

$\left(50 \mathrm{~km}^{3}\right)$

16. Honeycomb Hills, west-central Utab (1.5 $\left.\mathrm{km}^{3}\right)$
- Rhyolite domes and lava flows with underlying breccias and tuffs.

- Emplaced through $a_{-}^{-}$luwium and 0ligocene volcanic rocks.

- San, Q, plag, biot \pm hb.

- Topaz.

- Approximately contemporaneous with basaltic lavas in the region.

- Be 5, Nb 30 ppm.

$-10 \mathrm{~m} . \mathrm{y}$.

- Rhyolite domes and lava flows with underlying breccias and tuffs.

- Emplaced through alluvium and older. Tertiary volcanic rocks.

- San, Q, plag, Fe-Ti oxides \pm biot \pm hb \pm gt $(10-20 \%)$.

- Topaz, garnet, fluarite, bixbyite, pseudobrookite, beryl, Fe oxides, opal.

- $\mathrm{SiO}_{2}>72 \%$, F $0.2-0.6 \%$, U 5-20, Th 25-60, Be 2-11, L1 33, Nb 50-100, Sn 2 ppm.

$-6 \mathrm{~m} \cdot \mathrm{y}$.

- Dome with underlying tuff.

- Emplaced through allurium and basaltic lavas.

- San, Q, plag, biot, Fe-Ti oxides (40\%).

- Topaz, fluorite.

- $\mathrm{SiO}_{2}>75 \%(64 \%), \mathrm{F} 1.0 \%(8.0 \%)$, U 17 (150), Th 30, Be II (13), Li 130 (200), Nb 50 (80), Mo 3 (25). Concentrations in F-rich sample

$-\leftarrow .7 \mathrm{tn}$. y.
Erickson, 1963

Lind sey, 1975

Lindsey et al., 1975

Staatz and Carr, 1964

Lind sey, 1979

Turley et a1., 1979

Bikun, this report

McAnulty and Levinson, 1964

Turley et a1., 1979

This report 
17. Spor Mountain, wes:-central Utah

$\left(5 \mathrm{~km}^{2}\right)$

18. Sheep Creek Range; nor th-central Nevada

$\left(50 \mathrm{~km}^{2}\right)$

19. Jarbidge, northern Nevada
- Lava flow with underlying altered tuff; plug.

- Emplaced through Paleozoic carbonates; locally intrudes 01igocene rhyodacte.

- San, Q, plag, biot, Fe-Ti oxides (apatite, zircon) (40\%).

- Topaz, quartz, sanidine.

- Contemporaneous volcanics lacking in immediate vicinity; same age as trachyandesites in Wah Wah Mtns.

- $\mathrm{SiO}_{2}>73 \%$, F 0.8-1.5\%, U 37, Th 66, Be 63, Li 90, Nb 150, Sn 30 ppm.

- Be, U, F mineralization in altered tuff beneath lava.

$-21 \mathrm{~m} . \mathrm{y}$.

- Domes and lava flows.

- Intrudes $15 \mathrm{~m} . \mathrm{y}$. andesite.

- San, Q, plag, Fe-Ti oxides (25\%).

- Topaz, garnet.

- Nearly contemporaneous with basaltic andesite $\left(59 \% \mathrm{SiO}_{2}\right)$ and basaltic $\left(48 \% \mathrm{SiO}_{2}\right)$ lavas.

- $\mathrm{SiO}_{2}>76 \%$, F $0.3 \%$, U 12 ppm. (devitrified sample).

-14 m.y.

- Domes and lava flows with underlying tuffs.

- Emplaced through older volcanic rocks.

- San, Q, plag \pm biot \pm hb tcpx

- Topaz (In single occurrence), garnet, fluorite.

- F $500 \cdot \mathrm{ppm}$.

$-16 \mathrm{~m} . \mathrm{y}$.
Lindsey, 1979

Bikun, this report

Fries, 1942

Stewart et al., 1977

This report

Coats et al., 1977 
20. E1khorn Mountains, western Montana
- Plugs, dikes and lava flows overlying tuffs.

- Emplaced through Butte quartz monzonite.

- San, Q, plag, Fe-Ti oxides.

- Topaz, Q, fluorite.

- Approximately contemporaneots with basaltia lavas and rhyolitic ash flows.

- $\mathrm{SiO}_{2}>75 \%$, F $6.2-0.5 \%$, Be 1-20, Nb 30-100, Mo 5-10, Sr: 10-50 ppm.

- $\mathrm{Ag}, \mathrm{Pb}, \mathrm{Zn}$ mineralization locally within lavas and tuffs.

- $36 \mathrm{~m} . \mathrm{y}$.
Smedes, 1966

Greenwood et al., 1978

Chadwick, 1977

Note. The descriptive information is ordered as follows: mode of emplacement or structure; country rocks; phenocryst minerals (accessories) (volume \%); vapor-phase minerals that occur in cavities, in the groundmass or along fractures; contemforaneous magmatism in the immediate vicinity; chemistry; associated mineralization; and age.

Beneath each locality the approximate area $\left(\mathrm{km}^{2}\right)$ or volume $\left(\mathrm{km}^{3}\right)$ of each occurrence is given if obtainable. 
we also collected and analyzed samples from the McDermitt caldera, Nevada (19-15 m.y.; Rytuba, 1979) and Peña Blanca, Chihuahua, Mexico (Goodell, 1978). Both of these areas contain volcanogenic uranium deposits but are not known to contain topaz rhyolites. Additional information concerning sample locations and descriptions is given in Appendix 1.

Major elements were determined by $X$-ray fluorescence spectroscopy (Si, $\mathrm{Ti}, \mathrm{Al}, \mathrm{Fe}, \mathrm{Mn}, \mathrm{K}$ and $\mathrm{P}$ ) and atomic absorption spectrometry ( $\mathrm{Na}, \mathrm{Mg}$ ). Fluorine was determined by specific ion electrode methods and chlorine by ion chromatography. Rare earths, $\mathrm{Cs}, \mathrm{Rb}, \mathrm{Ba}, \mathrm{U}, \mathrm{Th}, \mathrm{Zr}, \mathrm{Ta}, \mathrm{Hf}, \mathrm{Co}, \mathrm{Cr}$ and Sc were determined by instrumental neutron activation at the University of Oregon. Additional uranium analyses were performed by a delayed neutron technique at the same institution. Other trace elements ( $\mathrm{L}, \mathrm{Be}$ and $\mathrm{Sn}$ ) were determined by atomic absorption.

Minerals were analyzed in polished thin sections and grain mounts with an ARL-SEM Q electron microprobe at the University of Arizona and some with a Cameca MS-46 microprobe at Arizona State University. Natural mineral standards were used with a Bence-Albee matrix correction (Bence and Albee, 1968).

\section{PETROGRAPHY}

Modal analyses of representative samples are listed in Table 2. The essential phenocrysts of topaz rhyolites are sanidine ( 0 r50), quartz and a sodic plagioclase, usually oligoclase. Quartz is commonly embayed and cumulophyric clots of feldspar are typical. Generally phenocrysts constitute only a few percent of the rock, but in some lavas and shallow intrusions the phenocryst content may be as high as $40 \%$ by volume. Ferromagnesian silicates are rare, but phenocrysts of biotite are present in the more crysta1-rich varieties; hornblende and garnet are rare as phenocrysts. Trace mineral phases include Fe-Mn-Ti oxides, apatite, fluorite, zircon, sphene and allanite.

Most topaz rhyolites are strongly flow-banded, expressed as layers with contrasting crystallinity. The groundmass of many of the samples is glassy with occasional small $(\sim 2 \mathrm{~mm})$ spherulites and perlitic fractures. In devitrified, or crystalline, samples the matrix consists of a felty intergrowth of alkali feldspar, quartz, and in many cases acicular topaz. Biotite occurs within the groundmass of some granophyrically crystallized lavas. Almost all topaz rhyolites contain well-formed lithophysae or 
Table 2. Modal compositions of representative samples of topaz rhyolites from the western U.S.

\begin{tabular}{|c|c|c|c|c|c|c|c|c|c|c|c|}
\hline Area & Sample & & & & & & & & & & \\
\hline Spor Mtn. & $S M-35$ & 60 & 20 & 12 & 5 & 11 & $\operatorname{Tr}$ & $\operatorname{Tr}$ & $\operatorname{Tr}$ & - & \\
\hline Thomas $\mathrm{R}$. & $S M-29-206$ & 80 & 10 & 5 & 4 & 1 & $\operatorname{Tr}$ & - & - & - & \\
\hline Honeycomb Hills & $\mathrm{HH}-2$ & 60 & 15 & 15 & 7 & 1 & $<1$ & $\operatorname{Tr}$ & - & - & \\
\hline Wah Wah Mtns. & STC-4 & 73 & 10 & 7 & 8 & $<1$ & $\operatorname{Tr}$ & $\operatorname{Tr}$ & $<1$ & - & \\
\hline B1ack $\mathrm{R}$. & $H C_{-}-8$ & 80 & 8 & 8 & 1 & 2 & $\operatorname{Tr}$ & - & - & $\operatorname{Tr}$ & \\
\hline Nathrop & NAT -1 & 98 & $<1$ & $\operatorname{Tr}$ & $\operatorname{Tr}$ & - & $\operatorname{Tr}$ & - & - & - & \\
\hline
\end{tabular}

Note. Values are in volume percent. $\operatorname{Tr}=$ trace. 
miarolites lined with quartz, sanidine, and topaz. Vapor-phase mineralization is usually concentrated along coarse-grained "flow" bands or as haloes around mafic rock inclusions, as in the lavas at Spor Mountain, Utah. Garnet, beryl, specularite, pseudobrookite, bixbyite and cassiterite occur in some localities within vugs or along fractures in topaz rhyolite lavas and tuffs. The samples from McDermitt caldera are generally phenocryst-poor welded ash-flow tuffs. Many are glassy and retain little evidence in thin section for their emplacement mechanism except for broken phenocrysts. Phenocrysts include alkali feldspar and quartz. Plagioclase is occasionally present and phenocrysts of subhedral ferroaugite are rare. The samples from Pena Blanca are from the Nopal Formation, a densely welded ash-flow tuff. Phenocrysts within this unit include alkali feldspar, plagioclase, biotite and Fe-Ti oxides.

\section{MINERALOGY}

\section{Feldspar}

Feldspar phenocrysts from eight samples of fluorine-rich rhyolite from Utah and New Mexico were analyzed. Their chemistry is summarized in Fig. 2. Analyses from five samples of the Spor Mountain rhyolite were indistinguishable and are plotted on a single diagram. Sanidine is always the dominant feldspar, but both feldspars are typically present, except in sample IP-2 from the Black Range of New Mexico where only sanidine was analyzed.

Alkali feldspar ranges from $\sim 0 \mathrm{Or}_{60} \mathrm{Ab}_{40}$ to $\sim \mathrm{Or}_{30} \mathrm{Ab}_{70}$, although most analyses fall between or $_{40}$ and ${ }^{\circ} 6_{60}$. The more fluorine-rich rhyolites (Spor Mountain rhyolite with $1 \% \mathrm{~F}$ ) have higher or contents $\left(\mathrm{Or}_{50}-\mathrm{Or}_{65}\right.$ ); this feature is also observed in the analyses of Turley et al. (1979) from rhyolites in westcentral Utah. Some of the feldspars are zoned and have distinctly sodic rims; tie lines connect core to rim analyses for sample WW-9. The sodic rims may be the result of rapid quench crystallization, but probably are not the result of devitrification and attendant vapor-phase alteration as WW-9 is a vitrophyre. Iron averages about 0.15 to $0.20 \%$ as $\mathrm{Fe}_{2} \mathrm{O}_{3}$ in sanidine from the Wah Wah Mountains. Molecular $\mathrm{Fe}^{+3}$ is generally one-half $\mathrm{Ca}^{+2}$ in these feldspars. Sanidines from the Black Range have iron contents near the upper part of this range $\left(0.20 \%\right.$ ) while $\mathrm{Fe}_{2} \mathrm{O}_{3}$ in the sanidines from rhyolites near Spor Mountain (both $21 \mathrm{~m} . \mathrm{y}$. and $6 \mathrm{~m} . \mathrm{y}$. ) averages about $0.07 \%$. 

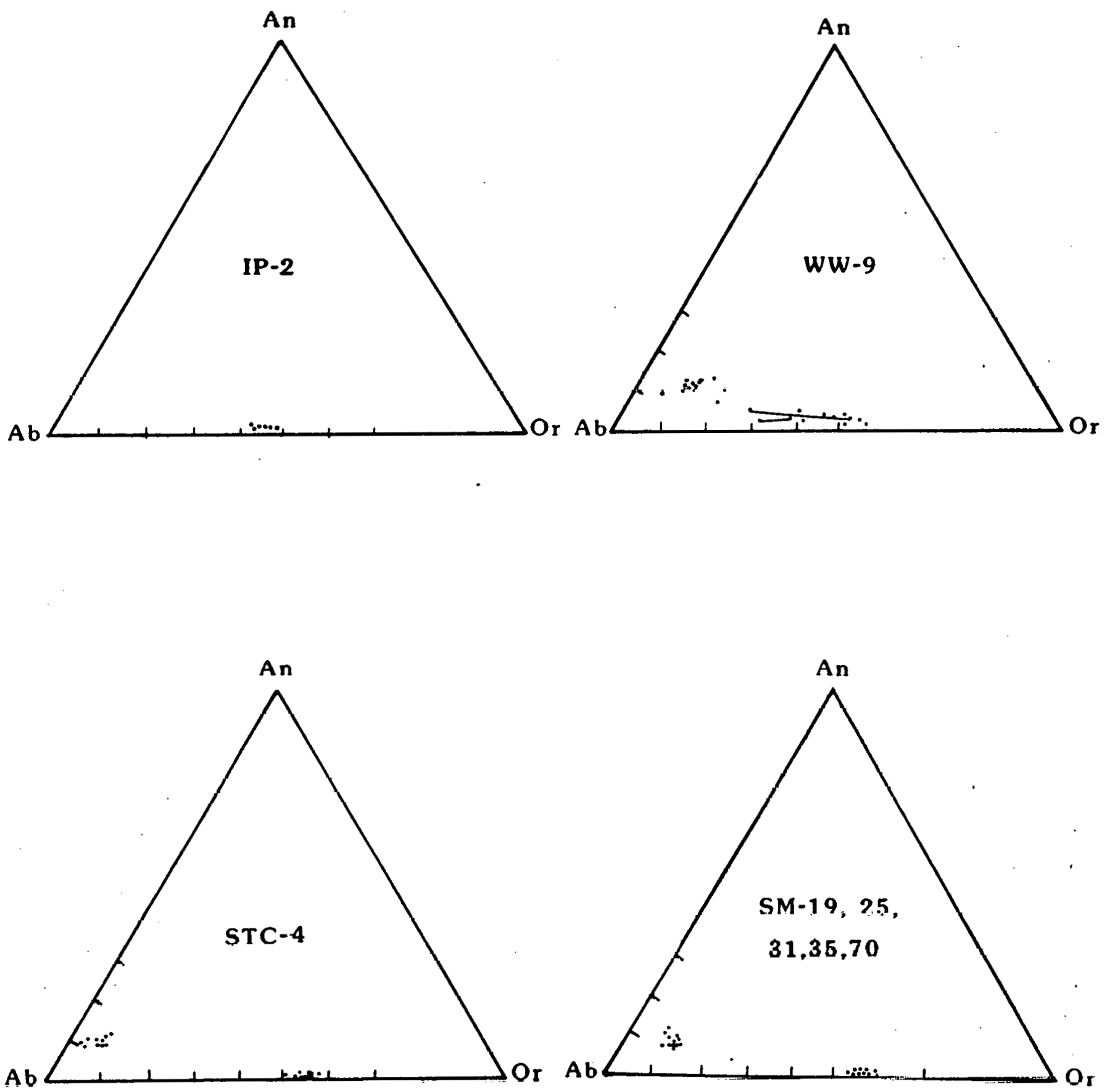

Fig. 2. Compositions of feldspar phenocrysts recast into end-member compositions, An (anorthite), Ab (albite) and Or (orthoclase). Tie lines connect analyses of zoned crystals. IP-2 (Black Range, New Mexico), WW-9 and. STC-4 (Wah Wah Mountains, Utah) and SM-19, 25, 31, 35, and 70 (Spor Mountain rhyolite, Utah). 
P1agioclase in the rhyolites is generally sodic oligoclase, ranging from about $\mathrm{Ab}_{80}$ to $\mathrm{Ab}_{90}$ with an anorthite content of about $\mathrm{An}_{10}$. These already sodic compositions are only slightly affected by zoning. Apparently the anorthite component is negatively correlated with F-content of the vitrophyres. The more F-rich rocks have less than $10 \%$ anorthite component and the Or component generally increases as a result. The analyses of Turley et al. (1979) bear this out. One sample with $8 \% \mathrm{~F}$ has an average composition of $\mathrm{Ab}_{86} \mathrm{An}_{8}$. Burt and Sheridan (this report). suggest that this may be the result of the removal of $\mathrm{Ca}$ as fluorite, but it may also be the effect of the extremely low equilibration temperatures for F-rich topaz rhyolites $\left(<700^{\circ} \mathrm{C}\right)$.

Since plagioclase and sanidine coexist in many topaz rhyolites, an approximate crystallization, or feldspar equilibration, temperature can be obtained from the two-feldspar geothermometer of Stormer (1975); see Table 3 . Calculations were performed for a nominal pressure of 100 bars; temperatures were calculated for pair SM-3.1A at 100, 500 and 1000 bars to determine the effect of pressure on the calculations. The compositions used were for sanidine and plagioclase grains in direct contact or average phenocryst compositions $(\mathrm{STC}-4)$. The equilibration temperature for a sample from the Thomas Range is $630^{\circ} \mathrm{C}$ (sample SM-29-206) and for the Spor Mountain rhyolite $680^{\circ} \mathrm{C}$ (average of SM-31 and SM-35). The rhyolite from near the Staats Mine, Wah Wah Mountains, equilibrated at $650^{\circ} \mathrm{C}$. We have not obtained Fe-Ti oxide temperatures, in part because of the scarcity of magnetite in the samples. However, Turley et a1. (1979) determined similar two-feldspar and Fe-Ti oxide temperatures $\left(660-710^{\circ} \mathrm{C}\right)$ for rhyolites from the Thomas Range and an exceptionally low equilibration temperature of $605^{\circ} \mathrm{C}$ for two $\dot{\mathrm{F}}-\mathrm{rich}(1 \%$ and $8 \% \mathrm{~F}$ ). samples from the Honeycomb Hills (Table 3). All of these temperatures are lower than those calculated for other bimodal rhyolites. The equilibration temperatures for these rhyolites are compared in Table 4.

\section{Biotite}

Although biotite is not abundant in many topaz rhyolites, (Table 2), it is ubiquitous in the phenocryst-rich spor Mountain rhyolite. The biotite phenocrysts are unzoned and dark-reddish brown in color. In devitrified samples, they of ten appear to be oxidized. Table 5 presents typical analyses of unoxidized biotites from vitrophyres of the Spor Mountain rhyolite (SM-31, $-35,-70)$. The Spor Mountain biotites have extremely low MgO (0.29 to 0.80\%) and FcO ie high (32.9 to $37 \%)$. Similar Fe-rich biotites 
Table 3. Geothermometry of topaz rhyolites from western Utah.

\begin{tabular}{|c|c|c|c|c|}
\hline Location & $\mathrm{T}_{\mathrm{Fe}-\mathrm{Ti} \text { oxides }}$ & $\left({ }^{\circ} \mathrm{C}\right)$ & $\mathrm{T}^{*} 2-\mathrm{Feld}$ spar $\left({ }^{\circ} \mathrm{C}\right)$ & Reference \\
\hline \multirow[t]{3}{*}{ Spor Mtn (SM-3Ia). } & - & & 686 & \multirow{3}{*}{$\begin{array}{c}\text { Bikun, this report } \\
\text { ". }\end{array}$} \\
\hline & - & & 6.91 (500. bars) & \\
\hline & - & & 6.98 (1000. bars) & \\
\hline \multirow{2}{*}{$\begin{array}{r}\text { Spor Mtn }(\mathrm{SM}-31 \text { average) } \\
(\mathrm{SM}-35 \text { average })\end{array}$} & - & & 682 & 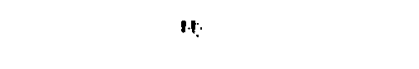 \\
\hline & - & & 679 & "1: \\
\hline Thomas Range (SM-29-206). & \multicolumn{2}{|l|}{-} & 6.30 & This report \\
\hline Wah Wah Mtns (STC-4) & - & & 6.50 & $n$ \\
\hline Thomas Range & 725 & & $690 \therefore 720$ & \multirow{2}{*}{$\begin{array}{c}\text { Turley et a1., } 19.79 . \\
\text { " }\end{array}$} \\
\hline Smelter Kno1ls & 665 & & $630-685$ & \\
\hline Honeycomb Ilills & - & & bUs & if. \\
\hline Mineral Range & $650-780$ & & $620 .-770^{\circ}(1$ bar $)$ & Nash, 1978 \\
\hline
\end{tabular}

Table 4. Geothermometry of rhyolites from bimodal associations

\begin{tabular}{lcc}
\hline Location & Fc-Ti oxidc T $\left.{ }^{\circ} \mathrm{C}\right)$ & Reference \\
\hline Arran, Scotland & $900-925$ & Ewart, $1979^{+}$ \\
Medicine Lake, California & $800-930$ & $"$ \\
S. Queensland, Australia & $830-980$. & \\
Mono Craters, California & $790-850$ & $"$ \\
Inyo Craters, California & $920-985$ & Hildreth, 1979 \\
B1shop Tuff, California & $720-790$ & \\
\end{tabular}

'compilation, not original source 
Table 5. Microprobe analyses of biotites from Spor Mountain rhyolite

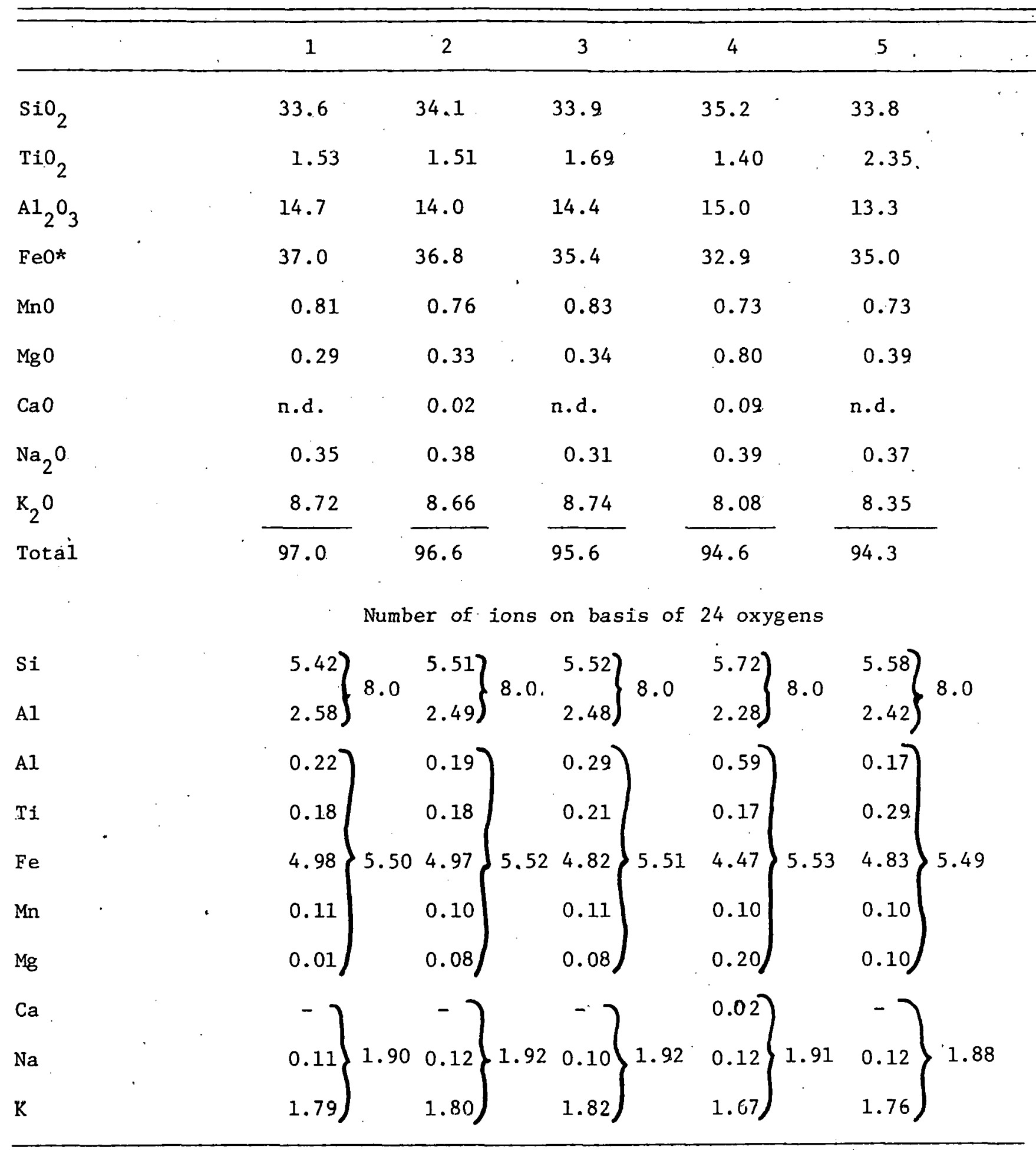

*All iron computed as FeO 
have been reported by Turley et al. (1979) from the Honeycomb Hills and Smelter Knolls, west-central Utah, and by Ewart et al. (1977) from some highly evolved Australian rhyolites. The Spor Mountain biotite compositions approach annite in composition (molecular $\mathrm{Al}=2$ vs. $\mathrm{Al}=2.5$ measured here), Fig. 3. Glassy samples of Spor Mountain rhyolite, that enclose these Fe-rich biotites, generally contain $1 \% \mathrm{~F}$ and up to $100 \mathrm{ppm} \mathrm{Li}$. The biotites are probably the major mineralogic sites for these elements. As noted by Turley et al: (1979) there may be an association between high $F$ and high $F e$ in biotites, despite some experimental evidence to the contrary (Munoz and Eugster, 1969; Munoz and Luddington, 1974). The experimentally observed correlation between $\mathrm{Mg}$ and $\mathrm{F}$ may break down in low temperature $\left(<700^{\circ} \mathrm{C}\right)$, Li-rich systems similar to topaz rhyolite magmas; lepidolites are generally F and Fe-rich as well (Rieder, 1971). Unfortunately Li cannot be analyzed with an electron microprobe.

The biotites have moderate to low $\mathrm{TiO}_{2}(1.5$ to $2.9 \%)$ and are fairly rich in MnO (0.7\%) compared to most igneous biotites. In each of these characteristics, as well as their Fe-enrichment, the biotites are similar to those in pegmatites, (Heinrich, 1946) and those crystallized in association with topaz, beryl or spodumene from other localities (Nockolds, 1947) and represent unusual phenocrysts for a volcanic rock. Their composition suggests that crystallization occurred under vapor-saturated conditions before eruption. Hildreth (1977) suggested that biotites within the Bishop Tuff were affected by the evolution of a discrete water-rich vapor immediately prior to eruption of the tuff. For the case of an F-rich magma, the vapor was probably F-rich and led to biotite compositions similar to those found in other F-rich vapor-dnminated systems such as pegmatites and greisens.

From the experimental data of Eugster and Wones (1962) for the reaction

$$
\underset{\text { annite }}{\mathrm{KFe}_{3} \mathrm{AlSi}_{3} \mathrm{O}_{10}(\mathrm{OH})_{2}}+\underset{\text { gas }}{1 / 2} \mathrm{O}_{2}=\underset{\mathrm{K}-\mathrm{fsp}}{\mathrm{KAlSi}_{3} \mathrm{O}_{8}}+\underset{3}{\mathrm{Fe}_{3} \mathrm{O}_{4}}+\underset{2}{\mathrm{Ht}}+\underset{\text { gas }}{\mathrm{H}_{2} \mathrm{O}}
$$

an approximate determination of the prevailing oxygen fugacity can be determined. Using the two-feldspar temperature of $680^{\circ} \mathrm{C}$, the assemblage annite + quartz + vapor is stable at $\mathrm{f}_{0_{2}}=10^{-19}$ to $10^{-18} \mathrm{~atm}$, at a pressure of 2070 bars (Fig. 6 of Eugster and Wones, 19.62). These values are very near the QFM oxygen buffer at $680^{\circ} \mathrm{C}$. Although the F-content of the actual biotites may expand their thermal stability field, Turley et a1. (1979) calculated a similar $\mathrm{f}_{2}$ of $10^{-20}$ atm from coexisting Fe-Ti oxides from a sample with 1ow-Mg biotite. 


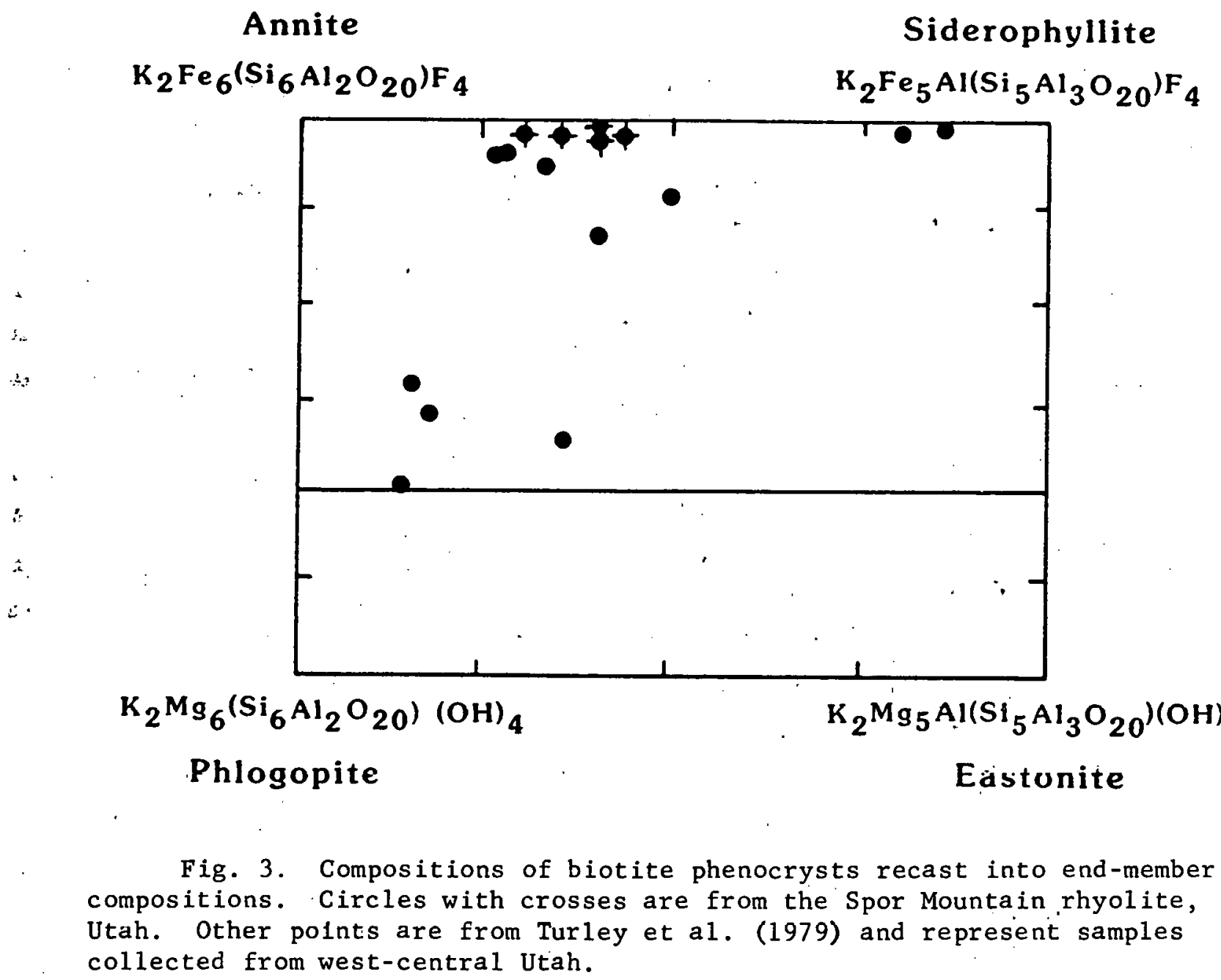


Additional mineralogic support for low oxygen fugacities during the evolution of some topaz rhyolite magmas is the apparent. absence of magnetite in many samples. Magnetite and hematite do occur in lithophysae, but are postmagmatic. Oxidation occurs after eruption during cooling in atmospheric conditions. In addition Ewart (1979) documents consistently low $\mathrm{f}_{\mathrm{O}_{2}}$ (NNO-QFM) for rhyolites that are members of bimodal associations, relative to ${ }^{2}$ rogenic rhyolites.

\section{$\underline{\text { Topaz }}$}

Although topaz does not occur in every sample analyzed, it does occur in each of the rhyolite bodies (domes, lava flows or intrusions) examined. Topaz has several different habits, and is generally the result of devitrification or vapor-phase crystallization. The most common, and least obvious, mode of occurrence is as small (several milimeters) acicular aggregates in a devitrified matrix. It is distinguishable in thin section by its high relief and slightly yellow coloration. Larger (up to a centimeter) opaque crystals, with a palegray color and irregular surfaces, may form within the matrix of rhyolites that have experienced intense vapor-phase alteration. The color and opacity are caused by numerous inclusions of quartz (Patton, 1908). Occasionally, as in the Black Range, New Mexico, small cavities develop around these crystals. Clear crystals, up to several centimeters long, develop within lithophysae or miarolitic cavities. These crystals are typically attached to the rhyolite matrix at one end, but doubly terminated crystals are found. 'lopaz in cavities can occur with garnet, bixbyite, fluorite, quartz, hematite, pseudobrookite, etc. Black topaz crystals, generally about a centimeter long, with complex penetrations have been found in the Thomas Range. The color is due to the zonal arrangement of Fe-Mn oxides with the crystal.

Few analyses of topaz from rhyolitic rocks exist in the literature (Table 6). Penfield and Minor (1894) found that topaz from the l'homas Range and from Nathrop, Colorado, is very nearly fluortopaz ( $\mathrm{Al}_{2} \mathrm{SiO}_{4} \mathrm{~F}_{2}$ ) with $20.37 \%$ and $20.42 \%$ F respectively; stoichiometric fluortopaz contains $20.65 \% \mathrm{~F}$. Turley et a1. (1979) reported fluorine analyses for topaz in two samples from the Honeycomb Hills, Utah, (19.6 and 19.9\%) and one from Smelter Knolls, Utah, (20.1\% F) that have similar fluorine contents.

The presence of topaz indicates that the lavas, and probably the magmas. as well, were peraluminous (Carmichael et a1., 1974) as topaz generally forms. by devitrification or granophyric crystallization of glass. The high F content of the topaz also demonstrates that the $\mathrm{f}_{\mathrm{HF}} / f_{\mathrm{H}_{2} \mathrm{O}}$ was high during its crystallization. 
Table 6. Chemical composition of topaz

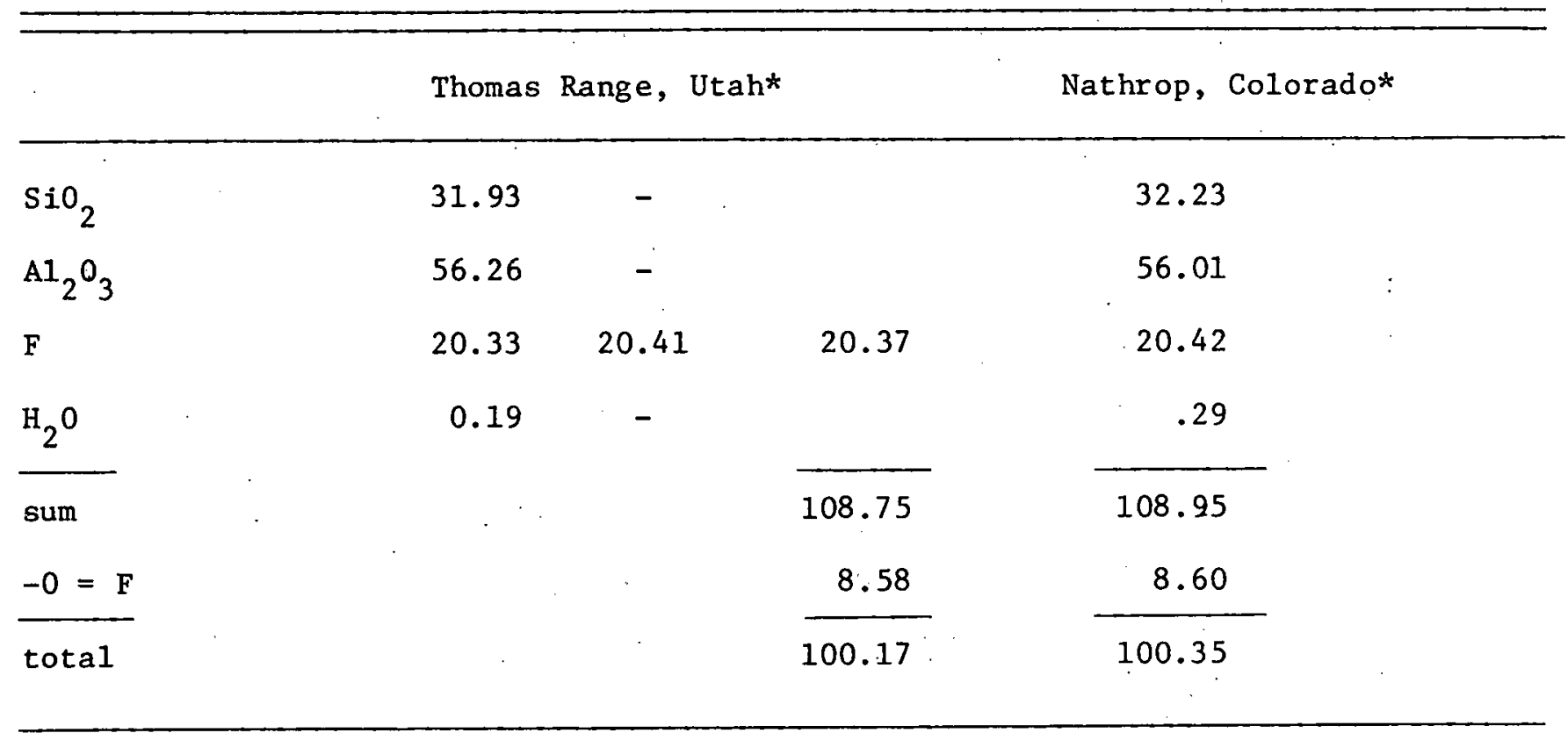

*Penfield and Minor (1894) 


\section{Garnet}

Garnet is occasionally an accessory mineral in F-rich rhyolites and commonly occurs as a lithophysal mineral associated with topaz. It is reported from the Thomas Range, Utah (Staatz and Carr, 1964), Rosita Hills, Colorado (Sharp, 1978; Cross, 1896), Nathrop, Colorado (Cross, 1886)., Tomichi Dome, Colorado (Stark and Behre, 1936), the Black Range, New Mexico (Fries et al.; 1942), Grants Ridge, New Mexico (Kerr and Wilcox, 1963), the Sheep Creek Range, Nevada (Fries, 1942), Lincoln County, Nevada (Patton, 1908) and in topaz-free rhyolite from near Ely, Nevada (Pabst, 1938). We have also found garnet in topaz rhyolites from near Burro Creek, western Arizona, and in the Wah Wah Mountains, Utah.

Garnets from the Thomas Range (Garnet Basin) and from the Ely occurrence were analyzed by electron microprobe (Table 7). Garnets from Ely occur in vugs or cavities within an intensely devitrified rhyolitic lava and they probably grew from a vapor phase separated from the magma after extrusion. Although vapor-phase garnet occurs elsewhere in the Thomas Range, those from Garnet Basin may be magmatic. They are not clearly related to vugs and have no point of attachment like vapor-phase garnets.

Figure 4 compares the composition of the garnets in terms of three endmembers relative to garnets from other volcanic rocks and from pegmatites. Not apparent from the diagram is the excess of the grossular component over pyrope. The garnets are both low in $\mathrm{TiO}_{2}$. Although not determined quantitatively, fluorine was detected by the microprobe during analyses of garnets from both localities. Garnets with up to $3.5 \% \mathrm{~F}$ have been found in greisens at Henderson, Colorado (Gunow and Munoz, 1977).

Miyashiro (1955) has suggested that vapor-phase garnets are richer in Mn than those that crystallize as phenocrysts and points out their similarity to spessartine-almandine solid solutions from pegmatites. Like those in pegmatites, lithophysal garnets crystallized under vapor-saturated conditions. However, magmatic garnets may be just as rich in the spessartine component. For example, garnets from a topaz-free rhyolitic tuff that outcrops in the Wah Wah Mountains, Utah, have similar Mn-rich compositions (Keith, 1980). Keith has demonstrated that these euhedral, inclusion-bearing garnets are products of crystallization within the magma prior to eruption. Miller and Stoddard (1978) have identified Mn-rich garnets in granite as well. Likewise, the garnets from the Thomas Range may represent magmatic crystallization in spite of their Mn-rich compositions. In contrast, garnet phenocrysts from rhyolite lavas in New Zealand contain substantially more Mg and less Mn than those considered here (Wood, 1974). 
Table 7. Microprobe analyses of garnets from Garnet Basin, Utah, and E1y, Nevada

E1y Garnet Basin

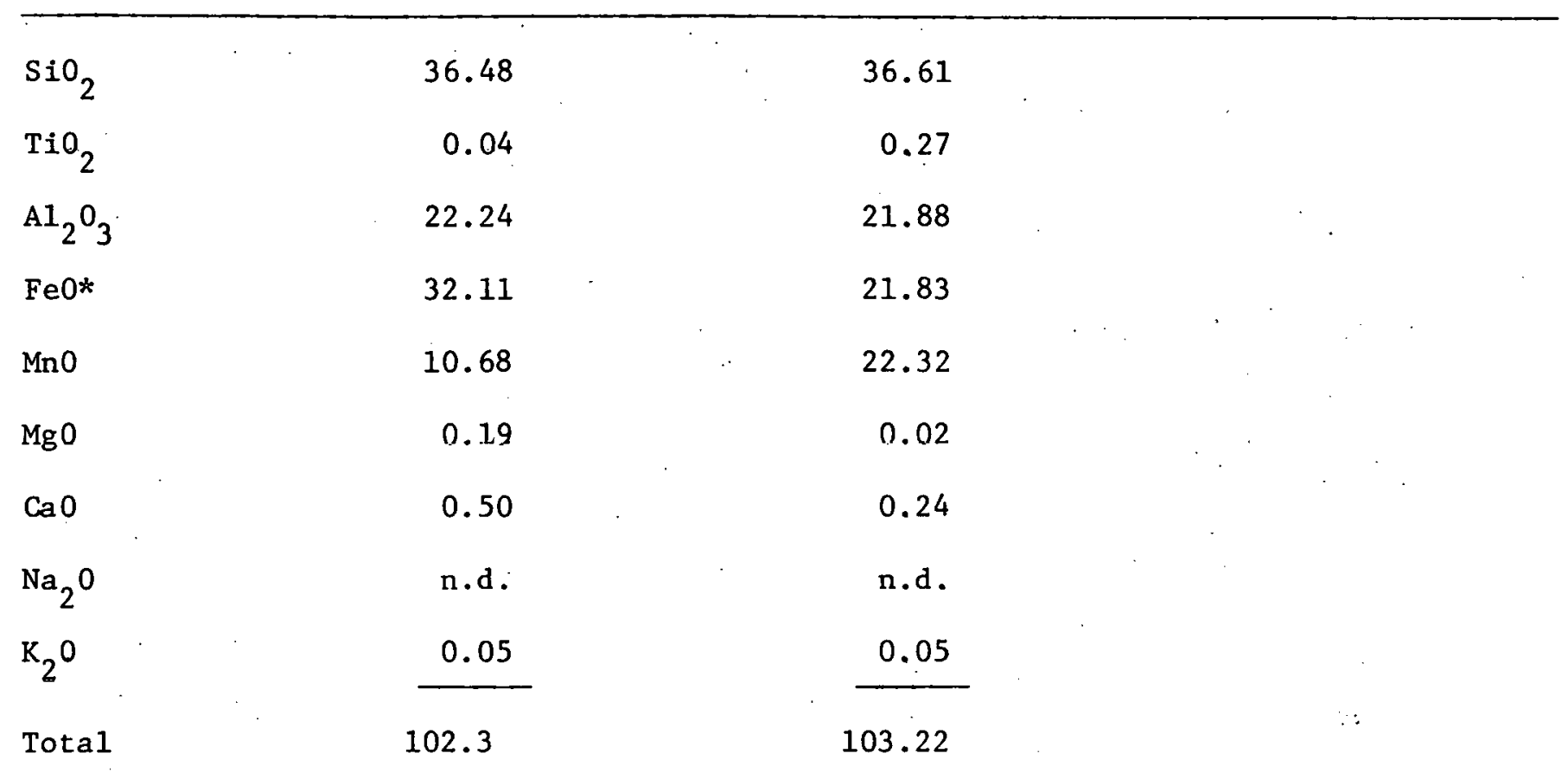

Number of ions on basis of 24 oxygens

Si

A1

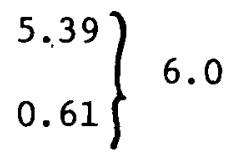

$\left.\begin{array}{l}5.53 \\ 0.47\end{array}\right\} 6.0$

A1 s.

3.26

$\mathrm{Fe}^{+3}$

$\mathrm{Ti}$

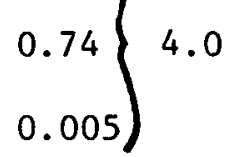

$\left.\begin{array}{l}3.42 \\ 0.55 \\ 0.03\end{array}\right\} 4.0$

$\mathrm{Mg}$

$\mathrm{Fe}^{+2}$

0.04

3.23

Mn

$\left.\begin{array}{l}1.34 \\ 0.08\end{array}\right\}^{4.69}$

$\left.\begin{array}{c}0.005 \\ 2.21 \\ 2.86 \\ .04\end{array}\right\}$

Almandine

0.731

0.487

Grossular

0.015

0.007

Pyrope

0.008

0.001

Spessartine

0.246

0.505

*A11 iron computed as Fe0

n.d. not detected 


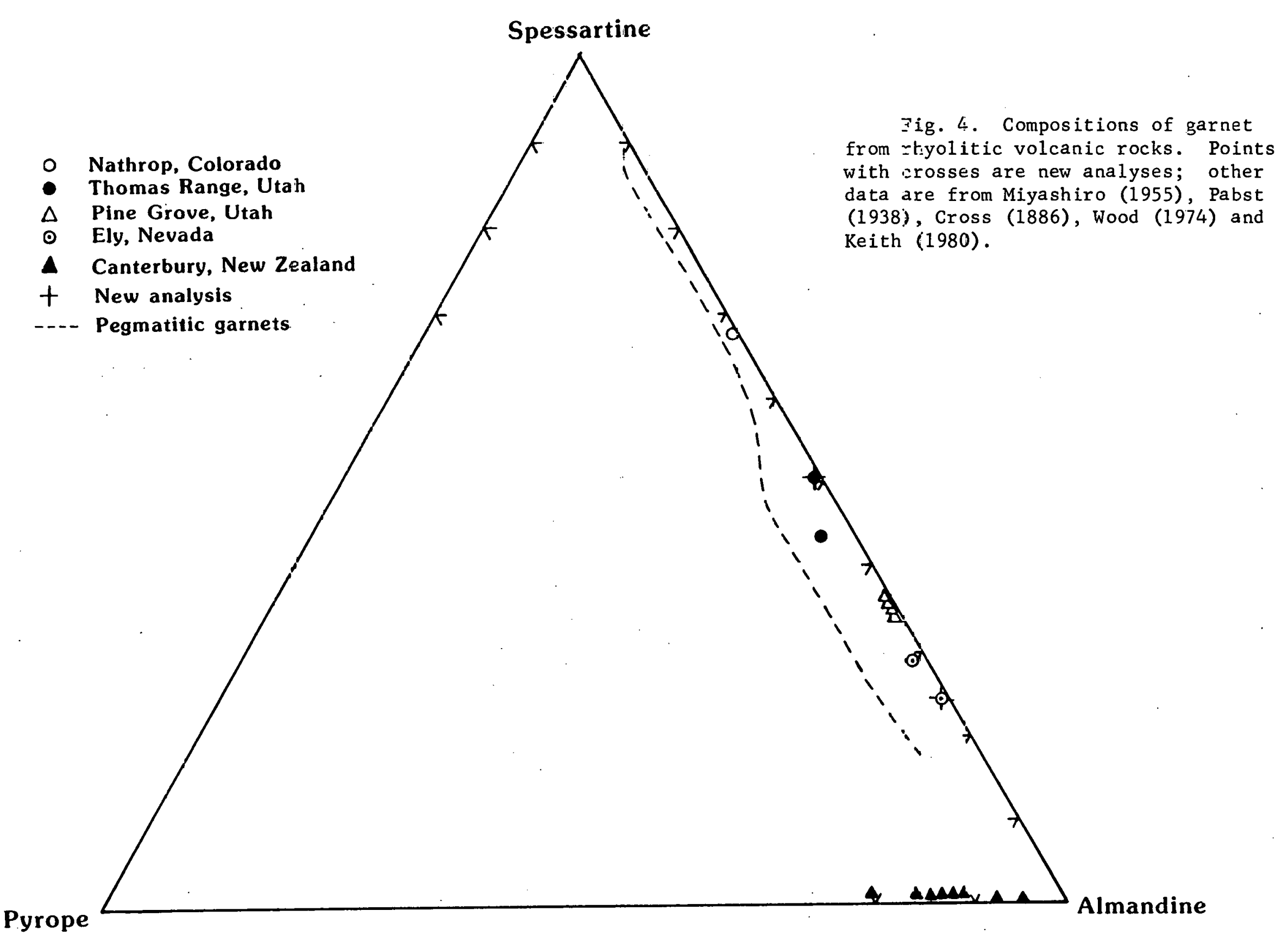


The origin of magmatic garnet in "granitic" magmas has been the subject of some controversy recently and its significance is still unclear. Green (1976, 1978) postulates that garnets are relics, indicative of high pressure (3-7 Kb) crystallization. Hall (1965). and Miller and Stoddard (1978). suggest that garnet is stabilized by Mn-enrichment of residual peraluminous magmas without regard to pressure. In view of the Mn-rich (high $\frac{\mathrm{Mn}}{\mathrm{Mg}+\mathrm{Ca}+\mathrm{Fe}}$ ) character of many topaz rhyolite magmas and the lack of evidence for high pressure crystallization, the latter hypothesis may explain their presence in these rocks.

Vapor-phase garnets may crystallize as a product of biotite decomposition due to partial oxidation and local $\mathrm{K}-1$ eaching during and after subaerial eruption. This process can be modeled by the reaction.

$$
\begin{gathered}
4 \mathrm{~K}(\mathrm{Fe}, \mathrm{Mn})_{3} \mathrm{AlSi}_{3} \mathrm{O}_{10}\left(\mathrm{~F}_{0.5} \mathrm{OH}_{0.5}\right)_{2}+\frac{3}{2} \mathrm{O}_{2}= \\
\text { biotite } \\
\begin{array}{c}
2(\mathrm{Mn}, \mathrm{Fe})_{3} \mathrm{Al}_{2} \mathrm{Si}_{3} \mathrm{O}_{12}+3(\mathrm{Fe}, \mathrm{Mn}) \mathrm{O}_{3}+6 \mathrm{SiO}_{2}+4 \mathrm{KF}+2 \mathrm{H}_{2} \mathrm{O} \\
\text { garnet } \\
\text { hematite quartz }
\end{array}
\end{gathered}
$$

If the vapor is too F-rich and oxidizing, garnet becomes unstable, by the reaction

$$
\begin{aligned}
& 2(\mathrm{Mn}, \mathrm{Fe})_{3} \mathrm{Al}_{2} \mathrm{Si}_{3} \mathrm{O}_{12}+\frac{3}{2} \mathrm{O}_{2}+4 \mathrm{HF}= \\
& \text { garnet } \\
& 2 \mathrm{Al}_{2} \mathrm{SiO}_{4} \mathrm{~F}_{2}+3(\mathrm{Mn}, \mathrm{Fe})_{2} \mathrm{O}_{3}+4 \mathrm{SiO}_{2}+2 \mathrm{H}_{2} \mathrm{O} \text {. } \\
& \text { topaz bixbyite quartz }
\end{aligned}
$$

This second reaction is demonstrated by the pseudomorphic replacement of garnet by topaz, Fe-Mn oxides, and quartz in lithophysae from the Thomas Range (Penfield and Foote, 1897; Ream, 1979, p. 270).

\section{CHEMISTRY}

\section{Major elements}

Chemical analyses of 24 samples from topaz rhyolites are reported in Table 8. Although topaz is not present in each sample (particularly the glasses) it has been identified in the same rhyolite flow or stratigraphic unit. There is little chemical diversity in the group as a whole. They are generally high in silica $(>75 \%), \mathrm{Na}_{2} \mathrm{O}(3.5-4.5 \%), \mathrm{K}_{2} \mathrm{O} / \mathrm{Na}_{2} \mathrm{O}$ ratio and fluorine $(0.1-1 \%)$ and low in $\mathrm{TiO}_{2}(<0.2 \%), \mathrm{CaO}(<0.9 \%), \mathrm{MgO}(<0.2 \%)$ and $\mathrm{P}_{2} \mathrm{O}_{5}(<0.01 \%)$ relative to most rhyolites. Nockold's (1954) average rhyolite is presented as analysis 25 . The analyses are similar to published compositions of other topaz rhyolites in the western U.S. (Staatz and Carr, 1964; Turley et al., 
Table 8. Chemical analyses and norms (calculated F-free) of topaz rhyolites from the western United States

\begin{tabular}{|c|c|c|c|c|}
\hline $\begin{array}{l}\text { analysis no. } \\
\text { sample no. }\end{array}$ & $\begin{array}{c}1 \\
S M-31 v\end{array}$ & $\begin{array}{c}2 \\
S M-35 v\end{array}$ & $\begin{array}{c}3 \\
S M-70 v\end{array}$ & $\begin{array}{c}4 \\
S M-34 v\end{array}$ \\
\hline $\mathrm{SiO}_{2}$ & 73.3 & 73.9 & 72.2 & 74.8 \\
\hline $\mathrm{TiO}_{2}$ & 0.06 & 0.06 & 0.04 & 0.06 \\
\hline $\mathrm{Al}_{2} \mathrm{O}_{3}$ & 13.2 & 13.1 & 13.9 & 13.3 \\
\hline $\mathrm{Fe}_{2} \mathrm{O}_{3}$ * & 1.48 & 1.43 & 1.19 & 1.52 \\
\hline $\mathrm{MnO}$ & 0.07 & 0.06 & 0.06 & 0.04 \\
\hline $\mathrm{MgO}$ & 0.05 & 0.08 & 0.06 & 0.07 \\
\hline $\mathrm{CaO}$ & 0.61 & 1.27 & 0.58 & 0.60 \\
\hline $\mathrm{Na}_{2} \mathrm{O}$ & 4.02 & 4.33 & 4.90 & 3.76 \\
\hline $\mathrm{K}_{2} \mathrm{O}$ & 4.22 & 3.65 & 4.90 & 4.81 \\
\hline $\mathrm{P}_{2} \mathrm{O}_{5}$ & 0.00 & 0.00 & 0.01 & 0.00 \\
\hline $\mathrm{F}$ & 0.82 & 1.06 & 1.25 & 0.66 \\
\hline sum & 98.60 & 98.94 & 99.17 & 99.62 \\
\hline$-0 \equiv F$ & 0.35 & 0.45 & 0.52 & 0.28 \\
\hline Total & 98.25 & 98.49 & 98.65 & 99.34 \\
\hline LOI & 2.96 & 3.55 & 3.00 & 0.50 \\
\hline$O_{i}$ & 29.49 & 21.57 & 29.43 & 28.42 \\
\hline$a b$ & 34.01 & 36.64 & 41.46 & 31.81 \\
\hline an & 3.03 & 5.56 & 1.1 .7 & 2.98 \\
\hline$q$ & 29.15 & 31.72 & 23.40 & 32.81 \\
\hline hy & 0.84 & 0.54 & 0.01 & 0.85 \\
\hline$d i$ & 0.00 & 0.64 & 1.42 & $n .0 n$ \\
\hline ap & n. กn & 0.00 & 0.02 & 0.00 \\
\hline il & 0.11 & 0.11 & 0.08 & 0.11 \\
\hline c & 0.07 & 0.00 & 0.00 & 0.81 \\
\hline $\mathrm{mt}$ & 1.03 & 1.00 & 0.83 & 1.06 \\
\hline Tota1 & 97.73 & 97.78 & 97.82 & 98.85 \\
\hline \multicolumn{5}{|c|}{$\begin{array}{l}\mathrm{v} \text { vitrophyre } \\
\text { * total } \mathrm{Fe} \text { as } \mathrm{Fe}_{2} \mathrm{O}_{3} \\
\text { LOI loss on ignition }\end{array}$} \\
\hline
\end{tabular}


Table 8 . continued

\begin{tabular}{|c|c|c|c|c|c|c|}
\hline $\begin{array}{l}\text { analysis no. } \\
\text { sample no. }\end{array}$ & $\begin{array}{c}5 \\
S M-61 \text { av }\end{array}$ & $\begin{array}{c}6 . \\
S M-61 b\end{array}$ & $\begin{array}{c}7 \\
S M-62 a v\end{array}$ & $\begin{array}{c}8 \\
S M-62 . b\end{array}$ & $\begin{array}{c}9 \\
\mathrm{SM}-29-206\end{array}$ & $\begin{array}{c}10 \\
\text { SM-42 }\end{array}$ \\
\hline $\mathrm{SiO}_{2}$ & .75 .0 & 74.22 & 76.1 & 75.41 & 76.2 & 75.9 \\
\hline $\mathrm{TiO}_{2}$ & $0 . .28$ & $0 . .28$ & 0.14 & 0.14 & 0.07 & 0.09 \\
\hline $\mathrm{Al}_{2} \mathrm{O}_{3}$ & 13.1 & 13.1 & 12.43 & 12.49 & 12.7 & 12.9 \\
\hline $\mathrm{Fe}_{2} \mathrm{O}_{3} *$ & 1.26 & 1.25 & 1.0 .4 & 1.00 & 0.9 .9 & 1.09 \\
\hline $\operatorname{Mn} 0$ & 0.04 & 0.06 & 0.0 .6 & 0.05 & 0.07 & 0.08 \\
\hline $\mathrm{MgO}$ & 0.19 & 0.26 & 0.12 & 0.30 & 0.05 & 0.09 \\
\hline $\mathrm{Ca} 0$. & 0.82 & 1.0 .6 & 0.76 & 1.9 .7 & 0.72 & 0.74 \\
\hline $\mathrm{Na}_{2} \mathrm{O}$ & 3.48 & 3.43 & 3.35 & 3.58 & 3.74 & 4.11 \\
\hline $\mathrm{K}_{2} \mathrm{O}$ & 5.51 & 5.46 & 5.40 & 5.15 & 4.80 & 4.69 \\
\hline $\mathrm{P}_{2} \mathrm{O}_{5}$ & 0.02 & 0.02 & 0.00. & 0.00 & 0.00 & 0.00 \\
\hline $\mathbf{F}$ & $0 . .20$ & - & 0.16 & - & 0.32 & 0.64 \\
\hline sum & 99.90 & 9.9 .18 & 9.9 .56 & 100.09 & 99.66 & 100.33 \\
\hline$-0 \equiv F$ & 0.0 .8 & - & .07 & - & 0.13 & 0.27 \\
\hline Total & 9.9 .82 & 9.9 .18 & 99.49 & 100.09 & 99.53 & 100.06 \\
\hline LOI & 2.97 & 2.80 & 2.83 & 1.66 & 2.84 & 3.11 \\
\hline or & 32.56 & 32.27 & 31.91 & 30.43 & 28.54 & 27.72 \\
\hline$a b$ & 29.45 & 29.02 & 28.35 & 30.29 & 31.65 & 34.78 \\
\hline an & 3.91 & 4.33 & 2.9 .3 & 2.80 & 3.49 & 2.79 \\
\hline Q & 31.59 & 30.84 & 34.17 & 31.57 & 34.15 & 32.32 \\
\hline hy & 0.66 & 0.57 & 0.31 & 1.76 & 0.56 & 0.35 \\
\hline$d i$ & 0.03 & 0.15 & 0.70 & 2.22 & 0.07 & 0.75 \\
\hline ap & 0.05 & 0.05 & 0.00 & 0.00 & 0.00 & 0.00 \\
\hline il & 0.53 & 0.53 & 0.27 & 0.27 & 0.13 & 0.11 \\
\hline c & 0.00 & 0.0 .0 . & 0.00 & 0.00 & 0.00 & 0.00 \\
\hline$m t$ & 0.88 & 0.87 & 0.72 & 0.70 & 0.69 & 0.76 \\
\hline Total & 99.66 & 98.63 & 99.36 & 100.04 & 99.28 & 9.9 .58 \\
\hline
\end{tabular}

- not determined 
Table 8. continued

\begin{tabular}{|c|c|c|c|c|}
\hline $\begin{array}{l}\text { analysis no. } \\
\text { sample no. }\end{array}$ & $\stackrel{11}{H H-1 v}$ & $\begin{array}{c}12 \\
\mathrm{HH}-3\end{array}$ & $\begin{array}{c}13 \\
W W-41 v\end{array}$ & $\begin{array}{c}14 \\
\text { STC-4. }\end{array}$ \\
\hline $\mathrm{SiO}_{2}$ & 74.8 & 75.2 & 75.8 & 75.8 \\
\hline $\mathrm{TiO}_{2}$ & 0.04 & 0.03 & 0.05 & 0.06 \\
\hline $\mathrm{Al}_{2} \mathrm{O}_{3}$ & 13.6 & 13.5 & 12.9 & 12.8 \\
\hline $\mathrm{Fe}_{2} \mathrm{O}_{3}$ * & 0.98 & 0.98 & 1.26 & 1.30 \\
\hline MnO & 0.06 & 0.06 & 0.12 & 0.05 \\
\hline Mg 0 & 0.08 & 0.06 & 0.04 & 0.11 \\
\hline $\mathrm{CaO}$ & 0.58 & 0.67 & 0.62 & 0.67 \\
\hline $\mathrm{Na}_{2} \mathrm{O}$ & 4.55 & 4.66 & 3.84 & 4.06 \\
\hline $\mathrm{K}_{2} \mathrm{O}$ & 4.40 & 4.5 .1 & 4.80 & 4.60 \\
\hline $\mathrm{P}_{2}{ }^{0}{ }_{5}$ & 0.00 & 0.00 & - & - \\
\hline $\mathrm{F}$ & 0.95 & - & 0.45 & 0.53 \\
\hline Sum & 100.04 & 99.67 & 100.05 & 99.98 \\
\hline$-0 \equiv F$ & 0.40 & - & .19 & .22 \\
\hline Tota1 & 99.64 & 99.67 & 99.86 & 99.76 \\
\hline LOI & - & - & 3.26 & 0.47 \\
\hline or & $26.0 n$ & 26.59 & 29.37 & 27.18 \\
\hline$a b$ & 38.50 & 39.43 & 32.49 & 34.35 \\
\hline an & 2.88 & 2.63 & 3.08 & 3.12 \\
\hline$Q$ & 29.82 & 29.18 & 32.62 & 32.64 \\
\hline hy & 0.89 & 0.55 & 1.07 & 1.04 \\
\hline $\mathrm{di}$ & 0.00 & 0.60 & 0.00 & 0.18 \\
\hline ap & 0.00 & 0.00 & 0.0 .0 & 0.00 \\
\hline il & 0.08 & 0.06 & 0.09 & 0.11 \\
\hline c & 0.30 & 0.00 & 0.08 & 0.00 \\
\hline$m t$ & 0.57 & 0.37 & 0.73 & 0.75 \\
\hline Total & 99.04 & 99.61 & 99.53 & 99.38 \\
\hline
\end{tabular}


Table 8. continued

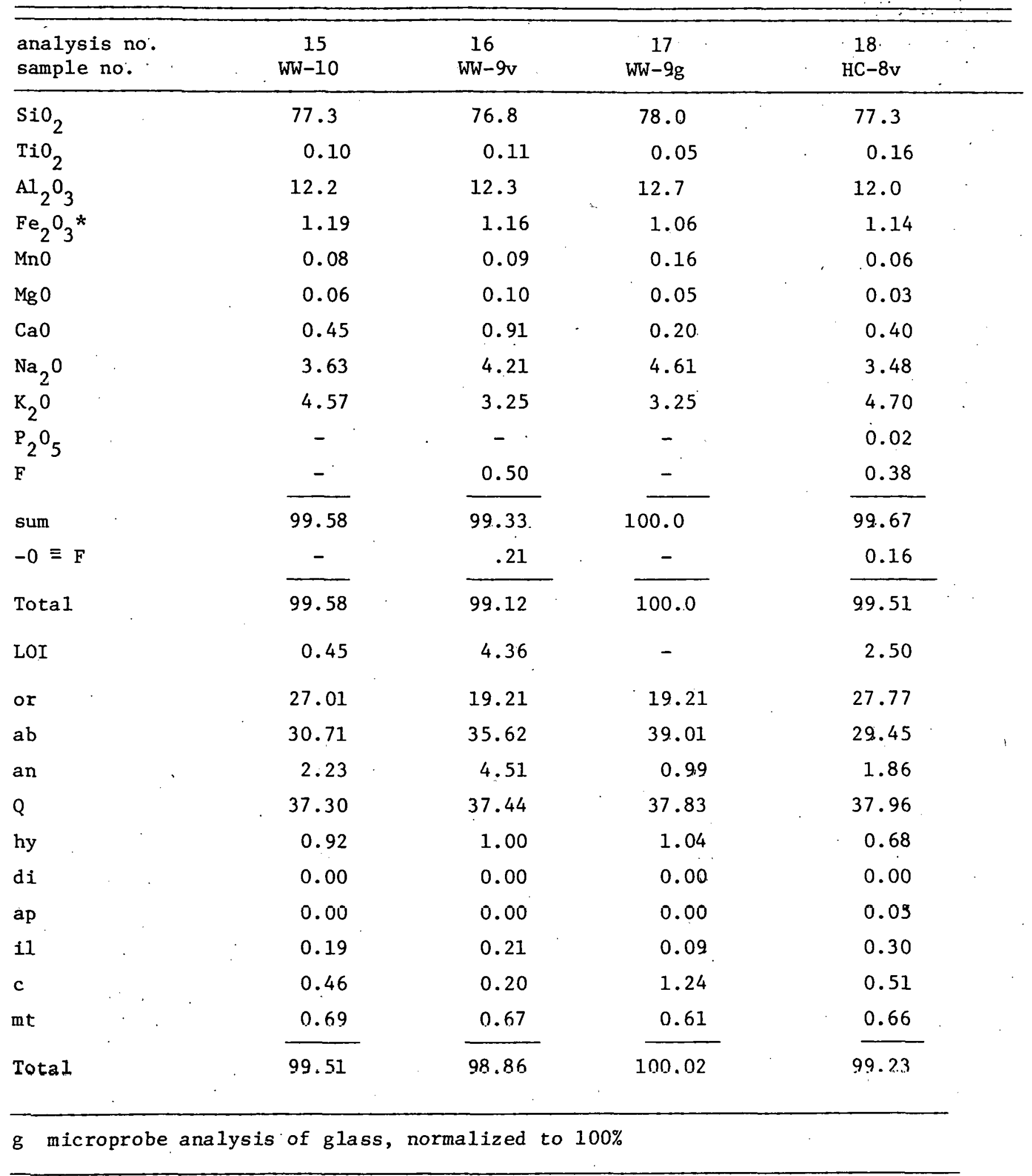


Table 8. continued

\begin{tabular}{|c|c|c|c|c|c|}
\hline $\begin{array}{l}\text { analysis no. } \\
\text { sample no. }\end{array}$ & $\begin{array}{c}19 \\
I P-2\end{array}$ & $\begin{array}{c}20 \\
B R-16\end{array}$ & $\begin{array}{c}21 \\
B R-28\end{array}$ & $\begin{array}{c}22 \\
N A T-I V\end{array}$ & \\
\hline $\mathrm{SiO}_{2}$ & 80.5 & 78.7 & 77.1 & 75.3 & \\
\hline $\mathrm{TiO}_{2}$ & 0.15 & 0.19 & 0.20 & 0.09 & \\
\hline $\mathrm{Al}_{2} \mathrm{O}_{3}$ & 9.47 & 11.1 & 12.7 & 13.1 & \\
\hline $\mathrm{Fe}_{2} \mathrm{O}_{3} *$ & 1.91 & 1.27 & 1.14 & 0.64 & \\
\hline $\mathrm{MnO}$ & 0.07 & 0.06 & 0.05 & 0.10 & \\
\hline $\mathrm{Mg} 0$ & 0.03 & 0.04 & 0.33 & 0.22 & \\
\hline $\mathrm{CaO}$ & 0.32 & 0.43 & 0.75 & 0.61 & \\
\hline $\mathrm{Na}_{2} \mathrm{O}$ & 2.85 & 3.29 & 2.96 & 4.26 & \\
\hline $\mathrm{K}_{2} \mathrm{O}$ & 3.76 & 4.59 & 4.73 & 4.97 & . \\
\hline $\mathrm{P}_{2} \mathrm{O}_{5}$ & 0.01 & 0.02 & 0.04 & 0.01 & \\
\hline F & - & - & - & 0.55 & \\
\hline sum & 99.07 & 99.69 & 100.01 & 99.85 & \\
\hline$-0 \equiv \mathrm{F}$ & - & - & - & 0.23 & \\
\hline Total & 99.07 & 99.69 & 100.01 & 99.65 & \\
\hline LOI & 0.50 & 0.30 & 0.55 & - & \\
\hline$u r$ & 22.22 & 27.12 & 27.95 & 29.37 & \\
\hline ab & 24.11 & 27.84 & 25.05 & 36.05 & \\
\hline an & 1.52 & 1.99 & 3.46 & 1.95 & \\
\hline Q & 48.13 & 40.68 & 39.47 & 23.21 & \\
\hline hy & 1.69 & 1.05 & 1.62 & 0.60 & \\
\hline$d i$ & 0.00 & 0.01 & 0.00 & $0.8 !$ & \\
\hline ap & 0.02 & 0.05 & 0.09 & 0.02 & \\
\hline iI & 0.19 & 0.36 & 0.38 & 0.17 & . \\
\hline$c$ & 0.00 & 0.00 & 1.46 & 0.00 & ' \\
\hline $\mathrm{mt}$ & 0.34 & 0.55 & 0.50 & 0.37 & \\
\hline Total & 98.88 & 99,65 & 99.99 & 99.27 & \\
\hline
\end{tabular}


Table 8. continued

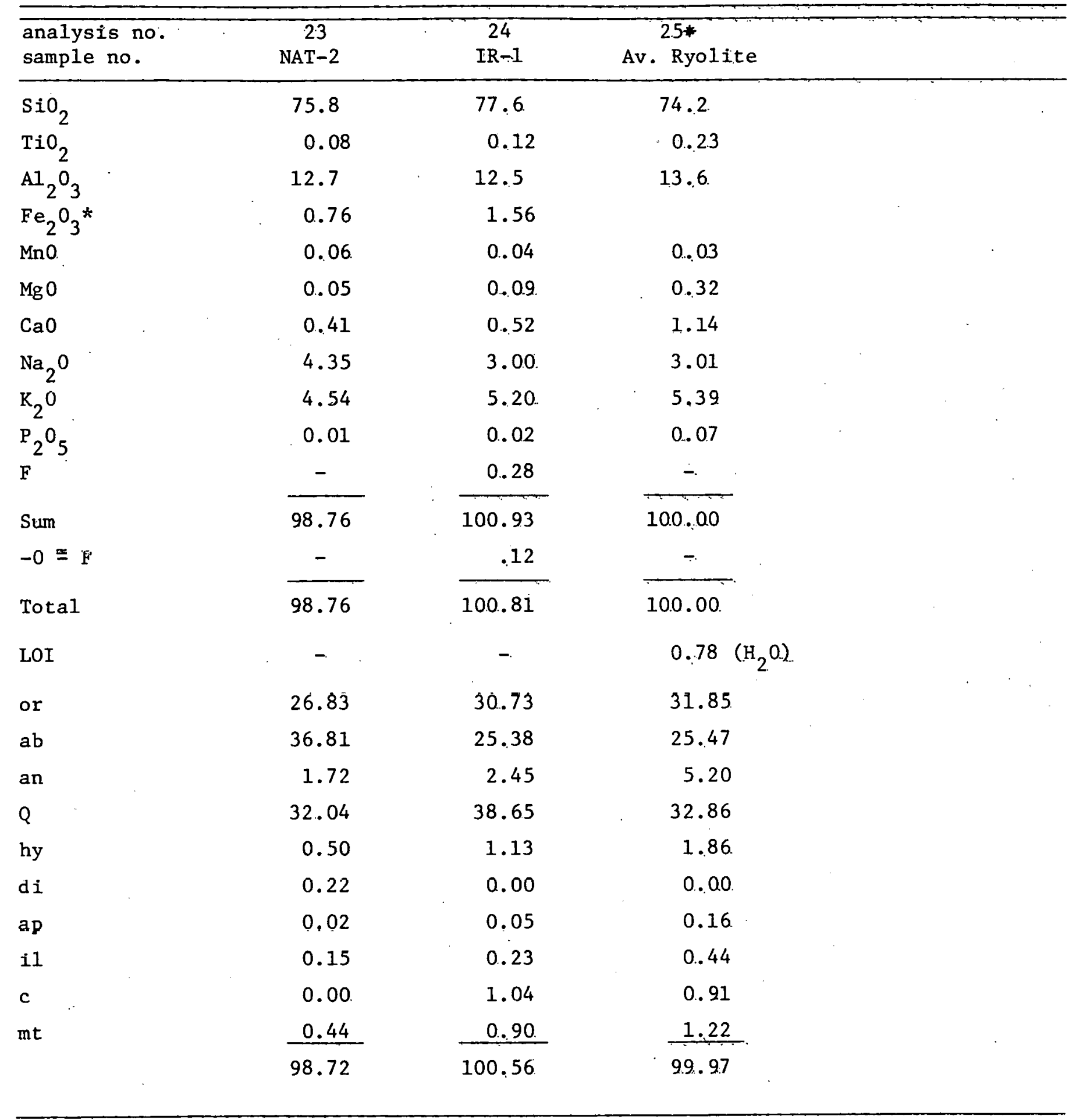

* Nockolds (19.54), total $\mathrm{Fe}$ as $\mathrm{Fe}_{2}{ }^{0}{ }_{3}$, calculated water-free. 
1979; Shawe, 1966; Lindsey, 1979) and have chemical characteristics common to rhyolites of many bimodal associations around the world (Evans, 1978; Ewart, 1979). Many of the rocks analyzed are peraluminous as demonstrated by normative corundum (c). This is especially true for those in which $F$ was included in calculating the normative mineralogy as $\mathrm{F}$ is assigned with $\mathrm{Ca}$ to form fluorite (fr), leaving an apparent excess of $\mathrm{Al}_{2} \mathrm{O}_{3}$ (Bikun, this report). In spite of this problem, many of the glasses probably represent quenched peraluminous magmas. The presence of topaz probably reflects alumina saturation; alkali fluoride minerals, such as cryolite $\left(\mathrm{Na}_{3} \mathrm{AlF}_{6}\right)$ or villiaumite ( $\mathrm{NaF}$ ), would form instead if a molecular excess of alkalies over aluminum existed within the melt (Burt, 1979). Residual glass (analysis 17) from sample WW-9 is also peraluminous. The crystallization of garnet, even as a vapor phase product, probably also indicates the peraluminous character of the lavas. Mafic vapor-phase minerals in silicic peralkaline rocks include aegerine and riebeckite--neither has been identified in topaz-bearing rhyolites. In addition, we found no reports of topaz occurring in decidedly peralkaline volcanic rocks. In short, although topaz rhyolites have been called "alkali" rhyolites (Lindsey, 1979; Rowley, et a1., 1978; etc.), following the arbitrary classification of Rittman (1952), they are not peralkaline. The term alkali rhyolite is better reserved for those with alkali pyroxenes and amphiboles as suggested by Streckeisen (1979). To avoid confusion with peralkaline rocks that are contemporaneous with topaz rhyolites in the western U.S., the term alkali feldspar rhyolite (IUGS classification, Streckeisen, 1979) should be used.

In spite of their overall similarity, some time/space differences can be detected among topaz rhyolites. Perhaps the most distinctive is the Spor Mountain rhyolite (Bikun, this report). It is associated with $B e, F$ and $U$ mineralization (Lindsey, 1979; Burt and Sheridan, 1980 and this report). Its distinctive major element characteristics include lower $\mathrm{SiO}_{2}(73.1 \%$, average of glassy samples), $\mathrm{Il}^{\prime} \mathrm{O}_{2}(0.05 \%)$, and higher $\mathrm{Al}_{2} \mathrm{O}_{3}(13.4 \%), \mathrm{Fe}_{2} \mathrm{O}_{3}(1.4 \%)$, total alkalies $(8.8 \%)$ and $F(1.2 \%)$ than most other topaz rhyolites.

\section{Trace Elements}

Trace element concentrations, as determined. by instrumental neutron activation, are shown in Table 9. All of the topaz rhyolites that we analyzed are enriched in heavy $\mathrm{REE}, \mathrm{Cs}, \mathrm{Rb}, \mathrm{U}, \mathrm{Th}, \mathrm{Ta}$, and $\mathrm{Zr}$ relative to many other rhyolitic magmas. They are slightly depleted in light REE and strongly depleted in $\mathrm{Ba}, \mathrm{Sr}$, and $\mathrm{Eu}$. Since $\mathrm{Th}$ and $\mathrm{Rb}$ have extremely low crystal/liquid distribution coefficients (Hanson, 1978), they are concentrated in liquids that have experienced crystal fractionation. Hildreth (1979). has also shown that these elements are concentrated 
iable 9. Trace element concentrations in topaz rhyolites

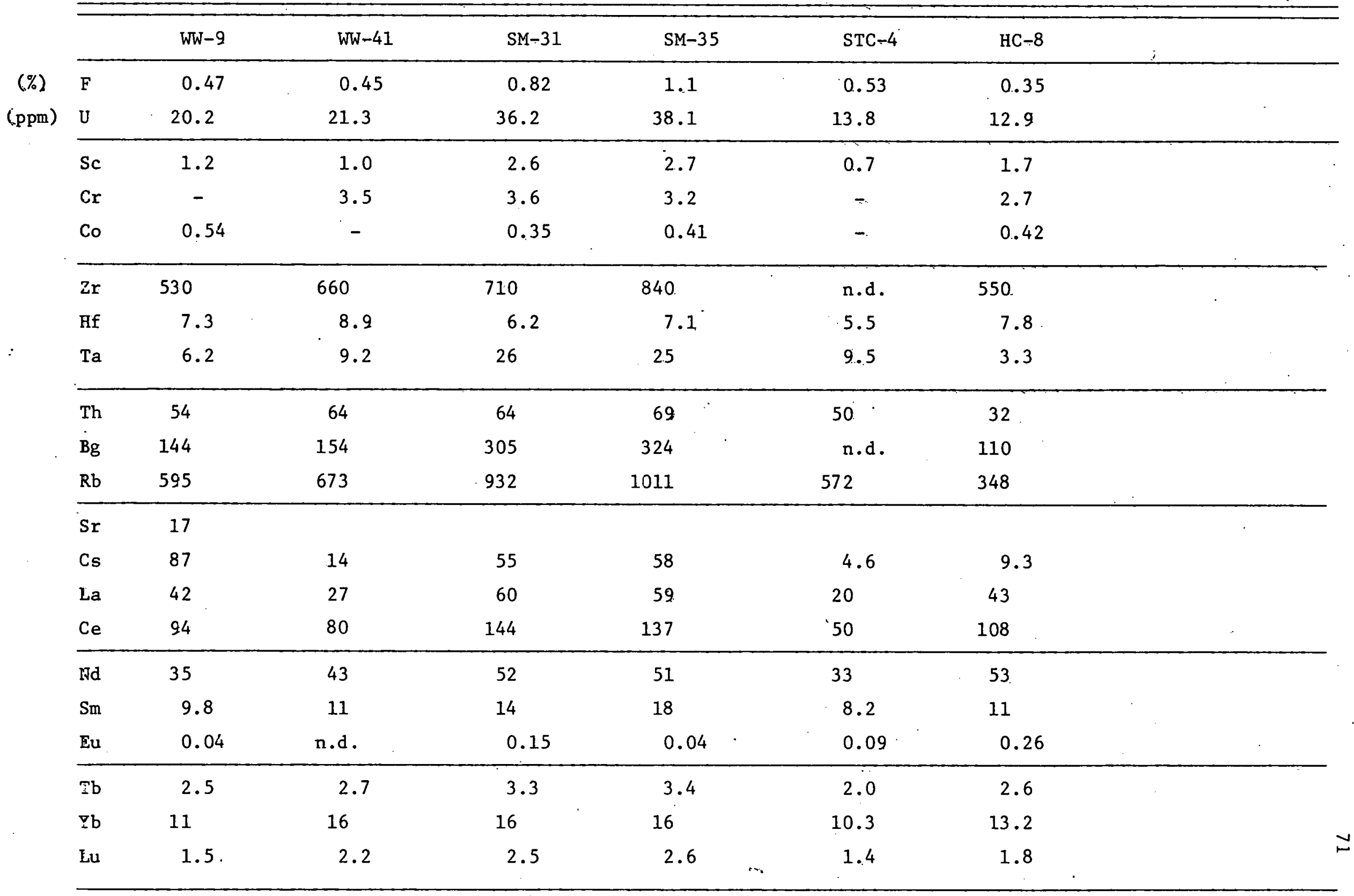

- not detected

n.d. not determined 
Table 9. continued.

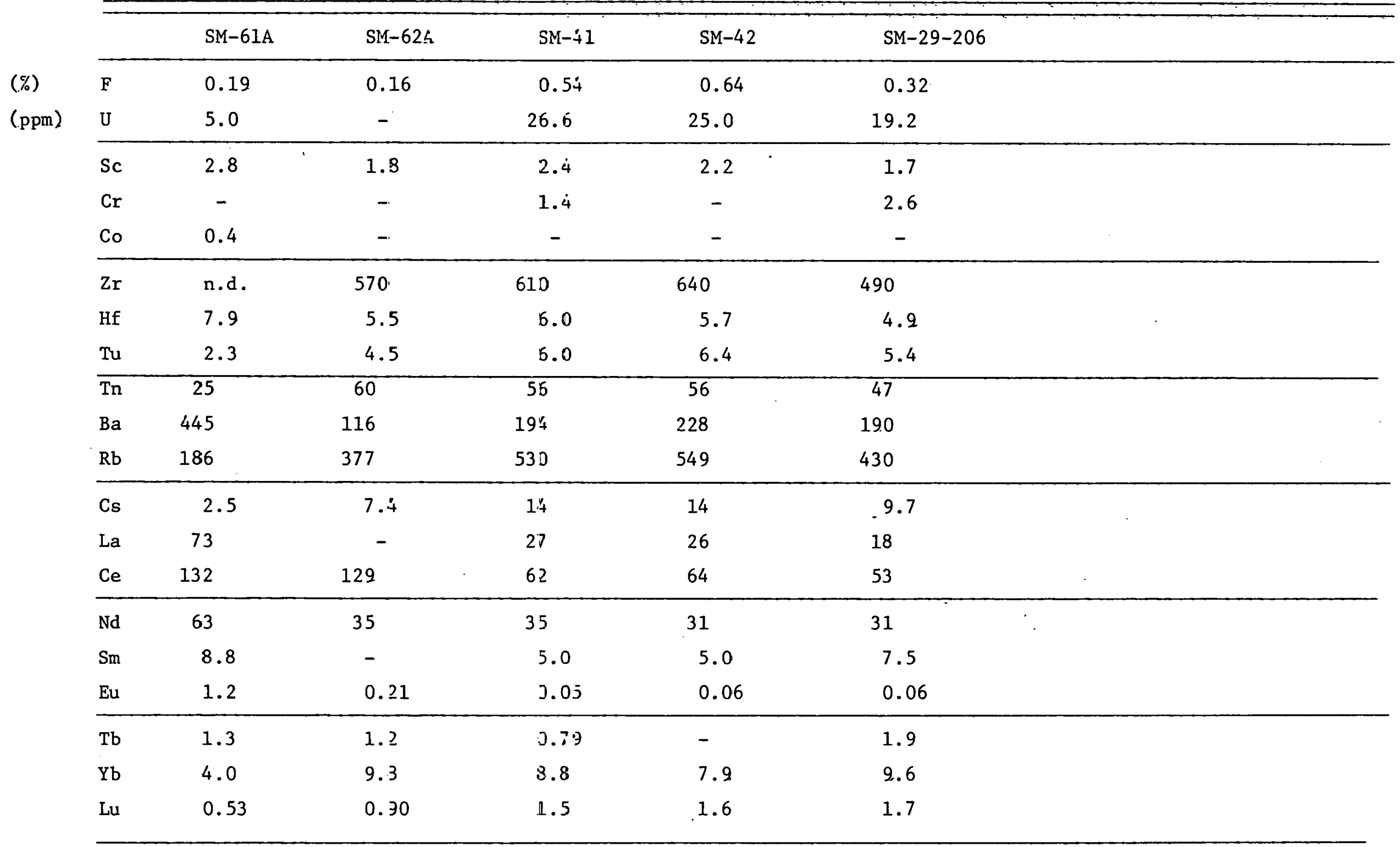


Table 10. Trace element concentrations in topaz rhyolites

\begin{tabular}{|c|c|c|c|c|c|c|c|c|c|c|}
\hline Sample.. & $\mathrm{U}$ & Th & $\mathrm{Be}$ & - Li & $\mathrm{Sn}$ & $\mathrm{Sr}$ & $\mathrm{F}$ & $\mathrm{Cl}$ & & \\
\hline SM-31 & 36 & 64 & 54 & · & & $<6$ & 0.82 & & & ' \\
\hline SM-34 & & & & & & & 0.65 & & & \\
\hline SM-35 & 38 & 69 & 52 & 80 & & 6 & 1.1 & 1680 & . & \\
\hline SM-70 & 26 & 45 & $44(82)$ & 100 & 30 & & 1.25 & 1060 & & \\
\hline SM-71 & 31 & 67 & $34(65)$ & 60 & & & 0.88 & & & \\
\hline SM-61a & 5 & 25 & 2 & 20 & 2 & & 0.19 & & & \\
\hline$S M-62 a$ & & 60 & 6 & 40 & & & 0.16 & & & \\
\hline SM-41 & 27 & 56 & & . & & & $0.54^{\circ}$ & & & \\
\hline SM-42 & 25 & 56 & & & & & 0.64 & & & \\
\hline 29.-206 & & & 7 & 60 & & 5 & 0.32 & & & \\
\hline $\mathrm{HH}-1$ & 22 & 26 & $28^{\circ}$ & 245 & & & 1.17 & 726 & & \\
\hline DL-7 & & & 6 & 590 & 65 & & 1.90 & & & \\
\hline STC-4 & 14 & 50 & 5 & & & 8 & 0.53 & & & \\
\hline WW-9 & 20 & 54 & 9 & 65 & 12 & 17 & 0.47 & 1227 & & \\
\hline WW-41 & 21 & 64 & & $\cdot$ & & $<5$ & 0.45 & & & \\
\hline $\mathrm{HC}-8$ & 13 & 32 & 6 & 23 & 25 & $<5$ & 0.38 & & & \\
\hline IR-1 & 12 & & & & & & 0.28 & & & \\
\hline NAT -1 & 16 & & & & & . & 0.55 & & & \\
\hline NAT -2 & 6 & 33 & & & & & & & & \\
\hline
\end{tabular}

all values in ppm, except F (as weight \%). 
without crystal fractionation in the upper, cooler parts of at least some silicic magma chambers. Magmas with high concentrations of either element have probably experienced large degrees of fractionation. Plots of other elemental concentrations against $\mathrm{Rb}$ or $\mathrm{Th}$ should reveal how they behaved during differentiation of topaz rhyolite magmas and perhaps yield some insight into the processes that were operating during magma evolution. The Utah rhyolites generally show definite trends in several elements (Fig. 5) with $\mathrm{Rb}$, Th and also with F (Fig. 6). Caution should be exercised when interpreting these trends as the samples are not all from a cogenetic suite and were collected from three localities hundreds of kilometers apart. However, comparisons with other rhyolites (cf. Ewart, 1979, or samples from McDermitt and Peñ Blanca) demonstrate their distinctive character as a group and their generally high degree of "evolution" as indicated by the high concentrations of incompatible elements.

Chondrite-normalized (Masuda et al., 1977) REE patterns for some topaz rhyolites are shown in Figure 7. Other investigators have reported similar values for the REE concentrations in topaz rhyolites (Turley et.a1., 1979; Keith, 1980). For comparison early and late phases of the Bishop Tuff are shown as well. The most striking feature of the patterns are their deep Eu anomalies $(E u / E u *=0.45-0.01)$. Perhaps even more significant is the flat nature of the patterns $\left(\mathrm{La} / \mathrm{Yb}_{\mathrm{N}}=12-1.2\right)$. REE's (except $\mathrm{Eu}$ ) occur in nearly chondritic proportions in the most evolved (as indicated by high $U$, Th and $\mathrm{Rb}$ ) vitrophyres from all three areas sampled. Comparison of the patterns suggest that with increasing evolution there is an enrichment of HREE, a decrease in LREE and a consequent increase in the depth of the Eu anomaly.

The extremely light trace elements, $L i$ and $B e$, are also enriched in topaz rhyolites. Their concentrations are shown in Table 10, along with elements determined by means other than instrumental neutron activation. Lithium ranges from 40 to $100 \mathrm{ppm}$ in most topaz rhyolites but is much lower in SM-61a. Samples from the Honeycomb Hills, Utah, have even higher Li contents; a glassy rhyolite has $245 \mathrm{ppm}$ and a pegmatitic clot from the lava has almost $600 \mathrm{ppm} \mathrm{Li}$. Beryllium ranges from 6 to $44 \mathrm{ppm}(82 \mathrm{ppm}$, determined in different laboratory). The samples from Spor Mountain are the most enriched. Beryllium ore is mined from beneath this rhyolite lava. The $21 \mathrm{~m} \cdot \mathrm{y}$. old spor Mountain rhyolite also contains anomalous amounts of $\mathrm{Ta}, \mathrm{Rb}, \mathrm{Cs}$, and $\mathrm{REE}$ relative to other topaz rhyolites, retaining: its distinctive character as seen from the major element data. 

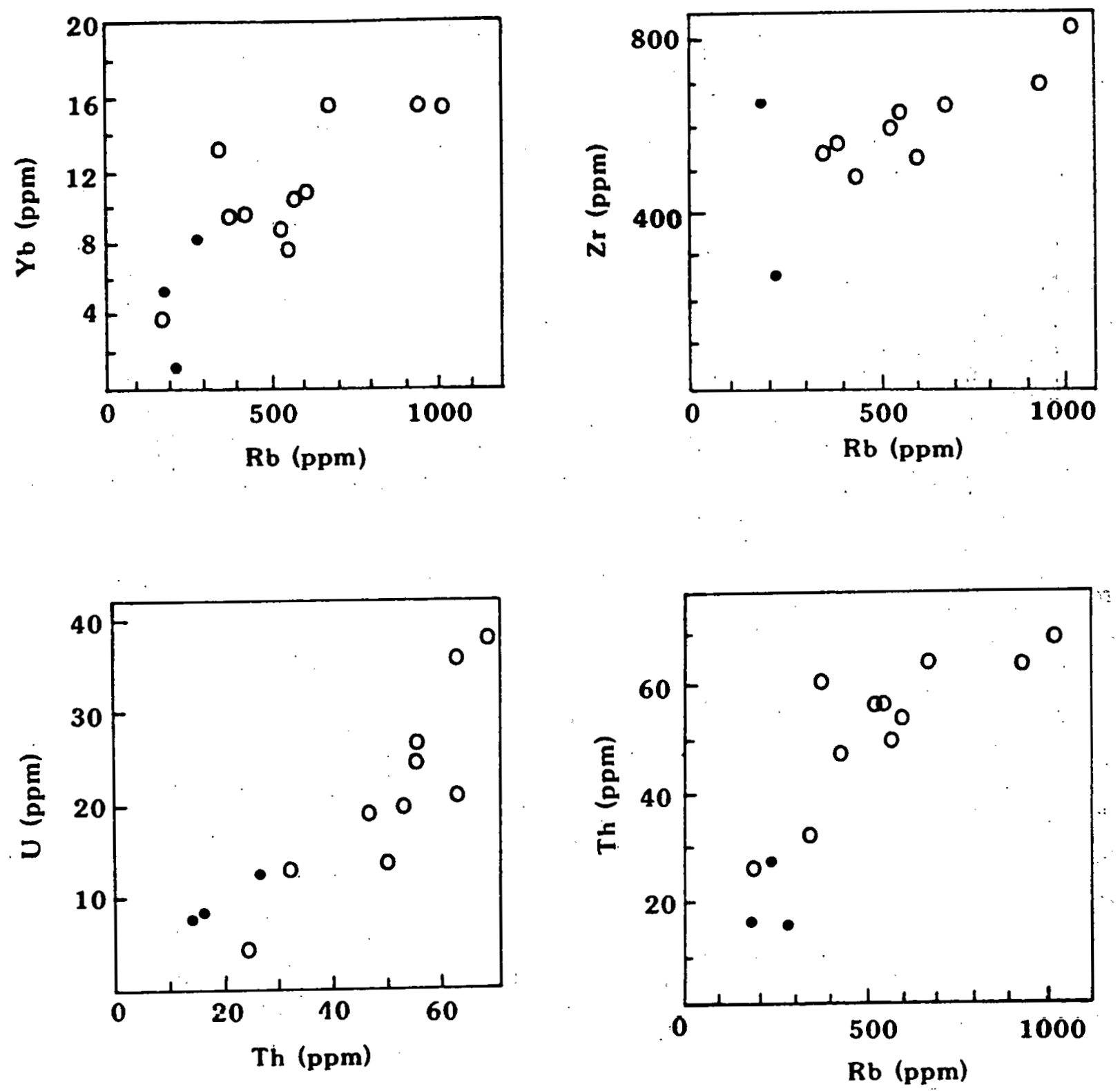

Fig. 5. Two element plots demonstrating the covariance of $\mathrm{Rb}, \mathrm{Th}, \mathrm{Yb}, \mathrm{U}$ and $\mathrm{Zr}$ in topaz rhyolites from the western USA. The filled circles represent samples from McDermitt caldera, Nevada (peralkaline rhyolite), and Pena Blanca, Mexico (cubalkaline rhyolite). 

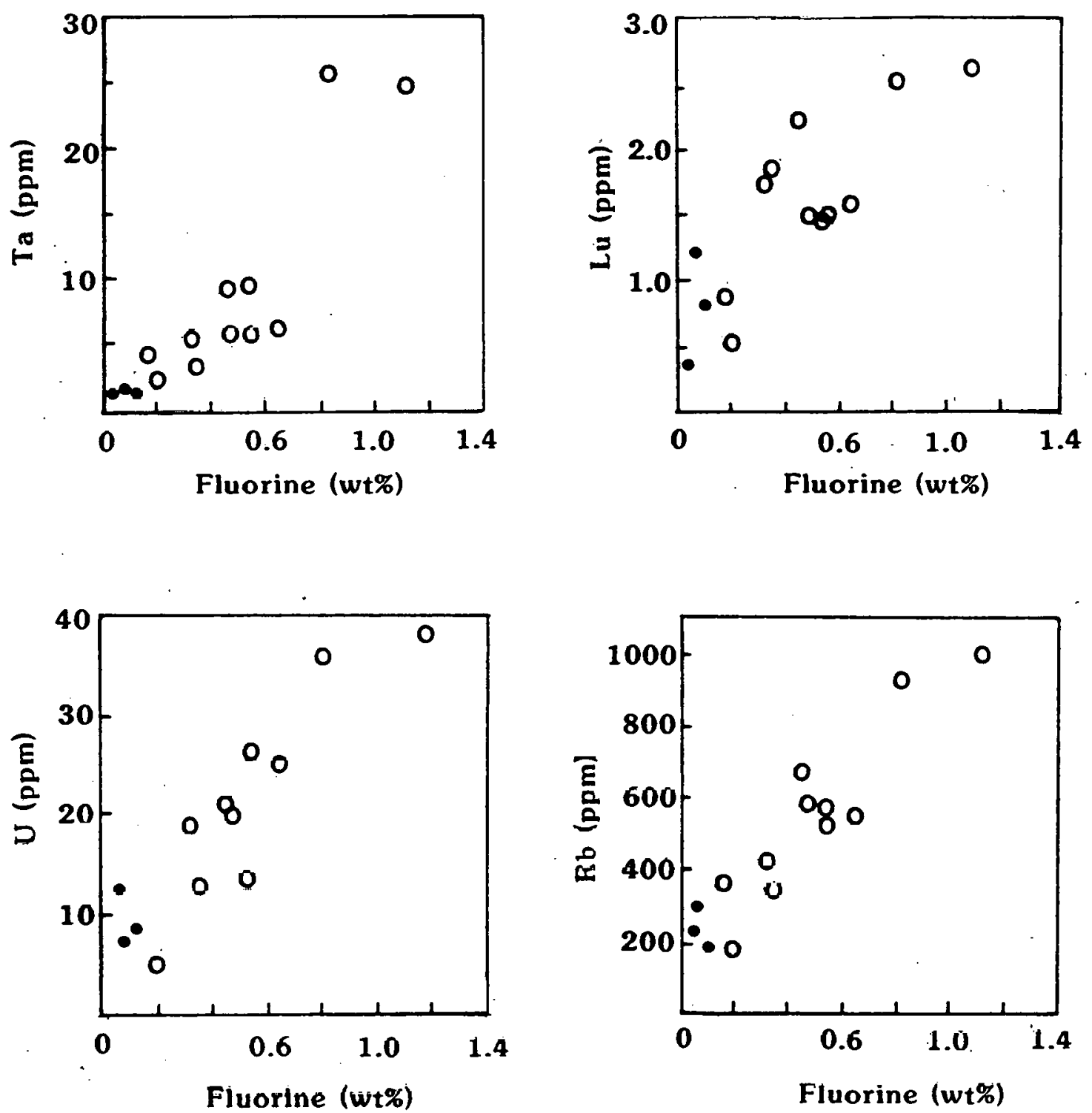

Fluorine (wt\%)

Fig. 6. Two element plots showing the covariance of fluorine with $\mathrm{Ta}, \mathrm{Lu}, \mathrm{U}$ and $\mathrm{Rb}$ in topaz rhyolites from the western USA. The concentration of these elements is taken to indicate the degree of magmatic evolution. Filled circles represent rhyolitic ash-flow tuffs from McDermitt caldera, Nevada (peralkaline) and Peña Blanca, Mexico (subalkaline). 


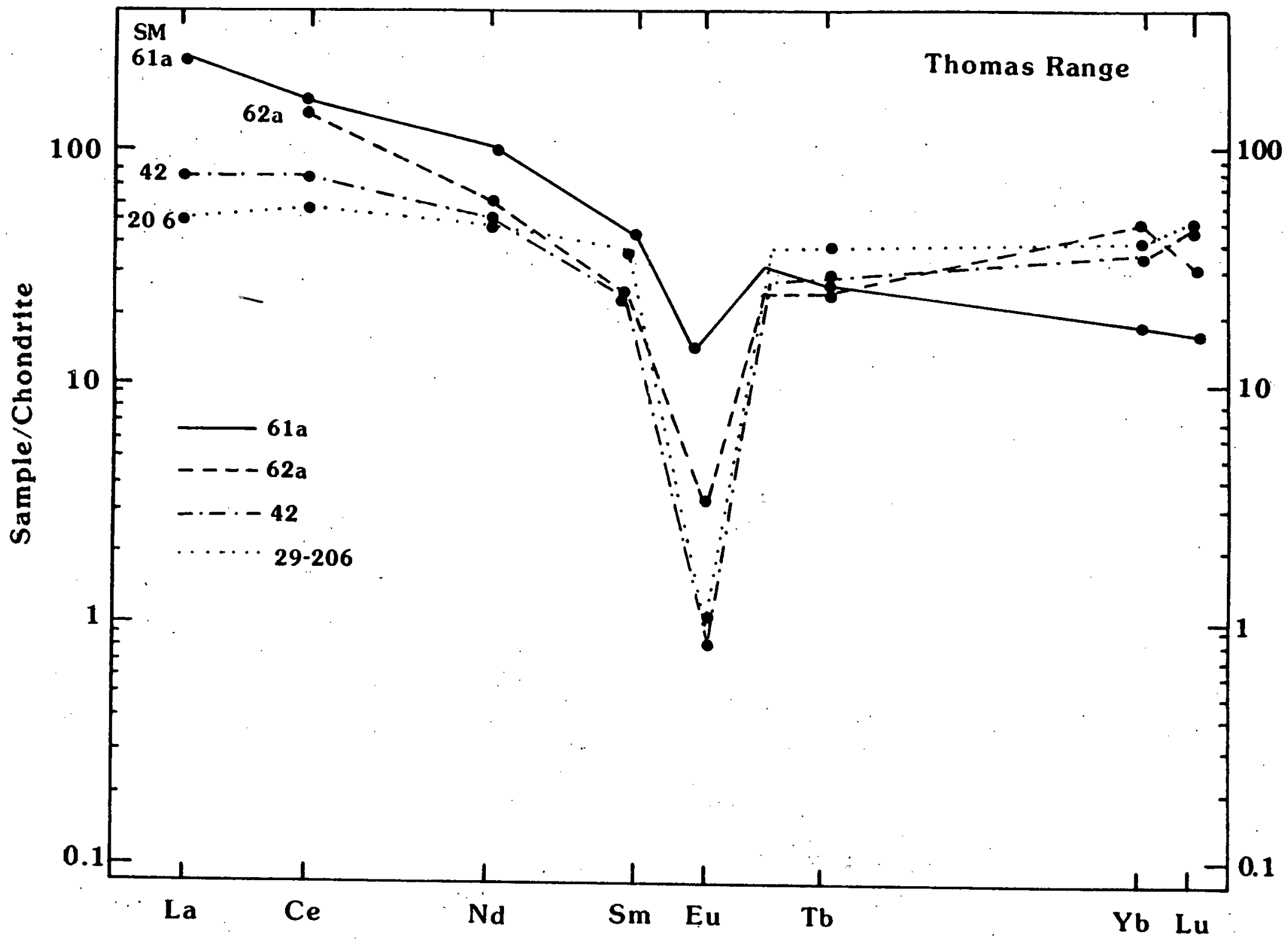

Fig. 7a. Chondrite-normalized REE pattern for topaz rhyolites from the Thomas Range, Utah. Sample 61a has low concentrations of $\mathrm{Rb}, \mathrm{U}$, Th and $\mathrm{F}$, while 29-206 contains high concentrations of these elements. 


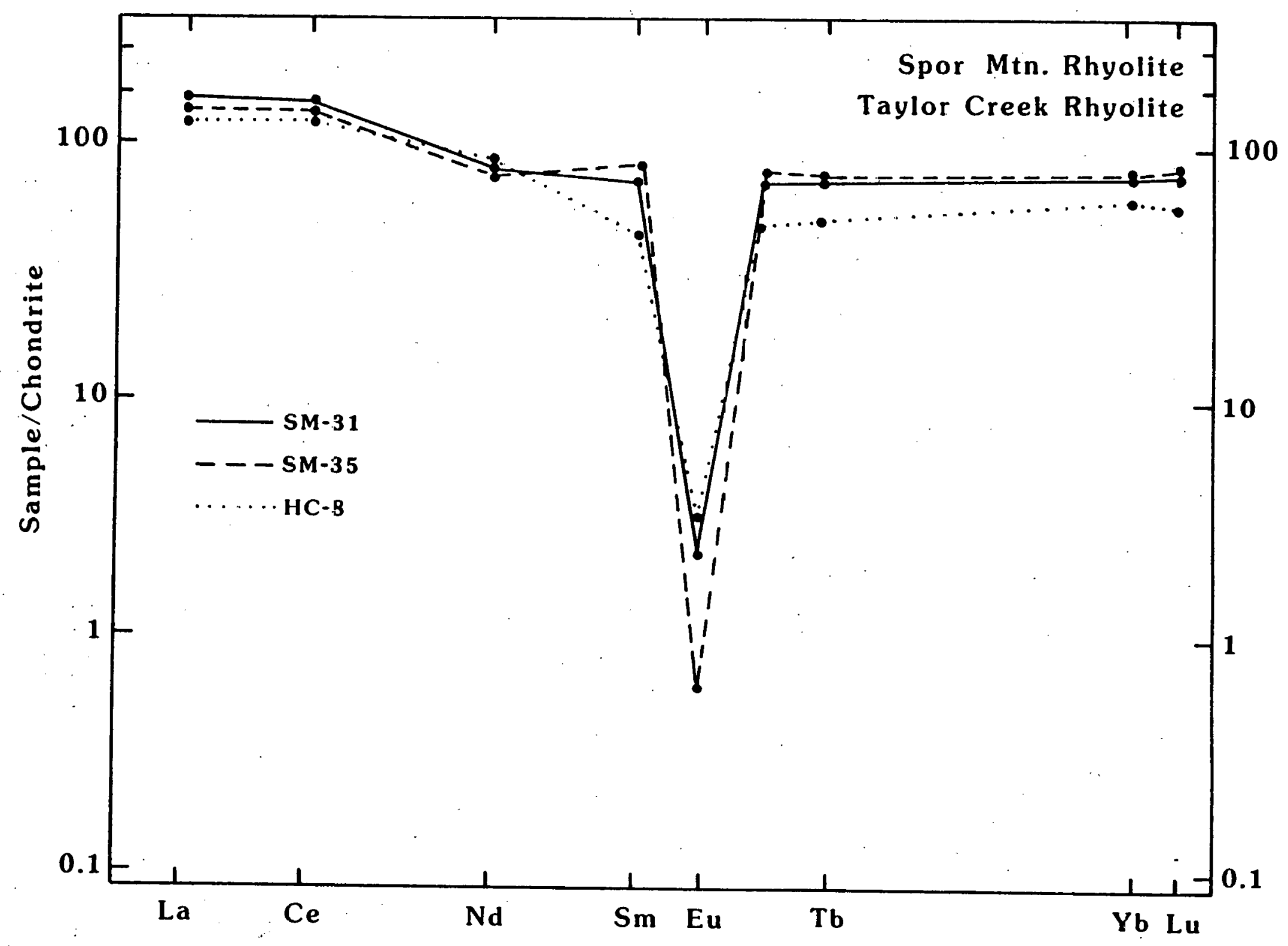

Fig. 7b. Chondrize-normalized REE patterms for topaz rhyolites from the Black Range, New Mexico $(\mathrm{HC}-8)$ and Spor Mountain, Utab (SM-31\& -35). 


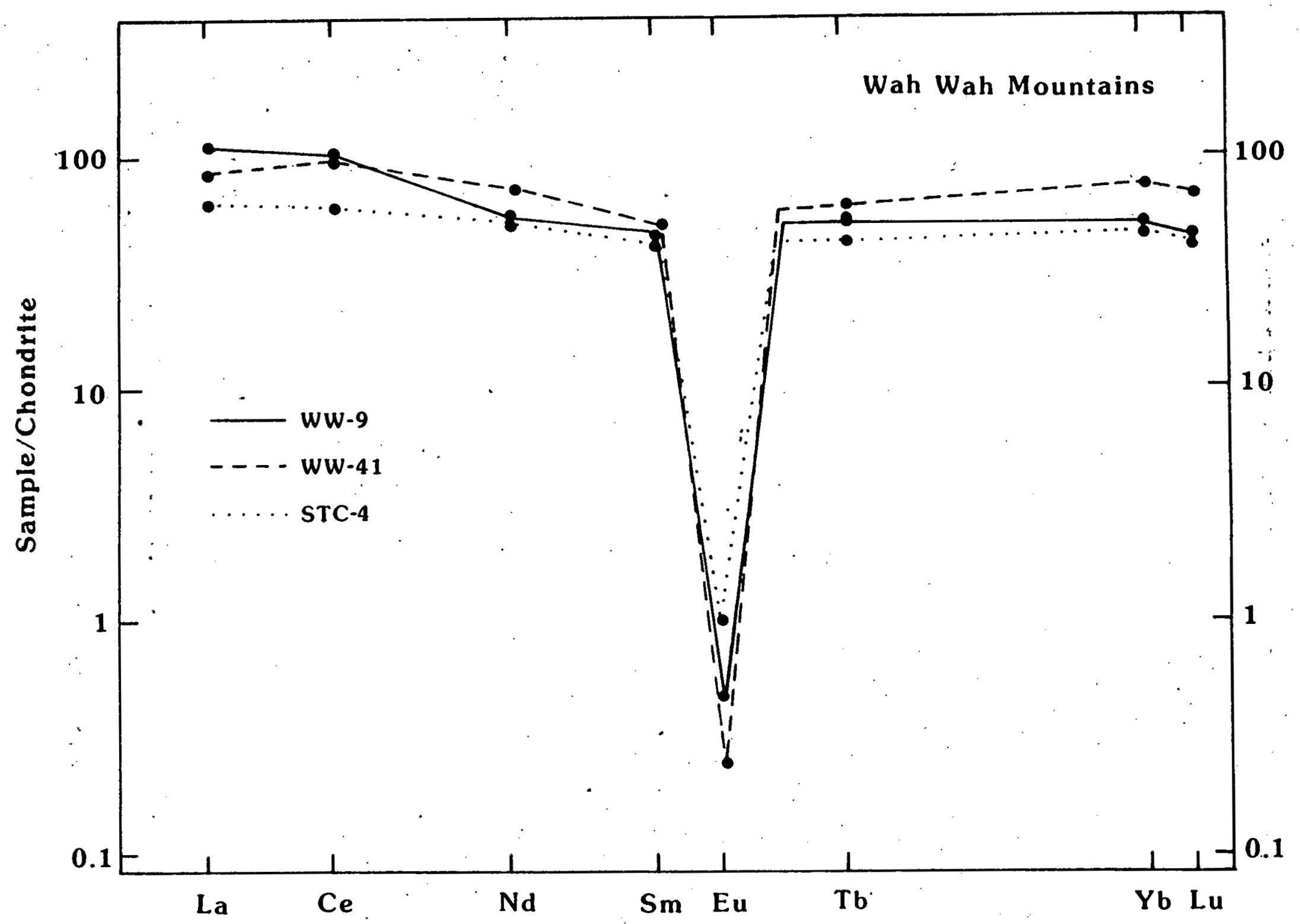

Fig. 7c. Chondrite-normalized REE patterns for topaz rhyolites from the Wah Wah Mountains, 


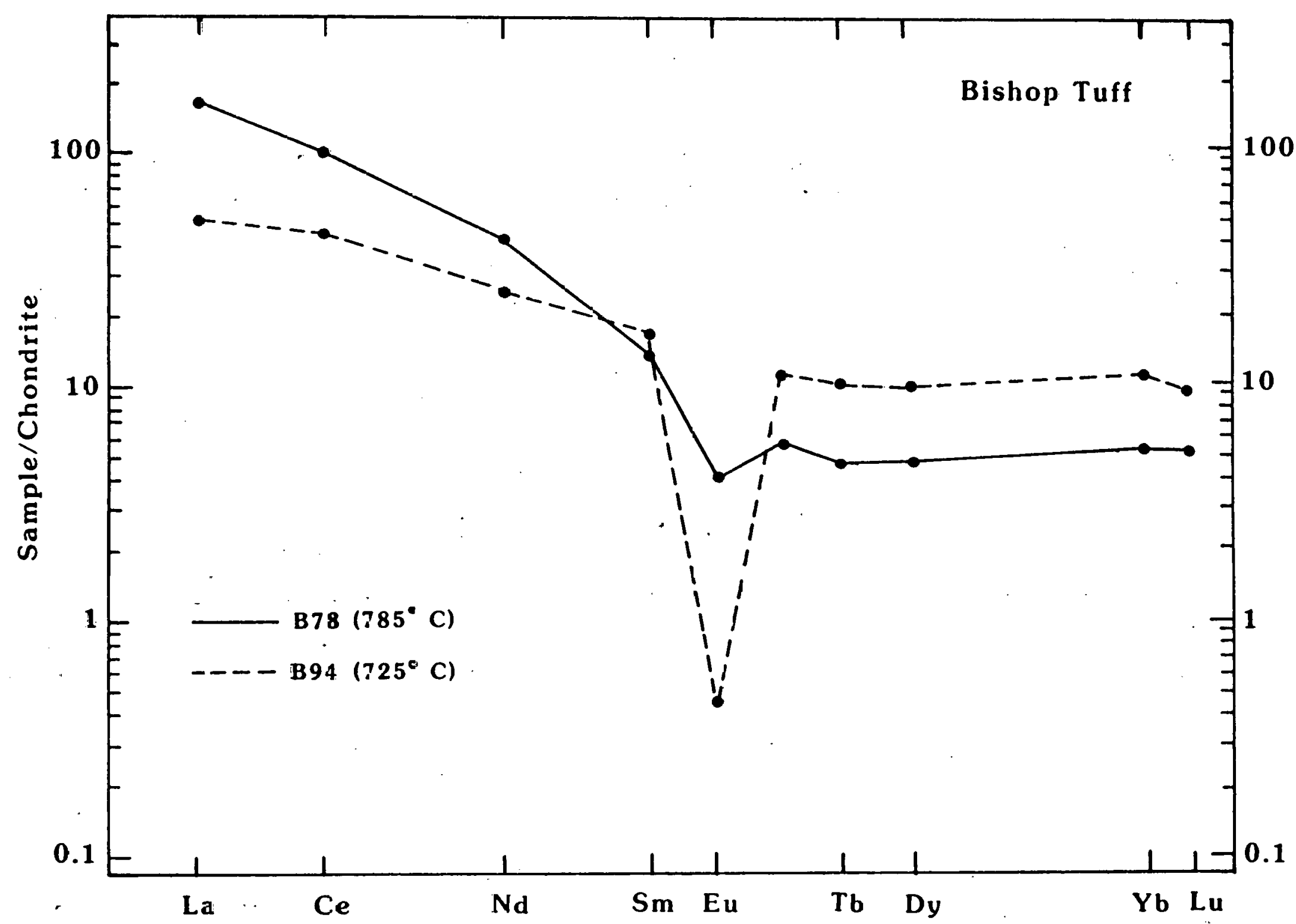

Fig. 7d. Chondrite-ncrmalized REE patterns for early (B94) and late (378) ash flows from Long Valley caldera, CaliEornia. Note the similarity of this relationship with that displayed by the cogenetic samples from the top $\equiv z$ rhyolites Exom the Thomas Range, Utah (Fig. 7ai; REE patterns become flatter with increased "evo-ution' and the c̈epth of the Eu anomaly increases. 
Fluorine is obviously enriched in these topaz-bearing rocks; in some cases it exceeds $1 \%$. Although $\mathrm{F}$ is generally concentrated in silicic 1iquids during differentiation (Fuge, 1977; Bailey, 1977), it is common1y found in volcanic eruption clouds and may escape during cooling or crystallization of rhyolites at or near the surface (Zielinski et al., 1977). Therefore, even the high measured F concentrations in vitrophyres may be less than the actual concentration within the magma during its evolution prior to eruption.

Four vitrophyres were also analyzed for $\mathrm{C} 1$. concentrations ranged from 1000 to $1700 \mathrm{ppm}$, much lower than for $\mathrm{F}$ in these same samples. There appears to be little correlation with fluorine content. Although these $\mathrm{Cl}$ concentrations are much higher than for average granites (200 ppm, according to Carmichael et al., 1974), they are substantially lower than the 2000 to $6000 \mathrm{ppm}$ concentrations in some silicic peralkaline glasses (Carmichael et al., 197.4).

\section{COMPARISONS WITH OTHER ROCK SUITES}

The topaz rhyolites of the western United States are part of a complex assemblage of Middle to Late Tertiary volcanic rocks. Over much of the region an older high-K calc-alkalic sequence of intermediate to silicic composition was followed by a younger suite composed predominantly of basalt (with minor andesite) and rhyolite. The initiation of topaz rhyolite volcanism falls near the transition between these two series in the Basin and Range province and along the Rio Grande rift; topaz rhyolites are partly contemporaneous with both suites, confusing the interpretation of their tectonic setting and their ultimate origin. Rhyolitic lavas and tuffs are well-represented in the calc-alkalic suite in the San Juan Mountains of Colorado and in the Basin and Range. Rhyolitic tuffs and lavas, many of which are peralkaline in the Great Basin, are part of the later bimodal suite. This section compares the chemistry of the calc-alkalic and peralkaline rhyolites with that of topaz rhyolites.

\section{Peralkaline Rhyolites}

Many occurrences of peralkaline rhyolites (mainly comendites) are associated with continental rift systems around the world, including the Basin and Range province. Peralkaline rhyolites are defined as having a molecular excess of $\mathrm{Na}_{2} \mathrm{O}$ $+\mathrm{K}_{2} \mathrm{O}$ over $\mathrm{Al}_{2} \mathrm{O}_{3}$, expressed in the norm as acmite (ac). The average composition of comendites and pantellerites with normative quartz greater than $20 \%$ is given in Table 11 (Macdonald, 1974). The most important chemical features of peralkaline rhyolites as compared to subalkaline rhyolites, are high $\mathrm{Fe}_{2} \mathrm{O}_{3}, \mathrm{MnO}, \mathrm{TiO}_{2}, \mathrm{~F}$ and $\mathrm{Cl}$, with relatively low $\mathrm{Al}_{2} \mathrm{O}_{3}$ contents. Except for F content, these characteristics are distinct from those of topaz rhyolites. Peralkaline rhyolites are enriched in REE (except Eu), $\mathrm{Zn}, \mathrm{Be}, \mathrm{U}, \mathrm{Th}, \mathrm{Zr}, \mathrm{Hf}, \mathrm{Nb}, \mathrm{Ta}$, Mo and $\mathrm{W}$. Depleted elements 


\section{THIS PAGE}

\section{WAS INTENTIONALLY LEFT BLANK}


Table 11. Average analyses and composition ranges of peralkaline obsidians (Macdonald, 1974) compared with topaz rhyolite from the Thomas Range, Utah.

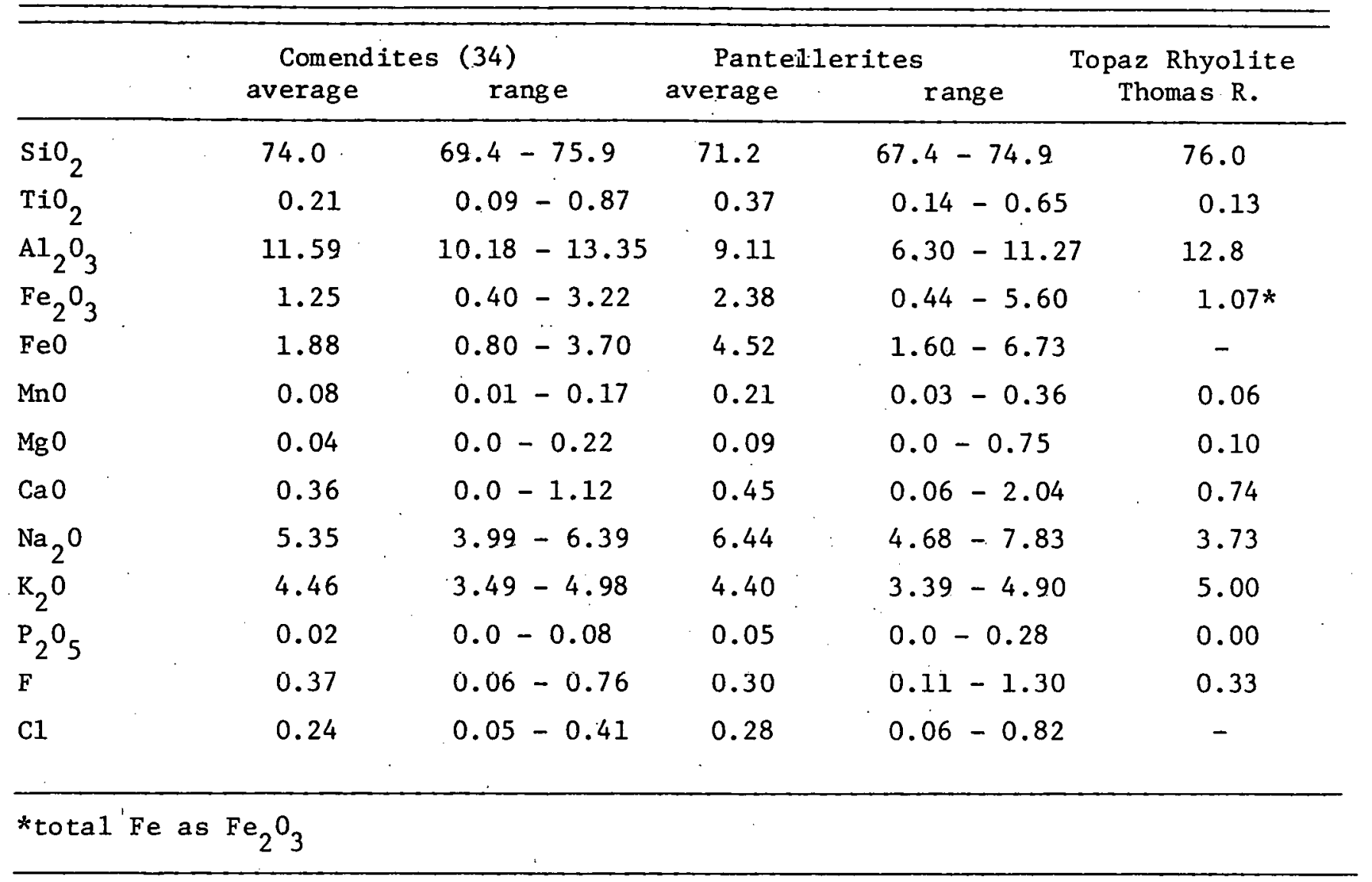


include $\mathrm{Ba}, \mathrm{Sr}, \mathrm{Sc}, \mathrm{V}, \mathrm{Cr}, \mathrm{Co}, \mathrm{Ni}, \mathrm{Cu}$ and $\mathrm{Eu}$. These trace element characteristics are similar in many ways to topaz rhyolites and testify to the generally fractionated nature of peralkaline rocks.

Peralkaline complexes in the Basin and Range province, according to Noble (1974), include the Kane Springs Wash caldera (13-14 m.y.), the Black Mountain center ( $\sim 7 \mathrm{~m} . \mathrm{y}$.$) , the Silent Canyon center ( 14 \mathrm{~m} . \mathrm{y}$.$) , McDermitt caldera (19.5-$ $15 \mathrm{~m} \cdot \mathrm{y} \cdot$; Rytuba, 1979) and numerous tuffs and lavas in northwestern Nevada (15-16 $\mathrm{m} \cdot \mathrm{y} \cdot)$.

Significant uranium deposits have been found near McDermitt caldera on the Nevada-Oregon border (Wallace and Roper, 1980). Samples were collected from several outflow sheets and ring-fracture domes from this complex in order to characterize the magma and to contrast it with topaz-bearing rhyolitic rocks. Analyses are presented in Table 12 and Appendix 2. The samples from the McDermitt area are generally slightly peralkaline with acmite in the normative mineralogy, in accord with published analyses (Greene, 1976). They show typical major element concentrations for comendites: $\mathrm{SiO}_{2}>74 \%, \mathrm{Al}_{2} \mathrm{O}_{3}<11 \%, \mathrm{Fe}_{2} \mathrm{O}_{3}>3 \%, \mathrm{Ca} 0<0.5 \%$, $\mathrm{K}_{2} \mathrm{O}+\mathrm{Na}_{2} \mathrm{O}>9 \%$ and $\mathrm{TiO}_{2}>0.2 \%$. In each of these characteristics, with the exception of $\mathrm{SiO}_{2}$ concentration, they are distinguishable from topaz rhyolites. Volcanogenic uranium deposits also occur within the Pena Blanca region of northern Mexico, where the ash-flow sheets are reportedly of a peralkaline nature (Goode11, 1978). Two samples from the Nopal Formation were analyzed, Table 13. However, the analyses do not indicate that the magma was peralkaline, but instead metaluminous to peraluminous (molecular $\mathrm{Al}_{2} \mathrm{O}_{3} / \mathrm{CaO}+\mathrm{Na}_{2} \mathrm{O}+\mathrm{K}_{2} \mathrm{O}=$ 1.04-1.08). Analyses of "fresh" rocks reported by Goodell (1978) from the same formation indicate peralkalinity, but few of the analyses total to $100 \%$ and low $\mathrm{Na}_{2} \mathrm{O} / \mathrm{K}_{2} \mathrm{O}$ ratios suggest alteration. Our analyses of the Nopal Formation display other characteristics atypical of peralkaline rocks, such as low $\mathrm{Fe}_{2} \mathrm{O}_{3}$ and $\mathrm{TiO}_{2}$, and high $\mathrm{MgO}$ and $\mathrm{CaO}$ (compare with the analyses from McDermitt caldera). In these respects they are more similar to calc-alkalic rhyolites or even topaz rhyolites, than to other peralkaline rocks.

Trace element concentrations for some of the samples from McDermitt and Pena Blanca are included in Table 14. Although these few samples probably are not representative of all peralkaline rhyolites in the Basin and Range they do indicate that topaz rhyolites are distinct from them in trace element concentrations. Both types of rocks are of ten concentrated in rare metals and fluorine, but the samples from McDermitt are general1y lower in U( $14 \mathrm{vs} . \sim 20 \mathrm{ppm}$ in vitrophyres) and Th( 15 vs. 40-60 ppm) than topaz rhyolites. Other characteristics include lower $\mathrm{Ta}$ and $\mathrm{Rb}$ and higher $\mathrm{Hf}$ In peralkaline rocks. Sample $\mathrm{MD}-36$ 
Table 12. Analyses of rhyolitic rocks from McDermitt caldera, Nevada

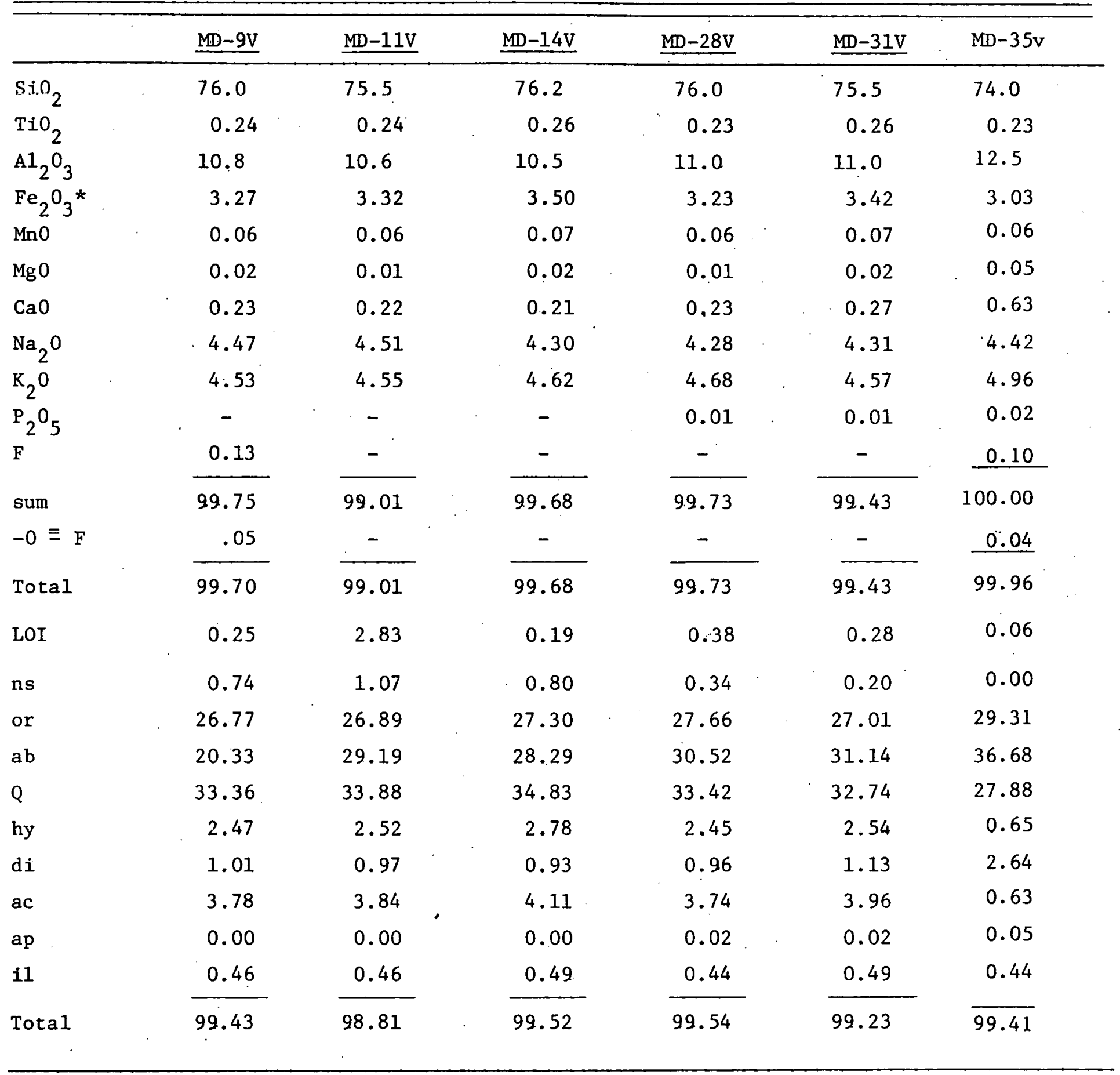


Table 13. Analyses of rhyolitic rocks from Peña Blanca region, Mexico.

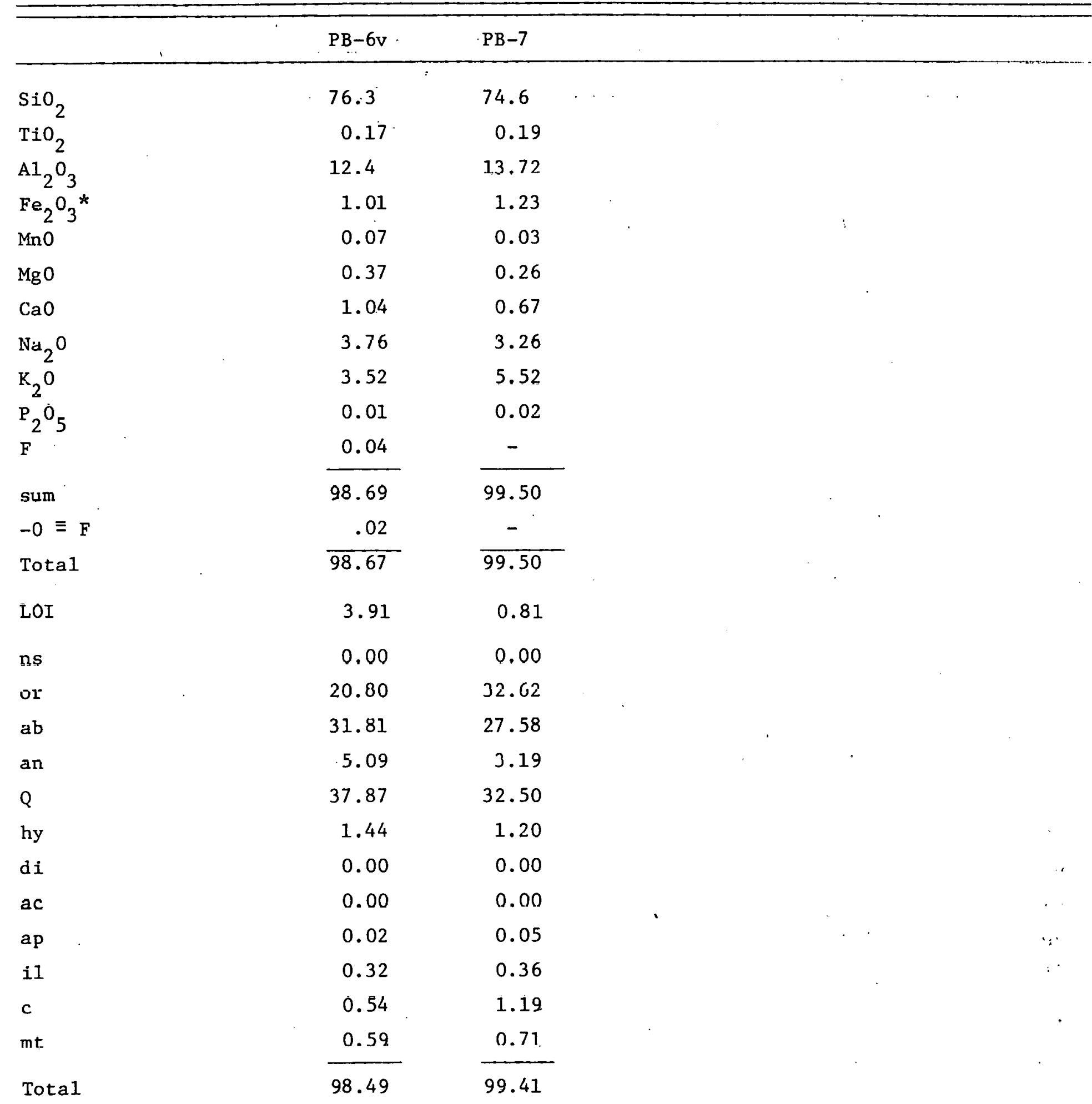


Table 14. Trace element composition of rhyolites from McDermitt caldera, Nevada (MD) and Peña Blanca, Mexico (PB)

\begin{tabular}{|c|c|c|c|c|c|c|}
\hline & $\mathrm{MD}-9$ & MD-35 & MD-36 & $\mathrm{PB}-6$ & Sample & $\mathrm{U}(\mathrm{ppm})$ \\
\hline$F$ & 0.13 & 0.10 & 0.06 & 0.04 & MD-8 & 10.5 \\
\hline $\mathrm{U}$ & 9.8 & 8.7 & 8.0 & 12.7 & $\mathrm{MD}-9$ & 9.8 \\
\hline $\mathrm{Be}$ & - & - & 3 & 2 & $M D-13$ & 10.8 \\
\hline Li & - & - & 30 & 10 & MD-14 & 15.8 \\
\hline $\mathrm{Sn}$ & - & - & 2 & $<2$ & $\mathrm{MD}-17$ & 20.4 \\
\hline $\mathrm{Zr}$ & - & 660 & - & 260 & MD-196 & 12.6 \\
\hline $\mathrm{Hf}$ & - & 9.3 & 9.8 & 2.6 & MD-35 & 8.7 \\
\hline $\mathrm{Ta}$ & - & 1.42 & 1.44 & 1.43 & $\mathrm{MD}-36$ & 8.0 \\
\hline Th & - & 16.2 & 14.9 & 27.3 & $\mathrm{~PB}-7$ & 12.7 \\
\hline $\mathrm{Ba}$ & - & 700 & 440 & 1050 & & \\
\hline $\mathrm{Rb}$ & - & 180 & 285 & 226 & & \\
\hline Cs & - & 8.2 & 104 & 18.5 & & \\
\hline La & - & 38 & 44 & 30 & & \\
\hline $\mathrm{Ce}$ & - & 72 & 94 & 52 & & \\
\hline $\mathrm{Nd}$ & - & 46 & - & - & & \\
\hline $\mathrm{Sm}$ & - & 8.3 & 10.7 & 3.8 & & \\
\hline $\mathrm{Eu}$ & - & 3.1 & 1.2 & 0.54 & : & \\
\hline $\mathrm{Tb}$ & - & 1.4 & 2.4 & 0.41 & & \\
\hline $\mathrm{Yb}$ & - & 5.3 & 8.4 & 1.3 & & \\
\hline $\mathrm{Lu}$ & - & 0.82 & 1.2 & 0.38 & & \\
\hline
\end{tabular}




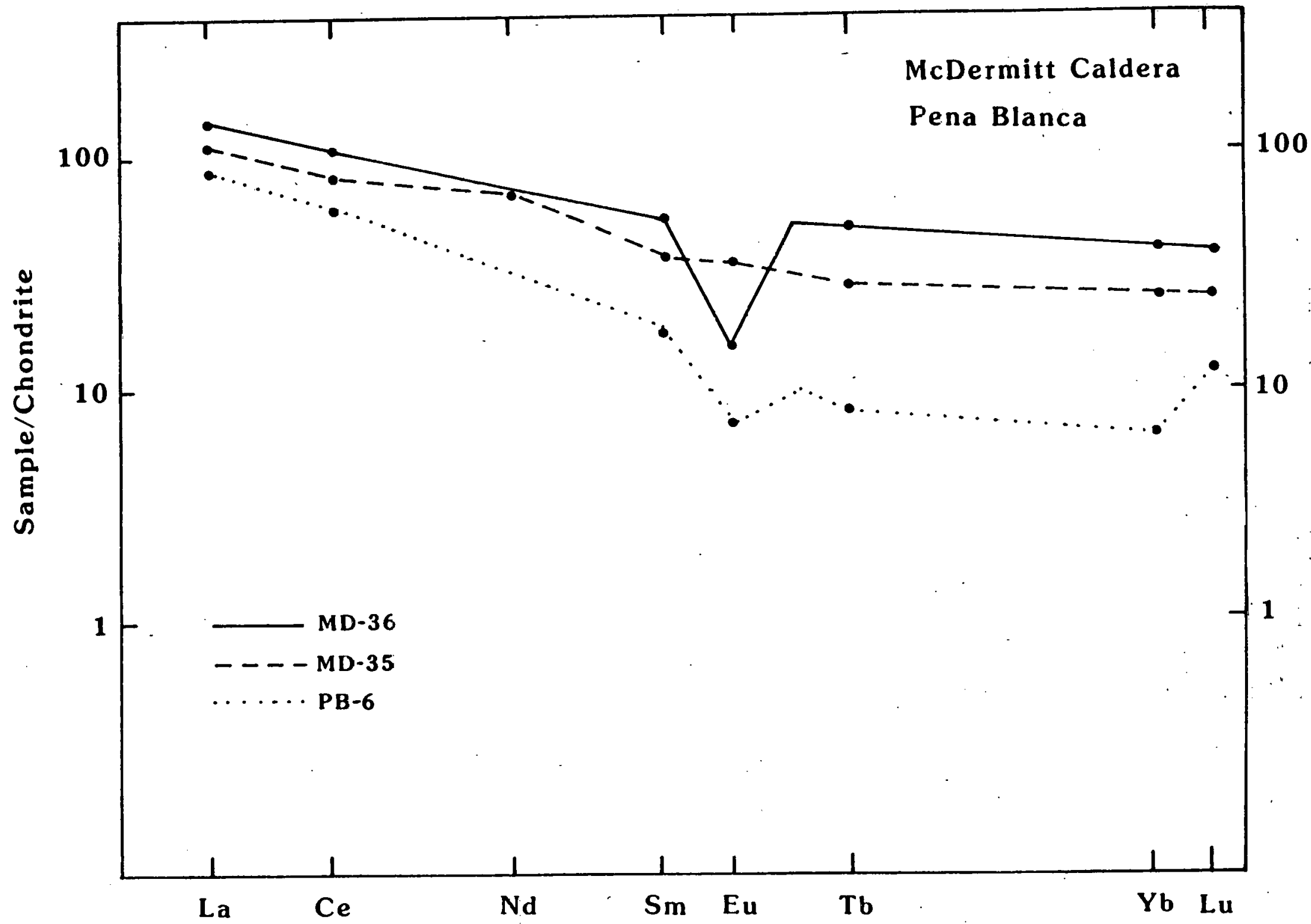

Fig. 8. Chondrite-normalizec REE pạtterns for samples from McDermitt caldera, Nevada (MD-36 \& -35) and Pena Blanca, Mexico (PB-6). Eoth are rhyolitic ash flows and do not 
also contains an extremely large amount of Cs ( $>100 \mathrm{ppm}$ ).

The REE patterns (Fig. 8) for these samples are strikingly different from those of most topaz rhyolites. The light REE/heavy REE ratio is slightly higher in all three samples and the Eu anomalies, typical of topaz rhyolites, are small or nonexistent. Tn the compilation of Noble et al. (1979), most peralkaline rhyolites have steep negative slopes $\left(\mathrm{La} / \mathrm{Yb}_{\mathrm{N}} \gg \mathrm{I}\right)$, even those with high concentrations of incompatible elements. However, the REE patterns are similar to SM-61a, the "lithophile-depleted" rhyolite from Utah's Thomas Range.

The petrogenesis of peralkaline rhyolites has been discussed extensively (Bailey et al., 1974, and references therein). Since peralkaline magmas occur in ocean islands as well as in continental rifts, and have low initial $\mathrm{Sr}$-isotope ratios, many petrologists think, they are the result of differentiation of mantle-derived mafic magmas. Others have suggested that the direct partial melting of the upper mantle or lower crust, with or without the involvement of an alkal1-bearing vapor, may result in peralkaline magmas (Bailey, 1974; Yoder, 1973).

\section{Orogenic Rhyolites}

Part of the orogenic volcanic series consists of intermediate to silicic rocks that display "calc-alkalic" differentiation trends (lack of iron enrichment) when plotted on an AFM ( $\left.\mathrm{Na}_{2} \mathrm{O}+\mathrm{K}_{2} \mathrm{O}, \mathrm{Fe} 0, \mathrm{Mg} 0\right)$ diagram. Calc-alkalic lavas and tuffs of mid-Tertiary age are prominent throughout the area of distribution of topaz rhyolites in the western U.S. Almost all of the suites in the western U.S. would be termed high-K, after the classification of Pecerillo and Taylor (1976). The distinction between calc-alkalic rhyolites and other types of highsilica volcanic rocks is difficult to make if just the silicic members of the sulles are cramined, as noted by Irvine and Baragar (1971). However, consideration of the trace element characteristics and mode of emplacement generally distinguishes orogenic rhyolites from topaz rholites.

Lindsey (1979) reports some information on the generally calc-alkalic sequence (42-32 m.y.) that preceded the eruption of topaz rhyolites at Spor Mountain and in the Thomas Range. Figures 9 and 10 show some of the major and trace element characteristics that distinguish the young topaz rhyolites from the older rhyolitic ash-flow tuffs and their precursors. Table 15 contains analyses of two highsilica tuffs that culminated the "calc-alkalic" volcanism in the Spor Mountain region. They are higher in $\mathrm{TiO}_{2}$ and $\mathrm{MgO}$ (both greater than $0.20 \%$ ) and have lower total alkalies $(\sim 7 \%)$ and MnO $(0.07 \%)$, than most topaz rhyolites in spite of their similarity in $\mathrm{SiO}_{2}$ and $\mathrm{Al}_{2} \mathrm{O}_{3}$ content and gross mineralogy to topaz rhyolites. Perhaps the most remarkable differences between topaz rhyolites and these calc- 


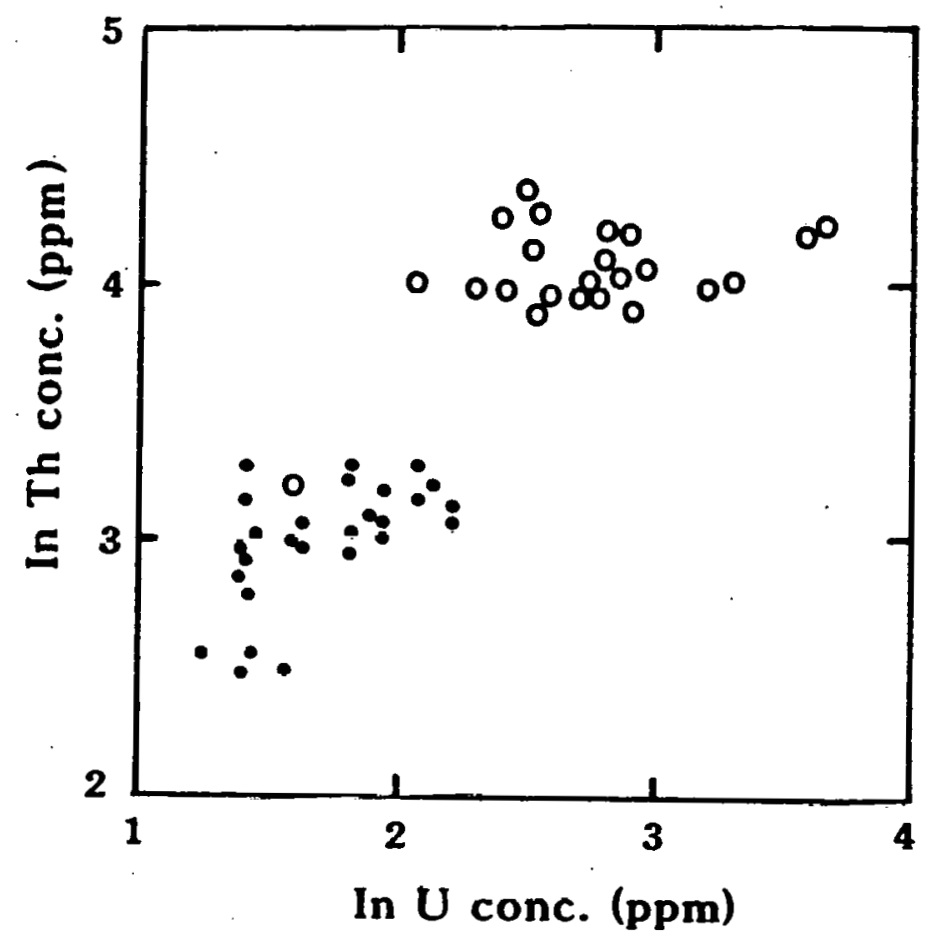

Fig. 9. Logarithmic plot of Th vs. U content of rhyolitic rocks from west-central Utah. Filled circles represent rhyolitic ash-flow tuffs ( $>25 \mathrm{~m} . \mathrm{y}$ ) and open circles represent topaz rhyolite lavas. Mata from Lind $3 \mathrm{cy}$ (1379) alld this report.

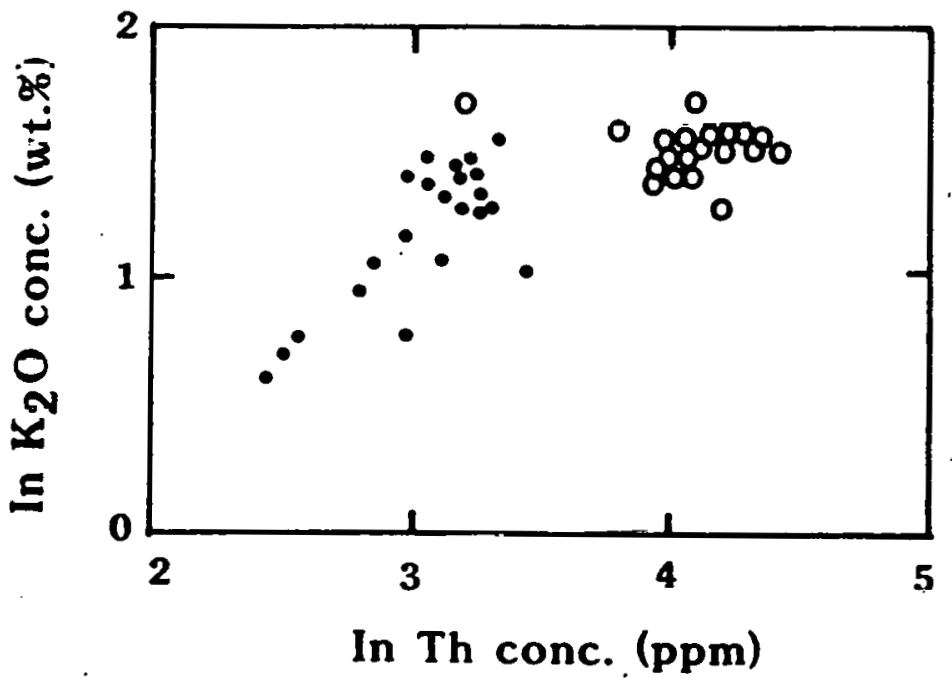

Fig. 10. Logarithmic plot of $\mathrm{K}_{2} \mathrm{O}$ vs. Th from rhyolitic rocks of westcentral Utah. Symbols are the same as those in Figure 9. 
Table 15. Comparison of calc-alkalic rhyolite ash-flow tuffs with topaz rhyolites from west-central Utah from the Thomas Range, Utah.

\begin{tabular}{|c|c|c|c|c|c|}
\hline & U $84^{1}$ & U155 ${ }^{2}$ & $\mathrm{U} 43^{3}$ & $\mathrm{SM}^{4}$ & $\mathrm{TR}^{5}$ \\
\hline $\mathrm{SiO}_{2}$ & 76 & 76 & 76 & 73.3 & 76.0 \\
\hline $\mathrm{TiO}_{2}$. & 0.2 & 0.3 & 0.3 & 0.06 & 0.13 \\
\hline $\mathrm{Al}_{2} \mathrm{O}_{3}$ & 12 & 13 & 13 & 13.4 & 12.8 \\
\hline $\mathrm{Fe}_{2} \mathrm{O}_{3}$ & 1.3 & 1.2 & 1.3 & 1.36 & 1.07 \\
\hline $\mathrm{MnO}$ & 0.09 & 0.04 & 0.07 & 0.06 & 0.06 \\
\hline Mg0 & 0.7 & 0.5 & 0.5 & 0.07 & 0.10 \\
\hline $\mathrm{CaO}$ & 1.1 & 1.1 & 1.4 & 0.79 & 0.74 \\
\hline $\mathrm{Na}_{2} \mathrm{O}$ & 2.1 & 3.1 & 3.3 & 4.41 & 3.73 \\
\hline $\mathrm{K}_{2} 0$ & 4.0 & 4.4 & 3.6 & 4.58 & 5.00 \\
\hline $\mathrm{P}_{2}{ }^{0}{ }_{5}$ & - & - & - & 0.00 & 0.00 \\
\hline $\mathrm{F}$ & - & - & - & 1.07 & 0.33 \\
\hline $\mathrm{Ba}$ & 500 & 1500 & 1000 & 315 & $200^{+}$ \\
\hline $\mathrm{Be}$ & 5 & 2 & 3 & 56 & $7^{+}$ \\
\hline $\mathrm{Ga}$ & 30 & 20 & 20 & $40^{+}$ & $30^{+}$ \\
\hline La & 50 & 70 & - & 59 & 35 \\
\hline $\mathrm{Nb}$ & 15 & 20 & 15 & $100^{+}$ & $70^{+}$ \\
\hline $\mathrm{Sr}$ & 200 & 300 & 500 & $20^{+}$ & 5 \\
\hline $\mathrm{Zr}$ & 70 & 100. & 100 & 775 & 600 \\
\hline $\mathrm{U}$ & 5 & 8 & 7 & 37 & 19. \\
\hline Th & 21 & 24 & 25 & 66. & 49 \\
\hline
\end{tabular}

1) Dell Tuff from Lindsey (1979), trare element analyses semi-quantitative.

2). Joy Tuff, Black Glass member (Lindsey, 1979).

3) Joy Tuff, crystal-rich member (Lindsey, 1979).

4). Average of 4 vitrophyres from Spor Mtn. (Bikun, this report).

5) average of 5 vitrophyres from Thomas Range (Bikun, this report).

+ ) with data from Lindsey (1979). 
Table 16. Comparison of Nathrop rhyolite with rhyolite from Summer Coon volcano.

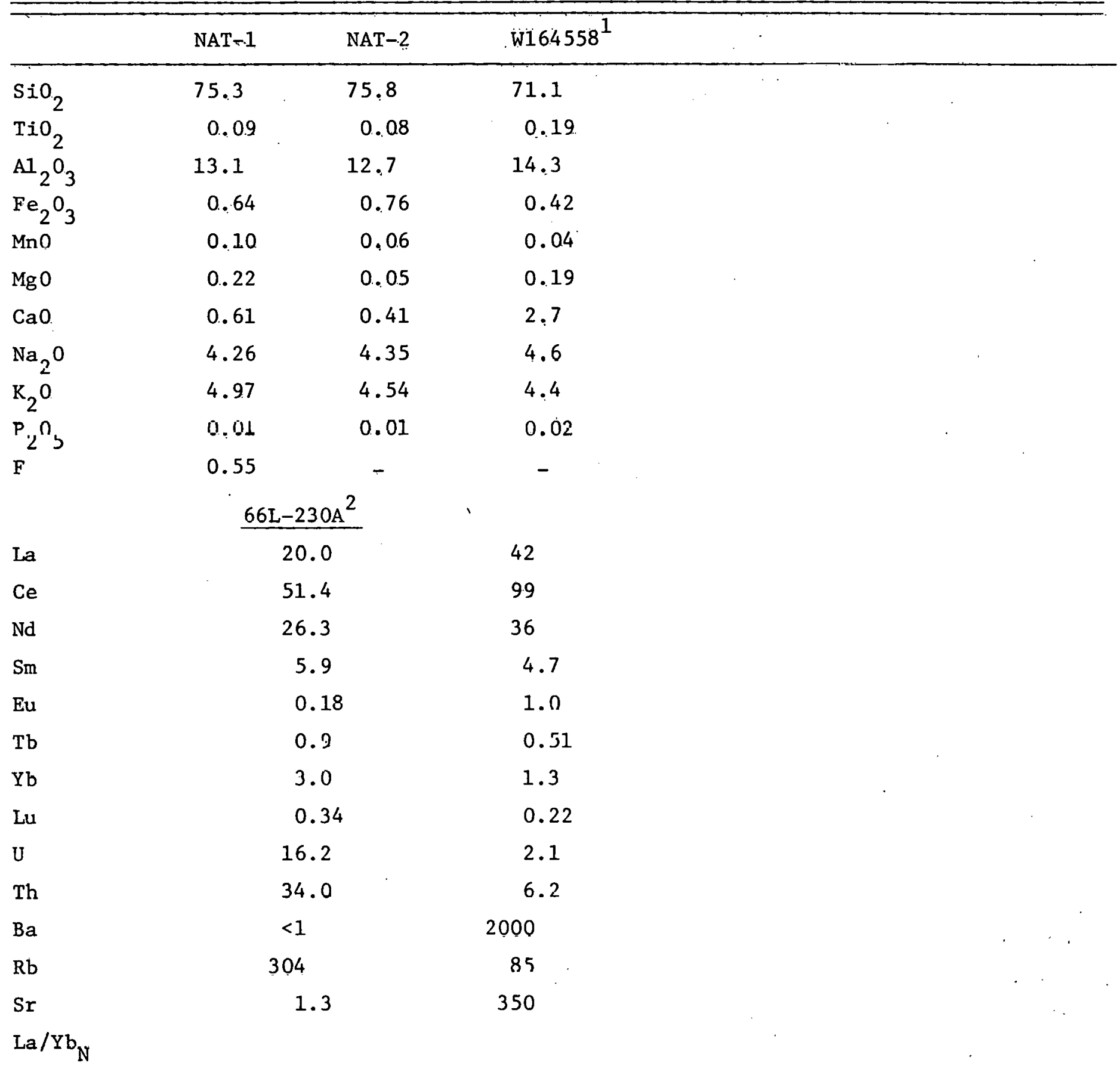

1) analysis $\mathbb{k}_{4}$, rhyolite lava (Zielinski and Lipman, 1976) Summer Coon volcano

2) (Zielinski et a1., 1977) Nathrop rhyolite 


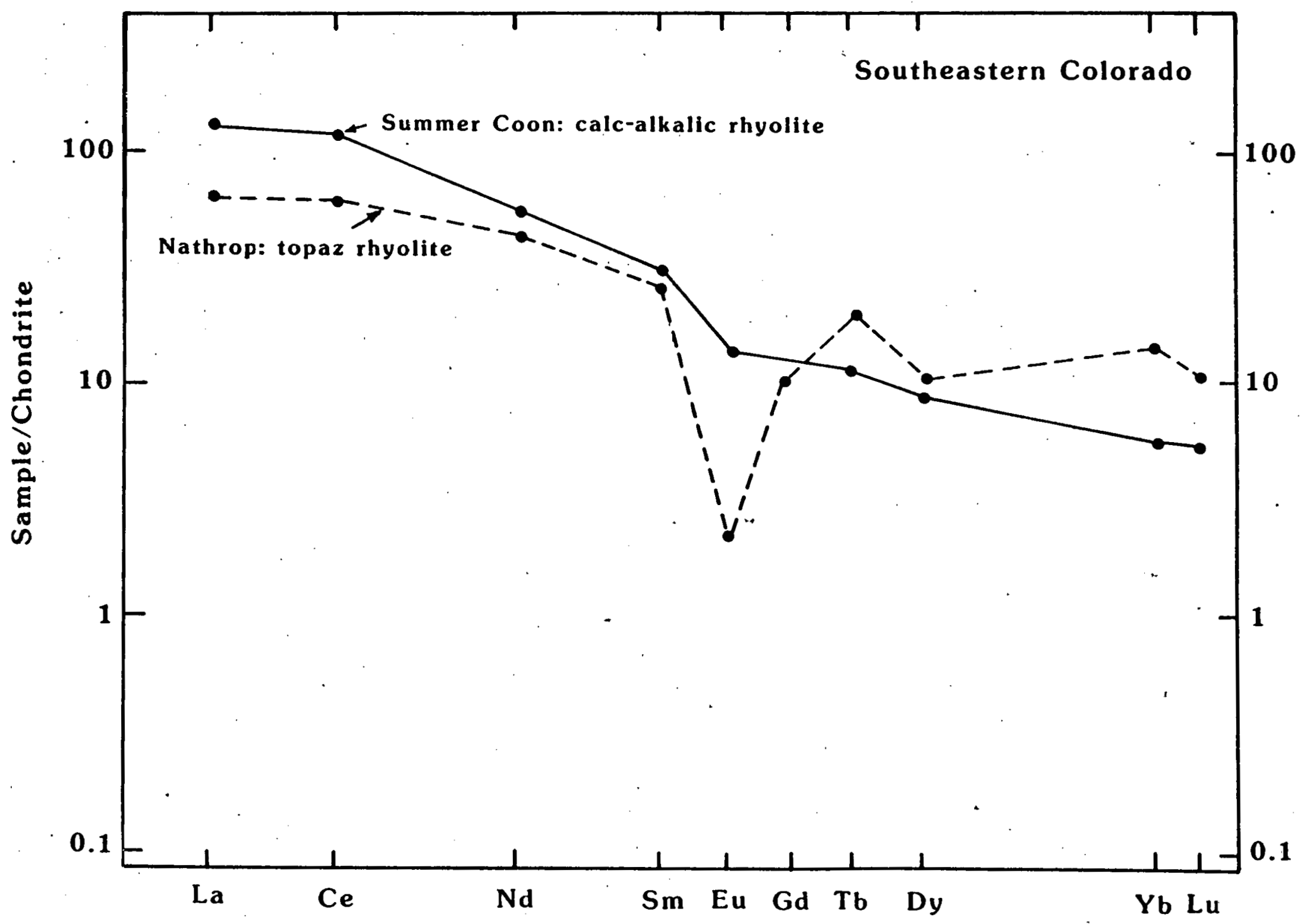

Fig. 11. Chondrite-normalized REE patterns for rhyolitic rocks from southwestern Colorado. Note the lower $\mathrm{La} / \mathrm{Yb}$ ratio and deeper Eu anomaly of the topaz rhyolite. These features are typical of comparisons between topaz rhyolites and nearby, often nearly contemporaneous, calc-al "orogenic" rhyolites. 
alkalic tuffs are their trace element contents. U( $\vec{\imath}_{14}$ vs. $<8$ ppm) and $\mathrm{Th}(>50$ vs. $<25 \mathrm{ppm})$ are dramatically higher in topaz rhyolites and $\mathrm{Ba}(<300$ vs. $>500 \mathrm{ppm})$ and $\mathrm{Sr}(<20 \mathrm{vs} .>200 \mathrm{ppm})$ are much lower.

In Colorado, the $28-29 \mathrm{~m} . \mathrm{y}$. old topaz rhyolite at Nathrop follows and is partly contemporaneous with a calc-alkalic suite in the nearby San Juan Mountains (35-26.5 m.y. old). Table 16 and Figure 11 compare the composition and REE patterns of rhyolites from both sequences (Zielinski et al., 1977; Zielinski and Lipman, 1976). Again, $\mathrm{Rb}, \mathrm{U}$ and Th are much higher in the topaz rhyolites, while compatible elements such as $\mathrm{Sr}, \mathrm{Ba}$ and $\mathrm{Ti}$ are much lower in the $\mathrm{F}-\mathrm{rich}$ rocks.

The features noted in these two cases are fairly typical of other calcalkalic rhyolites from around the world. Table 17 shows a collection of other analyses from the literature, demonstrating that the trace (high $\mathrm{Rb}, \mathrm{U}$, Th; low $\mathrm{Ba}, \mathrm{Sr}$ ) and major (low $\mathrm{Ti}, \mathrm{Ca}, \mathrm{Mg}$; high total alkalies, F) element sharacteristics of topaz rhyolites are distinctive when compared with orogenic rhyolites.

It is generally agreed that rhyolitic magmas can be produced from broadly andesitic parent melts formed in subduction zones by fractional crystallization of olivine or amphibole, followed by pyroxene and plagioclase. This sequence produces the necessary silica enrichment and inhibits the Fe-enrichment typical of tholeiitic differentiation trends. Other processes that can produce or modify rhyolitic magmas produced in arc-type settlings are crustal fusion (Ewart and Stipp, 1968; Ewart et a1., 19.77; DePaolo and Wasserburg, 1977) and thermogravitational diffusion (Hildreth, 1979). The relative importance of these three processes is not yet known and an assessment is beyond the scope of this paper.

From this admittedly brief review it is apparent that topaz rhyolites are distinct from calc-alkalic and peralkaline rhyolites even though they are in part contemporaneous with both types in the western United States. The major characteristics of each rhyolite suite are summarized in Table 18.

\section{DISCUSSTON}

Topaz rhyolites are widespread in western North America, (Fig. 1) and many others probably remain unrecognized. The emplacement of these rhyolites appears to have spanned most of the later half of the Cenozoic Era. Published isotopic ages are 1isted in Table 19. The oldest dated topaz rhynlite we know of is in the Elkhorn Mountains of Montana with a $35 \mathrm{~m} . \mathrm{y}$. age. Along the trend of the Rio Grande Rift a group of topaz and garnet rhyolites was erupted 29-24 m.y. ago in Colorado and New Mexico. Another group of shallow intrusions and extrusive domes near Lake City, Colorado, have younger ages of about $18 \mathrm{~m} . \mathrm{y}$. A distinctively younger $(3.3 \mathrm{~m} . \mathrm{y}$.$) . topaz rhyolite occurs near the margins of the Mt. Taylor$ 
Table 17. Comparison of calc-alkalic rhyolites with average topaz rhyolite.

\begin{tabular}{|c|c|c|c|c|c|c|c|c|}
\hline & 1 & 2 & 3 & 4 & 5 & 6 & 7 & 8 \\
\hline $\mathrm{SiO}_{2}$ & 74.4 & 73.7 & 71.6 & 75.3 & 72.2 & 74.2 & 73.8 & 76.0 \\
\hline $\mathrm{TiO}_{2}$ & 0.12 & 0.21 & 0.3 & 0.27 & 0.33 & 0.28 & 0.23 & 0.13 \\
\hline $\mathrm{Al}_{2} \mathrm{O}_{3}$ & 11.9 & 12.8 & 13.9 & 12.6 & 12.6 & 13.3 & 13.6 & 12.8 \\
\hline $\mathrm{Fe}_{2} \mathrm{O}_{3}$ & 0.83 & 1.66 & 2.6 & 2.55 & 4.37 & 1.89 & 1.91 & 1.07 \\
\hline MnO & 0.07 & 0.06 & 0.1 & 0.07 & 0.05 & 0.05 & 0.05 & 0.06 \\
\hline $\mathrm{Mg} 0$ & 0.2 & 0.4 & 0.5 & 0.24 & 0.58 & 0.28 & 0.30 & $0 . .10$ \\
\hline $\mathrm{CaO}$ & 0.8 & 1.9 & 1.7 & 1.25 & 2.07 & 1.59 & 1.53 & 0.74 \\
\hline $\mathrm{Na}_{2} \mathrm{O}$ & 3.5 & 3.9 & 4.5 & 4.02 & 3.45 & 4.24 & 3.71 & 3.73 \\
\hline $\mathrm{K}_{2} \mathrm{O}$ & 4.3 & 2.7 & 3.0 & 3.82 & 3.70 & 3.18 & 3.60 & 5.00 \\
\hline $\mathrm{P}_{2} \mathrm{O}_{5}$ & - & - & 0.1 & 0.02 & 0.02 & 0.05 & 0.05 & 0.00 \\
\hline $\mathrm{F}$ & - & - & $\pi$ & - & - & - & - & 3300 \\
\hline $\mathrm{Zr}$ & 59 & 147 & - & 150 & 160. & 145 & 142 & 600 \\
\hline $\mathrm{Rb}$ & 124 & 76 & 54 & 55 & 60 & 107 & 113. & 450 \\
\hline $\mathrm{Sr}$ & 109 & 269 & 313 & 20.0 & 245 & 106 & 140 & 5 \\
\hline $\mathrm{Ba}$ & 1135 & 970 & - & 645 & 575 & 859 & 961 & 200 \\
\hline Th & 13.7 & 7.5 & - & - & 15 & $11: 5$ & 11.4 & 49 \\
\hline $\mathrm{U}$ & .4 .3 & 2.5 & - & - & - & 2.6 & 2.5 & 19 \\
\hline $\operatorname{Sr} 87 / 86$ & \multicolumn{2}{|c|}{$0.7045 \pm 3$} & - & 0.7035 & 0.7035 & 0.7053 & 0.7052 & - \\
\hline
\end{tabular}

1 \& 2) Rose et al. (1979), Los Chocoyos ash, Guatemala.

3) White and McBirney (1978), average Oregon Cascades rhyolite.

4 \& 5) Lowder and Carmichael (197C), Talasea.

6). Ewert and Stipp (1968), average rhyolitic lava, Taupo volcanic zone, New Zealand.

7) Ewert and Stipp (1968), average rhyolitic ignimbrite Taupo volcanic zone, New Zealand.

8) Average topaz rhyolite from the Thomas Range, Utah. 
Table 18. Major characteristizs of topaz rhyolites, calc-alkalic (orogenic) rtyolites and topaz rhyolites.

\begin{tabular}{|c|c|c|c|}
\hline Rhyolite Type & Mode of occurrence & Mineralogy & Chemistry \\
\hline $\begin{array}{l}\text { Topaz rhyolites } \\
\text { Ref erences: } \\
\text { Turley et a1. (1979) } \\
\text { Lindsey (197.9) } \\
\text { This report }\end{array}$ & $\begin{array}{l}\text { small dcmes or short } \\
\text { lava flows underlain } \\
\text { by bzeccias and tuffs } \\
\text { - tikes and plugs }\end{array}$ & $\begin{array}{l}\text { sanidine } \\
\text { Na-plagioclase } \\
\text { quartz } \\
\text { biotite } \\
\text { fluorite } \\
\text { (topaz, garnet, } \\
\text { fluorite, bixbyite, } \\
\text { pseudobrookite, and } \\
\text { beryl occur in cavities) }\end{array}$ & 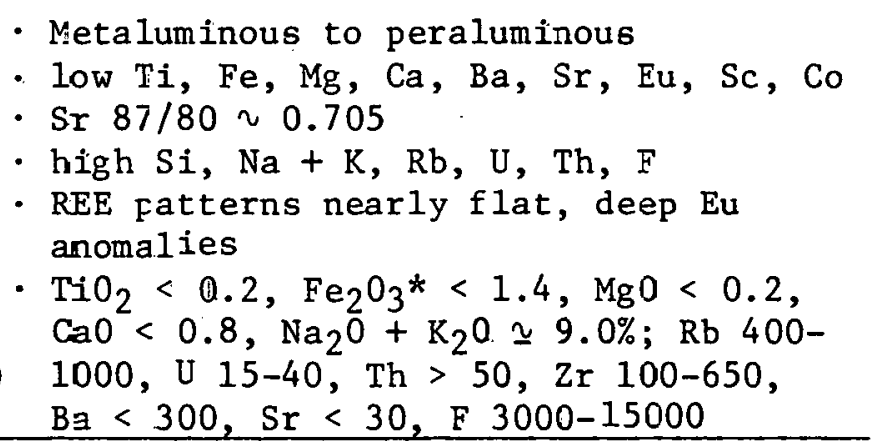 \\
\hline $\begin{array}{l}\text { Calc-alkalic } \\
\text { (orogenic) rhyolites } \\
\text { References: } \\
\text { Ewart (1979), } \\
\text { Tables } 15,16 \& 17 \text {, } \\
\text { This report }\end{array}$ & $\begin{array}{l}\text { - smali domes or lava } \\
\text { flows on the flanks } \\
\text { or within the craters } \\
\text { of composite volcanoes } \\
\text { - voluminous ash-flow } \\
\text { sheets } \\
\text { - eikes ard plugs within } \\
\text { composite volcanoes }\end{array}$ & $\begin{array}{l}\text { plagioclase } \\
\text { sanidine } \\
\text { quartz } \\
\text { hornblende } \\
\text { biotite } \\
\text { augite } \\
\text { hypersthene } \\
\text { fayalite }\end{array}$ & 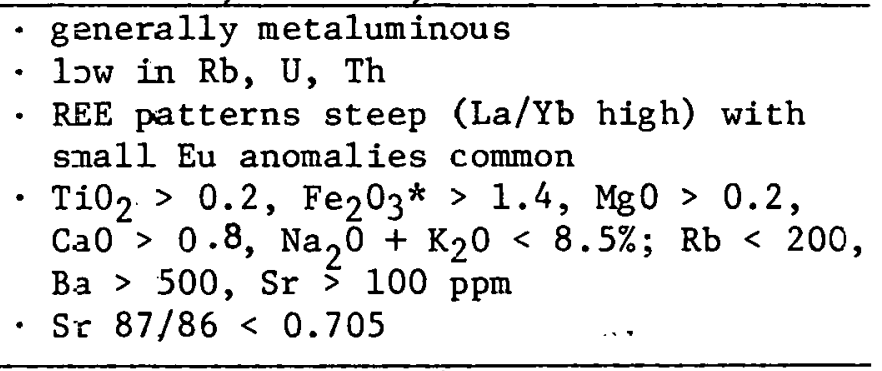 \\
\hline $\begin{array}{l}\text { Ref er ences: } \\
\text { Macdonald (1974) } \\
\text { Sutherland (1974) } \\
\text { Noble (1979) } \\
\text { This report }\end{array}$ & $\begin{array}{l}\text { volumincus ash-f low } \\
\text { sheets } \\
\text { - sma1l dones around } \\
\text { calderas } \\
\text { - cikes and plugs }\end{array}$ & $\begin{array}{l}\text { plagioclase } \\
\text { sanidine } \\
\text { quartz } \\
\text { aegirine-augite } \\
\text { Na-Fe hedenbergite } \\
\text { fayalite } \\
\text { (arfvedsonite and } \\
\text { riebeckite occur in the } \\
\text { groundmass and cavities) }\end{array}$ & 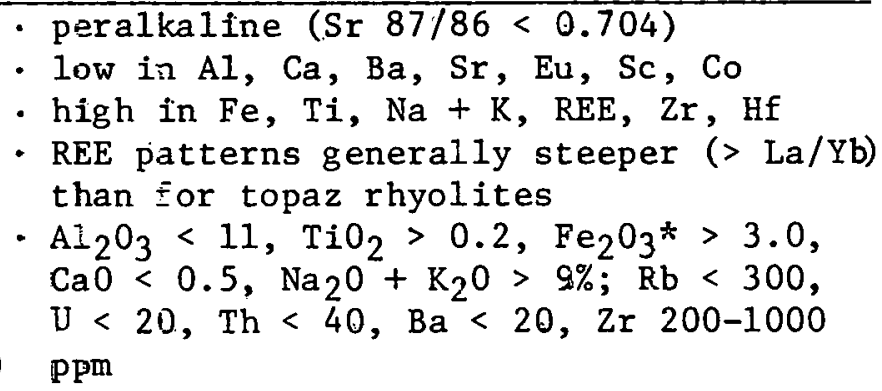 \\
\hline
\end{tabular}


Table 19. Isotopic ages for topaz rhyolites in the western United States.

Location

Nathrop; Colorado

Specimen Mountain, Colorado

Rosita Hills-Silver Cliff, Colorado

Black Range, New Mexico

Wah Wah Mountains, Utah

Spor Mountain, Utah

Staats Mine, Wah Wah Mtns., Utah

Nellie Creek, Lake City, Colorado

Jarbidge, Nevada

Izenhood Ranch, Sheep Creek Range, Nevada

Keg Mountains, Utah

Thomas Range, Utah

Honeycomb Hills, Utah

Smelter Knolls, Utah

Grants Ridge, New Mexico

Minera1 Mountains, Utah

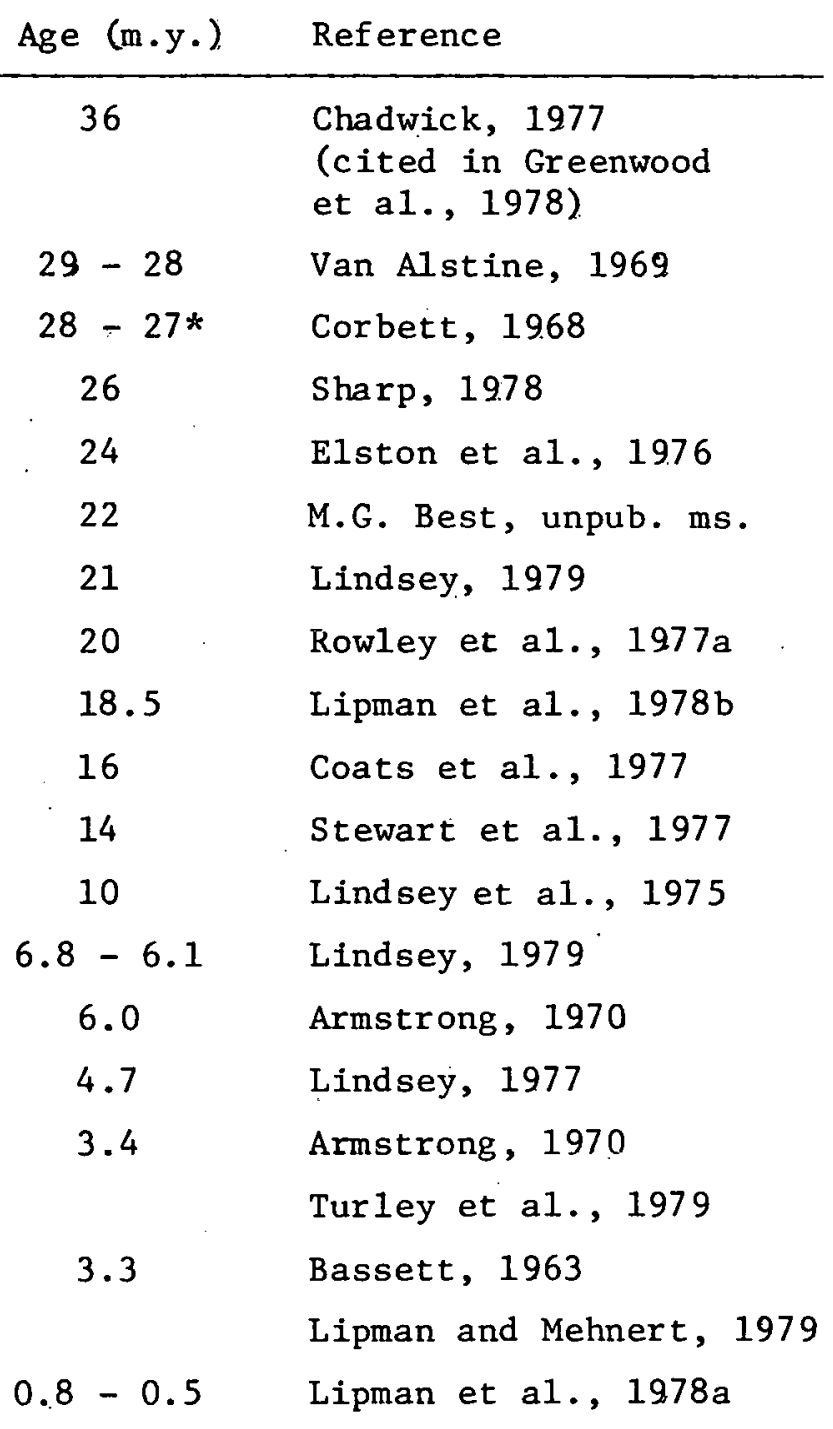
Chadwick, 1977
(cited in Greenwood et a1., 1978).

Van Alstine, 1969

Corbett, 1968

Sharp, 1978

E1ston et a1., 1976

M.G. Best, unpub. ms.

Lindsey, 1979

Rowley et a1., 1977a

Lipman et a1., 1978b

Coats et al., 1977

Stewart et a1., 1977

Lind sey et a1., 1975

Lindsey, 1979

Armstrong, 1970

Lind sey, 1977

Armstrong, 1970

Turley et al., 1979

Bassett, 1963

Lipman and Mehnert, 1979

Lipman et al., 1978a

* date on rorks assimed to be cogenetic with topaz rhyolite 
volcanic field near Grants, New Mexico. The topaz rhyolites in the Great Basin are all younger than about, $22 \mathrm{~m} . \mathrm{y}$, old and topaz has been reported from lava domes in the Mineral Mountains, Utah, that are less than $1 \mathrm{~m} . \mathrm{y}$, old.

The nature of contemporaneous volcanic and tectonic activity reveals much about the setting of topaz rhyolite magmatism. The distribution of these rhyolites suggests that they commonly occur in areas that have experienced calc-alkalic magmatism (Fig. 12). However, topaz rhyolites are generally erupted as small coalescing domes and lava flows distinct from the caldera activity that preceded them in many cases. The Oligocene topaz rhyolites of Montana occur near the transition from silicic ash-flow volcanism to bimodal basalt-rhyolite volcanism (Chadwick, 1977). The Miocene Taylor Creek rhyolite of New Mexico has been related to the rise and emplacement of a granitic pluton into the upper crust (Elston, 1979), and in Colorado, a variety of calc-alkalic lavas and tuffs are contemporaneous with the older ( $>24 \mathrm{~m} \cdot \mathrm{y}$.$) topaz rhyolites (Steven, 1975). Trachyandesite 1avas$ were contemporaneous with topaz rhyolites during the Miocene in Utah (Best et al., ms.). Basaltic andesite $\left(\sim 57 \% \mathrm{SiO}_{2}\right)$ lavas were nearly contemporaneous with the Lake City occurrences in the San Juan Mountains of Colorado (Lipman, et al., 1978a). The topaz rhyolites younger than $15 \mathrm{~m} . \mathrm{y}$. are associated with basaltic magmatism in the Great Basin (Honeycomb Hills, Thomas Range, Mineral Range, Utah and the Sheep Creek Range and Jarbidge occurrences in Nevada) and at Grants Ridge, New. Mexion.

Topaz rhyolite volcanism generally coincides with periods of presumed lithospheric extension along the Kio Grande rift that developed initially approximately $30 \mathrm{~m} . \mathrm{y}$. ago (Eaton, 1979), in the Great Basin where the main phase of basin and range taulting began $21-20 \mathrm{~m} . \mathrm{y}$. ago (Rowley et al., 1978 ) and in Montana where. block faulting began about $36 \mathrm{~m} . \mathrm{y}$. ago (Chadwick, 1977).

The assocation in space and time of topaz rhyolites and two different types of mafic magmatism (calc-alkalic and basaltic) suggests that they may be derived from melting of the continental crust caused by the passage of hot magmas through the crust or by a rise in the geothermal gradient that also caused the more mafic magma, rather than by differentiation of either of the two contrasting magma types. This suggestion, along with their extensional tectonic setting and their geochemical features, implies that topaz rhyolites may be the extrusive equivalents of "anorogenic" (Loiselle and Wones, 1979; Wones, 1979; Petro, et a1., 1979). or "R-type" granites (for residual, White, 19.79). Some anorogenic granites are thought to result from small degrees of partial melting of an already waterdepleted (and F-enriched). crustal source from which earlier water-rich magmas were removed under conditions of granulite facies metamorphism--hence the residual nature of the source. Fillippov et a1. (1974) have shown that biotites 


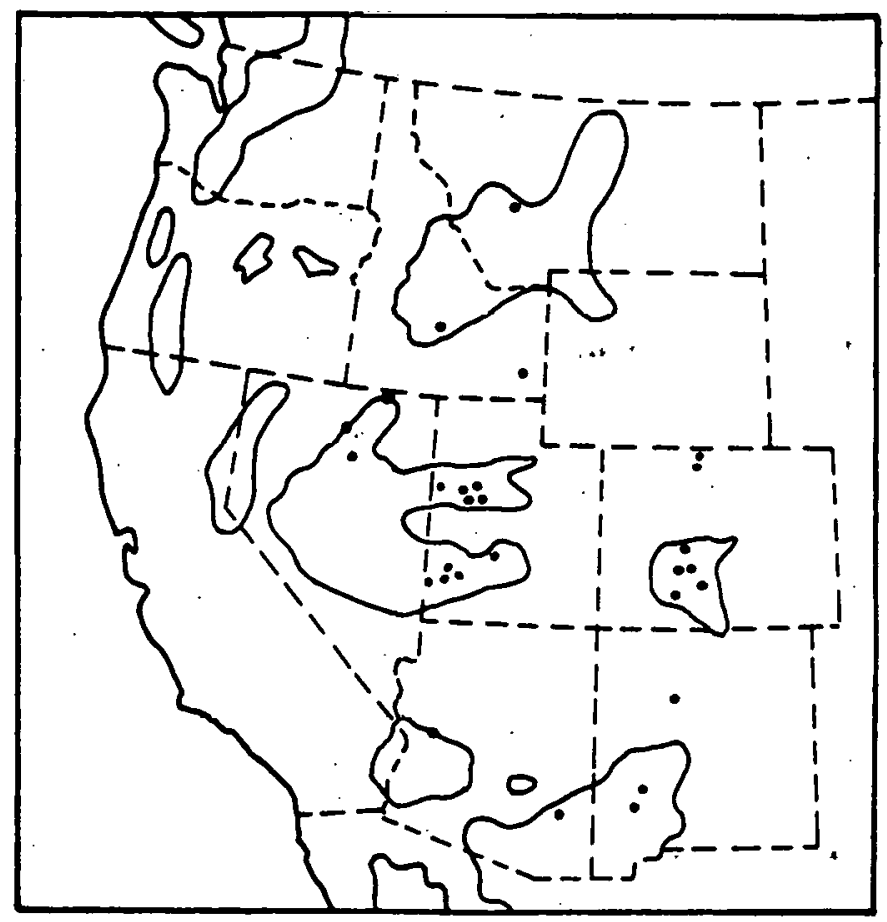

Fig. 12. Distribution of known topaz rhyolites (dots) compared with the approximate area covered by mid-Cenozoic calc-alkalic lavas and tuffs. 
from granulite facies metamorphic rocks contain greater amounts of $F$ than those in amphibolite facies rocks $(0.65 \% \mathrm{~F}$ vs. $0.24-0.38 \% \mathrm{~F})$. Since anorogenic magmas typically have high contents of incompatible trace elements (REE - except Eu, $\mathrm{Zr}, \mathrm{Nb}, \mathrm{Ta}, \mathrm{Sn}, \mathrm{U}, \mathrm{Th})$ and F, White (1979) suggests that the breakdown of F-rich biotites and amphiboles provides the volatiles for partial melting. These F-rich melts may then complex highly charged cations (U, Th, $\mathrm{Zr}$ ) that were rejected by earlier water-rich melts. Differentiation may further enrich portions of the melt in $\mathrm{F}$ and these generally incompatible elements. Figure 13 shows the alkal1 compositional fields of various granite types from SE Australia compared to topaz rhyolites from the western United States. Other characteristics of anorogenic granites are compared with those of topaz rhyolites in Table 20; the similarities are quite striking.

White (1979) and Loiselle and Wones (1979) include peralkaline granites in this category. Although peralkaline magmas are quite distinct from topaz rhyolites, it is important to remember that peralkaline magmatism was contemporaneous with topaz rhyolite volcanism in the Great Basin. Loiselle and Wones (1979) suggest that there are two types of anorogenic granites: crustal melts caused by the residence of alkali basalts in the continental crust, and the end products of extreme crystal fractionation of alkali basalts, producing contemporaneous high Sr 87/86 (probably peraluminous) and low Sr 87/86 (probably peralkaline) granites. The White Mountain magma series (Foland and Friedman, 19.77) and the younger Nigerian granites (van Breeman et al., 1975) display this two-fold character. Presumably topaz rhyolites and peralkaline rhyolites of the Great Basin could be related to one another in the same fashion; topaz rhyolites result when $\overline{\mathrm{F}}-\mathrm{rich}$ high-grade metamorphic crust is melted by basaltic magmas and peralkaline rhyolites are produced as the residuum of extreme fractional crystallization of the basaltic magmas themselves (Noble and Parker, 1974). A similar relationship may exist between some Miocene and older calc-alkalic rhyolites and contemporaneous topaz rhyolites. The topaz rhyolites may be the product of partial melting of the crust caused by the passage of "andesitic" magmas through the crust. The andesitic magmas may differentiate by crystal fractionation to give rise to rhyolites with calcalkalic affinities.

If topaz rhyolites are indeed the products of crustal anatexis, they should reflect the chemical nature of the source from which they were derived. Several isotopic studies indicate that the crust underlying the western United States is distinctive because of its radiogenic character (Silver, 1976; Leeman, 19.79). Fluorite and beryl-bearing Precambrian granites occur near topaz rhyolite localities in Arizona (Heinrich, 1960), Utah (Moore and Sorensen, 1978) and Colorado (Eckel, 1961). A crust with these chemical characteristics would be the ideal source rock for $U$, Th, Be and F-rich rhyolites. From the $F$ and Be contents of 


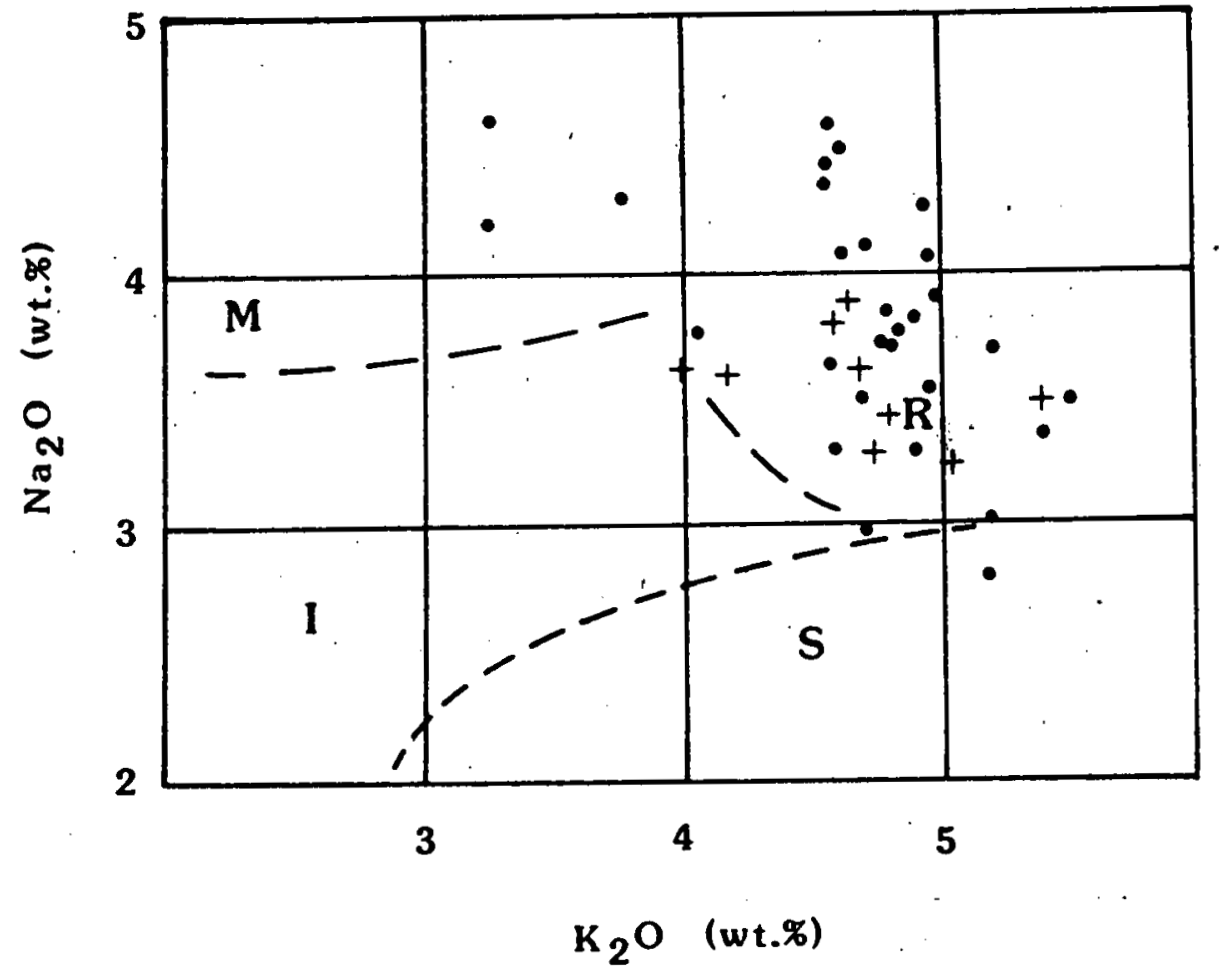

Fig. 13. Diagram showing the $\mathrm{Na}_{2} \mathrm{O}-\mathrm{K}_{2} \mathrm{O}$ fields of various granite types and their sources as delineated by White (1979). R - residual (or anorogenic); $M$ - mantle; I - igneous; and S - sedimentary, Crosses are data from Turley et a1. (1979) and dots are data from this report. 
Table 20. Geochemical comparison of anorogenic granites and topaz rhyolites.

\begin{tabular}{|c|c|c|}
\hline Feature & Anorogenic granite ${ }^{1}$ & Topaz rhyolite ${ }^{2}$ \\
\hline $\mathrm{fH}_{2} \mathrm{O}$ & low & low (topaz, biotite compositions) \\
\hline $\mathrm{HF} / \mathrm{H}_{2} \mathrm{O}$ & high & high (topaz, biotite compositions) \\
\hline $\mathrm{fO}_{2}$ & low to moderate & low (near. QFM) \\
\hline $\mathrm{T}$ & high & low $\left(600-800^{\circ} \mathrm{C}\right)$ \\
\hline $\mathrm{SiO}_{2}$ & high $(\sim 76 \%)$ & high $(73-78 \%)$ \\
\hline $\mathrm{Na}_{2} \mathrm{O}$ & high & moderate-high $(3-4.5 \%)$ \\
\hline $\mathrm{CaO}$ & low & low $(<0.8 \%)$ \\
\hline \multicolumn{3}{|l|}{ Trace elements } \\
\hline REE & high, except Eu & $\begin{array}{l}\text { moderate LREE, } \\
\text { higli HREE, low Eu }\end{array}$ \\
\hline Enriched & $\mathrm{Ga}, \mathrm{Y}, \mathrm{Nb}, \mathrm{Sn}, \mathrm{Zr}, \mathrm{Ta}$ & $\mathrm{Ga}, \mathrm{Y}, \mathrm{Nb}, \mathrm{Sn}, \mathrm{Zr}, \dot{\mathrm{T}} \mathrm{a}(\mathrm{Rb}, \mathrm{Th}, \mathrm{U}, \mathrm{Li})$ \\
\hline Depleted & $\begin{array}{l}\mathrm{Co}, \mathrm{Sc}, \mathrm{Cr}, \mathrm{Ni}, \mathrm{Ba} \\
\mathrm{Sr}, \mathrm{Eu}\end{array}$ & $\mathrm{Co}, \mathrm{Sc}, \mathrm{Cr}, \mathrm{Ni}(?), \mathrm{Ba}, \mathrm{Sr}, \mathrm{Eu}$ \\
\hline F and 1 & high & $\begin{array}{l}\text { high; } F(0.3-1.5 \%) \\
\quad \text { C1 }(700-1700 \mathrm{ppm})\end{array}$ \\
\hline $\mathrm{Fe} / \mathrm{Fe}+\mathrm{Mg}$ & high & high \\
\hline $\mathrm{K}_{2} \mathrm{O} / \mathrm{Na} 2^{\mathrm{O}}$ & high & moderate to high \\
\hline
\end{tabular}

1) früm Whıle (1979), Loiselle and Wones (1979) and Wones (1979).

2) from this report and Turley et a1. (1979). 
volcanic rocks and the distribution of fluorite deposits, Goats (1962, 1963), Shawe and Bagnold (1966) and Peters (1958) have shown that certain areas in the western U.S. are anomalously high in these elements and suggest that the enrichment is derived from geochemical anomalies that have persisted since the Precambrian. The importance of fluorine and uranium-rich Precambrian crust for the generation of topaz rhyolites is further emphasized in Figure 14, where known topaz rhyolite occurrences are compared with the inferred location of the edge of the Precambrian (>850 m.y.) continent (Stewart, 1972; King, 1977; Sears and Price, 1978). We know of no topaz rhyolites along the western margin of the Great Basin in California and Nevada, in spite of high heat-flow similar to that of its eastern margin (Blackwell, 1978) and young bimodal basalt-rhyolite volcanism, e.g. Long Valley $c$ dera, the Kern P lateau and the Coso volcanic field. Presumably the lack of F-rich rhyolites in the western Great Basin is due, at least in part, to the absence of the apparently anomalous Precambrian crust beneath part of this region. Rhyolitic magmas in this area may result from partial melting of a younger crustal component accreted to the continent after the Precambrian ( $2850 \mathrm{~m} . \mathrm{y}$.$) .$ rifting of the continent suggested by Stewart (19.72).

The geophysical character of the Great Basin, where most young ( $<15 \mathrm{~m} . \mathrm{y}_{\cdot}$ ) topaz rhyolites occur, is suggestive of crustal anatexis. It has characteristically high heat flow, $2.1 \mathrm{hfu}$, a thin crust, 25-30 km thick, and low upper mantle seismic velocities, $<7.4 \mathrm{~km} / \mathrm{sec}$ (Prodehl, 1979). The coincidence of these features beneath the Thomas Range area, where topaz rhyolites as young as $3.4 \mathrm{~m} . \mathrm{y}$. old occur (Armstrong, 1970; Turley, et al., 1979), is unusually striking. Based on an extrapolation of the heat flow observed at the surface, Lachenbruch and Sass (1978) have proposed that partial melting could occur locally within the crust. Smith (1978) suggests that a seismic low-velocity zone, detected within the crust of the Great Basin, may be the result of the presence of partially molten rock.

Based on this preliminary evidence topaz rhyolite magmas may be the product of partial melting of the distinctive Precambrian continental crust of the western U.S. Lithospheric extension appears to be intimately related to their genesis and emplacement. Fluorine-rich source materials for topaz rhyolites may have been prodired by the removal of an $\mathrm{H}_{2}$ 0-enriched component from the crust during the voluminous Tertiary (or older) calc-alkalic magmatism that generally preceded the topaz rhyolite volcanism. The calc-alkalic magmas themselves may have been the heat source for crustal. melting during the older episodes ( $>20 \mathrm{~m} . \mathrm{y}$.$) . Basaltic$ magmatism and regional high heat flow were the probable heat sources for the younger topaz rhyolites in the Great Basin and at Grants Ridge, New Mexico. 


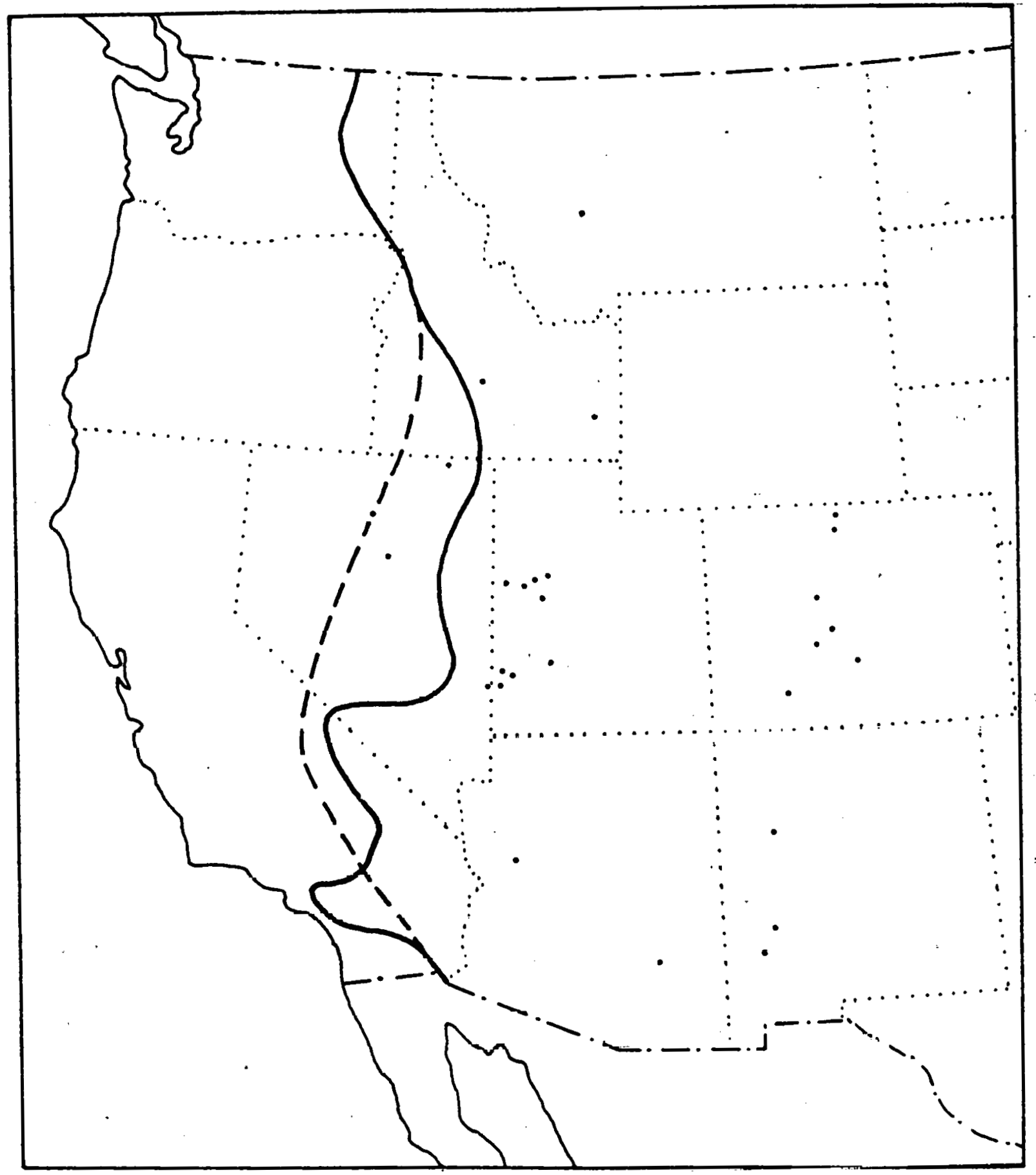

Fig. 14. Known topaz rhyolite occurrences (dots) compared with the edge of the ancient Precambrian crust. Solid line King (1977) -- known outcrop limit; dashed line inferred edge from Sears and Price (1978). 
The role of fluorine in the evolution of topaz rhyolites cannot be overlooked. The addition of $\mathrm{F}$ to silicate mineral assemblages dramatically lowers their solidus and 1iquidus temperatures (Wyllie and Tuttle, 19.61). For a granite- $\mathrm{H}_{2} \mathrm{O}$ mixture at $2.75 \mathrm{~kb}$ with $5 \% \mathrm{HF}$ the solidus occurs at $603^{\circ} \mathrm{C}$ and with water only it occurs at $665^{\circ} \mathrm{C}$. In addition, F-rich melts have lower viscosities and efficient crystal growth and separation can occur. Because of their water-depleted and F-rich nature parental magmas for topaz rhyolites can rise high into the crust without completely crystallizing. Large ash-flow eruptions, caused by the rapid exsolution of volatiles, are not common in these F-rich magmas because $F$ has a low vapor/melt partition coefficient (Bailey, 1977) and increases the $\mathrm{H}_{2}$-solubility of the magma (Burnham, 1967; Fuge, 1977). Von Platen (1965) and von Platen and Winkler (1961) showed that $0.5 \mathrm{M} \mathrm{HF}$ changes the crystallization order from that observed in $\mathrm{H}_{2} \mathrm{O}^{-}$ rich melts (magnetite, biotite, K-feldspar, quartz and plagioclase) to quartz, plagioclase, biotite and K-feldspar. Bailey (1977) suggests that quartz, topaz, and feldspars all crystallize before biotite. These observations may explain the absence of modal biotite in all but the more crystalline samples, and if true could have dramatic effects on the evolution of the melt if crystal fractionation operates.

Fluorine stabilizes highly charged trace elements in the melt at the source and may act to further enrich these and other elements in the apical zones of evolving magma chambers either by diffusion (Kogarko, 1974; Hildreth, 1979) or by the evolution and migration of a discrete fluorine-rich vapor (Burnham, 1967). Be, U, Li, Sn, Rb, Cs, Ga, W, Th and the heavy REE are al1 concentrated in the upper parts of magma chambers as a result (Bailey, 1977; Kozlov, 1974; Groves, 1974; Odikadze, 1973). of their association with F. Shaw et a1. (1976) and Hildreth (1979). have recently proposed a variant of these liquid-state differentiation processes and called it convection-aided thermogravitational diffusion. Hildreth (1979) proposed this mechanism to account for the trace element variations within the Bishop Tuff. Judging from the trace element variations observed in cogenetic topaz rhyolites and similar variations in the Bishop Tuff, thermogravitational diffusion may have played an important role in the evolution of topaz rhyolite magmas and may have produced some of their extreme geochemical features. Figure 15 compares the "enrichment factors" for three samples from the Thomas Range to sample SM-61a, a 1ithophile-depleted vitrophyre from the northern Thomas Range. The elemental ratios found by comparing early and late eruptions of the Bishop Tuff are shown for comparison. Although the enrichment factors are generally in the same direction and with approximately the same magnitude as the Bishop Tuff, several anomalies are apparent. Li, Be, Cs, Thi and $U$ have substantially larger enrichment ratios than in the Bishop Tuff. 


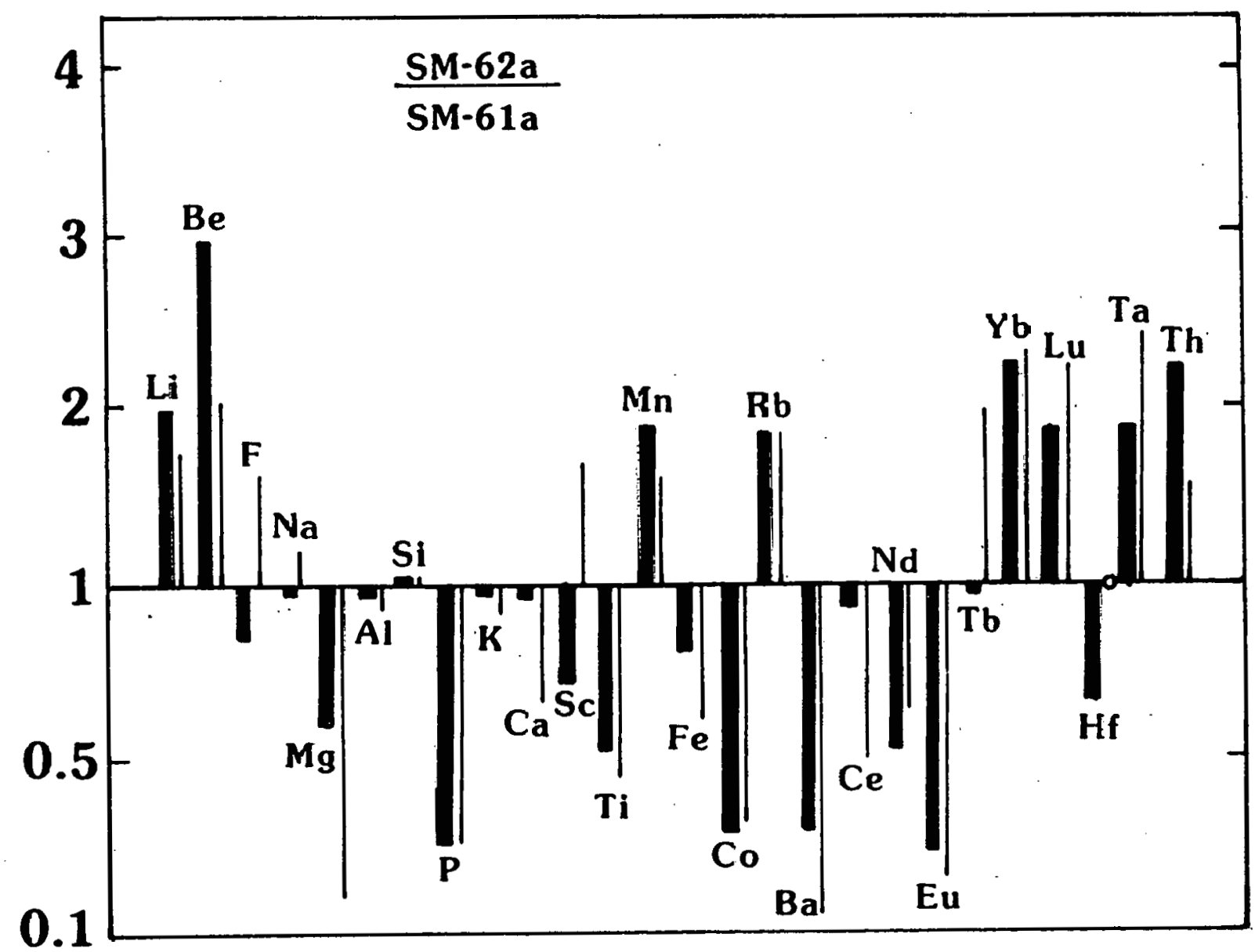

Fig. 15a. Enrichnent factors for 30 elements lerived by comparing evolved (high $U$ and $T h$ ) samples with unevolved sample (SM-6la, low U, Th, etc.) fron the Thomas Range. The samples are from lavas that are presured to be cogenetic. Inrichment factors (Hilcreth, 1979) from the Bishop Tuff are similar (thin lines). 


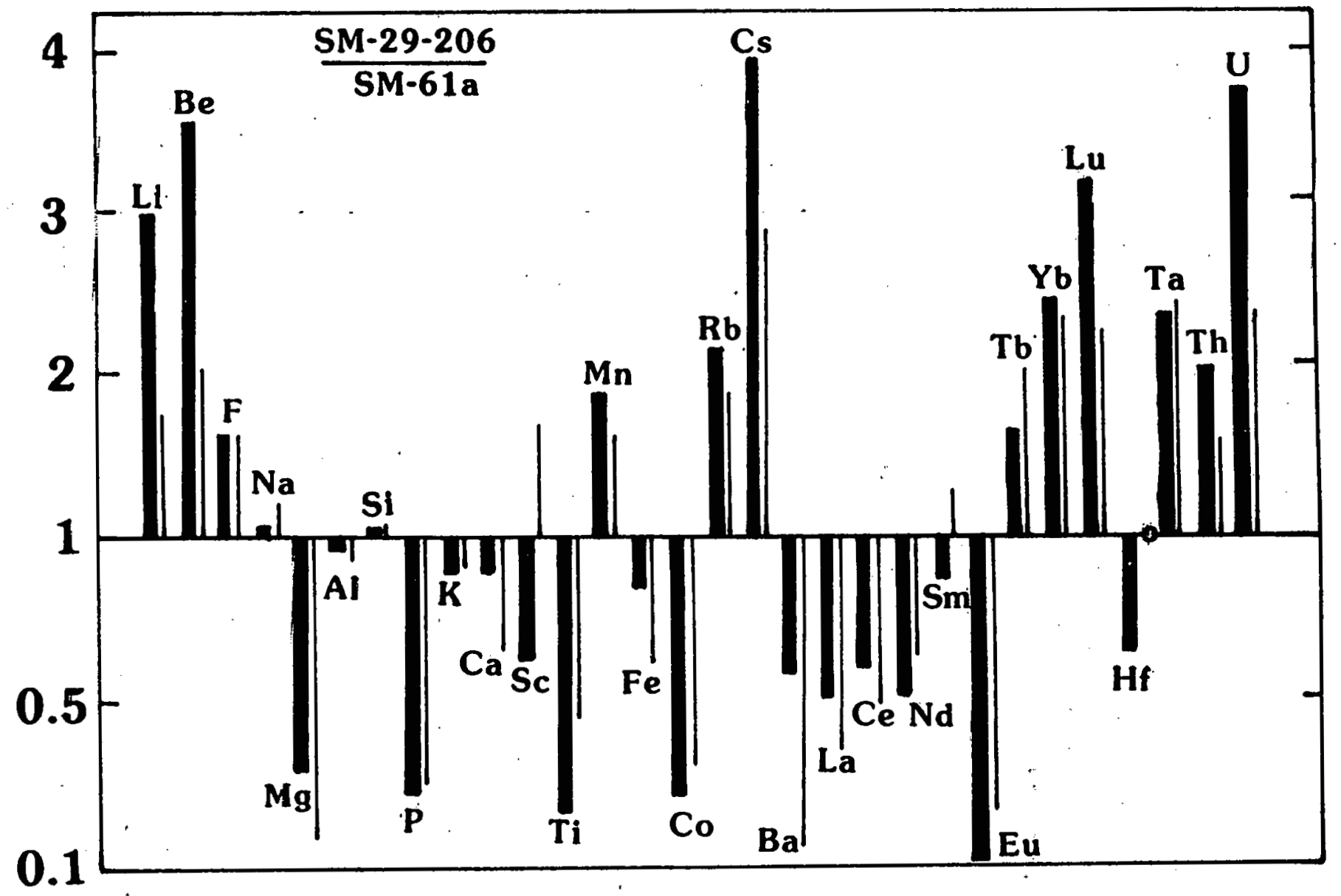

Fig 15b. Errichment factors for samples from the Thomas Range, continued. 


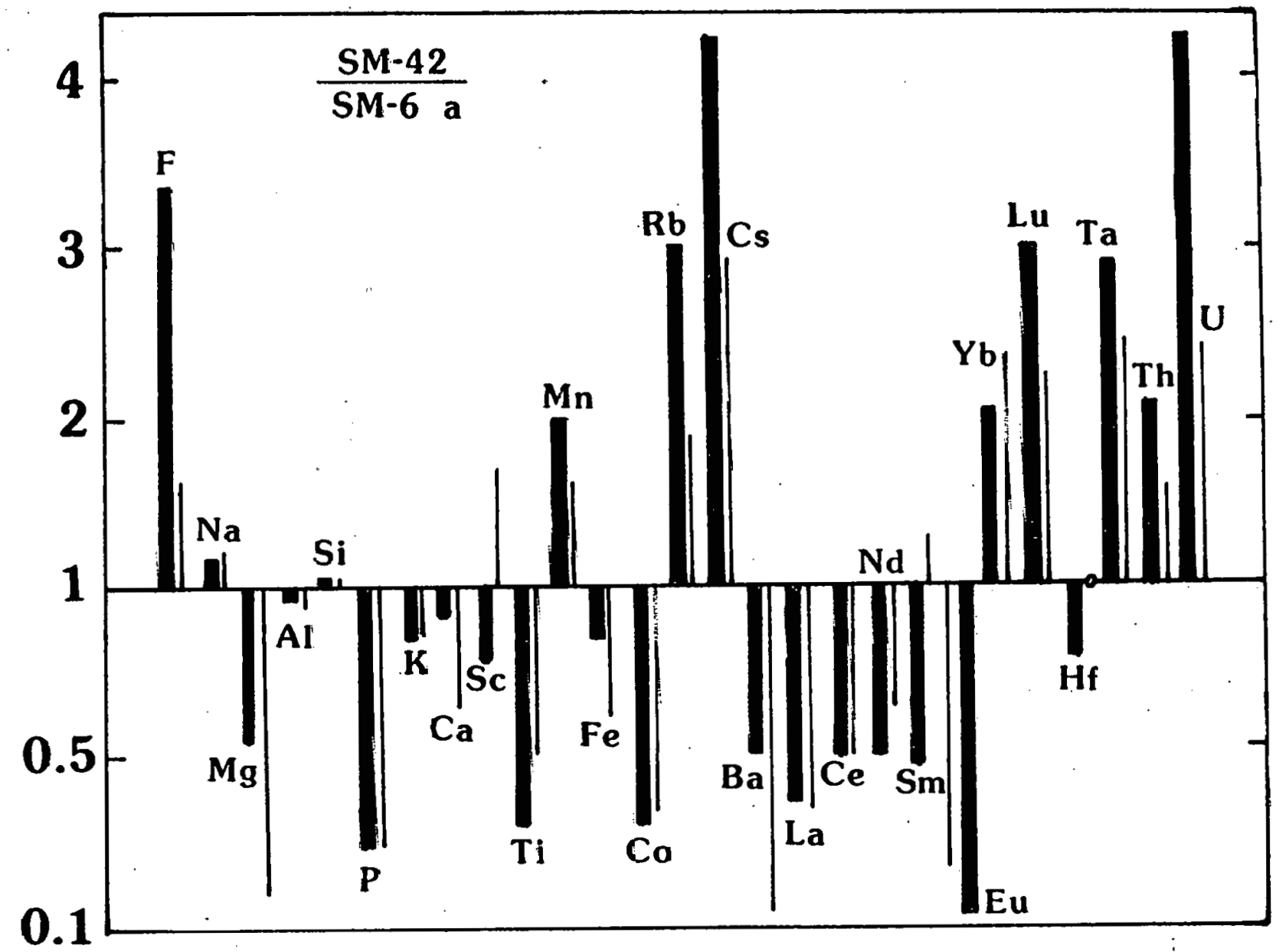

Fig. 15c. Enrichment factc:s for samples from the Thomas Range, contimied. 
This may be due to the increased affinity of these extremely incompatible elements for $F$ or F-rich fluids and their consequent migration toward the top of evolving F-rich magma chambers. Sc, Sm and Hf all show signiflcant depletion in the "evolved" topaz rhyolites relative to SM-61a. Hildreth (1979) could detect no change for Hf and showed that an enrichment of Sc existed in the early erupted portion of the Bishop Tuff. However, Bacon et al. (19.79). detected Sc and Hf depletion with differentiation in some rhyolites from the Kern Plateau, California. The changes observed in the REE can be examined on the chondrite-normalized plots in Figure 7. The changes from LREE-enrichment and small Eu anomaly in sample SM-61a, to HREEenrichment and large $\mathrm{Eu}$ anomalies in the evolved samples are paralleled by the changes Hildreth documented for the Bishop Tuff with increasing evolution and decreasing temperature. It is unlikely that the 5-fold enrichment of $U$, Th, etc. could be produced by crystal fractionation of SM-61a, as all of the samples from the Thomas Range are crystal-poor and have major element chemistries that are very similar.

Some of the features, particularly the elemental concentrations, of R-type granites (White, 1979) can be produced by thermogravitational diffusion in silicic magma chambers. However, even the most "primitive" rhyolite we analyzed from the Thomas Range retains the chemical characteristics of R-type, or anorogenic, granites. Of course, there is also the possibility that SM-61a is a derivative, 1ithophiledepleted, rock produced in the lower part of a thermogravitational convection cell and in this case would not be representative of the magma as a whole, but would appear to be less enriched in $\mathrm{U}, \mathrm{Rb}$, $\mathrm{Th}$, etc. It is likely that the peculiar chemical nature of R-type magmas (high $\mathrm{SiO}_{2}, \mathrm{~F}$ and $\mathrm{Cl}$ ) make them particularly susceptible to liquid-state differentiation prior to, and partly contemporaneous with, thelr erystallization.

\section{CONCLUSIONS}

A distinctive suite of topaz-bearing rhyolites was erupted throughout most of the latter half of the Cenozoic Era in the western United States. Their mineralogy suggests that they crystallized at low temperatures $\left(800-600^{\circ} \mathrm{C}\right)$. The similarity of biotite and garnet phenocrysts to the compositions of those minerals in pegmatiles and grcieens bears this out and further implies that some topaz rhyolites crystallized under vapor-saturated conditions. The vapor was probably F-rich and quite likely played a significant role in transporting rare metals (Be, U, $\mathrm{Th}, \mathrm{Rb}, \mathrm{Li}, \mathrm{Sn}$, etc.) to the apices of evolving magma chambers. Granites $\mathrm{rich}$ in these elcments are nften associated with Sn-W-Mo mineralization. Topaz rhyolites appear to be enriched in these elements; their intrusive equivalents, including some that may not have vented to the surface, may be hosts for economic mineral 
deposits.

Geochemically, topaz rhyolites are similar to anorogenic granites, produced as crustal temperatures are elevated by basaltic, or calc-alkalic, magmatism. In this sense they appear as part of a bimodal (in terms of $\mathrm{siO}_{2}$ content). sequence of magma types. However, they are often nearly contemporaneous with rhyolites of calc-alkalic or peralkaline lineage. Extensional tectonism was contemporaneous with their emplacement and may have allowed topaz rhyolite magmas to be emplaced near the surface without mixing with their more mafic progenitors, as suggested by Lipman et al. (1978a) to explain the evolution of the San Juan volcanic field.

Although many of the geochemical features of topaz rhyolites are inherited from their sourre rocke (probably Lhe $F$ and lithophile-element-rich Precambrian crust which underlies much of the western United States), they have apparently undergone substantial magmatic differentiation. Part of this evolution is superficially similar to the trends supposed to result from thermogravitational diffusion, possibly aided by the separation of an F-rich fluid, but they may have experienced crystal fractionation as well. Topaz rhyolites appear to be a distinct type of bimodal rhyolite. Further detailed study will not only elucidate their genesis and the development of associated ore deposits but may also reveal much about the nature of the crust in the western United States.

\section{ACKNOWLEDGEMENTS}

We thank M. F. Sheridan, B. P. Correa and B. A. Murphy for sharing their ideas and analytical work with us. The cooperation of Dr. C. H. Liu (Arizona State University) and f. Goles (Univeraity of Oregun) In performing the analytical work is acknowledged. Thanks are also crtcnded to $\mathrm{G}$. Selkirk for preparing the 1llustrations and $S$. Nelson for typing the manuscript. 
REFERENCES

Alling, A.N., 1887, On the topaz from the Thoms Range, Utah: American Journal of Science, 3rd ser., v. 33, p. 146-147.

Anthony, J.W., Williams, S.A., and Bideaux, R.A., 1977, Mineralogy of Arizona: The University of Arizona Press, Tucson.

Armstrong, R.L., 1970, Geochronology of Tertiary igneous rocks, eastern Basin and Range Province, western Utah, eastern Nevada, and vicinity, U.S.A.: Geochimica et Cosmochimica Acta, v. 34, p. 202-232.

Bacon, C.R., Macdonald, R., and Metz, J., 1979, Petrogenesis of the Quaternary high-silica rhyolites of the Coso Range geothermal area, California (abstr.): Geological Society of America Abstracts with Programs, v. 11, p. 382.

Bailey, D.K., Barberi, F., and Macdonald, R. Eds., 1974, Oversaturated peralkaline volcanic rocks: Bulletin Volcanologique, v. 38, n. 3, p. 498-860.

Bailey, D.K., 1974, origin of alkaline magmas as a result of anatexis, b. Melting in the deep crust, in H. Sorensen, Ed., The Alkaline Rocks, John Wiley, London, $\therefore$ p. 436-442.

Bailey, J.C., 1977, Fluorine in granitic rocks and melts: A review: Chemical Geology, v. 19, p. 1-42.

Basset, W.A., Kerr, P.F., Schaeffer, O.A., and Stoerner, R.W., 1963, Potasium-argon ages of volcanic rocks north of Grants, in Geology and Technology of the Grants Uranium Region, New Mexico Bureau of Mines and Mineral Resources Memoir. 15, p. $214-216$.

Bence, A.E. and Albee, A.L., 1968, Empirical correction factors for the electron mIcroannalysis of silicates and oxides: Journal of Geology, v. 76, p. 382-403. Blackwe11, D.D., 1978, Heat flow and energy loss in the Western United States, in R.B. Smith, and G.P. Eaton, Eds., Cenozoic tectonics and regional geophysics of the western Cordillera: Geological Society of America Memoir 152, p. 145-174. Burnham, C.W., 1967, Hydrothermal fluids at the magmatic stage, in H.L. Barnes, Ed., Geochemistry of Hydrothermal Ore Deposits: Holt, Rinehart and Winston, New York, p. 34-76.

Burt, D.M., 1979, Geometrical analysis of cryolite and related mineral stabilities in the system $\mathrm{Na}_{2} \mathrm{O}-\mathrm{Al}_{2} \mathrm{O}_{3}-\mathrm{SiO}_{2}-\mathrm{F}_{2} \mathrm{O}_{-1}$ (abstr.): EOS, v. 60, p. 965.

Burt, D.M. and Sheridan, M.F., 1980, A model for the formation of uranium/lithophile element deposits in fluorine-enriched volcanic rocks (abstr.): American 
Association of Petroleum Geologists, Southwest section Annual Meeting, Technical Program and Abstracts, p. 18.

Carmichael, I.S.E., Turner, F.J., and Verhoogen, J., 1974, Igneous Petrology: McGrawHil1, New York, p. 739.

Chadwick, R.A., 19.77, Overview of Early Tertiary volcanism in the northern Rockies region (abstr.): Geological Society of America Abstracts with Programs, v. 9, p. 715-716.

Coats, R.R., Barnett, P.R., and Conklin, N.M., 1962, Distribution of beryllium in unaltered silicic volcanic rocks of the western conterminous United States: Economic Geology, v. 57, F. 963-968.

Coats, R.R., Fnss, W.n., and Rador, L.F., 1263, Distitultion of fluorinc in unaltered silicic volcanic rocks of the western United States: Economic Geology, v. 58, p. 941-951.

Coats, R.R., Green, R.C., Cress, L.D., and Marks, L.Y., 1977, Mineral resources of the Jarbldge Wilderness and adjacent areas, Elko County, Nevada: U.S. Geological Survey Bulletin 1439, p. 79.

Conn, A.A., 1939, Volcanic rocks from Specimen Mountain in Rocky Mountain National Park, Colorado: Pennsylvania Academy of Science, Proceedings, v. 13, p. 134-135.

Corbett, Marsha11 K., 1968, Tertiary volcanics of the Specimen - Lulu - Iron Mounta1n area northcentral Colorado: Colorado School of Mines Quarterly, v. 63, no. 3, p. 1-37.

Cross, W., 1886, On the occurrence of topaz and garnet in lithophyses of rhyolite; American Journal of Science, 3rd ser., v. 31, p. 432-438.

Cross, W., 1896, Geology of Silver Cliff and the Rosita Hills, Colorado; U.S.

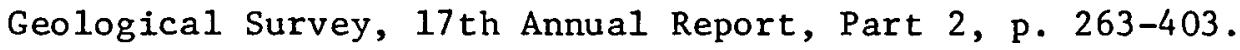

Cross, W. and Hillebrand, W.F., 1885, Contributions to the mineralogy of the Rocky Mountains: U.S. Geological Survey Bulletin 20, p. 221-332.

DePaolo, D.J. and Wasserburg, G.J., 1977, The sources of island arcs as indicated by Nd and Sr isotopic studies: Geophysica1. Research Letters, v. 4, p. 465-468. Eaton, G.P., 19.79, A plate tectonic model for Late Cenozoic crustal spreading in the western United States, in R.E. Riecker, Ed., Rio Grande rift: Tectonics and Magmatism: American Geophysical Union, Washington, D.C., p. 7-32. 
Eckel, E.B., 1961, Minerals of Colorado, a 100-year record: U.S. Geologica1 Survey Bulletin 1114, p. 399.

Elston, W.E. and Bornhorst, T.J., 1979, The Rio Grande rift in context of regional post $-40 \mathrm{~m} \cdot \mathrm{y}$. volcanic and tectonic events, in R.E. Riecker, Ed., Rio Grande rift: Tectonics and magmatism: American Geophysical Union, Washington, D.C., p. 416-438.

Elston, W.E. Rhodes, R.C. and Erb, E.E., 1976, Control of mineralization by midTertiary Volcanic centers, southwestern New Mexico: New Mexico Geological Society Special Publication 5, p. 125-130.

Epis, R.C. and Chapin, C.E., 1968, Geologic history of the Thirtynine Mile Volcanic field, central Colorado: Colorado School of Mines Quarterly, v. 63, no. 3, p. 51-85.

Erickson, M.P., 1963, Volcanic geology of western Juab County, Utah, in B.J. Sharp and N.C. Williams, Eds., Beryllium and uranium mineralization in western Juab County, Utah: Utah Geological Society Guidebook 17, p. 23-35.

Eugster, H.P. and Wones, D.R., 1962, Stability relations of the ferruginous biotite, annite: Journal of Petrology, v. 3, p. 82-125.

Evans, S.H., 1978, Studies in Basin and Range volcanism: Ph.D. Thesis, University s of Utah, Salt Lake City.

Evans, S.H. and Nash, W.P., 1978, Quaternary rhyolite from the Mineral Mountains, Utah, U.S.A.: Department of Energy, Contract EY-7.6-5-07-1601, Final Report, v. 77-10, p. 59 .

Ewart, A., 1979, A review of the mineralogy and chemistry of Tertiary-Recent dacitic, latitic, rhyolitic, and related salic volcanic rocks, In F. Barker, Ed., Trondhjemites, dacites, and related rocks: Elsevier, Amsterdam, p. 13-121.

Ewart, A. and Stipp, J.J., 1968, Petrogenesis of the volcanic rocks of the central North Island, New Zealand, as indicated by a study of $\mathrm{Sr}^{87 / 86} \mathrm{ratios}$, and $\mathrm{Sr}$, $\mathrm{Rb}, \mathrm{K}, \mathrm{U}$ and Th abundances: Geochimica of Cosmochimica Acta, v. 32, p. 699-735.

Ewart, A., Brothers, R.N., Mateen, A., 1977, An outline of the geology and geochemistry, and the possible petrogenetic evolution of the volcanic rocks of the Tonga-KermadecNew Zealand island arc: Journal of Volcanology and Geothermal Research, v. 2, p. 205-250.

Filippov, L.V., Savimova, Y.N., Kapitónova, T.A., dud Andreyeva, T.P., 1974, Fluorine in $\mathrm{Mg}-\mathrm{Fe}$ micas from granitoids of various magmatic formations in the folded belt of Central Asia: Geochemistry International, v. 11, p. 185-194. 
Foland, K.A. and Friedman, I., 1977, Application of $\mathrm{Sr}$ and 0 isotope relations to the petrogenesis of the alkaline rocks of the Red Hill complex, New Hampshire, USA: Contributions to Mineralogy and Petrology, v. 65, p. 213-225.

Fries, C., 1942, Tin deposits of northern Lander County, Nevada: U.S. Geological Survey Bulletin 931-L, p. 279-294.

Fries, C. Schaller, W.T., and Glass, J.J., 1942, Bixbyite and pseudobrookite from the tin-bearing rhyolite of the Black Range, New Mexico: American Mineralogist, v. 27 , p. $305-322$.

Fuge, R. 1977, On the behavior of fluorine and chlorine during magmatic differentiation: Contributions to Mineralogy and Petrology, v. 61, p. 245-249.

Goode11, P. C., 1978, Geologic setting of the Pena Blanca uranium deposits Chihuahua, Mexico, in C. D. Henry and A. W. Walton, Eds., Formation of uranium ores by diagenesis of volcanic sediments: U. S. Department of Energy, Open file report, GJBX 22 (79), P. (IX) 1 - (IX) 38 .

Green, T.H., 1976, Experimental generation of cordierite- or garnet-bearing granitic liquids from a pelitic composition: Geology, v, 4, p. 85-88.

Green, T.H., 1978, A model for the formation crystallization of corundum-normative calc-alkaline magmas through amphibole fractionation: A discussion: Journal of Geology, v. 86, p. 269-272.

Greene, R.S., 1976, Volcanic rocks of the McDermitt Caldera, Nevada-Oregon: U.S. Geological Survey Open-File Report 76-753.

Greenwood, W.R., Ludington, S., Miller, W.R., Hanna, W.F., and others, 19.78, Mineral resources of the Elkhorn Wilderness study area, Montana: U.S. Geological Survey Open-File Report 78-325, p. 342 .

Groves, D.I., 1974, Geochemical variation within tin-bearing granites, Blue Tier Batholith, NE Tasmania, in M. Stemprok, Ed., Metallization associated with acid magmatism, v. 1, Geologicäl Survey, Prague, p. 154-158.

Gunow, A.J. and Munoz, J.L., 1977, Evidence for high fluorine activity in magmatic and hydrothermal fluids at the Henderson molybdenite deposit, Colorado (abstr.): Geological Society of America Abstracts with Programs, v. 9, p. 1000.

Ha11, A., 1965, The origin of accessory garnet in the Donegal granite: Mineralogica1 Magazine, v. 35, p. 628-633.

Hanson, G.N., 1978, The application of trace elements to the petrogenesis of igneous rocks of granitic composition: Earth and Planetary Science Letters, v. 38, p. 26-t

Heinrich, E.W., 1946, studies in the mica group; the biotite-phlogopite series: American Journal of Science, v. 244, p. 21. 
Heinrich, E.W., 1960, Some rare-earth mineral deposits in Mohave County, Arizona: Arizona Bureau of Mines Bulletin 167, p. 22.

Hildreth, E.W., 1977. The magma chamber of the Bishop Tuff: Gradients in temperature, pressure, and composition: Ph.D. Thesis, University of California, Berkeley, p. 328 .

Hildreth, E.W., 1979, The Bishop Tuff: Evidence for the origin of compositional zonation in silicic magma chambers, in C.E. Chapin and W.E. Elston, Eds., Ashflow Tuffs: Geological Society of America Special Paper 180, p. 43-75.

Hillebrand, W.F., 1905, Red beryl from Utah: American Journal of Science, 4th ser., v. 19 , p. $330-331$.

Irvine, T.N. and Baragar, W.R.A., 1971, A guide to the chemical classification of the common volcanic rocks: Canadian Journal of Earth Sciences, v. 8, p. 523548 .

Keith, J.D., 1980, Miocene porphyry intrusions, volcanism and mineralization, southwestern Utah and eastern Nevada: M.S. Thesis, University of Wisconsin, Madison, p. 166.

Kerr, P.F. and Wilcox, J.T., 1963, Structure and volcanism, Grants Ridge area, in Geology and Technology of the Grants Uranium Region: New Mexico Bureau of Mines $\because$ and Mineral Resources Memoir 15, p. 205-213.

King, P.B., 1977, The Evolution of North America: Princeton University Press, Princeton, p. 197.

Kogarko, L.N., 19.74, Role of volatiles, in H. Sorensen, Ed., The Alkaline Rocks, Wiley, London, p. 474-487.

Kozlov, V.D., 1974, The sequence of phases and facies in the massifs of raremetal granites in Transbaikalia and the problem of their ore-bearing capacity, in M. Stemprok, Ed., Metalligation Associated with Acid Magmatism, v. 1, Geologica1 Survey, Prague, p. 201-205.

Lachenbruch, A.H. and Sass, J.H., 1978, Models of an extending lithosphere and heat flow in the Basin and Range province, in R.B. Smith and G.P. Eaton, Eds., Cenozoic Tectonics and Regional Geophysjcs of the Western Cordillera: Geological Society of America Memoir 152, p. 209-250.

Lamarre, A.L. and Hodder, R.W., 1978, Distribution and genesis of fluorite deposits in the western United States and their significance to metallogeny: Geology, v. 6, p. 236-238. 
Leeman, W.P., 1979, A tectonic interpretation of strontium isotopic variations in Late Cenozoic lavas--western U.S. (abstr.): Geological Society of America Abstracts with Programs, v. 11, p. 464.

Lindsey, D.A., 19.75, The effect of sedimentation and diagenesis on trace-element.' composition of water-laid tuff in the Keg Mountain area, Utah: U.S. Geological Survey Professional Paper 818-C, p. 35.

Lindsey, D.A., 1977, Epithermal beryllium deposits in water-laid tuff, western Utah: Economic Geology, v. 72, p. 219-232.

Lindsey, D.A., 1979, Preliminary report on Tertiary volcanism and uranium mineralization in the Thomas Range and Drum Mountains, Juab County, Utah: U.S. Geologica1 Survey, Open-File Report 79-1076, p. 101.

Lindsey, D.A., Naeser, C.W., Shawe, D.R., 1975, Age of volcanism, intrusion, and minera1ization in the Thomas Range, Keg Mountain, and Desert Mountain, western Utah: U.S. Geological Survey, Journal of Research, v. 3, p. 597-604.

Lipman, P.W. and Mehnert, H.H., 1979, Potassium-argon ages from the Mount Taylor volcanic field, New Mexico: U.S. Geological Survey Professional Paper 1124 B, p. $\mathrm{B} 1-\mathrm{B} 8$

Lipman, P.W., Doe, B.R., Hedge, C.E., and Steven, T.A., 1978a, Petrologic evolution of the San Juan volcanic field, southwestern Colorado: $\mathrm{Pb}$ and $\mathrm{Sr}$ isotope evidence: Geological Society of America Bulletin, v. 89, p. 59-82.

LIpman, P.W., Rowley, P.D., Mehnert, H.H., Evans, S.H., Nash, W.P., Brown, F.H., and others, 1978b, Pleistocene rhyolite of the Mineral Mountains, Utah--Geothermal and archeological significance: U.S. Geological Survey, Journal of Research, v. 6, p. $133-1.47$.

Loiselle, M.C. and Wones, D.R., 1979, Characteristics and origin of anorogenic gran1ces (abstr.): Geological Society of America Abstracts with Programs, v. 11, p. 468 .

Lowder, G.G. and Carmlchael, I.S.E., 1970, The volcanoes and caldera of l'alasea, New Britain: Geology and petrology: Geological Society of America Bulletin, v. 81, p. $17-38$.

Lufkin, J.L:, 1976, Oxide minerals in miarolitic rhyolite, Black. Range, New Mexico: American Mineralogist, v. 61, p. 425-430.

Lufkin, J.L., 1977, Chemistry and mineralogy of wood-tin, Black Range, New Mexico: American Mineralogist, v. 62, p. 100-106. 
Macdonald, R., 1974, Nomenclature and petrochemistry of the peralkaline oversaturated extrusive rocks: Bulletin Volcanologique, v. 38, p. 498-516.

McAnulty, W.N. and Levinson, A.A., 1964, Rare alkali and beryllium mineralization in volcanic tuffs, Honeycomb Hills, Juab County, Utah: Economic Geology, v. 59, p. 768-774.

Miller, C.F. and Stoddard, E.F., 1978, Origin of garnet in granitic rocks: An example of the role of Mn from the old Woman - Piute Range, California (abstr.):

. Geological Society of America Absracts with Programs, v. 10, p. 456.

Miyashiro, A., 1955, Pyralspite garnet in volcanic rocks: Journal of the Geological Society of Japan, v. 61, p. 463-470.

Moore, W.J. and Sorensen, M.L., 1978, Metamorphic rocks of the Granite Peak area, Tooele County; Utah (abstr.): Geological Society of America Abstracts with Programs, v. 10, p. 234.

Munoz, J.L. and Eugster, H.P., 1969, Experimental control of fluorine reactions in hydrothermal systems: American Mineralogist, v. 54, p. 943-9.59.

Munoz, J.L. and Luddington, S.D., 1974, Fluorine-hydroxyl exchange in biotite: American Journal of Science, v. 274, p. 396-413.

Nash, W.P., 19.76, Petrology of the Quaternary volcanics of the Roosevelt KGRA, and adjoining area, Utah: National Science Foundation, contract GI-43741, Final Report, v. 1, p. 99.

Noble, D.C. and Parker, 1974, Peralkaline silicic volcanic rocks of the western United States: Bulletin Volcanologique, v. 38, p. 803-827.

Noble, D.C., Rigot, W.L., and Bowman, H.R., 1979, Rare-earth-element content of some highly differentiated ash-flow tuffs and lavas, in C.E. Chapin and W.E. E1ston, Eds., Ash-Flow Tuffs: Geological Society of America Special Paper 180 , p. $77-85$.

Nockolds, S.R., 19.47, The relation between chemical composition and paragenesis in the biotite micas of igneous rocks: American Journal of Science, v. 245, p. 401-420.

Nockolds, S.R., 1954, Average chemical compositions of some igneous rocks: Geological Society of America Bulletin, v. 65, p. 1007-1032. 
Odikadze, G.L., 1973, contents of $\mathrm{K}, \mathrm{Rb}, \mathrm{Cs}$ and $\mathrm{F}$ in some Caucasus volcanic formations: Geochemistry International, v. 10, p. 163-173.

Pabst, A., 1938, Orientation of bixbyite on topaz: American Mineralogist, v. 23, p. $342-347$.

Patton, H.B., 1908, Topaz-bearing rhyolite of the Thomas Range, Utah: Geological Soclety of America Bulletin, v. 19, p. 177-192.

Pear1, R.M., 1939, Chalk Mounta1n, Colorado: Compass, v. 19, p. 137-140.

Peccerillo, A. and Taylor, S.R., 1976, Geochemistry of Eocene calc-alkaline volcanic rocks from the Kastamonu area, northern Turkey: Contributions to. Mineralogy and Petrology, v. 58, p. 63-81.

Penfield, S.L. and Foote, H.W., 1897, On bixbyite, a new mineral, and nntes on the assuclated topas: Allerican Journal of Scfence, 3rd ser., v. 47, p. 387-396.

Peters, W.C., 1958, Geologic characteristics of fluorspar deposits in the western United States: Economic Geology, v. 53, p. 663-688.

Petro, W.L., Vogel, T.A., and Wilband, J.'T., 1979, Major element geochemistry of plutonic rock suites from compressional and extensional plate boundaries: Chemical Geology, v. 26, p. 217-235.

Prodehl, C., 1979, Crustal structure of the western Uniled States: U.S. Geological Survey Professional Paper 1034, p. 74.

Rieder, M., 1971, Stability and physical properties of synllet1c lithium-iron micas: American Mineralogist, v. 56, p. 256-280.

Rittman, A., 1952. Nomenclature of volcanic rocks: Bulletin Volcanologique, v. 12, p. 75-102.

Ruse, W.I., Grant, N.K., and Easter, J., 1979, Ccochemibtry of the Los Chocoyos Aslı, Quezaltenango Valley, Guatemala, in C.F. Chapin and W.E. Elston, Eds., Ashflow l'uffs: Geological Society of America Special Paper 180, p. 87-99.

Rowley, P.D., Anderson, J.J., Williams, P.I. and F1,eck, R.J., 1978a, Age of structural differentiation between the Colorado Plateaus and Basin and Range provinces in southwestern Utah: Geology, v. 6, p. 51-55.

Rowley, P.D., Lipman, P.W., Mehnert, H.H., Lindsey, D.A., and Anderson, J.J., 19.78b, Blue Ribbon lineament, an east-trending structural zone within the Pioche mineral belt of southwestern Utah and eastern Nevada: U.S. Geological Survey, Journal of Research, v. 6, p. 175-19.2. 
Rytuba, J.J., 1979, Structural and petrologic associations of uranium deposits within the McDermitt caldera complex, Nevada-Oregon (abstr.): Geological Society of America Abstracts with Programs, v. 11, p. 508.

Sears, J.W. and Price, R.A., 1978, The Siberian connection: A case for Precambrian separation of the North American and Siberian cratons: Geology, v. 6, p. 267-270. Sharp, W.N., 1978, Geologic map of the Silver Cliff and Rosita volcanic centers, Custer County, Colorado: U.S. Geological Survey Miscellaneous Investigations Map I-1081.

Shaw, H.R., Smith, R.L., and Hildreth, W., 1976, Thermogravitational mechanisms for chemical variations in zoned magma chambers (abstr.): Geological Society of America Abstracts with Programs, v. 8, p. 1102.

Shawe, D.R., 1966, Arizona-New Mexico and Nevada-Utah beryllium belts: U.S. Geological Survey, Professional Paper 550-C, p. C206-C213.

Shawe, D.R. and Bernold, S., 1966, Beryllium content of volcanic rocks: U.S. Geologica1 Survey Bulletin 1214-C, p. 11.

Siems, P.L., 1968, Volcanic geology of the Rosita Hills and Silver Cliff district, Custer County, Colorado: Colorado School of Mines Quarterly, v. 63, no. 3, p. 89124 .

Silver, L.T., 1976, A regional uranium anomaly in the Precambrian basement of the Colorado plateau (abstr.): Geological Society of America Abstracts with Programs, v. 8, p. 1107-1108.

Smedes, H.W., 1966, Geology and igneous petrology of the northern Elkhorn Mountains, Jefferson and Broadwater Counties, Montana: U.S. Geological Survey Professional Paper 510, p. 116 .

Smith, R.B., 1978, Seismicity, crustal structure, and intraplate tectonics of lie interior of the western Cordillera, in R.B. Smith and G.P. Eaton, Eds., Cenozolc tectonics and regional geophysics of the western Cordillera: Geological Society of America Memoir 152, p. 111-144.

Staatz, M.H. and Carr, W.J., 1964, Geology and mineral deposits of the Thomas and Dugway Ranges, Juab and looele Counties, Utah: U.S. Geologica1 Survey Professional Paper 415, p. 188 .

Stark, J.T., 1934, Heavy minerals in the Tertiary intrusives of central Colorado: American Mineralogist, v. 19, p. 586-592.

Stark, J.T. and Behre, C.H., 1936, Tomichi Dome flow: Geological Soctety of America Bulletin, v. 47 , p. 101-110. 
Steven, T.A., 1975, Mid-Tertiary volcanic field in the southern Rocky Mountains: Geological Society of America Memoir 144, p. 75-94.

Steven, T.A., Lipman, P.W., Fisher, F.S., Bienlewski, C.L., Meeves, H.C., and others, 1977, Mineral resources of study areas continguous to the Uncompahgre Primitive Area, southwestern Colorado: U.S. Geological Survey Bulletin 1391-E, p. 126 .

Stewart, J.H., 1972, Initial deposits in the Cordilleran Geosyncline: Evidence of a late Precambrian ( $<850 \mathrm{~m} . \mathrm{y}$.$) continental separation: Geological Society$ of America Bulletin, v. 83, p. 1345-1360.

Stewart, J.H., McKee, E.H., and Slager, H.K., 1977, Geology and mineral depusits uf Lander County, Nevada: Nevada Bureau of Mines and Geology Bulletin 88, p. 106. Stormer, J.C., 1975, A. practical twu=feldspar geothermometer: American Mineralogist, v. 60 , p. 667-674.

Streckeisen, A., 1979, Classification and nomenclature of volcanic rocks, lamprophyres, carbonatites, and melitic rocks: Recommendations and suggestions of the IUGS Subcommission on the systematics of igneous rocks: frenlogy, v. 7, p. 331- .: 335 .

I'urley, C.H., Nash, W.P., and Brown, F.H., 1979, Petrology and geochronology of Lale Tertiary and Quaternary volcanic rocks in the eastern margin of the Basill and Range province, Utah: U.S. Geological Survey, Contract 14-08-0001-G343, Final Report, v. 1, p. 78 .

Van Alstine, R.E., 1969, Geology and mineral deposits of the Ponca Springs NE quadrangle, Chaffee County, Colorado: U.S. Geological Survey Professional Paper G26, p. 52 .

Van Breeman, O., Hutchinson, J., and Bowden, P., 1975, Age and origin of the Nigerian Mesozoic granites: A Rb-Sr isotopir study: Contrlbutlons to Mineralogy and Petrology, v. 50, p. 157-172.

Von Platen, H., 1965, Kristallisation granitischer Schmeigen: Contributions to Mineralogy and Petrology, v. 11, p. 334-381.

Von Platen, H. and Winkler, H,G.F., 19.6.1, Kristallization eines Ob.sidians bei Anwesenheit von $\mathrm{H}_{2} \mathrm{O}, \mathrm{NH}_{3}$, $\mathrm{HCl}$ und $\mathrm{HF}$ unter 2000 atm. Druck (abstr.).: Fortschritt der Mineralogie, v. 39, p. 355. 
Wahlstrom, E.E., 1941, Hydrothermal deposits in the Specimen Mountain volcanics, Rocky Mountain National Park, Colorado: American Mineralogist, v. 26, p. 551-561.

Wahlstrom, E.E., 1944, Structure and petrology of Specimen Mountain, Colorado:

Geological Society of America Bulletin, v. 55, p. 77-90.

Wallace, A.B. and Roper, M.W., 1980, Geology and uranium deposits along the northeastern margin of the McDermitt caldera complex, southern Malheur County, Oregon (abstr.): American Association of Petroleum Geologists Southwest section Annual Meeting, Technical Program and Abstracts, p. 59.

Ward, S.H., Parry, W.T., Nash, W.P., Sill, W.R., Cook, K.L., Smith, R.B., Chapman, D.S., Brown, F.H., Whelan, J.A., and Bowman, J.R., 1978, A summary of the geology, geochemistry, and geophysics of the Roosevelt Hot Springs thermal area, Utah: Geophysics, r. 43, p. 1515.

White, A.J.R., 1979, Sources of granite magmas (abstr.): Geological Society of America Abstracts with Programs, v. 11, p. 539.

-White, C.M. and McBirney, A.R., 1978, Some quantitative aspects of orogenic volcanism in the Oregon Cascades, in R.B. Smith and G.P. Eaton, Eds., Cenozoic tectonics and regional geophysics of the western Cordillera: Geological Society of America Memoir 152, p. 369-388.

Wones, D.R., 1979, Intensive parameters during the crystallization of granit1c plutons (abstr.): Geological Society of America Abstracts with Programs, v. 11, p. 543.

Wood, C.P., 1974, Petrogenesis of garnet-bearing rhyolites from Canterbury, New Zealand: New Zealand Journal of Ceology and Geophysics, v. 17, p. 759-787. Wyllie, P.J, and lutcle, O.F., 1961, Experimental investigation of silicate systems containing two volatile components, II. The effects of $\mathrm{NH}_{3}$ and $\mathrm{HF}$, in addition to $\mathrm{H}_{2} \mathrm{O}$, on the melting temperatures of albite and granite: American Journal of Science, v. 259, p. 128-143.

Yoder, H.S., 1973, Contemporaneous basaltic and rhyolitic magmas: American Mineralogist, v. 58, p. 153-171.

Zielinski, R.A., 1977, Minor-element abundances in obsldian, perlite, and felsite of calc-alkalic rhyolites: Amer1can Mineralogist, v. 62, p. 426-437.

Zielinski, R.A. and Lipman, P.W., 1976, Trace-element variations at Summer Coon volcano, San Juan Mountains, Colorado, and the origin of continental-interior andesite: Geological Society of America Bulletin, v. 87, p. 1477-1485. 
Appendix 1. Location and description of samples.

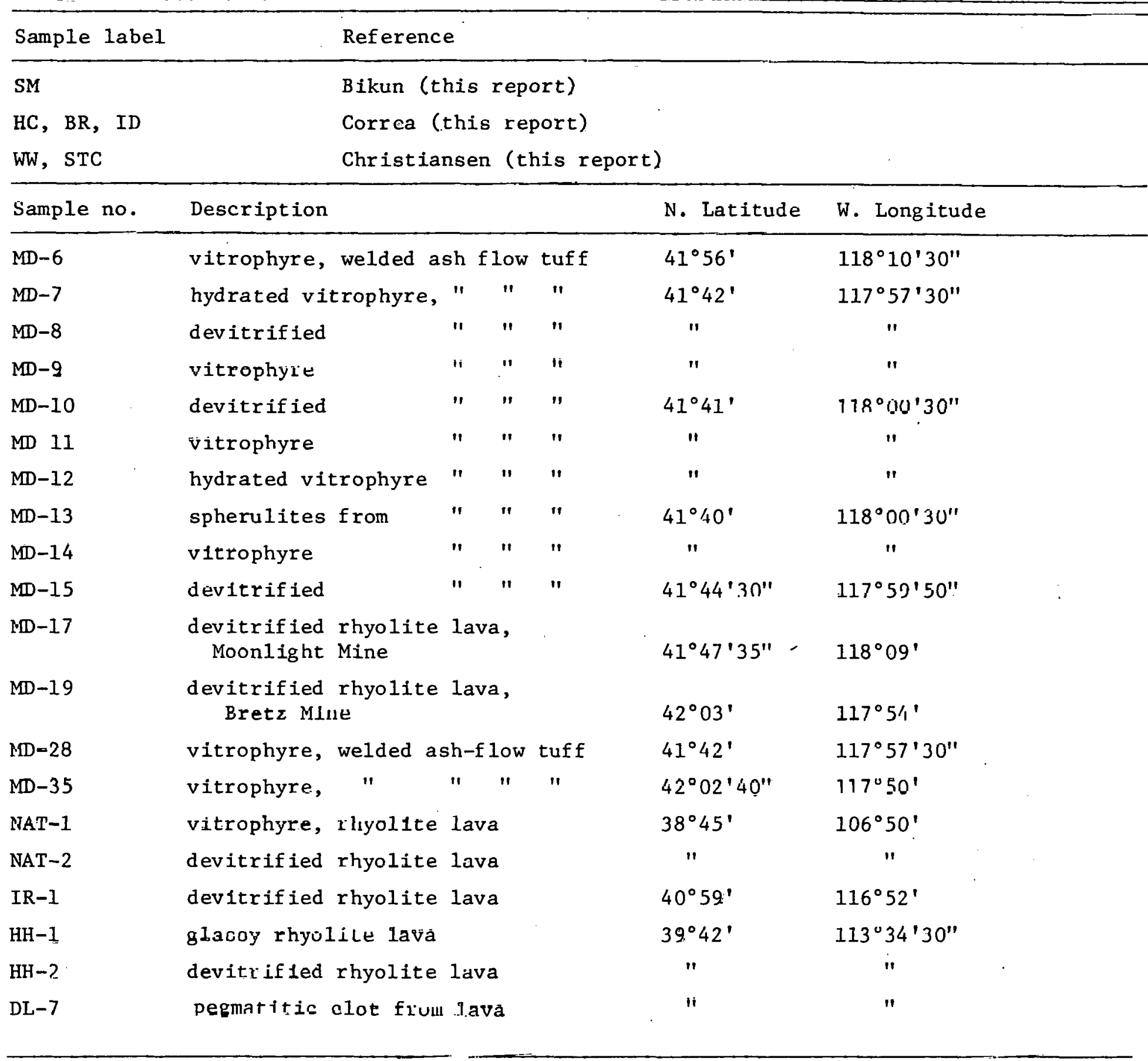


Appendix 2. Composition and norms of samples from McDermitt caldera, Nevada

\begin{tabular}{|c|c|c|c|c|c|c|c|}
\hline sample & no. & MD-6V: & $M D-7 h$ & $M D-8$ & $M D-10$ & $M D-12$ & $\therefore$. \\
\hline $\mathrm{SiO}_{2}$ & & 71.4 & 74.6 & 76.1 & 75.7 & 75.8 & \\
\hline $\mathrm{TiO}_{2}$ & & 0.42 & 0.26 & 0.24 & 0.27 & 0.28 & \\
\hline $\mathrm{Al}_{2} \mathrm{O}_{3}$ & & 12.5 & 11.47 & 10.8 & 10.6 & $10 . .7$ & \\
\hline $\mathrm{Fe}_{2} \mathrm{O}_{3}$ * & & 4.60 & 3.45 & 3.17 & 3.45 & 3.40 & \\
\hline $\mathrm{MnO}$ & & 0.13 & 0.06 & 0.05 & 0.0 .7 & 0.07 & \\
\hline $\mathrm{MgO}$ & & 0.07 . & 0.82 & 0.04 & 0.06 & 0.01 & \\
\hline $\mathrm{CaO}$ & & 1.18 & 0.79 & 0.18 & 0.27 & 0.25 & \\
\hline $\mathrm{Na}_{2} \mathrm{O}$ & & 3.46 & 2.90 & 3.97 & 4.66 & 4.05 & \\
\hline $\mathrm{K}_{2} \mathrm{O}$ & & 5.79 & 4.42 & 4.62 & 4.66 & 4.97 & \\
\hline $\mathrm{P}_{2} \mathrm{O}_{5}$ & & - & - & - & - & - & \\
\hline Total & & 99.55 & 98.77 & 99.17 & 99.74 & 99.53 & \\
\hline LOI & & 3.34 & 4.61 & 0.22 & 2.83 & 0.37 & \\
\hline ns & & 0.00 & 0.00 & 0.00 & 1.47 & 0.57 & \\
\hline or & & 34.22 & 26.12 & $27.30^{\circ}$ & 27.54 & 29.37 & \\
\hline$a b$ & & 29.28 & 24.54 & 29.83 & 28.58 & 27.37 & \\
\hline an & & 1.48 & 3.92 & 0.00 & 0.00 & 0.00 & \\
\hline$Q$ & & 26.25 & 37.01 & 34.69 & 33.63 & 33.98 & \\
\hline hy & & 0.73 & 4.00 & 2.42 & 2.63 & 2.48 & \\
\hline $\mathrm{di}$ & & 3.86 & 0.00 & 0.79 & 1.19 & 1.10 & \\
\hline ac & & 0.00 & 0.00 & 3.31 & 3.99 & 3.93 & \\
\hline ap & & 0.00 & 0.00 & 0.00 & 0.00 & 0.00 & \\
\hline il & & 0.80 & 0.49 & 0.46 & 0.51 & 0.53 & \\
\hline c & & 0.00 & 0.51 & 0.00 & 0.00 & 0.00 & \\
\hline $\mathrm{mt}$ & & 2.67 & 2.00 & 0.18 & 0.00 & 0.00 & \\
\hline Total & & 99.28 & 98.60 & 98.98 & 99.54 & 99.33 & \\
\hline
\end{tabular}


Appendix 2. continued.

\begin{tabular}{|c|c|c|c|c|c|c|}
\hline samp1e no. & MD-13 & MD-15 & $\mathrm{MD}-17$ & $\mathrm{MD}-19 \mathrm{~b}$ & $\mathrm{LC}-2 \mathrm{v}$ & $L C-3 v$ \\
\hline $\mathrm{SiO}_{2}$ & 75.4 & 75.6 & 76.0 & 75.2 & 75.9 & 74.6 \\
\hline $\mathrm{TiO}_{2}$ & 0.28 & 0.25 & 0.50 & 0.23 & 0.13 & 0.29 \\
\hline $\mathrm{Al}_{2} \mathrm{O}_{3} *$ & 11.1 & 11.3 & 11.8 & 14.0 & 11.5 & 11.7 \\
\hline $\mathrm{Fe}_{2} \mathrm{O}_{3}$ * & 3.55 & 3.11 & 1.60 & 0.75 & 1.96 & 2.28 \\
\hline MnO & 0.06 & 0.07 & 0.02 & 0.02 & 0.05 & 0.13 \\
\hline $\mathrm{MgO}$ & $0: 10$ & 0.05 & 0.02 & 0.33 & 0.02 & 0.13 \\
\hline $\mathrm{CaO}$ & 0.24 & 0.08 & 0.04 & 0.33 & 0.23 & 0.12 \\
\hline $\mathrm{Na}_{2} \mathrm{O}$ & 4.15 & 2.92 & 0.22 & 3.05 & 4.23 & 4.68 \\
\hline $\mathrm{K}_{2} \mathrm{O}$ & 4.26 & .5 .92 & 9.65 & 5.65 & 4.45 & 4.72 \\
\hline $\mathrm{P}_{2} \mathrm{U}_{5}$ & - & 0.04 & 0.10 & 0.04 & 0.00 & 0.02 \\
\hline Total & 99.14 & 99.34 & 99.95 & 99.60 & 98.47 & 98.67 \\
\hline LOI & - & - & - & - & - & - \\
\hline ns & 0.00 & 0.00 & 0.00 & 0.00 & 0.00 & 0.63 \\
\hline or & 25.17 & 34.98 & 57.03 & 33.39 & 26.30 & 27.89 \\
\hline$a b$ & 33.38 & 24.71 & 1.02 & 25.81 & 34.38 & 33.90 \\
\hline an & 0.00 & 0.14 & 0.00 & 1.38 & 0.00 & 0.00 \\
\hline Q & 33.85 & 35.02 & 38.22 & 34.68 & 33.62 & 30.34 \\
\hline hy & 2.13 & 1.90 & 0.32 & 0.98 & 1.04 & 2.14 \\
\hline $\mathrm{d} i$ & 1.05 & 0.00 & 0.00 & 0.00 & 1.01 & 0.41 \\
\hline ac & 1.53 & 0.00 & 0.00 & 0.00 & 1.25 & 2.64 \\
\hline ap & 0.00 & 0.09 & 0.23 & 0.09 & 0.00 & 0.05 \\
\hline il & 0.53 & 0.47 & 0.95 & 0.44 & 0.25 & 0.55 \\
\hline c & 0.00 & 0.04 & 1.16 & 2.36 & 0.00 & 0.00 \\
\hline $\mathrm{mt}$. & 1.29 & 1.80 & 0.93 & 0.43 & 0.51 & 0.00 \\
\hline Total & 98.93 & 99.16 & 99.86 & 99.56 & 98.36 & 98.54 \\
\hline
\end{tabular}




\section{Chapter III}

ERUPTION AND EMPLACEMENT OF RHYOLITIC

PYROCLASTIC DEPOSITS AND LAVAS

by

S. Self

D. M. Burt

M. F. Sheridan 


\section{INTRODUCTION}

In order to evaluate the processes of uranium concentration in volcanic rocks it is essential that the host and source rocks be accurately identified. A further step in understanding can be gained if an eruption mechanism can be inferred. This chapter reviews the literature on eruption mechanisms and suggests new insights on the interpretation of eruption mechanisms from volcanic rocks. It stresses Be-U-F mineralization at Spor Mountain and the Thomas Range Utah, i.e. eruptions of fluorine-rich, alkaline silicic magma batches. Such eruptions tend to be small in volume when compared to calc-alkaline rhyolites, and are explosive at first, proceeding to less-explosive effusion of lava.

Silicic magmas such as rhyolites are very viscous. In the near-surface environment this high viscosity controls the diffusion of magmatic gas exsoiving from the magma, and hence controls the growth of bubbles (vesiculation). In some cases, the slow growth of bubbles compared to ascent rates of the magma implies eruption in a state of "arrested" vesiculation with many volatiles being still trapped in the magma. In other cases, especially if the magma is held in an upper crustal environment (magma chamber) for any period of time, vesiculation may proceed until the magma becomes a froth of small bubbles with micron sized bubble-walls (Sparks, 1978). This vesiculation increases the viscosity of and expands the magma, thereby increasing pressure on the enclosing rocks. It is under these conditions that the magma body may erupt by overcoming lithostatic pressure.

Due to processes such as volatilc diffusion, the upper part of a magma body (at a lower pressure) may become more extensively vesiculated than the lower parts and will erupt explosively, forming pyroclastic deposits composed largely of pumice. As an eruption proceeds the lower part will erupt less explosively, largely as a lava flow. This eruptive sequence is reflected in many pyroclastic 
deposits and was described by Sparks et al. (1973; Fig. 1). Each unit, pyroclastic fall, pyroclastic surge, pyroclastic flow and the lava flow is produced by a different phase of the eruption.

Highly alkaline magmas tend to be less viscous than their calc-alkaline counterparts, as Figure 2 shows. Viscosity may be appreciably depressed by the lower $\mathrm{Al}$ and higher $\mathrm{Na}, \mathrm{K}, \mathrm{Fe}$ and volatile (F, Cl) contents. Due to this lowered viscosity, alkalic magmas may have different vesiculation histories than calc-alkaline magmas in that volatiles can diffuse faster and it is easier for bubbles to coalesce. A less thoroughly vesiculated magma may result and this may change the eruptive style towards less explosive, more effusive types. In a study of peralkaline (F-rich) magmatic eruptions in the Azores, Self (1976) showed that the full eruption and deposit sequence, as shown in Figure 1 , is not developed. Instead there is a tendency towards weaker (subplinian) explosive phases followed by lava extrusion or pyroclastic flows alone.

Most magmatic pyroclastic material is glassy and consists of a wide range of sizes (pumice to ash); Table 1 gives a summary of useful terminology. The glassy deposits are easily devitrified and geochemically altered. In general, alkaline magmas occur as smaller magma batches than calc-alkaline types.

If ground or surface water is met by the rising and vesiculating magma it may react explosively, fragmenting the magma to a much greater degree than would occur by explosive vesiculation alone. This drastically alters the style of the eruption and the grain size characteristics of the resulting deposits. The volatiles making up silicic magmatic gas are generally considered to be waterdominated and contain also $\mathrm{CO}_{2}$, small amounts of sulfur, and halogens. In fluorine-rich magmas, $\mathrm{F}$ is dominant over $\mathrm{Cl}$ and may be more abundant than $\mathrm{S}$, (Shepard, 1938; White and Waring, 1963). If the magma body sits for any time in the upper crust, there is the possibility of incorporation of meteoric water 


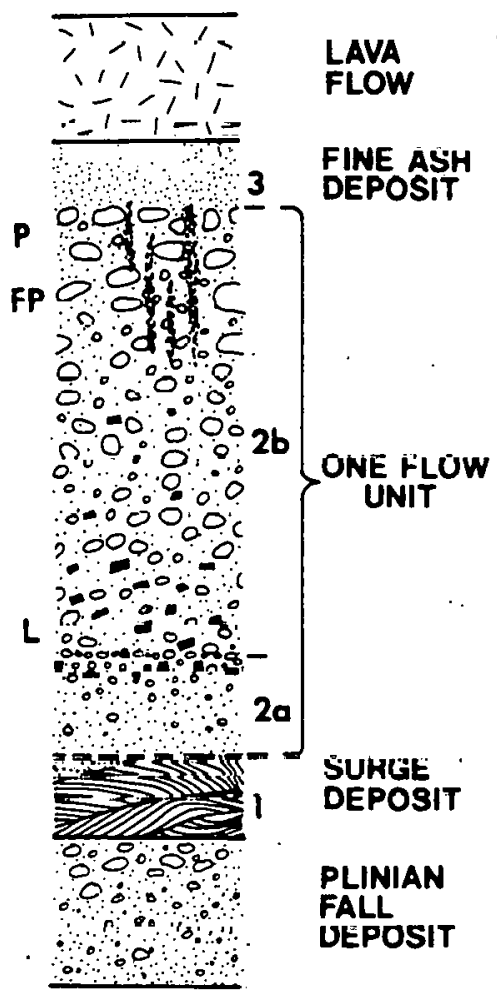

Figurc 1. Sichematic diagrain shuwing the deposits of an explosive silicic eruption episode. An inversely graded plinian fall bed is overlain by a surge deposit (1) of sandwave, massive, or planar facies (Wohletz and Sheridan, 1979). The basal layer of the pyroclastic flow (2á) may show inverse glading, whereas in the main part of the flow (2b) lithic inclusions (L) are concentrated near the base, and pumice fragments ( $P$ ) are concentrated toward the top. Fumarolic pipes (FP) may be present throughout the flow. Deposits of fine co-ignimbrite ash (3) occur above the flow unit. A lava flow might cap the sequence, which reflects the eruption of increasingly volatile-poor magma. (Modified after Sparks et al., 1973). 


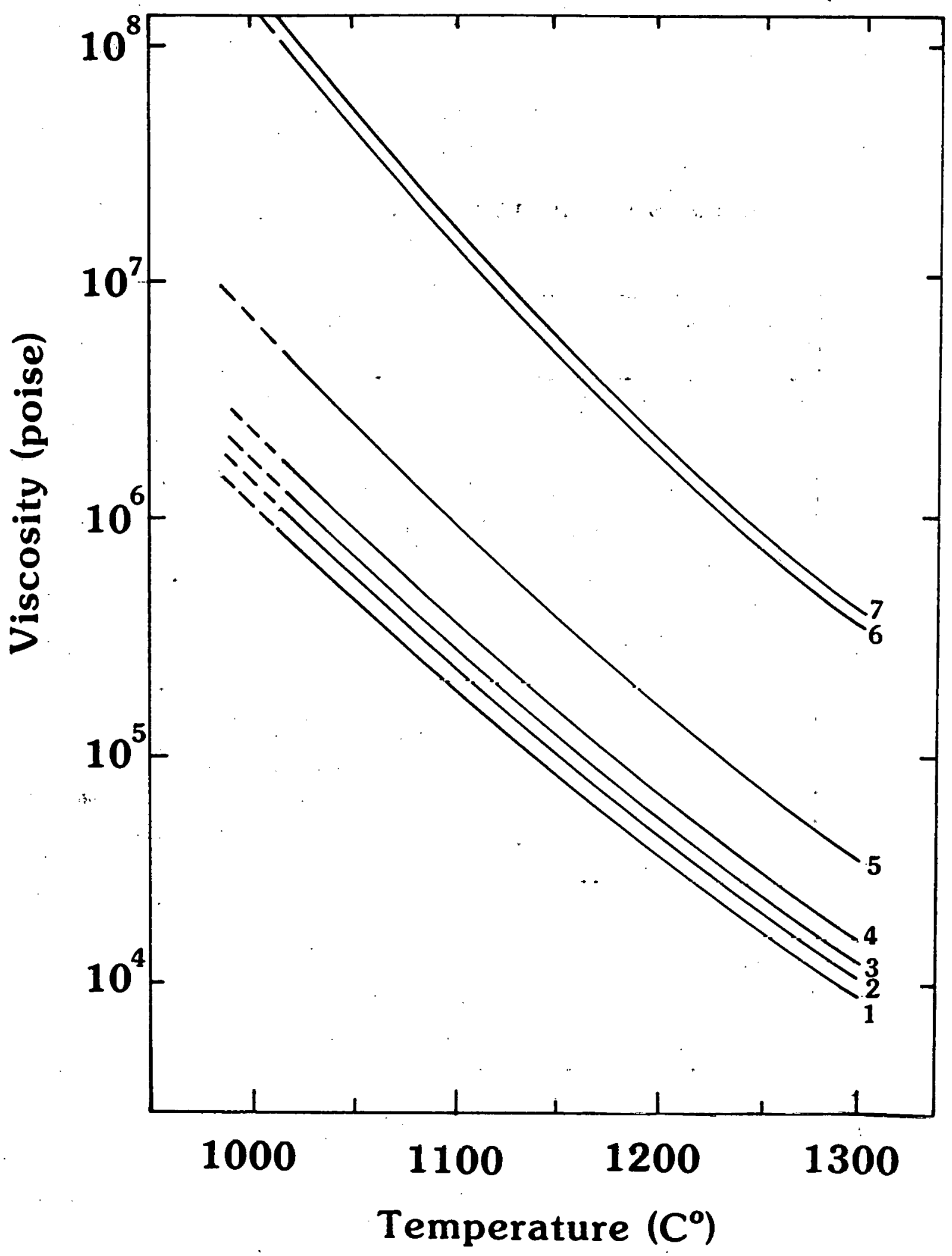

Figure 2. Visiosity vs. temperature curves, calculated by the method of Shaw (1972), for a calc-alkaline rhyolite ash flow tuff and lava (curves 6 and 7 ) and alkaline and peralkaline tulffs (curves 1-5), after Wolff and Wright (in press). 
TABLE 1. GRAIN SIZE LIMITS FOR PYROCLASTIC FRAGMENTS AFTER FISHER (1961)

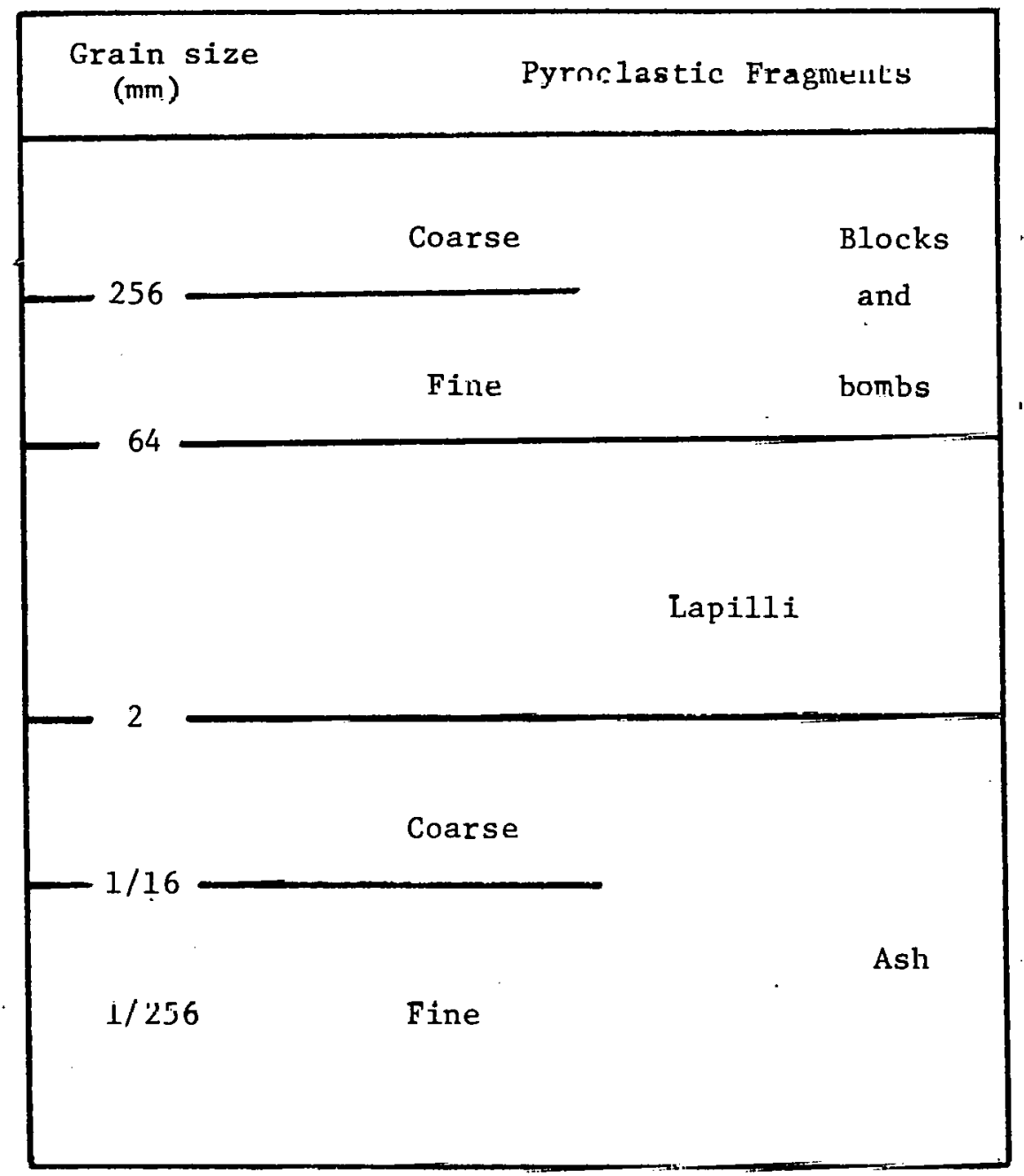


into the magma. The relative amounts of meteoric, as opposed to magmatic, water in these magmas is a current topic of debate.

With the above very generalized picture in mind we will examine the types of pyroclastic deposits associated with uranium mineralization in F-rich silicic volcanics and show how eruption mechanisms may be interpreted from these deposits.

\section{EXPLOSIVE ERUPTIONS AND THEIR DEPOSITS}

The main physical factors affecting eruption mechanisms include rate of magma eruption, volume of magma erupted, composition (viscosity) of the magma, distribution and content of volatiles, and size and shape of existing volcanic structures (such as conduits and vents). Only a relatively few common associations are formed from eruptions of silicic magma: 1) late-stage domes from central-vent volcanoes, 2) pyroclastic deposits associated with central composite or strato-volcanoes, 3) isolated lava dome and pyroclastic complexes, unrelated to previous or subsequent volcanic structures, 4) domes and associated pyroclastic complexes that are precursors to caldera formation, 5) domes and pyroclastic deposits that form subsequent to caldera collapse, and 6) regional pyroclastic flow (ash-flow) sheets associated with calderas (Smith, 1960a; Ross and Smith, 1961). The erupted volume for these deposits covers sevenorders of magnitude from $10^{-4}$ to $10^{3} \mathrm{~km}^{3}$ (Smith, 1960a); associations are listed above approximately in order of increasing volume. In addition, 7) rising magma contacting ground water will explode causing craters surrounded by tuff rings (maar type volcanoes) and these often are later filled by lava domes in the same eruptive sequence.

For the purposes of this study the details of actual eruption styles are of less importance than the thorough characterization of various pyroclastic and lava deposits produced, and the correlation of these into a recognizable eruption sequence. This sequence can then be related to an eruptive style. 
The types of styles discussed here are largely those within the scope of this study, i.e. associations $3,4,5$ and 7 above.

\section{Explosive Eruptions}

The style of eruption controls the resulting deposits. Current physical models of magma emplacement and eruption are adequately summarized by Williams and McBimey (1979, p. 71-96). Basically eruptions can be divided into two types: 1) those involving ground or surface water (phreatic, phreatomagmatic, or hydrovolcanic) and 2) those driven only by internal gas pressure (magmatic).

Phreatic explosions result when meteoric water is vapnri z.en with sufficient pressure to rupture and eject the confining rocks. Purely phreatic explosions expel no juvenile (magmatic) material. Phreatic explosions are generally single bursts that produce a circular crater surrounded by a layer of unstratified breccia. Multiple explosions produce overlapping craters and breccias.. The clasts and matrix may be strongly altered prior or subsequent to eruption through the action of hydrothermal solutions.

Phreatomagmatic (surtseyan) eruptions are produced by the interaction of ground or surface water and magma, and may eject much 1ithic material (nonjuvenile), as well as juvenile material. Explosions are repeated at regular short intervals so that the deposits are well-stratified. Both vertical eruption columns and pyroclastic surges (base surges) are prodiced by this type of explosion. Around the vent the deposit has the morphology of a tuff ring or a tuff cone (Wohletz and Sheridan, 1979) and there is a fairly localized ash fall blanket. Examples are the Surtsey, 1964 eruption and the Ukinrek, 1977 eruption (Self et al., 1980). These are basaltic eruptions but silicic examples are common, e.g. Mono Craters California (Wood, 1977); Spor Mountain Utah (Bikun, 1980). 
Vulcanian eruptions generally refer to repeated cannon-1ike explosions from intermediate to silicic strato-volcanoes (Nairn and Self, 1978; Self et al., 1979). They are generally restricted to the more viscous magmas, as strength of the magma plays a role in allowing substantial pre-explosion pressures to be built up. Crystal-rich magmas appear to be particularly prone to producing vulcanian explosions. Dome growth, as evidenced by the active dacite domes and lava flows of Santiaguito, Guatemala (Rose, 1973), is often accompanied by both vulcanian explosions and small pyroclastic flows of dense or partially vesiculated material (true nuees ardentes: Rose et a1., 1977). This latter type of eruption may be correctly termed pelean, after the 1902 eruption of Mt. Pelee, Martinique.

Plinian emptions are powerful; continuous gas-blast eruptions that eject tremendous volumes of pumice (Walker and Croasdale, 1971). The turbulent eruption column has two components (Sparks and Wi1son, 1976): 1) a lower gasthrust region, the high-velocity gas and ejecta jet discharged into the atmosphere, which passes up into 2) the convective thrust zone, that rises by thermal buoyancy. For water contents, vent radii, and initial velocities typical of plinian events the top of the gas-thrust zone is from 3.0 to $9.0 \mathrm{~km} \mathrm{high} \mathrm{(Wilson,}$ 1976; Sparks et al., 1978), and the top of the whole eruption column is between 20 and $50 \mathrm{~km}$ high.

Sub-plinian eruptions are, as the name suggests, scaled-down plinian eruptions. The gas blast eruption is not so continuous and stratified deposits (several fall units) result. The eruption column is lower and hence dispersal of the pumice fall layer is more restricted. Sub-plinian eruptions frequently preceed or accompany dome growth, especially in alkali-rich silicic lavas, as in the peralkaline pumice deposits and domes of Terceira, Azores (Self, 1976). Pyroclastic flow (also called ignimbrite-forming or ash-flow) eruptions can occur if fallout of large clasts and expansion of incorporated air into a 
vertical eruption column of plinian, subplinian or vulcanian type are not sufficient to induce buoyant uplift in the column at the end of the gas-thrust zone. Gravitational column collapse then occurs and this produces pyroclastic flows (Wilson, 1976; Sparks and Wilson, 1976; Sparks et al., 1978; Fig. 3). Vent radius increase or volatile content decrease may both act to produce a critical condition where the column density at the top of the gas-thrust zone remains greater than that of the surrounding atmosphere and collapse ensues. Pyroclastic flows travel down the volcanic edifice and deposit on low ground. The resulting rock is known by various names including ignimbrite and ash fluw luff. There is no widely accepted term for this eruptive style or phase, but pyroclastic flow, ash flow or, outside the U.S.A., ignimbrite (-forming) eruption is a suitable informal term, depending on the scale of the eruption (Wright et al., in press). The name pelean is sometimes used but is now known to be incorrectly. applied.

Some eruptions of this type terminate with lava extrusion, generally forming domes. A sequence of plinian fall, pyroclastic flow and lava extrusion has been interpreted for several historic silicic and intermediate eruptions, o.g. Katmai, Alaska 1912 (Curtis, 1968), Krakatau 1883 (Self, unpublished data), Mt. Pelee 1902 (Roobol and Smith, 1975), and has been interpreted from many Quaternary examples studied, e.g. the Bandelier Tuffs, Valles Caldera, New Mexico (Smith and Bailey, 1966; Fisher, 1979). This commonly repeated eruptive sequence produces deposits in a certain order (Sparks et al., 1973), as shown on Fig. 1. The sequence as suggested in 1973 has recent.ly heen modifiẹd by Sheridan (1979) and Fisher (1979) to include pyroclastic surge beds. The complete sequence is not always present. For example, the 1902 plinian eruption of Santa Maria, Guatemala was not succeeded by a pyroclastic flow phase, but lava extrusion (from the same magma chamber) began from the 1902 vent in 1922; the dacite lava dome, Santiaguito, is still growing today. 


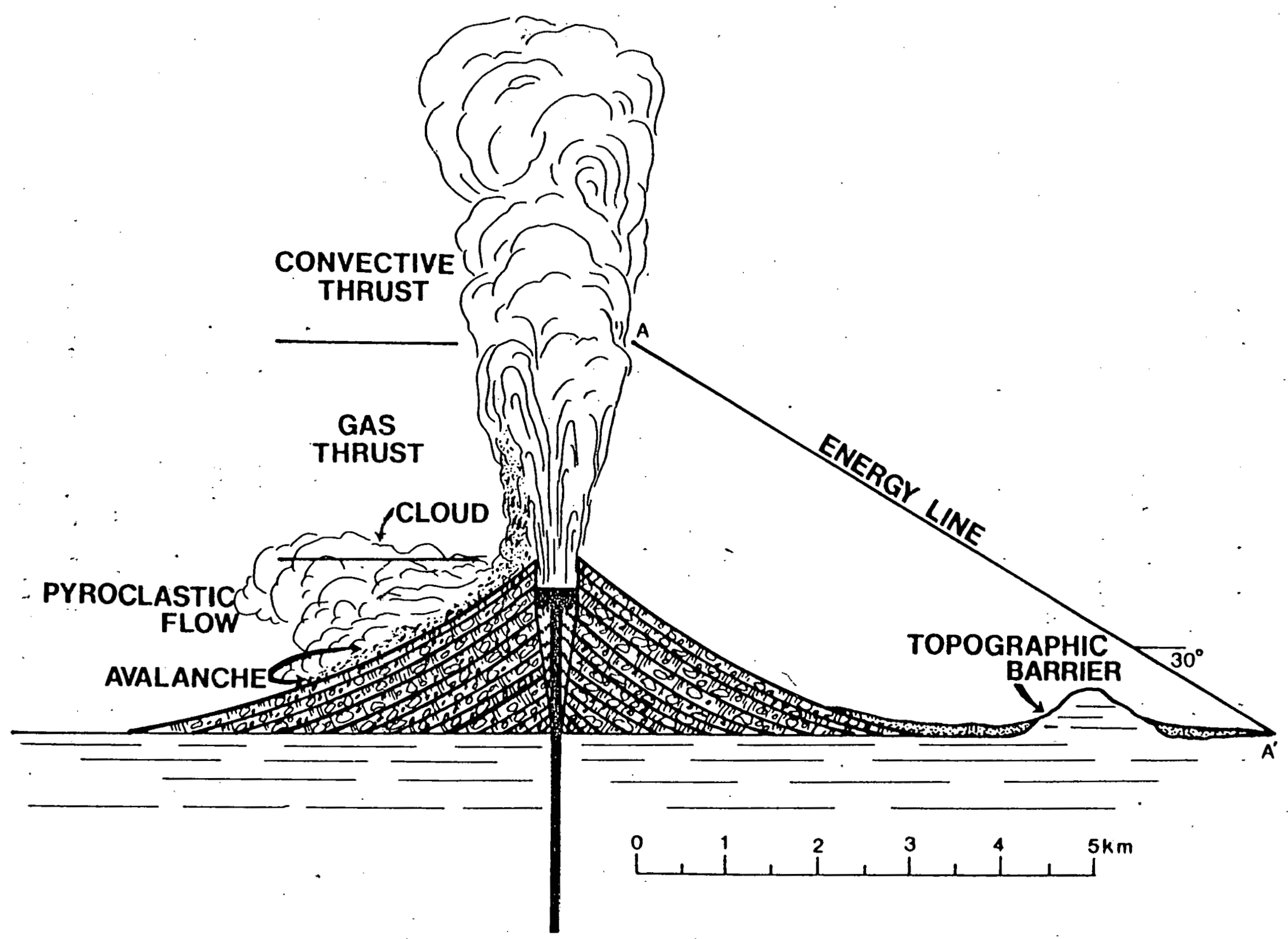

Eigure 3. Schematic diagram of a plinian eruption from a composite volcano showing the gas-thrust and convective-thrust regions of the eruption column. The energy line (A-A') traces the potential flow head from the top of the gas-thrust zone to the distal top of the flow. Column collapse within the gas-thrust region could produce a pyroclastic flow compose of a dense avalanche and a dilute overriding cloud. The pyroclastic flow may overrun topographic barriers that do not extend above the energy line (from Sheridan, 1979). 
The term pyroclastic surge has been introduced into this discussion and it is appropriate to mention here that this is a newly recognized type of pyroclastic deposit, of which there are so far three types known. There is not a particular type of "pyroclastic surge eruption", rather pyroclastic surges are produced as accessory volcanic phenomena by three types of eruptions: phreatomagmatic (base-surge), plinian-pyroclastic flow (ground surge and ash-cloud surge) and dome forming or pelean (ground surge and ash-cloud surge). A brief summary of various types of explosive eruptions is given in Table 2 .

\section{Pyroclastic Deposits}

Pyroclastic deposits may be grouped into a three-fold classification (Sparks and Walker, 1973; Sheridan, 1979; Wright et al., in press): (1) fall, (2) surge, and (3) flow. There are two additional types of pyroclastic deposits that should be mentioned: explosion breccias and volcanic mudflow (lahars). Relaxation time (the time required for equilibrium to be established with the transport medium, load, and substance) is critical for the development of textures in pyroclastic deposits; hence transitional types are found. In these transitional types the specification of a class is subjective, but it should not affect the interpretation of the deposit as a whole.

1) Pyroclastic fall deposits are produced when material is explosively ejected from the vent into the atmosphere producing an eruption column in the fnrm of a convective plume. The plume expands and pyroclasts fall back under the influence of gravity at varying distances down wind from the source. The geometry and size of the deposits reflects the eruption column height, and wind velocity and direction. The primary feature of air-fall transport is the uninterrupted path of individual particles that attain velocities controlled by ballistic trajectory, air-drag and wind. Air-fall deposits are the best sorted of all pyroclastic beds. Fall deposits show mantle bedding and maintain a uniform thickness over 
TABLE 2. TYPES OF EXPLOSIVE ERUPTIONS AND DEPOSITS: SUMMARY

1. Strombolian - Cone-forming, moderate to small fraction of fines, inverse-graded avalanche beds on steep slopes, many superimposed scoria beds. Generally basaltic-andesitic magma.

2. Surtseyan (phreatomagmatic) - Mildly cone-forming, abundant fines, stratified, associated with base surge deposits, abundant lithics, weakly vesiculated juvenile clasts, impact sags common.

3. Vulcanian - Moderately sheet-forming, abundant fines, abundant lithic clasts, associated with small pyroclastic (scoria and ash) . flows.

4. Plinian and Sub-plinian - Strongly sheet-forming, but mantling, lower fraction of fines, single bed of decimeters to meters thickness, strongly vesiculated pumice, may have inverse size-grading, maybe associated with pyroclastic flow and surge deposits.

5. Ignimbrite forming (ash flow) - Sheet-forming, depression-filling, thick (meters to 100's meters) deposits formed by collapse of pliniantype eruption columns or weakly convective columns.

6. Peléan - Dome growth accompanied by explosive activity producing air-fall, pyroclastic flow and surge deposits. 
restricted areas while draping all but the steepest topography (Fig. 4a). They are generally well sorted $(\sigma \phi \underline{2} 2.0)$ and sometimes show internal stratification due to variations in eruptive column conditions. Fall deposits are produced by plinian, sub-plinian and vulcanian eruptions and as an accessory to some pyroclastic flow eruptions.

2) Pyroclastic surge deposits result from a pulsating series of explosions in which a sequence of dilute density flows that are blasted outward from the vent rapidly dissipate their kinetic energy. Surge formation involves the lateral movement of pyroclasts as expanded, turbulent, low concentration gas-solid dispersions. Deposits do mantle topography but tend to accumulate more thickly in depressions (Fig. 4c). Characteristically they show unidirectional sedimentary bedforms (cross-stratification, dunes, planar lamination, antidunes, pinch and swell structures, and chute and pool structures) and individual laminae are generally well-sorted (Fisher and Waters, 1970; Waters and Fisher, 1971; Crowe and Fisher, 1973; Schmincke et al., 1973; Schmincke et'a1., 1973; Sparks, 1976; Wohletz and Sheridan, 1979).

Pyroclastic surges range from relatively low temperature base surges to high temperature ground surges related to vulcanian-type explosions, directed blasts, or collapsing eruption columns. Surge blasts often interact with materials of other origin by incorporating fragments or modifying primary textures. Vertiçal gradational contacts from fall through surge to flow are common (Fig. 1). Tables 3 and 4 summarize pyroclastic surge eruption and deposits (after Wrighl el al., in press).

3) Pyroclastic flow deposits involve the lateral movement of pyroclasts as a gravity-controlled, hot, high concentration gas-solid dispersion, which may in some instances be partly fluidized (Sparks, 1976). This classification includes all flows that are denser than air; ash flows (more strictly pumice and ash flows) are the most voluminous type. Deposits are topographically controlled, 

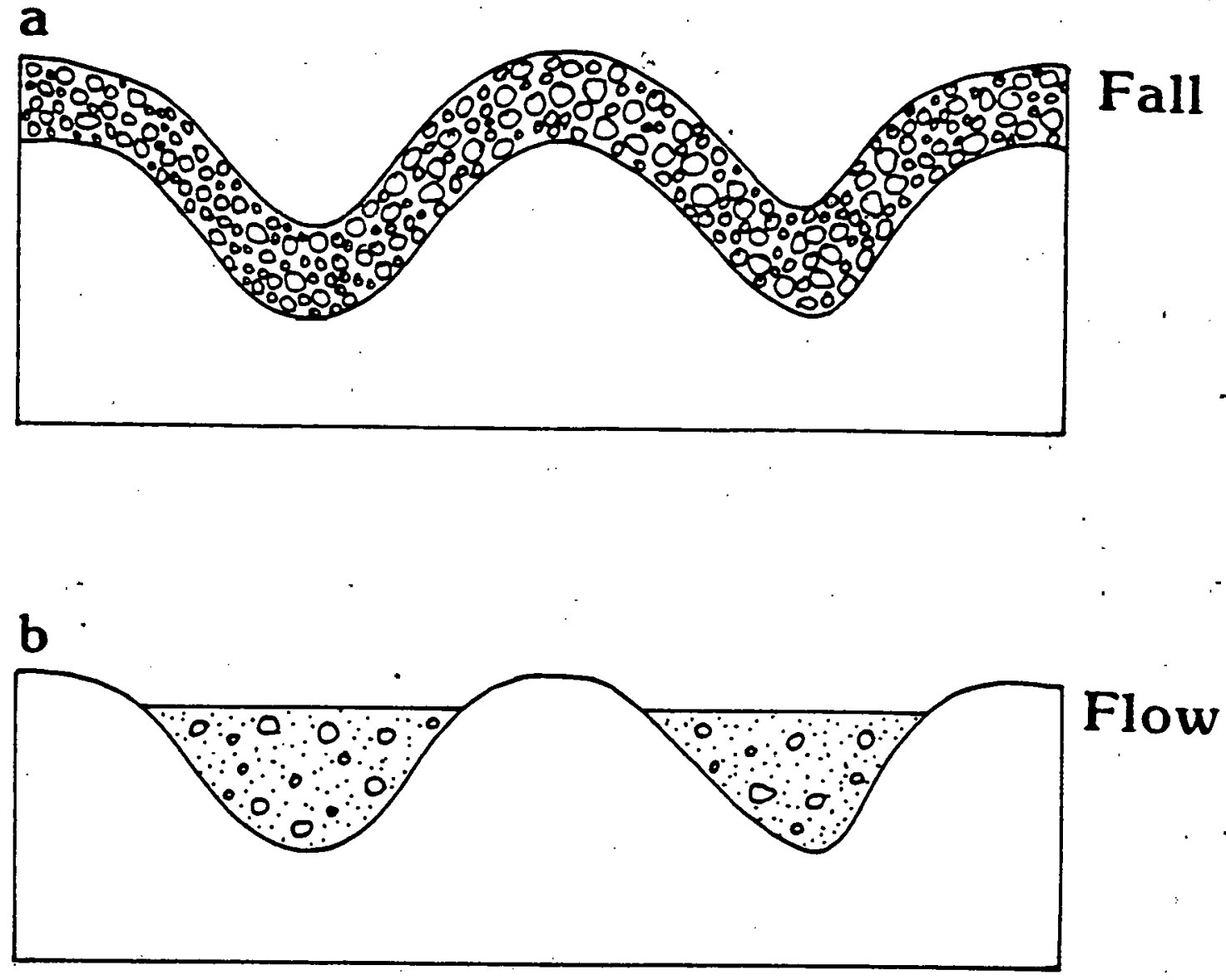

Flow

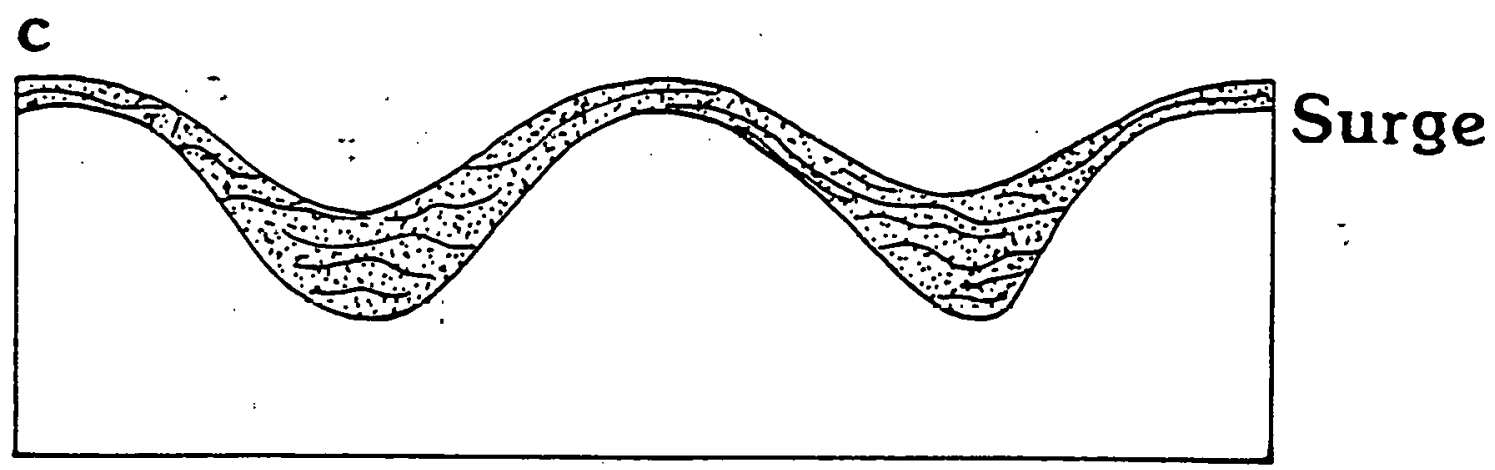

Figure 4. Geomorphic relations of the three main types of pyroclastic deposit overlying the same topography. 
TABLE 3. GENETIC CLASSIFICATION OF PYROCLASTIC SURGES

ESSENTIAL FRAGMENT ERUPTIVE MECHANISM TYFE OF SURGE HISTORIC EXAMPLES COMMENTS

\section{VESICULATED}

NON-VESICULATED
COLLAPSE OF A PHREATO- - BASE SLRGE MAGMATIC ERUPTICN COLUMN
TAAL, PHILIPPINES, 1965, I 966; CAPELINHOS, FAIAL, AZORES, 1957-1958

Base surges result from the explosive interaction of magmatic material and water and are consequently cool. They are of ten associated with maar volcanoes and tuff rings. The historic examples described are both basaltic but older phonolitic base surges are known from the Laacher See area, Germany (Schmincke et al., 1973) and rhyolitic ones from the Minoan eruption of Santorini (Bond and Sparks, 1976).

ACCOMPANYING PYRDCLASTIC FIOWS

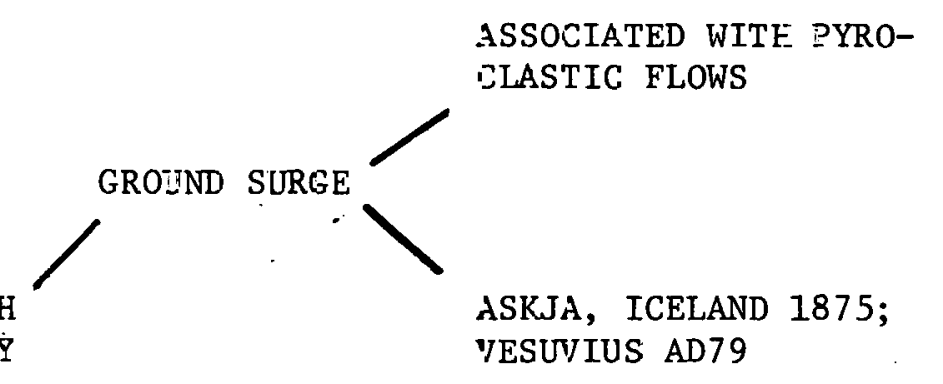

ALSO ASSOCIATED WITH AIR-FALL DEPOSITJ BY COLNAPSE OF ANT ERUPTION COLUMN BDT WITHOUT GENERATION OF PYROCLASTIC F_OW

ASH CLOUD SURGE
Ground surge, although orfginally introduced by Sparks and Walker (1973) to encompass all pyroclastic surges, is here used to describe those surges found at the base of pyroclasflow deposits, as well as those produced without any accompanying pyroclastic flow.

MT. PELEE, MARTINIQUE; 1902
Ash cloud surges (Fisher, 1979) are the turbulent, low density flows derived from the overriding gas-ash cloud of pyroclastic flows. These may in some cases become detached from the parent pyroclastic flow and move independently. 
TABLE 4. DISTINCTIONS BETWEEN BASE SURGES AND GROUND SURGES, AND THEIR DEPOSITS

\section{BASE SURGES}

formed by horizontal blast accompanying vertical eruption column

wet, involving groundwater

range up to $10 \mathrm{~km}$ from source but usually $<5 \mathrm{~km}$

\section{BASE SURGE DEPOSITS}

found in deposits around maars or tuff rings

usually associated with monogenetic volcanoes (i.e. those that erupt once only: e.g. Capelinhos, 1957)

mostly contain both juvenile (magmatic) and accessory material but can have no juvenile material if produced by a true phreatic eruption

show cross bedding, pinch and swell (lensoid) bedding, plastering against vertical obstructions

vegetation is destroyed and flat tened but not charred; vegetal matter may be incorporated into deposits

are of ten interstratified with beds containing accretionary lapilli

beds may show plastic deformation under bomb sags

coarse to fine grain-size depending on distance from source. Poorly sorted with some large blocks and many fines

base surge deposits often become consolidated and indurated forming a hyaloclastite tuff (palagonite tuff in the case of basaltic deposits)

\section{GROUND SURGES}

formed by flow front processes at head of pyroclastic flow or directed blast

dry, magmatic gas only

range up to many $10^{\prime} \mathrm{s} \mathrm{km}$ from source

\section{GROUND SURGE DEPOSITS}

most often associated with ash flows (ignimbrites) but also with other pyroclastic flow deposits

found around calderas, strato-volcanoes and domes

generally composed of juvenile material, but ground surges of mainly lithic (accessory) material are known to exist

cross bedding less distinct (may be less efficiently maintained because lack cohesiveness of wet base surge deposits)

often contains charred wood, indicating vegetation destroyed by hot gases

may only rarely be associated with beds containing accretionary lapilli

no bomb sags

generally poorly sorted but lack fines. Large blocks may be transported several kilometers if slope is favorable

generally non-consolidated 
filling valleys and depressions (Fig. 4b). They are poorly-sorted and sometimes show coarse-tail grading (Smith, 1960a; Sparks, 1976). Poor sorting in flow deposits is attributed to high particle concentration and not turbulence, with the dominant flow mechanisms probably being laminar and/or plug flow (Sparks, 1976). Individual deposits generally lack internal stratification, although superposition of a number of flow units (each flow unit being regarded as the deposit of a single pyroclastic flow) can give the appearance of stratification. They sometimes contain fossil fumarole pipes in which the fine ash fraction has been lost making the pipes enriched in crystals, lithics or vesicular fragments (Walker, 1971, 1972; Roobol and Smith, 1975).

There is probably a complete gradation from high concentration, high density pyroclastic flows to low concentration, low density surges. Indeed, ash-cloud surge deposits represent the lateral equivalents of pyroclastic flows (Fisher, 1979). Of course, surges are a type of flow, but the term pyroclastic flow has traditionally been associated with high concentration flows and it is appropriate here to consider the fundamentally different types of deposits produced by flows and surges separately. Table 5 summarizes the known types of pyroclastic flow deposits (after Wright et al., in press). 4) Explosion breccias are the result of violent bursts of energy that fragment magma, lava, or country rock. They are commonly produced by phreatic or phreatomagmatic explosions. The deposits formed may sometimes be essentially in place, as in the case of vent or pipe breccias, but typically they form a peel-back blanket around the vent. Emplacement of explosion breccia differs from that of air-fall in that it is a mass turn-out of material, commonly with an inverted stratigraphy (the effect of air drag on size sorting of fragments being negligible). Breccia pipes, the exhumed conduits of maar-type volcanoes, are thought to be produced largely by phreatomagmatic eruptions and are often sites for mineralization. 
TABLE 5. TYPES OF PYROCLASTIC FLOWS

ESSENTIAL FRAGMENTS ERUPTIVE MECHANISM $\quad: \quad$ PYROCLASTIC FLOW: DEPOSIT COMMENTS

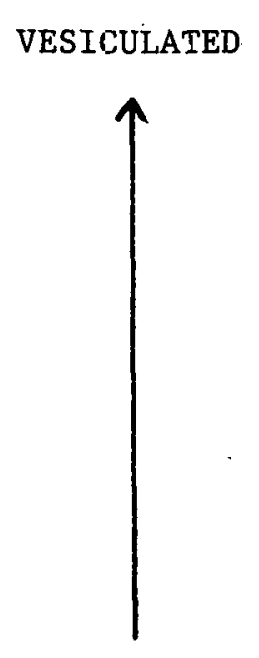

Decreasing average density of juvenile clas:s

NON-VESICULATED

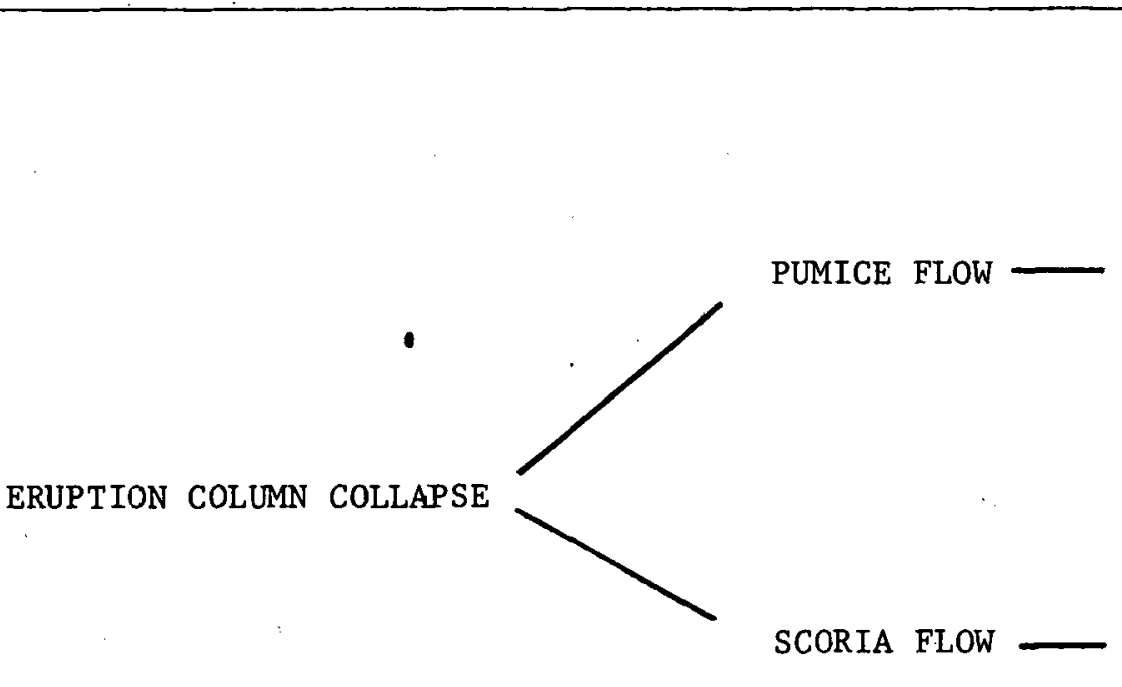

SCORIA AND PUMICE AND ASH DEPOSIT Basalt to andesite in composition. Some deposits do contain large un-

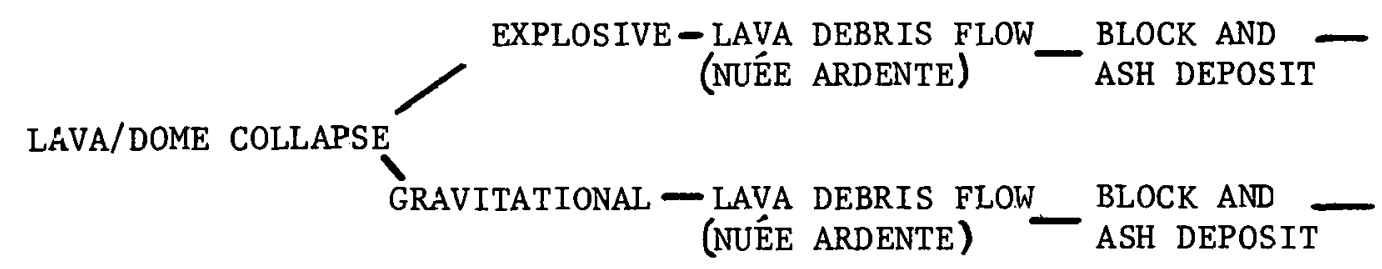

Small volume deposits probably formed by interrupted column collapse as in the case of scorla flows described below. Intermedlate to silicic in composition.

Small volume deposits probably formed by interrupted column collapse produced by short explosions (see Nairn and Self, 1978). vesiculated blocks.e.g. those of

Ngauruhoe 1975.

Large volume deposits formed by continuous collapse of a plinian Sparks et al. (1978). Silicic in composition.

Small volume deposits, usually andesite or dacitic in composition.

Small volume deposits usually andesitic or dacite in composition. 
Deposits are commonly a single unstratified, nongraded bed that mantles existing topography. It may be interbedded with. or gradational into inverselygraded avalanche deposits, air fall beds, or stratified surgc deposits. The thickness is uniform at the outcrop scale, exceeding a few meters only for exceptionally large explosions. There is generally a regular decrease in thickness and size of clasts with distance from the vent, yet some explosion breccias show the inverse relationship (Self et al., 1980). Impact sags containing blocks or bombs are present at the base of the deposit and beyond the continuous blanket.

5) Volcanic mud flows (lahars) are water-mobilized flows of freshly deposited pyroclastic ejecta and may be associated with phreatic and phreatomagnatic activity, or subsequent re-mobilization of flow or fall deposits by rainfall. There is a gradational transition from surge and flow deposies into lahars. In rogions of high rain fall they may be very large and voluminous. They are sometimes hard to distinguish from pyroclastic flow deposits in the field. Excelient descriptions of lahars are given by Crandell (1971) and Neall (1976).

Each of the above five emplacement mechanisms produces depostes with variable, but distinctive, features that are generally adequate for identification. The next major section gives further details on the main field characteristics of sub-aerial pyroclastic deposits.

Subaqueous Deposition of Pyroclastic Deposits

The depusition of pyroclastic fall material into water produces bedds to laminated deposits with different grain size characteristics than the equivalent subaerial deposit. Many factors are involved, including water depth and typc of pyroclastic particle. One important point is that pumice generally decreases in density with increasing size and this may give an inverse size grading in waterlain deposits. Also bigger pumice clasts float for longer. 
All things considered aqueous fall deposits should still be recognizable by their grain size characteristics.

Pyroclastic surges may travel across water (e.g. Taal, 1965 eruption: Moore et al., 1966), although recognizable of characteristics surges may be obliterated by intervening bodies of water.

Pyroclastic flows are generally denser than water (estimated densities are 1.2-1.7; Sparks, 1976; Sparks et al., 1980) and may be able to enter water virtually undisturbed. They should travel underwater and leave deposits still recognizable as pyroclastic flows by their texture and character. Such rock bodies have been described by Fiske and Matsuda (1964) and Roobol (1976), but are in need of better documentation.

\section{CHARACTERIZATION OF PYROCLASTIC DEPOSITS AND ERUPTION SEQUENCES BY FIELD EXAMINATION}

This section deals with useful concepts and recent developments in the understanding of eruption mechanisms via the resulting deposits. It encompasses fall (plinian, sub-plinian and vulcanian), surge and pyroclastic flow deposits of both magmatic and phreatomagmatic types.

Pyroclastic fall deposits may be classified by their dispersal pattern and degree of fragmentation, following Walker (1973). The dispersal (D) is defined as the area in square kilometers within the isopach contour equivalent to $1 \%$ of the maximum thickness. The degree of fragmentation (F) is defined as the fraction less than $1 \mathrm{~mm}$ in the deposit along the dispersal axis where the thickness is 0.1 of the maximum thickness. The deposit is considered cone-like nr sheet-like depending on whether $D$ is less than or greater than $5 \mathrm{~km}^{2}$. Phreatomagmatic eruptions generally produce deposits with higher values of $F$, except for very powerful plinian emuptions," where fragmentation is also high. According to Walker (1973), deposits from the common eruption types can be separated on a diagram of F vs. D (Fig. 5). 


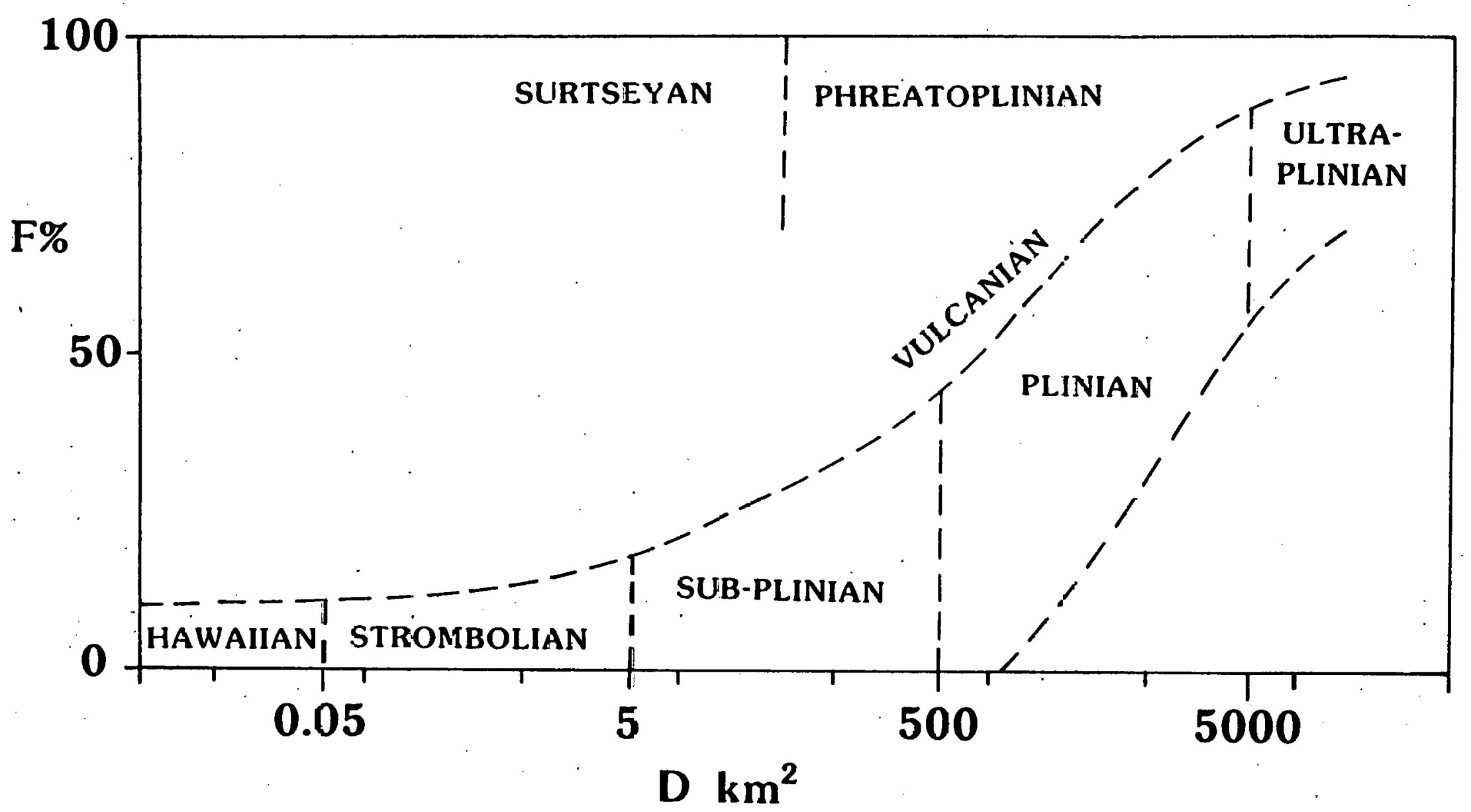

Figure 5. Classification scheme of pyroclasicic fall deposits after Walker (1973). Plot of F (wt. percentage of deposit finer than $1 \mathrm{~mm}$ on the axis of dispersal where it is crossed by 0.1

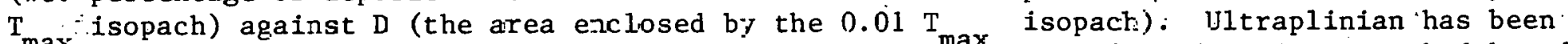
introduced by Walker (1979) for the mest widely dispersed plinian fall deposits. Dashed boundaries are arbitrary. 
Due to the great variety of eruption types and initial size distributions, there is a wide diversity in textural features of air-fall deposits. These are briefly summarized in Table 2 .

Primary air-fall textures are subject to modification by many factors. Widespread inverse grading in plinian and subplinian deposits can be produced by changing conditions in the vent and eruption column. Increasing vent size may promote higher eruption columms which would produce an inversely-graded bed; fluctuations in colum height may produce more than one inversely-graded fall unit (Self, 1976; Wilson, 1976). Also, air-fall deposits may locally occur with thick inversely graded beds where they have avalanched down steep slopes.

Hot fragments may be soft enough to fuse on contact producing welded scoria or welded pumice layers near the vent (Sparks and Wright, 1979) and these are particularly common in alkaline and peralkaline rhyolite magmas. The deposit may resemble a welded ignimbrite (ash-flow) but should be distinguishable by morphology (Fig. 4) and limited lateral extent. Surges or flows contemporaneous with or following air-falls may incorporate their clasts to form a complete spectrum of mixed deposits. Finally, fine-grained air-fall deposits can easily be eroded by sheet-wash to produce 1 ahars.

Pyroclastic surge deposits are found in several associations. Firstly, they occur in the deposits of tuff-rings which surround flat-bottomed, dishshaped explosion craters called maars (Wohletz and Sheridan, 1979) and in tuffcones. These are base surge deposits (Moore, 1967); their occurrence is not restricted to any particular composition of magma. Very frequently these cross-bedded deposits have been mistaken for water-lain ash. Sheridan and Updike (1973) recognized three prominent hedding types 1) sandwave, 2) massive and 3) planar. Studies of further examples led to a facies concept for the 
distribution of these bedforms around a source crater. Facies change reflects the deceleration of the surge cloud. Fig. 6 shows a simple facies model for a base surge deposit: the sandwave bedding characterizes the fastest, highenergy flow regime, the massive beds the medium energy regime, where a large part of the suspended load has subsided to become a bed 1oad, and the planar beds are produced by the slowest surge transport i.e. ground level grain-flow. Examples of deposits produced by sequences typical of tuff ring and tuff coneforming eruptions are shown in Fig. 7 .

Ground surges and ash cloud surges (Fisher, 1979) are prodused by the mcchanisill of pyroclastic fluw and are often associated with ash flows. Ground surges may also be produced by separate blast emptions (Sparks and Walker, 1973). Fig. 8 shows a typical example of the occurrence of ground surge and ash-cloud surge from the Bandelier Tuff, New Mexico.

Pyroclastic flows occur over an eight-order volume range (Smith, 1960a) from small scoria and ash.flows like those of the 1968 eruption of Mayon volcano (Moore and Melson, 1969) to great ash flows that deposited tuff sheets like the Bandelier Tuff (Smith and Bailey, 1966) around large calderas (Table 5). At one extreme arc pyruclastic avalanches such as those at Ngauruhoe (Nairn and Self, 1978) that rest with angles of repose from $6^{\circ}$ to $25^{\circ}$ on the flanks of composite volcanoes. At the other extreme are large pyroclastic flows with excessive mobility that have surmounted topographic barriers at great distances (e.g. the Ito flow: Yokoyama, 1.974).

The fundamental deposit formed by the passage of a sillglc flow is a pyroclastic flow unit (ash flow of Smith, 1960a). The general characteristics of pyroclastic flows have been reviewed by Smith (1960a) and Ross and Smith (1961). Current models of generation and emplacement of pyroclastic flows have been described by Sheridan (1979). The thickness of pyroclastic flow units ranges from $0.05 \mathrm{~m}$ to more than $100 \mathrm{~m}$, with a mean thickness between 1 and $10 \mathrm{~m}$; 


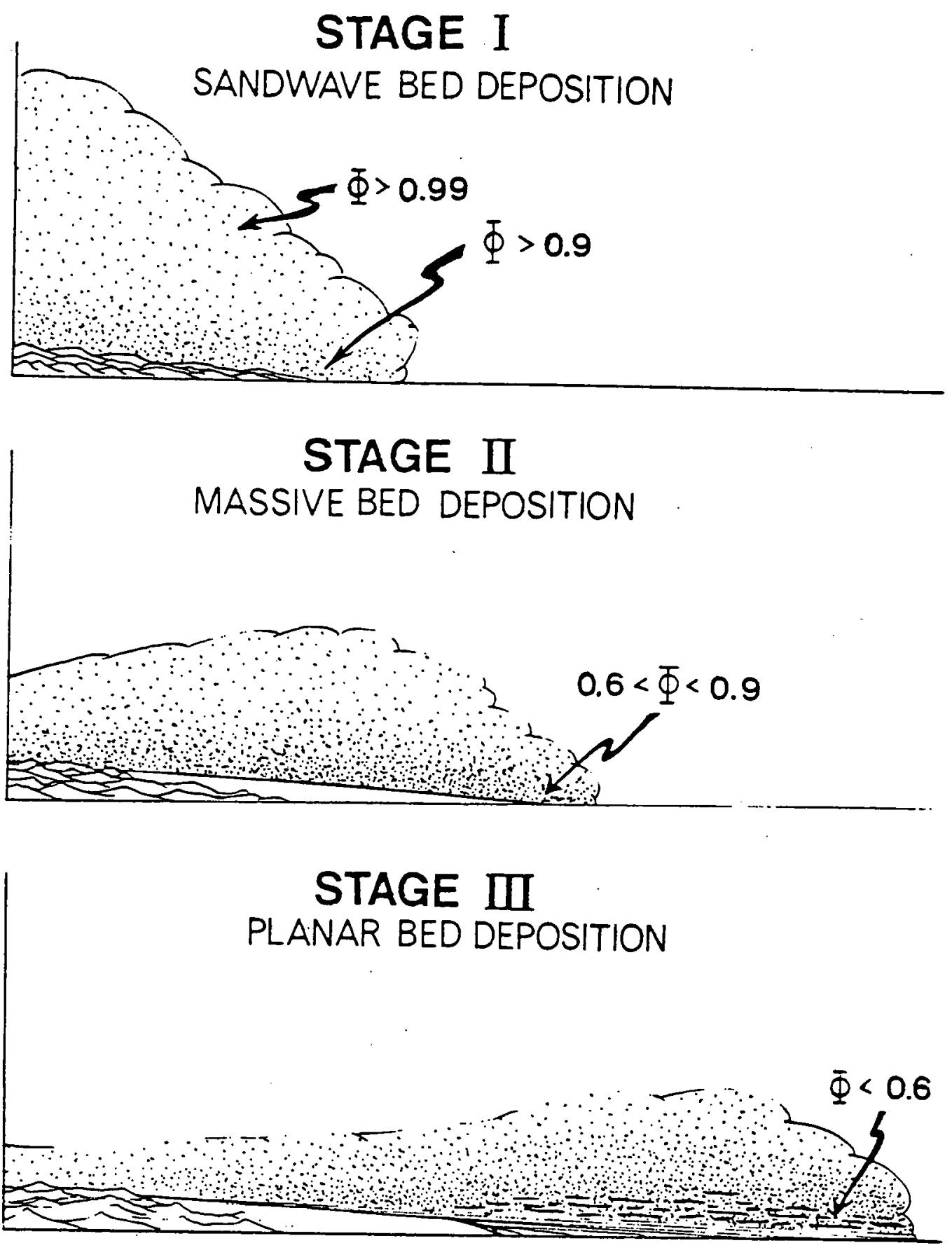

Figure 6a. Diagrammatic illustration of a surge cloud at three stages of its development: Stage I near the vent, Stage II at intermediate distances from the vent, and Stage III near the terminus of its flow. During Stage I, flow is highly inflated $(\phi>0.9)$, and deposition of sandwave beds results. At Stage II the cloud has deflated $(0.6<\phi<0.9)$, with massive bed deposition resulting. Finally, at Stage III, the cloud has deflated until it is an avalanching-type flow $(0.5<\phi<0.6)$, planar beds are deposiced, and the flow stops (after Wohletz and Sheridan, 1979). 


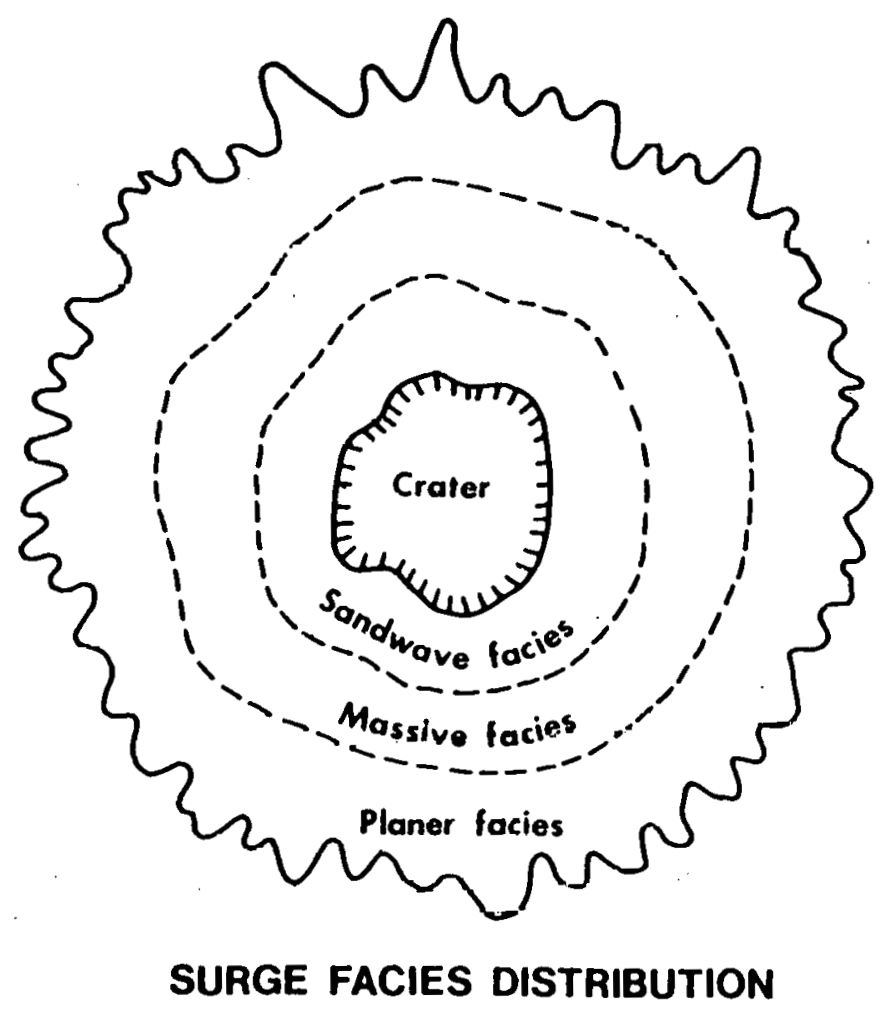

Figure 6b. Dlagrammatic 1llustration of surge facies distribution arnund a hydromatmalic vent after Wohletz (1980). 
Tuff Cone

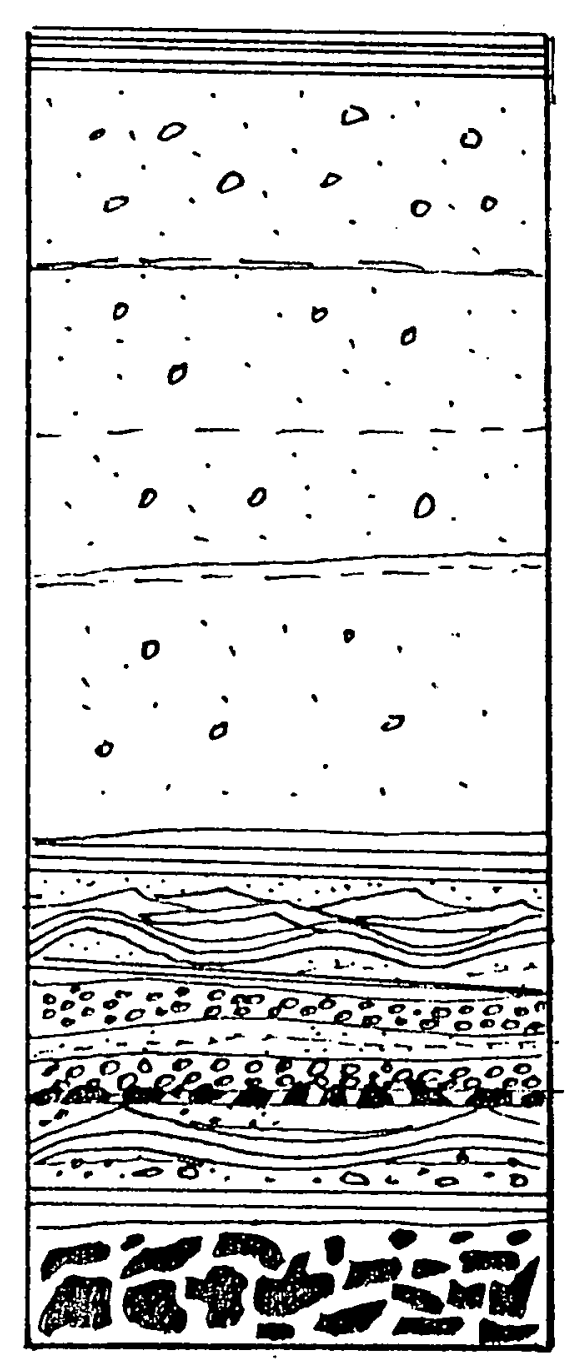

Surge

Massive tuff

Surge

Breccia
TUFF RING

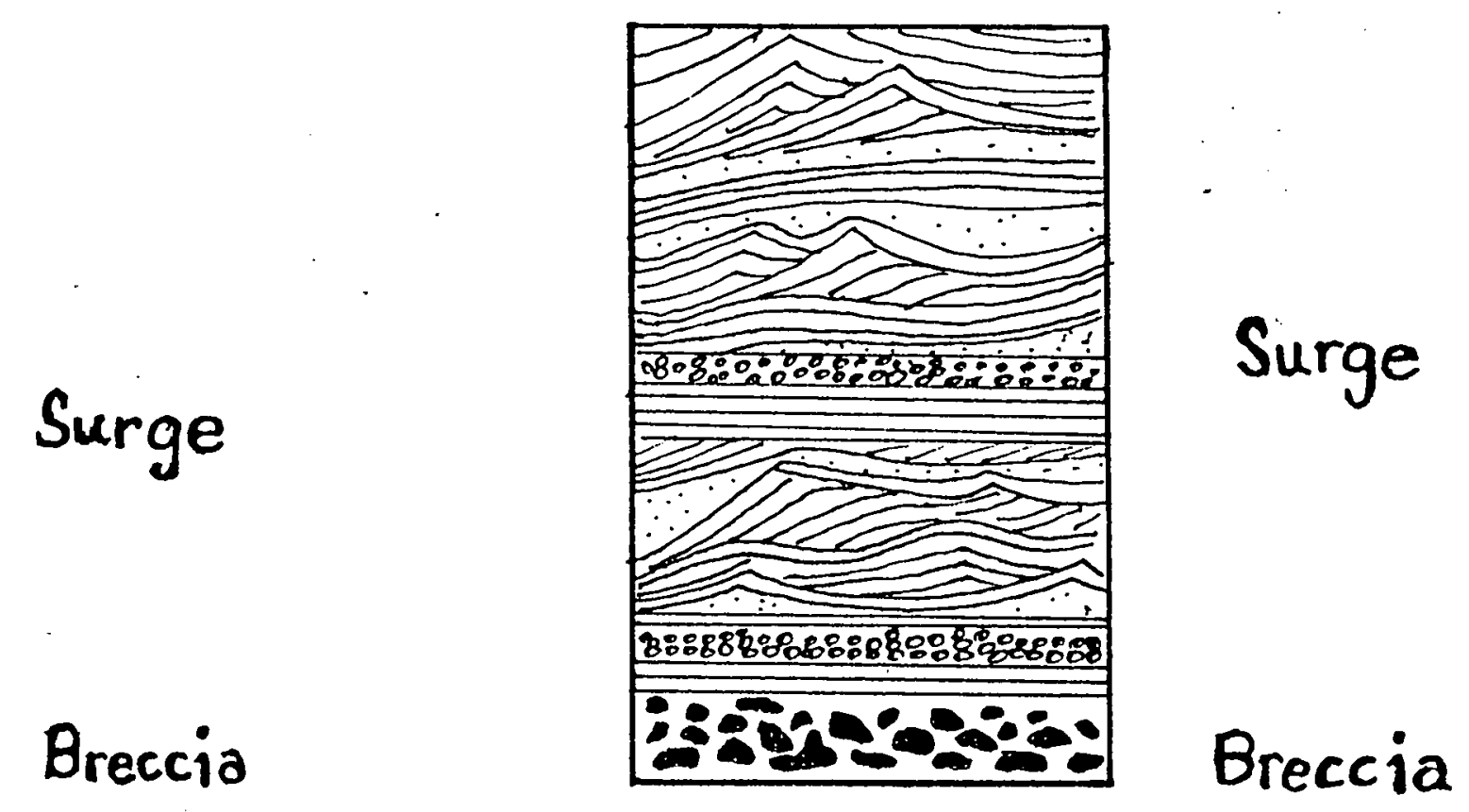

Figure 7. Diagrammatic stratigraphic sections showing typical deposit sequences for a tuff cone and a tuff ring, af ter Wohletz (1980).

芺 


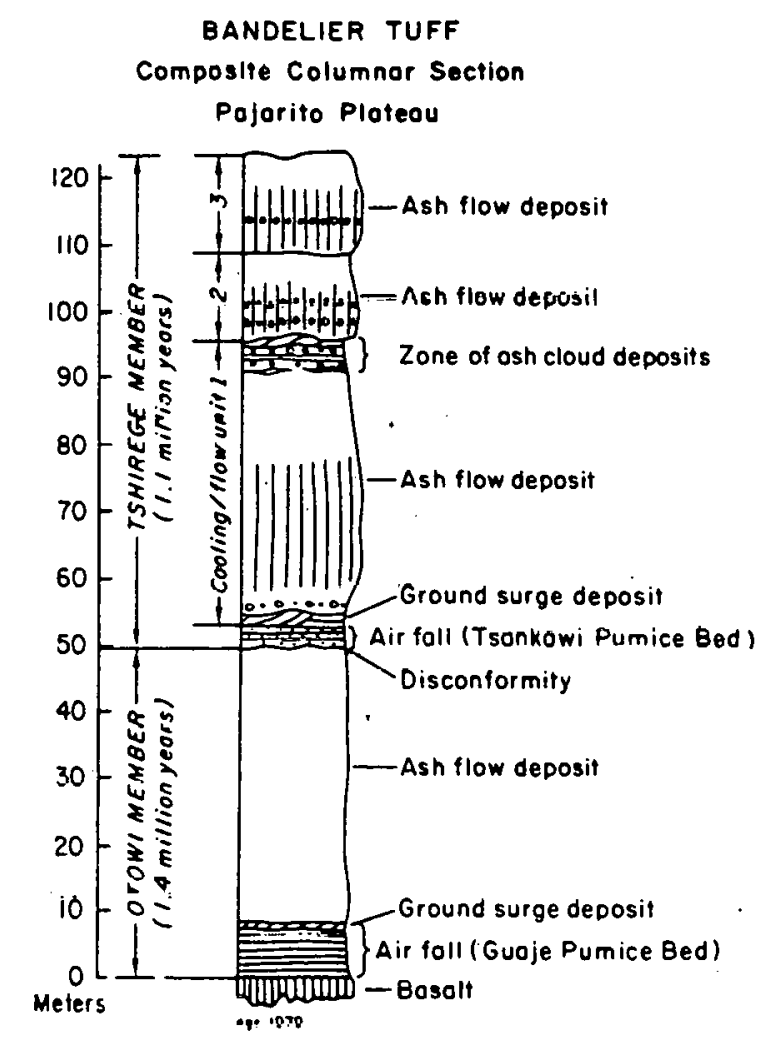

Figure 8. Composite columnar section of Bandelier Tuff, Pajarito Plateau area, after Fisher (1979), showing yluund surge under ash flow unit and ash cloud (surge) above. 
The run-out may extend to more than $100 \mathrm{~km}$, but it is generally much more restricted.

A complete eruptive episode may produce numerous pyroclastic flows as well as falls, surges, and lavas. Pyroclastic flow deposits commonly display a "standard ignimbrite flow unit" (Sparks et a1., 1973; Sparks, 1976) (Fig. 1). An inversely-graded plinian air-fall deposit composed of coarse-grained angular lapilli commonly underlies ash-flow deposits. Ground surge deposits (Fig. 1, layer 1), at the top of the air-fall deposit may correspond to sandwave, massive or planar facies, as defined by Wohletz and Sheridan (1979), depending on distance from the vent. The overlying pyroclastic flow units may have a finegrained, inversely-graded basal layer (Fig. 1, layer 2a) due to shear (Sparks et al., 1973). The main body of the flow unit (Fig. 1, layer 2b) may be either uniform in texture or exhibit a normal grading of lithic fragments and an inverse grading of pumice (Sparks et a1., 1973). Fumarolic pipes may occur throughout flow units (Smith and Bailey, 1966; Yokoyama, 1974; Sheridan and Ragan, 1976). Above some flow units may be a coignimbrite air-fall deposit (Fig. 1, layer 3) of fine ash depleted in lithic and crystal fragments (Sparks et al., 1973; Sparks and Walker, 1977). Eruptive sequences sometimes terminate with lava extrusion.

Full development of the above sequence at any one locality is rare. Actual sections are generally more complex. In some cases a proximal co-ignimbrite lag-fall deposit occurs beneath one or more of the pyroclastic flows (Wright and Walker, 1977). These are composed of blocks too heavy to be transported by pyroclastic flows, may comprise very thick basal breccias near large vents.

In distal localities, : plinian air-fall deposit of fine grain size may occur below flow units and extend beyond the limits of the ash flow; surge deposits are lacking and flow units have fewer lithic clasts; concentrations of pumice occur at the top of flow units. All the above observations on 
pyroclastic flow deposits may be fitted together as a facies mode1, presented in Figure 9. Part a). shows an idealized ash flow deposit (after Wright et al., 1980) and part b) shows idealized proximal and distal ash flow sequences (after Sheridan, 1979). These facies models are probably applicable with slight modification to pyroclastic flows of all sizes, especially those pumice-rich flows such as ash-flows. The small ash-flows such as are often associated with eruptions of alkaline, fluorine-rich magmas, e.g. the Canary Island ignimbrites (Schmincke and Swanson, 1967), the Tercei ra. (Azores) ignimbrites (Sclf, 1076), and the Acatlan ignimbrite, Mexicn (J, V. Wright, personal communication) all show features interpretable by these models. Furthermore, they show several important postemplacement features, which will be discussed below.

\section{RHYOLITIC LAVA FLOWS AND DOMES}

lhe effusion of silicic lava has been mentioned in two contexts in this study, both being common occurrences for alkaline, F-rich rhyolites. The first is extrusion of a dome into a tuff ring (maar) formed by phreatomagmatic eruption. In this case the dome would overlie thinly-bedded surtseyan fall deposits with interstratified base surge beds composed of poorly vesiculated pumice, ash crystals and lithics. The second is lava extrusion following the fa11, surge, pyroclastic flow eruption sequence, Here the dome may be apparently disassociated in the field from the other deposits, or it may overlie any of them. If the dome is intruded into the same conduit as that used for the pyroclastic eruption, it should abut or overlie proximal plinian or subplinian air-fall deposits and proximal-type ash flows (Fig. 9b). In the case of post-caldera domes, if a caldera collapse followed the explosive eruption, the lavas may be separated from the preceding pyroclastic deposits by faulting.

Whatever the association, viscous rhyolite lava extrusions are fairly similar in form. They form domes and thick, stubby flows, generally known as coulees. Depolymerization of the melt by high alkali content and fluorine may 


\section{FACIES MODEL OF FOR PYROCLASTIC DEPOSITS OF EXPLOSIVE ERUPTIONS, after Wright et al., (1980)}

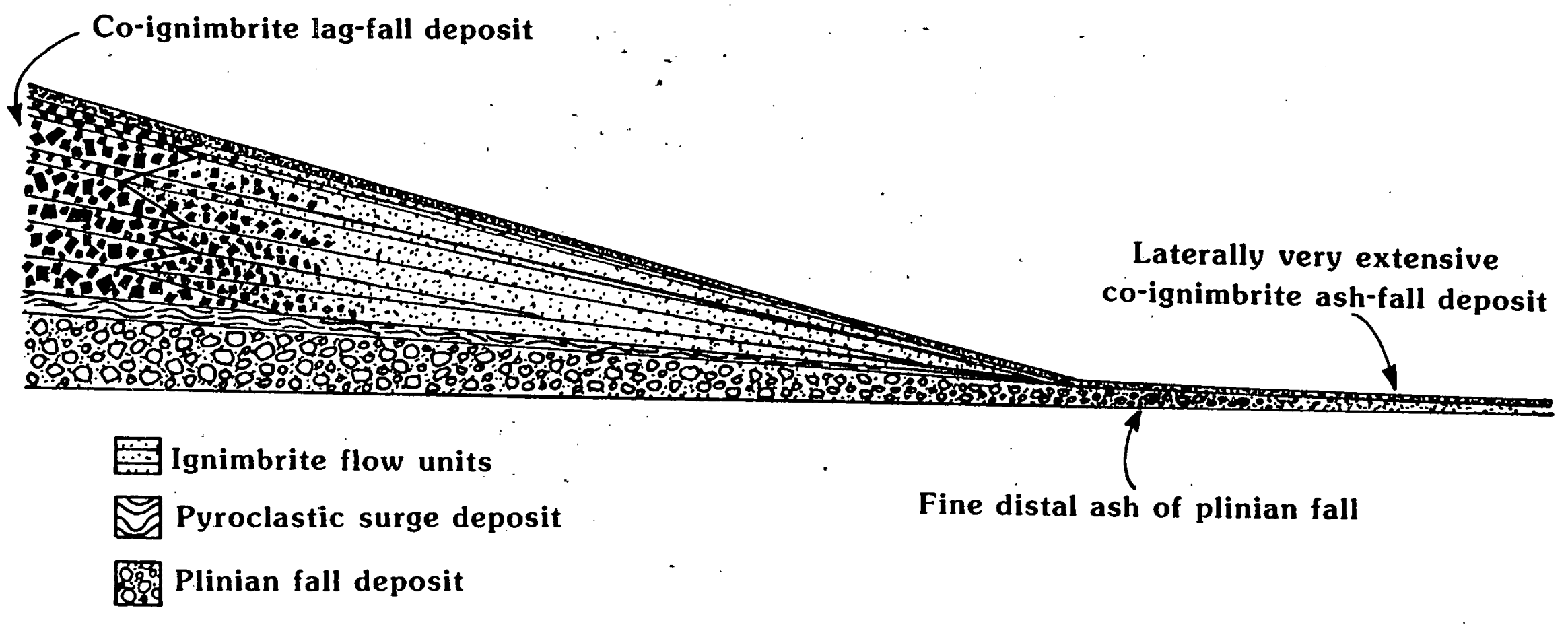

Figure 9a. Facies model for pyroclastic deposits of explosive eruptions, after Wright et al., (1980). 


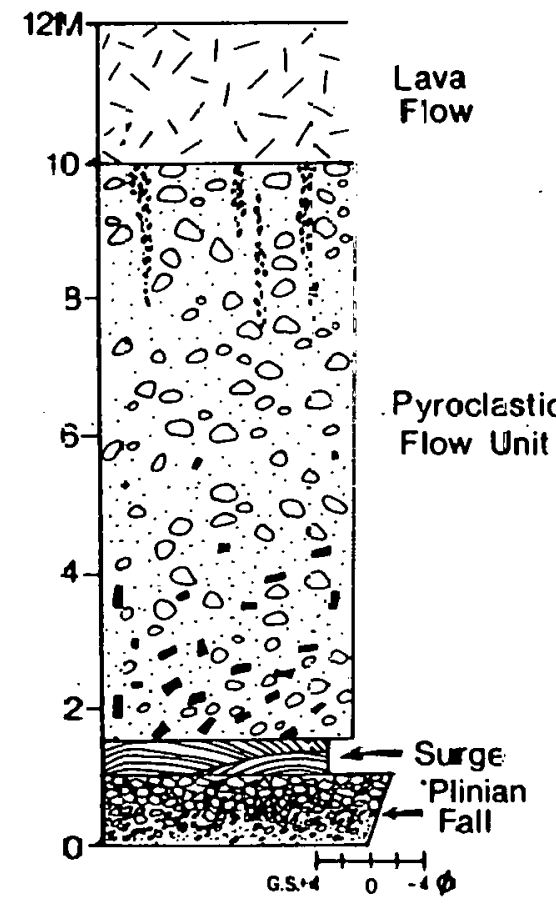

PROXIMA:

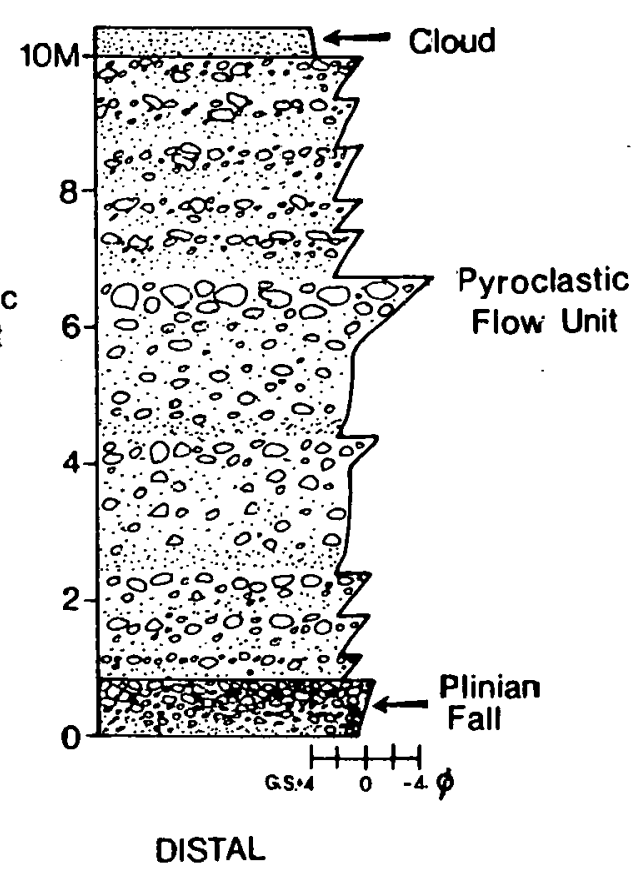

Figure 9b. Proximel and distal facies of intermeciate to large pyrcclastic flow units, from Sheridan (1979). 
significantly lower the viscosity of the lava (Fig. 2), resulting in longer, thinner lava flows in alkaline than in calc-alkaline flows. Many domes grow by expansion due to new magma being intruded.internally (endogenous domes: Fig. 10), and flows form by rupturing of the dome "skin" followed by outflow. Emplacement is probably very slow.

Several zones are developed with domes (Fig. 10): these are, a) more or less massive or blocky center which may be cryptocrystalline-glassy (but not obsidian) rhyolite lava; it may have pronounced jointing and also show some flow banding (alignment of phenocrysts and groundmass minerals) on all scales; b) an outer carapace gradational to a), of strongly flow-banded, layered obsidian and frothy lava; local flow-banding may bear no relation to the overall dome structure; c) a blocky (brecciated) top and base made of rhyolite in all different states of vesiculation, including an underlying brecciated, scoriaceous zone which the flow overran. The high viscosity of extrusion (108-1012 poises), and cooling at the surface, produce a very brittle material which undergoes. much autobrecciation. Talus slopes of blocks are constructed around the domes. These exterior, brecciated zones are favored sites for alteration. Spherulitic lava may be more common in the massive center parts of domes and flows, and in the outer zones where there are obsidian layers, lithophysae are common. Fink (1980) has recently discussed folding features on the surfaces of rhyolite flows.

\section{SECONDARY (POSTEMPLACEMENT) FEATURES OF RHYOLITES}

Secondary changes can occur in rhyolites regardless of their temperature of emplacement, but are most intense in pyroclastic rocks that are emplaced hot (ash flows, welded air-falls) and in lavas. Although thin and cool pyroclastic deposits retain their glassy characteristics and preserve their primary emplacement textures, some deposits; especially ash-flow tuffs (ignimbrites), cool so slowly that their character is dominated by secondary textures. Smith 


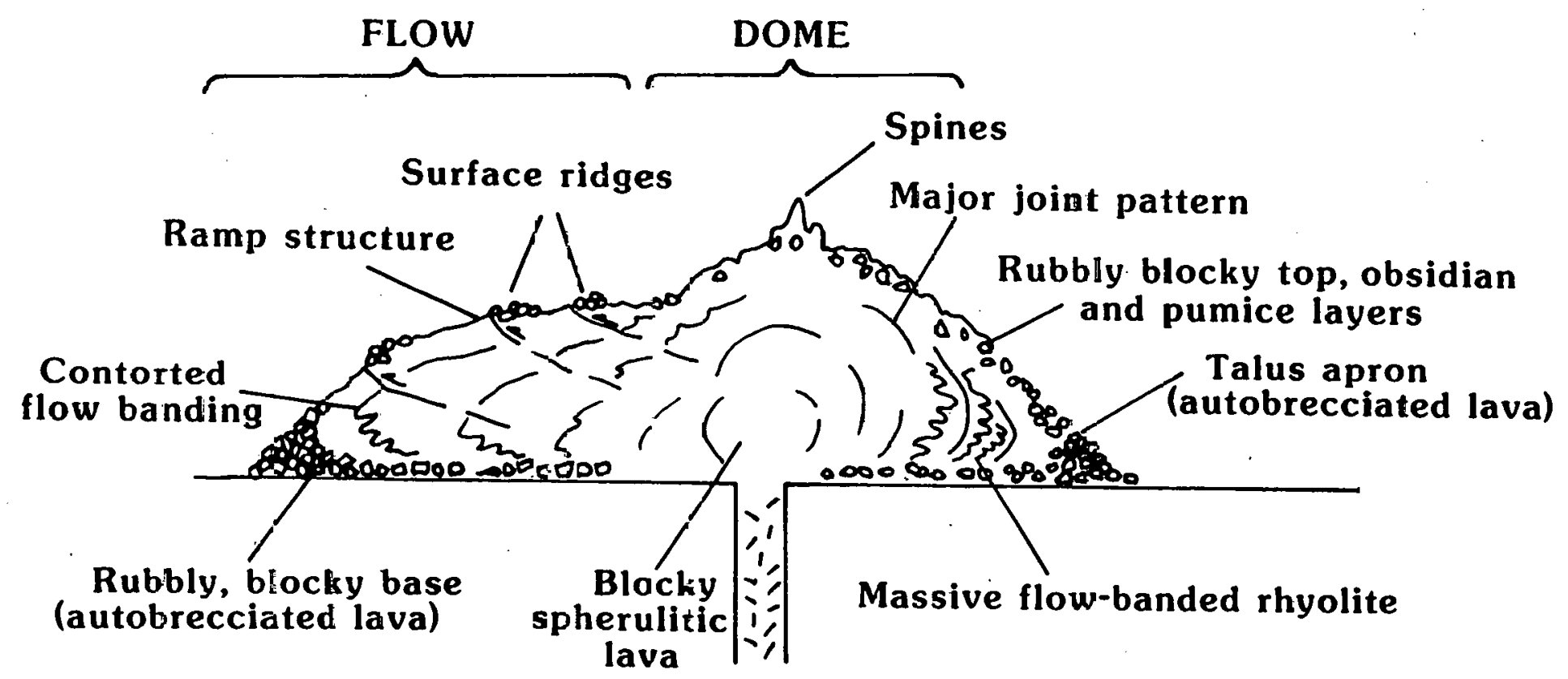

Figure 10. Generalized schematic diagran of extrusion and growth of a endogenous dome flows. 
(1960b) has described the main secondary features of ash-flow tuffs and many of these are applicable to lavas and (welded) air-falls. At emplacement temperatures above $550^{\circ} \mathrm{C}$ glassy fragments will plastically depress and fuse under load pressure. Superimposed on the welded tuffs in a zonal pattern of secondary crystallization that includes: devitrification, granophyric crystallization, vapor phase crystallization, formation of fumaroles, and development of lithophysae and miarolic cavities. After initial cooling, circulating fluids may produce another series of zones with potassic, zeolitic, and related alterations. All of these processes have an effect on the physical and chemical properties of the rock mass and on resulting mineralization, if any. The two major types of secondary changes are discussed below.

\section{Welding in Pyroclastic Deposits}

Welding is directly related to temperature at time of emplacement, thickness of the unit and gas content. Within an ash-flow unit, welding is almost always accompanied by pumice deformation due to overload. Both large clasts and the shard matrix become oriented with their long axes perpendicular to the strain direction (which is also sub-parallel to the direction of flow). Compression of these juvenile clasts produces flattened elongate fragments which partly give welded ash flow tuffs the eutaxitic texture first recognized by Fritsch and Reiss (1868). In strongly-welded zones, such elongate juvenile clasts may have a dense, black, glassy nature and have been described as fiamme (Zavaritsky, 1947) or "flames". Intensely-welded zones are also the most dense; in some ash flows the clasts and matrix homogenize into a glassy layer (vi.trophyre).

Smith (1960b) has proposed the terms simple and compound cooling units. A simple cooling unit is a single flow unit or a series of flow units showing a non-welded hase and top with the zone of most dense welding somewhere below the middle of the deposit (Sheridan and Ragan, 1976). Zones of 1css dense welding will be exhibited above and below the most intensely welded zone. Such 
simple units, comprising a number of flow units that have cooled as a single unit, reflect post-depositional temperature equalization between flow units. A compound cooling unit results from burial of one cooling unit by another flow unit (or set of flow units) after sufficient time has elapsed to considerably cool the top of the unit below. Figure 11 shows an idealized welding profile for a simple cooling unit, as represented by a density profile. Slow cooling in thick units and the weight of overlying material favor welding, but thickness alone is probably not the controlling factor, since welding may occur in units of less than one meter thickness (Se1f, 1976), especially in peralkaline ash flows.

The emplacement temperature of pyroclastic flows range from that of steam for block avalanches associated with phreatic eruptions to nearly magmatic values for densely-welded sheets. The minimum temperature for incipient welding in rhyolitic cooling units 10 to $40 \mathrm{~m}$ thick in $600^{\circ} \pm 25^{\circ} \mathrm{C}$ (Riehle, 1973). Therefore, nonwelded sheets of comparable thickness and composition must have been emplaced at cooler temperatures.

Evidence from the degree of welding and sernndary crystallization suggests that many large sheets, such as the Bandelier Tuff (Smith and Bailey, 1966) and the Bishop Tuff, show an increase in cmplacement temperature with time (Ragan and Sheridan, 1972). The compaction profile calculations of Riehle (1973) may prove useful in estimating increasing emplacement temperatures attributed to lesser quantities of ambient air being mixed into the eruptive column. An explanation is that progressively deeper and hotter 1cvrils of the majllid chumber were tapped, as in the case of the Bishop Tuff (Hildreth, 1979).

Welding in Alkaline and Peralkaline Ash-Flow Tuffs and Air-Fall Deposits Welded peralkaline tuffs exhibit several textural features that suggest a different mode of emplacement from their calc-alkaline counterparts (Schmincke, 


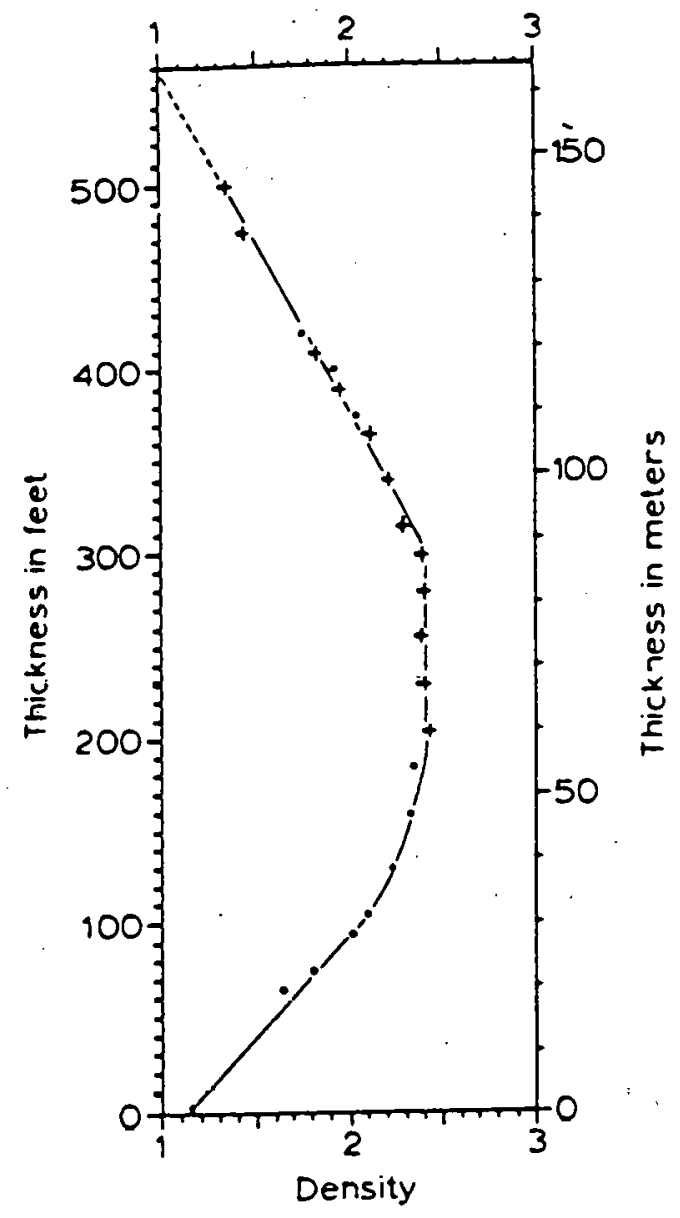

Figure 11. Density profile through the Bishop Tuff in Owens Valley, California. The most intense welding corresponds to the zone of highest density (from Ragan and Sheritan, 1972). 
1974). Many show evidence of postdepositional flowage (rheomorphism), i.e. the flow was so plastic upon stopping that it moved up to tens of meters by secondary laminar creep. Vertical compaction has produced most laminar welding fabrics in calc-alkaline welded tuffs (Ragan and Sheridan, 1972; Sheridan and Ragan, 1976). Peralkaline ignimbrites, however, have undergone equal volume deformation (shear strain) prior to final emplacement (Schmincke and Swanson, 1967). The important differences between calc-alkaline and peralkaline welded tuffs are as follows (Schmincke, 1974, p. 605-607): 1) cooling units are thin (generally less than $30 \mathrm{~m}$ ), 2) cooling unit volumes are small (less than $5 \mathrm{~km}^{3}$ ), 3) round bubbles are present in a previously deformed matrix, 4) large gas cavities may be unrelated to individual clasts. Primary structures that indicate laminar flowage include: (a) extremely deformed pumice lapilli with final shape ratio up to 100:1 or more, (b) pronounced lineations on parting planes, (c) folds and ramp structures on several scales, and (d) pull-apart structures. For these tuffs the successive stages of flowage, deflation, and compaction welding (Sheridan and Ragan, 1976) are overlapping. Welding in such flows is so rapid that flowage and formation uf late gas cavitios may take place betore the sheet has couled lu $\perp$ ls minimum weldillb lomporature. Mnnsaly welded tuffs, especially those "rheoignimbrites" that show evidence ot rhèmorphism, are often difficult to distinguish from lava flows on an outcrop $\operatorname{sca} 1 \mathrm{~s}$.

Post-Emplacement Crystallization Processes

Smith (1960b) describes four types of post-emplacement crystallization: devitrification, vapor-phase crystallization, granophyic crystallization, and fumarolic alteration.

Glass fragments in ash flow tuffs are frequently devitrified to micro- 
crystalline cristobalite and alkali feldspar. This process occurs during cooling of the tuff as a result of glass instability at high temperatures in the presence of volatiles, and is most complete in thick units when cooling is slow. Devitrification proceeds from pyroclast boundaries inward; axiolitic structure results from the alignment of crystal fibers normal to shard boundaries. Vapor-phase crystallization may accompany the compaction of tuffs and tends to be more pronounced in thicker units or where units are buried before cooling is completed. Gas escapes from the flow units and travels upwards and outwards, especially from the zone of greatest welding. For this reason it is often more obvious in the upper parts of ash flow units. Tridymite, cristobalite, alkali feldspar and minor amounts of other minerals are deposited in open spaces between fragments or within the pores of incompletely collapsed pumice. Lithophysal and crystal-lined cavities may occur even within the most densely-welded zones. Vapor-phase minerals are generally coarser-grained than those resulting from devitriftcation. Vapor.phase crystallization also accompanies devitrification, as volatiles are expelled from glass during devitrification (Lofgren, 1968).

Granophyric intergrowths of quartz and alkali feldspar within very thick cooling units may result from very slow cooling (Smith, 1960b), or from later conversion of tridymite and cristobalite to quartz.

Fumarolic activicy may alter and cement ignimbrites, especially in non- or poorly welded zones (Allen and Zies, 1923; Lovering, 1957; Sheridan, 1970). Williams (1942) reports fumarolic deposits of iron oxide, kaolin and opal from. Crater Lake, Oregon ash flow deposits. Sulfates and halides are common elsewhere (Stoiber and Rose, 1974). Finally, normal weathering and alteration of glass by percolating ground water may produce zeolites and associated minerals (Wa1ton, 1975; Henry and Walton, 1978). The effectiveness of zeolitization in mobilization of uranium is problematical. Most uranium seems to be trapped in place in opal and Fe-Mn oxides (Zielinski et al., 1980). 


\section{Bibliography}

Allen, E.T. and Zies, E.G., 1923, A chemical study of the fumaroles of the Katmai region: National Geographic Society, Contributed Technical, Papers, Katmai Series, No. $2,75 \mathrm{p}$.

Bikun, J.V., 1980, Fluorine and lithophile element mineralization at Spor Mountain, Utah: Unpublished M.S. Thesis, Arizona State University, Tempe, Arizona, 195 p.

Bond, A. and Sparks, R.S.J., 1976, The minoan eruption of Santorini, Greece: Journal of the Geological Society of London, v.132, p. 1-16.

Crandell, D.R., 1971, Postglacial lahars from Mount Ranier volcano, Washington: U.S. Geological Survey Professional Paper 677, 75p.

Crowe, B.M. and Fisher, R.V., 1973, Sedimentary structures in base-surge deposits with special reference to cross-bedding, Ubehebe Craters, Death Valley, California: Geological Society of America Bulletin, v.84, p. 663-682.

Curtis, G.H., 1968, The stratigraphy of the ejecta from the 1912 eruption of Mount Katmai and Novarupta, Alaska: Geolngical Survey of America Memoir 116, p. 153210 .

Fink, J., 1980, Surface folding and viscosity of rhyolite flows: Geology, v.8, p. 250-254.

Fisher, R.V., 1961, Proposed classification of volcaniclastic sediments and rocks: Geological Society of America Bulletin, v.72, p. 1409-1414.

Fisher, R.V., 1979, Models for pyroclastic flows: Journal of Volcanology and Geothermal Research, v.6, p. 305-318.

F1sher, R.V. , and Waters, A.C., 1970, Base surge bed torms in maar volcanoes: American Journal of Science, v.268, p. 157-180.

Fiske, R.S. and Matsuda, T., 1964, Submarine equivalents of ash flows in the Tokiwa formation, Japan: American Journal of Science, v.262, p. 76.106.

Fritsch, K.V. and Reiss, W., 1868, Genlog1sche Beschrelbung der Insel Tenerife: Winterthur, Verlag von Wurster, 494 p.

Henry, C.D. and Walton, A.W., 1978, Formation of uranium ores by diagenesis of volcanic sediments: U.S. Department of Energy, Open-File Report GJBX-2.2 (79), $444 \mathrm{p}$.

Hildreth, W., 1979, The Blshop Tuff: Evidence for the origin of compositional zonation in silicic magma chambers: Geological Society of America Special Paper 180, p: 43-75.

Lofgren, G.E., 1968, Experimental devitrification of rhyolite glass: Unpublished Ph.D. dissertation, Stanford University, Stanford, California, 98 p. 
Lovering, T.S., 1957, Halogen-acid alteration of ash at Fumarole No. 1, Valley of Ten Thousand Smokes, Alaska: Geological Society of America Bulletin, v. 68, p. $1585-1604$.

Moore, J.G., 1967, Base surge in recent volcanic eruptions: Bulletin Volcanologique, v. 30, p. $337-363$.

Moore, J.G. and Melson, W.G., 1969, Nuées ardentes of the 1968 eruption of Mayon Volcano, Phillippines: Bulletin Volcanologique, v.33, p. 600-620.

Moore, J.G., Nakamura, K., and Alcaraz, A., 1966, The 1965 eruption of Taal Volcano: Sclence: v. 151, p. 955-960.

Nairn, I.A., and Self, I.A., 1978, Explosive eruptions and pyroclastic avalanches from Ngauruhoe in February, 1975: Journal of Volcanology and Geothermal Research: v.3, p. 39-60.

Nea11, V.E., 1976, Lahars-Global occurrence, origins and annotated bibliography: Victoria University of Wellington, New Zealand, Publication No. 5, 18p.

Ragan, D.M. and Sheridan, M.F., 1972, Compaction of the Bishop Tuff, California: Geological Society of America Bulletin, v.83, p. 95-106.

Riehle, J.R., 1973, Calculated compaction profiles of rhyolitic ash-flow tuffs: Geological Society of America Bulletin, v.84, p. 2193-2216.

Roobol, M.J., 1976, Post-eruptive mechanical sorting of pyroclastic material-an example from Jamaica: Geological Magazine, v.113, p. 429-440.

Roobol, M.J; and Smith, A.L., 1975, A comparison of the recent eruptions of Mt. Pelee, Martinique and Soufrière, St. Vincent: Bulletin Volcanologique, v.39-2, p. 1-28.

Rose, W.I., Jr., 1973, Pattern and mechanism of volcanic activity at the Santiaguito Volcano, Guatemala: Bulletin Volcanologique, v.40-1, p. 1-16.

Ross, C.S. and Smith, R.L., 1961, Ash-flow tuffs, their origin, geologic relations and identification: U.S. Geological Survey Professional Paper 336, $81 \mathrm{p}$.

Schmincke, H.U., 1974, Volcanological aspects of peralkaline s11icic welded ash-flow tuffs: Bullet1n Volcanologique, v.38, p. 594-636.

Schmincke, H.U., Fisher, R.V., and Waters, A.C., 1973, Antidune and chute and pool structures in base surge deposits of the Laacher See area, Germany: Sedimentology, v. 20, p. 553-574.

Schmincke, H.U. and Swanson, D.A., 1967, Laminar viscous flowage structures in ash-flow tuffs from Gran Canaria, Canary Islands: Journal of Geology, v.75, p. 641-664.

Self, S., 1976, Recent volcanism on Terceira, Azores: Journal of the Geological Society of London, v.132, p. 645-666.

Self, S., Kienle, J., and Huot, J.P., 1980, Ukinrek Maars, Alaska II. Deposits and formation of the 1977 craters: Inurnal of Volcanology and Geothermal Research, v.7, p. 39-65. 
Self, S., Wilson, L., and NaIrn, I.A., 1979, Vulcanian eruption mechanisms: Nature, v. 277, P. 440-443.

Shaw, H.R., 1972, Viscosity of magmatic silicate liquids: an empirical method of of prediction: American Journal of Science, v.272, p. 870-893.

Shepard, G.S., 1938, Gases in rocks and some related problems: American Journal of Science, v.35A, p. 311-351.

Sheridan, M.F., 1970, Fumarolic mounds and ridges of the Bishop Tuff, California: Geological Society of America Bulletin, v.31, p. 851-868.

Sheridan, M.F., 1979, Emplacement of pyroclastic flows: a review: Geological Society of America, Special Paper 180, p. 125-136.

Sheridan, M.F. and Ragan, D.M., 1976, Compaction of ash-flow tuffs, in Chilingarian, G.V. and Wolt, K.H., eds., Compaction of coarse-grained sediments, II: Amsterdam, Elsevier, p. 677-713.

Sheridan, M.F. and Updike, R.G., 1975, Sugarloaf Mountain Tephra -- a Pleistocene rhyolite deposit of base-surge origin in Northern Arizona: Gcological Society of America Bulletin, v.86, p. 571-581.

Smith, R.L., 1960a, Ash flows: Geological Society of America Bulletin, v.71, p. 795-842.

Sm1th, R.L., 1960b, Zones and zonal variations in welded ash flows: U.S. Geological Survey Professional Paper 354-F, p. 149-159.

Smith, R.L., and Bailey, R.A., 1966, The Bandelier Tuff. a study nf ash-flow eruprion cycles from zoned magma chambers: Bulletin Volcanologique, v.29, p. B3 $=104$.

Sparks, R.S.J., 1976, Grain size variations in ignimbrites and implications for the transport of pyroclastic flows: Sedimentology, v.23, p. 147-188.

Sparks, R.S.J., 1978, The dynamics of bubble formation and growth in magma: a review and analysis: Journal of Volcanology and Geothermal Research, v.3, p. $1-37$.

Sparks, R.S.J., Self, S., and Walker, G.P.L., 1973, Products of igniwilite eruptions: Geology, v.1, p. 115-118.

Sparks, R.S.J., Sigurdsson, H., and Carey, S.N., 1980, The entrance of pyroclastic flows into the sea: Journal of Volcanology and Geothermal Research, v.7, p. 87-105.

Sparks, R.S.J. and Walker, G.P.L., 1973, The ground surge deposit: a third type of pyroclastic rock: Nature, Physical Science, v.241, p. 62-64.

Sparks, R.S.J. and Walker, G.P.L., 1977, The significance of vitric-enriched air fall associated with crystal-enriched ignimbrites: Journal of Volcanology and Geothermal Research, v.2, p. 329-341. 
Sparks, R.S.J. and Wilson, L., 1976, A model for the formation of ignimbrite by gravitational column. collapse: Journal of the Geological Society of London, v.132, p. 441-452.

Sparks, R.S.J., Wilson, L., and Hulme, G., 1978, Theoretical modelling of the generation, movement and emplacement of pyroclastic flows by column collapse: Journal of Geophysical Research, v.83, B4, p. 1727-1739.

Sparks, R.S.J. and Wright, J.V., 1979, Welded air-fall tuffs: Geological Society of America, Special Paper 180, p. 155-166.

Wa1ker, G.P.L., 1971, Grain size characteristics of pyroclastic deposits: Journal of Geology, v.79, p. 696-714.

Walker, G.P.L., 1972, Crystal concentration in ignimbrites: Contributions to Mineralogy and Petrology, v.36, p. 135-146.

Walker, G.P.L., 1973, Explosive volcanic eruptions -- a new classification scheme: Geologische Rundschau, v.62, p. 431-446.

Walker, G.P.L., 1980, The Taupo Pumice: produce of the most powerful known (ultraplinian) eruption?: Journal of Volcanology and Geothermal Research (in press).

Walker, G.P.L, and Croasdale, R., 1971, Two Plinian-type eruptions in the Azores: Journal of the Geological Society of London, v.127, p. 17-55.

Walton, A.W., 1975, Zeolitic diagenesis in Oligocene volcanic sediments, TransPecos Texas: Geological Society of America Bulletin, v.86, p. 615-624.

Waters, A.C. and Fisher, R.V., 1971, Base surges and their deposits: Capelinhos and Taal Volcanoes: Journal of Geophysical Research, v.76, p. 5596-5614.

White, D.E. and Waring, G.A., 1963, Volcanic emanations: U.S. Geological Survey Professional Paper 440-K, p. K1-K27.

Williams, H., 1942, Geology of Crater Lake National Park, Oregon: Carnegie Institution of Washington Publication 540, $162 \mathrm{p}$.

Williams, H. and McBirney, A.R., 1979, Volcanology: San Francisco, Freeman, Cooper and Co., $397 \mathrm{p}$.

Wilson, L., 1976, Explosive volcanic eruptions, III. Plinian eruption columns: Geophysical Journal of the Royal Astronomical Society, v.45, p. 543-556.

Wohletz, K.H., 1980, Mechanism of phreatomagmatic volcanism: Unpublished Ph.D Thesis, Arizona State University, Tempe, Arizona.

Wohletz, K.H. and Sheridan, M.F., 1979, A model of pyroclastic surge: Geological Society of America, Special Paper 180, p. 177-194.

Wolff, J.A. and Wright, J.V., 1980, Rheomorphism of welded tuffs: Bulletin Volcanologique (in press).

Wood, S.H., 1977, Dislribution, corrclation and radinrarhon dating of late Holocene tephra, Mono and Inyo Craters, Southern California: Geological Society of America Bulletin, v.88, p. 89-95. 
Wright, J.V., Smith, A.L., and Self, S., 1980, A working terminology for pyroclastic rocks: Journal of Volcanology and Geothermal Research (in press).

Wright, J.V. and Walker, G.P.L., 1977, The ignimbrites source problem: significance of a co-ignimbrite lag-fall deposit: Geology, v.5, p. 729-732.

Yokoyama, S., 1974, Mode of movement and emplacement of Ito pyroclastic flow from Aira caldera, Japan: Science Report Tokyo Kyoiku Daigaku, Sect. C, v.12, p. 17-62.

Zavaritsky, A.N., 1947, The ignimbrites of Armenia (in Russian): Izvestiya Akademia Nauk SSSR, Ser. Geol. v.3, p. 3-18.

Zielinski, R.A., Lindsey, D.A., and Rosholt, J.N., 1980, The distribution and mobility of uranium in glassy and zeolitized tuff, Keg Mountain area, Utah, U.S.A.: Chemical Geology, v.29, p. 139-162. 


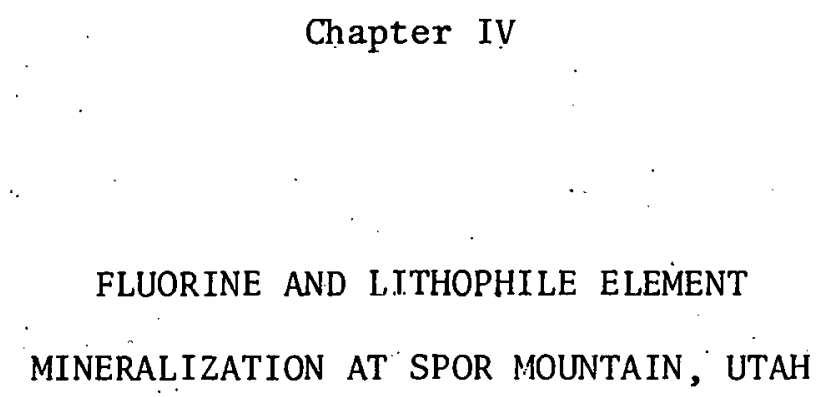

by

James V. Bikun 
Note by D. M. Burt

Jim Bikun left Arizona State University in June, 1980 following the successful defense of his M.S. thesis, and has been unavailable for consultation on this report. His figure originals went with him. This chapter has therefore been reproduced directly from my copy of his M.S. thesis of the same title. Page numbers (i-xv, 1-195) should run from 167 to 376. 


\section{ABSTRACT}

Two groups of topaz rhyolite flows and associated tuffs occur in close proximity in the Thomas Range and peripheral to spor Mountain in west-central Utah. The Topaz Mountain Rhyolite of the Thomas Range was emplaced 6 to $7 \mathrm{~m} . \mathrm{y}$. ago in at least three eruptive episodes and forms a flat-lying dissected volcanic plateau. The topaz rhyolite of the Spor Mountain Formation has been dated at $21 \mathrm{~m} \cdot \mathrm{y}$. and has been tilted by basin and range faulting. Eruptive episodes for each rhyolite commenced with the emplacement of a series of ignimbrites, minor air fall sheets, and pyroclastic surge units, and were terminated by the effusion of rhyolite lavas.

Outcrops of welded cooling units have been found within the tuffs of the Topaz Mountain Rhyolite, and thin fused zones sometimes occur in the pyroclastics immediately beneath the overlying rhyolite. These pyroclastic units consist of pumice in an ashy matrix and minor lithics of foreign volcanic rocks. Often a flow breccia consisting mostly of vitrophyric blocks is found above. the tuffs. This flow breccia grades upward with increasing matrix and decreasing block size into the overlying holocrystalline gray rhyolite. Holocrystalline Topaz Mountain Rhyolite is markedly flow-banded, has a spherulitic groundmass, and is widely known for its lithophysae, which bear topaz, bixbyite, pseudobrookite, and other minerals. 
The Spor Mountain Formation has been divided into two members, the Beryllium Tuff and the capping Porphyritic Rhyolite, and was emplaced over Paleozoic quartzites and dolomites. Unique to the Beryllium Tuff are the great number of carbonate lithics that occur throughout its stratigraphic column. Fluorine, beryllium, 1ithium, niobium, tin, and uranium mineralization occurs in the upper part of the Beryllium Tuff directiy under the Porphyritic Rhyolite associated with carbonate lithics altered to fluorite-chalcedony nodules and feldspathized glass shards. This restricted mineralization and alteration is areally extensive in the Beryllium Tuff and apparently is not associated with any permeability controls such as welding. The holocrystalline Porphyritic Rhyolite has a groundmass consisting of a mosaic of subhedral quartz and alkali feldspar (granophyric texture). with secondary topaz. It is not markedly flow-banded. Dark reddish brown mafic inclusions occur in the rhyolite around which have formed white halos containing miarolitic cavities with topaz crystals.

A comparison of the vitrophyres from the Porphyritic Rhyolite and the Topaz Mountain Rhyolite shows the former enriched by a factor of at least five in beryllium, fluorine, lithium, tin, and uranium compared to the latter. The holocrystalline Porphyritic Rhyolite is much depleted in beryllium, fluorine, and "ranium with respect to its vitrophyre and has concentrations of these elements about equal to those in the holocrystalline Topaz Mountain Rhyolite, which is not significantly depleted in these elements with respect to its vitrophyre. 
Evidently granophyric textures in the Porphyritic Rhyolite result from processes which also depleted the holocrystalline Porphyritic Rhyolite in beryllium, fluorine, and uranium. Both metals were probably mobilized by fluids rich in fluorine. Beryllium and uranium fluoride complexes in fluids expelled both upward and downward by the cooling Porphyritic Rhyolite or in groundwaters which leached unstable compounds formed by these fluids in the Porphyritic Rhyolite presumably are responsible for much of the mineralization and alteration at the top of the Beryllium Tuff. These fluoride complexes became unstable due to $\mathrm{pH}$ changes and decrease in total fluorine content brought about by fluorite deposition. Other elements concentrated in this zone include arsenic, manganese, and tungsten, but not antimony, molybdenum, strontium, or zirconium. Both rhyolites belong to a clan of late Tertiary high-silica rhyolites (alkali or "rare metal" rhyolites) recognized in much of the western United States. The rhyolites are probably also the extrusive equivalents of R-type or A-type granites. Initial depletion of the source rock by pertial fusion that produced the parent melt of the $21 \mathrm{~m} \cdot \mathrm{y}$. old Porphyritic Rhyolite could have resulted in lower abundances of beryllium, fluorine, lithium, tin, and uranium in the second partial fusion that produced the parent melt of the 6-7 m.y. old Topaz Mountain Rhyolite. 


\section{ACKNOWLEDGMENTS}

There is possibly no work in science which does not rest on the work and ideas of others, and this report is no exception. Discussions and collaborations with my co-workers E. H. Christiansen, B. P. Correa, and B. A. Murphy are greatly appreciated and helped to clarify many. of my thoughts set forth in this report. The invaluable ideas acquired from instruction by Drs. D. M. Buit, J. M. Fcrry, J. R. Holloway, R. B., Moore, S. Self, and M. F. Sheridan at Arizona State University are present throughout this work. Special thanks go to Drs. D. M. Burt and M. F. Sheridan for making this report possible by allowing me to work as an assistant on their research project: The Study of Uranium Mineralization in Fluorine-Enriched Rocks, Bendix Field Engineering Corporation subcontract 79-270-E. Frank and candid discussions with. Dr. D. A. Lindsey of the U.S. Geological Survey concerning his excellent geologic map and numerous publications pertaining to the Spor Mountain District are gratefully acknowledged. Beside the numerous people named in this report, I would also like to extend my thanks to: R. Satkin and A. Yates for their assistance with my analytical work; Dr. D. LaPoint and R. Dorman of Plateau Resources, Limited, for their assistance with my field work; the emplnyees of the Brush-Wellman Corporation. for allowing me to work on the company's properties; and Scott Borg, Dennis Dunn, and the rest of my fellow graduate students at Arizona State University for helping to make my life very pleasant these past three years. 
TABLE OF CONTENTS

Page

LIST OF FIGURES . . . . . . . . . . . . . . . . . . . . . x x

INTRODUCTION . . . . . . . . . . . . . . . . . . . 1

PURPOSE AND SCOPE OF STUDY . . . . . . . . . . . . . . . . . 7

LITERATURE REVIEW . . . . . . . . . . . . . . . . . 10

Volcanic Geology . . . . . . . . . . . . . . . 10

The Fluorspar Pipes . . . . . . . . . . . . . . 18

Uranium Geology . . . . . . . . . . . . . . . . . 21

Sandstone Uranium . . . . . . . . . . . . . 22

Opal Veinlets . . . . . . . . . . . . . . . . 24

Uranium in Fluorspar Pipes... . . . . . . . . . . 25

Uranium in the Beryllium Tuff . . . . . . . . . . . 25

The Beryllium Deposits . . . . . . . . . . . . . . 26

PRESENT WORK . . . . . . . . . . . . . . . . . . . 31

Introduction ...................... . 31

Emplacement of the Beryllium Tuff and
Porphyritic Rhyolite . . . . . . . . . . . . . . 31

New Data... . . . . . . . . . . . . . 32

Interpretation . . . . . . . . . . . . . . . 4 48

Emplacement of the Topaz Mountain
Rhyolite-Tuff Sequences . . . . . . . . . . . . . . . 57

New Data. . . . . . . . . . . . . . 57 
Page

Interpretation . . . . . . . . . . . . . . 78

Mineralization in the Beryllium Tuff and

in the Stratified Tuff . . . . . . . . . . . . . . . 83

The Beryllium Tuff . . . . . . . . . . . . . . 83

The Stratified Tuff . . . . . . . . . . . . 108

Conclustons ........................ 108

Petrography and Petrology of the Porphyritic

Rhyolite and the Alkali Rhyolite... . . . . . . . 125

Glassy Rocks . . . . . . . . . . . . . . . 125

Crystalline Rhyolites . . . . . . . . . . . . 129

Major Element Geochemistry . . . . . . . . . . . 134

Minor Element Geochemistry . . . . . . . . . . . 138

Conclusions . . . . . . . . . . . . . . . . . 139

Origin of the Beryllium and Uranium

Mineralization in the Spor Mountain

District . . . . . . . . . . . . . . . . 139

Petrogenesis of the High-Silica Rhyolites

at the Spor Mountain District . . . . . . . . . 145

SUGGESTIONS FOR FURTHER RESEARCH . . . . . . . . . . . . . 155

UEHERENCES UITED . . . . . . . . . . . . . . . . . . . . 157

Appendix 1. Microprobe analysis of a ferrohastingsite from the Alkali Rhyolite . . . . . . . . . 165

Appendix 2. Microprobe analyses of feldspars from the Porphyritic Rhyolite . . . . . . . . . . 167

Appendix 3. Lithologic key for the geochemically analyzed samples . . . . . . . . . . . 175

Appendix 4. Whole rock major element analyses on an ignited basis and fluorine-free normative computations of the Porphyritic Rhyolite . . . . 178 
Appendix 5. Whole rock major element analyses on an

ignited basis and fluorine-free normative

computations of the Alkali Rhyolite . . . . . . 180

Appendix 6. Normative computations making use of

available fluorine determinations . . . . . . 182

Appendix 7. Whole rock minor element analyses of the Porphyritic Rhyolite . . . . . . . . . . . 184

Appendix 8. Whole rock minor element analyses of the Alkali Rhyolite................ 186

Appendix 9. Beryllium, fluorine, and uranium mineralization mass balance calculations for the Beryllium Tuff .............. 188 


\section{LIST OF FIGURES}

Figure

Page

1. Location map of west-central Utah . . . . . . . . . . 2

2. Map of the Spot Mountain District . . . . . . . . . . 4

3. Suggested correlation of volcanic rock units in the Spor Mountain District, Utah . . . . . . . . 13

4. Measured Section Spor Mountain Formation, Bendix Field Engineering Corporation Spor Mountain Drilling Project Hole Number 6, Southwest Spor Mountain . . . . . . . . . . . . . 34

5. Measured Section Spor Mountain Formation, Bendix Field Engineering Corporation Spor Mountain Drilling Project Hole No. 18, Southwest Spor Mountain . . . . . . . . . . . 36

6. Measured Section Spor Mountain Formation, Blue Chalk Pit, Brush-Wellman Beryllium Mines, Southwest Spor Mountain . . . . . . . . . . 39

7. Bomb sag in Blue Chalk Pit ................ 40

8. Measured Section Spor Mountain Formation, North Roadside Pit, Brush-Wellman Beryllium Mines, Southwest Spor Mountain . . . . . . . . . .

9. Measured Section Spor Mountain Formation, North Fluoro Pit, Brush-Wellman Beryllium Mines, Southwest Spor Mountain . . . . . . . . . .

10. Co-ignimbrite lag-fall unit exposed in North Roadside Pit . . . . . . . . . . . . . . . 46

11. North face of Yellow Chief Mine... . . . . . . . . 47

12. Black vitrophyre bed on north face of Taurus Pit dipping left . . . . . . . . . . . . . . . 
13. Matrix supported vitrophyre blocks in the Beryllium Tuff . . : . . . . . . . . . . . . . .

14. Comparison of a standard ignimbrite section with a section measured through an epiclastic volcanic debris flow . . . . . . . . . . . . . .

15. Co-ignimbrite lag-fall units . . . . . . . . . . . . 55

16. Measured Section Topaz Mountain Rhyolite-Tuff, Bendix Field Engineering Corporation Spor Mountain Drilling Project Hole Number 1, Southwest Thomas Range . . . . . . . . . . . . .

17. Measured Section Topaz Mountain Rhyolite-Tuff, near Autunite No. 8 Prospect, Southeast Thomas Range

18. Mèasured Section Topaz Mountain Rhyolite-Tuff, near Wildhorse Spring, West-Central Thomas Range . . . . . . . . . . . . . . . . . . .

19. Measured Section Topaz Mountain Rhyolite-Tuff, Northwest Thomas Range .. . . . . . . . . . 68

20. Measured Section Topaz Mountain Rhyolite-Tuff, Southwest Thomas Range . . . . . . . . . . . 70

21. Black, glassy, flattened, relict pumice occurring in a welded ignimbrite of the stratified Tuff near the Autunite No. 8 Prospect

22. Densely welded bomb bed outcropping near the Autunite No. 8 Prospect . . . . . . . . . . . . . . . 72

23. Densely welded ignimbrites near Wildhorse Spring . . . . . 74

24. Vitrophyre block breccia resting on pyroclastic beds of the Stratified Tuff behind the meter stick and outcropping near Fig. 19 . . . . . . . . .

25. Vitrophyre breccia containing interstitial rhyolite matrix, stratigraphically above Fig. 24 
Figure

Page

26. Rhyolitic groundmass supported vitrophyric breccia, stratigraphically above Fig. 25

27. Close-up of block flow unit behind meter stick in Fig. 24 . . . . . . . . . . . . . . . . 79

28. An ignimbrite contact in the Stratified Tuff near the Autunite No. 8 Prospect with a paleofumarole... . . . . . . . . . . . . .

29. Concentration of Be versus depth, Beryllium Tuff, drill hole umbur 18 . . . . . . . . . . . . . 8/

30. Concentration of $F$ versus depth, Beryllium Tuff, drill hole number 18 . . . . . . . . . 85

31. Concentration of $\mathrm{Li}$ versus depth, Beryllium Tuff, drill hole number 18 . . . . . . . . . . . 86

32. Concentration of Mn versus depth, Beryllium Tuff, drill hole number 18 . . . . . . . . . . . . . 87

33. Concentration of $\mathrm{Pb}$ versus depth, Beryllium Tuff, drill hole number 18 . . . . . . . . . . 88

34. Concentration of $\mathrm{U}_{3} \mathrm{O}_{8}$ versus depth, Beryllium Tuff, drill hole number 18 ............. 9 . .

35. Concentration of eU versus depth, Beryllium Tuff, drill hole number 18 ............. 91

36. Concentration of $\mathrm{Zn}$ versus depth, Beryllium Tuff, drill hole number 18 . . . . . . . . . . . 92

37. Concentration of Be versus depth, Beryllium Tufl, drill hóle number 6............... 93

38. Concentratiun of $F$ versus depth, Beryllium Tuff, drill hole number 6. . . . . . . . . . . . 94

39. Concentration of $\mathrm{U}_{3} \mathrm{O}_{8}$ versus depth, Beryllium Tuff, drill hole number $6 .$. . . . . . . . . . . 95

40. Concentracion of eU versus depth, Beryllium Tuff, drill hole number 6 . 
41. Concentration of eU versus depth from in-hole gamma-ray spectrometer measurements, Beryllium Tuff, drill hole number $6 . .$. . . . . . . . . .

42. Concentration of As versus depth, Beryllium Tuff, drill hole number 18 . . . . . . . . . . .

43. Concentration of $\mathrm{Nb}$ versus depth, Beryllium Tuff, drill hole number 18 . . . . . . . . . . . .

44. Concentration of Sn versus depth, Beryllium Tuff, drill hole number 18 . . . . . . . . . . 100

45. Concentration of $W$ versus depth, Beryllium Tuff, drill hole number 18 . . . . . . . . . . 101

46. Concentration of $\mathrm{Nb}$ versus depth, Beryllium

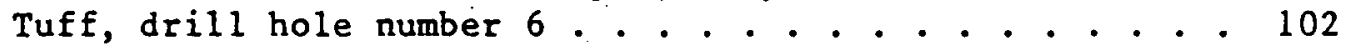

47. Concentration of Sn versus depth, Beryllium Tuff, drill hole number 6............. 103

48. Concentration of Sb versus depth, Beryllium Tuff, drill hole number 18 . . . . . . . . . . . 104

49. Concentration of $\mathrm{Cu}$ versus depth, Beryllium Tuff, drill hole number 18 .............. 105

50. Concentration of La versus depth, Beryllium Tuff, drill hole number 18 . . . . . . . . . . . 106

51. Concentration of Mo versus depth, Beryllium Tuff, drill hole number 18 ........... 107

52. Concentration of $\mathrm{Sr}$ versus depth, Beryllium Tuff, drill hole number 18 ........... 109

53. Concentration of eTh versus depth, Beryllium Tuff, drill hole number 18 .............. 110

54. Concentration of $\mathrm{Zr}$ versus depth, Beryllium Tuff, drill hole number 18

55. Concentration of $\mathrm{Sb}$ versus depth, Topaz Mountain Rhyolite Tuff, drill hole number 1 
Figure

Page

56. Concentration of Be versus depth, Topaz Mountain

Rhyolite Tuff, drill hole number 1 . . . . . . . . 113

57. Concentration of $\mathrm{Pb}$ versus depth, Topaz Mountain

Rhyolite Tuff, drill hole number 1. . . . . . . . . 114

58. Concentration of $\mathrm{Li}$ versus depth, Topaz Mountain

Rhyolite Tuff, drill hole number l . . . . . . . . 115

59. Concentration of Mn versus depth, Topaz Mountain

Rhyolite Tuff, drill hole number 1 . . . . . . . . . 116

60. Concenteation of $\mathrm{Nb}$ versus depth, Topaz Mountain

Rhyolite Tuff, drill hole number 1 . . . . . . . . 117

61. Concentration of eU versus depth, Topaz Mountain

Rhyolite Tuff, drill hole number 1 . . . . . . . . 118 .

62. Concentration of $\mathrm{U}_{3} \mathrm{O}_{8}$ versus depth, Topaz

Mountain Rhyolite Tuff, drill hole number 1 . . . . . . 119

63. Concentration of $\mathrm{Zn}$ versus depth, Topaz Mountain

Rhyolite Tuff, drill hole number 1 . . . . . . . . . 120

64. Concentration of $F$ versus depth, Topaz Mountain

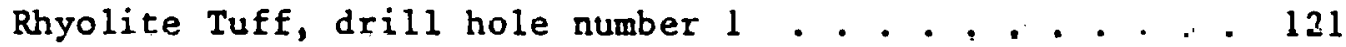

65. Concentration of eTh versus depth, Tupaz Mountain

Rhyolite Tuff, drill hole number 1 . . . . . . . . 122

66. Concentration of $\mathrm{Zr}$ versus depth, Topaz Mountain

Rhyolite Tuff, drill hole number 1 . . . . . . . . 123

67. Concentration of Ca versus depth, Beryllium

Tuff, drill hole number $6 . . . . . . . . . . . . . ~: ~ 120$

68. Concentration of $\mathrm{Ca}$ versus depth, Beryllium

Tuff, drill liule number 18 . . . . . . . . . . 127

69. Ternary composition of phenocryst feldspars

in the Porphyritic Rhyolite... . . . . . . . 130

70. Two-feldspar geothermometry of the Porphyritic

Rhyolite .................... 
Figure

71. Mafic inclusion in the Porphyritic Rhyolite exposed at the Blue Chalk Pit . . . . . . . . . . 133

72. CIPW normative qt-ab-or composition of the

Porphyritic Rhyolite on a fluorine free basis . . . . . . 137

73. CIPW normative qt-ab-or composition of the Alkali Rhyolite on a fluorine free basis . . . . . . . 138

74. Gallium versus alumina in R-type and I-type granites .. . . . . . . . . . . . . 151

75. Soda versus potash in various granite types . . . . . . 152

76. Chondrite-normalized rare-earth patterns for the Porphyritic Rhyolite . . . . . . . . . . . 153

77. Chondrite-normalized rare-earth patterns for the Alkali Rhyolite . . . . . . . . . . . . . . 154. 


\section{INTRODUCTION}

Spor Mountain is located in west-central Utah approximately 45 miles $(72 \mathrm{~km})$ northwest of Delta, Utah, and $100 \mathrm{miles}(161 \mathrm{~km})$ southwest of Salt Lake City, Utah. The area is bounded by the lines of latitude $\mathrm{N} 39^{\circ} 40^{\prime}$ and $\mathrm{N} 39^{\circ} 50^{\prime}$ and the lines of longitude $\mathrm{W} 113^{\circ} 00^{\prime}$ and $\mathrm{W} 113^{\circ} 15^{\prime}$. Al1 of this terrain is in western Juab County and appears on the Topaz Mountain and the Dugway Range 15 minute quadrangle sheets. (Fig. 1).

West-central Utah lies in the Basin and Range Province, and most ranges in this area trend northwest. Three ranges are traditionally included in the Spor Mountain area (Fig. 2). The largest is the Thoma Range, which covers an araz of about 9 by 14 miles ( 14 by $22 \mathrm{~km}$ ) and is composed of late Tertiary topaz rhyolites. About 1 to 2 miles ( 1 to 3 $\mathrm{km}$ ) west of the Thomas Range lies Spor Mountain, a northwest-trending range, 2 by 6 miles ( 3 by $10 \mathrm{~km}$ ), composed of Ordovician to Silurian dolomites, quartzites, and shales with plugs and dikes of Tertiary topaz rhyolite. The Black Rock Hills, located 5 miles ( $8 \mathrm{~km}$ ) north of Spor Mountain and 2 miles $(3 \mathrm{~km}$ ) west of the Thomas Range, are about 5 miles $(8 \mathrm{~km})$ in diameter and are compoed of Ordovician tu Silurian sediments with some early Tertiary rhyolites. An intermontane valley, named the Dell, separates the Thomas Range from Spor Mountain. The valley is floored with Quaternary Lake Bonneville gravels and alluvium, but isolated outcrops of Paleozoic sediments and Tertiary rhyolites occur as small hills. A north-trending fault, known as the Dell Fault, lies on 


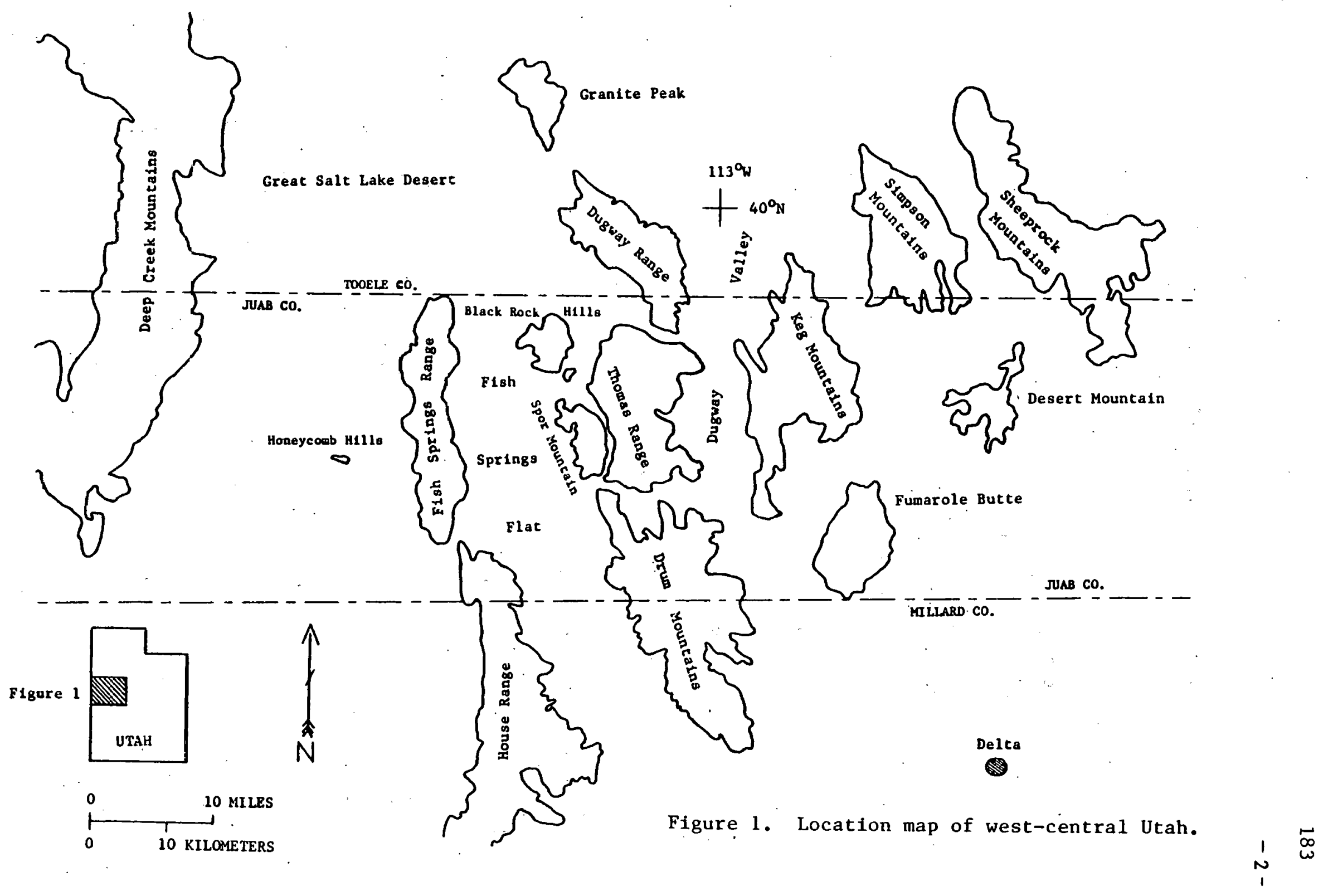


Figure 2. Map of the Spor Mountain District

\section{KEY}

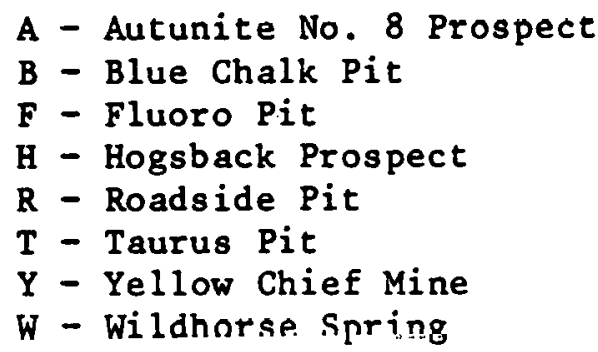

Drill Hole Number

$$
1
$$$$
6
$$$$
8
$$$$
18
$$$$
26
$$$$
29
$$

$$
\begin{gathered}
\text { Map } \\
\text { Location }
\end{gathered}
$$

11

4

13

5

9

14
Sample

Number

31

34

35

37

41

47

58

59

$61 a, b, c$ $62 a, b$

63

Measured Section

Fig. 4

Fig. 5

Fig. 6

Fig. 8

Fig. 9

May
Location
R
B
B
B
12
8
16
17
1
2
7

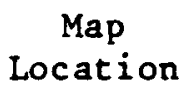

4

5

B

R

F
Sample Number

h7

70

71

1-63

1-93

6-358

8-938

18-113

26-112

29-124

29-206

Measured

Section

Fig. 16

Fig. 17

Fig. 18

Fig. 19

Fig. 20

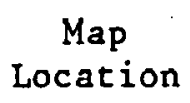

$B$

T

$T$

11

11

4

13

5

9

14

14

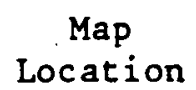

11

15

3

2

10 
185

KEY

Drill Hole

$x$. Location Point

- Open Pit Mine or Prospect

$\rightarrow$ Contour Line
$-4-$

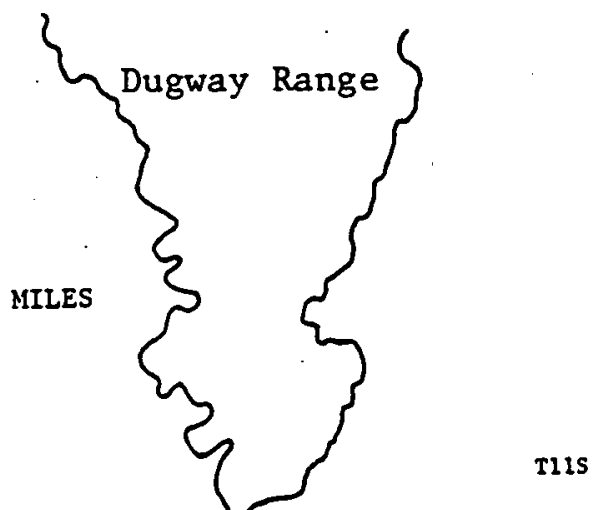

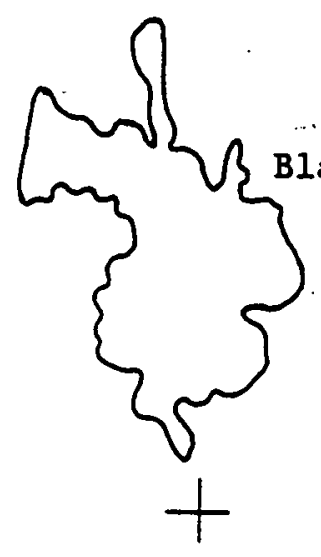
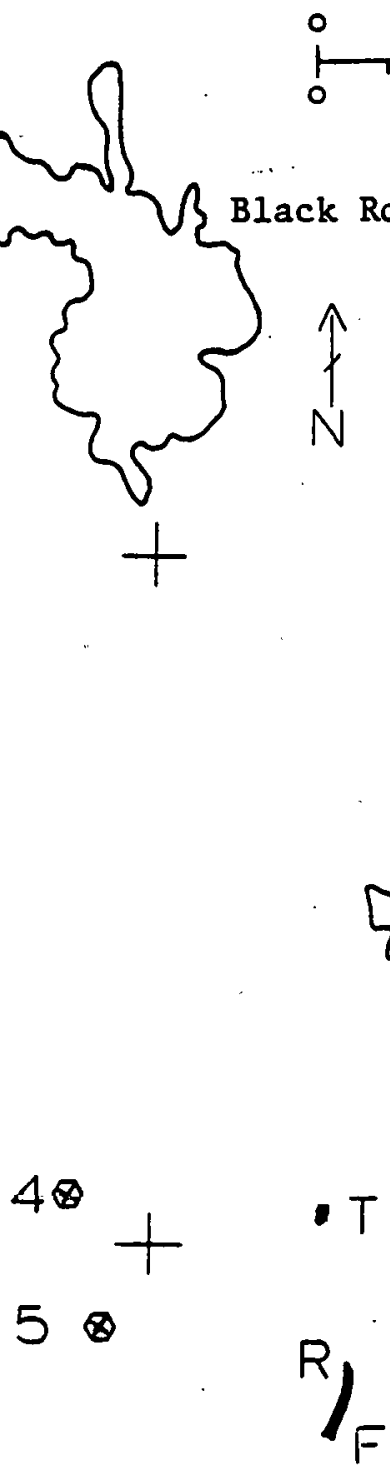

$2 \times\left\{\begin{array}{l}\text { thomas Range } \\ w_{\text {Th a }}+\end{array}\right.$

wis

$x_{1}$

KILOMETERS 
the eastern flank of Spor Mountain in the Dell. Two broad alluvialfilled valleys, Fish Springs Flat and the Dugway Valley, are located to the west and to the east, respectively, of the Spor Mountain area.

The regional setting of the spor Mountain rocks is shown in Figure 1. The neighboring ranges will be discussed beginning with the Simpson Mountains and then proceeding in a clockwise fashion around Spor Mountain (mostly from Morris, 1978). The Simpson Mountains, located 30 miles $(48 \mathrm{~km})$ northeast of Spor Mountain, are a fault-block range composed of Precambrian metasedimentary, Paleozoic sedimentary, and Tertiary silicic intrusive rocks. The Sheeprock Mountains are located 40 miles $(64 \mathrm{~km})$ east-northeast of Spor Mnuntain. This range is similar to the Simpson Mountains except for the occurrence of beryl rosettes and wolframite greisens in some of the Tertiary silicic intrusives (Cohenour, 1959, 1963). The Desert Mountains, located 30 miles (48 km) east of Spor Mountain, are primarily Tertiary silicic extrusive and intrusive rocks and small exposures of Precambrian metasedimentary rocks. A basaltic shield volcano of Quaternary age which locally caps some Tertiary rhyolites is found 20 miles $(32 \mathrm{~km})$ southeaot of 3 purs Mountain and is known as Fumarnle Butte. Immedialely sotith of the Thomas Range and extending southward some 25 miles $(40 \mathrm{~km})$ are the Drum and Little Drum Mountains. These fault-block ranges are made up of Tertiary extrusive silicic rocks including some topaz rhyolites, Paleozoic sedimentary rocks, and some small Tertiary silicic plugs. A major arcuate fault system, known as the Joy Fault, cuts the northern Drum Mountains. The House Range lies 20 miles $(32 \mathrm{~km}$ ) southwest of Spor Mountain and is a fault-block of Paleozoic sedimentary rocks containing 
a Tertiary silicic stock. Twenty miles $(32 \mathrm{~km})$ to the west of Spor Mountain, across Fish Springs Flat, lies a body of fault-blocked Paleozoic sedimentary rocks known as the Fish Springs Range. Just to the west of the Fish Springs Range, 25 miles $(40 \mathrm{~km})$ west of Spor Mountain, are two domelike bodies of $5 \mathrm{~m} . \mathrm{y}$. old topaz rhyolite known as the Honeycomb Hills (McAnulty and Levinson, 1964; Turley and others, 1979). The Deep Creek Range lies 45 miles $(72 \mathrm{~km})$ west of Spor Mountain and is a fault-block of Paleozoic sedimentary rocks overlying Precambrian granitic and metasedimentary rocks with some Tertiary silicic stocks (Bick, 1966). Immediately north of the Thomas Range and extending 15 miles $(24 \mathrm{~km})$ north is a fault-block of Paleozoic sedimentary rocks and some topaz rhyolite extrusives known as the Dugway Range. The Granite Mountains, 30 miles $(48 \mathrm{~km})$ north of Spor Mountain, are Precambrian granites cut by Tertiary lithophile-element-rich pegmatites with a minor amount of metasedimentary rocks (Park, 1968; Moore and Sorensen, 1978).

In this report, the beryllium, fluorspar, and uranium deposits near Spor Mountain will be informally grouped into the Spor Mountain Mining District (Shawe, 1968). The Thomas Range District (Bullock, 1976) and the Topaz District (Trover, 1961) have also been used to refer to this group of deposits. North of the Spor Mountain District, in the Dugway Range, the Dugway District has deposits of lead, zinc, copper, and silver (Staatz and Carr, 1964). The Detroit District, in the Drum Mountains, has deposits of manganese, copper, and gold (Lindsey, 1979a). 
PURPOSE AND SCOPE OF STUDY

This study was undertaken to investigate the two topaz rhyolites and their associated tuffs of the Spor Mountain District. Only one of these tuffs, the Beryllium Tuff, is known to be mineralized. The object of investigation was to elucidate differences in the two topaz rhyolite and their tuffs that might be related to the genesis of mineralization in the Beryllium Tuff.

This study involved three aspects of investigation. Field work was undertaken in the spring and sumer of 1979 and was directed toward the first phase of investigation, the description of stratigraphic sections in the two tuff-topaz rhyolite sequences in the Spor Mountain District. During this period, the collertinn of oamples fur the second and third phases of this study was also accompliehed. This work was greatly assisted in the spring of 1979 by M. F. Sheridan, D. M. Burt, E. H. Christiansen, B. P. Correa, and B. A. Murphy, and in the summer of 1979 by $R$. Cole while at Bendix Field Engineering Corporation facilities at Grand Junction, Colorado, working with drill core from the Spnt Mountain area.

The second phase of investigation, during the fall of 1979 , required the study of 85 petrographic thin sections in order to describe the petrography of the two topaz rhyolites in the Spor Mountain District. 
During the fall of $1979^{\circ}$ and the winter 'of' 1980 , geochemical studies of the two tuff-topaz rhyolite sequences were carried out as part of the third phase of investigation. Twenty-six whole rock analyses were determined in part by $X$-ray fluorescence (XRF) and atomic absorption (AA) techniques at Arizona State University at Tempe. Fluorine analyses were performed by a specific ion probe technique at Arizona State University with E. H. Christiansen and by Skyline Labs of Tucson, Arizona, on 15 rock samples. Two rocks were analyzed for chlorine by $K$. Evans by an induction furnace-ion chromatograph technique.

Minor element analyses were also performed. The beryllium contents of 12 samples were determined by AA techniques at Arizona State University with B. P. Correa and Skyline Labs of Tucson, Arizona. Skyline Labs of Tucson also performed eight lithium and two tin analyses by AA techniques. Strontium and rubidium contents of three samples were determined courtesy of CONOCO Inc. by XRF methods. Fifteen samples were determined for uranium by delayed neutron analyses by $G$. Goles at the University of Oregon at Corvallis. Finally, an instrumental neutron activation analysis (I.N.A.A.) for Sc, Zr, Hf, Ta, Th, U, Ba, Rb, Cs, La, $C e, N d, S m, E u, T b, Y b$, and $L u$ on six samples was performed at the University of Oregon by G. Goles.

Microprobe analyses on selected feldspars and a hornblende in seven polished thin sections were performed on 35 crystals by $E$. $H$. Christiansen, B. P. Correa, and B. A. Murphy at Arizona State University at Tempe and at the University of Arizona at Tucson. 
B. C. Morrison of Bendix Field Engineering Corporation provided information on and geochemical analyses of three drill cores from the Spor Mountain District which had penetrated the two tuff-topaz rhyolites of interest (Morrison, 1980). Interpretation of this information in conjunction with my descriptions of these three drill cores was accomplished during the winter of 1980 and proved to be an cosential part of this report. 


\section{LITERATURE REVIEW}

The extensive literature published before 1949 on the Thomas Range rhyolites deals mostly with the mineralogy of the lithophysae. This report will concern itself with the fluorine-enriched volcanic rocks and the beryllium, fluorine, and uranium mineralization of the Spor Mountain District. Hence, only articles published beginning with those which deal with the fluorspar pipes will be considered. Earlier literature is surveyed by Staatz (1963) and Staatz and Carr (1964). The Spor Mountain District will be discussed beginning with the volcanic geology. Next, the mineralization will be considered, in the sequence of fluorspar, uranium, and beryllium. This sequence reflects the order of initial discovery, exploration, and development for each type of deposit, and the increased understanding of the local geology as models for each type of mineralization were proposed.

\section{Volcanic Geology}

The volcanic rocks of the Spor Mountain District can be divided, for purposes of this discussion, into two groups, the younger being topaz rhyolites and the older being silicic rocks without topaz. These two groups of rocks can be found in the Thomas Range, Spui Mountain, the. Black Rock Hills, the Dugway Range, the Keg Mountains, and the Drum Mountains. 
The older volcanic rocks were first recognized and mapped as units of latite, tuff, and rhyolite around Spor Mountain and in the Dell (Staatz and Osterwald, 1959). These units were included in the Keg Mountain Ignimbrite Tuff, whose source area and type locality lay in the Keg Mountains (Erickson, 1963). The Keg Mountain Ignimbrite Tuff included all of the older volcanic rocks at Spor Mountain and the Thomas Range. Later, on the basis of detailed mapping, eight major volcanic unito were recognized in the Thomas Range, Spor Mountain, and the Dugway Range area, but the stratigraphic relationship between these latites and tuffs was unclear (Staatz and Carr, 1964).

Understanding of the volcanic geology of the Spor Mountain District was advanced by radiometric age determinations and ideas concerning volcanic structures. The Dell and iny fault systems were first recognized as the western margin of a caldera (Shawe, 1972). The eastern margin of this caldera was propused to lie in the Keg Moumlains, and its collapse was the proposed source of the ash-flow tuffs comprising the older volcanic rocks in the Spor Mountain District. Latitic flows were recognized as precaldera lavas. Age determinations and geochemical analysis of the tuffs in the area first. indicated a yrup of $38 \mathrm{~m} . \mathrm{y}$. old rhyodacitic to latitic tuffs and flows and a large amount of 32 m.y. nld rhyolitir tuffo, which were attributed to the collapse of the Thomas Caldera (Lindsey and others, 1975). Further mapping and age determinations revealed a very large amount of $38 \mathrm{~m} \cdot \mathrm{y}$. old rhyodacitic tuff and gave the precollapse latitic flows an age of $41 \mathrm{~m} . \mathrm{y}$. (Lindsey, 1978a). 
The most recent study of the area (Lindsey, 1979a,b) clarifies the relationship of volcanism to tectonism and formally proposes new names for the older volcanic units. (Fig. 3). Latitic to rhyodacitic precaldera flow rocks are dated at $41.8 \mathrm{~m} . \mathrm{y}$. and have been named the Drum Mountains Rhyodacite. The formation of the Thomas Caldera is now thought to have occurred $39 \mathrm{~m} . \mathrm{y}$. ago with the eruption of the rhyodacitic Mt. Laird Tuff. Following the formation of the Thomas Caldera, the collapse of the nested Dugway Valley Caldera emplaced the Joy Tuff, a rhyolitic ash-flow tuff. The western margin of the Dugway Valley Caldera lies 2.5 miles east of the Dell-Joy fault system. Eruptions of the Joy Tuff and possible piecemeal collapse of the Dugway Valley Caldera continued for several million years. Most of the tuff remained ponded within the Thomas Caldera. A second period of rhyolitic tuff eruption around $32 \mathrm{~m} . \mathrm{y}$. ago emplaced the Dell Tuff. No source for this tuff has been identified. Chalcophile and siderophile mineralization in the Detroit District is associated with the latites and rhyodacites $41.8 \mathrm{~m} \cdot \mathrm{y}$. to $39 \mathrm{~m} \cdot \mathrm{y}$. old, and the $38 \mathrm{~m} \cdot \mathrm{y}$. to $32 \mathrm{~m} \cdot \mathrm{y}$. old rhyolites lack any associated mineralization (Lindsey, 1979a, p. 60).

After a period of volcanic quiescence lasting $11 \mathrm{~m} . \mathrm{y}$. , the first of two periods of topaz rhyolitic volcanism occurred. This 21.5 m.y. old episode was followed by another long hiatus which ended with the emplacement, of a second topaz rhyolite $6.3 \mathrm{~m} . \mathrm{y}$. ago (Armstrong, 1970; Lindsey, 1979a). The composition of both of these topaz rhyolites fall on the borderline beween rhyolite and alkali-rhyolite fields, according to Rittmann (1952) (Lindsey, 1979a, p. 36, 40). No intermediate rocks that are compositionally or temporally transitional between the 
Figure 3. Suggested correlation of vclcanic rcck units in the Spor Mountain District, Utah

Erickson (1963)

Topaz Mounta in Rhyolite with Int rusive Breccla

Topaz Mountain thyolite TAf with Heryllium Juff
Sraatz and Sarr $(19 j c)$

TJpaz Mountaln Rhyolite

VItric Tuft

Ulth Beryll lum Tuf
Shave (1972)

Alka11 Rhyolite

Water-la1d Tuf

with Beryllsum Tuf
LIndrey $(1979 a, b)$

Topaz Mountain Rhyolite (6-7 m.y.)

Alkall Rhyolite

Stratifled Tuff

BASIN AID RANGE FAULTING

Spor Mountaln Pormation

with some brecclas
(21 m.y.)

Porphyrtic Rhyolite Member

Iotrue.lve Baseccla

Porphyrit1c Rhyolite

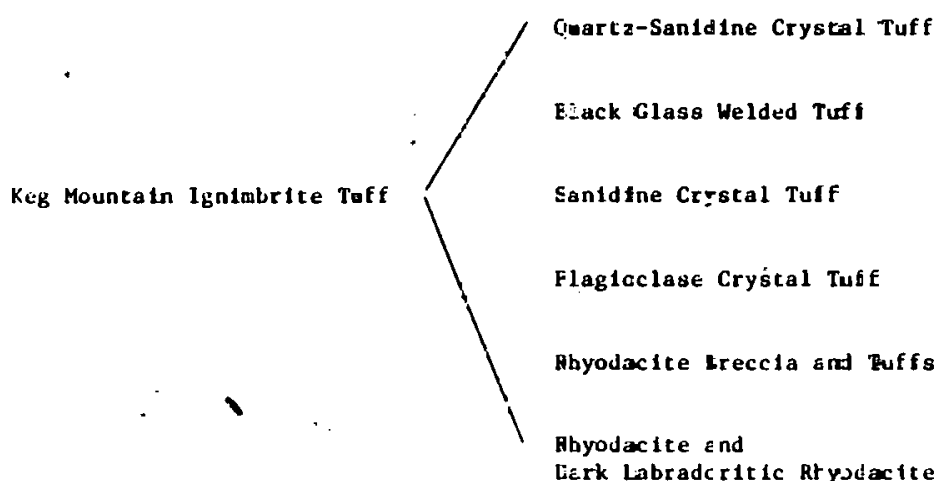

Licrk Labradcritic Rfysdacte
Intrusive Breccla

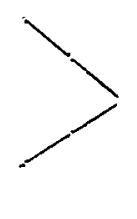

Rhyolite velded ash flow tuf

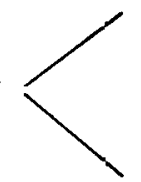

Quartz-latite velded

ash flow tuff

Latite, andesite, and basalt flows and agglomerate
Beryll1um Tuff Member

Dell Tuf (32 m.y.)

Joy Tuff - Black Glass Member ( $33 \mathrm{~m}$ m.y.)

- Crystal Rich Member (38 a.y.)

Mt. Lalrd Tuff
(39 w.y. $)$

Drum Mountalns Rhyodacite (41 m.y.). 
caldera rhyolites and the topaz rhyolites occur in the Spor Mountain District. The topaz rhyolites contain greater soda and potash and less lime and titania than the earlier rhyolites (Lindsey, 1979a). Barium contents can be used to distinguish the topaz rhyolites from earlier rhyolites and rhyodacites. The topaz rhyolites have barium contents of less than $200 \mathrm{ppm}$, whereas the rhyolites and the rhyodacites have barium contents of 500-1,000 ppm and 1,000-2,500 ppm, respectively (Lindsey, 1979a, p. 58). Both topaz rhyolites are anomalous in their trace amounts of $\mathrm{Li}, \mathrm{Be}, \mathrm{U}, \mathrm{Th}, \mathrm{Nb}, \mathrm{Sn}$, and $\mathrm{Rb}$ compared to other rhyolites in the western United States (Lindsey, 1979a; Turley and others, 1979).

The $21.5 \mathrm{~m} . \mathrm{y}$. old topaz rhyolites comprise part of the spor Mountain Formation which includes two members: the Porphyritic Rhyolite, maximum thickness $500 \mathrm{~m}$; and the Beryllium Tuff, maximum thickness $60 \mathrm{~m}$ (Lindsey, 1979b). Both members are found peripheral to spor Mountain where flows and domes of Porphyritic Rhyolite overlie the Beryllium Tuff. Numerous small plugs and dikes of the Porphyritic Rhyolite are found on Spor Mountain cutting the Paleozoic sedimentary rocks (Lindsey 1979a,b). Where the Porphyritic Rhyolite is in contact with the Beryllium Tuff, the base of the rhyolite is commonly brecciated and stained reddish-brown (Park, 1968, p. 16). Vents have been mapped in the nnrthern Dell, the east-central Dell, and the southwestern part of Spor Monntain (Lindsey, 1979b). Spor Mountain has been interpreted as a thin-skinned trap door structure over a subvolcanic massif (Fitch and others, 1949; Lindsey, 1979a, p. 50). The Porphyritic Rhyolite can be geochemically distinguished from the $6.3 \mathrm{~m} . \mathrm{y}$. old topaz rhyolites by its greater Ga, Li, $\mathrm{Nb}, \mathrm{Sr}, \mathrm{Y}$, and $\mathrm{Yb}$ trace element content (Lindsey, 1979a, 
p. 58). The Beryllium Tuff will be discussed in detail in the section on the beryllium deposits.

The $6.3 \mathrm{~m} . \mathrm{y}$. old topaz rhyolites are known as the Topaz Mountain Rhyolite (Erickson, 1963; Lindsey, 1979a, p. 7). The type section is located in the Thomas Range, and included in the unit are interbedded tuffs, vitrophyres, breccias, and flow-banded rhyolites (Lindsey, 1979a, p. 38). The rhyolite makes up most of the Thomas Range and extends into the southern Dugway Rauge and the northern Drum Mountains (Staatz and Carr, 1964; Newe11, 1971; Lindsey, 1979b). A slightly older topaz rhyolite, $10 \mathrm{m.y.}$, outcrops in the Keg Mountains (Lindsey and others, 1975). The rhyolite was emplaced as domes and flows locally over cogenetic tuffs. Twelve vents have been mapped in the southern Thomas Range and northern Drum Mountains. Often at the base of the flowlayered rhyolite a breccia, a vitrophyre, or both can occur (Lindsey, 1979a, p. 38). At least three tuff-breccia-vitrophyre-finw-layerod rhyolite sequences occur in stratigraphic succession in the Thomas Range (Lindsey, 1979a,b). The maximum stratigraphic thickness of the Topaz Mountain Rhyolite is $700 \mathrm{~m}$, and the total volume of material erupted has been estimated to be $50 \mathrm{~km}^{3}$ (Lindsey, 1979b; Turley and others, 1979).

The Topaz Mountain Rhyolite is richer in molybdenum and uranium than the Porphyritic Rhyolite (Tindsuy, 1979a, p. 38 ).

The Stratified Tuff of the Topaz Mountain Rhyolite has a maximum thickness of $30 \mathrm{~m}$ in low areas of the paleotopography over which it was deposited (Lindsey, 1979a, p. 40). The stratified nature of the tuff apparently resulted from its deposition by sheetwash, air fall, and small ash flows (Lindsey, 1979a, p. 41). The shards and pumice 
fragments are glassy to zeolitized, and the zeolitized tuff is not depleted in uranium or thorium compared to the glassy tuff (Lindsey, 1979a, p. 76). The upper contact of the tuff is sometimes fused by the overlying rhyolite (Lindsey, 1979a, p. 41). The major element chemistry of the tuffs is similar to that of the overlying rhyolites (Lindsey, $1979 a$, p. 41 ).

Early workers concerned with the fluorspar pipes recognized topaz as an accessory mineral in the rhyolitic plugs and dikes of Spor Mountain (Fitch and others, 1949; Thurston and others, 1954; Staatz and Osterwald, 1959). A single magmatic episode was postulated to produce the topaz rhyolites on Spor Mountain and in the Thomas Range. Faulting on Spor Mountain was recognized to occur before and after the emplacement of these plugs and dikes (Staatz and Osterwald, 1959). The rhyolite on Spor Mountain and some petrographically similar outcrops in the Dell were first named the Porphyritic Rhyolite by Staatz and Carr (1964). This unit was assigned an age predating basin and range faulting and thus was distinctly earlier than the topaz rhyolites of the Thomas Range which are not cut by most basin and range faults. As recent mapping shows, many outcrops of Porphyritic Rhyolite on earlier maps were misidentified and other outcrops were not recognized, noticeably southwest of Spor Mountain (Lindsey, 1979b; Staatz and Carr, 1964). The areal extent of this unit was therefore poorly defined.

Early workers in the beryllium deposits southwest of Spor Mountain correlated the mineralized host rocks with the tuffs exposed in the Thomas Range, and the beryllium mineralization was thought to be related to late magmatic fluids derived from the source of the Topaz 
Mountain Rhyolite (Staatz and Griffits, 1961; Staatz, 1963, p. 34; Trover, 1961). As originally defined, the Topaz Mountain Rhyolite included the rhyolite-tuff sequences that host the beryllium mineralization on the southwest side of Spor Mountain (Erickson, 1963). Park (1968, p. 14) noted that many fauls cut the topaz rhyolite-tuff sequences southwest of Spor Mountain and stated that these sequences could not be correlative with the Topaz Mountain Rhyolite, but the author did not correlate these sequences with the Porphyritic Rhyolite. Before accurate age determinations of the topaz rhyolites, emplacement of the Beryllium Tuff was thought to have been coeval with the tuffs of the Thomas Range (Shawe, 1972; Lindsey and others, 1973; Lindsey, 1975; Lindsey and others, 1975).

Glassy volcanic rocks rich in beryllium have been demonstrated to be also enriched in the other lithophile elements $B, W, N b, T a, S n$, Th, U, Cs, REE, Li, and Rb (Coats and others, 1962). Beryllium in oversaturated rocks has a positive correlation with both silica and fluorine (Coats and others, 1963; Griffiths and Powers, 1963; Shawe and Bernold, 1966). Volcanic rocks in the western linited States havy a provincial distribution of beryllium (coate and uthers, 1962; Cohenour, 196.3; Shawe, 1966). An east-west belt of beryllium anomalies exists from the Duep Creek Range to the Sheeprock Mountains (Cohenour, 1963; Shawe, 1966).

The topaz rhyolites of the spor Mouncain District were emplaced after the completion of the earlier caldera cycle; ring fractures near the Dell provided a favorable structural framework for the intrusions of the topaz rhyolite magmas (Shawe, 1972). Basalt and alkali-rhyolite 
magmatism is associated with the extensional basin and range tectonism after $21 \mathrm{m.y}$. ago (Lindsey, 1979a, p. 64). Because no young basalts are associated with the topaz rhyolites in the Spor Mountain District, except for Fumarole Butte, genesis of these topaz rhyolites by differentiation from a basaltic parent magma is unlikely (Lindsey, 1979a, p. 63). Crustal fusion, produced by high heat flow and periodic intrusions of basalt related to the extensional tectonics of the basin and range, followed by a long magma chamber residence time to allow a high degree of chemical evolution, is a possible model for the petrogenesis of the Spor Mountain District topaz rhyolites (Lindsey, 1979a; Turley and others, 1979). The Precambrian granite terrain, cut by $20 \mathrm{~m} \cdot \mathrm{y}$. old berylliumrich pegmatites in the Granite Mountains, is rich in lithophile elements and would be a good crustal source material for the two topaz rhyolite magmas (Moore and Sorensen, 1978; Park, 1968; Lindsey, 1979a).

Heat flow in the Topaz Mountain Rhyolite tuff has been measured and found to be anomalously high at $3.0 \pm 0.3 \mu \mathrm{cal} / \mathrm{cm}^{2} \mathrm{sec}$ (Costain and Wright, 1973). The anomalously high heat flow also in the Keg Mountains and in the Sheeprock Mountains defines a region named the South Bonneville Anomaly (Darling and Chapman, 1979).

\section{The Fluorspar Pipes}

The fluorspar pipes on Spor Mountain were the first deposits to be found and exploited in the district. In 1936, the first fluorspar find was made by the spor brothers, who staked the deposit in 1941 . They began production from their claims in 1944. A major prospecting effort took place in 1948-49. Presently, there are approximately 28 
fluorspar prospects and mines on Spor Mountain (Bullock, 1976). As of 1975, 225,000 tons (204,000 metric tons) of fluorite ore with grades of. 60-95 percent have been shipped from the Spor Mountain District. The Lost Sheep Mine has produced 90,000 tons $(82,000$ metric tons) of ore and has been the largest producer in the district, followed by the Fluorite Queen Mine $(36,000$ tons, 32,600 metric tons) and the Bell Hill Mine (26,194 tons, 23,758 metric tons) (Bullock, 1976).

The cuuntry rock for the fluorspar pipes is a thick sequence of dolomites underlain by a quartzite and minor shale unit beneath which . occurs another dolomite sequence (Thurston and others, 1954). These Ordovician to Silurian rocks have been tilted approximately 35 degrees northwest by basin and range faulting primarily along the Dell fault; but numerous minor faults are found on Spor Mnuntain (Etaatz and Osterwald, 1959). Many plugs and dikes of Porphyritic Rhyolite have been intruded into the Palenzoic ocdiments of spor Mountain, and the rhyolite is found both to cut and to be displaced by faults on spor. Mountain (Staatz and Osterwald, 1959, p. 43). Bodies consisting of shatcced and unaltered fragments of dolomite, quartzite, rhyndacite, and Porphyritic Rhyolite in various proportinns with a matrix of rock powder or Porphyritic Rhyolite have been termed Intrueive Breccia (Staatz, 1963, p, 17; Stdatz and Usterwald, 1959, p. 37). These deposits have been interpreted as gaseous explosion features (Staatz and Osterwald, 1959, p. 38). Some outcrops previously mapped as Intrusive Breccia are now construed to be landslide deposits related to caldera wall collapse near the present east flank of Spor Mountain and in the Dell (Lindsey, 1979a,b; Staatz and Carr, 1964). 
The fluorspar occurs as soft friable masses or as resistant boxworks with fine quartz veining and is white, blue, purple, or mixed in color (Staatz and Osterwald, 1959). Relict bedding which can be traced into the dolomite occurs in some deposits, and fluorite is found replacing fossils (Staatz and Carr, 1964). Gangue minerals include calcium-magnesium montmorillonite, quartz, chalcedony, and dolomite (Staatz and Carr, 1964). Most fluorspar is found in breccia pipes from 1 foot $(0.3 \mathrm{~m}$ ) in diameter to 155 by 105 feet ( 47 by $32 \mathrm{~m}$ ) (Staatz and Carr, 1964). Less than 1 percent of the commercially minable deposits are in veins associated with fault breccias (Bullock, 1976). All fluorspar pipes discovered to date occur in the dolomites above the quartzite and shale unit. The lower dolomites appear barren at Spor Mountain (Bullock, 1976). The fluorspar pipes narrow with depth, and the amount of gangue increases (Staatz and Carr, 1964). At the quartzite-dolomite contact, the fluorite disappears as thin stringers into the quartzite (Staatz and Carr, 1964). Presently, the deepest proven fluorspar is 425 feet $(130 \mathrm{~m})$ below the surface (Bullock, 1976). Many pipes are spatially related to fault intersections, Porphyritic Rhyolite plugs, or Intrusive Breccia bodies (Staatz and Carr, 1964; Fitch and others, 1949). Where fluorspar pipes occur next to Porphyritic Rhyolite plugs or Intrusive Breccia bodies, thin stringers of fluorite are found in them, but in the Bell Hill Mine a topaz-bearing tuff cuts the fluorspar mineralization (Staatz and Carr, 1964; Bullock, 1976). Beryllium concentrations ranging from 4 to 20 ppm have been observed in the fluorspar (Staatz, 1963, p. 25). The uranium in the fluorspar pipes will be discussed in the section on uranium deposits. 
Descriptions of individual deposits can be found in Thurston and others (1954), Staatz and Osterwald (1959), Staatz and Carr (1964), and Bullock (1976).

The fluorspar deposits have been classed as epithermal pipes and veins, because of the low-temperature origin indicated by the gangue mineralogy' and the fine grain size of the fluorite (Staatz and Osterwald, 1959, p. 61). Since the early workers on the fluorspar pipes were nol aware that two episodes of topaz rhyolite emplacement had occurred, the deposies were related to fluorine-rich gases of solutions. which were derived from a magma body related to the topaz rhyolites of the Thomas Range. The association between fluorspar pipes and fault intersections (Staatz and Osterwald, 1959, p, 48) and between fluorspar pipes and Porphyritic Rhyolite plugs (Fitch and others, 19/9) have been given genetic importance. The direction of mineralization is primarily vertical, and mineralizing fluids could either have mnved downward froüi a crystallizing Porphyritic Rhyolite mass or have moved upward from a solidifying magma body below (Staatz and Osterwald, 1959; p. 61).. Upward-migrating fluids have been preferred because pressure release is usually upward and the numerous plugs of Porphyritic Rhyolite seem to indicate a shallow pluton below spor Mountain (Staatz and Ooterwald, 1959, P. 61).

\section{Uranium Geology}

Discovery of uranium in the Spor Mountain District led to the second major exploration effort in the vicinity from 1952 to 1954 
(Staatz, 1963). Four types of uranium occurrences have been identified in the area. Each type of deposit will be considered separately.

\section{Sandstone Uranium}

The only production of uranium in the Spor Mountain District as of 1979 has been from the Yellow Chief Mine. In 1954, the Yellow Chief and the Goodwill discoveries were made on the present site of the Yellow Chief Mine in the Dell. The mine was developed from 1959 to 1962 as an open pit which reached horizontal dimensions of 1,200 by $300-500$ feet (366 by $91-152 \mathrm{~m}$ ) and a depth of 100-150 feet (30-46 m). Approximately 100,000 tons $(90,700$ metric tons) of $0.20-0.23$ percent uranium ore was produced from the deposit (Bowyer, 1963).

The host rock for the uranium deposits is primarily a tuffaceous clastic rock, about $118 \mathrm{ft}$ thick, and an overlying limestone conglomerate that ranges in thickness from 1 inch $(2.5 \mathrm{~cm})$ to 10 feet $(3 \mathrm{~m})$ (Bowyer, 1963; Lindsey, 1978a). This sedimentary sequence rests on the Dell Tuff and is faulted down against the Dell Tuff by a north-trending fault on the west side of the mine (Lindsey, 1979a, P. 34, 71). Two facies of the tuffaceous clastic rock exist in the mine, both of which are primarily derived from the Dell Tuff (Lindsey, 1979a, p. 34). The lower facies is a conglomerate with cobles of Drum Mountain Rhyodacite, and the upper facies is a sandstone (Lindsey, 1978a). Both facies have carbonate cement (Bowyer, 1963; Staatz and Carr, 1964). The overlying limestone conglomerate is a channel deposit (Bowyer, 1963). Conformably overlying the clastic sequence is a bentonite bed, about 49 feet. ( $15 \mathrm{~m}$ ) thick, which has relect pumice fragments and crystals of quartz and 
sanidine (Bowyer, 1963; Lindsey, 1979a, p. 33). The entire sequence exposed in the Yellow Chief Mine above the Dell Tuff is included in the Beryllium Tuff (Lindsey, 1979a).

In the tuffaceous clastic rocks, the ore is in lenses, partially concordant to bedding, that are about 20 by 300 feet ( 6 by $91 \mathrm{~m}$ ) in section, and the ore is found throughout the vertical extent of the conglomerates and sandstones (Bowyer, 1963; Lindsey, 1978b). Ore in the limestone conglomerate is associated with altered clasts (Lindsey, 1979a). The two uranium minerals mined as ore in the deposit are beta-uranophane, in the tuffaceous clastic rocks, and weeksite, in 1/4-inch ( $6 \mathrm{~mm}$ ) rinds on altered clasts in the limestone conglomerate. All uranium minerals described from the deposit have uranium in the plus six oxidation state, and no organic matter or pyrite has been found in the host rock (Lindsey, 1979a). Traverses across the ore lenses in tuffaceous clastic rocks show no $\mathrm{Cu}, \mathrm{V}, \mathrm{Cr}, \mathrm{Pb}, \mathrm{Ag}$, or Mo associated with the uranium as is comonily the case in the Colorado Plateau deposits (Lindsey, 1979a, p. 72). The traverses also show no $\mathrm{F}, \mathrm{Be}$, or $\mathrm{Li}$ anomalies in the ore lenses (Lindsey, 1979a, p. 72).

The origin of the uranium in the Yellow Chief is in dispute. Hydrothermal fluids asssociated with the fluorspar deposits have been cited as the source of the deposit (Staatz and Carr, 1964). The hydrothermal fiuids are considered'to have moved up major faults and then spread laterally into the more permeable tuffaceous clastic rocks. Later oxidation produced the plus six uranium minerals (Statz and Carr, 1964). Bowyer (1963) considers the faults to be post-ore and not part of a hydrothermal system. Erosion of the fluorspar pipes on Spor 
Mountain has been proposed as the source for the uranium (Bowyer, 1963). The lack of any beryllium or fluorine anomalies associated with the uranium can be evidence against a hydrothermal origin, because these elements are all enriched in the beryllium and fluorspar deposits (Lindsey, 1979a, p. 72). A mechanism whereby tuff-derived uranium traveled complexed with carbonate ions in the plus six state in groundwaters and was precipitated when carbonate cement formed in the tuffaceous clastic rocks of the Yellow Chief Mine has been proposed to explain the origin of this deposit (Lindsey, 1979a, p. 75).

\section{Opal Veinlets}

The first reported discovery of uranium in the Spor Mountain District was at the Autunite No. 8 Prospect in 1950. At this prospect and at the Buena No. 1 Prospect (1954) the uranium is in opal which occurs as swarms of $1 / 32$ to $1 / 2$ inch $(0.8-13 \mathrm{~mm})$ fracture filling (Staatz and Carr, 1964; Lindsey, 1978a). Opalized fracture fillings are very common in the Spor Mountain District and can be found in nearly all the volcanic rock types (Lindsey, 1978a). At the Autunite No. 8 Prospect, the veinlets are found in the Joy Tuff (Lindsey, 1979a, p. 75). The veinlets are 75 to 100 percent opal, and accessory minerals include calcite, fluorite, and weeksite (Staatz and Carr, 1964 ). Detailed investigation of the opal shows that the uranium is zoned parallel to the walls of the fractures (Zielinski, 1977). Geochronology by uranium-lead isotope analysis gives ages of 3.4 to $4.9 \mathrm{~m} . \mathrm{y}$. old for the opalized veinlets at the Autunite No. 8 Prospect (Ludwig and others, 1980). 
The opalized veinlets in the Spor Mountain District have been considered to be hydrothermal in origin (Staatz and Carr, 1964). Recent workers maintain that the opal is related to hot spring activity after the emplacement of the Topaz Mountain Rhyolite (Henry, 1978; Ludwig and. others, 1980).

Uranium in Fluorspar Pipes

The radioastivity of the fluorspar pipes wae firet noted by prospectors searching for Eluorspar on Spor Mountain (Fitch and others, 1949). Analysis of the pipes showed uranium to vary from 0.005 to 0.33 percent, and the uranium content of the pipes decreased with depth (Staatz and Osterwald, 1959; Bullock, 1976). Pipes at the south end of Spor Mountain have been reported to be four times'richer in uranium than those at the north end (Sharp, 1963).

The uranium is primarily substituting for calcium in the fluorite matrix, although some carnotite coatings have been observed (Sharp, 1963; Staatz and Carr, 1964). Slow leaching of uranium by rainwaters and reprecipitation by evaporation has produced a secondary concentration of uranium near the surface and is thought responsible for the vertical zonation of uranium in the pipes (Staatz and.Osterwald, 1959, p. 58),

Uranium in the Beryllium Tuff

The occurrence of uranium in the Beryllium Tuff will be discussed in the following section. 


\section{The Beryllium Deposits.}

The Beryllium Tuff southwest of Spor Mountain was first recognized simply as a disseminated fluorite occurrence in an unnamed tuff unit (Staatz and Osterwald, 1959, p. 90). These deposits attracted the attention of rockhounds because of the purple fluorite nodules that could be found in the area, and one collector, who for some reason was intrigued to know the beryllium content of a nodule, discovered the beryllium potential of the Spor Mountain District (Staatz, 1963). A major beryllium exploration effort took place from 1960 to mid-1961 in the area (Staatz, 1963). The beryllium was recognized to be primarily in the mineral bertrandite (Staatz and Griffitts, 1961; Montoya and others, 1962). Mining of the deposit had to await the perfection of a new beryllium extraction process and on the construction of a mill in Lynndyl, near Delta, Utah. Mine production began in the late sixties (Davis, 1978). All ore is presently mined by open-pit methods (Davis, 1978).

The stratigraphic position of the mineralized tuffs was not recognized until recently. Some early workers felt that a number of tuff units of different ages in the district had been mineralized (Staatz and Griffitts, 1961; Staatz, 1963, p. 33). Later workers correlated the mineralized tuff-topaz rhyolite sequences with the topaz rhyolites exposed in the Thomas Range (Erickson, 1963; Shawe, 1968; Lindsey, 1973; Lindsey and others, 1975; Lindsey, 1975). Park (1968, p. 14) recognized that the mineralized tuff southwest of Spor Mountain was. cut by numerous basin and range faules, and thought this unit was 
emplaced before basin and range faulting occurred in the area. Thus, the mineralized tuff and the Thomas Range tuffs were not correlative, because the tuffs in the Thomas Range are not cut by most basin and range faults. Geochronology by $\mathrm{K}-\mathrm{Ar}$ and fission track methods and detailed mapping has shown that all known beryllium deposits found to date are in the $21.5 \mathrm{~m} . \mathrm{y}$. old Beryllium Tuff, and this tuff is not correlative with the Stratified Tuffs of the Topaz Mountain Rhyolite emplaced 6.J m.y. ago (Armstrong, 1970; Lindsey, 1978a; Lindsey, 1979a,b). The Beryllium Tuff southwest of Spor Mountain has been divided into three members. The bottom member, comprising about $2 / 3$ of the thickness of the tuff, is generally unaltered and contains numerous dolomite lithics; the middle member, present only where the tuff is thickest, has been interpreted as a welded tuff; and the top member is mineralized with altered dolomite lithics (Williams, 1963). Later interpretation has divided the Beryllium Tuff into 5 facico, which are exposed at various localities in the Spor Mountain District (Lindsey, 1979a, p. 33). From top to bottom, these facies are: tuffaceous breccia, thinly stratified tuff, bedded massive ash flow tuff, bentonite, and tuffaceous sandstone and conglomerate. The 1 ast two facies are exposed in the Yellow Chief Mine. Detailed mapping has shown the Beryllium Tuff to be 20 to 60 m thick and to occur in the Dell, southwest of Spor Mountain, and westward into Fish Springs Flat (Lindsey, 1979b).

The mode of emplacement of the Beryllium Tuff is in dispute. An explosive origin of emplacement in the form of ash flows and air falls has been recognized for the deposits southwest of Spor Mountain 
(Erickson, 1963; Williams, 1963). The term water-laid tuff has been applied to the Beryllium Tuff and to the Stratified Tuff of the Topaz Mountain Rhyolite when the two tuffs were thought to be coeval (Shawe, 1968). The emplacement of the water-laid tuff was attributed to torrential streams and mudflows in order to account for the poor sorting, crude stratification, and heterogeneous density mixtures found in the deposits (Lindsey, 1977). Epiclastic, air fall, and ash flow components all have been used together to explain the origin of the Beryllium Tuff (Lindsey, 1979a).

There is general agreement that high beryllium concentrations occur at the top of the Beryllium Tuff somewhat below the overlying Porphyritic Rhyolite and that the beryllium mineralization is tabular in shape (Griffitts and Rader, 1963; Staatz, 1963, p. 26; Williams, 1963; Park, 1968, P. 32; Shawe, 1968; Lindsey and others, 1973, p. 9; Lindsey, 1977; Lindsey, 1979a). Associated with the high beryllium concentrations at the top of the tuff are anomalous $F, F e, M n, 2 n, P b, M g$, Li, and REE concentrations (Griffitts and Rader, 1963; Park, 1968, p. 32-35). The degree of dolomite alteration increases upward from dolomite lithics at the base of the tuff through a zone of calcite nodules to fluorite nodules at the top of the tuff (Park, 1968, p. 19; Lindsey and others, 1973). Alteration of the ash in the Beryllium Tuff is most intense at the top where a feldspathic zone occurs and decreases downward into an argillic alteration zone (Lindsey and others, 1973). The high beryllium concentration coincides with the occurrence of fluorite nodules and the feldspathic zone at the top of the tuff (Lindsey, 1977). Uranium is found in concentrations up to $2,000 \mathrm{ppm}$ in 
the tuff and is localized below the beryllium mineralization in the calcite nodule zone (Lindsey, 1978a; Lindsey, 1979a, p. 68).

The origin of the beryllium deposits has been attributed to solutions moving up faults near Spor Mountain into the Beryllium Tuff (Staatz, 1963, p. 34; Park, 1968, p. 45; Shawe, 1968; Lindsey and others, 1973, p. 4; Lindsey, 1977; Lindsey, 1979a, p. 77). The fluorspar pipes have been considered to be exposed conduits for these solutions (Williams, 1963; Park, 1968, p. 44), although Lindsey (1979a, p. 52) maintains that Spor Mountain was a high area $21.5 \mathrm{~m}, \mathrm{y}$. ago and was never extensively covered by the Porphyritic Rhyolite or the Beryllium Tuff. The beryllium and other metals are thought to have traveled as fluoride complexes, and deposition of the metals occurred when the ore-bearing solutions reacted with the dolomite lithics in the Beryllium Tuff (Staatz, 1963, p. 34; Williams, 1963; Shawe, 1968; Lindsey and others, 1973, p. 17; Lindsey, 1977; Lindsey, 1979a, p. 77). These fluids, which rose via caldera and basin and range faults, spread out laterally through the porous Beryllium Tuff, which is situated between the relatively impermeable underlying Paleozoic sediments and the overlying Porphyritic Rhyolite (Staats, 1963, p. 35; Lindsey, 1978a). The mineralizing fluids have been considered to be magmatic-hydrothermal waters derived from or groundwaters which leached a pluton associated with the extrusive Spor Mountain Formation (Lindsey, 1978a). Because the Stratified Tuffs of the Topaz Mountain Rhyolite are barren, the age of the beryllium mineralization is thought to be between $21.5 \mathrm{~m} \cdot \mathrm{y}$. and $6.3 \mathrm{~m} . \mathrm{y}$. old (Lindsey, 1979a). Park (1968, p. 45) notes that faults in the Beryllium Tuff cut the beryllium mineralization and have not been 
found to be mineralized. Groundwater leaching of the overlying Porphyritic Rhyolite has also been proposed as a source of the beryllium in the tuff (Park, 1968, P. 49). 
PRESENT WORK

\section{Introduction}

The nature of the two topaz rhyolite-tuff sequences in the Spor Mountain District will be examined and then cumpared in the following sections from three aspects, (1) emplacement, (2) mineralization and chemical anomalies, and (3) geochemistry and petrography. From consideration of these three aspects, differences in the petrogenesis of the Spor Mountain District's two topaz rhyolites will be specified and the relation of these differences to the mineralization in the district will be hypothesized.

\section{Emplacement of the Beryllium Tuff} and Porphysilic Rhyolite

The Beryllium Tuff and the overlying Porphyritic Rhyolite have been recognized as nearly coeval units and have been ranked as members of the Spor Mountain Formation (Lindsey, 1977a,b). Also included in the Beryllium Tuff Member by Lindsey (1979a) are the uranium-bearing sediments exposed in the Yellow Chief Milu. The style of emplacement of the Beryllium Tuff is in dispute, as previous workers have considered the tuff both to be volcanogenic in origin (Erickson, 1963; Williams, 1963) and an epiclastic volcanic sediment (Shawe, 1968; Lindsey, 1977; Ludwig and others, 1980). Workers who attributed the deposition of the tuff to secondary processes have characterized it as having poor 
sorting, crude stratification, and heterogeneous density mixtures and have emphasized emplacement by torrential streams, mudflows, and sheetwash to account for these features. Workers who hypothesized a pyroclastic origin for the tuff published their findings before later investigators had established criteria for the recognition of pyroclastic surge units, ignimbrites, and air fall units (Sparks and others, 1973; Sheridan, 1979; Wohletz and Sheridan, 1979).

New Data

In order to evaluate what processes were important in the emplacement of the Beryllium Tuff, five sections were measured in detail through the Spor Mountain Formation and observations pertaining to its emplacement were made at three additional sites. Three sections were measured from cuts in the Blue Chalk, North Fluoro, and North Roadside open-pit beryllium mines of the Brush-Wellman Corporation southwest of Spor Mountain (Fig. 2). Two additional sections through the Spor Mountain Formation were described from drill cores of the Bendix Field Engineering Corporation in Grand Junction, Colorado. These drill sites were also located southwest of Spor Mountain (Fig. 2). Observations. of the Spor Mountain Formation were made southwest of Spor Mountain in Brush-Wellmann's Taurus Pit and in the Dell at the Hogsback Prospect and at the Yellow Chief Mine (Fig. 2).

From the drill core, two types of units were described from the Beryllium Tuff (Figs. 4 and 5). Both types of units are characterized by pumice and rock fragments supported in an indurated ash matrix with. dipyramidal smoky quartz and biotite. The most numerous type of unit 
Figure 4. Measured Section Spor Mountain Formation, Bendix Field Engineering Corporation Spor Mountain Drilling Project Hole Number 6, Southwest Spor Mountain. 


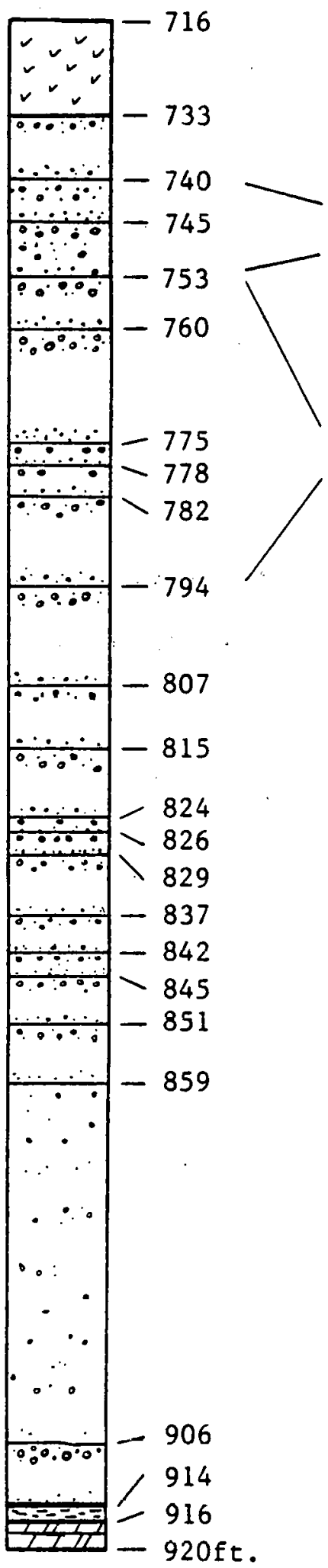

Hole Elevat1on 4462ft. / NEלSWr, sec 36, T12S, R1 3W

Porphyritic Rhyolite Flow Breccla

Altered Ignimbrites: ash with black manganese staln; pumlce altered to pink clay; and purple and white mottled nodules.

Ntered Ignimbrites: pumice altered to pink clay and calcite nodules with purple fluorite rims.

Alered Ignimbrites: dolomite lithics altered to whice calcite nodules.
Ignimbrites: greenish whice Induraced ash with broken biotiteg, <0.11n, and dipyramidal smoky quartz, 0.1 in.: lighe pink vesicular pumice Eragäients tu $l . i t a$. With Lo.11n. biotice; dark to light gray angular dolomice lithics to 1.21n.; and minor dark red thyodacite (Drum Mtn. Rhyodactee) lithics; Individual flow unfts recognized by lithic rich base and pumice rich top, $61 \mathrm{in}$. ashy intervals at base of some flow units, flow unies. In section 2 to loft. thick; some cote intervals poorly preserved and lack sufflelent cricerta to diselngulsh individual flow unles.

Terra Rosa: yellowish whice to red, very fine gralned. laminaced, calcareous $311 \mathrm{es}$.

Dolomite: dark, massive, sparry calicite valnlets. 
Figure 5. Measured Section Spor Mountain Formation, Bendix Field Engineering Corporation Spor Mountain Drilling Project Hole Number 18, Southwest Spor Mountain. 


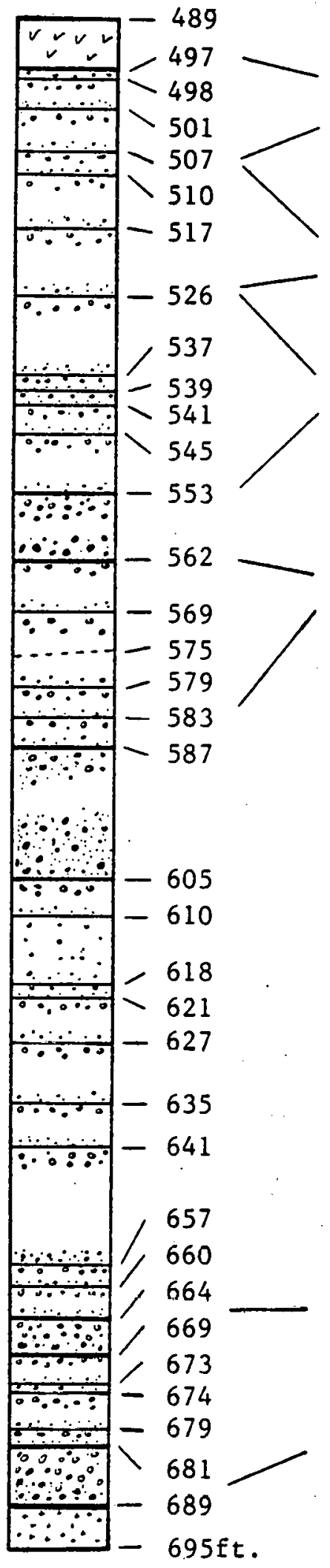

Hole Elevation 4506ft. / NEhSWl, gecl, T13S, R1 3W

Porphyrtetic Rhyolfte Flow Breccla

Altered Ignimbrites: ash with black manganese atain; pumbe altered to plnk clay; and purple and white mottled nodules.

Altered Ignimbrites: punice altered to pink clay and calcite nodules with purple fluorice sias.

Altered Ignimbrites: dolomite lithics altered to white calcite nodules.

Altered 8lock Flow Unte: calcite nodules to $3 \mathrm{ft}$.

Alcered Ignimbrifes: dolomite lithics altered to white calcire nodules.

Faule: opal replacement.

Ignimberite

Block Flow Unit: dolomite lithics to 2.jitt. and sparse shyodaclte 11thics to $3.21 \mathrm{n}$.

Ignimbrites: greenish whice Induraced ash with broken biocites, $0.11 \mathrm{n}$. and dipyramidal gmoky quartz. 0.11a.; Lighe pink vesicular pumice fragmencs to l.41a. with $60,11 \mathrm{n}$. blotter; dark to 11 ghe gray angular jolomite lichics to 1.21n.: and iutnor dark red rhyodacice (Drum Mta. Rhyodac1ee) lithics: individual flow units recognized by lithic elch base and punice eich cop, 6in. ashy incervals at base of some flow units, flow units in section 2 to $10 f t$. Chick; some core intervals poorly preserved and lack sufficient criteria to Jistingulsh individual flow units.

Bloek Blow Init: dolomite lithics to $61 n$.

Ignimbetees

8lock Flow Unit: lighe plnk to whice indurated ash with broken smoky quartz, 0.1 in, and biotite, <0.11n.; whice vesicular pumice iragments to $2 .+1$. With sparse. quartz and biotite; dark to lighe gray angular dolonite lithics co 8in.; and sparse lithics of Dell Tuff.

Dell Tuff(?): graylsh white, quartz and feldopar abundatut wh afnot.blotite, sparse pumice. 
was recognized by inversely graded subrounded vesicular pumice fragments and normally graded angular rock fragments. This grading results in units with pumice-rich tops and rock fragment-rich bases. A second type of bed was recognized that is similar to the first except for the presence of distinctly larger rock fragments. In both types of beds, the pumice and rock fragments are poorly sorted, and fine-giained bases below the zone of highest rock fragment concentration sometimes occur. The ruck fragments are nearly 90 percent dolomitic, and the remainder are quartzite and rhyodacite. Faults and fractures with opal are common in the drill core.

The measured section from the Blue Chalk pit (Fig. 6) differs from the drill core in that the individual units are much thinner and, unlike the exposures in the North Rnadside and the North Fluoro pits, are not very continuous laterally. In addition to the units found in the drill core, two new types occur in the Blue Chalk pit. A pumicerich unit, which is moderately well-sorted and into which blocks of Porphyritic Rhyolite sag (Fig. 7), outcrops at the top of the Beryllium Tuff. The second new type of unit is characterized by ash, fine rock fragments, and small well-rounded pumico in a sandwave bed form. A thick brecciated zone is found at the base of the Porphyritic Rhyolite in the Blue chalk pit and is undoubtedly similar to that described by Park (1968). Sparse, small blocks of vitrophyre are found in this breccia zone.

The North Roadside pit section evidently lacks the capping Porphyritic Rhyolite due to erosion (Fig. 8), because of the proximity of the Porphyritic Rhyolite to the west (Lindsey, 1979b). Graded units 
$-38-$

Figure 6. Measured Section Spor Mountain Formation, Blue Chalk Pit, Brush-Wellman Beryllium Mines, Southwest Spor Mountain. 
Top of Section Not Measured

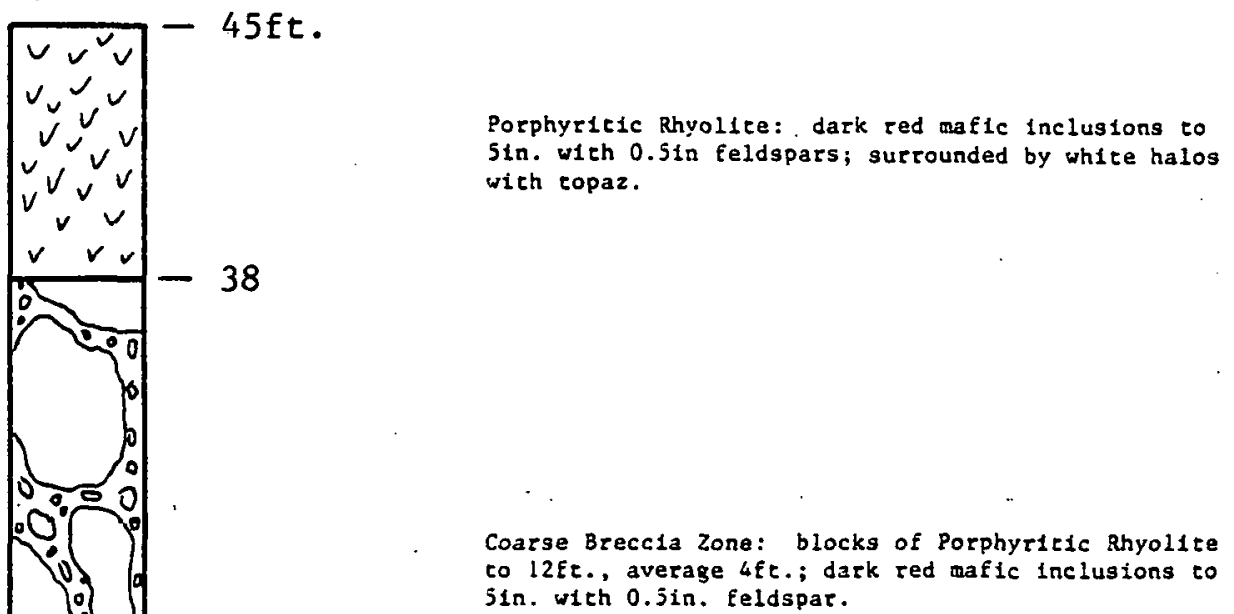
5in. with $0.51 \mathrm{n}$ feldspars; surrounded by white halos

Breccla Zone: blocks of angular black vicrupilyre dild Porpinyritic Rhyolite, 4in. to $3 f e$.

\author{
Altered Alr Fall Unle: black nanganiferous stained \\ asli dild pumlice. \\ Altered Ignimbrite: pink to vellow Indurated ash; \\ black nodules with purple fluorice rims: and solid \\ purple Eluorite nodules. \\ Aleered Ignimbrice: Pluk Ludutalied ash wich black \\ nanganfferous seained calcite nodules. \\ Alcered Ground Surge lnit: pink Indurated ash, sand- \\ wave bed form, dipyramidal quartz. \\ Base of Section So30ft. / SECAVE, sec10,T13S,R12W
}




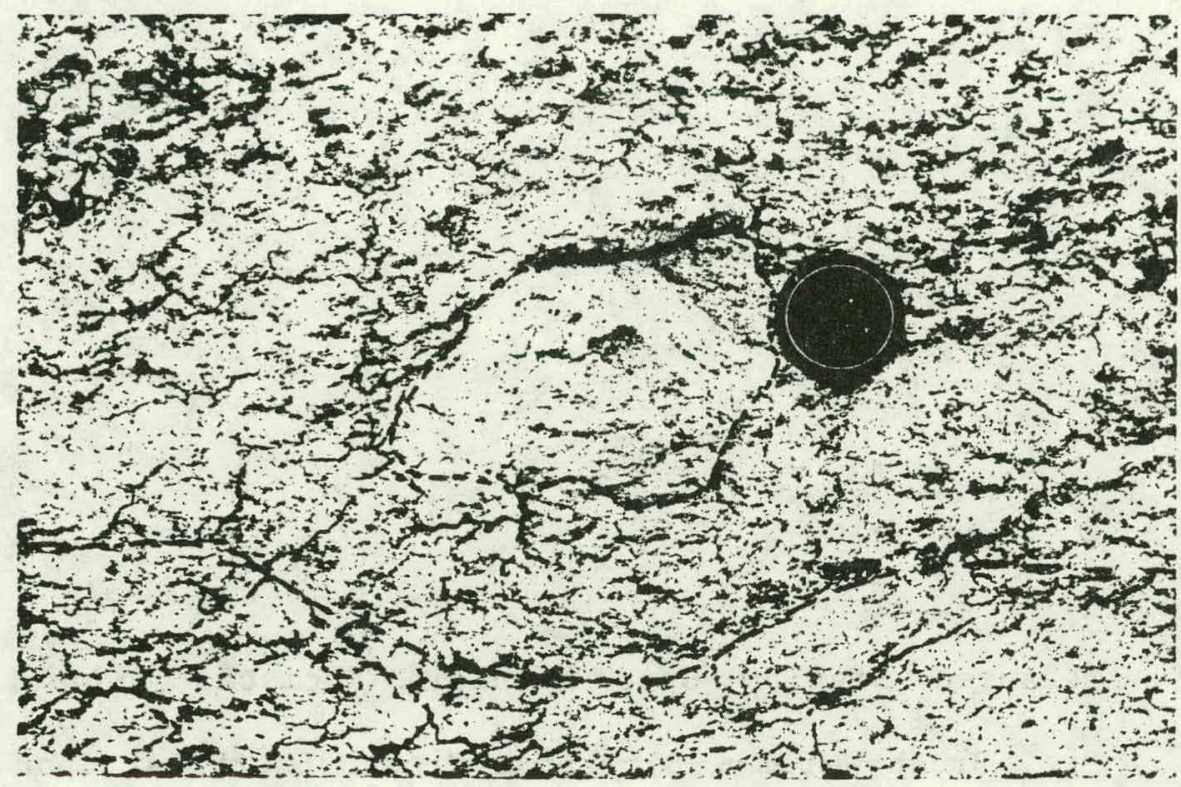

Figure 7. Bomb sag in Blue Chalk Pit. Note bomb immediately left of lens cap, and darkly altered air fall unit sagged below bomb. 
Figure 8. Measured Section Spor Mountain Formation, North Roadside Pit, Brush-Wellman Beryllium Mines, Southwest Spor Mountain. 


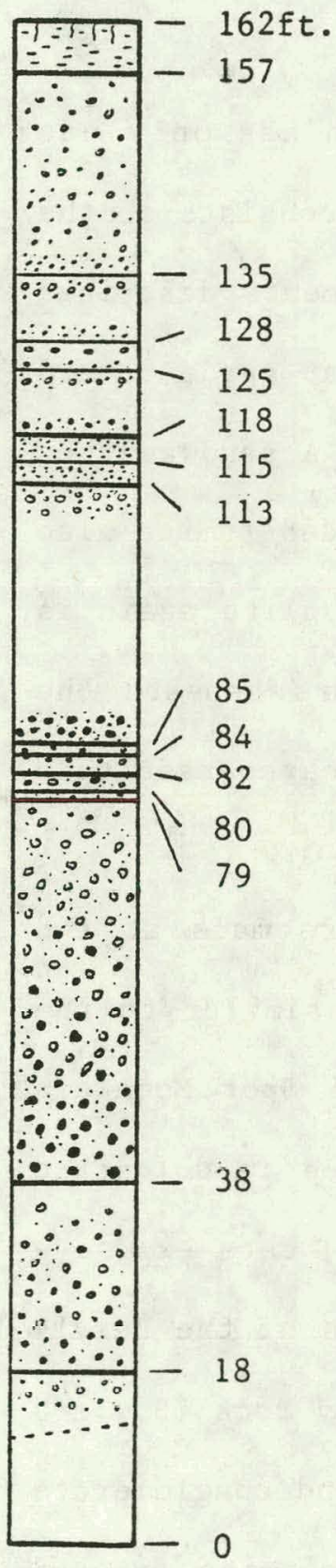

So11 Cover

Altered Ignimbrites: stratified flow units 1.5 to 3.0 ft. thick; lithics to $2 \mathrm{in}$.; fluorite nodules.

Alcered Ignimbrite: fine grained base.

Altered Ignimbrite

Altered Ignimbrite

Ground Surge Unit: planar bed forms.

Ground Surge Unit: Incerbedded massive and Sandwave bed forms.

Altared Ignimbrite: lithic riçh.

Altered Block Flow: Lithics to $8 \mathrm{fn}$.

Altered Ignimbrice

Altered Block Flow Unit: lithics to $\rightarrow$ in.

Alcered Ignimbrite: light brown ash.

Atered Block Flow Unit: calcite nodules to $121 \mathrm{n}$, some completely replaced by purple fluorite.

Altered Block Flow Unit: Grayish white indurated ash with quartz and biotice; pumice to 6 in.; calcite nodules to $8 \mathrm{in}$. with purple flluorite rims; rhuodacice lithics; and vicrophyre ilehies.

Fault: with opal replacement.

Altered Ignimbrite: grayish white indurated ash with abundant smoky quartz; white pumice; and calcite nodules to $4 \mathrm{in}$. with rims of purple fluorite.

Base of Section $4820 f t$. / SEYSEל, sec5, T13S,R12W 
with large rock fragments and pumice in this section are more numerous and generally thicker than similar beds found in the drill core sections. Beds with ash, fine rock fragments, and small, rounded pumice occur in sandwave bed forms but are also found in planar and massive bed forms. The top of this section has numerous thin, poorly sorted graded units.

In the North Fluoro pit, the measured section has only one poorly sorted graded unit (Fig. 9). Most of the section consists of the type of poorly sorted graded units with large rock fragments described earlier and beds with bases that are very block-rich that grade upward into poorly sorted pumice-rich graded units (Fig. 10). A sandwave bed form unit with ash, fine rock fragments, and small, rounded pumice also occurs in this section. The base of the Porphyritic Rhyolite again is brecciated, but a thin zone with flattened clasts occurs beneath the massive rhyolite. This section of Beryllium Tuff is much coarser than the other sections measured in the Spor Mountain Formation.

Observations of the Spor Mountain Formation were made at two localities in the Dell. The Hogsback Prospect is very similar to the occurrences of the spor Mountain Formation southwest of spor Mountain in that Porphyritic Rhyolite overlies Beryllium Tuff rich in dolomitic rock fragments. At the Yellow Chief Mine pit (Fig. 11), cuts expose a sequence which has been interpreted as the lowest facies of the Beryllium Tuff (Lindsey, 1979a). This facies is a sedimentary rock (Bowyer, 1963; Lindsey, 1978b). The lower tuffaceous sandstone and conglomerate lacks cobbles of the Porphyritic Rhyolite and of the dolomite exposed at Spor Mountain. Dolomite clasts are found in the upper limestone 
- $44-$

Figure 9. Measured Section Spor Mountain Formation, North Fluoro Pit, Brush-Wellman Beryllium Mines, Southwest Spor Mountain. 
Top of Section Not Measured

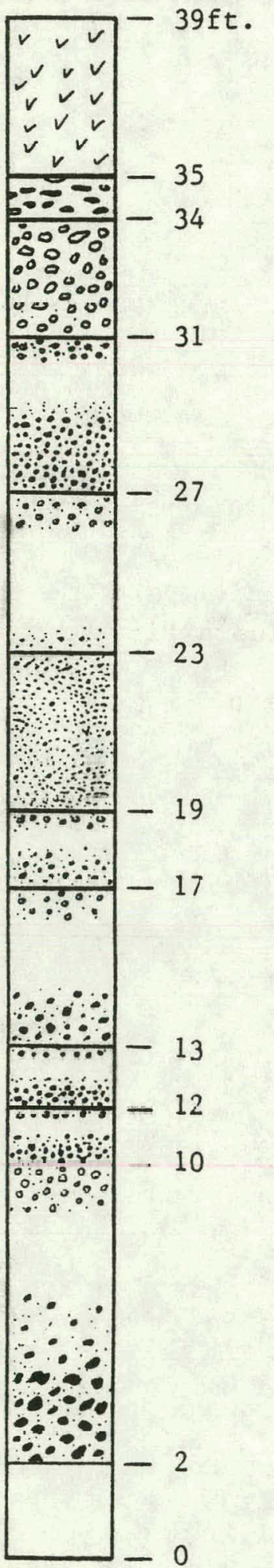

Porphyritfe Rhyolite: dark red mafic inclusions to 3 in. with $0.4 \mathrm{in}$. Feldspar; surrounded by white halos with topaz.

Fused Breecia: flattened cobbles of Porphyritic Rhyolite.

Breccia: angular cobbles of Porphyritic Rhyolite with some dark red matic 11 chlis.

Lo-1gnimbtite Lag-tall Unit: Some dark red matic inclusions with $0.41 \mathrm{n}$. feldspar.

Ignimbrice

Ground Surze Unies: poorly vesicular pumice to $0.3 \mathrm{in}$. with sandwave bed forms; lithics to $21 \mathrm{n}$.

Block Flow Unit

Block Flow Unit

Co-Ignimbrite Lag-Fall Unit

Co-Ignimbrite Lag-Fall Unit: base with $81 n$. angular lithics grading upward into a pumice rich ignimbrite.

Block Flow Unit

Base of Secrion Covered

Base of Section $4770 \mathrm{ft}$. / NWhEE/ $, \sec 8, \mathrm{~T} 13 \mathrm{~S}, \mathrm{R} 12 \mathrm{~W}$ 


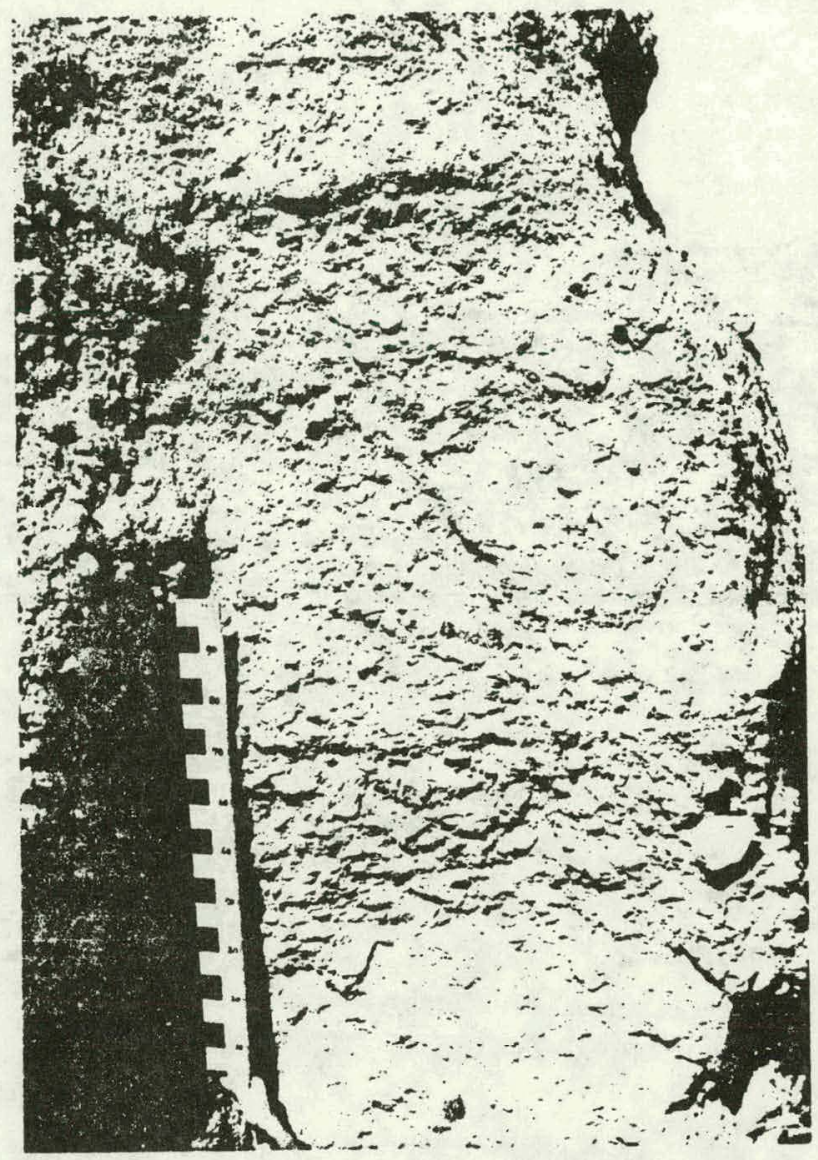

Figure 10. Co-ignimbrite lag-fall unit exposed in North Roadside Pit. Behind the meter stick, a lithic-rich base, overlying an ignimbrite, grades upward with increasing pumice and matrix into a lithic-rich ignimbrite. 


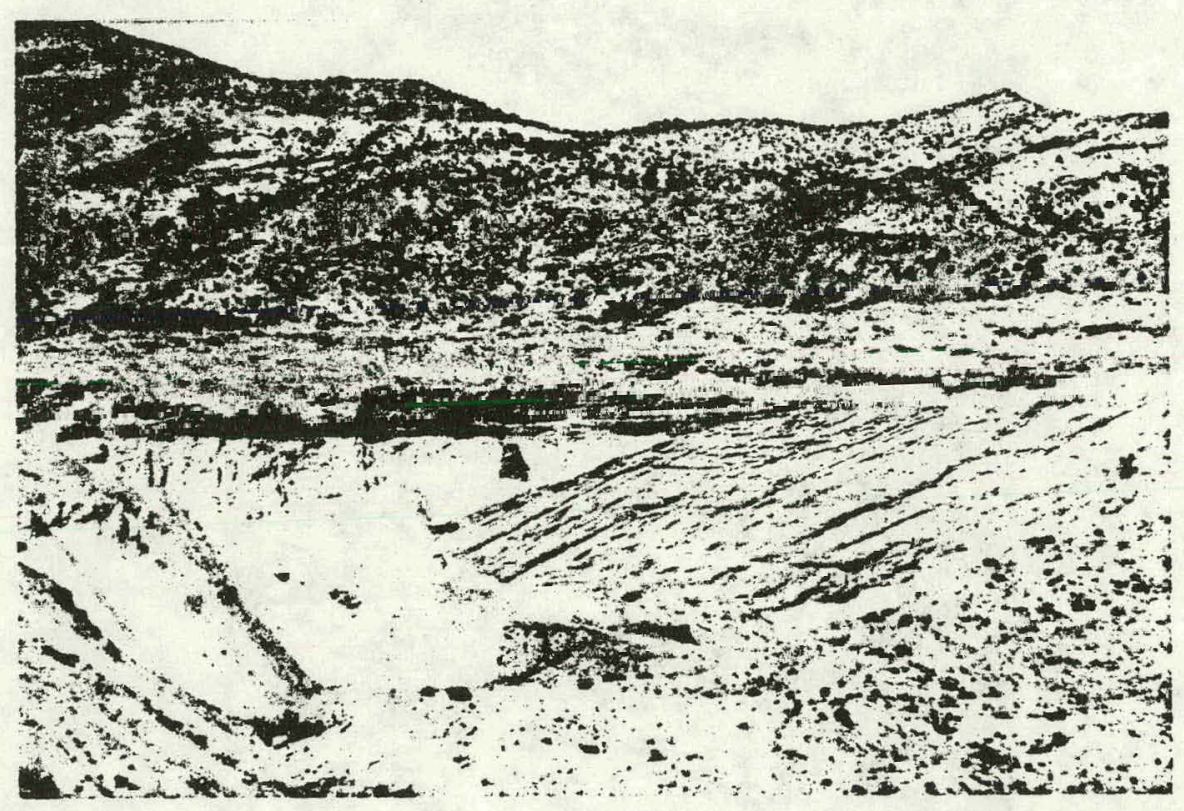

Figule 11. North tace of Yellow Chief Mine. Tilted toward the left, white bentonitic Beryllium Tuff conformably(?) overlies gray uraniferous epiclastic volcanic sediment. 
conglomerate at the mine. Cobbles of Dell Tuff and of Drum Mountain Rhyodacite found in the tuffaceous sediments are rounded to subrounded and suspended in a sand-sized matrix.

An unusual feature of the Beryllium Tuff exposed in the Taurus pit southwest of Spor Mountain is a conformable 7 feet $(2.1 \mathrm{~m})$ thick vitrophyre bed found on the north wall (Fig. 12). In the tuff, both above and below the vitrophyric bed, are matrix-supported blocks of vitrophyre up to 2 feet $(0.6 \mathrm{~m})$ across (Fig. 13). The vitrophyre bed is oriented $\mathrm{N} 34^{\circ} \mathrm{E} 45^{\circ} \mathrm{NW}$.

\section{Interpretation}

The textures described in the Beryllium Tuff in the five measured sections are all typical primary pyroclastic textures. Beds with lithic-rich bases and pumice-rich tops that are poorly sorted and have rounded to subrounded pumice fragments are typical ignimbrites or pyroclastic flow units (Sparks and others, 1973; Sheridan, 1979). The fine-grained bases found in beds represent the development of thin shear zones at the base of some pyroclastic flows (Sparks and others, 1973). Beds similar to the ignimbrites, but having large lithics and pumice, are block-flow units (Ross and Smith, 1961). Beds characterized by moderate sorting and angular pumice are air fall units (Ross and Smith, 1961; Sparks and others, 1973). The ashy beds with fine lithics and small, rounded pumice and sandwave and planar bed forms are pyroclastic surge units (Fisher, 1979; Wohletz and Sheridan, 1979).

Lithics in the Beryllium Tuff originated from country rock through which the parent magma vented. The Spor Mountain Formation is 


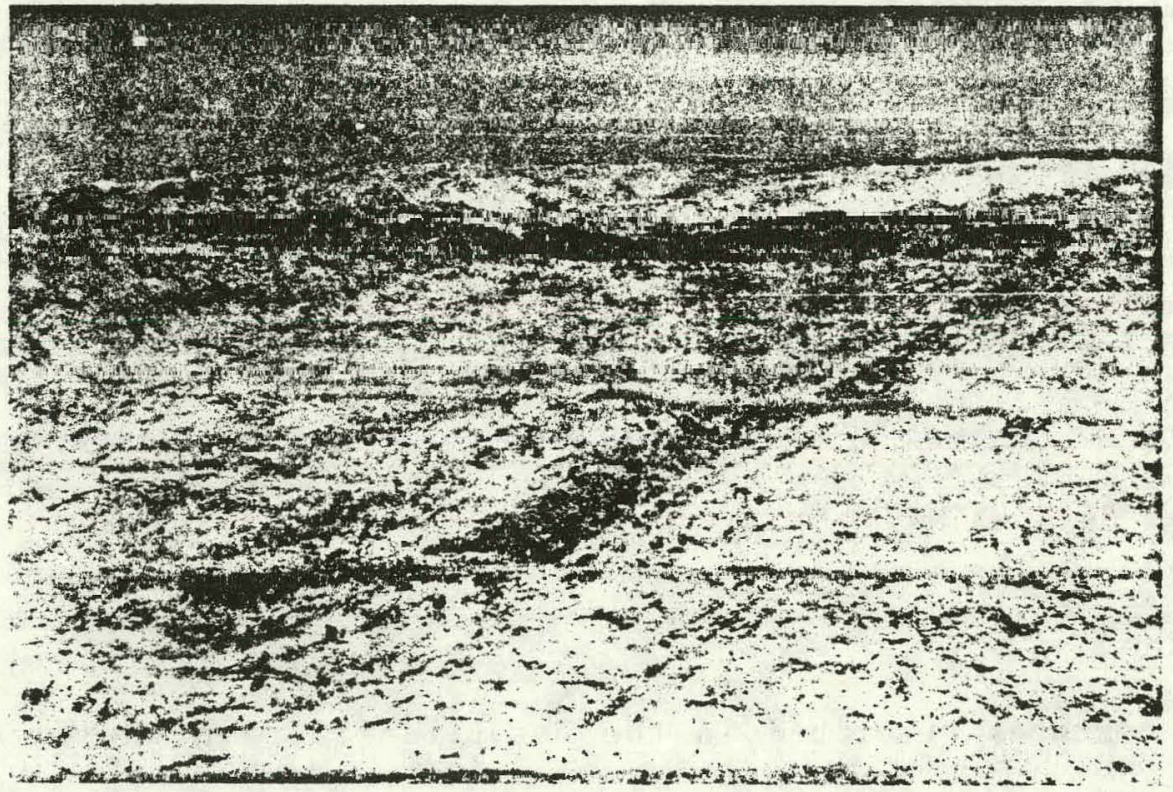

Figure 12. Black vitrophyre bed on north face of Taurus Pit dipping left. Bench levels are on 10 feet spacings. 


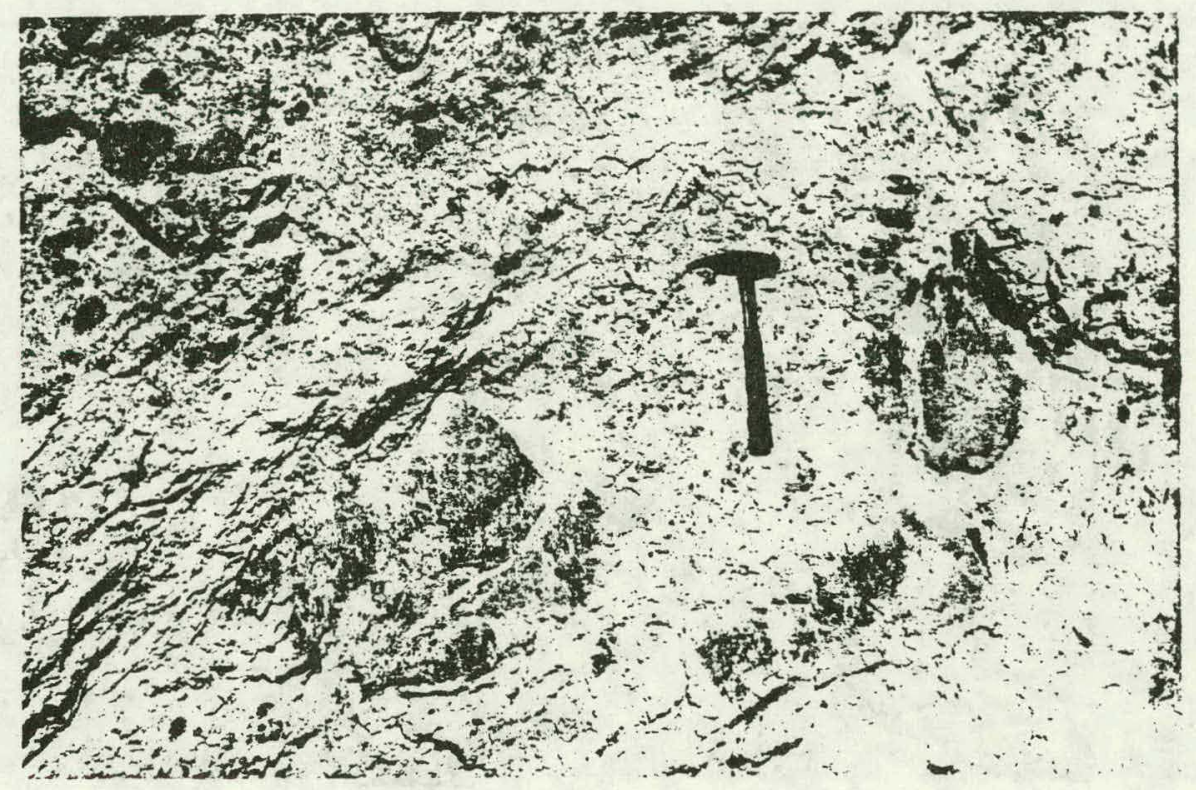

Figure 13. Matrix supported vitrophyre blocks in the Beryllium Tuff. This outcrop is immediately below vitrophyre bed in Fig. 12 on the second bench from base of photograph. 


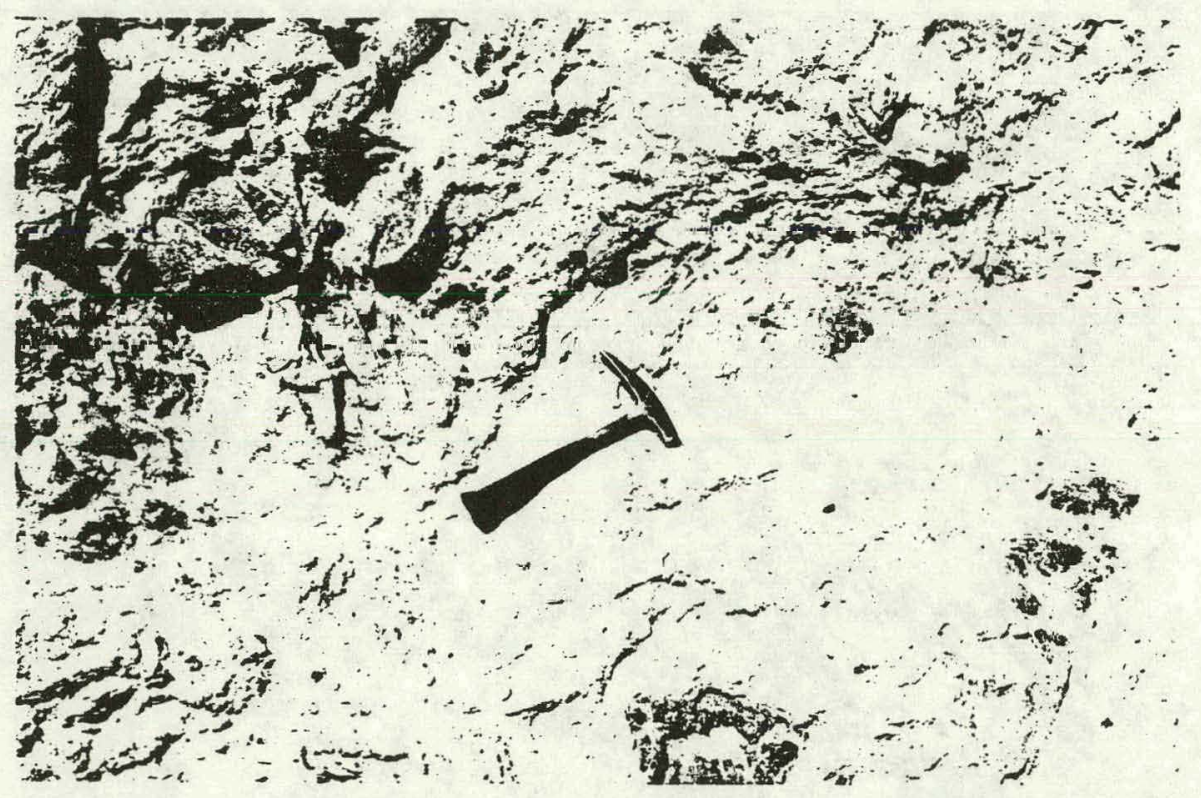

Figure 13 (Continued). Matrix supported vitrophyre blocks in the Beryllium Tuff. This outcrop is immediately above vitrophyre bed in Fig. 12 on the second bench from base of photograph. 
known to overlie both Paleozoic sedimentary rocks and Drum Mountain Rhyodacite from surface and subsurface data (Williams, 1963; Lindsey, 1979b). Near-surface explosive activity during the emplacement of the Beryllium Tuff entrained foreign lithics from the immediate country rock into juvenile pyroclastic material moving through the vent.

Water-reworked tuffaceous sediment has textures which distinguish it from pyroclastic beds. Large volcanic mudflows or debris flows differ from ignimbrites in that pumice and glass shards are nearly always absent; the coarsest rock fragments occur in the centers of flow units (Fig. 14) and pumice framents when present are well rounded and often permeated with mud (Schmincke, 1967; Parsons, 1969; Neal1, 1976). Epiclastic volcanic breccias, from their fluvial origin, have rounded to subrounded clasts, moderate sorting, good stratification, and often are interbedded with volcanic sandstone (Parsons, 1969). No textures indicative of an epiclastic origin were recognized in the measured sections of the Beryllium Tuff.

Rhyolitic domes and flows overlying consanguineous pyroclastic rocks are a common association (Williams, 1932). In the literature, such sequences have been described for example from Mono Craters, California (Loney, 1968; Smith, 1973), John Kerr Peak dome complex, New Mexico (Smith, 1976), Tarawara, New Zealand (Cole, 1970), and Santiaguito volcanic dome, Guatemala (Rose, 1973).

The North Fluoro section is distinctive in that it is the coarsest section measured in the Beryllium Tuff. Stratigraphically, the standard ignimbrite forms only a minor part of the column. The units described with coarse lithic-rich bases grading up into an ignimbrite 

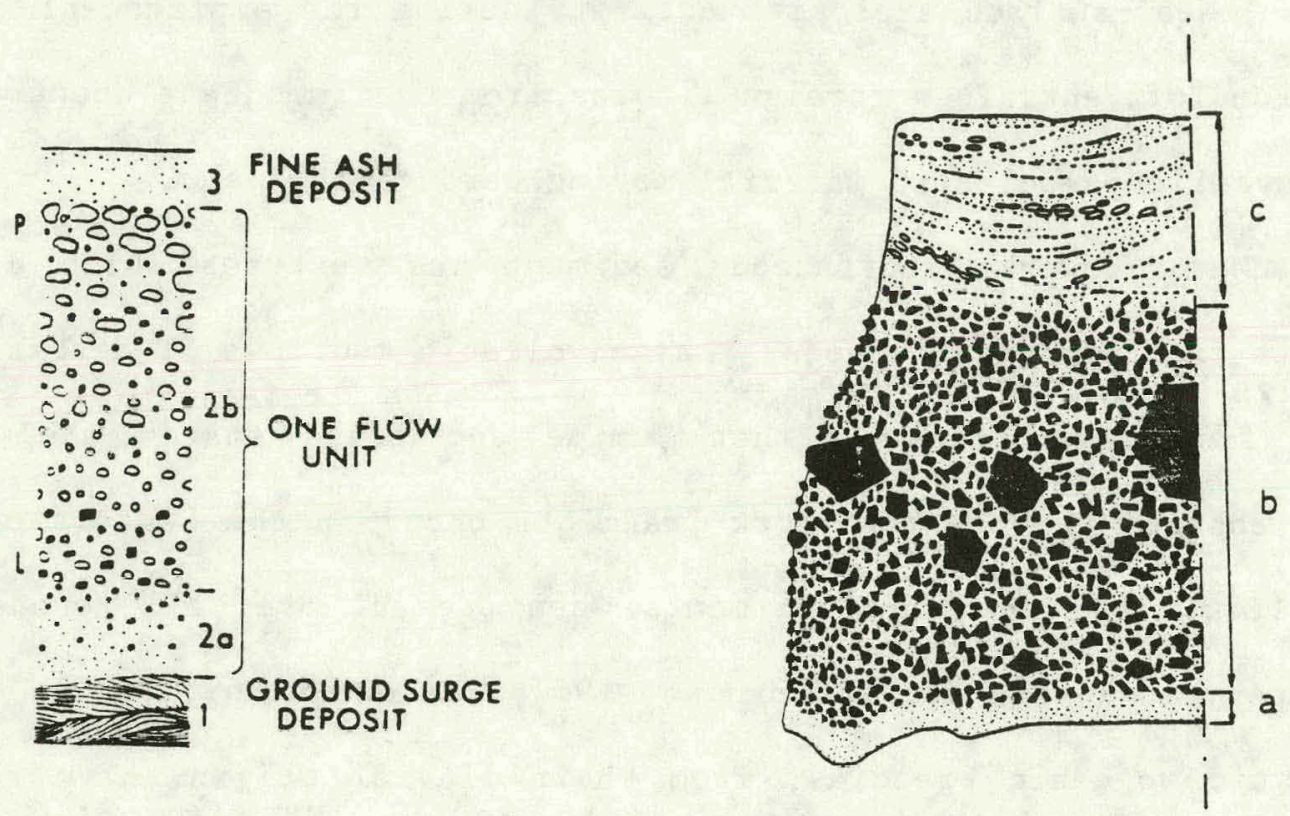

Figure 14. Comparison of a standard 1gnimbrite section (left) with a section measured through an epiclastic volcanic debris flow (right). Note the absence of pumice and the lack of normally graded lithics in the debris flow ( $a$ and $b$ ). A fine-grained basc (a and $2 a$ ) is common to both sections. Cross-bedded fluvial tuffaceous sediment coulaining rounded pumice (c) is commonly associated with epiclastic volcanic debris flows. $P=$ pumice, $L=$ lithics (Modified from Schmincke, 1967 and Sparks and others, 1973). 
have been termed co-ignimbrite lag-fall units (Wright and Walker, 1977). These units are interpreted as a near-vent facies of an ignimbrite (Fig. 15). This interpretation at this locality is consistent with the general coarse nature of the section.

The black vitrophyre of the Taurus Pit (Fig. 12) is probably an exposed portion of the discontinuous middle welded zone of the Beryllium Tuff recognized by Williams (1963) from subsurface data. Above and below the vitrophyre, the occurrence of matrix-supported blocks of vitrophyre (Fig. 13) cannot be explained by a compaction welding model. If these blocks represent bombs, this vitrophyre can be interpreted as a vitrophyric bomb bed within the Beryllium Tuff.

Since the Spor Mountain Formation at the Hogsback Prospect is similar to those sections measured southwest of Spor Mountain, and Lindsey (1979b) has recognized similar sections in the northern Dell, the distribution of the tuff and the overlying rhyolite included areas east and west of Spor Mountain. Drilling north of Spor Mountain by Bendix Field Engineering Corporation has encountered the Porphyritic Rhyolite and the Beryllium Tuff in contact (Morrison, 1980), and mapping by Lindsey (1979b) has shown both members of the Spor Mountain Formation in contact south of Spor Mountain. Hence, the distribution of the 21 m.y. old tuff and overlying rhyolite was widespread peripheral to Spor Mountain.

The tuffaceous sandstone and conglomerate of the Yellow Chief Mine (Lindsey, 1978b) appears to be an epiclastic volcanic sediment (Parsons, 1969). If so, this gives the Yellow Chief facies of the Spor Mountain Formation a distinctly different origin than the Beryllium Tuff 


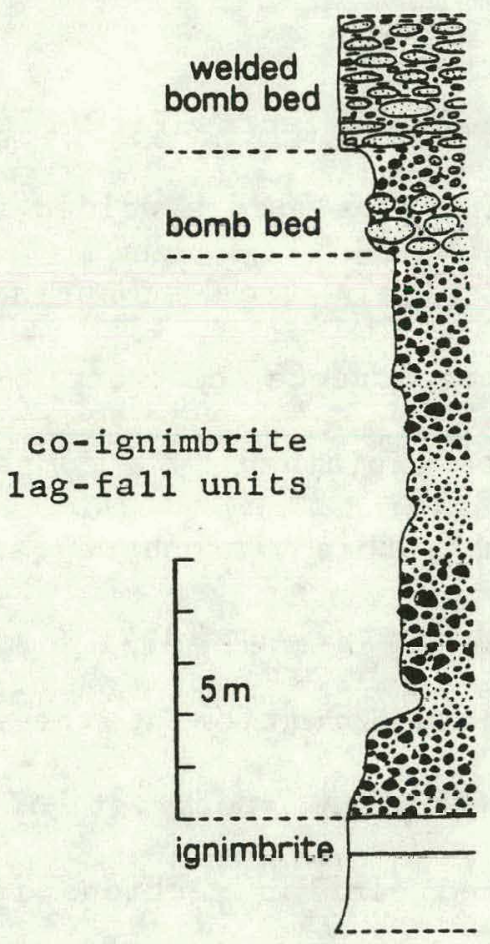

Figure 15. Co-ignimbrite lag-fall units. Note lithic rich bases overlain by ignimbrites. (Modified frum Wright and Walker, 1975) 
exposed beneath the Porphyritic Rhyolite in the measured sections. Because the sediments include debris from the Dell Tuff, lack fragments of the Porphyritic Rhyolite, and are overlain by pyroclastics of the Spor Mountain Formation, they were deposited between $32 \mathrm{~m} \cdot \mathrm{y}$. and $21 \mathrm{~m} \cdot \mathrm{y}$. ago. The limestone conglomerate, which is a channel fill deposit overlying the tuffaceous sandstone and conglomerate, may represent debris shed from a rising (magmatically domed?) paleo-Spor Mountain shortly before the eruption and emplacement of the pyroclastics of the Beryllium Tuff.

The stratigraphic section measured across the rhyolite-tuff contact in the Blue Chalk Pit (Fig. 6) has several interesting relations. The thin localized units in the Beryllium Tuff may have been derived from nuees ardentes and associated air falls produced from the advancing flow front of the Porphyritic Rhyolite (Richards, 1959). At the North Roadside Pit (Fig. 8), the thin ignimbrites at the top of the column may be in a stratigraphic position similar to that of the pyroclastic units in the Blue Chalk section. Above the Beryllium Tuff, a breccia zone is well exposed at the base of the Porphyritic Rhyolite in the Blue Chalk Pit (Fig. 6). This breccia can be interpreted as an overridden talus apron. These aprons commonly form at the front of advancing rhyolitic lava flows and are well exposed around the coulees or steep-fronted flows of Mono Craters, California (Loney, 1968; Cole, 1970; Fink, 1980). Only a small percentage of the clasts in the breccia are vitrophyric blocks; the great majority of clasts are microcrystalline Porphyritic Rhyolite. 
Emplacement of the Topaz Mountain Rhyolite-Tuff Sequences

The 6 to $7 \mathrm{~m} \cdot y$. old Topaz Mountain Rhyolite-Tuff sequences are wel1-exposed on steep escarpments in the Thomas Range (Fig. 2). Stratigraphically, at least three rhyolite-tuff sequences occur in the Thomas Range (Lindsey, 1979b). The rhyolites were emplaced as domes and flows over the tuffs and are termed the Alkali Rhyolite of the Topaz Mountain Rhynlite (Lindsey, 1979a). Lindsey (1979a) has concluded that these tuffs were emplaced as air falls, small ash flows, and sheetwashes (restricted to the northern Thomas Range), and in his stratigraphic nomenclature includes all tuff horizons collectively in the stratificd Tuff of the Topaz Mountain Rhyolite. Some previous workers have considered the Stratified Tuff to be entirely waterlaid (Shawe, 1968, 1972). Generally the tuff is overlain by a breccia and the rhyolite is underlain by a vitrophyre, but a complete sequence of stratified Tuff, breccia, vitrophyre, and rhyolite does not occur everywhere in the Thomas Range (Lindsey, 1979a). Some exposures have fused tuff beneath rhyolite (Lindsey, 1979a).

New Data

Five sections of the Topaz Mountain Rhyolite were measured in order to elucidate the emplacement of the Stratified Tuff and the origin of the breccia and vitrophyre at the base of the Alkali Rhyolite (Fig. 2). One section was described from drill core obtained by Bendix Field Engineering Corporation from the southwestern Thomas Range (Fig. 16). Other sections were measured from outcrops in the Thomas Range. On the 
Figure 16. Measured Section Topaz Mountain Rhyolite-Tuff, Bendix Field Engineering Corporation Spor Mountain Drilling Project Hole Number 1, Southwest Thomas Range. 


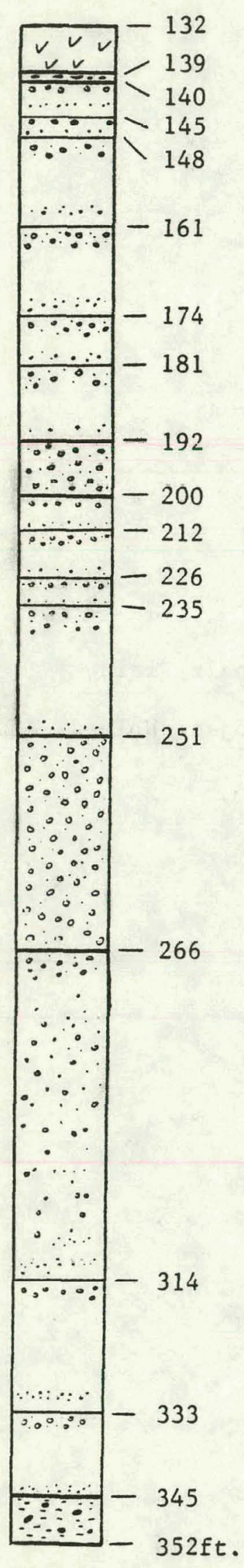

Hole Elevation 5350ft. / NW'LNE $\frac{1}{4}, \sec 13, T 13 S, R 12 W$
Fused Ignimbrite: flattened black glass punice.

Air Fall Unit: pumice to 2.81 n.

Ignimbrites

Air Fall Unit: pinkish white Indurated ash with very sparse quartz and blotite; grayish white to white, angular, vesicular pumice ranging in size from 0.6 to 2in. with quartz and biotite; sparse lithics.

Ignimbrites: pinkish to grayish white indurated ash with broken smoky quartz, 0.11n. and black blotite, 40.11n.; white vesicular pumice fragments with quartz, $0.11 \mathrm{a}$. and blotite, $60.11 \mathrm{n}, \mathrm{f}$ voleanic 11 this fragments to $0.61 \mathrm{n}$. , average $0.2 \mathrm{in} . ;$ and obsidian fragments to $0.6 \mathrm{in}$., average $0.21 \mathrm{n}$; ; individual flow un $1 \mathrm{ts}$ recognized by ashy intarvals ar hase, fin., by lithics near base, and pumice at top; flow units 3 to $15 \mathrm{ft}$. thick; some core intervals poorly preacrued and lack oufficlent criterla to distinguish individual flow units.

Paleosol: 1ight reddish brown silt with weathered volcanic cobbles. 
southeastern side of the Thomas Range, near the Autunite No. 8 Prospect, a section was measured through the Topaz Mountain Rhyolite (Fig. 17). Near Wildhorse Spring, on the west-central side of the Thomas Range, a third section was measured (Fig. 18). Two additional sections were described from the northwestern and the southwestern margins of the Thomas Range (Figs. 19 and 20).

The measured section from drill hole number 1 was broken into numerous units with lithic-rich bases and pumice-rich tops (Fig. 16). Both the pumice and the lithics are matrix-supported, and the units can be characterized as poorly sorted. The lithics are mostly older volcanic rock fragments and various amounts of obsidian fragments. No carbonate lithics were observed. The pumice are subrounded and vesicular. Other units were characterized by high proportions of angular pumice and few lithics. These units are moderately sorted and contain some vitrophyre fragments. At the top of the section flow-banded alkali rhyolite overlies a thin bed with lensoidal black glass.

In addition to beds similar to those described from drill hole number 1 , the section measured near the Autunite No. 8 Prospect contains several additional types of units (Fig. 17). Ashy beds with fine lithics and small, rounded pumice that have sandwave and planar bed forms are found near the base of the section. Near the top of the Stratified Tuff, graded units are found with black lensoidal glass in a reddish-white matrix in place of pumice at the tops of units (Fig. 21). Immediately below the vitrophyre in the Autunite No. 8 column is a bed with large flattened spheroids of obsidian in a gray matrix (Fig. 22), 
$-61-$

Figure 17. Measured Section Topaz Mountain Rhyolite-Tuff, near Autunite No. 8 Prospect, Southeast Thomas Range. 

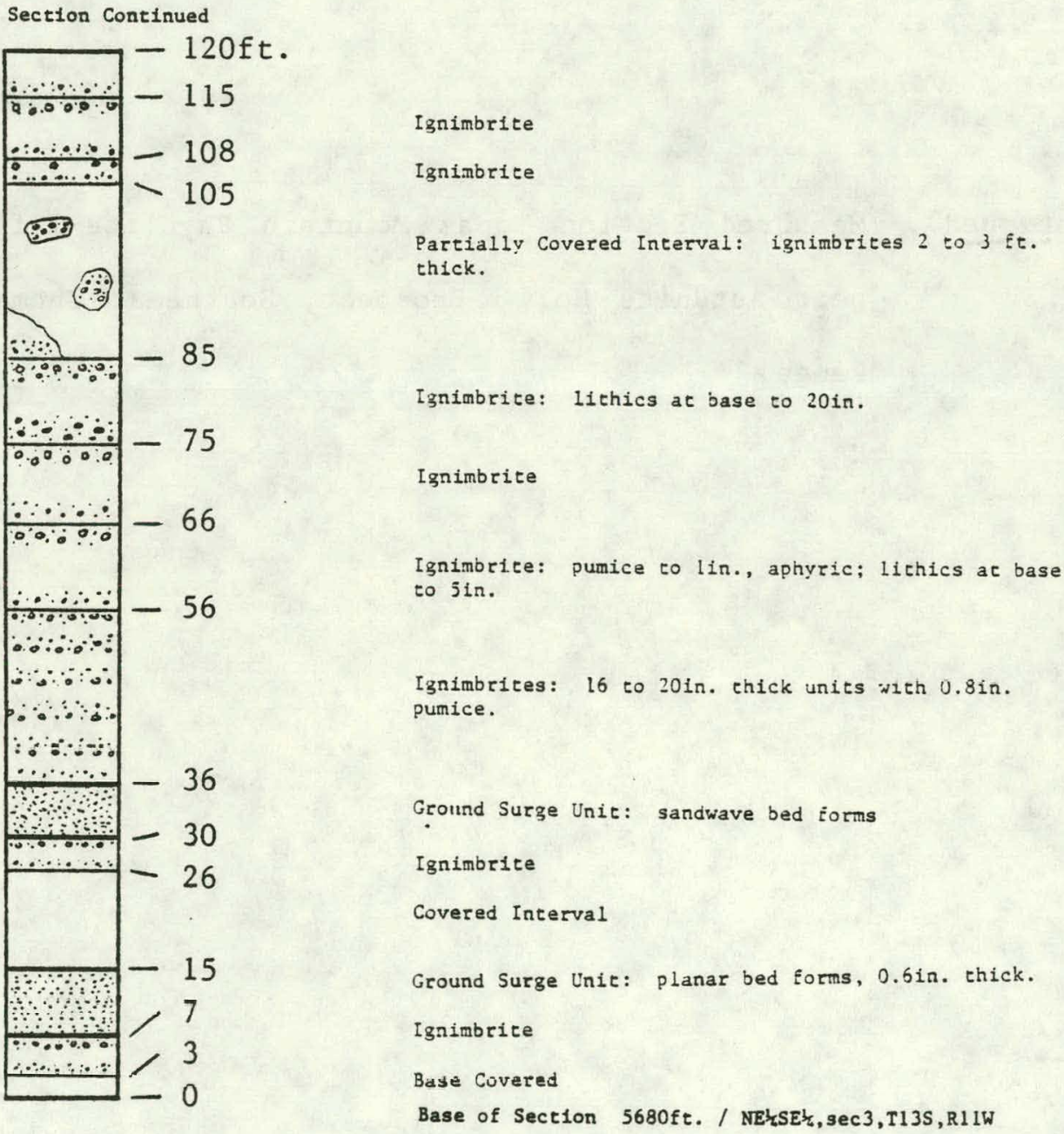
$-63-$

Figure 17 (Continued). Measured Section Topaz Mountain Rhyolite-Tuff, near Autunite No. 8 Prospect, Southeast Thomas Range. 
Top of Section Not Measured

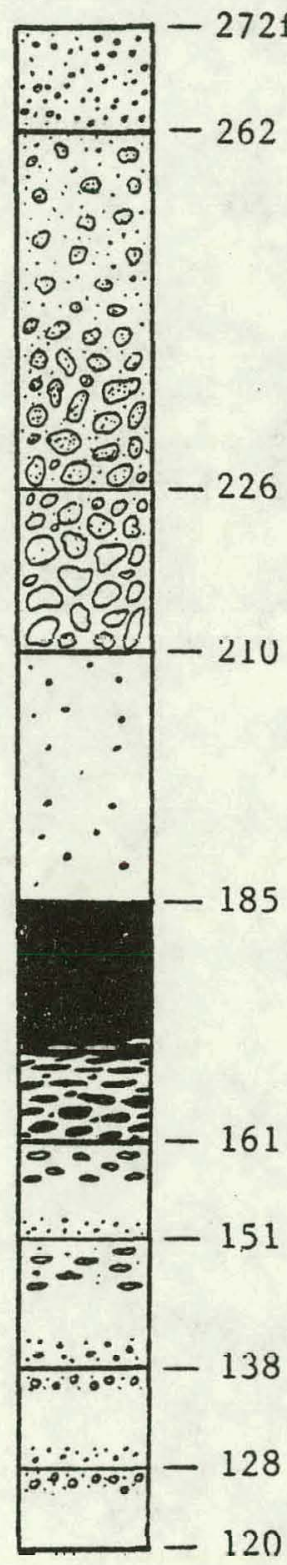

Section Continued
Spherulitic Rhyolite

Altered 3reccia: similar to below with spherulitic devitrification increasing upward.

Breccia: lighe gray rhyolfte clasts to $12 \mathrm{in}$. in reddish brown matrix.

Alcered Ignimbrite: incense vapor phase alteration with some $4 i n$. Ifthics.

Vitrophyre: massive grading downward to welded bomb bed with 6 in. black glass bombs in gray macrix.

Partially Welded Ignimbrite: reldish white matrix with slightly flattened black glass relict pumice with many $0.3 i n$. lithics.

Partially Welded Ignimbrite: reddish white matrix with slightly flattened black glass relict pumice.

Ignimbrice: 161n. thick ashy base.

Ignimbrite 
$-65-$

Figure 18. Measured Section Topaz Mountain Rhyolite-Tuff, near Wildhorse Spring, West-Central Thomas Range. 
Top of Section Not Measured

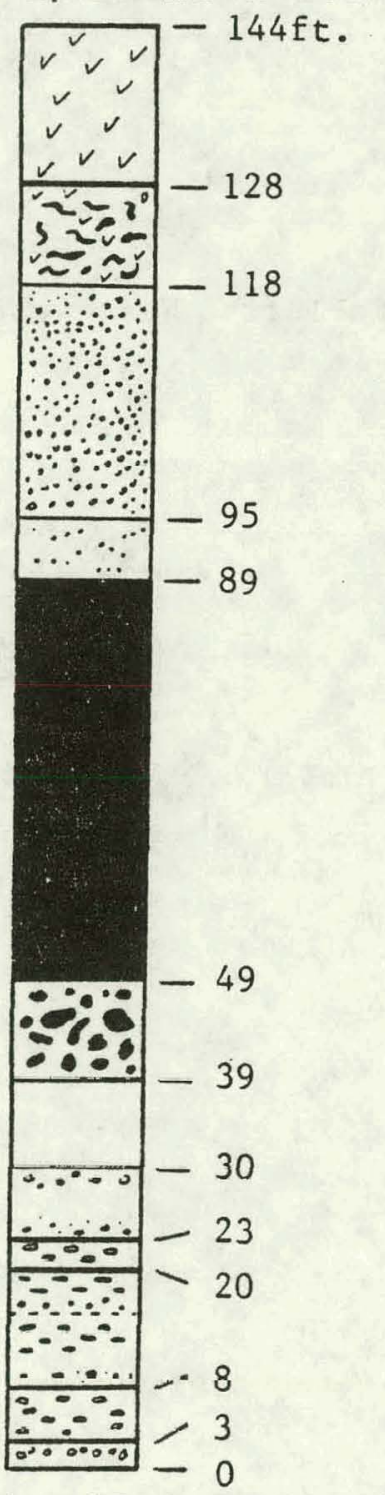

Topaz Mouncain Rhyolice

Partially Crystalline Glass: contorted banding of felsite and glass.

Spherulitic Glass: intense spherulite formation.

Partially Devitrified Glass: minor spherulite formation.

Vitrophyre: chilled base of Topaz Mountain Rhyolite with $0.4 \mathrm{in}$. 1ithophysae.

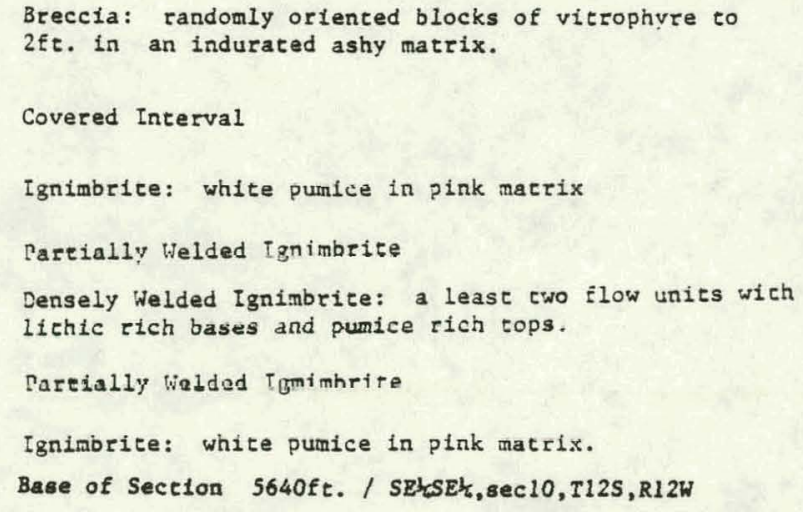


$-67-$

Figure 19. Measured Section Topaz Mountain Rhyolite-Tuff, Northwest Thomas Range. 
Top of Section Not Measured

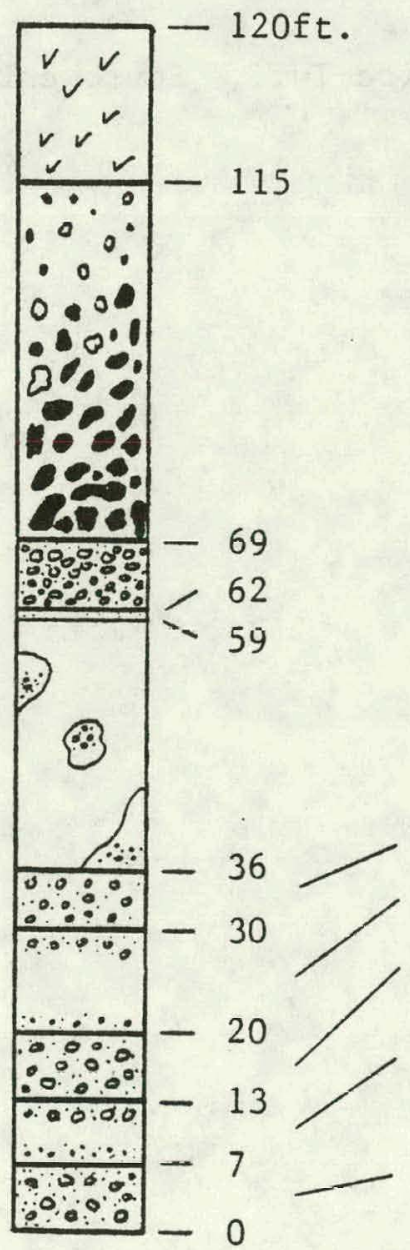

Topaz Yountain Rhyolite

Breccla: partially spherulitically devitrfied glassy blocks to $4.9 \mathrm{ft}$, average $1.6 \mathrm{ft}$., grading upward with increasing proportion of felsic clast, decreasing clast size, and increasing felsitic matrix; clasts floating in felsitic matrix near top.

Block Flow Unit: grayish white indurated ash with slighely rounded, moderately vesicular pumice to $\mathrm{sin}$. and black glass fragments to $0.5 i n$.

Ignimbrice: black glass eragments to lin

Partially Covered Interval: ignimbrites and air Eall units.

Air Fall Unit

Ignimbrite

Air Fall Unit: black glass fragments to $0.3 i n$.

Ignimbrite: light pink indurated ash with $0.81 \mathrm{n}$. punice, $1.2 i n$. volcanic lithics, and $0.2 i n$. black glass fragments.

dit Fall Unit: 11ght pink indurated ash with grayish white angular pumice to $3 i n$.

Base of Section So00ft. / SWh SE $\frac{1}{6}, \sec 33, T 11 S, R 12 W$ 
Figure 20. Measured Section Topaz Mountain Rhyolite-Tuff, Southwest Thomas Range. 
Top of Section Not Measured

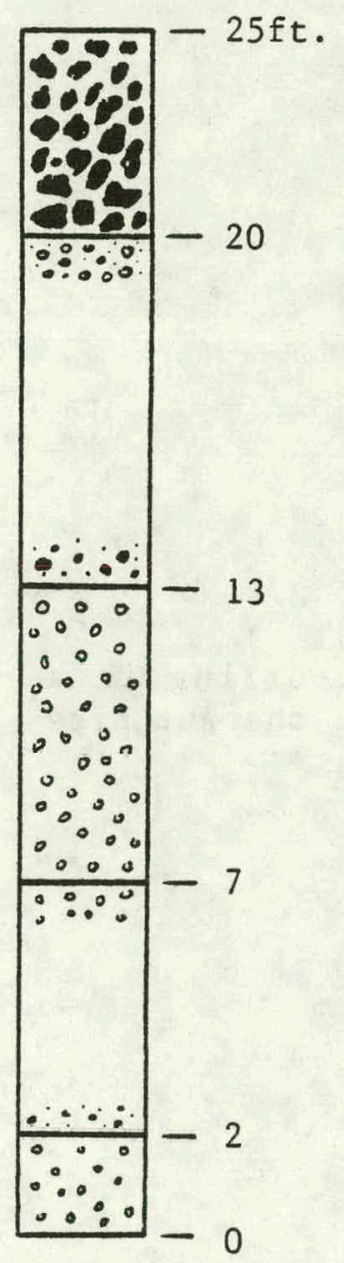

Breccia: 1.2 to 3.0 ft. partially spherulitically devitrified vitrophyric blocks.

Ignimbrite: $0.3 \mathrm{in}$. pumice rich top and 0.2 to $0.4 \mathrm{in}$. lithic rich base.

Als Fall Unit: 0.4 to $1.2 \mathrm{in}$. pumfre.

Ignimbrite: grayish white indurated ash with volcanic lithic concentration at base.

Afr Fall Unit: grayish whice indurated ash with 0.8 to $2.81 \mathrm{n}$. angular pumice.

Base of Section 5240ft. / NEESWl's, sec11,T13S, R12W 


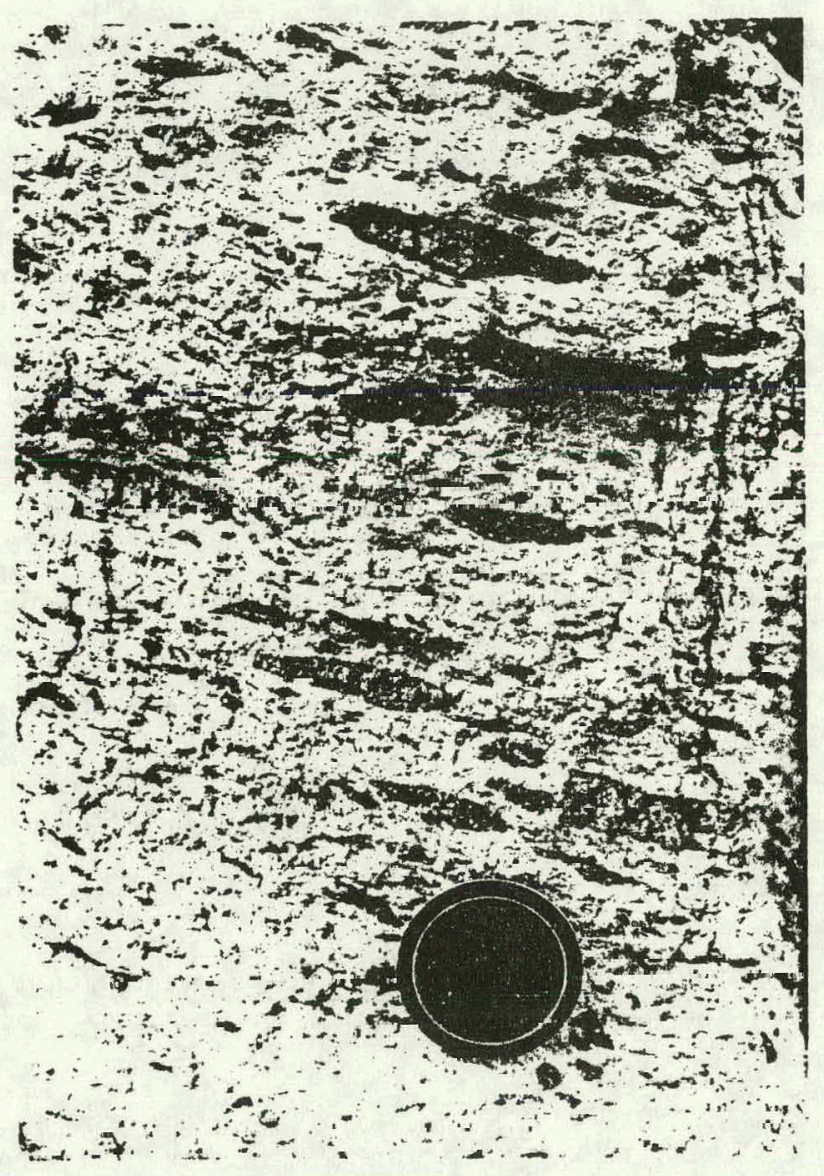

Figure 21. Black, glassy, flattened, relict pumice occurring in a welded ignimbrite of the Stratified Tuff near the Autunite No. 8 Prospect. 


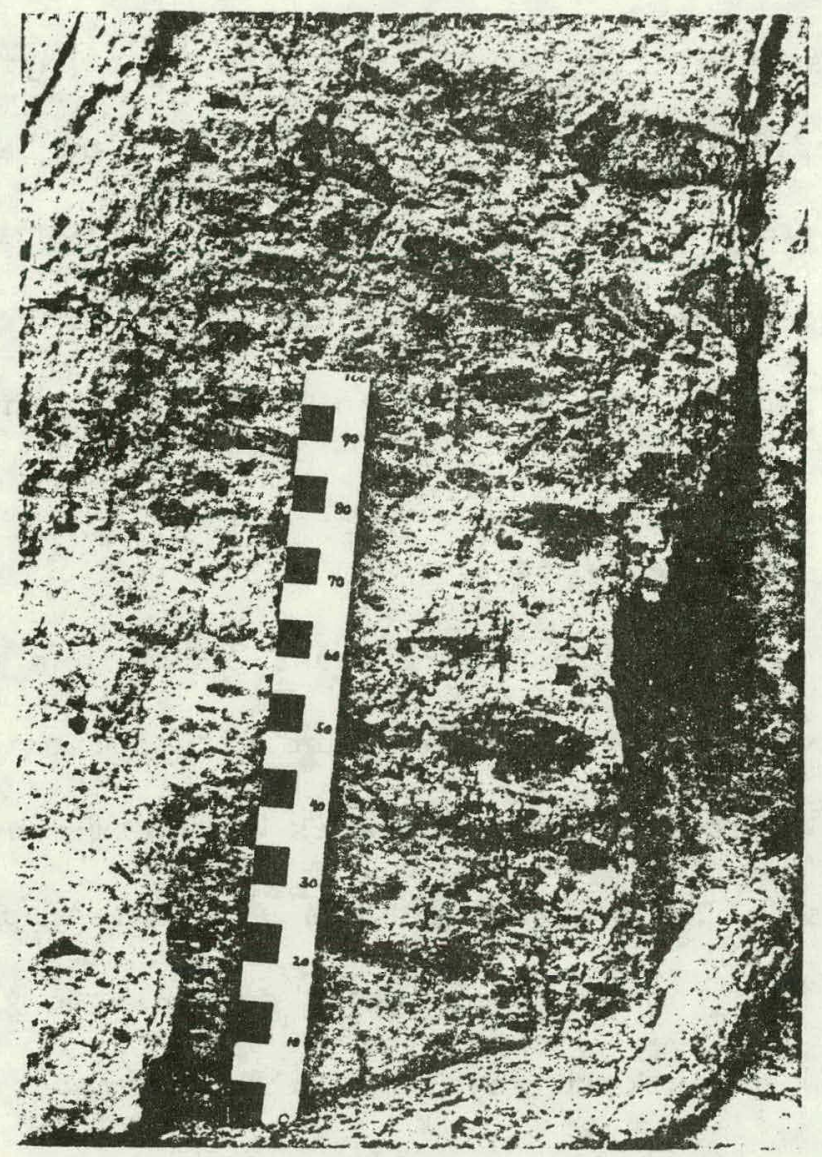

Figure 22. Densely welded bomb bed outcropping near the Autunite No. 8 Prospect. Note the welded ignimbrite exposed to the left and at the base of the meter stick. 
which disappears into the overlying massive vitrophyre. An altered rock, which has sparse lithics, overlies the vitrophyre and appears to have lost its original texture. Below the flow-banded spherulitic alkali rhyolite at the top of the section, a breccia of light gray rhyolite in a reddish-brown matrix occurs. The breccia grades upward with increasing spherulitic alteration and matrix into the overlying rhyolite.

At Wildhorse Spring (Fig. 18), two units with normally graded lithics and very flattened lensoidal glass occur in a red glassy matrix (Fig. 23). Overlying these units is a bed with a lithic-rich base and a pumice-rich top. Below the vitrophyre is a matrix-supported breccia of vitrophyre blocks. The vitrophyre has small lithophysae and grades upward with increasing spherulites into a spherulitic glass. At the top of the section is an alkali rhyolite with a microcrystalline texture that grades downward into the spherulitic glass.

Both of the sections measured on the northwestern (Fig. 19) and southwestern (Fig. 20) flanks of the Thomas Range have excellent exposures of vitrophyre breccia. The breccia in these localities rests directly on the stratified tuff (Fig. 24). Grading of this breccia up into the overlying rhyolite is nicely exposed in the column described from the northwestern Thomas Range. The breccia becomes less coarse upward and gray microcrystalline rhyolite occurs as interstitial matrix (Fig. 25). Upward through the section, the blocks become smaller with more spherulitic alteration and are supported by the gray microcrystalline groundmass (Fig. 26). The breccia eventually grades upward with an increasing percentage of matrix into alkali rhyolite. In the section 


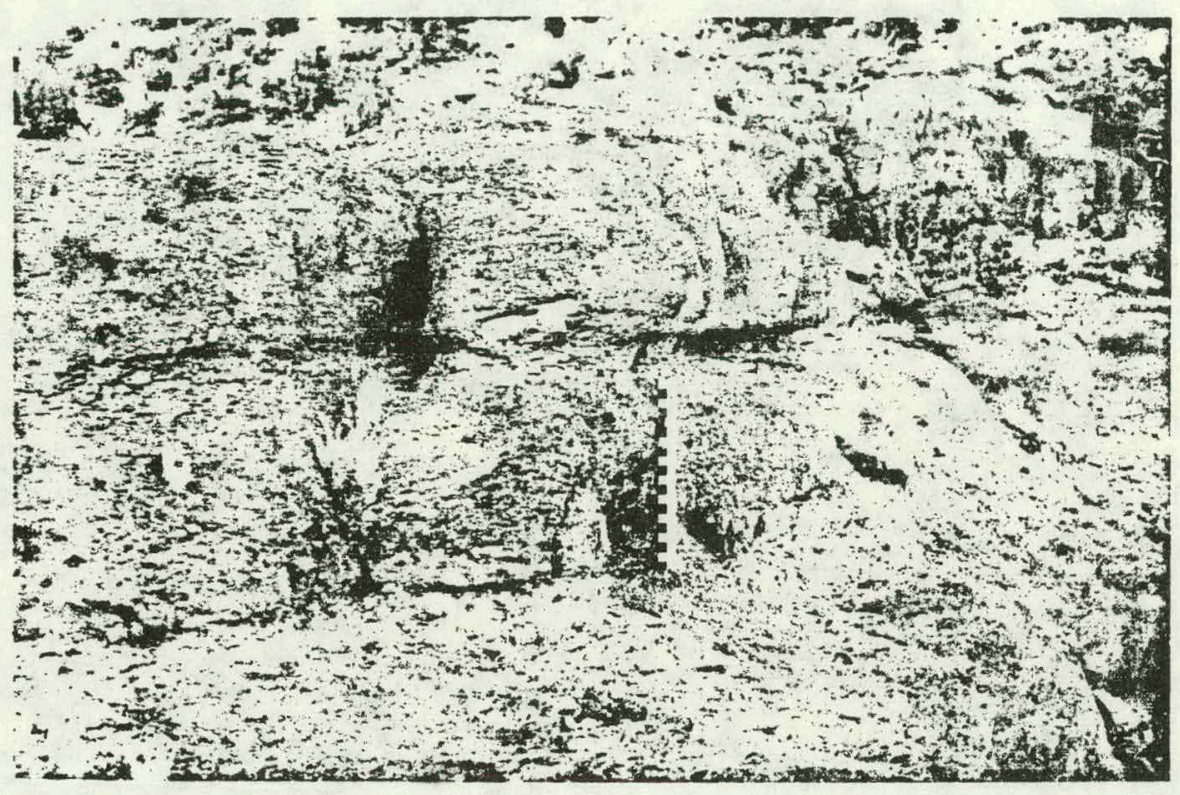

Figure 23. Densely welded ignimbrites near Wildhorse Spring. At least two flow units have been welded, as the ledge above the meter stick was a pumice-rich zone, typical of the tops of flow units. 


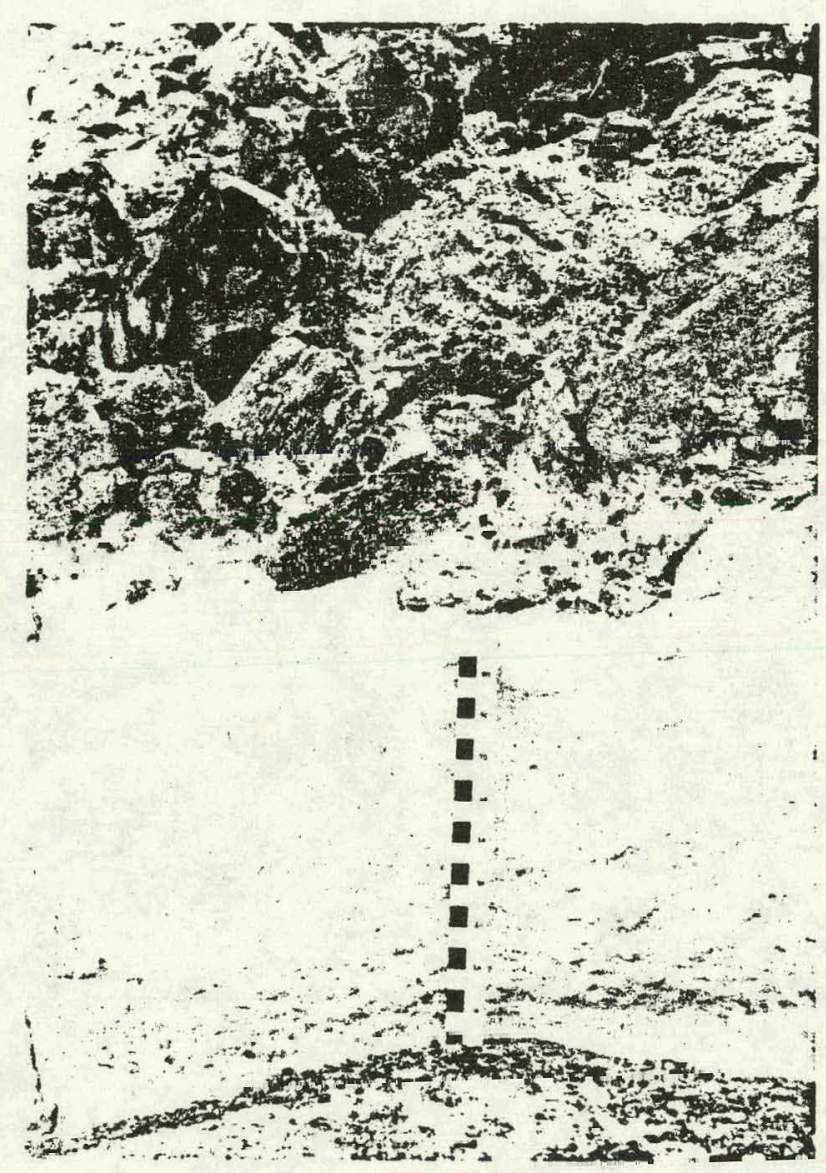

Figure 24. Vitrophyre block breccia resting on pyroclastic beds of the Stratified Tuff behind the meter stick and outcropping near Fig. 19. 


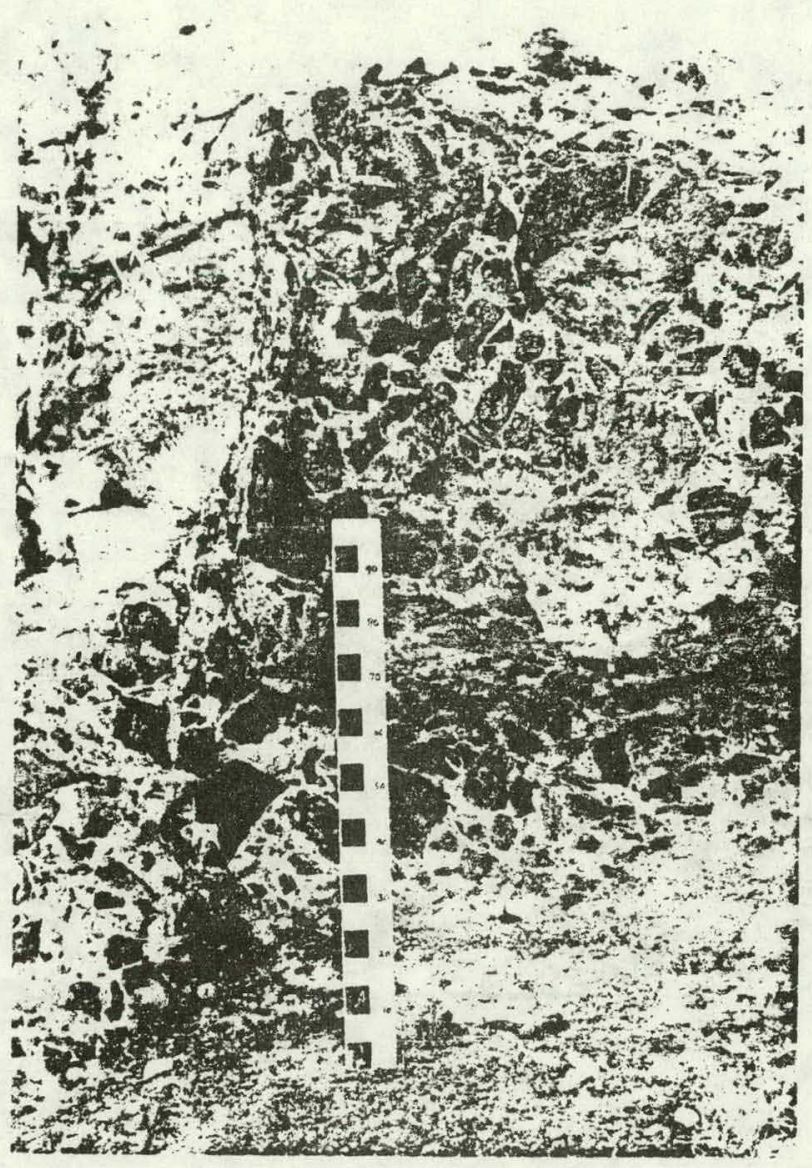

Figure 25. Vitrophyre breccia containing interstitial rhyolite matrix, stratigraphically above Fig. 24 . 


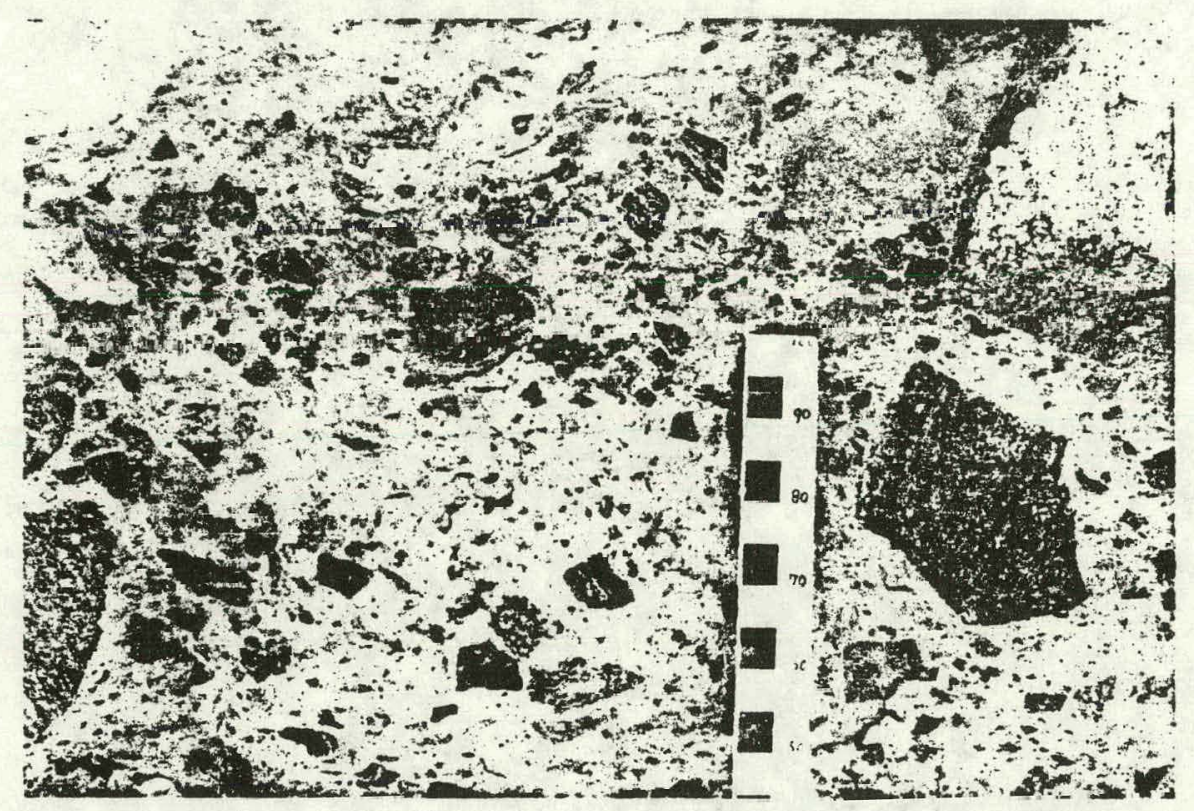

Figure 26. Rhyolitic groundmass supported vitrophyric breccia, stratigraphically above Fig. 25 . 
measured on the northwestern face of the Thomas Range, a bed occurs below the breccia zone which is distinctive due to the great abundance of subrounded pumice and the many fine obsidian fragments in the unit (Fig. 27).

\section{Interpretation}

Consistent with the discussion of Lindsey (1979a), many of the beds in the measured sections are ignimbrites and air fall units. The ignimbrites characteristically have inverse grading of pumice and normal grading of lithics, and the air fall units consist of angular pumice with moderate sorting (Sparks and others, 1973). At the Autunite No. 8 Prospect section (Fig. 17), the ashy units with small, rounded pumice and fine lithics in planar and sandwave bed forms are pyroclastic surge units (Fisher, 1979; Wohletz and Sheridan, 1979). Also at this locality, near the contact of two ignimbrites, paleofumaroles are found (Fig. 28) (Sheridan, 1970). This evidence can be interpreted as indicating that trapped gases escaped after the deposition of the host unit. This is a common process after the emplacement of ignimbrites (Sheridan, 1970).

The lensoidal black glass in units described from the Autunite No. 8 Prospect (Fig. 17) and from Wildhorse Spring (Fig. 18) are distinctive features which occur in partially to densely welded ignimbrites (Ross and Smith, 1961). At the section measured near Wildhorse Spring, the heat required to weld the ignimbrites cannot have been derived from the overlying rhyolite flow, as a nonwelded ignimbrite outcrops above the welded units (Fig. 18). Hence, the ignimbrites must 


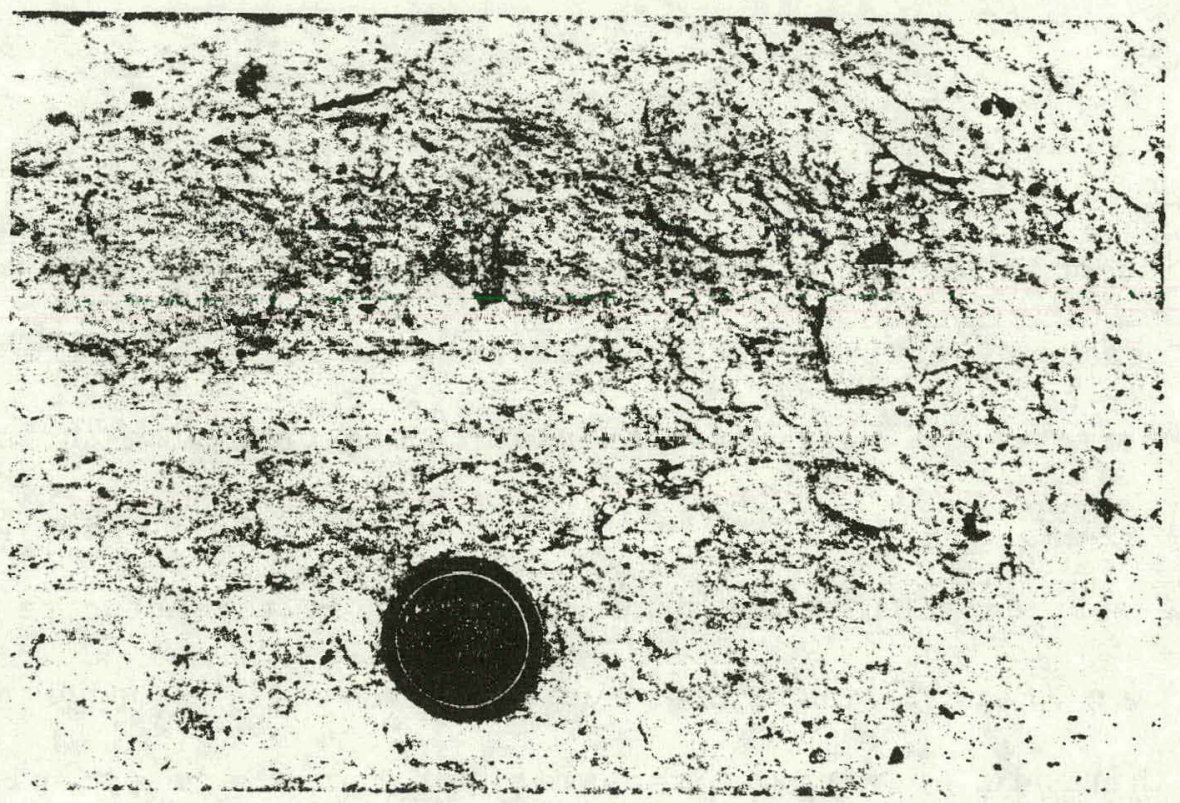

Figure 27. Close-up of block flow unit behind meter stick in Fig. 24. 


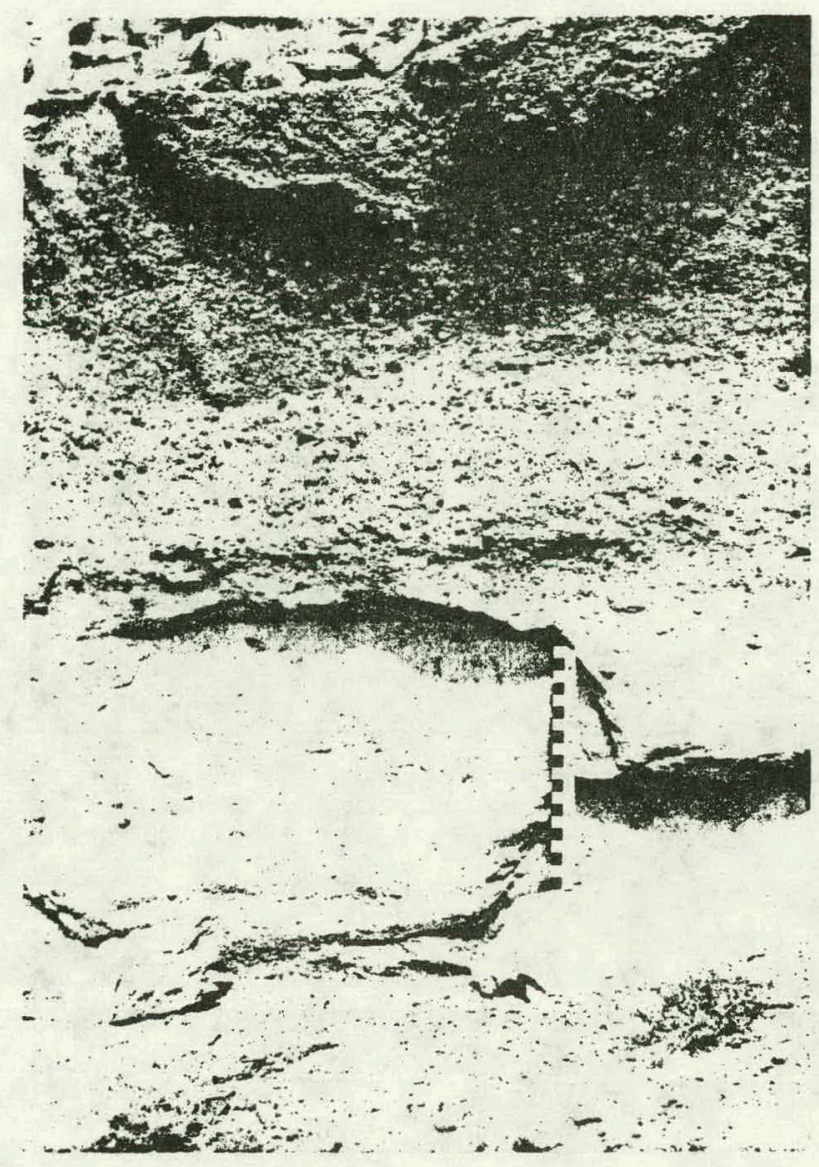

Figure 28. An ignimbrite contact in the Stratified Tuff near the Autunite No. 8 Prospect with a paleofumarole. Contact is slightly above the meter stick. 


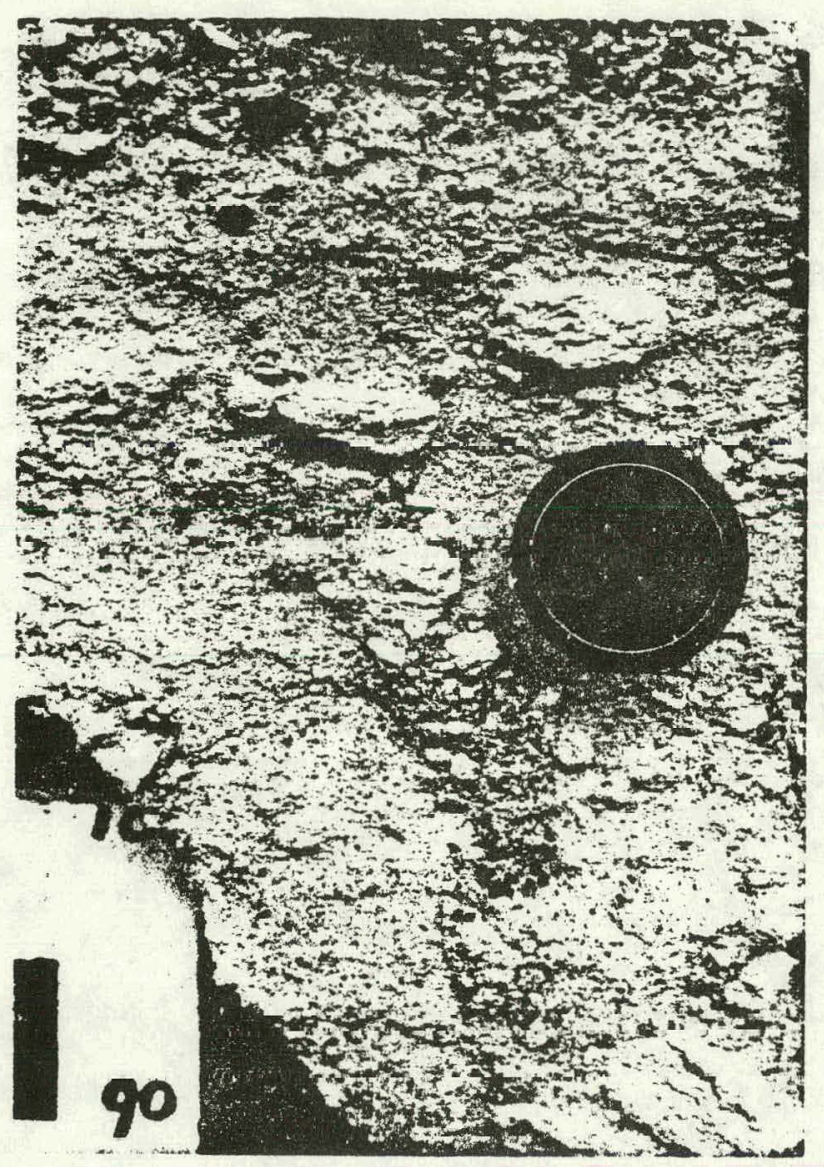

Figure 28 (Continued). An ignimbrite contact in the Stratified Tuff near the Autunite No. 8 Prospect with a palcofumarole. Paleofumarole, left of lens cap, near the ignimbrite contact in Fig. 28 a. 
have been emplaced hot and fairly rapidly to form a single cooling unit (Fig. 23) (Ross and Smith, 1961). The unusually large, flattened spheroids found below the vitrophyre in the section near the Autunite No. 8 prospect (Fig. 22) appear to be flattened bombs in a welded matrix. Above the vitrophyre in this column an intensely vapor-phasealtered zone occurs which, from the lithics found in the unit, may be a pyroclastic unit (Fig. 17). Vapor-phase alteration is comonly found above vitrophyres (Ross and Smith, 1961).

Except for the drill core section, breccia zones are found at the base of the alkali rhyolite in the measured sections. These breccias originated as talus aprons that commonly form around rhyolite flows (Loney, 1968). As the flow advanced, the lava overrode part of the talus apron, and much of the breccia talus became mixed to varying degrees with the base of the lava flow (Cole, 1970; Fink, 1980). The contact of the alkali rhyolite and the Stratified Tuff in the drill section (Fig. 16) differs from the other sections in that the top of the stratified Tuff is fused. This difference may be related to the temperature or the thickness, or both, of the overlying lava flows. The present escarpments of the Thomas Range, where the other sections were measured, may not have been eroded back significantly from the original egearpments of the dnmes and flows that existed $6 \mathrm{~m} \cdot \mathrm{y}$. ago and are where cooler and thinner facies of a flow might be expected. Spherulitic devitrification is found in the alkali rhyolite, the vitrophyre, and the breccia clasts to varying degrees at the tops of all of itut sections. 
Mineralization in the Beryllium Tuff

and in the Stratified Tuff

The Beryl1ium Tuff

The beryllium mineralization in the Beryllium Tuff was recognized by previous workers to be tabular in shape and to occur somewhat below the overlying Porphyritic Rhyolite (Griffitts and Rader, 1963; Staatz, 1963; Williams, 1963; Park, 1968; Shawe, 1968). Associated with the beryllium mineralization at the top of the tuff, anomalous concentrations of $\mathrm{F}, \mathrm{Li}, \mathrm{Mn}, \mathrm{Pb}, \mathrm{REE} \mathrm{S}^{\mathrm{s}} \mathrm{U}, \mathrm{U}$, and $\mathrm{Zn}$ have been described (Griffitts and Rader, 1963; Park, 1968; Lindsey, 1979a). High uranium concentrations apparently do not coincide with high beryllium concentrations, and these data have been used in part to show that the highest uranium values are displaced downward from the highest beryllium values in the tuff (Lindsey, 1979a).

Two Bendix Field Engineering Corporation drill holes, number 6 and number 18, penetrate the Beryllium Tuff and have been analyzed for a wide variety of elements (Morrison, 1980). Elements were analyzed for from splits usually obtained from rnre intervale 10 feet $(3.05$ un) long and thus repieseul averages. In order to illustrate elemental variations with depth in the Beryllium Tuff, elemental concentrations at midpoints of individual analyzed intervals were plotted against depth in the following graphs. These graphs confirm the existence of Be, $\dot{F}, \mathrm{Li}$, $\mathrm{Mn}, \mathrm{Fb}, \mathrm{U}$, and $\mathrm{Zn}$ anomalies at the top of the Beryllium Tuff in the drill holes. The tuff in hole number 18 occurs from 497 to 689 feet $(151$ to $210 \mathrm{~m})$ and has anomalous beryllium (Fig. 29), fluorine (Fig. 30), lithium (Fig. 31), manganese (Fig. 32), lead (Fig. 33), $\mathrm{U}_{3} \mathrm{O}_{8}$ 


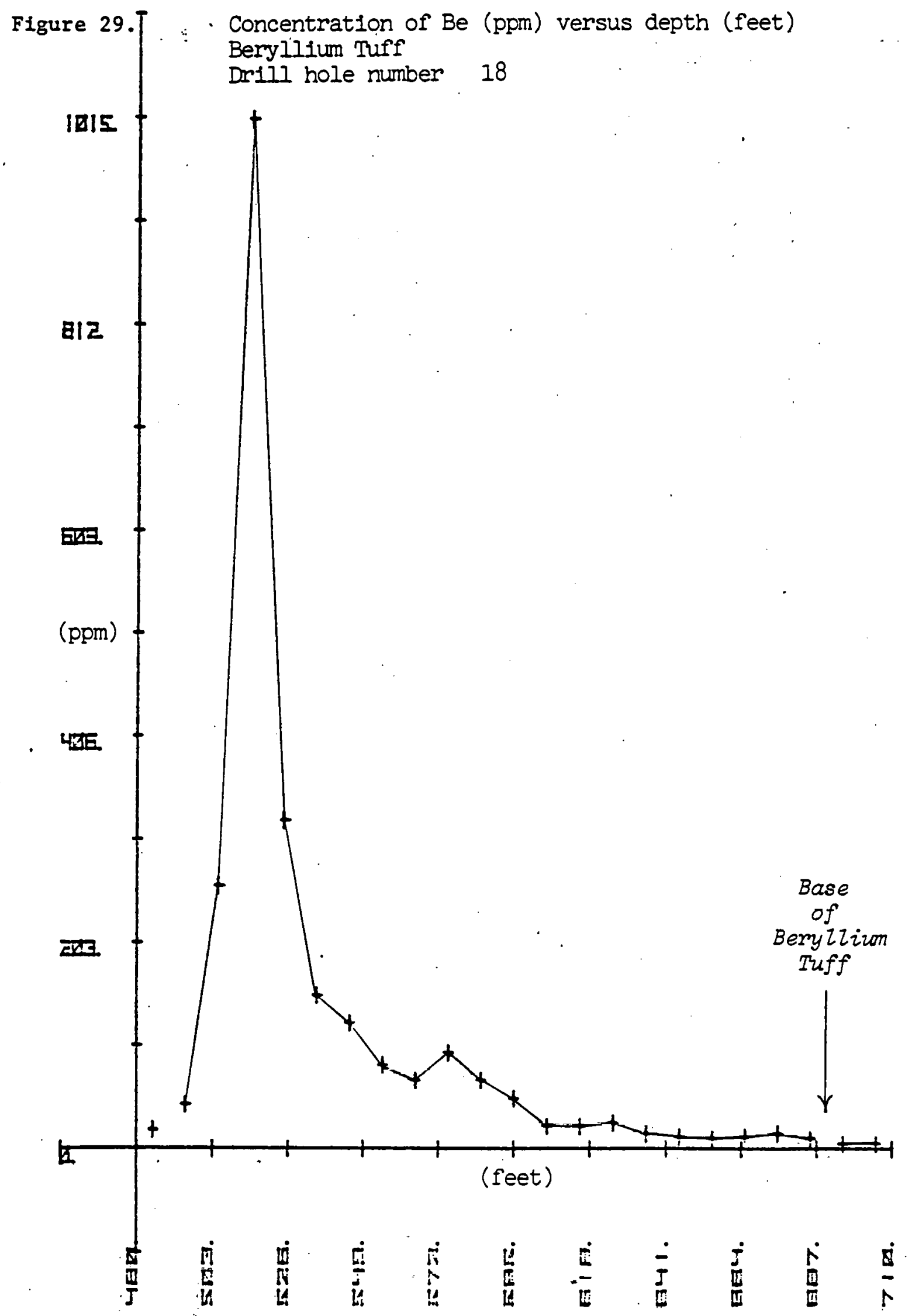



F1gure 30. $\left[\begin{array}{l}\text { Concentration of } F \quad(\mathrm{ppm}) \text { versus depth (feet) } \\ \text { Beryllium Tuff }\end{array}\right.$

Drili hole number 18

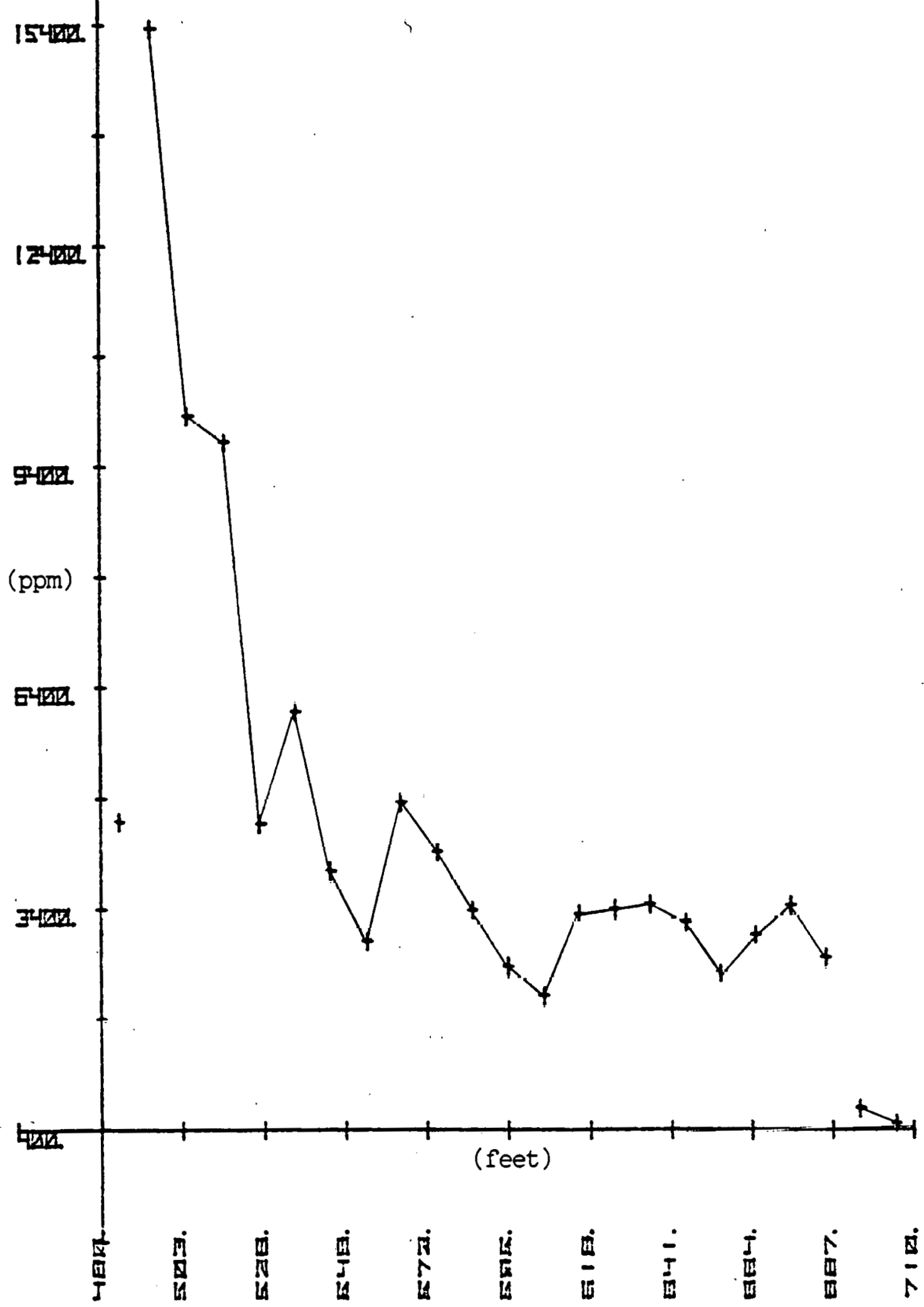




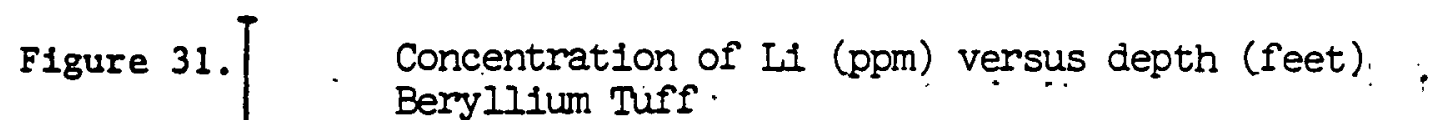
Drill hole number. 18 .

$5 \pi 5$.

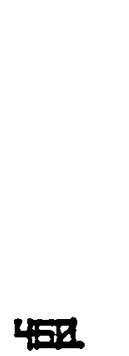
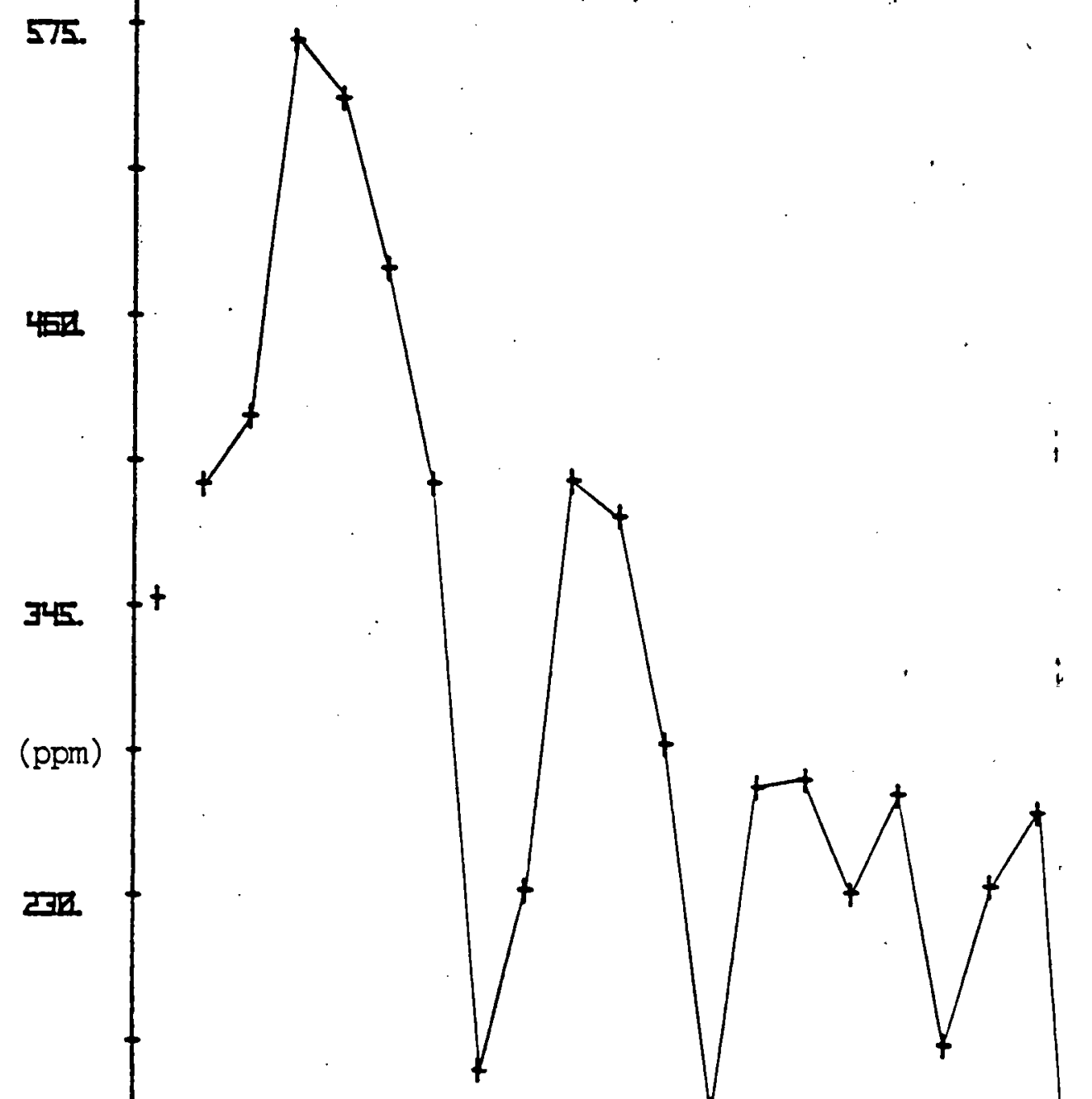

115.

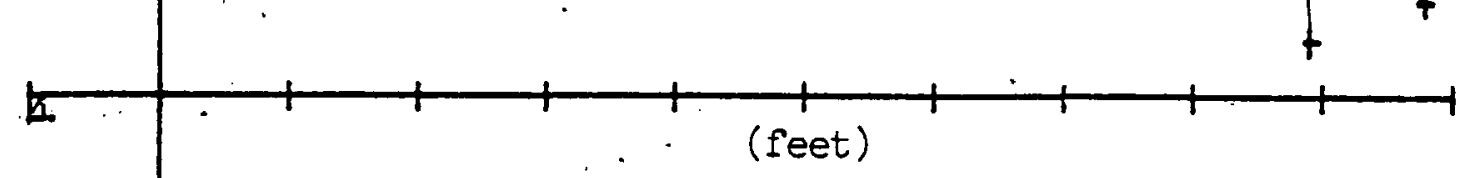

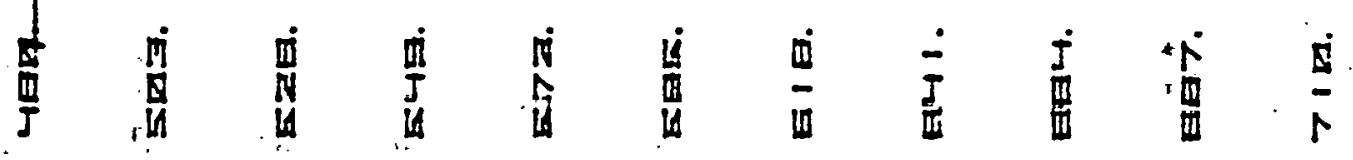


Figure 32.

Concentration of $\mathrm{Mn}(\mathrm{ppm})$ versus depth (feet) Beryllium Tuff

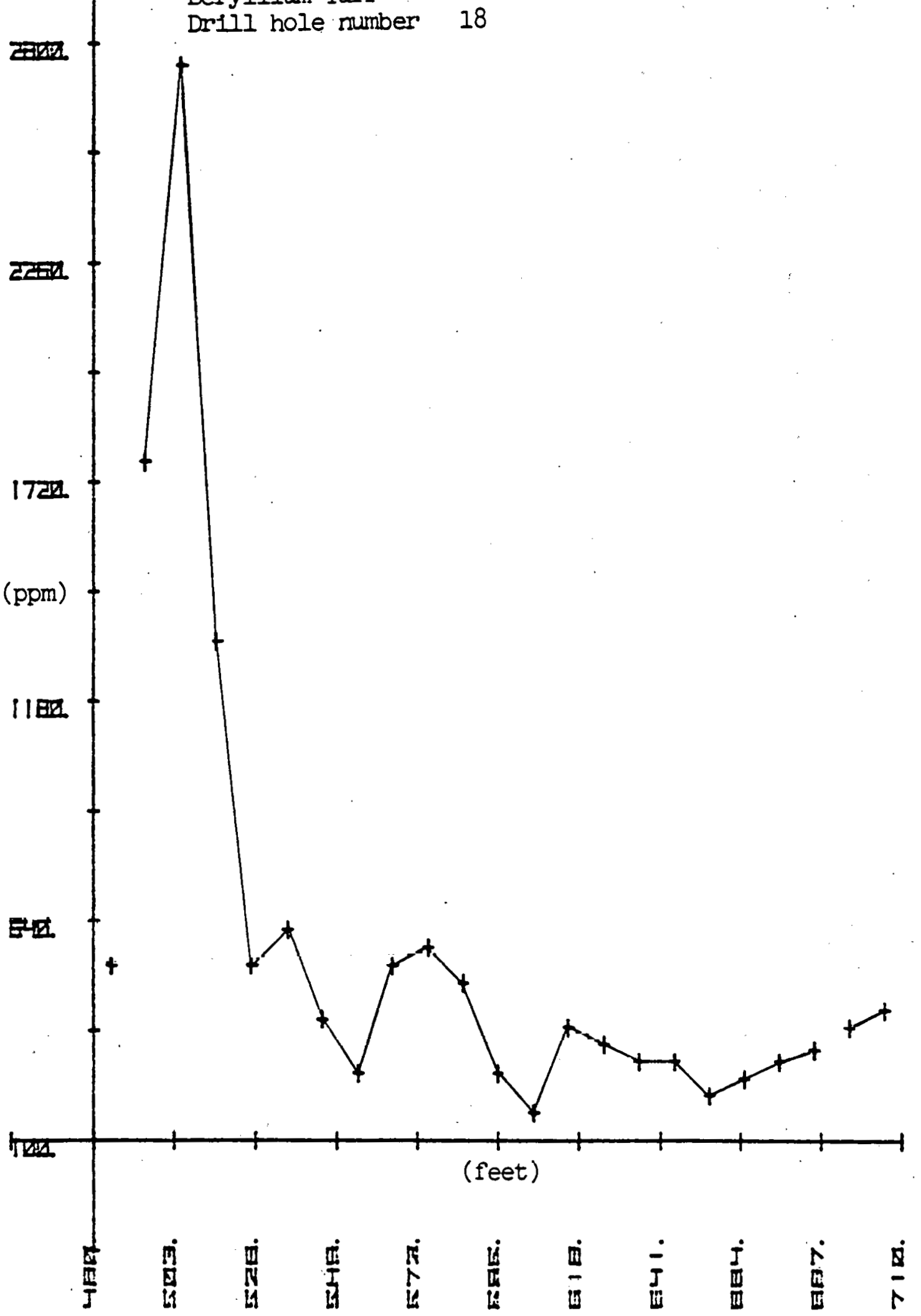


269

- 88 -

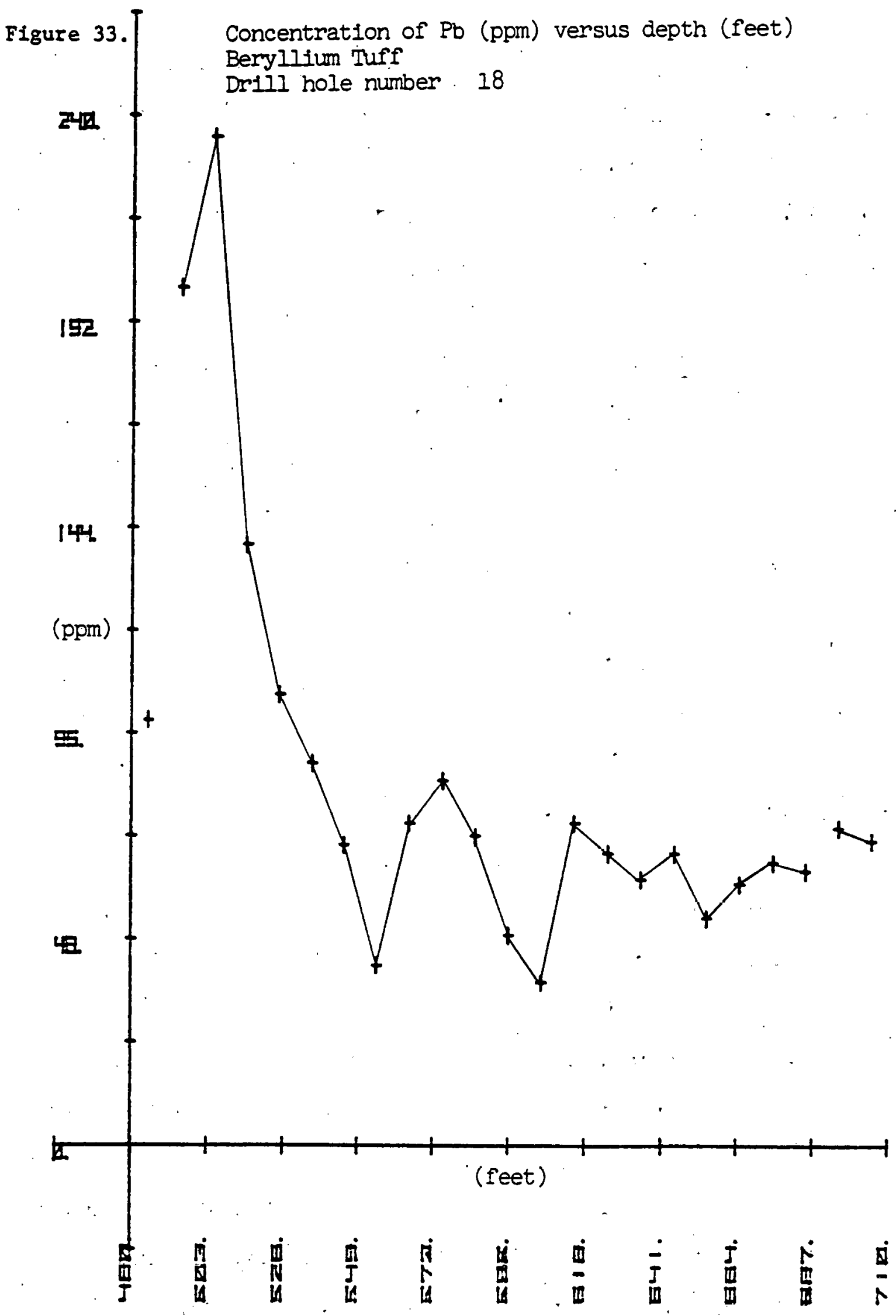


(Fig. 34), equivalent uranium, estimated concentration from spectrographic gamma-ray measurements (Fig. 35), and zinc (Fig. 36) near the top of the unit. Hole number 6 also has anomalous berylilium (Fig. 37), fluorine (Fig. 38), $\mathrm{U}_{3} \mathrm{O}_{8}$ (Fig. 39), and equivalent uranium (Fig. 40) in the upper part of the Beryllium Tuff, which was cored from 733 to 914 feet ( 223 to $279 \mathrm{~m}$ ) in the hole. In both holes, equivalent uranium and $\mathrm{U}_{3} \mathrm{O}_{8}$ anomalies are not displaced downward from the beryllium anomalips. Park (1968) came to a similar conclusion from an analysis of five sections. Equivalent uranium measurements made in hole number 6 every 6 inches $(15 \mathrm{~cm}$ ) from an in-hole gamma ray spectrometer by Bendix Field Engineering Corporation shows a regular variation in uranium content with a cycle of 5 to 7 feet $(1.5$ to $2.1 \mathrm{~m})$ at the top of the Beryllium Tuff from 726 to 756 feet $(22.1$ to $230 \mathrm{~m})$ (Fig. 41). Duc to inaccuracies in depth measurements, the readings of the geophysical logs are displaced approximately 4 feet $(1.2 \mathrm{~m})$ upward from the drill core (La Point, personal communication, 1980).

Further analysis of the data presented by Morrison (1980) reveals several additional elemental anomalies at the top of the Beryllium Tuff previously not described in the literatura. Elamental depth profiles for hole number 18 show arsenic (Fig. 42), niobium (Fig. 43), Lin ( $\overline{\mathrm{F}}$ ig. 44), and tungsten (Fig. 45) anomalies in the upper part of the tuff. Niobium (Fig. 46) and tin (Fig. 47) are also anomalous at the top of the Beryllium Tuff in hole number 6 .

Some elements show no enrichment above background stratigraphically through the Beryllium Tuff. These include antimony (Fig. 48), copper (Fig. 49), Ianthanum (Fig. 50), molybdenum (Fig. 51), strontium 


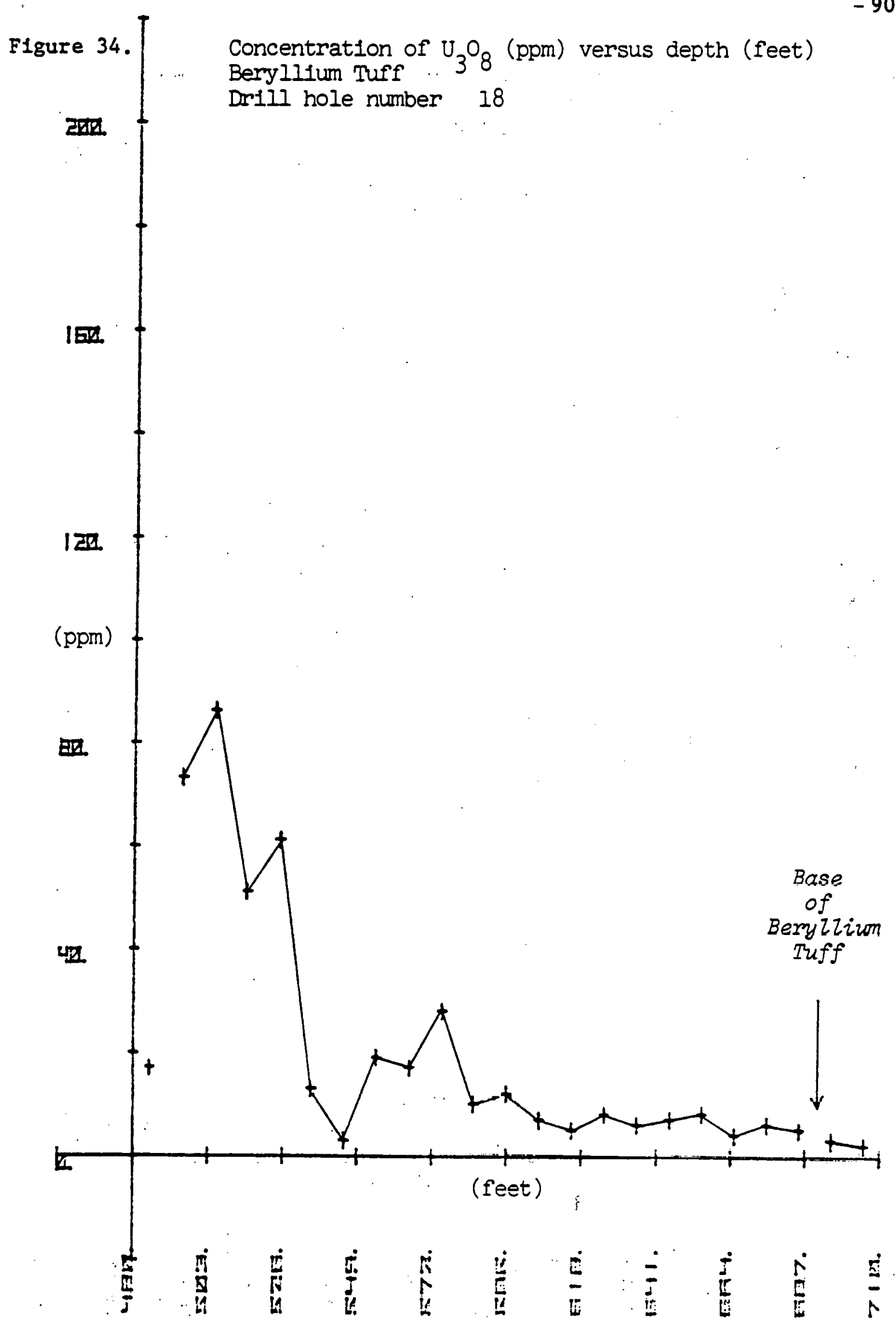


Figure 35.

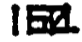

I ב्I

(ppm)

812.

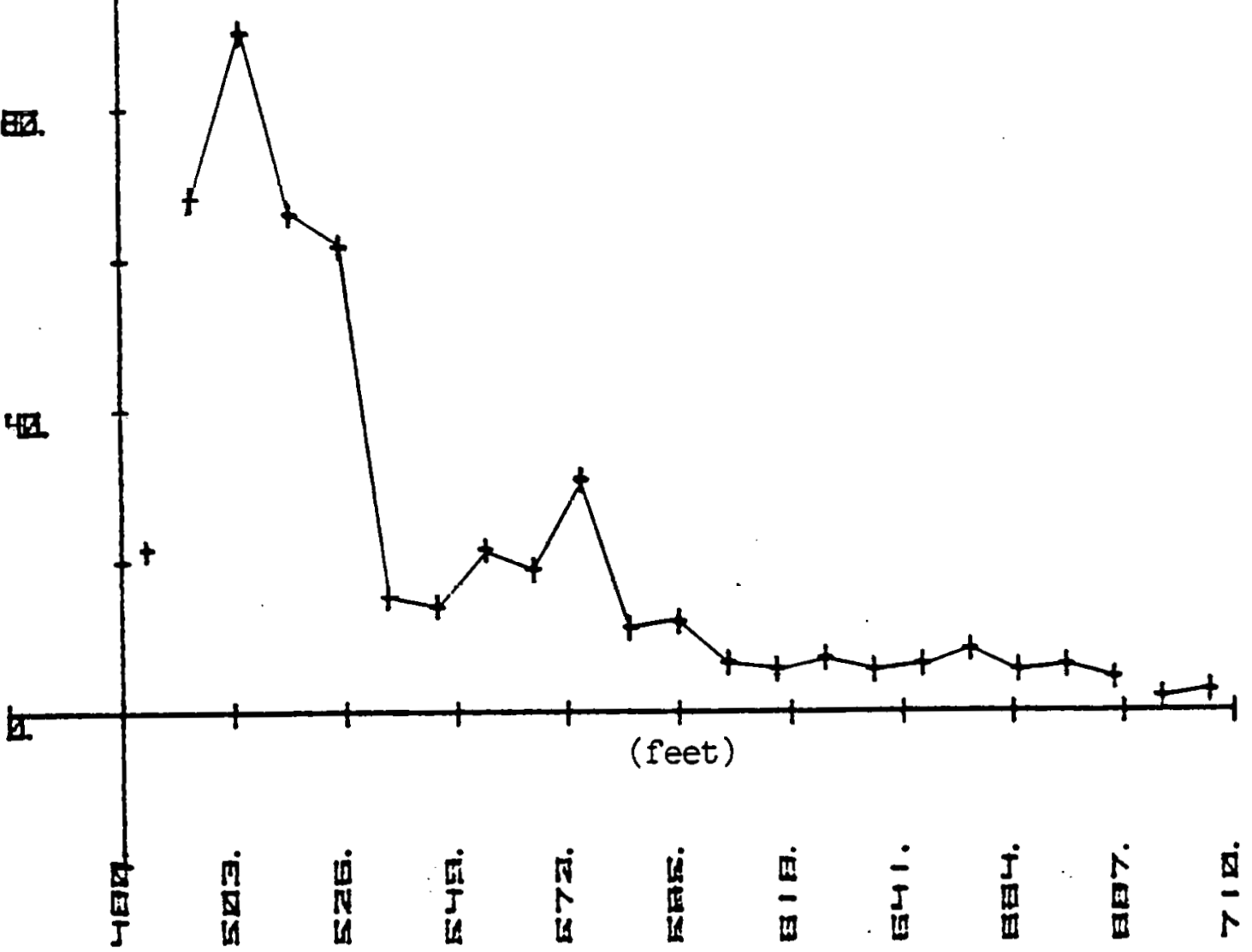



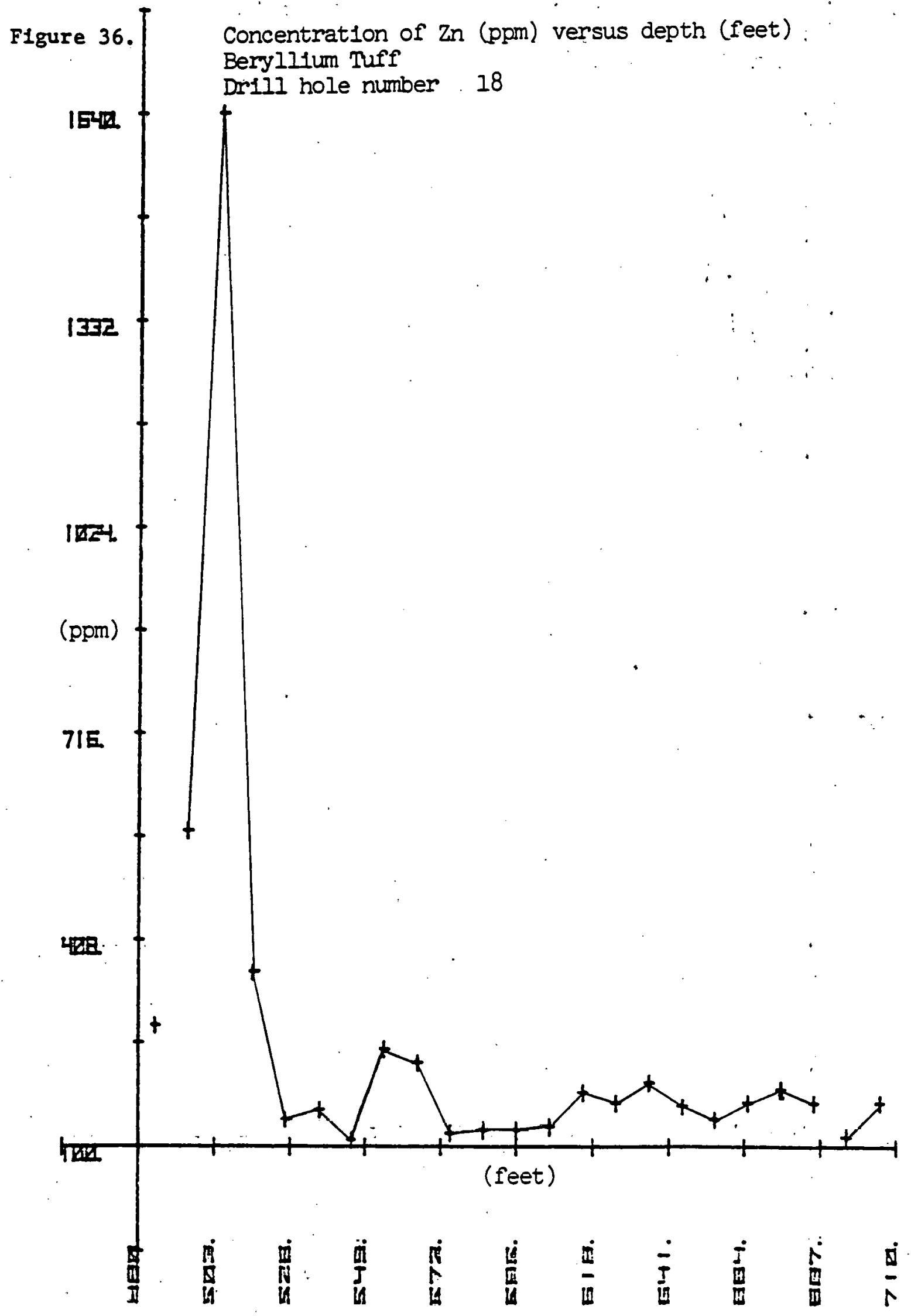


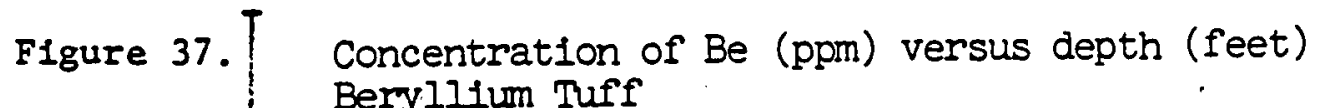

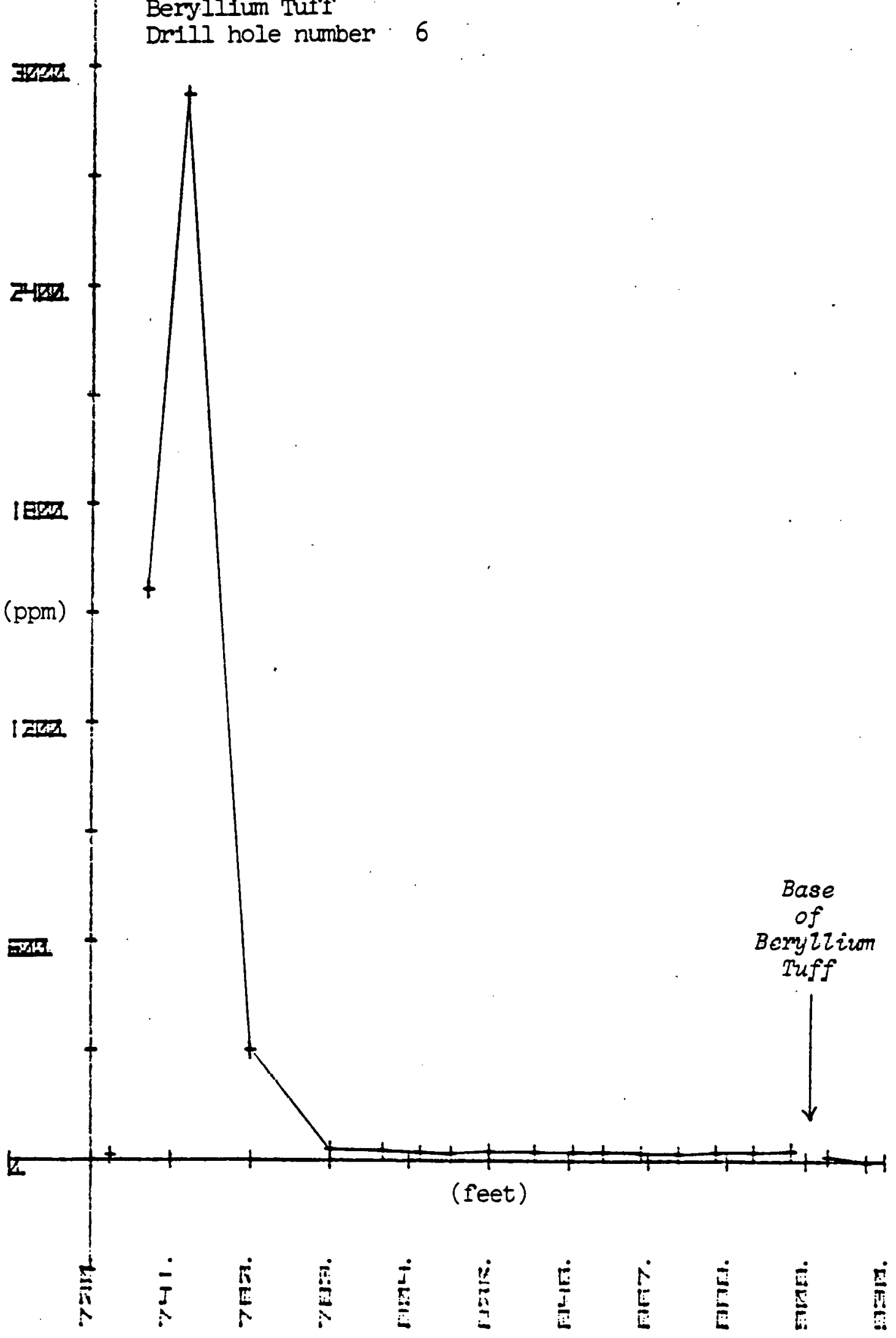


275

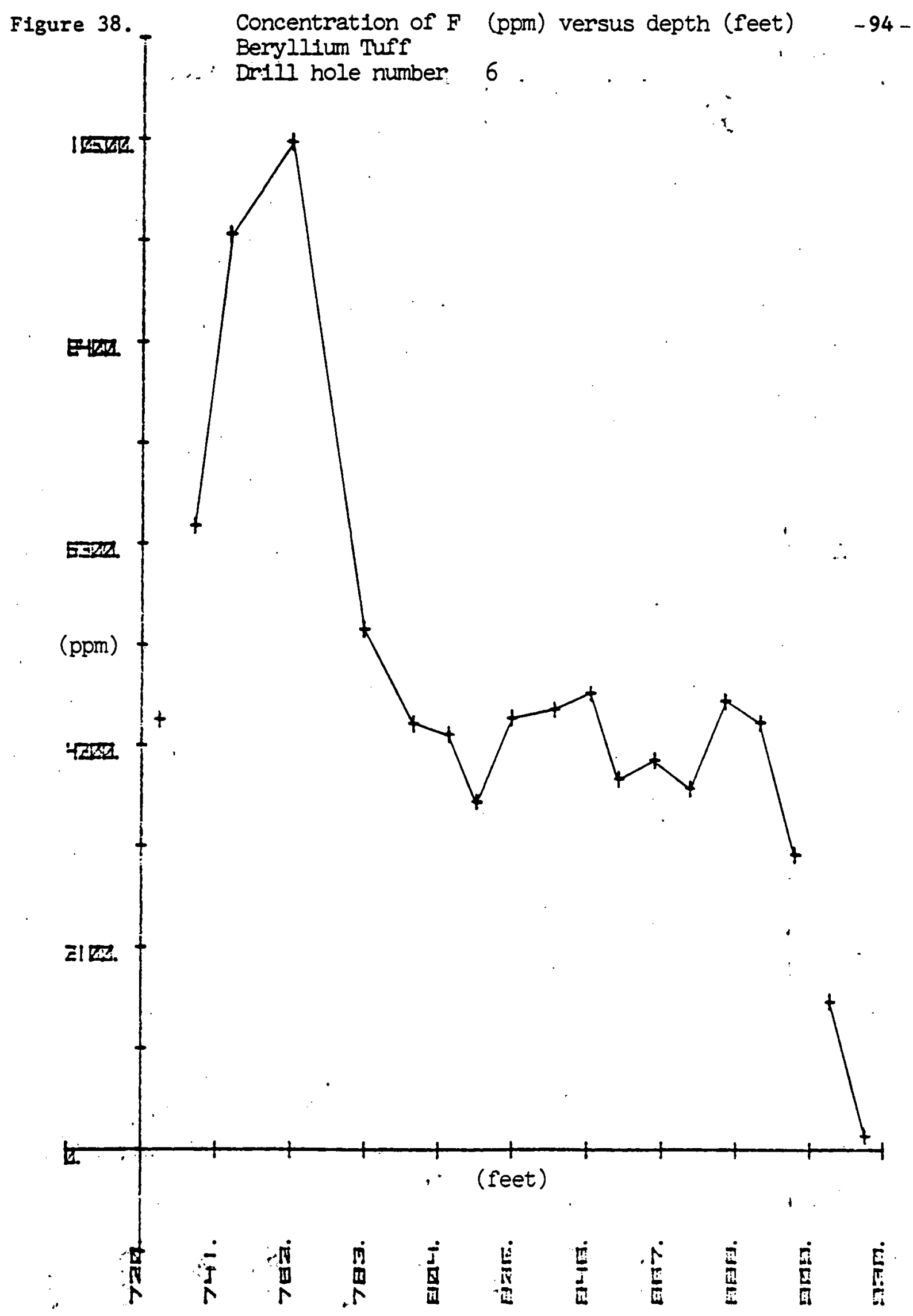




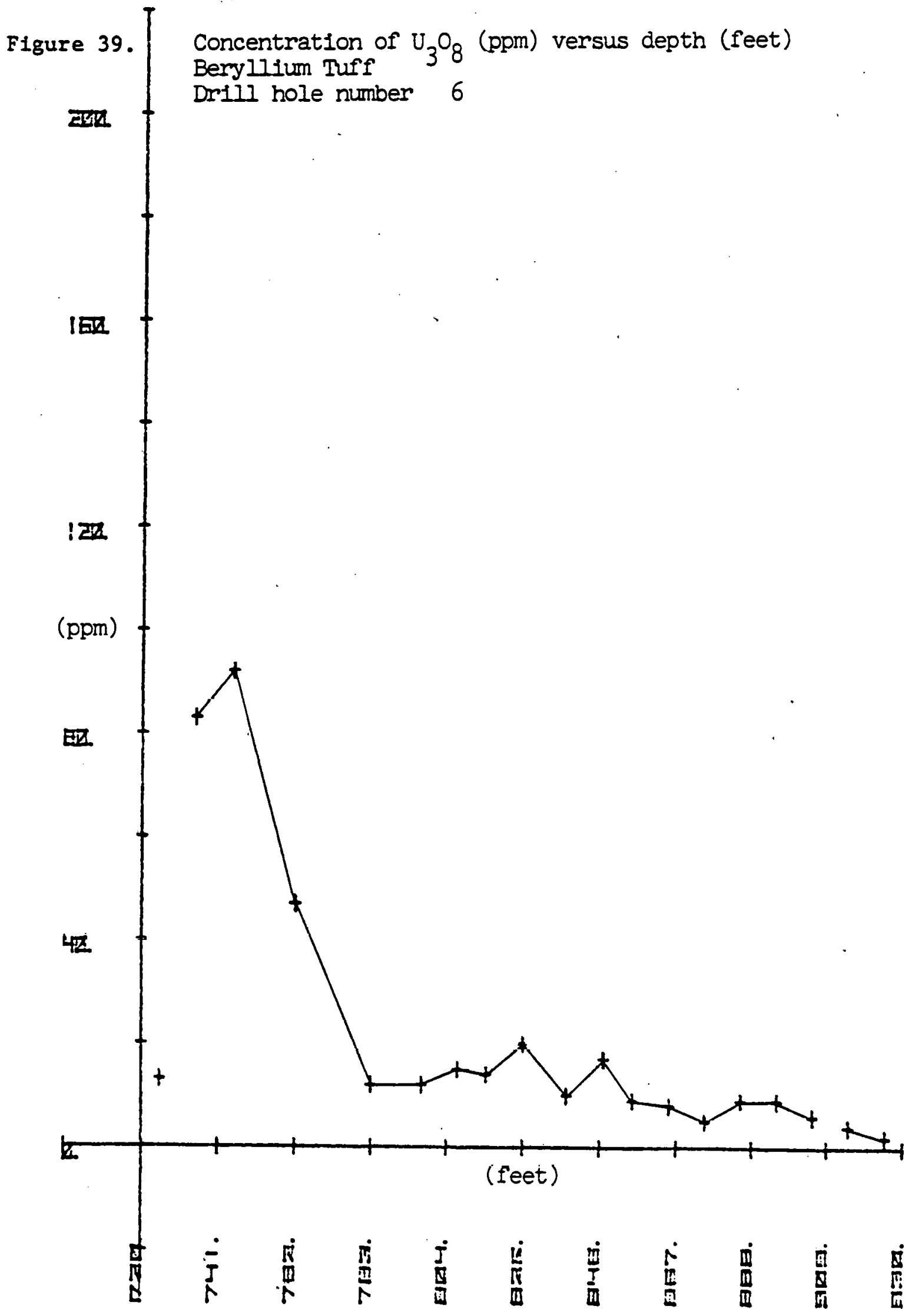




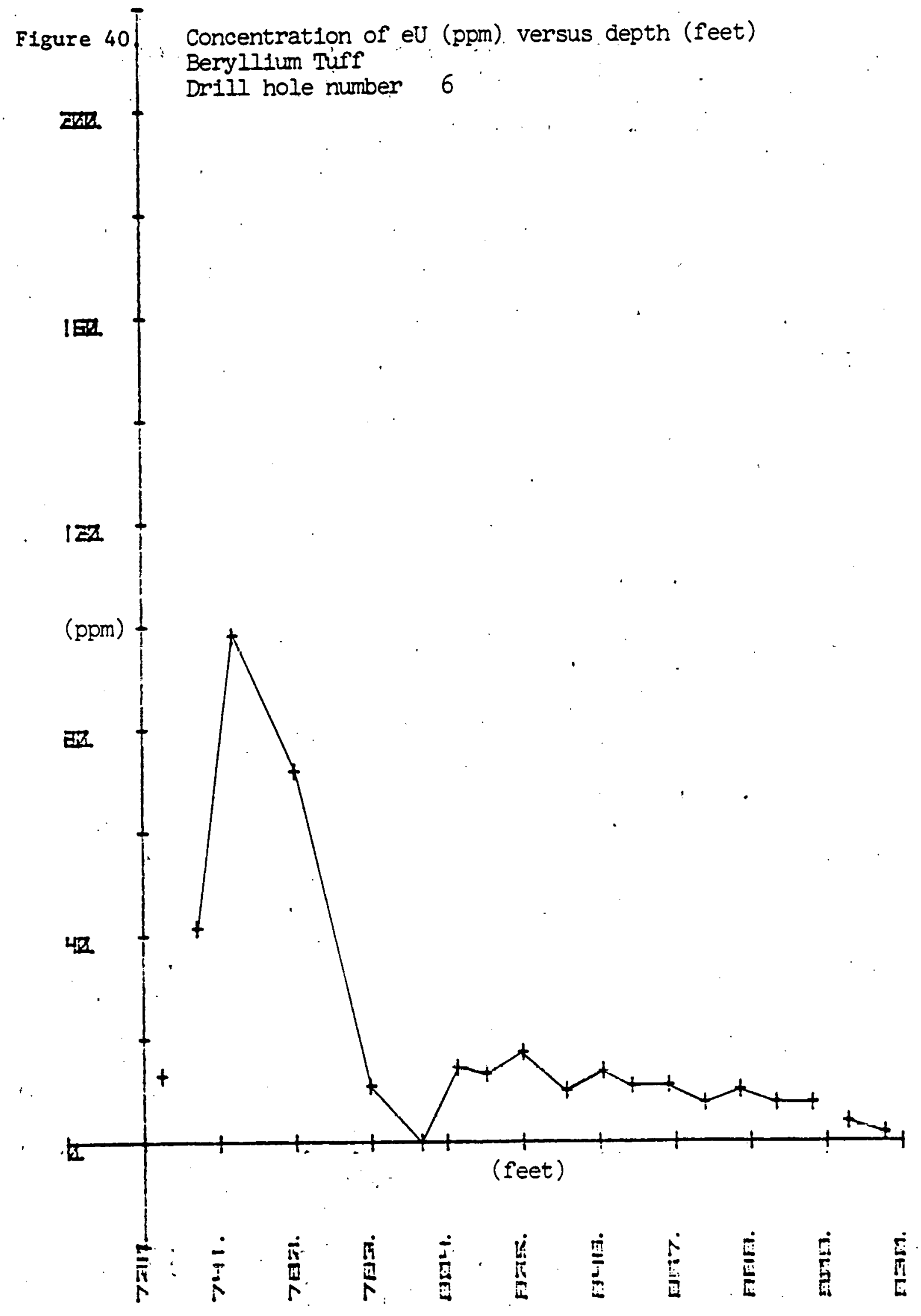




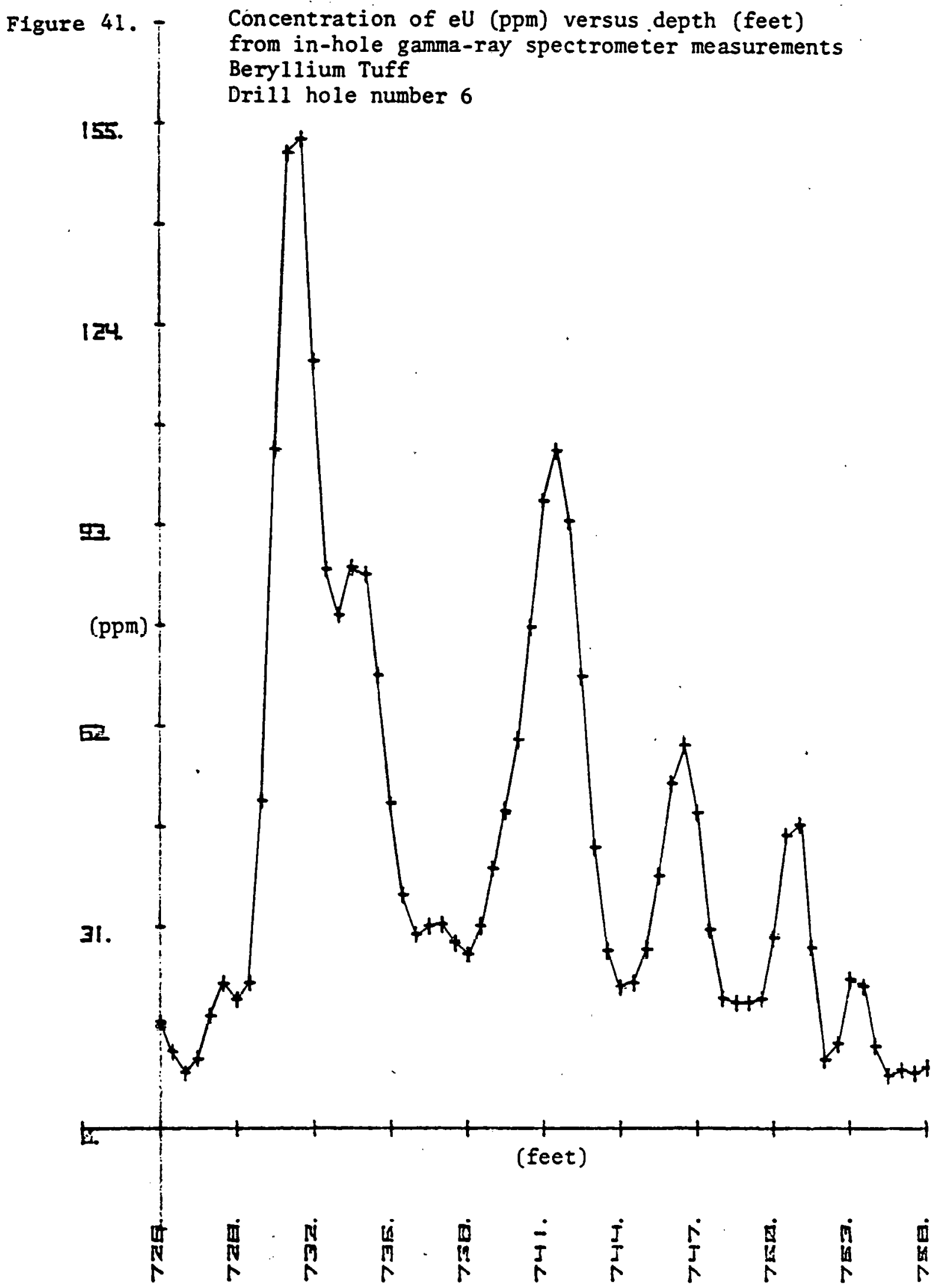




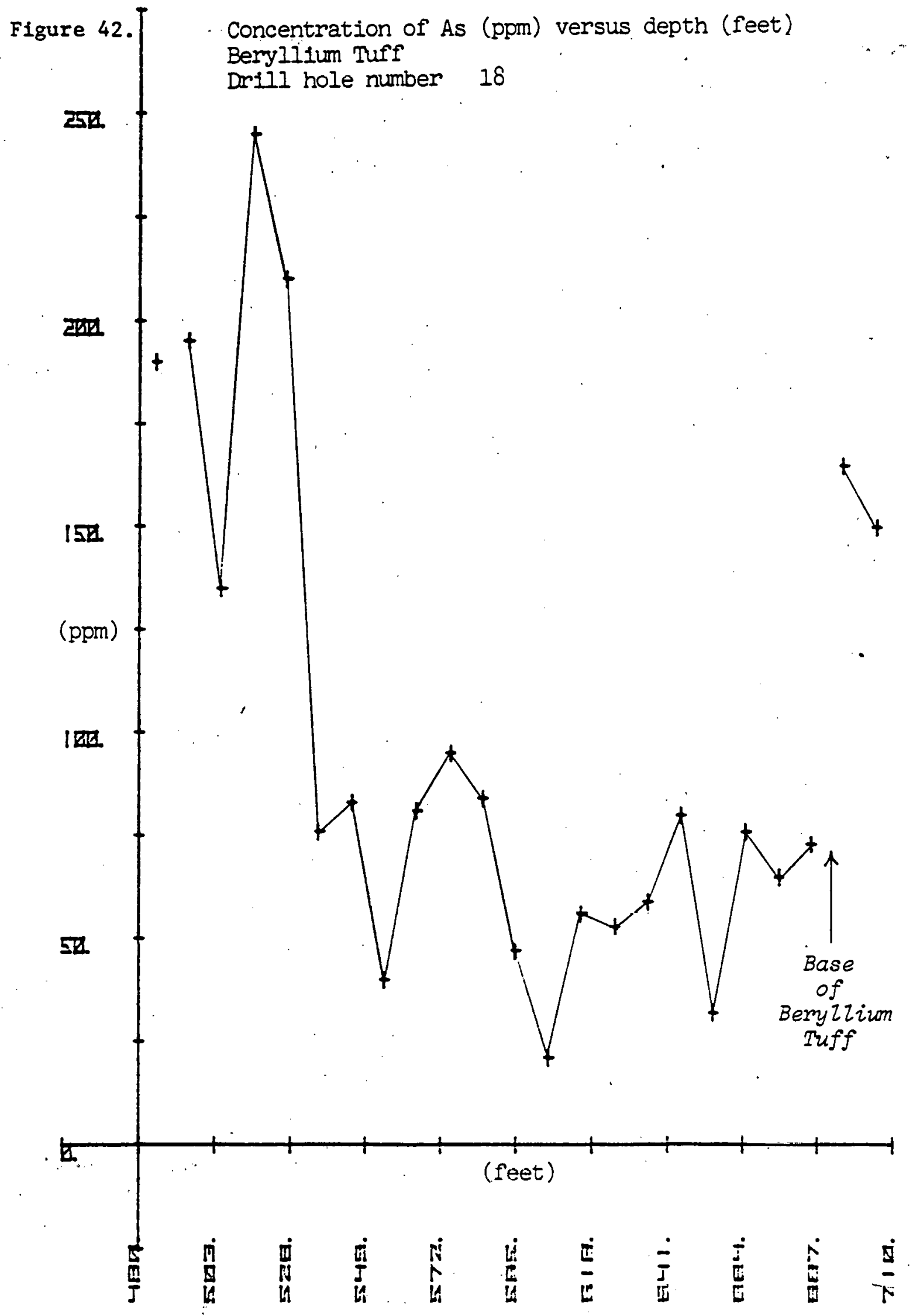




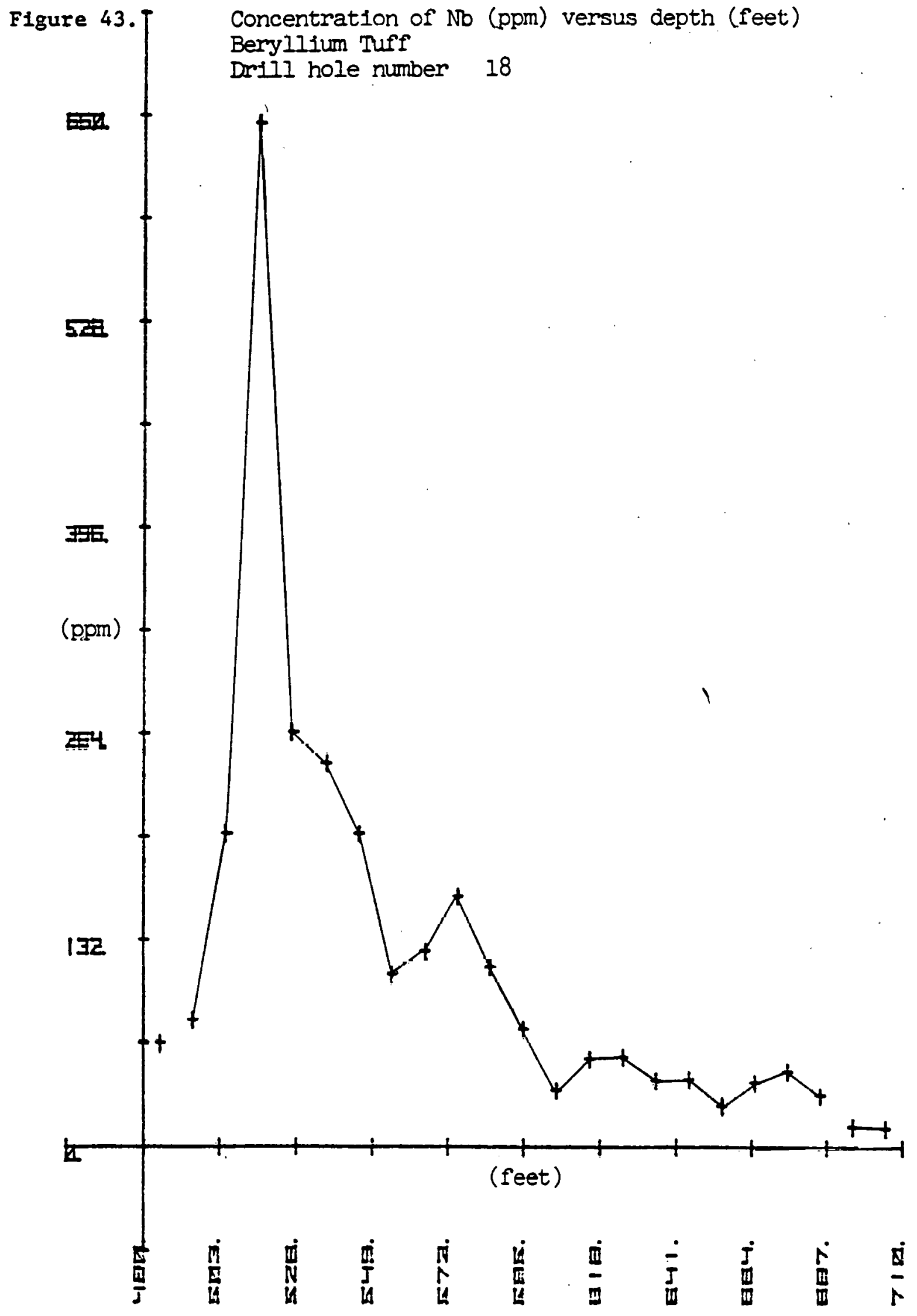


281

$-100-$

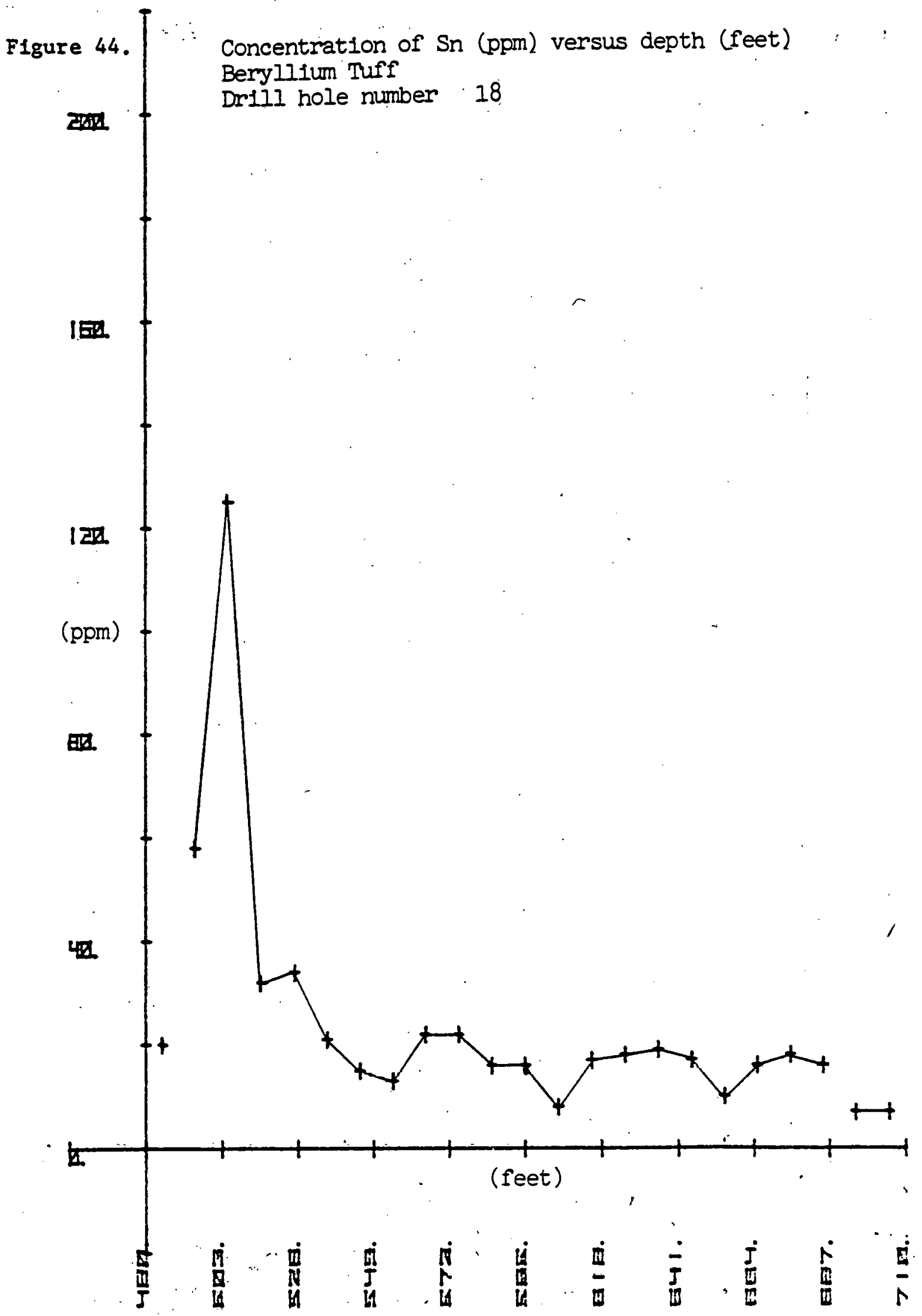


F1gure 45. $\begin{aligned} & \text { Concentration of } \mathrm{W} \text { (ppm) versus depth (feet) } \\ & \text { Beryllium Tuff }\end{aligned}$

Drill hole number 18

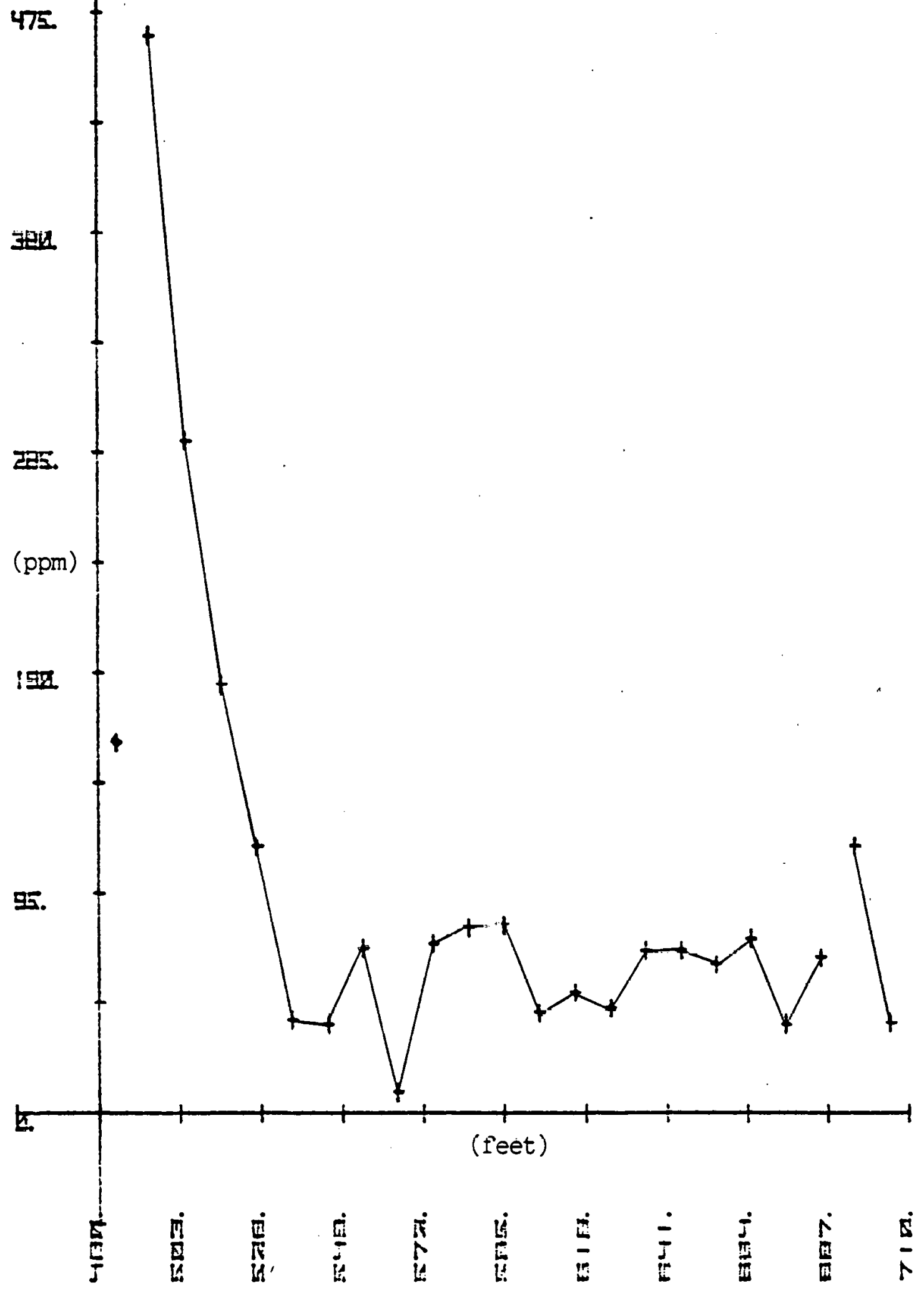


283

$-102-$

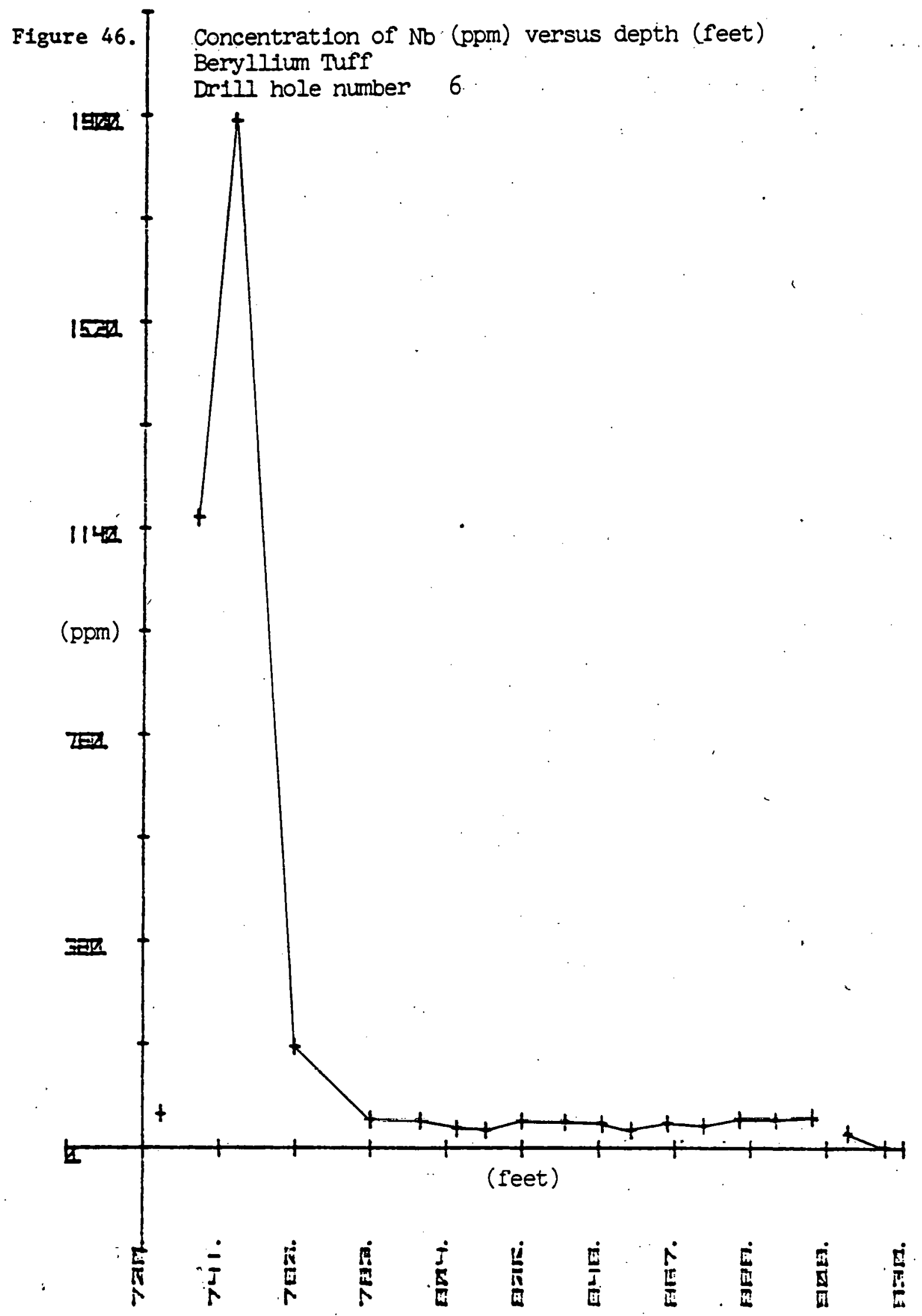


Figure 47. Concentration of $\mathrm{Sn}$ (ppm) versus depth (feet)

Beryllium Tuff

בnua $f$ Drill hole number 6

IEV

BA.

(ppm)
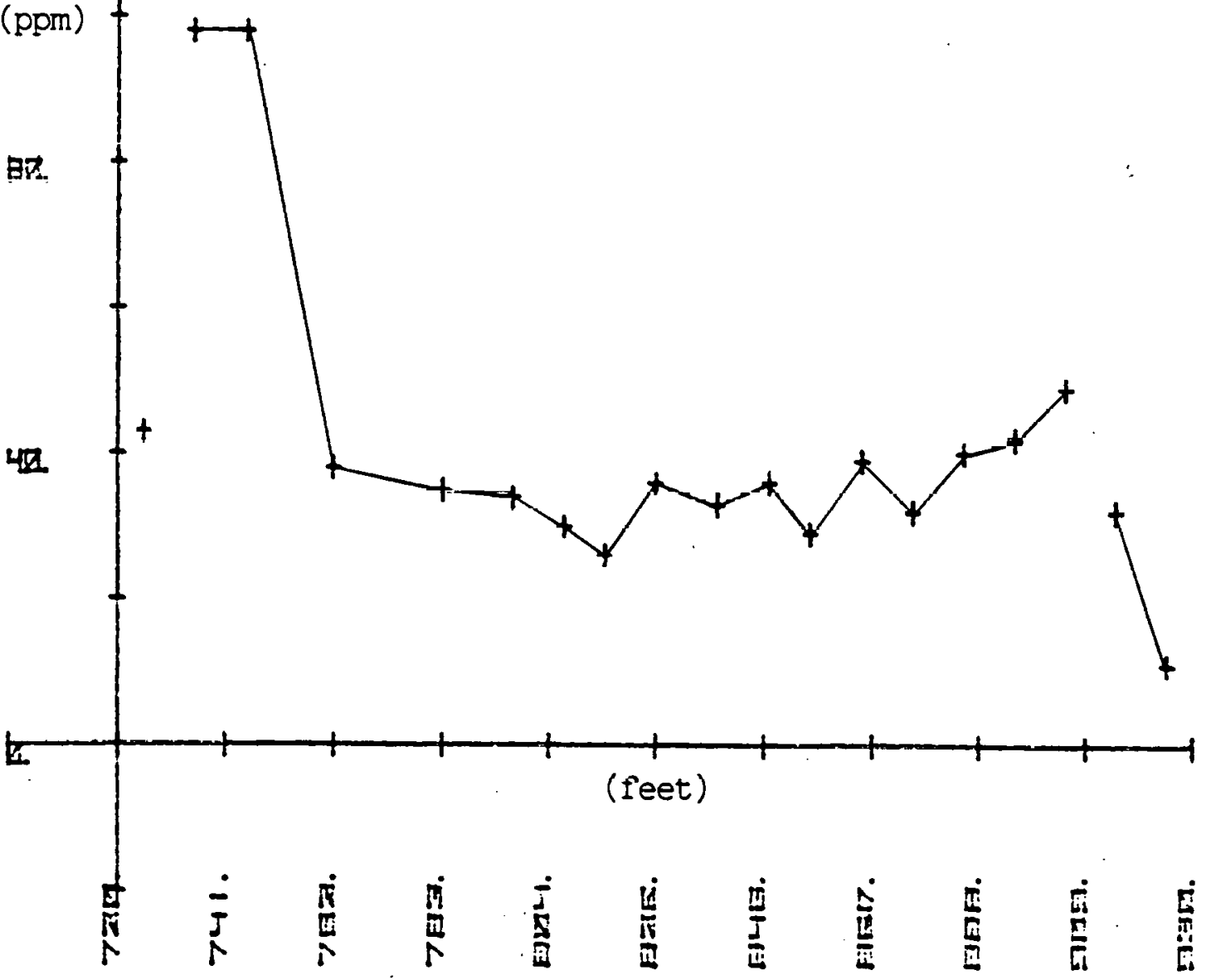
Figure 48 .

D但

198.

己2.

$(\mathrm{ppm})$

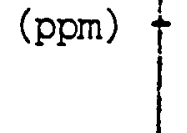

Concentration of Sb (ppm) versus depth (feet) Berylilum Tuff

Drill hole number. 18
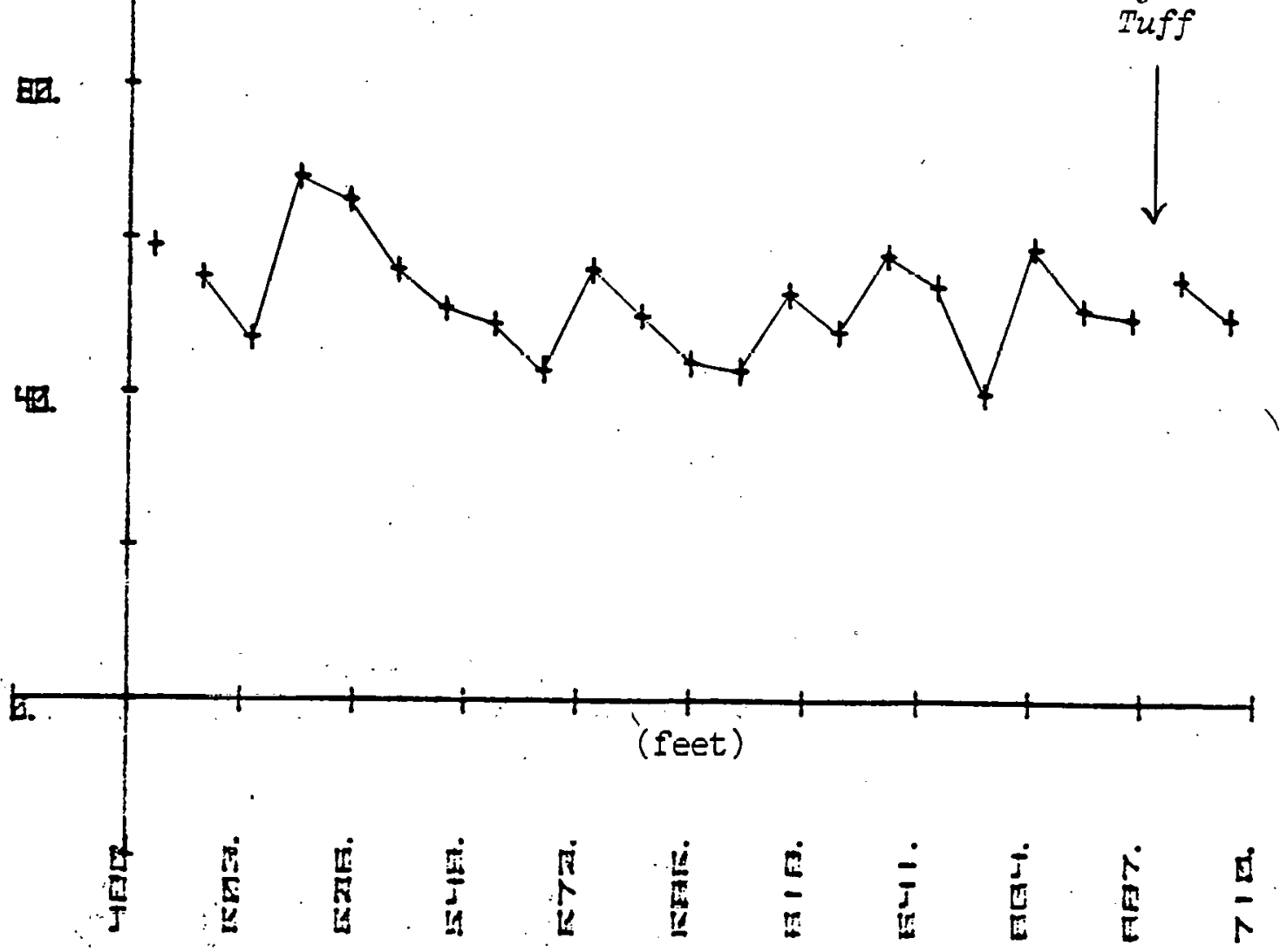
Figure 49.

ट्याम

IED.

国

Concentration of $\mathrm{Cu}$ (ppm) versus depth (feet)

Beryllium Tuff

Drill hole number 18

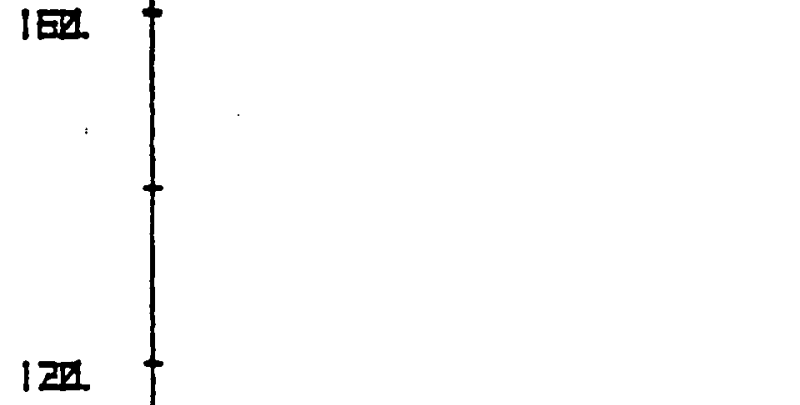

E.

(ppm)

$f$

町.

(2)

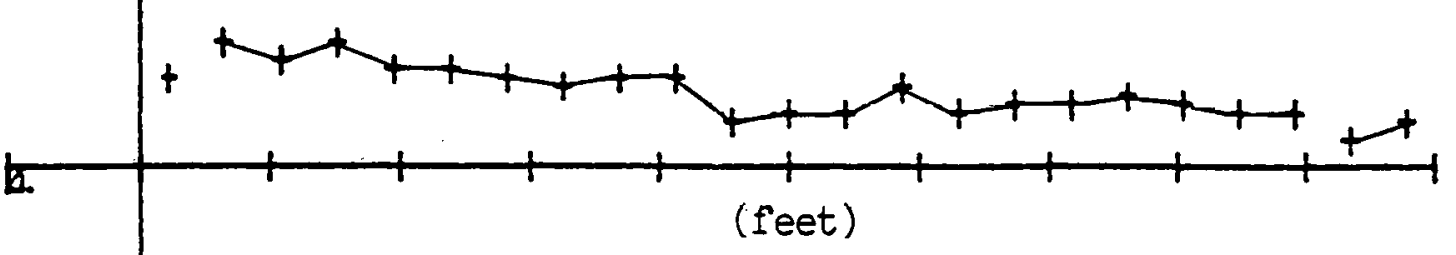

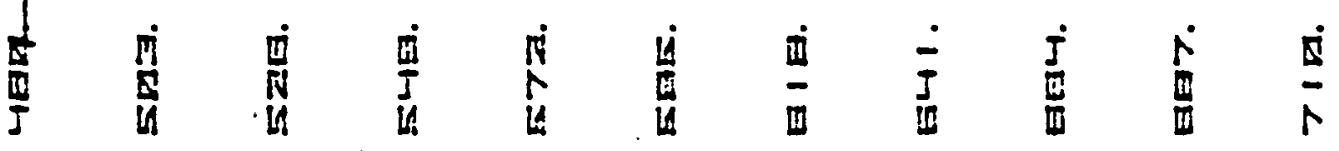



F1gure 50. $[\because \quad$ Concentration of La (ppm) versus depth (feet)

IE⿰亻 Drill hole number 18

IEIII

ER.

1221.

(ppm)

䢖.

i
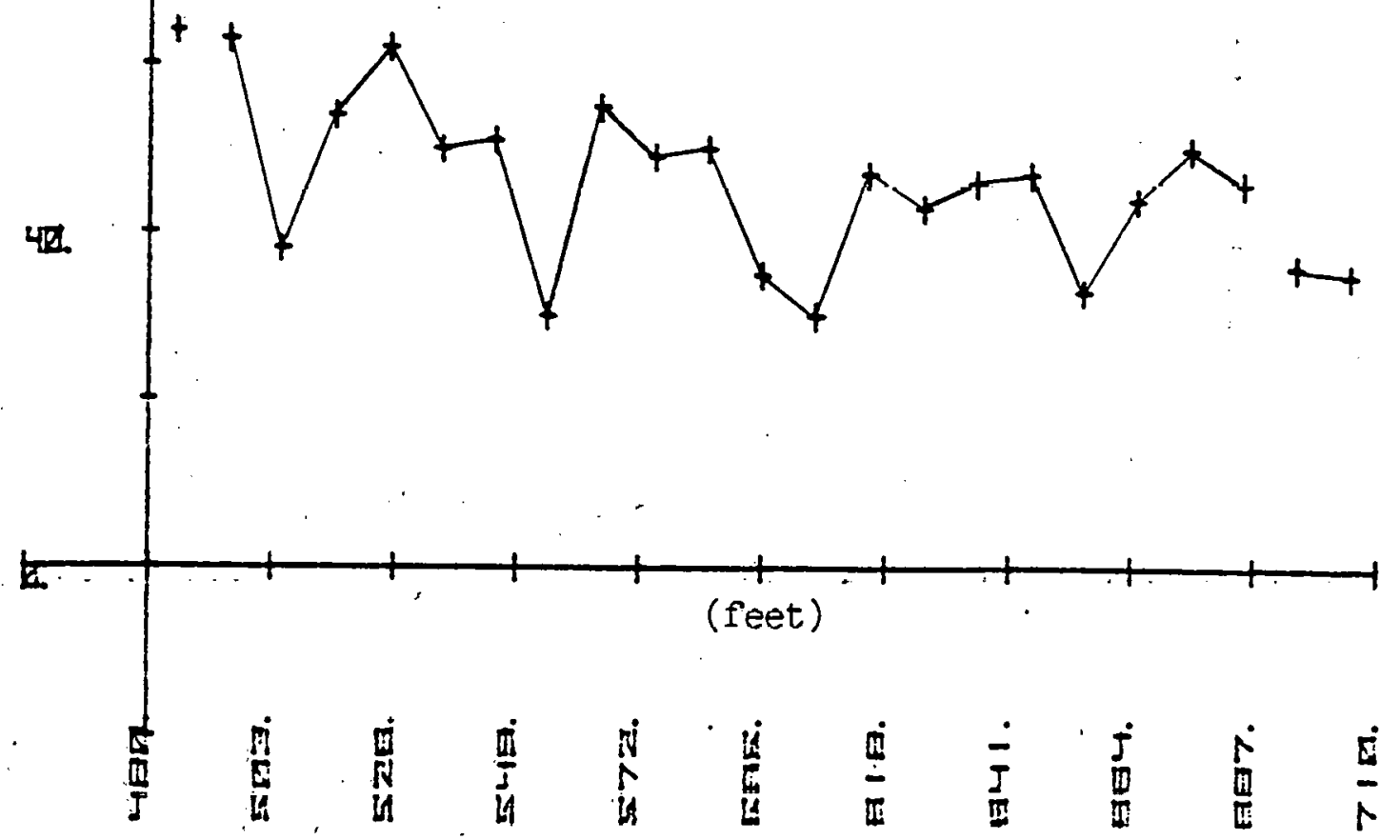


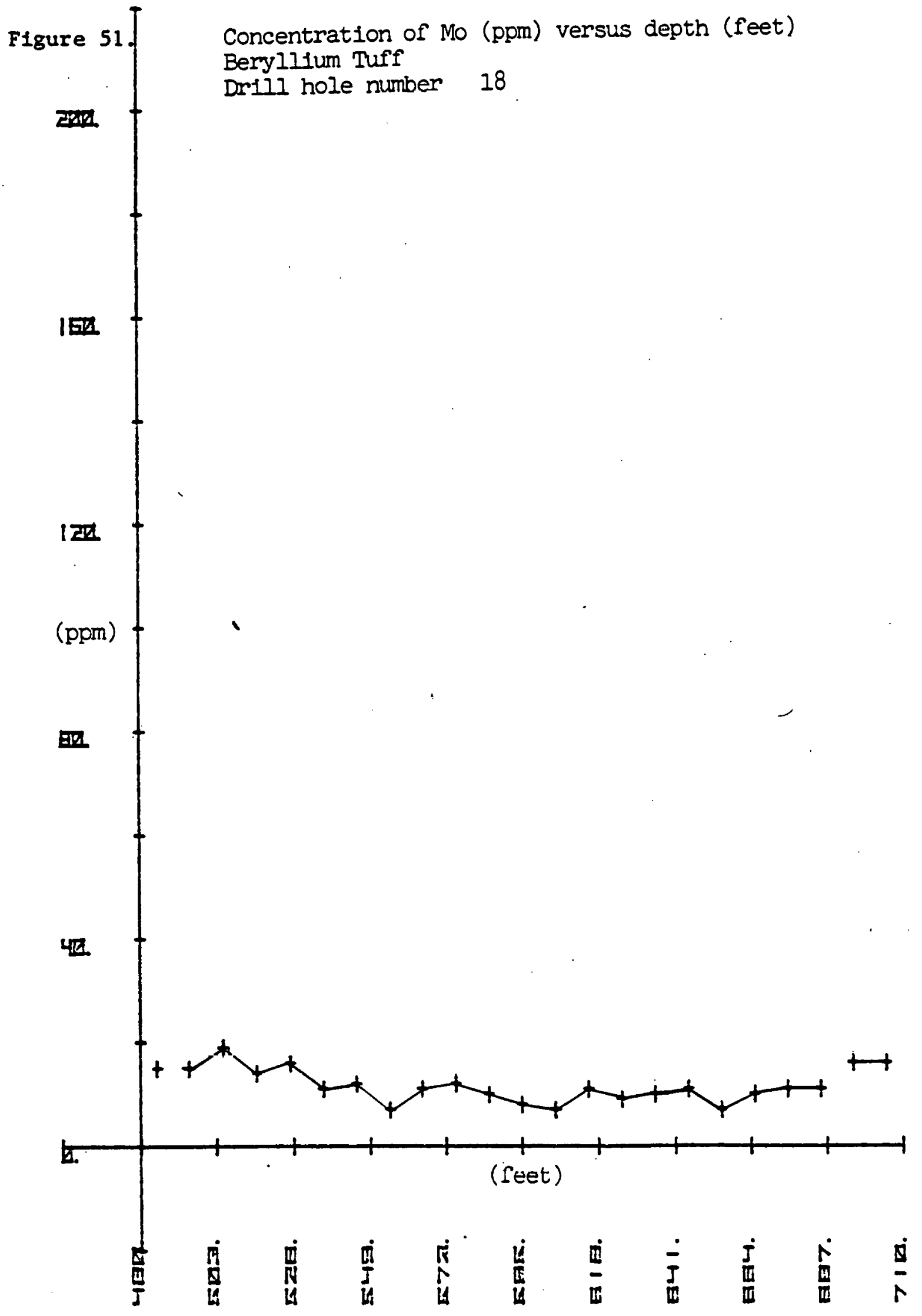


(Fig. 52), equivalent thorium (Fig. 53), and zirconium (Fig. 54) as shown for hole number 18 .

\section{The Stratified Tuff}

Until age dating of the Porphyritic Rhyolite by Lindsey (1978a), the Spor Mountain Formation and the Topaz Mountain Rhyolite were considered to be coeval and the Beryllium Tuff and the stratified Tuff were not distinguished. The Stratified Tuff has been recognized as being unmineralized, but no diagrams illustrating elemental concentration variation with depth are in the literature.

For drill hole number 1 (Fig. 16), antimony (Fig. 55), berylilium (Fig. 56), lead (Fig. 57), lithium (Fig. 58), manganese (Fig. 59), niobium (Fig. 60), equivalent uranium (Fig. 61), and $\mathrm{U}_{3} \mathrm{O}_{8}$ (Fig. 62) show no enrichment at the top of the stratified Tuff, as they do at the top of the Beryllium Tuff. Zinc (Fig. 63) concentrations'fluctuate widely but show no enrichment at the top of the tuff. Fluorine shows a slight enrichment at the top of the tuff (Fig. 64). Equivalent thorium, estimated concentration from spectrographic gamma-ray measurements (Fig. 65), and zirconium (Fig. 66), which show no enrichment at the top of the Beryllium Tuff, also are not enriched at the top of the stratified Tuff.

Conclusions

The topaz rhyolites associated with both tuffs, the numerous fluorspar mines in the Spor Mountain District, and the high concentration of fluurine ar the eop of the Beryllium Tuff have directed previous workers to regard fluorine as an important mineralizer in the Beryllium Tuff (Staatz, 1963, p. 34; Williams, 1963; Lindsey and others, 1973, 
290

$-109=$

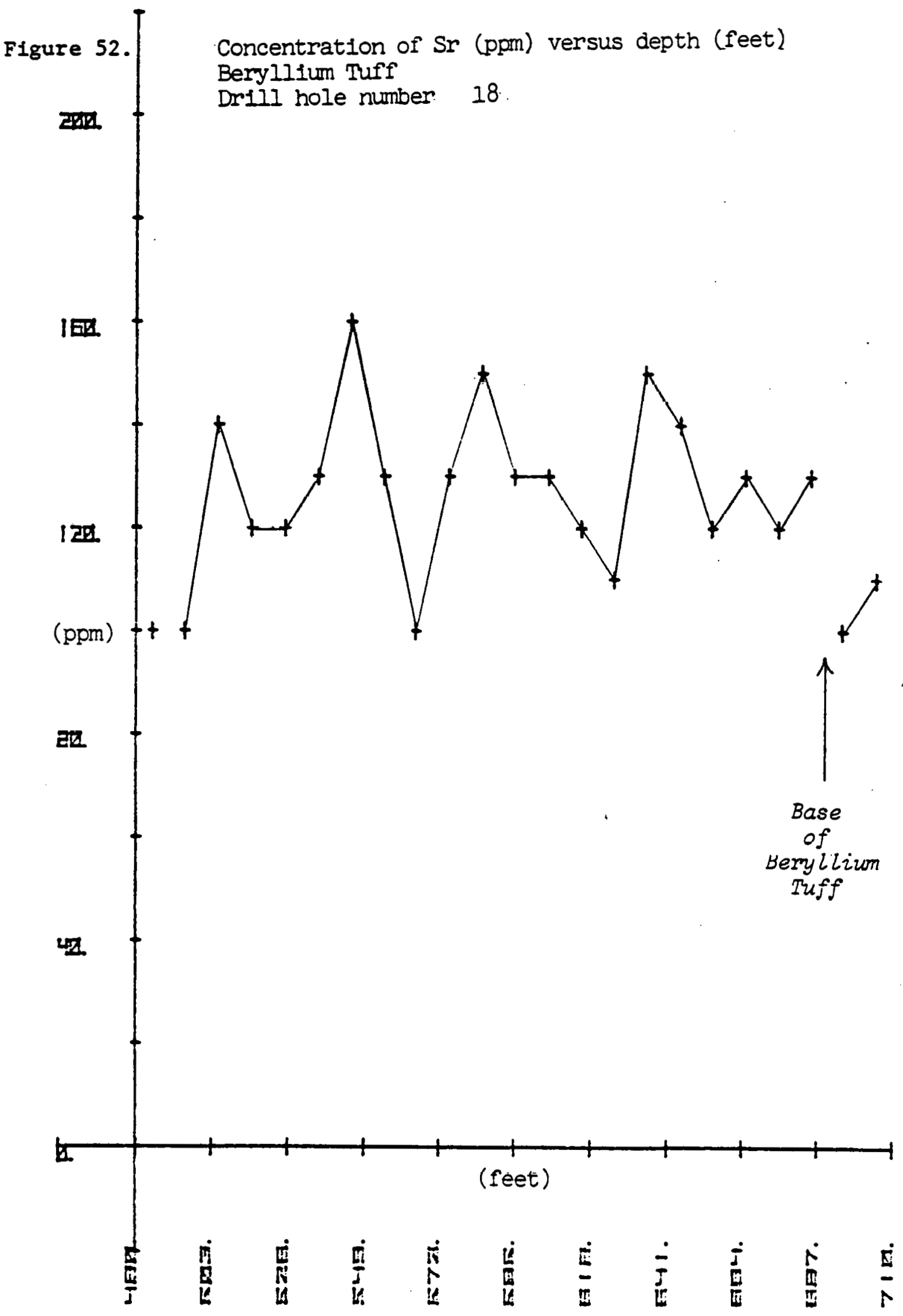




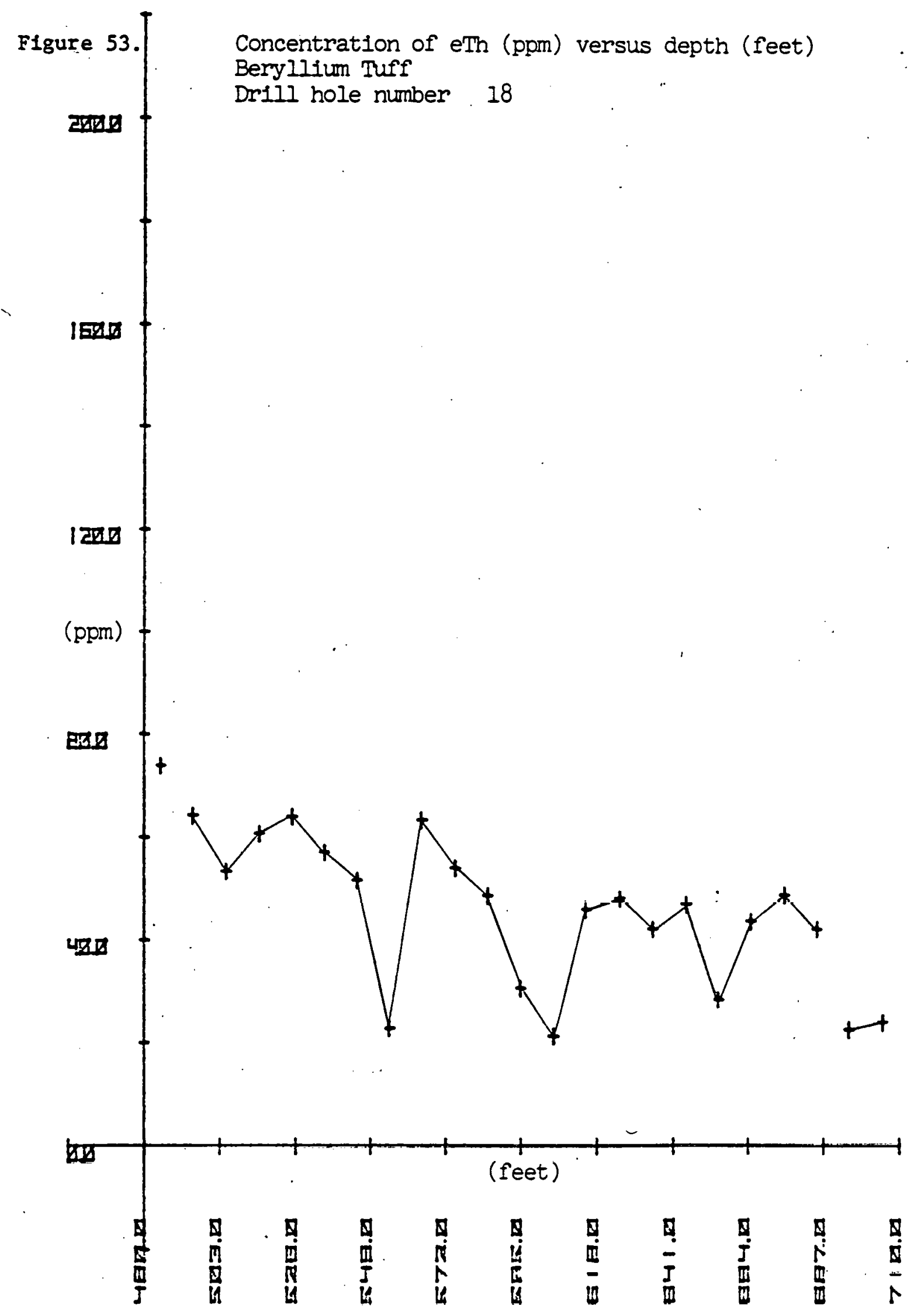


Figure 54. T Concentration of $\mathrm{Zr}$ (ppm) versus depth (feet) Berylilum Tuff

a13.

Drill hole number 18

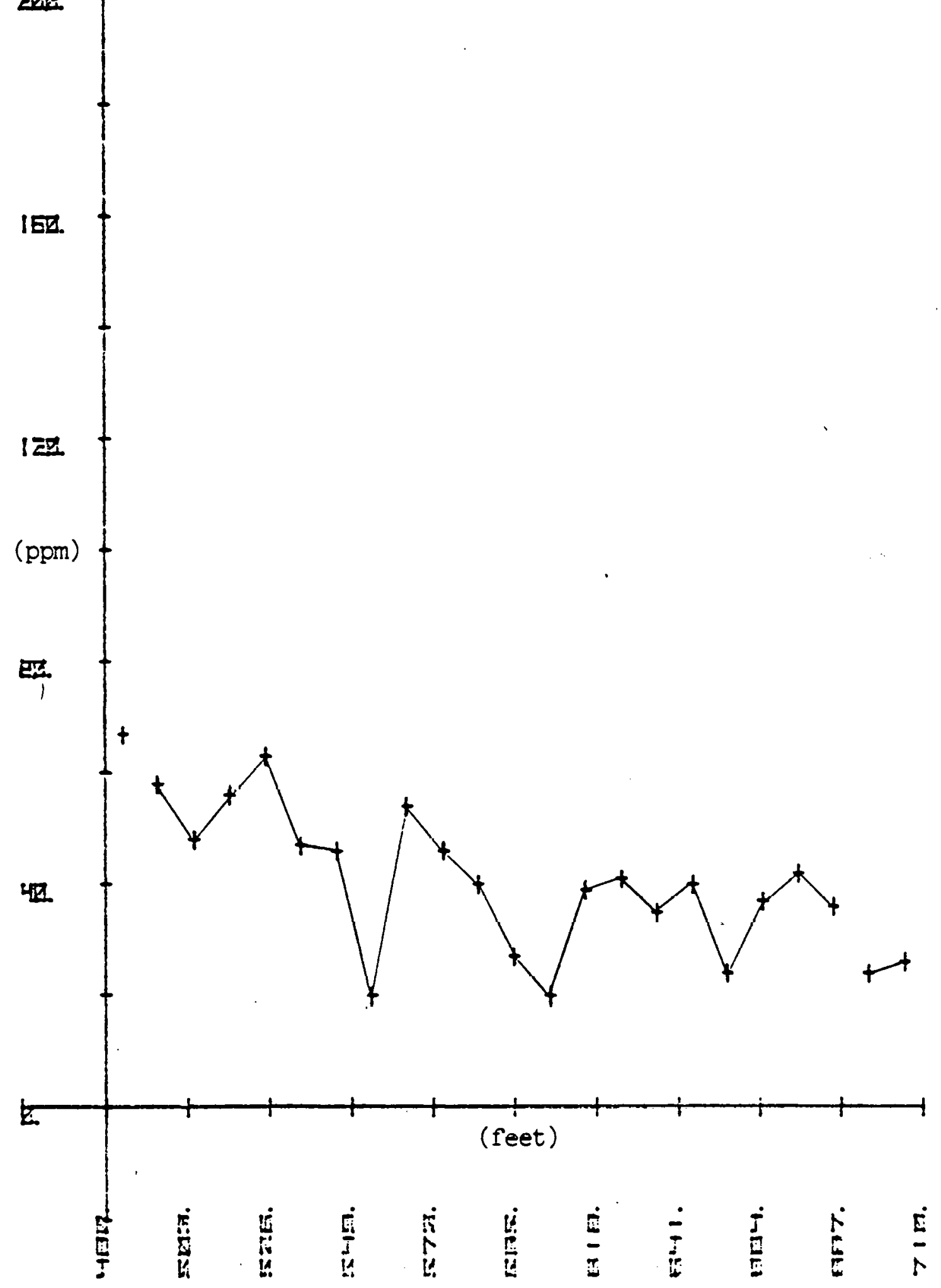




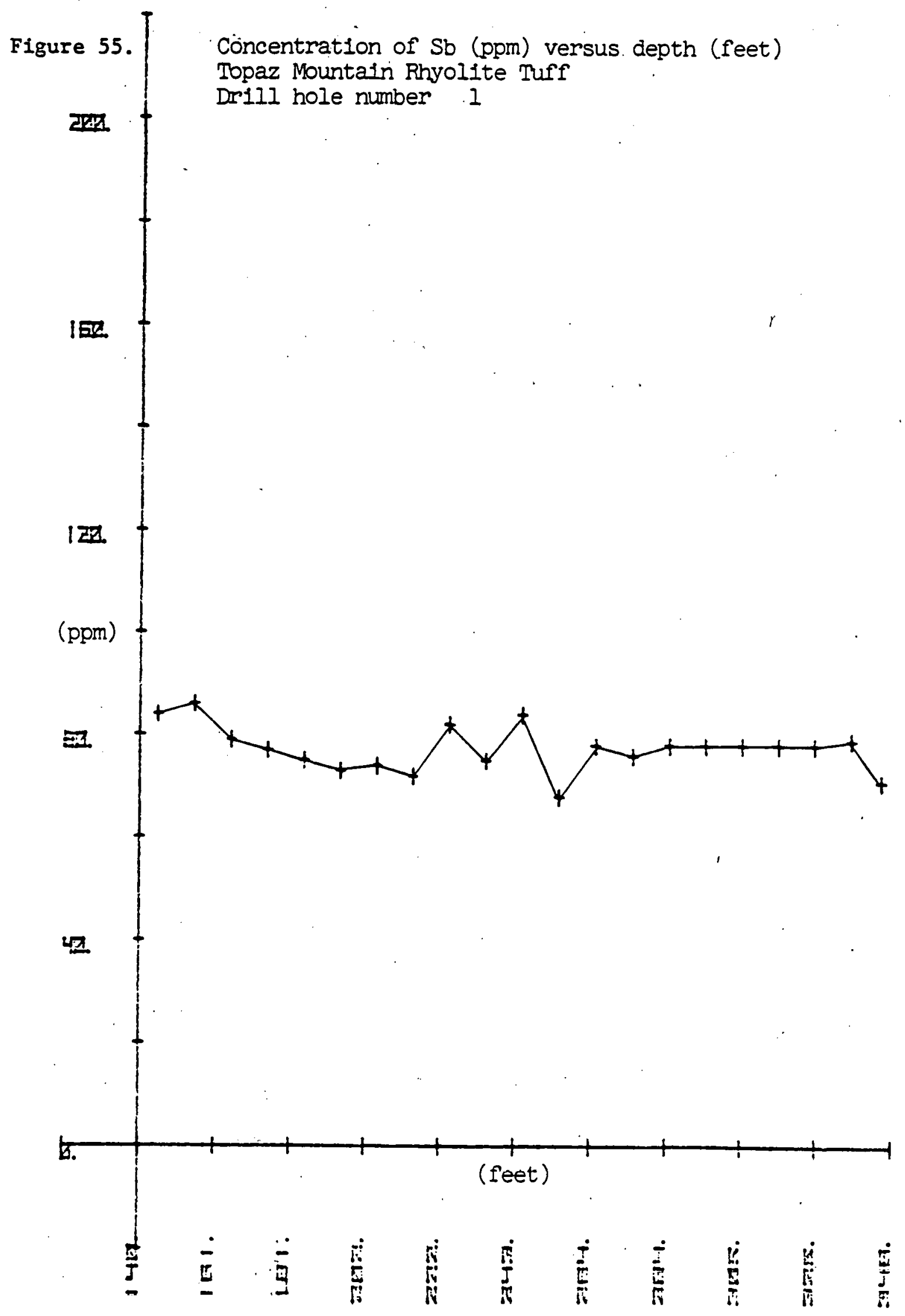


Figure 56.

בृम2

1 Eed.

1표.

(ppm)

ga

42.

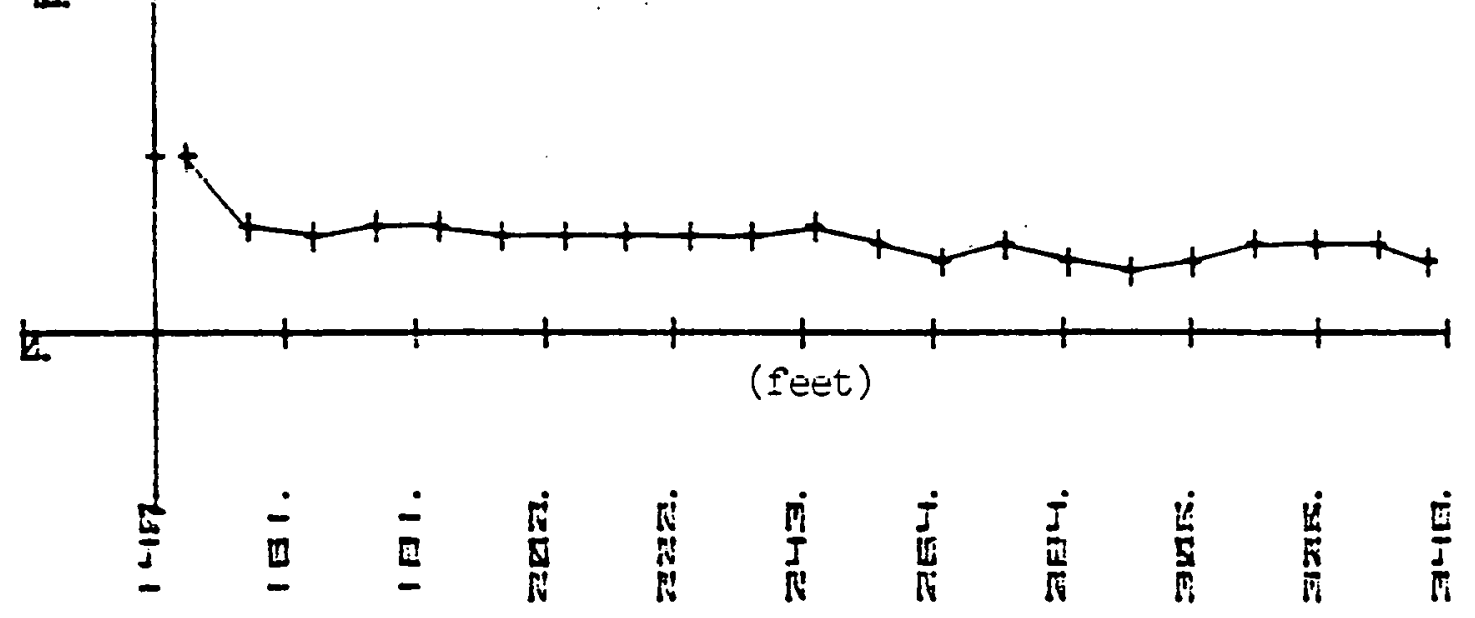




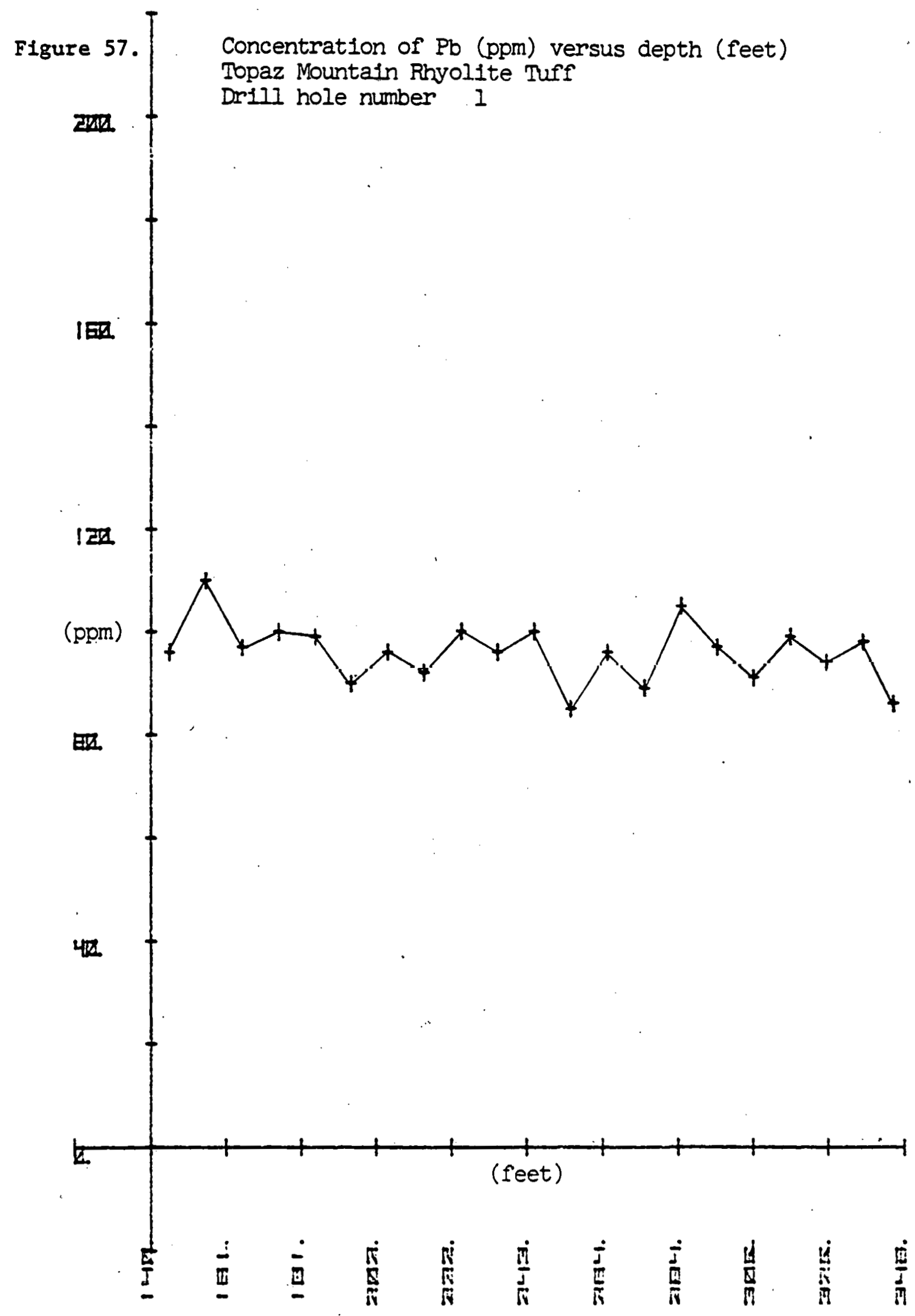


Figure 58. Concentration of $\mathrm{Li}$ (ppm) versus depth (feet)

Topaz Mountain Rhyolite Tuff

2क्रू $f$ Drill hole number 1

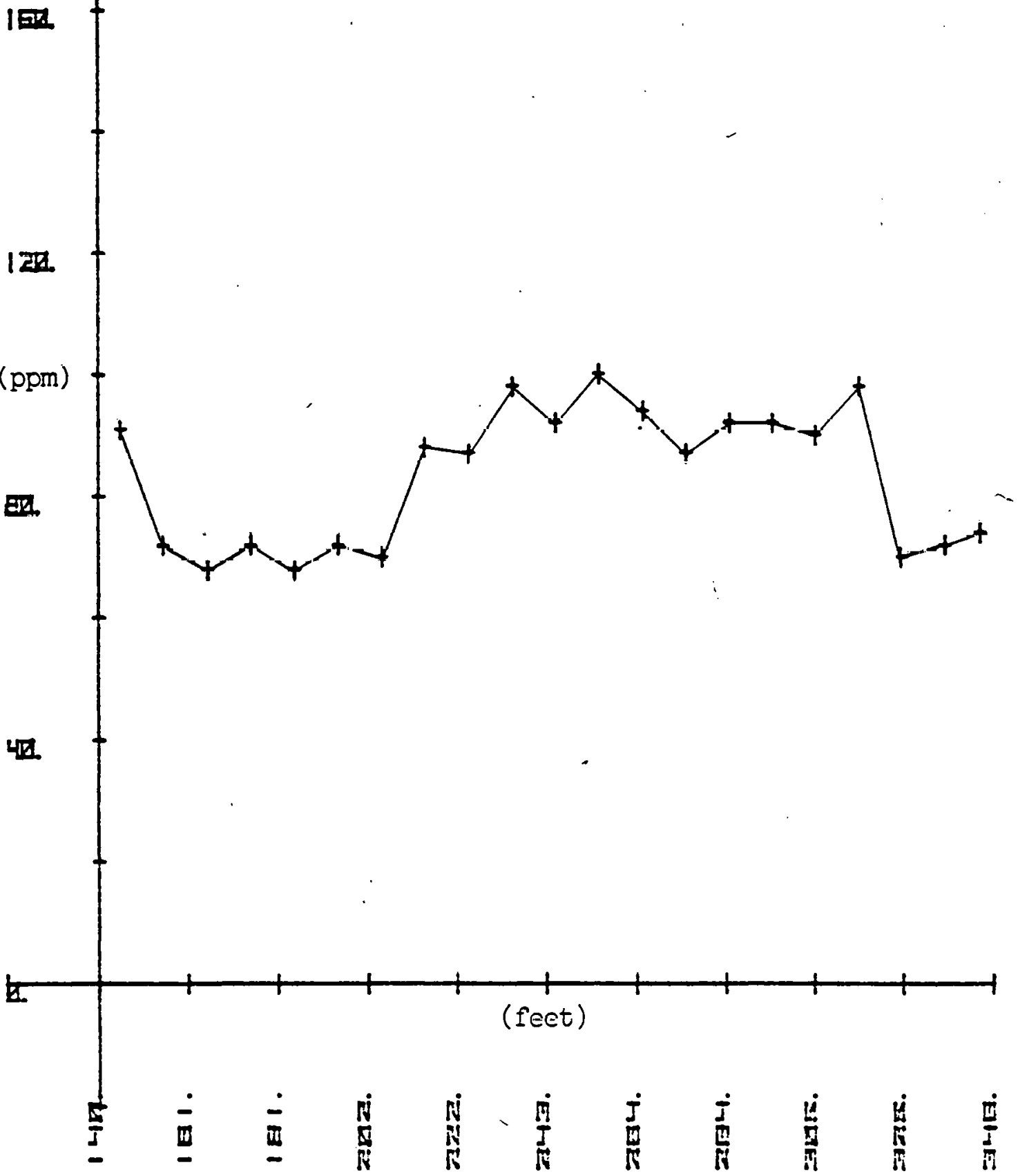




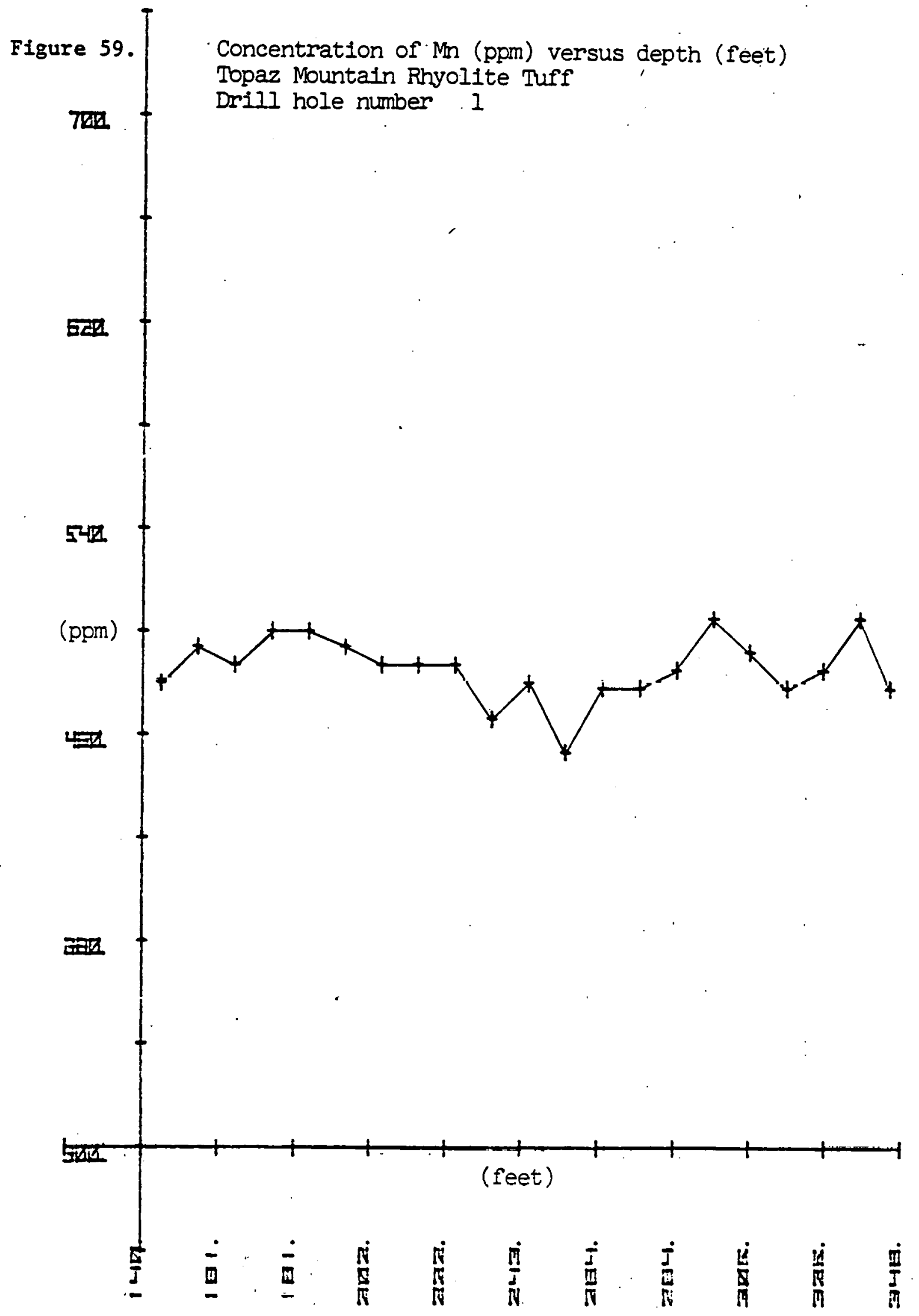



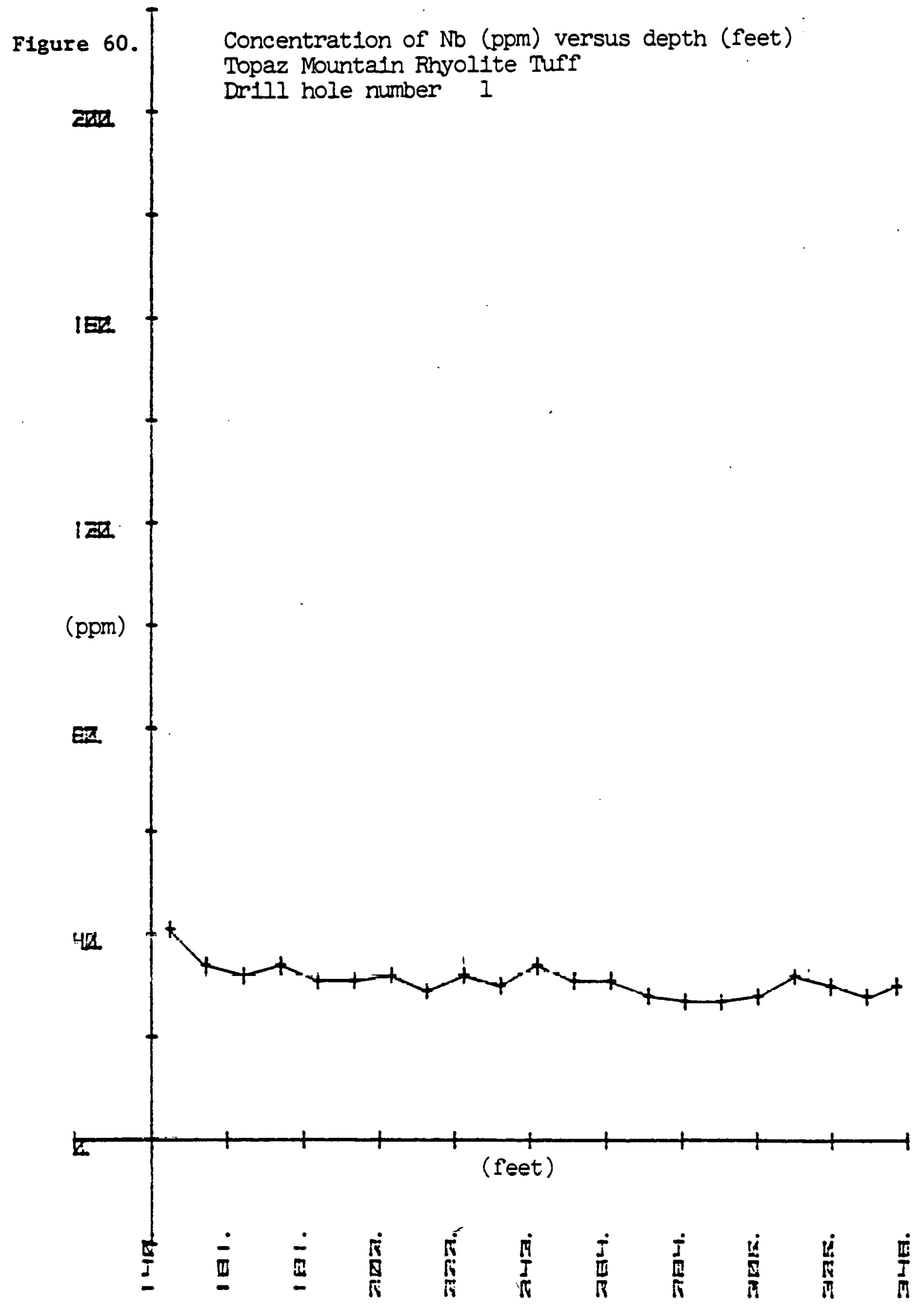


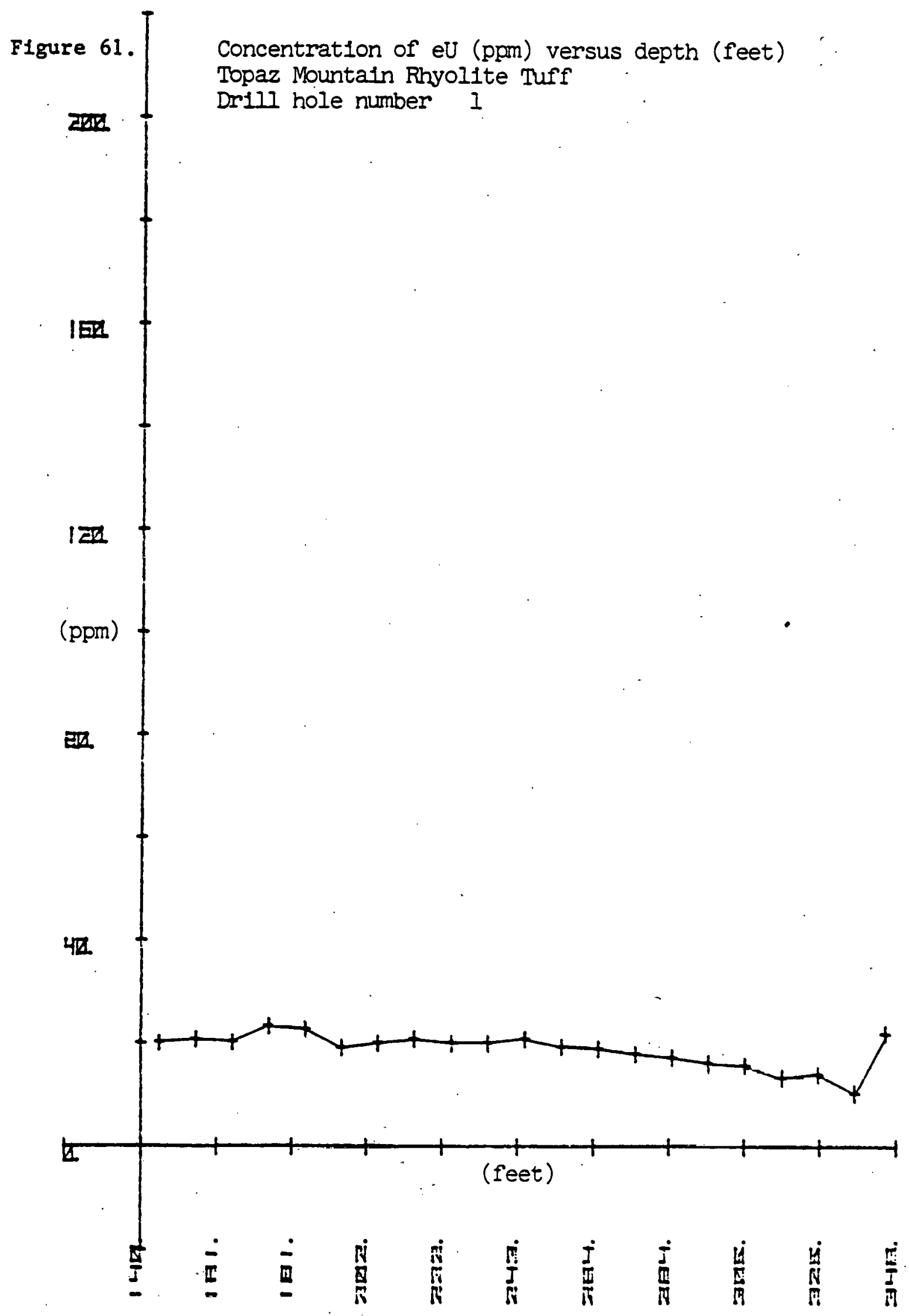


Figure 62. Concentration of $\mathrm{U}_{3} \mathrm{O}_{8}$ (ppm) versus depth (feet)

Topaz Mountain Rhyolite Turf

durf $f$ Drill hole number 1

IEA

IE

(ppm)

표

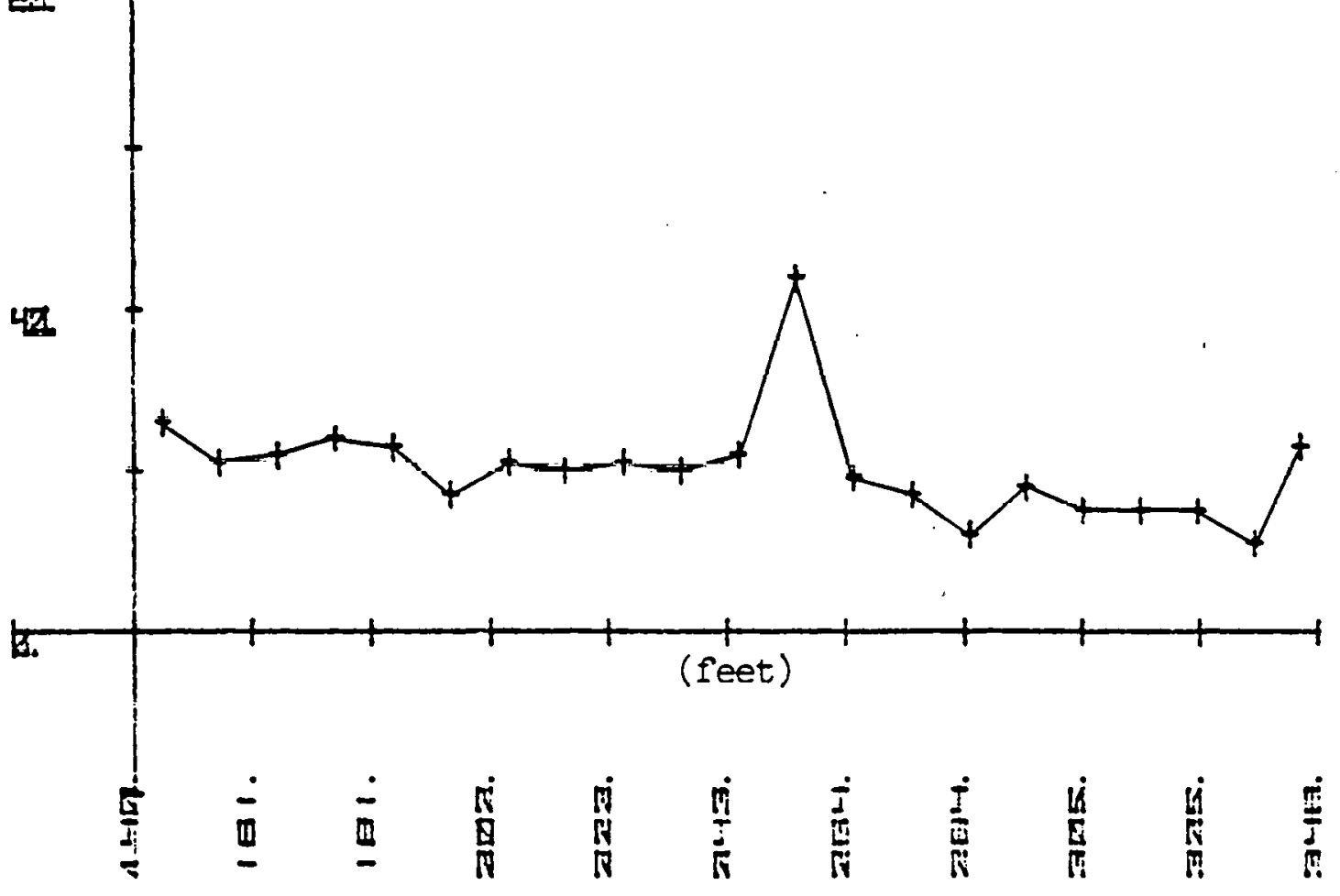


301

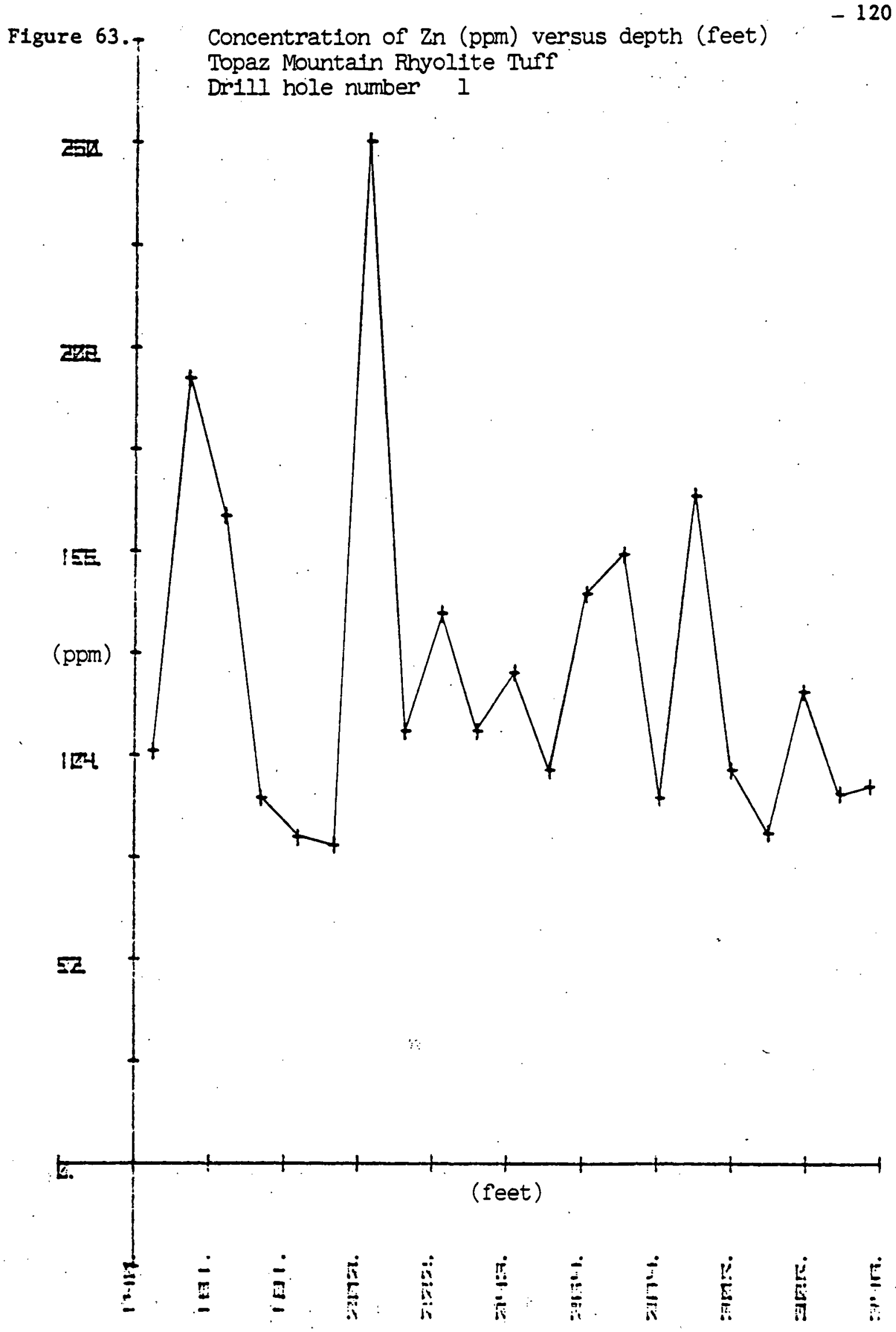


Figure 64.T $\begin{aligned} & \text { Concentration of } F(\mathrm{ppm}) \text { versus depth (feet) } \\ & \text { Topaz Mountain Rhyolite Tuff }\end{aligned}$

Drill hole number I

Is]

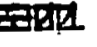




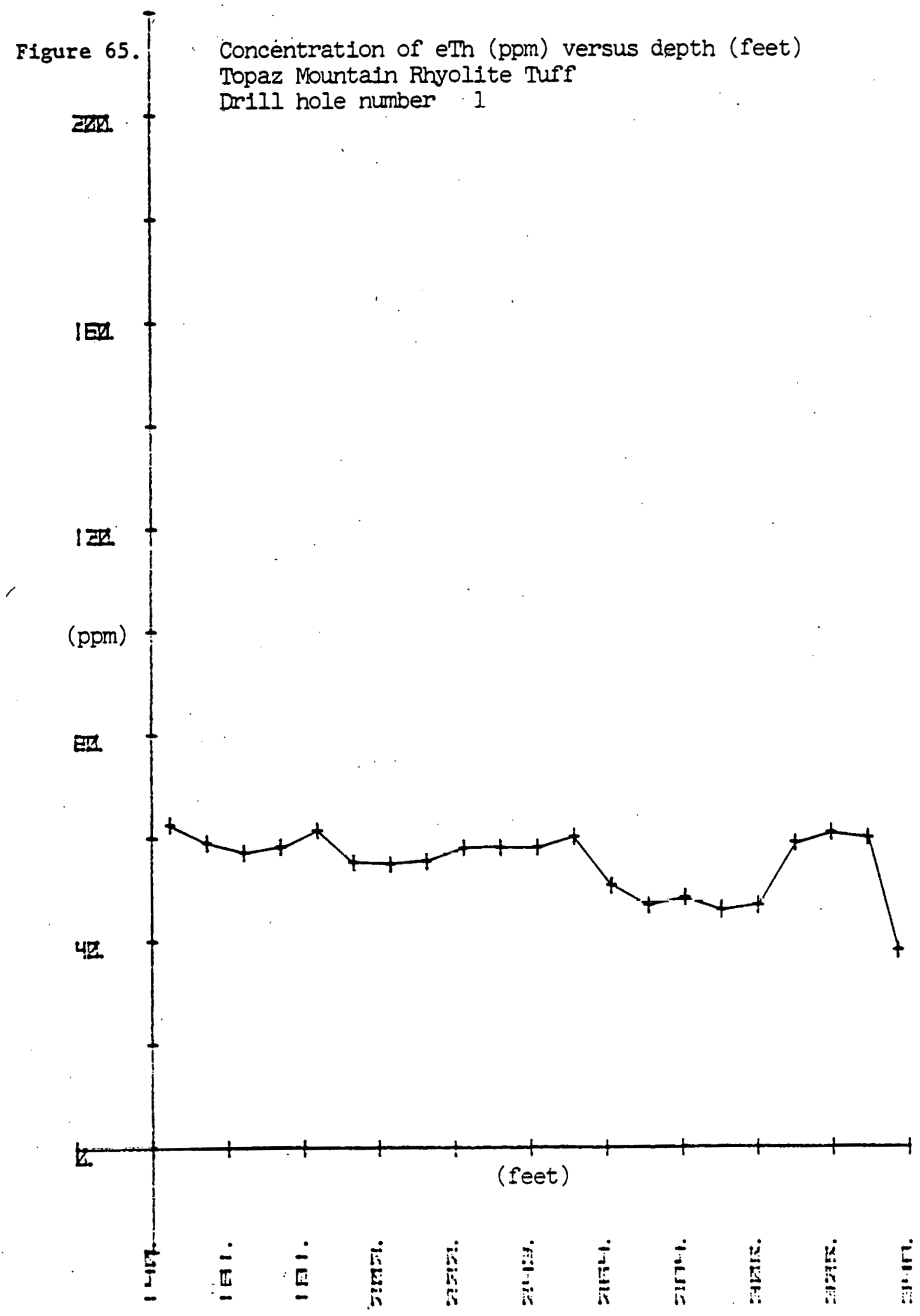


Figure 66.

ב्यद्य.

Concentration of $\mathrm{Zr}$ (ppm) versus depth (feet)

Topaz Mountain Rhyolite Tuff

Drill hole number 1

IER.

枉年

(ppm)

Q2

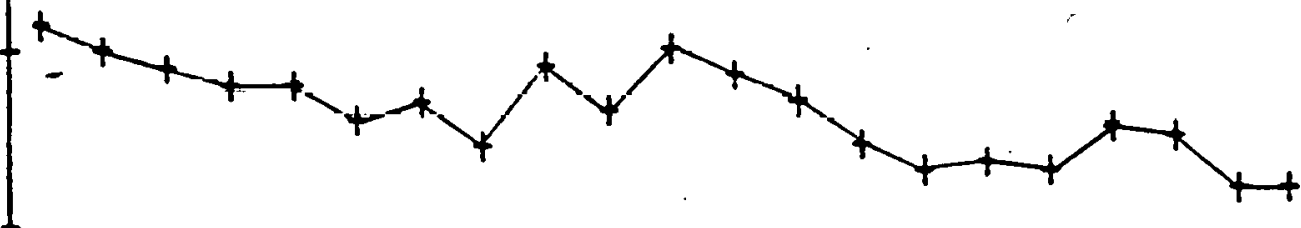

42

4.

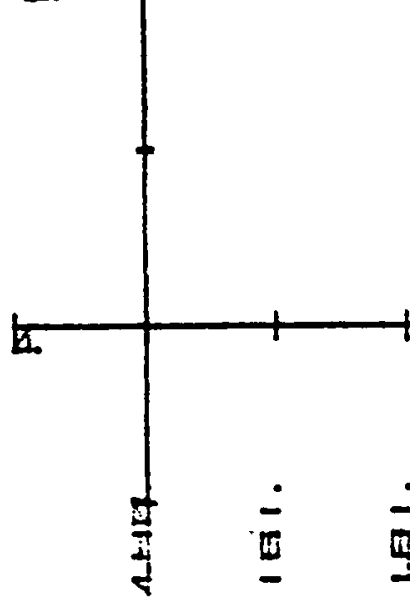

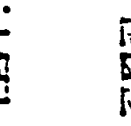

蕰

$\frac{i}{i t}$

$\frac{i}{\pi}$

$\frac{5}{i \pi}$

$\frac{i}{i !}$

$\stackrel{i}{i} \frac{\dot{E}}{i}$


p. 17; Lindsey, 1979a, p. 77). Fluoride complexes are thought to have formed with beryllium and other metals in solutions which moved through the Beryllium Tuff. A change in $\mathrm{pH}$ and fluoride ion activity in these solutions, brought about by the carbonate lithics of the Beryllium Tuff reacting with fluorine to produce fluorite, is generally accepted as the mechanism for the formation of the beryllium deposits in the tuff (Staat2, 1963; Williams, 1963; Shawe, 1968; Lindsey, 1979a).

The secondary processes which have acted to alter and mineralize the Beryllium Tuff failed to take place in the Stratified Tuff. Both tuffs are associated with topaz rhyolites and were emplaced by similar mechanisms. The lack of dolomite lithics in the Stratified Tuff is perhaps the most significant primary difference between the two tuffs. Any fluorine-enriched mineralizing solutions moving through the Stratified Tuff would probably not be greatly altered in $\mathrm{pH}$, and the mechanism proposed for ore genesis in the Beryllium Tuff could not occur. The slight fluorine anomaly at the top of the Stratified Tuff in hole number 1 (Fig. 64) is probably associated with the fused tuff also recognized at the top of the tuff (Fig. 16).

The small-scale cyclic variations in equivalent uranium (Fig. 41) may represent 1 ithic concentrations in the bases of thin ignimbrites not recognized due to poor preservation at the top of hole number 6 (Fig. 4). It is significant that the maximum concentration of equivalent uranium occurs in the uppermost cycle, because this mirrors on a small scale the elemental anomalies recognized at the top of the Beryllium Tuff in Figures $34,35,39$, and 40 for $U_{3} 0_{8}$ and equivalent uranium. These data differ are inconsistent with interpretation of 
Lindsey (1979a) in that uranium is not displaced from beryllium (Figs. 29 and 37). Apparently the process (or processes) which displaced uranium from beryllium did not act equally everywhere in the tuff. Whether this displacive process (or processes) was associated with a primary mineralizing episode in the Beryllium Tuff or with later secondary groundwater mobilization is not clear from this study.

The restriction of elemental anomalies to the top of the Beryllium Tuff constrains the location of the fluid migration which mineralized the tuff. From the measured sections, ignimbrites with carbonate 1ithics are common through the stratigraphic thickness of the tuff (Figs. 4 and 5), and although its concentration varies, calcium is also abundant through the stratigraphic thickness of the tuff in drill holes 6 and 18 (Figs. 67 and 68), The amount of calcium in the Beryllium Tuff reflects the original calcium carbonate abundance, because the lime content of the Porphyritic Rhyolite is low, less than one percent (Appendix 4). Except for the welded bomb bed in the Taurus Pit, secondary compaction welaing processes seem not to have affected the Beryllium Tuff. So, no apparent permeability or porosity controls for fluid migration and no calcium concentration variations exist in the Beryllium Tuff that would restrict the mineralization to the top of the tuff.

Petrography and Petrology of the Porphyritic

$$
\text { Rhyolite and the Alkali Rhyolite }
$$

\section{Glassy Rocks}

The Alkali Rhyolite vitrophyres commonly have 10 to 20 percent phenocrysts, although the alkali rhyolite of Antelope Ridge contains 37 
Figure 67. $\quad$ Concentration of $\mathrm{Ca}$ (pct) versus depth (feet)

Beryllium Tuff
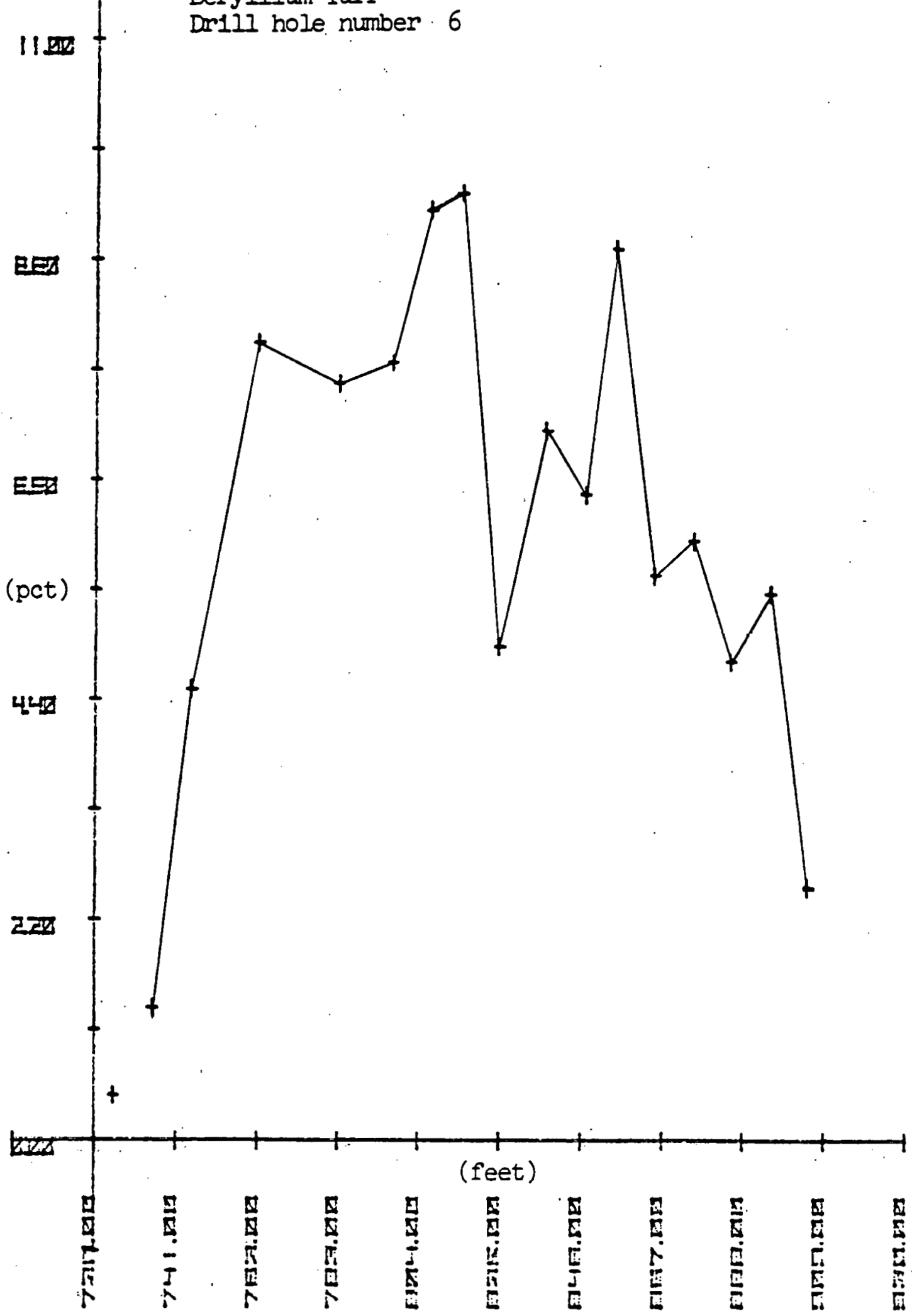


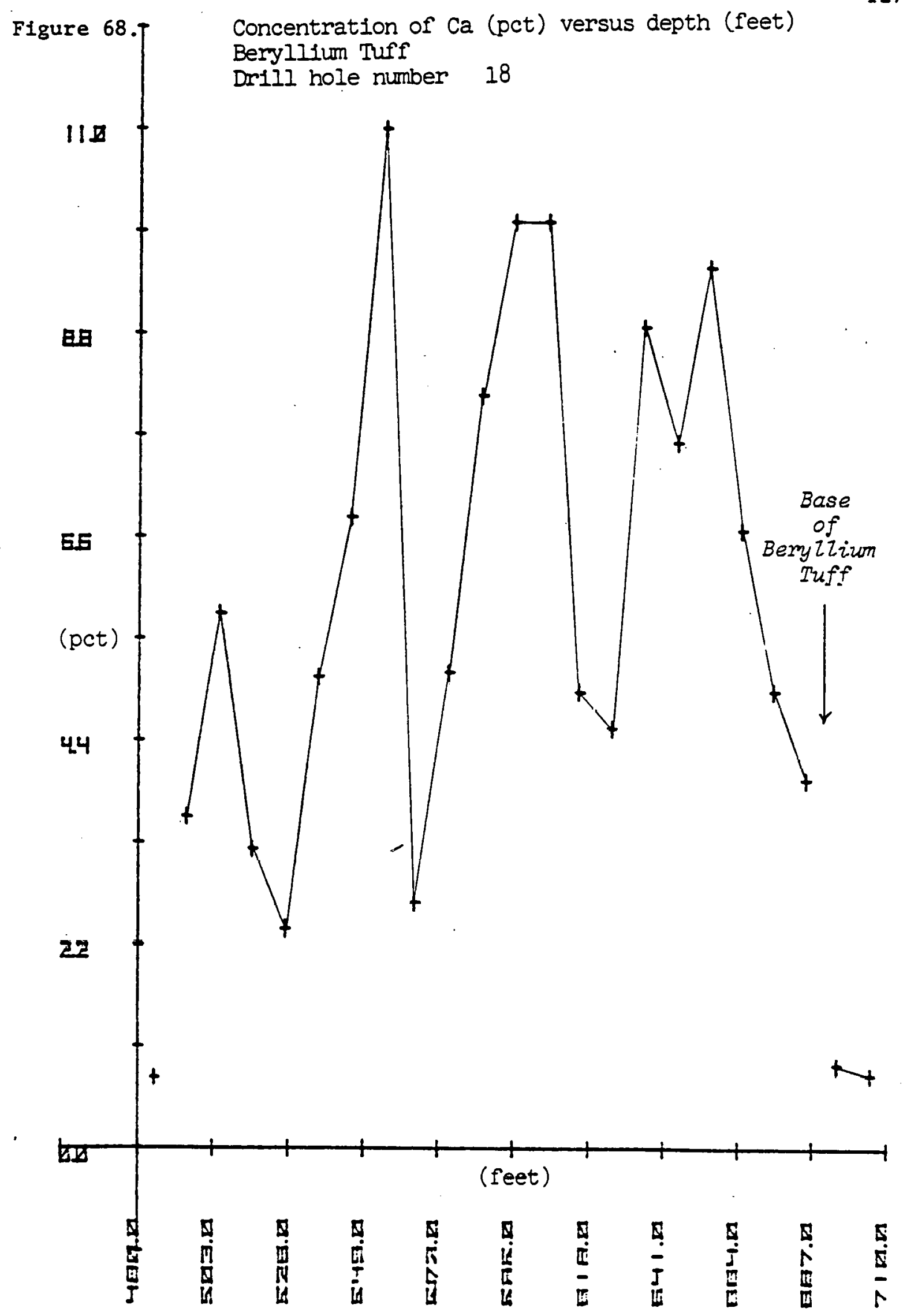


percent phenocrysts (Lindsey, 1979a; Turley and others, 1979). The most abundant phenocrysts are the alkali feldspars (Ab360r63-Ab480r52) (Turley and others, 1979). After quartz, unzoned plagioclase is the next most abundant phenocryst and has an average composition of $\mathrm{Ab}_{74} \mathrm{An}_{17}$ (Turley and others, 1979). Both feldspars are low in barium, no more than 0.04 percent (Turley and others, 1979). Red-brown biotites are the least abundant major mineral (Lindsey, 1979a). Accessory sphene and zircon occur in the vitrophyres (Turley and others, 1979). Ferrohastingsite is also an accessory phase in the vitrophyres (Appendix 1). The plagioclase are commonly mantled by alkali feldspars. The glassy matrix is flow-banded, and small acicular crystallites define the flow-banding. Feldspar thermometry after stormer (1975) indicates a mean equilibrium temperature of $720^{\circ} \mathrm{C}$ at 100 bars (Turley and others, 1979).

The Porphyritic Rhyolite contains approximately 40 percent phenocrysts (Lindsey, 1979a): Subhedral alkali feldspars are the most common phenocrysts in the vitrophyre of the Porphyritic Rhyolite and range in somposition from $\mathrm{Ab}_{42} \mathrm{An}_{1} \mathrm{O} 57$ to $\mathrm{Al}_{46} \mathrm{An} \mathrm{I}_{53}$ (Appendix 2). The next most abundant phenocrysts are embayed quartz. Anhedral to subhedral unzoned plagioclases that have an average composition of Ab81AngOr 11 are the third most abundant phenocrysts in the vitrophyre (Appendix 2). The feldspars have low barium contents (< 0.04 percent). The least abundant major phenocryst is dark brown subhedral to euhedral biotite. Minor amounts of zircon are also found. Plagioclase mantles biotite and alkali feldspar mantles plagioclase in the vitrophyres. Flow-banding is poorly developed in the vitrophyres and is defined by 
acicular crystallites. Figure 69 shows microprobe analyses of the feldspars plotted on a ab-or-an diagram. Two-feldspar geothermometry of the Porphyritic Rhyolite gives a mean equilibrium temperature of $681^{\circ} \mathrm{C}$ at 100 bars (approximately $0.3 \mathrm{~km}$ ) and increases $12^{\circ} \mathrm{C}$ if an equilibrium pressure of $1 \mathrm{kbar}$ is assumed (Fig. 70).

\section{Crystalline Rhyolites}

The holocrystalline porphyritic facies of the Alkali Rhyolite and the Porphyritic Rhyolite are quite distinct petrographically and in outcrop. Outcrops of crystalline Alkali Rhyolite in the Thomas Range have a characteristic honeycomb weathering pattern, whereas the Porphyritic Rhyolite is massive appearing in outcrop.

The felsophyric or holocrystalline porphyritic facies of the Alkali Rhyolite in thin section has phenocrysts similar to those of the vitrophyric facies except that some biotites are ragged in outline. Spherulites and lithophysae are common in the groundmass and are often surrounded by anhedral crystals of quartz and alkali feldspar (20 $\mu \mathrm{m}$ ) with an allotriomorphic-granular texture. Topaz, garnet, and beryl are mainly restricted to the lithophysae, but groundnass copaz does occur. Acicular crystallites and oxides persist in the microcrystalline groundmass and sometimes define flow-banding. Some light green chlorite is found in the groundmass. Argillization of the groundmass is evident in some thin sections. The felsophyric facies of the Alkali Rhyolite is dominated by spherulites or lithophysae or both, and varying amounts of allotriomorphic-granular texture quartz and alkali feldspar occur between these features. 


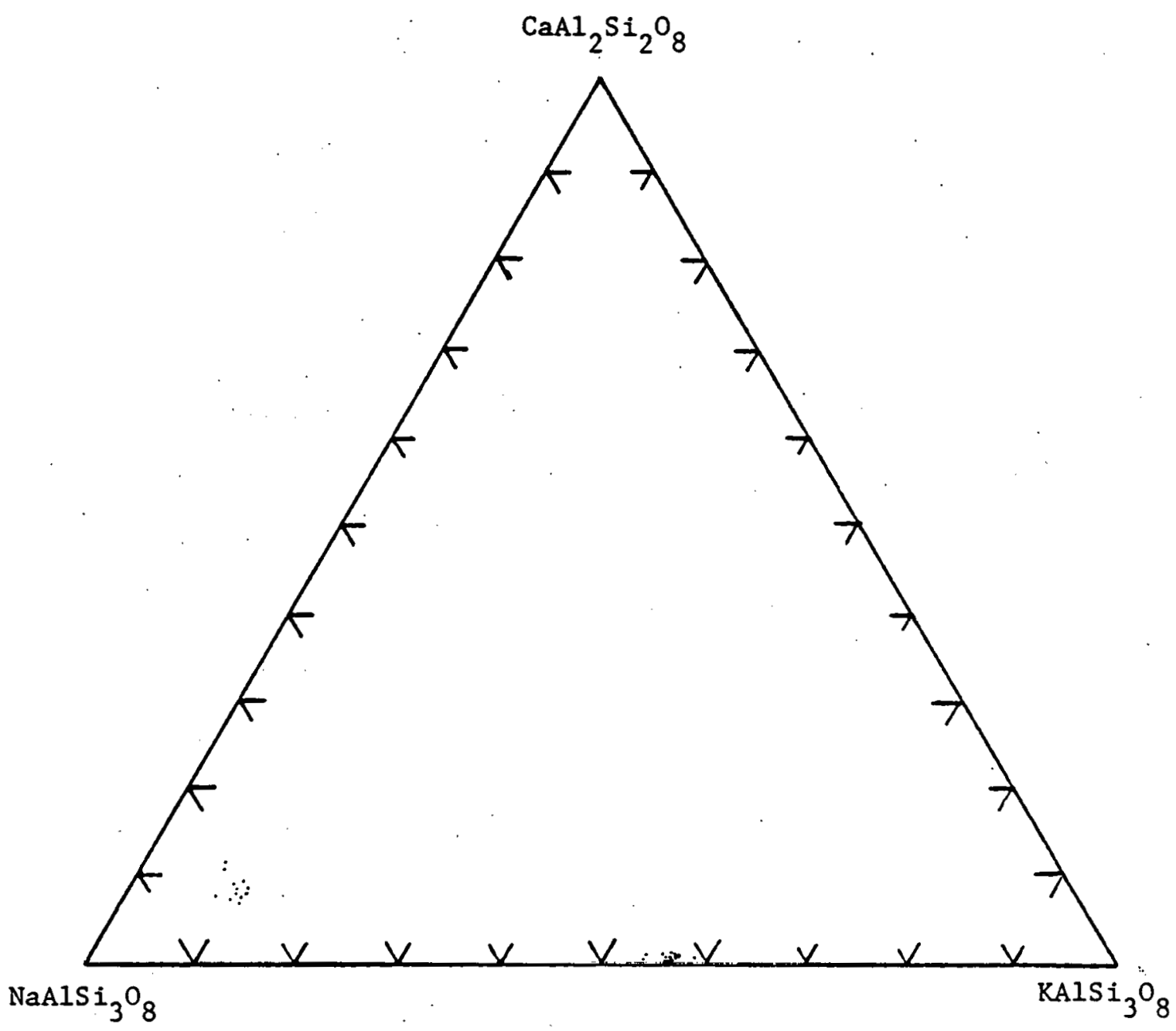

Figure 69. Ternary composition of phenocryst feldspars in the Porphyritic Rhyolite. 
Figure 70. Two-feldspar geothermometry of the Porphyritic Rhyolite (after Stormer, 1975).

\begin{abstract}
$\mathrm{AK}$ - mole fraction of $\mathrm{NaAl} \mathrm{Si}_{3} \mathrm{O}_{8}$ component in alkali feldspar
$\mathrm{HL}$ - mole fraction of $\mathrm{NaAl} \mathrm{Si}_{3} \mathrm{O}_{8}$ component in plagioclase feldspar
\end{abstract}

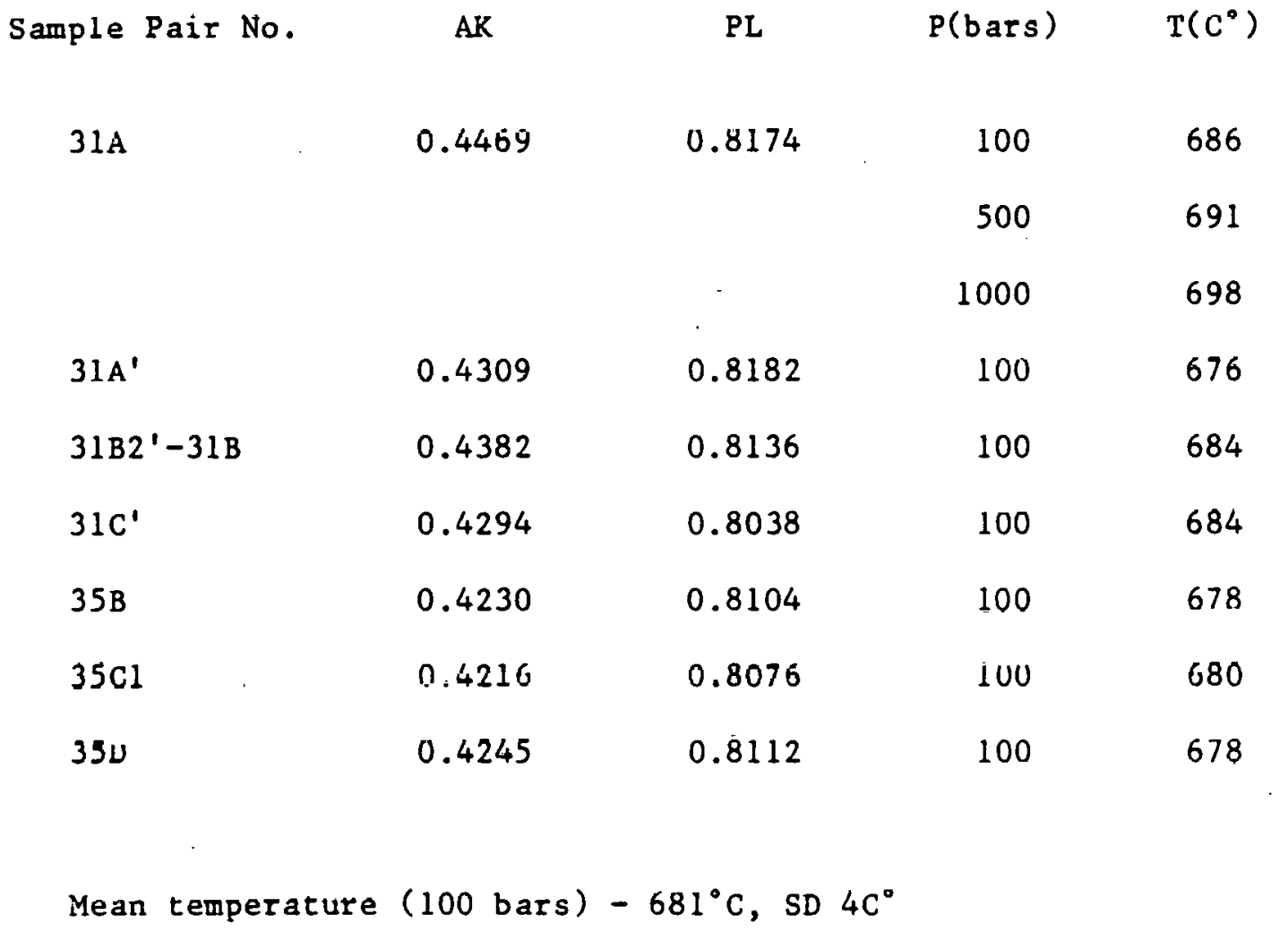


The felsophyric facies of the Porphyritic Rhyolite has a hypidiomorphic-granular to microphenocrystic texture and is formed of quartz, alkali feldspar, and ubiquitous biotite, all 20 to $40 \mu \mathrm{m}$ in diameter. Phenocrysts in the felsophyres are similar to those found in the vitrophyres except that biotites are typically altered to oxides and rimmed by secondary biotites similar to those found in the groundmass, and that the phenocrysts occasionally have scalloped borders. The groundmass lacks spherulitic and lithophysal textures, but miarolitic cavities occur. No crystallites are present in the groundmass. Dark red inclusions, up to 6 inches $(15 \mathrm{~cm}$ ), surrounded by white haloes which contain megascopic topaz in cavities, are common in the felsophyric facies of the Porphyritic Rhyolite (Fig. 71). Occasionally these inclusions are elongate, but usually they are subrounded in outline. A distinctive feature of these inclusions is their large plagioclase phenocrysts (Appendix 2). Topaz is common in the groundmass of the Porphyritic Rhyolite and occurs both as rosettes, in which individual crystals reach $0.1 \mathrm{~mm}$, projecting into miarolitic cavities, and as spongy inclusion-rich crystals. The miarolitic topaz appears to be a result of vapor-phase processes. The groundmass texture of the Porphyritic Rhyolite has been classified as a granophyric texture in other rhyolite lava flows (Henry and Tyner, 1978), and is distinctly different from the dominantly spherulitic and lithophysal textured groundmass of the Alkali Rhyolite. 


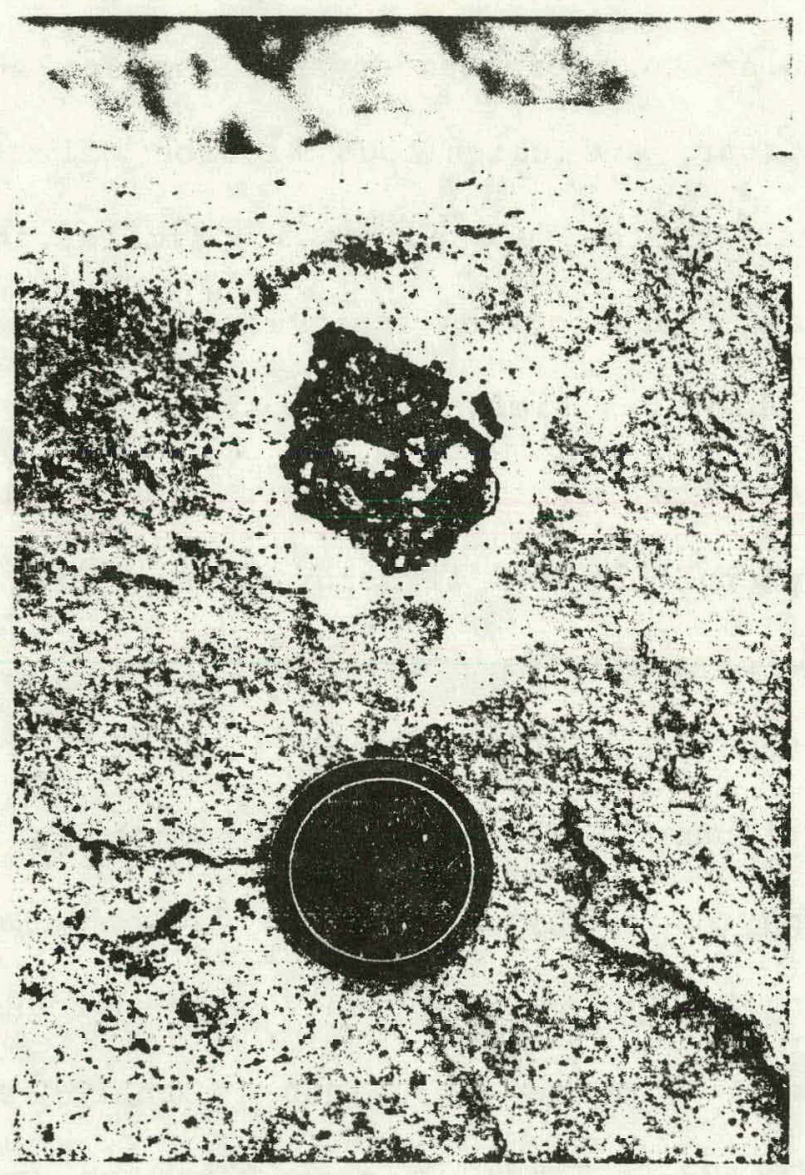

rigure 71. Mafic inclusion in Lhe Puspliysitic Khyolite exposed at the Blue Chalk Pit. Note white halo around inclusion and large phenocryts within the inclusion. 
Major Element Geochemistry

Major element geochemistry of the Porphyritic Rhyolite and the Alkali Rhyolite (Appendices 3, 4, and 5) shows them to belong to the high-silica rhyolite class of the western United States (Christiansen and Lipmann, 1972; Evans and Nash, 1978; Elston and Bornhorst; 1979). Typical of this class are silica values greater than 72 percent, high total alkalis, low lime, low magnesia, and low titania. For the Porphyritic Rhyolite, the mean and standard deviation for silica $73.93(0.82)$ percent, total alkalis $8.82(0.46)$ percent, lime, $0.61(0.27)$ percent, magnesia $0.11(0.06)$ percent, and titania $0.05(0.01)$ percent of the analyses are representative of the high-silica rhyolite class. Similarly, for analyses of the Alkali Rhyolite, the mean and standard deviation for silica $75.60(0.71)$ percent, total alkalis $8.79(0.22)$ percent, 1 ime $0.83(0.37)$ percent, magnesia $0.15(0.07)$ percent, and titania $0.14(0.09)$ percent are typical of those for the highsilica rhyolite class. These have been called rare metal rhyolites by R. Wilson (personal communication, 1980). Both the Porphyritic Rhyolite and the Alkali Rhyolite are classified as borderline between alkali-soda rhyolite and rhyolite from the scheme of Rittmann (1952). Because of the topaz in the mode of both rhyolites, these rocks also belong to a little-studied suite of topaz rhyolites that occur in the western United States and Mexico (Shawe, 1976; Burt and Sheridan, 1980).

Vitrophyres of the two rhyolites can be distinguished from their major element geochemistries. Silica, alumina, titania, magnesia, and fluorine contents of the vitrophyres are distinct and characterize each rhyolite. The Alkali Rhyolite has greater silica, magnesia, and titania 
than the Porphyritic Rhyolite with comparative mean values.at 75.89 $(0.53)$ percent and $73.12(0.86)$ percent for silica, respectively, 0.10 (0.04) percent and $0.06(0.02)$ percent for magnesia, respectively, and $0.14(0.07)$ percent and $0.05(0.01)$ percent for titania, respectively (with some data from Turley and others, 1979). The Porphyritic Rhyolite has greater alumina and fluorine than the Alkali Rhyolite, with comparative values at $13.39(0.42)$ percent and $12.53(0.41)$ percent for alumina, respectively, and $1.19(0.31)$ percent and $0.23(0.08)$ percent for fluorine, respectively (with some data from Turley and others, 1979). The fluorine content of the vitrophyre from the we11-known 28 m.y. old topaz rhyolite at Nathrop, Colorado, is only 0.17 percent (Van Alstine, 1969, Zielinski and others, 1977), and the average for all high-silica rhyolites (alkali rhyolites) in the western United States is 0.22 percent (Shawe, 1976).

Normative determinations from the geochemical analyses of both rhyolites also distinguish them. When fluorine is considered in the norms, all of the fluorine is first combined with the calcium to produce fluorite, and for these low-calcium rocks diopside and often anorthite disappear from the norm and all rocks become corundum-normative (Appendix 6). Because anorthite is a component in the feldspars from both rhyolites (Appendix 2) (Turley and orhers, 1979) and fluorice has not been identified in the mode of either vitrophyre, it would seem that fluorine does not combine with calcium, at least early in the crystallization of a melt, and it seems justified to compare the norms of the rhyolites on a fluorine-free basis (Appendix 4 and 5). Following this procedure, the norms from the Porphyritic Rhyolite are mostly 
corundum-normative, and the norms from the Alkali Rhyolite are mostly diopside-normative. Obviously, this reflects differences in the lime and alumina contents of both rocks. Plots of normative qt-ab-or for the Porphyritic Rhyolite (Fig. 72) and for the Alkali Rhyolite (Fig. 73) fall near the water-saturated granite minimum at 1 kbar.

\section{Minor Element Geochemistry}

The beryllium, lithium, rubidium, tin, and uranium abundances in the vitrophyres of the Porphyritic Rhyolite and of the Alkali Rhyolite are distinctive and fall into separate groups (Appendices 7 and 8) (some data from Turley and others, 1979). A comparison of the vitrophyres of the Porphyritic Rhyolite and of the Alkali Rhyolite shows that the former is enriched in beryllium 63 (17) ppm versus 7 (3) ppm, lithium 90 (14) ppm versus 33 (16) ppm, rubidium 1,015 ppm versus 376 (170) ppm, tin $30 \mathrm{ppm}$ versus $2 \mathrm{ppm}$, cesium $56 \mathrm{ppm}$ versus 10 (4.8) ppm, tantalum $25 \mathrm{pfm}$ versus $4(1.6) \mathrm{ppm}$, thorium $66 \mathrm{ppm}$ versus 48 (12) ppm, zirconium $775 \mathrm{ppm}$ versus 577 (65) ppm, and uranium. $37 \mathrm{ppm}$ versus 16 (6.7) ppm, compared to the latter. Strontium in both vitrophyres is about 5 ppm. Chondrite-normalized ratios of lanthanum to ytterbium for two analyzed samples of the Porphyritic Rhyolite differ slightly, being 2.46 and 2.52, whereas for the Alkali Rhyolite this ratio varies from 1.24 to 12.1 (Appendices 7 and 8). The heavy rare-earth elements are enriched in the Porphyritic khyolite with respect to the Alkali Rhyolite (Appendices 7 and 8 ).

When only the felsophyres of the Alkali Rhyolite and of the Porphyritic Rhyolite are compared, the relationship between beryllium, 


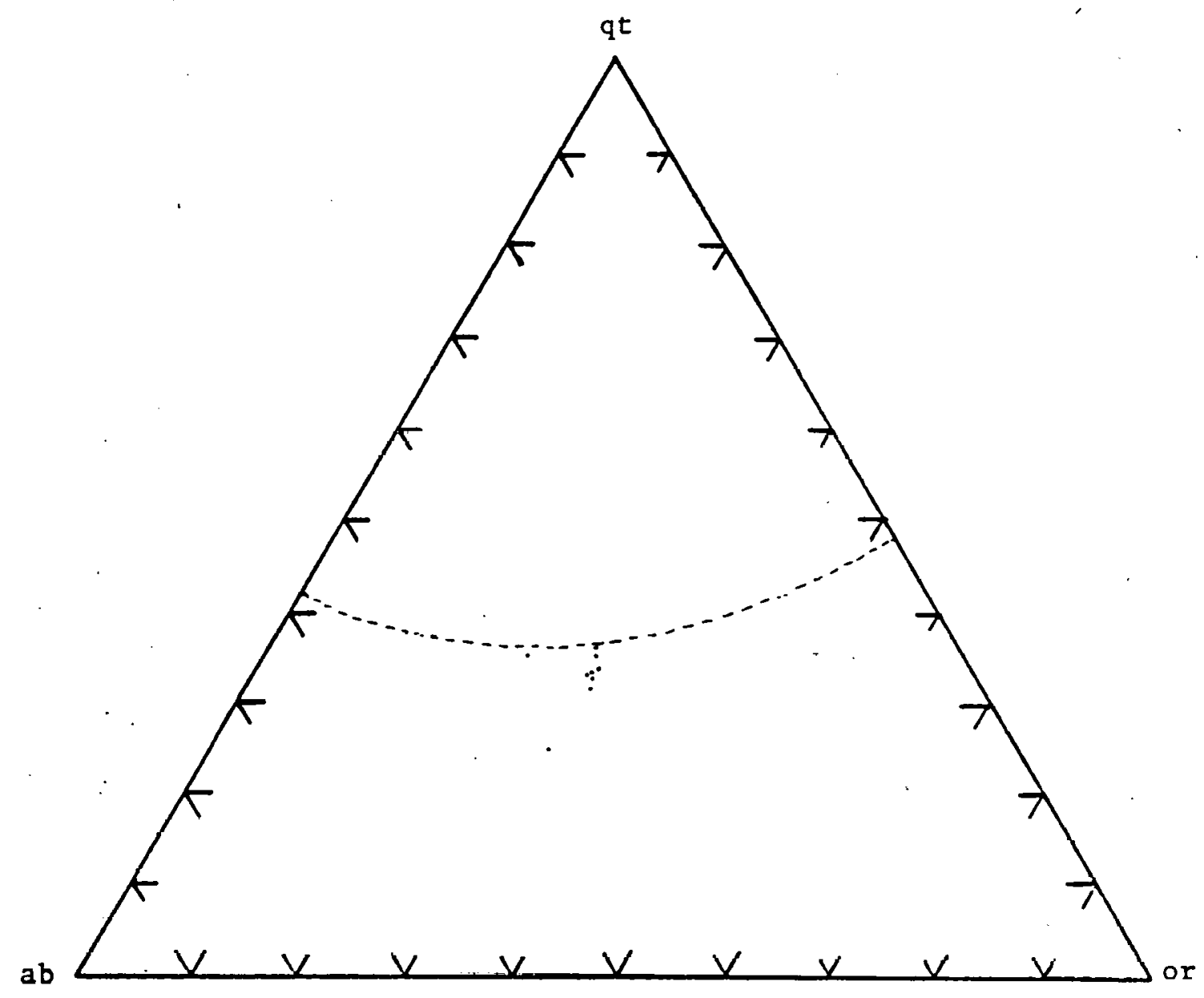

Figure 72. CIPW normative qt-ab-or composition of the Porphyritic Rhyolite on a fluorine free basis. Dashed line is 1 kbar water-saturated equilibrium curve (Tuttle and Bowen, 1958). 


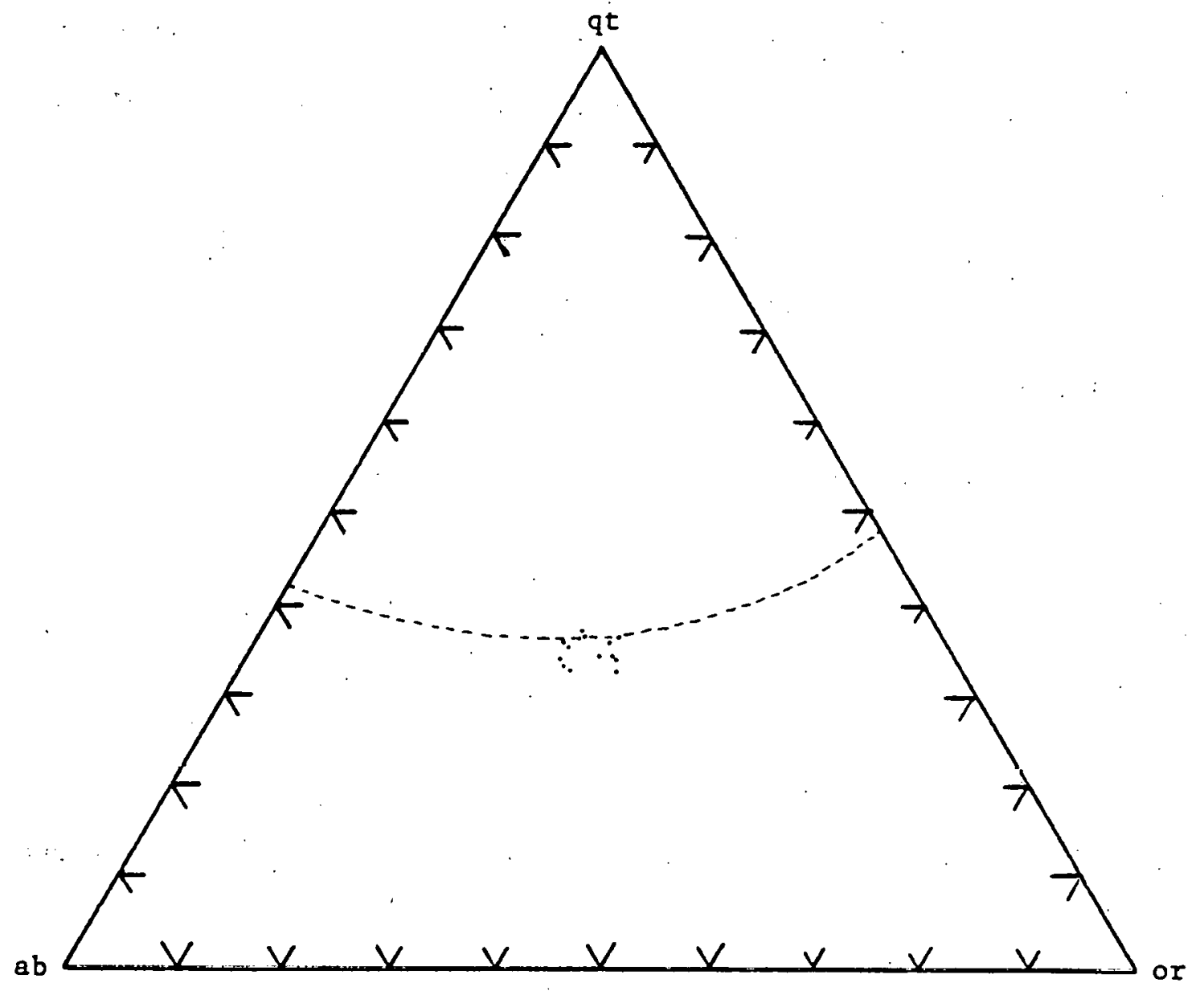

Figure 73. CIPW normative qt-ab-or composition of the Alkali Rhyolite on a fluorine free basis. Dashed Iine is 1 kbar water-saturated equilibrium curve (Tuttle and Bowen, 1958). 
fluorine, and uranium in the two rhyolites is changed (some data from Lindsey, 1979a, and Turley and others, 1977). The magnitude of the difference between beryllium 12 (6) ppm versus 8 (3) ppm, and fluorine 0.61 (0.17) percent versus $0.19(0.07)$ percent, in the Porphyritic Rhyolite and the Alkali Rhyolite, respectively, is smaller. Uranium in felsophyres from the Alkali Rhyolite, 16 (4) ppm, is greater than in felsophyres from the Porphyritic Rhyolite, 14 (3) ppm, and this relationship is reversed from that in the vitrophyres.

\section{Conclusions}

Origin of the Beryllium and Uranium

Mineralization in the Spor

Mountain District

If the vitrophyres of the Forphyritit Rlyolite and the Alkali Rhyolite can be construed to be similar in composition to the parent lava, then differences in elemental concentrations between respective vitrophyres and felsophyres may represent losses or gains upon formation of a crystalline matrix. A comparison of vitrophyres and felsophyres from the Porphyritic Rhyolite exhibits changes of 51 ppm beryllium, 0.58 percent fluorine, and $23 \mathrm{ppm}$ uranium. In the Alkali Rhyolite, the vitrophyres and felsophyres have differences of 0 ppm in beryllium, $4 \mathrm{ppm}$ in fluorine, and $6 \mathrm{ppm}$ in uranium. In volcanic complexes with large elemental differences between vitrophyres and felsophyres, ore deposits are sometimes formed (Shatkov and others, 1970).

Whether or not uranium is lost from a rhyolite crystallizing on the surface is dependent upon what crystallization mechanisms operated 
during solidification. Two high-temperature surface crystallization phenomena in rhyolites have been recognized: high-temperature glass devitrification forming spherulitic textures, and granophyric crystallization forming hypidiomorphic-granular textures (Henry and Tyner, 1978). Spherulitic textures are favored by undercooling and low nucleation densities (Henry and Tyner, 1978). Little or no uranium loss is associated with spherulitic crystallization, whereas granophyric textures are found in rhyolites which have lost uranium (Henry and Tyner, 1978). Uranium can be trapped in a crystallizing rhyolite by accessory minerals (Shatkov and others, 1970); however, granophyric crystallization may be associated with the separation of a fluid phase rich in volatile uranium complexes, and the loss of such complexes from the melt could prevent the incorporation of uranium into accessory minerals. Besides uranium loss upon surface crystallization, fluorine and beryllium have been shown to be depleted in some crystalline rocks compared to their related vitrophyres (Noble and others, 1967; Shatkov and others, 1970; Zielinski and others, 1977).

The textures and the elemental differences found between the felsophyres and the vitrophyres of the Porphyritic Rhyolite and of the Alkali Rhyolite are consistent with the preceding discussion. The Porphyritic. Rhyolite with a granophyric texture has high elemental differences compared to its vitrophyre, and the Alkali Rhyolite with a spherulitic texture has very low elemental differences compared to its vitrophyre.

Large differences in beryllium, fluorine, and uranium in the felsophyric facies Porphyritic Rhyolite may ultimately be related to 
the chemistry of the lava. Fluorine and hydroxyl ions both lower viscosity, but hydroxyl ions, which are charged into a vapor phase at higher temperatures than fluorine ions in granitic melts (Bailey, 1977), are rapidly lost on eruption. Persisting lowered viscosity would favor a higher nucleation density in the more fluorine-enriched lava, because diffusion would be increased. Water and fluorine are also known to depress the melting point of granitic composition, and a loss of water to the vapor phase in a fluorine-enriched lava probably would not increase the temperature of the solidus enough to cause undercooling. These factors, high nucleation densities and persisting lowered solidus temperatures, presumably promoted granophyric textures over spherulitic textures in the Porphyritic Rhyolite. The high fluorine concentration very likely promoted the formation of complex flunrite inns of uranium and beryllium which may have prevented their entry into accessory minerals (Shatkov and others, 1970; Rosholt and others, 1971). These fluoride complexes may have escaped in a fluid phase as crystallization occurred. Even under anhydrous conditions, minimum melting in the system $\mathrm{BeF}_{2}-\mathrm{UF}_{4}-\mathrm{NaF}$ occurs at temperatures as low as $339^{\circ} \mathrm{C}$ (Eichelberger and others, 1963).

The lithophysal and spherulitic textures found in the Alkali Rhyolite are probably related to the apparent lower fluorine content of its lava. The two-feldspar equilibrium temperatures of the Alkali Rhyolite and the Porphyritic Rhyolite indicates that the Alkali Rhyolite's parent melt equilibrated at a higher temperature, $720^{\circ} \mathrm{C}$, than the Porphyritic Rhyolite's parent melt, $680^{\circ} \mathrm{C}$. This is consistent with its apparently lower fluorine content compared to the Porphyritic Rhyolite, 
as fluorine is known to lower the melting temperatures of granitic melts (Bailey, 1977). A higher equilibrium temperature may indicate a higher temperature of extrusion for the Alkali Rhyolite. Although water is known to lower viscosities of granitic magmas, lithophysae found even in the vitrophyres of the Alkali Rhyolite indicate that the water was lost rapidly upon cooling. Lithophysae can result from high vapor pressures of water in a lava, because they represent a frozen sequence of intermittent bubble expansion. When water loss occurred from the Alkali Rhyolite lava, the apparently lower fluorine content of the lava resulted in a rapid increase in both the viscosity and the temperature of the solidus of the rhyolitic lava. These rapid changes in the lava's physical properties promoted the formation of spherulitic undercooling textures. Without the separation of a fluid phase, thought associated with the formation of granophyric textures, the acicular crystallites and oxides found in the felsophyres of the Alkali Rhyolite may have trapped much of the original uranium in the lava.

In a tuff-rhyolite sequence such as the Spor Mountain Formation; . mineralizing fluids have been postulated to move laterally through the tuff and to be restricted to the top of the tuff, because the capping rhyolite could have acted as a heat source, which would have elongated circulation cells formed around the cooling vent complex of these rocks (Burt and Sheridan, 1980). The present stratigraphic thickness of the Beryllium Tuff, 20 to $60 \mathrm{~m}$, and of the Porphyritic Rhyolite, up to $500 \mathrm{~m}$, indicates that this tuff-rhyolite sequence probably was an imposing constructional feature on the landseape $21 \mathrm{~m} \cdot \mathrm{y}$. ago, sowewhat similar to the moderately dissected Thomas Range of today in both areal 
extent and stratigraphic height. For any circulation cell model to work in this sequence, such as postulated by Burt and Sheridan (1980) for some tuff-rhyolite sequences, the water table would have had to rise to the top of the Beryllium Tuff before significant cooling had occurred in the Porphyritic Rhyolite. The only outcrop of the Beryllium Tuff which is suggestive of subaqueous deposition is exposed in the Yellow Chief Mine, where the bentonite facies (Lindsey, 1979a, p. 33) overlies an epiclastic volcanic sediment. Fluid migration up into the Beryllium Tuff via fault conduits as proposed by Staatz (1963) and Shawe (1968) lacks evidence such as mineralized faults in the Beryllium Tuff (Park, 1968) and a mechanism whereby mineralization would be restricted to the top of the tuff, as no apparent mineralization controls exist in the tuff itself.

Because the Porphyritic Rhyolite was emplaced over a permeable and porous unaltered Beryllium Tuff, there is no reason to require that all fluids expelled from the Porphyritic Rhyolite need to have migrated upward, as is proposed for fluids which commonly produce vapor phase alteration in tuffs above densely welded ignimbrites. The type of fluid with fluorine-complexed metal ions postulated to be mobile during surface crystallization of rhyolites (Shatkov and others, 1970; Rosholt and others, 1971) is very similar to the type of fluid suspected of mineralizing the Beryllium Tuff. Alternately, the formation of a fluid phase charged with fluorine-complexed metal ions may have prevented the entry of these metals into insoluble accessory minerals in the Porphyritic Rhyolite and instead placed them into readily leachable compounds. Ground waters percolating down through the Porphyritic Rhyolite into the 
Beryllium Tuff and leaching these compounds may then be responsible for the mineralization at the top of the tuff. Mass balance calculations show that, assuming $51 \mathrm{ppm}$ loss of beryllium from the 548 feet (167 m) of Porphyritic Rhyolite presently existing above the Beryllium Tuff in hole number 6 (Fig. 4), sufficient beryllium is derived to mineralize the top of the tuff to an average grade of 1,154 ppm beryllium as calculated from drill hole information (Fig. 37) (Appendix 9). This model neglects lateral fluid migration and the amount of eroded Porphyritic Rhyolite, so these conclusions give a minimum estimate of the amount of beryllium available for mineralization. Analogous calculations for fluorine and uranium demonstrate that more than adequate quantities of these elements were available to mineralize the tuff (Appendix 9). The excess uranium and fluorine produced by the surface crystallization of the Porphyritic Rhyolite may have mixed with grounds. water and mineralized the Yellow Chief sediments. Although Lindsey (1979a) reports no fluorine anomalies associated with the ore lenses of the Yellow Chief Mine, fluorite has been identified as an accessory mineral (Bowyer, 1963). Alternately, weathering of local volcanic rocks may have released uranium into the groundwaters which mineralized these sediments.

The unmineralized Stratified Tuff lacks carbonate clasts and is overlain by Alkali Rhyolite which is spherulitic and lithophysal. Hence, the surface mechanisms which produced the mineralization in the Spor Mountain Formation did not occur in the Topaz Mountain Rhyolite. Of course, the Alkali. Rhyolite, although anomalous in beryllium, 
fluorine, and uranium, is much depleted in these elements compared to the Porphyritic Rhyolite.

Petrogenesis of the High-Silica

Rhyolites at the Spor

Mountain District

In the regional volcanic and tectonic syntheses of Christiansen and Lipman (1972), Eaton (1979), and Elston and Bornhorst (1979), the generation of the high-silica rhyolite clan in the western United States has been related to regional extension. Regional extension is now thought to have occurred in two episodes. From 30 to $20 \mathrm{~m} . \mathrm{y}$. ago, crustal rifting was associated only with extension behind a calc-alkalic volcanic arc, but for the past $20 \mathrm{~m} . \mathrm{y}$. crustal extension has been related both to transform shearing spreading northward associated with movement along the San Andreas Fault, which produced a pronounced episode of block faulting between 7 and $4 \mathrm{~m} . \mathrm{y}$. ago, and with waning back-arc rifting (Eaton, 1979). High-silica rhyolites were emplaced during both periods of crustal extension (E1ston and Bornhorst, 1979). These rhyolites are thought to be produced by hot mafic magmas rising into the crust in response to extensional faulting that induced partial melting of the lower crust (E1ston and Bornhorst, 1979).

The Spor Mountain District is located in an area identified by Prodehl (1979) in west-central Utah as a semicircular region of anomalously thin crust and in a region of anomalously high heat flow (Darling and Chapman, 1979). These two conditions are favorable for relatively shallow crustal fusion, although the age of these anomalies is not known. 
Some constraints on the possible source region for the Porphyritic Rhyolite and the Alkali Rhyolite can be gained from their major element geochemistries. The Porphyritic Rhyolite is peraluminous because of the corundum that appears in its fluorine-free norms, and the alkali rhyolite is metaluminous because of the diopside that appears in its fluorine-free norms. Carmichael and others (1974, p. 265) maintain that it is difficult to generate a peraluminous melt by normal crystal fractionation in a granitic melt and that peraluminous granitic melts are the products of the partial fusion of aluminum-rich source regions! The two-mica granites, granite gneisses, metaquartzites, and mica schists that outcrop in the Precambrian of Granite Mountain have been proposed as a possible source for the Porphyritic and Alkali Rhyolites because of Tertiary lithophile element-rich pegmatites which cut these Precambrian rocks. (Moore and Sorensen, 1978). These mica-rich Precambrian rocks and similar rocks exposed in the Simpson, Sheeprock, and Desert Mountains would have been. ideal source type material for the $21 \mathrm{~m} . \mathrm{y}$. old and the 6 to $7 \mathrm{~m} . \mathrm{y}$. old topaz rhyolites also because of their aluminum-rich nature.

The $F / O H$ ratios of micas in the parent material for the topaz rhyolites very likely were increased when they were heated by thermal events associated with the generation of the Drum Mountains Rhyodacite, the Mt. Laird Tuff, the Joy Tuff, and the Dell Tuff. Experimental evidence has shown that the fluoride ion is partitioned into pargasite over the hydroxyl ion relative to a basaltic melt (Holloway and Ford, 197.5). The partitioning of fluoride and hydroxyl ions into micas relative to a granitic melt may be analogous to the pargasite 
determinations, as it has been demonstrated that fluoride is partitioned into micas over hydroxyl and chloride relative to a fluid phase (Carmichael and others, 1974, p. 315; Fuge, 1977). Thus, successive melt-biotite equilibriums in the source rocks for the Spor Mountain District's pretopaz rhyolite volcanic rocks may have increased the F/OH ratios of the residual micas.

When rising isotherms and thinning crust. $21+m \cdot y$. agn allnwer a mafic magma to enter these fluorine-rich micaceous rocks, a peraluminous, fluorine-rich melt was generated that was the parent of the Porphyritic Rhyolite. A second thermal event associated with the generation of the parent melt of the Alkali Rhyolite may have partially remelted the same source rocks, due to the close spatial association of the two rocks. If so, the $21+m \cdot y$. old partial melting event probably. depleted the source material in modal mica, and the second partial melting event, around 6 to $7 \mathrm{~m} . \mathrm{y}$. ago, produced a metaluminous melt poorer in fluorine than the first. Alternatively, melting of crustal material originally poorer in micas and richer in feldspars may have occurred when the parent melt of the Alkali Rhyolite was generated. Because $H F$ is known to both lower the melting temperature and decrease the viscosity of granitic melts, high temperatures or large quantities of melt need not be required to generate these melts (Bailey, 1977). Although the volatile-rich magma chamber caps, which produced the pyroclastics beneath these two rhyolite lavas, may have been generated by the interaction of the magma with groundwater, the possibility also exists that volatiles were concentrated in the upper part of the magma chamber by liquid-state differentiation (Hildreth, 1979). 
The high rubidium contents of both vitrophyres is consistent with their derivation from a source region rich in micas and alkali feldspars, and the low barium and strontium concentrations probably reflect the melts' equilibrium with alkali feldspars in the magmas' source rocks. The large europium anomalies of the Alkali Rhyolite and of the Porphyritic Rhyolite (Appendices 7 and 8) (Figs. 76 and 77) may be interpreted as a result of both rhyolitic magmas having been in equilibrium with feldspars. Because of the common interrelationship in micas of high fluorine and high lithium values, the residual fluorineenriched micas postulated in the source, region of the rhyolites may have also been enriched in lithium. As the Precambrian granite and metasedimentary terrain of Granite Mountain is anomalous in other lithophile elements, the postulated fluorine-enriched micas and other phases such as beryl and zircons may have been host in the source rock for the other anomalous elements such as beryllium, tin, and uranium found in the two rhyolite lavas.

The effects of crystal fractionation and liquid-state differentiation on the parent magmas of the Porphyritic and Alkali Rhyolites are difficult to evaluate. The Alkali Rhyolite's geochemistry seems to indicate magmatic evolution by a liquid-state differentiation process (Hildreth, 1979). As evidence, a comparison of the chondrite-normalized rare-earth patterns (Fig. 77) and the major element geochemistries (Appendix 5) of a stratigraphically older(?), 61a, to a stratigraphically younger(?), 42, vitrophyre (Lindsey, 1979a) shows a respective: (1) flattening of the rare-earth patterns and an increase in the europium anomalies, (2) increase in the $\mathrm{Na} / \mathrm{K}$ ratios and manganese concentrations, 
and (3) decrease in the phosphorus and magnesium concentrations. These factors are considered diagnostic of liquid-state differentiation by thermogravitational diffusion (Hildreth, 1979, p. 71). The change in geochemistry of the various flows and domes of Alkali Rhyolite may have been related to the periodic leaking of a differentiating magma chamber. Simply from a consideration of incompatible trace elements such as Veiyllium, cesium, lithium; rubidium, uranium, and zirconium in the twn topaz rhyolites, the greater abundance of these elements in the Porphyritic Rhyolite with respect to the Alkali Rhyolite implies that the Porphyritic Rhyolite has undergone a much greater degree of liquid-state differentiation or crystal fractionation, or both, than the Alkali Rhyolite. The relative amounts of fluorine, magnesia, and titania in the two rhyolites are consistant with this interpretation. But the greater amount of silica in the Alkali Rhyolite than in the Porphyritic Rhyolite is difficult to evaluate because both mechanisms would be expected to increase silica. Silica may be depleted from an acid melt by partitioning into a fluid phase such as $\mathrm{SiF}_{4}$ according to the reaction $4 \mathrm{NaF}+\mathrm{SiO}_{2}=\mathrm{SiF}_{4}+2 \mathrm{Na}_{2} \mathrm{O}$ (Kogarko and others, 1968; Lamarre and Hodder, 1978). These considerations lead me to believe that, although crystal fractionation and liquid-state differentiation may have modified each of the two melts, the much greater enrichment of the Porphyritic Rhyolite in beryllium, fluorine, lithium, tin, and uranium relative to the Alkali Rhyolite cannot be attributed entirely to these mechanisms and must reflect differences in source regions.

The tectonic setting and the geochemistry of the two topaz rhyolites in the Spor Mountain District place them in a suite of granitic 
rocks termed R-type granites (White, 1979) due to their proposed origin from a residual source rock (A-type in the terminology of some authors: Loiselle and Wones, 1979). The following discussion is taken largely from White (1979). R-type granites are formed late in the history of orogenic belts, and thus the tectonic setting of the Porphyritic Rhyolite and the Alkali Rhyolite is consistent with this characteristic in that they are associated with extension that occurred in the waning stages of or after the early Tertiary Andean style orogeny in the western United States. The major element geochemistries of R-type granites are characterized by low calcium, high total alkalis, high fluorine, and high silica. A plot of gallium versus alumina (Fig. 74) and a plot of soda versus potash (Fig. 75) characterize R-type granites and include the topaz rhyolites of the Spor Mountain District. Like the Porphyritic Rhyolite and the Alkali Rhyolite, R-type granites are also characterized by an abundance of 'lithophile elements (Loiselle and Wones, 1979). Chondrite-normalized rare-earth element patterns for the Porphyritic Rhyolite (Fig. 76) and the Alkali Rhyolite (Fig. 77) have large europium anomalies but are enriched in the remaining 1 anthanide series elements. This pattern is typical of R-type granites. According to White (1979), the volcanic equivalents of R-type granites are commontly glassy and form lava flows as well as ash fluws. 


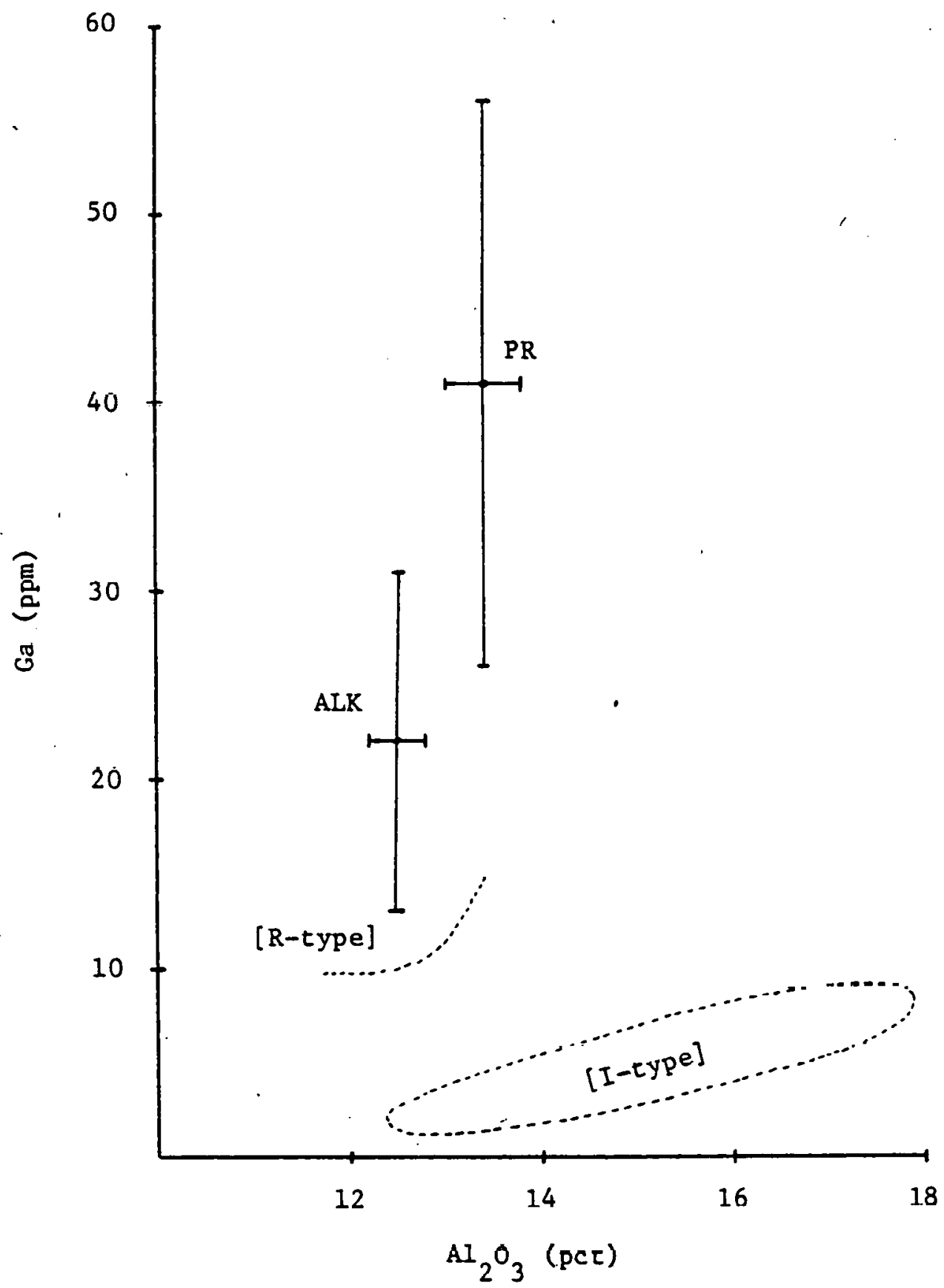

Figure 74. Gallium versus alumina in $R$-type and $I-t y p e$ granites (modified from White, 1979; with some data from Lindsey, 1979a). PR = Porphyritic Rhyolite Mean Composition, $A L K=$ Alkali Rhyolite Mean Composition, Error Bars $=1$ std. dev. 


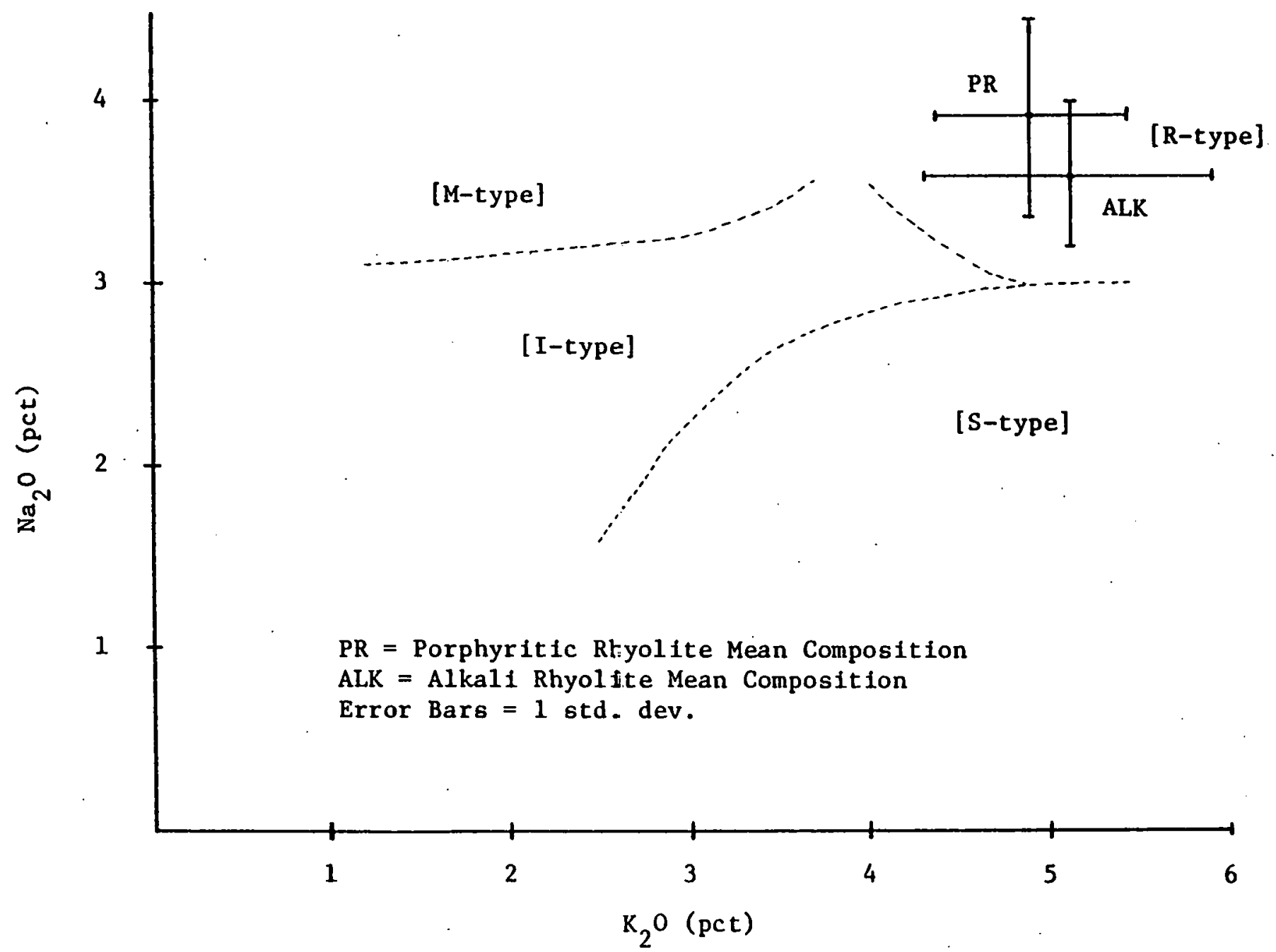

Figure 75. Soda versus potash in varlous granite types. (modifled from White, 1979; with some data from Staatz and Carr, 1964) 


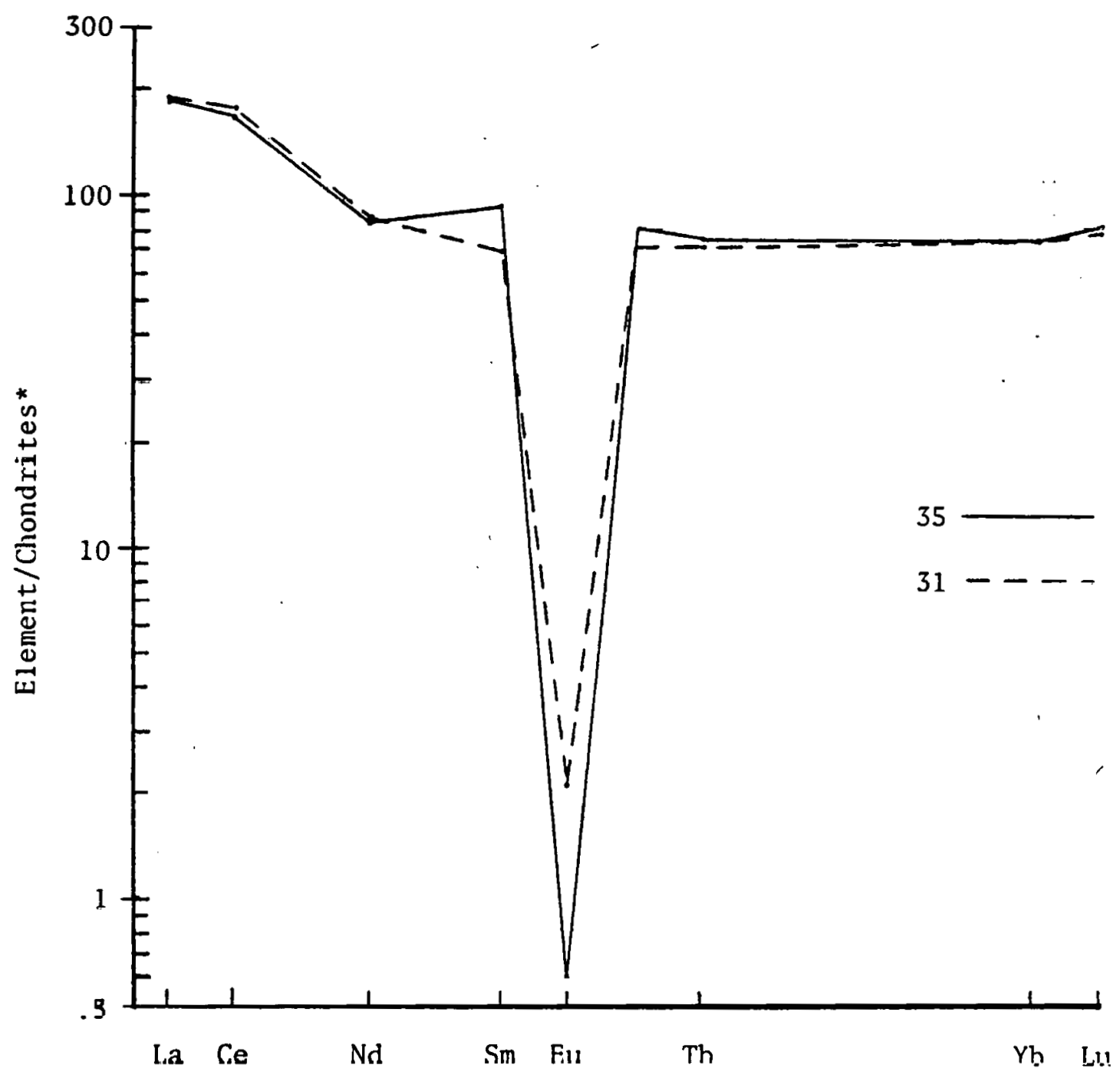

Figure 76 . Chondrite-normalized rare-earth concentrations for the Porphyritic Rhyolite.

*Normalized to $0.83 .3 \times$ leedey chnndrite values (Masuda and others, 1973; G. Goles personal communication, 1980) 


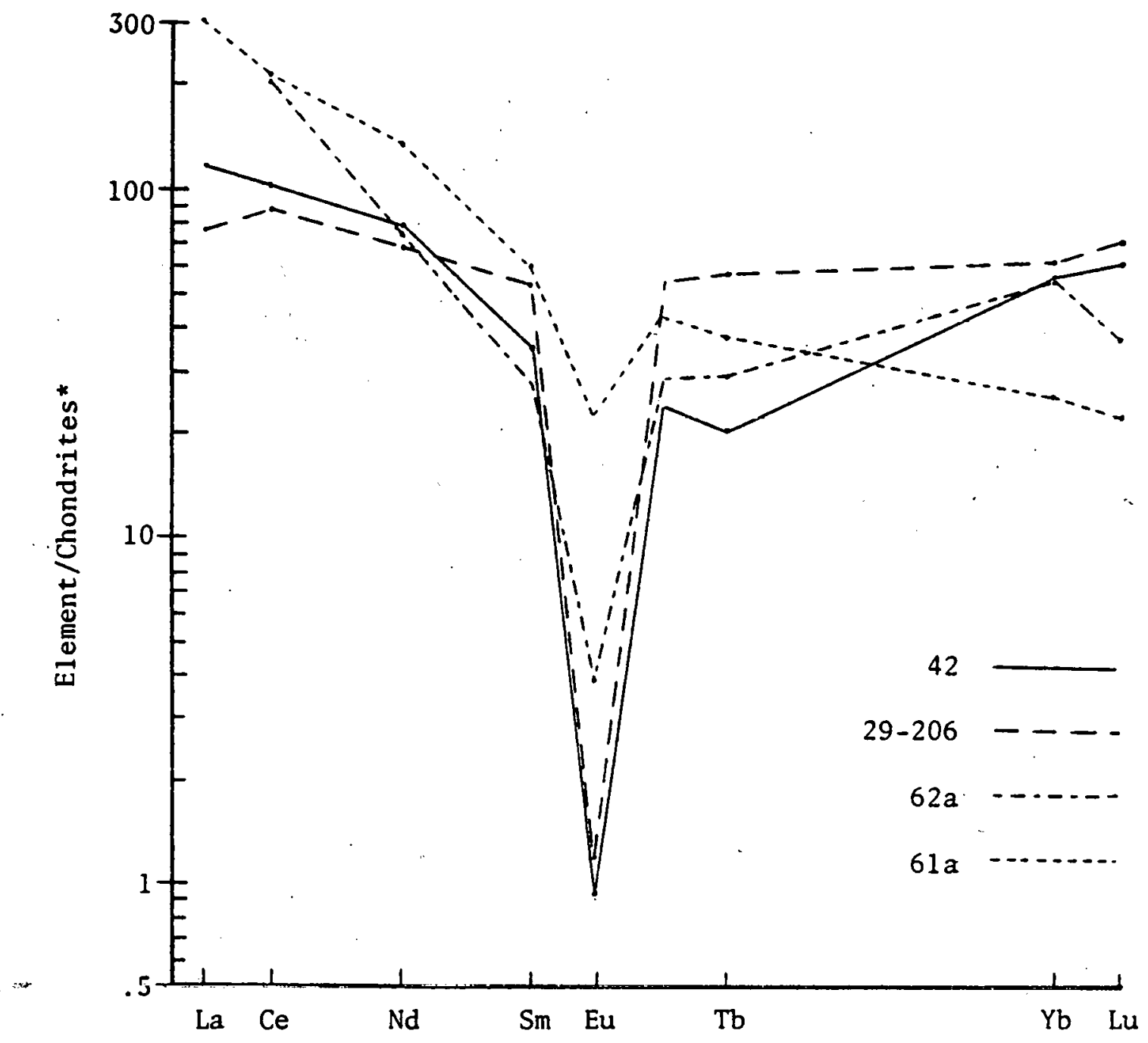

Figure 77. Chondrite-normalized rare-earth concentrations for the Alkali Rhyolite.

*Normalized to $0.833 \times$ Leedey chondrite values (Masuda and others, 1973; G. Goles personal communication, 1980) 


\section{SUGGESTIONS FOR FURTHER RESEARCH}

Much insight into the genesis of the topaz rhyolites and the ore deposits of the Spor Mountain District might be gained if additional investigations were directed at understanding some of the fundamental problems related to fluorine-enriched volcanic rocks. The paucity of information available on the behavior and effects of fluorine in silicic melts points toward the great need for more research in this area. Fluorine's properties as a mineralizer certainly warrant further experimental attention. Perhaps related to fluorine's properties as a mineralizer is how different rhyolitic lava solidification processes, such as granophyric crystallization and spherulitic devitrification, bear upon the release of uranium and other elements. The distribution of topaz rhyolites, their ages, and their geochemistries may shed some light on how this suite of rocks fits into the volcanic and tectonic evolution of the western United States. Recognition of the intrusive equivalents of topaz rhyolites and their related mineralization would aid both in the understanding of fluorine-enriched magmatism and in evaluating the potential of topaz rhyolites as ore deposit exploration guides.

Further studies of the Spor Mountain District would certainly include mapping of the Thomas Range in great detail. Once a detailed stratigraphy was worked out, temporal geochemical and mineralogical changes could be investigated in the Topaz Mountain Rhyolite. An 
337

$-156-$

investigation of choride, fluoride, and hydroxyl ion substitution in hydrous minerals of the various volcanic units recognized in the district in addition to fluorine and chlorine determinations of these rocks could be a case study for the evolution of volatiles in a suite of spatially related volcanic rocks. Perhaps a scanning electron microscope study of the ash from the oogenetic pyroclastics of the 21 and 6-7 my. old topaz rhyolites could evaluate the role of hydromagmatic processes in the formation of these tuff. 
REFERENCES CITED

Armstrong, R. L., 1970, Geochronology of Tertiary igneous rocks, eastern Basin and Range Province: Geochimica et Cosmochimica Acta, v. 34, no. 2, p. 203-232.

Bailey, J. C., 1977, Fluorine in granitic rocks and melts, A review: Chemical Geology, v. 19, p. 1-42.

Bick, K. F., 1966, Geology of the Deep Creek Mountains, Utah: Utah Geological and Minerological survey Bulletin 77, 120 p.

Bowyer, B., 1963, Yellow Chief uranium mine, Juab County, Utah: in Sharp, B. J., and Williams, N. C., eds., Beryllium and uranium mineralization in western Juab County, Utah, Utah Geological Society Guidebook, n. 17, p. 15-22.

Bullock, K. C., 1976, Fluorite occurrences in Utah: Utah Geological and Mineral Survey, Bulletin 110, p. 1-89.

Burt, D. M., and Sheridan, M. F., 1980, A model for the formation of uranium/lithophile element deposits in fluorine-enriched volcanic rocks: American Association of Petroleum Geologists Southwest Section Annual Meeting, El paso, l'exas, Technical Program and Abstract, p. 18.

Carmichael, I. S. E., Turner, F. J., and Verhoogen, J., 1974, Igneous Petrology: New York, McGraw-Hill Book Co., 739 p.

Christiansen, R. L., and Lipman, P. W., 1972, Cenozoic volcanism and plate-tectonic evolution of the western United States. II. Lace Cenozoic: Royal Society of London Philosophical Transactions A, v. 271 , p. 249-284.

Coats, R. R, , Barnett, P. R, and Conklin, N. M., 1962, Distributon of beryllium in unaltered silicic volcanic rocks of the western conterminous United States: Economic Geology, v. 57, p. 963-968.

Coats, R. R., Goss, W. D., and Rader, L. F., 1963, Distribution of fluorine in unaltered silicic volcanic rocks of western conterminous United States: Economic Geology, v. 58, n. 6, p. 941-951.

Cohenour, R. E., 1959, Sheeprock Mountains, Tooele and Juab Counties, Precambrian and Paleozoic stratigraphy, igneous rocks, structure, geomorphology and economic geology: Utah Geological and Mineralogical Survey, Bulletin 63 . 
Cohenour, R. E., 1963, Beryllium and associated mineralization in the Sheeprock Mountains: in Sharp, B. J., and Williams, N. C., eds., Beryllium and uranium mineralization in western Juab County, Utah, Utah Geological Society Guidebook, n. 17, p. 8-13.

Cole, J. W., 1970, Structure and eruptive history of the Tarawera volcanic complex: New Zealand Journal of Geology and Geophysics: v. 13, p. 872-902.

Costain, J. K., and Wright, P. M., 1973, Heat flow at Spor Mountain, Jordan Valley, Bingham, and LaSal, Utah: Journal of Geophysical Research, v. 78 , n. 35 , p. 8687-8698.

Darling, R., and Chapman, D. S., 1979, Heat flow in western Utah: Geological Society of America, Abstracts with Programs, v. 11, n. 6, p. 269.

Davis, L. J., 1978, Spor Mountain beryllium district, Juab County, Utah: in Shawe, D. R., ed., Guidebook to the mineral deposits of the central Great Basin, Nevada Bureau of Mines, Geology Report 32, p. 62-64.

Eaton, G. P., 1979, A plate-tectonic model for late Cenozoic crustal spreading in the western United States: in Riecker, R. E., ed, Rio grande rift: tectonics and magmatism: Washington, D.C., American Geophysical Union, p. 7-32.

Eichelberger. J. F., Hudgens, L. V., Jones, G. P., Rhinehammer, T. B., Tucker, P. A., and Wittenberg, L. J., 1963, Phase equilibria for the tertiary fused-salt system $\mathrm{NaF}-\mathrm{BeF}_{2}-\mathrm{UF}_{4}$ : Journal of the American Ceramic Society, v. 46, p. 279-283.

E1ston, W. E., and Bornhorst, T. J., 1979, The Rio grande rift in context of regional post -40 m.y. volcanic and tectonic events: in Riecker, R. E., ed, Rio grande rift: tectonics and magmatism: Washington, D.C., American Geophysical Union, p. 416-438.

Erickson, M. P., 1963, Volcanic geology of western Juab County, Utah: in Sharp, B. J., and Williams, N. C., eds., Beryllium and uranium mineralization in western Juab County, Utah, Utah Geological Society Guidebook, n. 17, p. 23-35.

Evans, S. H., and Nash, W. P., 1978, Quaternary rhyolite from the Mineral Mountains, Utah, U.S.A.: Department of Energy, Contract EY-76-S-07-1601, Final Report, v. 77-10, 59 p.

Fink, J., 1980, Surface folding and viscosity of rhyolite flows: Geology, v. 8, p. 250-254. 
Fisher, R. V., 1979, Models for pyroclastic surges and pyroclastic flows: Journal of Volcanology and Geothermal Research, v. 6, p. 305-318.

Fitch, C. A., Jr., Quigley, J. E., and Barker, C. S., 1949, Utah's new mining district (Topaz Mountain): Engineering and Mining Journal, v. 150 , P. $63-66$.

Griffitts, W. R., and Powers, H. H., 1963, Beryllium and fluorine content of some silicic volcanic glasses from western United States: U.S. Geological Survey Professional Paper 475-B, P. B18-B19.

Griffitts, W. R., and Rader, L. R., Jr., 1963, Beryllium and fluorine in mineralized tuff, Spor Mountain, Juab County, Utah: U.S. Geological Survey, Professional Paper 475-B, P. B16-B17.

Henry, C. D., 1978, Origin of uraniferous opal: in Henry, C. D., and Walton, A. W., eds., Formation of Uranium Ores by Diagenesis of Volcanic Sediments: U.S. Department of Energy GJBX 22 (79) (X)-1(X)22.

Henry, C. D., and Tyner, G. N., 1978, Alteration and uranium release from rhyolitic igneous rocks: Examples from the Mitchell Mesa Rhyolite, Santana Tuff, Chinati Mountains Group, and Allen Compex, Irans-Pecos Texas: in Henry, C. D., and Walton, A. W., eds., Formation of Uranium Ores by Diagenesis of Volcanic Sediment: U.S. Department of Energy, GJBX 22(79), p. (VII) 1-(VII) 109 .

Hildreth, W., 1979, The Bishop Tuff: Evidence for the origin of compositional zonation in silicic magma chambers: in Chapin, C. E., and Elston, W. E., eds., Ash-flow tuffs: Geological Society of America Special Paper 180, p. 43-75.

Holloway, J. R., and Ford, C. E., 1975, Fluid-absent melting of the fluoro-hydroxy amphibole pargasite to 35 kilobars: Earth and Planetary Science Letters, v. 25, p. 44-48.

Rogarko, L. N., Rrigman, L. D., and Sharudilo, N. S., 1968, Experimental investigations of the effect of alkalinity of silicate melts on the separation of fluorine into the gas phase: Geochemistry International, v. 5, p. 782-790.

Lamarre, A. L., and Hodder, R. W., 1978, Distribution and genesis of fluorite deposits in the western United States and their significance to metallogeny: Geology, v. 6, p. 236-238.

Lindsey, D. A., 1975, Mineralization halos and diagenesis in water-laid tuff of the Thomas Range, Utah: U.S. Geological Survey, Professional Paper 818B, P. B1-B19. 
Lindsey, D. A., 1977, Epithermal beryllium deposits in water-laid tuff, western Utah: Economic Geology, v. 72, n. 2, p. 219-232.

Lindsey, D. A., 1978a, Geology of volcanic rocks and mineral deposits in the southern Thomas Range, Utah: A brief summary: Brigham Young University Geology Studies, v. 25, part 1, p. 25-31.

Lindsey, D. A., 1978b, Geology of the Yellow Chief Mine, Thomas Range, Juab County, Utah: in Shawe, D. R., ed., Guidebook to the mineral deposits of the central Great Basin, Nevada Bureau of Mines, Geology Report 32, p. 65-68.

Lindsey, D. A., 1979a, Preliminary report on Tertiary volcanism and uranium mineralization in the Thomas Range and Drum Mountains, Juab County, Utah: U.S. Geological Survey, Open File Report 79-1076, $101 \mathrm{p}$.

Lindsey, D. A., 1979b, Geologic map and cross-sections of Tertiary rocks in the Thomas Range and Northern Drum Mountains, Juab County, Utah: U.S. Geological Survey, Miscellaneous Investigations Map I-1176, $1: 62,500$.

Lindsey, D. A., Ganow, H., and Mount joy, W., 1973, Hydrothermal alteration associated with beryllium deposits at Spor Mountain, Utah: U.S. Geological Survey, Professional Paper 818A, p. A1-A20.

Lindsey, D. A., Naeser, C. W., and Shawe, D. R., 1975, Age of volcanism, intrusion, and mineralization in the Thomas Range, Keg Mountain, and Desert Mountain, western Utah: U.S. Geological Survey, Journal of Research, v. 3, n. 5, p. 597-604.

Loiselle, M. C., and Wones, D. R., 1979, Characteristics and origin of anorogenic granites: Geological Society of America Abstracts with Programs, v. 11 , p. 468 .

Loney, R. A., 1968, Flow structure and composition of the southern coulee, Mono Craters, California--A pumiceous rhyolite flow: in Coats, R. R., Hay, R. L., and Anderson, C. A., eds., Studies in volcanology: Geological Society of America Memoir 116, p. 415-440.

Ludwig, K. R., Lindsey, D. A., Zielinski, R. A., and Simmons, K. R., 1980 , U-Pb ages of uraniferous opals and implications for the history of beryllium, fluorine, and uranium mineralization at Spor Mountain, Utah: Earth and Planetary Science Letters, v. 46, p. 221-232.

Masuda, A., Nakamura, N., and Tanaka, T., 1973, Fine structures of mutually normallized rare-earth patterns of chondrites: Geochimica. et Cosmochimica Acta, v. 37, p. 239-248. 
McAnulty, W. N., and Levinson, A. A., 1964, Rare alkali and beryllium mineralization in volcanic tuffs, Honey Comb Hills, Juab County, Utah: Economic Geology, v. 59, p. 768-774.

Montoya, J. W., Havens, R., and Bridges, D. W., 1962, Beryllium-bearing tuff from Spor Mountain, Utah: Its chemical, mineralogical, and physical properties: U.S. Bureau of Mines, Report of Investigations $6084,15 \mathrm{p}$.

Moore, W. J., and Sorensen, M. L., 1978, Metamorphic rocks of the Granite Peak area, Tooele County, Utah: Geological Society of America, Abstracts with Programs, v. 10, n. 5, p. 234.

Morris, H. T., 1978, Preliminary geologic map of Delta 2 west-central Utah: U.S. Geological Survey, Open File Report 78-705, 9 p.

Morrison, B. C., 1980, A summary geologic report on the Spor Mountain drilling project in Juab County, Utah (preliminary): U.S. Department of Energy, GJBX-19(80), 211 p.

Neal1, V. E., 1976, Lahars-global occurrence and annotated bibliography: Publication of the Geology Department, Victoria University of We1lington, New Zealand, no. 5, p. 1-18.

Newe11, R. A., 1971, Geology and geochemistry of the northern Drum Mountains, Juab County, Utah: Unpublished M.S. thesis, Colorado School of Mines, $115 \mathrm{p}$.

Noble, D. C., Smith, V. C., and Peck, L. C., 1967, Loss of halogens from crystallized and glassy silicic volcanic rocks: Geochimica et Cosmochimica Acta, v. 31, p. 215-223.

Park, G. M., 1968, Some geochemical and geochronologic studies of the beryllium deposits in western Utah: Unpublished M.S. thesis, Univer- . sity of Utah, $105 \mathrm{p}$.

Parsons, W. H., 1969, Criteria for the recognition of volcanic breccias: Review: in Larson, L. H., ed., Igneous and Metamorphic Geology: Geological Society of America Memoir 115, p. 263-303.

Prodehl, C., 1979, Crustal structure of the western United States: U.S. Geological Survey Professional Paper 1034, p. 1-55.

Richards, A. F., 1959, Geology of the Islas Revillagigedo, Mexico: Bulletin Volcanologique, ser. 2, v. 22, p. 73-123.

Rittman, A., 1952, Nomenclature of volcanic rocks: Bulletin Volcanologique, ser. $2, \mathrm{v} .12, \mathrm{p} .75-102$. 
Rose, W. I., 1973, Pattern and mechanism of volcanic activity at the Santiaguito volcanic dome, Guatemala: Bulletin Volcanologique, v. 37 , p. 73-94.

Rosholt, J. N., Prijana, and Noble, D. C., 1971, Mobility of uranium and thorium in glassy and crystallized silicic volcanic rocks: Economic Geology, v. 66, p. 1061-1069.

Ross, C. S., and Smith, R. L., 1961, Ash-flow tuffs: Their origin and geologic relations and identification: U.S. Geological Survey Professional Paper 366, 81 p.

Schmincke, H.-V., 1967, Graded lahars in the type section of the Ellensburg Formation, south-central Washington: Journal of Sedimentary Petrology, v. 37, p. 438-448.

Shatkov, G. A., Shatkova, L. N., and Gushchin, Ye. N., 1971, The distribution of uranium, thorium, fluorine, chlorine, molybdenum, and niobium in liparites and acid volcanic glasses: Geochemistry International, no. 7, p. 1051-1063.

Sharp, B. J., 1963, Uranium in fluorite, Spor Mountain, Utah: in Sharp, B. J., and Williams, N. C., eds., Beryllium and uranium mineralization in western Juab County, Utah, Utah Geological Society Guidebook, n. 17 , p. 14 .

Shawe, D. R., 1966, Arizona-New Mexico and Nevada-Utah beryllium belts: U.S. Geological Survey, Professional Paper 550-C, p. C206-C213.

Shawe, D. R., 1968, Geology of the Spor Mountain beryllium district, Utah: in Ridge, J. D., ed., Ore deposits in the United States, 1933-1967, v. 2: New York, American Institute of Mining Engineers, p. 1148-1161.

Shawe, D. R., 1972, Reconnaissance geology and mineral potential of Thomas, Keg, and Desert Calderas, central Juab County, Utah: U.S. Geological Survey, Professional Paper 800-B, p. B66-B77.

Shawe, D. R., ed., 1976, Geology and resources of fluorine in the United States: U.S. Geological Survey, Professional Paper 933, 99 p.

Shawe, D. R., and Bernold, S., 1966, Beryllium content of volcanic rocks: U.S. Geological Survey Bulletin 1214C, 11 p.

Shawe, D. R., Mountjoy, W., and Duke, W., 1964, Lithium associated with beryllium in rhyolitic tuff at Spor Mountain, western Juab County, Utah: U.S. Geological Survey, Professional Paper 501-C, p. C86-C87.

Sheridan, M. F., 1970, Fumarolic mounds and ridges of the Bishop Tuff, California: Geological Society of America Bulletin, v. 81 , p. 851-868. 
Sheridan, M. F., 1979, Emplacement of pyroclastic flows: A review: in Chapin, C. E., and Elston, W. E., eds., Ash-flow tuffs: Geological Society of America Special Paper 180, p. 125-136.

Smith, E. I., 1973, Mono Craters, California: A new interpretation of the eruptive sequence: Geological Society of America Bulletin, v. 84 , P. 2685-2690.

Smith, E. I., 1976, Structure and petrology of the John Kerr Peak dome complex, southwestern New Mexico: in Elston, W. E., and Northrop, S. A., eds., Cenozoic volcanism in southwestern New Mexico: New Mexico Geological Society Special Publication No. 5, P. 71-78.

Sparks, R. S. J., Self, S., and Walker, G. P. L., 1973, Products of ignimbrite eruptions: Geology, v. 1, p. 115-118.

Staatz, M. H., 1963, Geology of the beryllium deposits in the Thomas Range, Juab County, Utah: U.S. Geological Survey, Bulletin 1142-M, 36 p.

Staatz, M. H., and Carr, W. J., 1964, Geology and mineral deposits of the Thomas and Dugway Ranges, Juab and Tooele Counties, Utah: U.S. Geological Survey, Professional Paper 415, 188 p.

Statz, M. H., and Griffitts, W. R., 1961, Beryllium-bearing tuff in the Thomas Range, Juab County, Utah: Economic Geology, v. 56, p. 941-950.

Staatz, M. H., and Osterwald, F. W., 1959, Geology of the Thomas Range fluorspar district, Juab County, Utah: U.S. Geological Survey, Bulletin 1069 .

Stomer, J. C., 1975, A practical two-feldspar geothermometer: American Mineralogist, v. 60, p. 667-674.

Thurston, W. R., Staatz, M. H., Cox, D. C., and others, 1954, Fluorspar deposits of Utah: U.S. Geological Survey, Bulletin 1005, $53 \mathrm{p}$.

Trover, W. M., 1961, Geology of the Topaz Mountain area: Engineering and Mining Journal, v. 162, n. 9, p. 91-93.

Turley, C. H., Nash, W. P., and Brown, F. H., 1979, Petrology and geochronology of late Tertiary and Quaternary volcanic rocks in the eastern margin of the Basin and Range Province, Utah: U.S. Geological Survey, Contract 14-08-0001-G343, Final Report, v. 1, 78 p.

Tuttle, O. F., and Bowen, N. L., 1958, Origin of granite in the light of experimental studies in the system $\mathrm{NaAlSi}_{3} \mathrm{O}_{8}-\mathrm{KAlSi}_{3} \mathrm{O}_{8}-\mathrm{SiO}_{2}-\mathrm{H}_{2} \mathrm{O}$ : Geological Society of America Memoir 74, 53 p. 
Van Alstine, R. E., 1969, Geology and mineral deposits of the Poncha Springs, NE Quadrangle, Chaffee County, Colorado: U.S. Geological Survey Professional Paper, 15-18.

White, A. J. R., 1979, Sources of granite magmas: Geological Society of America Abstracts with Programs, v. 11, p. 539.

Will,iams, H., 1932, The history and character of volcanic domes: University of California Publications, Bulletin of the Department of Geological Sciences, v. 21, p. 51-146.

Williams, N. C., 1963, Beryllium deposits, Spor Mountain, Utah: in Sharp, B. J., and Williams, N. C., eds., Beryllium and uranium mineralization in western Juab County, Utah, Utah Geological Society Guidebook, n. 17, p. 36-59.

Wright, J. V., and Walker, G. P. L., 1977, The ignimbrite source problem: Significance of a co-ignimbrite lag-fall deposit: Geology, v. 5, p. 729-732.

Wohletz, K. H., and Sheridan, M. F., 1979, A model of pyroclastic surge: in Chapin, C. E., and Elston, W. E., eds., Ash-flow tuffs: Geologi$\overline{c a l}$ Society of America Special Paper 180, p. 177-194.

Zielinski, R. A., Lipman, P. W., and Millard, H. T., Jr., 1977, Minor element abundances in obsidian, perlite, and felsite of calc-alkalic rhyolites: American Mineralogist, v. 62, p. 426-437. 
Appendix 1. Microprobe analysis of a ferrohastingsite from the Alkali Rhyolite.

Analyst - B. Correa

ARL-SEMQ Electron Microprobe, University of Arizona, Tuesun, Arizona 


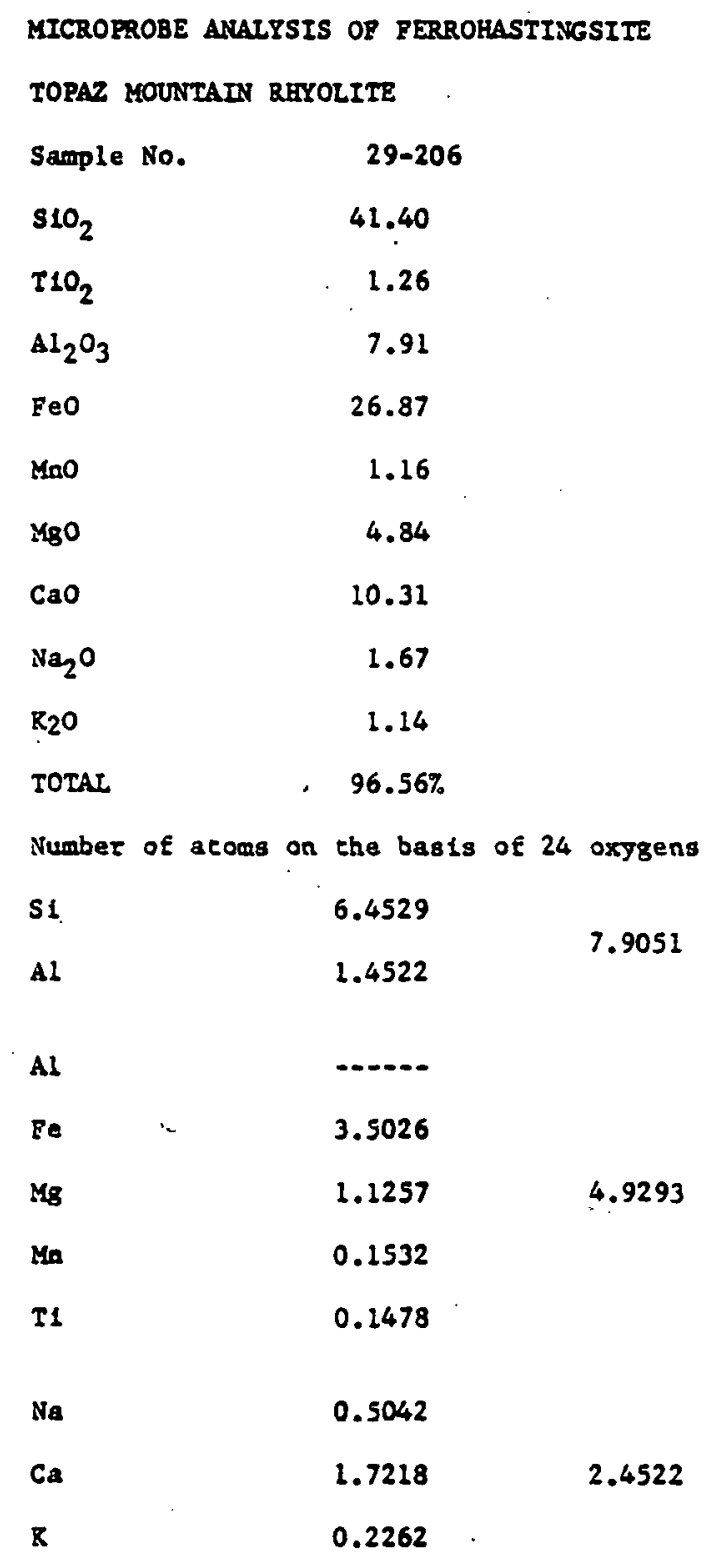


Appendix 2. Microprobe analyses of feldspars from the Porphyritic Rhyolite.

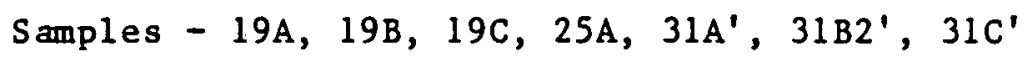

Analysts - E. Christiansen, B. Murphy

Cameca MS-46 Electron Microprobe, Arizona State University, Tempe, Arizona

Samples - 31A, 31B, 31C, 31E, 35B, 35BB, 35C1, 35C2, 35CC2, $35 \mathrm{D}, 67 \mathrm{~A}, 67 \mathrm{~B}, 67 \mathrm{C}, 67 \mathrm{D}, 67 \mathrm{E}, 70 \mathrm{~A}, 70 \mathrm{E}, 70 \mathrm{~F}$

Analyst - B. Correa

ARL-SEMQ Electron Microprobe, University of Arizona, l'ućsóón, Aríizoñá

(n.d. - not determined) 
MICROPROBE ANALYSES OF ALKALI FELDSPARS - PORPHYRITIC RHYOLITE

Sample No.

$19 A$

$19 B$

25A

$31 \mathrm{~A}$

$31 A^{\prime}$

$\mathrm{S}_{2} \mathrm{O}_{2}$
$\mathrm{IIO}_{2}$
$\mathrm{Al}_{2} \mathrm{O}_{3}$
$\mathrm{Fe}_{2} \mathrm{O}_{3}$
$\mathrm{MnO}$
$\mathrm{MgO}$
$\mathrm{CaO}$
$\mathrm{Na}_{2} \mathrm{O}$
$\mathrm{K}_{2} \mathrm{O}$
$\mathrm{BaO}$

65.59

66.95

67.75

66.57

66.57

a.d.

n.d.

a.d.

n.d.

0.02

18.66

18.16

18.32

18.56

19.35

0.02

0.06

0.05

a.d.

0.08

n.d.

a.d.

n.d.

n.d.

0.00

n.d.

n.d.

n.d.

a.d.

0.00

0.04

0.03

0.12

0.18

0.18

4.99

4.86

6.64

5.05

4.79 .

9.66

9.64

n.d.

n.d.

6.86

9.35

9.46

Total

$98.96 \%$

$99.70 \%$

a.d.

0.03

n.d.

Number of atoms on the basis of 32 oxygens

$\begin{array}{lcrrrr}\mathrm{S1} & 11.9774 & 12.1066 & 12.1210 & 12.0336 & 11.9442 \\ \mathrm{AI} & .4 .0159 & 3.8710 & 3.8630 & 3.9541 & 4.0919 \\ \mathrm{Fe}^{+3} & 0.0027 & 0.0079 & 0.0072 & & 0.0114 \\ \mathrm{II} & & & & & 0.0022 \\ \mathrm{Mn} & & & & & 0.0000 \\ \mathrm{Mg} & 0.0088 & 0.0051 & 0.0227 & 0.0352 & 0.0000 \\ \mathrm{Ca} & 1.7670 & 1.7027 & 2.3020 & 1.7712 & 1.6666 \\ \mathrm{Na} & 2.2501 & 2.2237 & 1.5652 & 2.1574 & 2.1654 \\ \mathrm{~K} & & & & 0.0022 & \\ \mathrm{Ba} & & & & & \end{array}$

For the formula $x_{4}{ }_{16}{ }^{\circ} 32^{\prime}$ where $X=\mathrm{Ca}, \mathrm{Na}, \mathrm{K}$ and $Z=S 1, \mathrm{Al}$

$\begin{array}{lrrrrr}Z & 15.9933 & 15.9777 & 15.9840 & 15.9877 & 16.0361 \\ x & 4.0259 & 3.9315 & 3.8899 & 3.9637 & 3.868 \\ \text { Reciliculated mole percenc } & & & & \\ \mathrm{Ab} & 43.89 & 43.31 & 59.18 & 44.69 & 43.09 \\ \mathrm{An} & 0.22 & 0.13 & 0.58 & 0.89 & 0.92 \\ \text { Or } & 55.89 & 56.56 & 40.24 & 54.43 & 55.99\end{array}$


MTCROPROBE ANALYSES OF ALKAII FELOSPARS - PORPHYRITIC RYYOLITE

\begin{tabular}{|c|c|c|c|c|c|}
\hline Sample No. & $312^{\prime}$ & $31 c^{\prime}$ & $35 B$ & $35 \mathrm{Cl}$ & $35 C 2$ \\
\hline $\mathrm{S}^{10} \mathrm{O}_{2}$ & 65.97 & 66.51 & 65.85 & 65.31 & 65.14 \\
\hline $\mathrm{I} 1 \mathrm{O}_{2}$ & 0.00 & 0.02 & 0.00 & 0.00 & 0.01 \\
\hline $\mathrm{Al}_{2} \mathrm{O}_{3}$ & 10.63 & 19.50 & 19.25 & 19.22 & 19.11 \\
\hline $\mathrm{Fe}_{2} \mathrm{O}_{3}$ & 0.08 & 0.08 & 0.03 & 0.06 & 0.13 \\
\hline uno & 0.02 & 0.04 & 0.04 & 0.00 & 0.03 \\
\hline $\mathrm{MgO}$ & 0.00 & 0.01 & 0.02 & 0.00 & 0.00 \\
\hline $\mathrm{CaO}$ & 0.20 & 0.20 & 0.19 & 0.18 & 0.23 \\
\hline $\mathrm{Na}_{2} \mathrm{O}$ & 5.02 & 4.84 & 4.86 & 4.86 & 4.95 \\
\hline $\mathrm{K}_{2} \mathrm{O}$ & 9.61 & 9.61 & 9.92 & 9.98 & 9.85 \\
\hline Iotal & $100.54 \%$ & $100.81 \%$ & $100.18 \%$ & $99.62 \%$ & $99.47 \%$ \\
\hline
\end{tabular}

Number of atoms on the basts of 32 oxygens

\begin{tabular}{|c|c|c|c|c|c|}
\hline$\$ 1$ & 11.8617 & 11.9100 & 11.8985 & 11.8778 & 11.8717 \\
\hline Al & 4.1605 & 4.1161 & 4.1007 & $4.120 n$ & $4 . \ln 38$ \\
\hline $\mathrm{Fe}^{+3}$ & 0.0108 & 0.0114 & 0.0042 & 0.0085 & 0.0183 \\
\hline I1 & 0.0000 & 0.0022 & 0.0005 & 0.0000 & 0.0017 \\
\hline Mn & 0.0037 & 0.0060 & 0.0068 & 0.0000 & 0.0053 \\
\hline$Y_{8}$ & 0.0000 & 0.0019 & 0.0055 & 0.0010 & 0.0000 \\
\hline $\mathrm{Ca}$ & 0.0383 & 0.0377 & 0.0361 & 0.0359 & 0.0444 \\
\hline $\mathrm{Na}$ & 1.7497 & 1.6806 & 1.7039 & 1.7136 & 1.7504 \\
\hline K & 2.2049 & 2.1959 & 2.2877 & 2.3153 & 2.2893 \\
\hline \multicolumn{6}{|c|}{ For the formula $x_{4} z_{1}$} \\
\hline 2 & 16.0222 & 16.0261 & 15.9992 & 15.9978 & 15.9755 \\
\hline$x$ & 3.993 & 3.914 & 4.028 & 4.065 & 4.084 \\
\hline \multicolumn{6}{|c|}{ Recalculaced mole percent } \\
\hline Ab & 43.82 & 42.94 & 42.30 & 42.16 & 42.36 \\
\hline An & 0.96 & 0.96 & 0.90 & 0.88 & 1.09 \\
\hline Or & 55.22 & 56.10 & 56.90 & $j 6.96$ & 56.05 \\
\hline
\end{tabular}


MICROPROBE ARALYSES OF ALKALI FELDSPARS - PORPHYRITIC RHYOLITE

\begin{tabular}{|c|c|c|c|c|c|}
\hline Sample No. & $35 \mathrm{sc} 2$ & 350 & 700 & $70 \mathrm{E}$ & $70 F$ \\
\hline 510.2 & 66.12 & 66.13 & 65.58 & 66.93 & 66.28 \\
\hline $\mathrm{T}^{10} \mathrm{O}_{2}$ & 0.04 & 0.07 & 0.04 & 0.02 & 0.03 \\
\hline $\mathrm{Al}_{2} \mathrm{O}_{3}$ & 19.03 & 19.16 & 19.18 & 19.65 & 19.39 \\
\hline $\mathrm{Fe}_{2} \mathrm{O}_{3}$ & 0.15 & 0.08 & 0.12 & 0.00 & 0.02 \\
\hline Mno & 0.00 & 0.00 & 0.03 & 0.00 & 0.01 \\
\hline $\mathrm{MgO}$ & 0.00 & 0.00 & 0.00 & 0.00 & 0.03 \\
\hline $\mathrm{CaO}$ & 0.23 & 0.20 & 0.13 & 0.11 & 0.09 \\
\hline $\mathrm{Na}_{2} \mathrm{O}$ & 5.07 & 4.92 & 5.02 & 5.11 & 4.86 \\
\hline $\mathrm{K}_{2} \mathrm{O}$ & 9.69 & 9.96 & 8.93 & 9.06 & 9.35 \\
\hline Total & $100.33 \%$ & $100.52 \%$ & $99.04 \%$ & $100.88 \%$ & $100.07 \%$ \\
\hline \multicolumn{6}{|c|}{ Number of atoms on the basis of 32 oxygens } \\
\hline S1 & 11.9234 & 11.9108 & 11.9243 & 11.9328 & 11.9332 \\
\hline dI & 4.0436 & 4.0680 & 4.1104 & 4.1295 & 4.1149 \\
\hline $\mathrm{Fe}^{+3}$ & 0.0205 & 0.0108 & 0.0158 & 0.0000 & 0.0024 \\
\hline T1 & 0.0056 & 0.0090 & 0.0051 & 0.0022 & 0.0039 \\
\hline Yn & 0.0000 & 0.0000 & 0.0068 & 0.0000 & 0.0022 \\
\hline $\mathrm{Mg}_{\mathrm{g}}$ & 0.0000 & 0.0000 & 0.0000 & 0.0000 & 0.0070 \\
\hline $\mathrm{Ca}$ & 0.0436 & 0.0387 & 0.0249 & 0.0217 & 0.0179 \\
\hline $\mathrm{Na}$ & 1.7733 & 1.7169 & 1.7683 & 1.7673 & 1.6976 \\
\hline $\mathrm{K}$ & 2.2299 & 2.2890 & 2.0709 & 2.0602 & 2.1469 \\
\hline
\end{tabular}

For the formula $\mathrm{X}_{4} 2_{16}{ }^{\mathrm{O}} 32$, where $\mathrm{X}=\mathrm{Ca}, \mathrm{Na}, \mathrm{K}$ and $\mathrm{z}=\mathrm{St}, \mathrm{H}$

$\begin{array}{lccccc}Z & 15.9670 & 15.9788 & 16.0347 & 16.0623 & 16.0481 \\ \mathrm{X} & 4.047 & 4.045 & 3.864 & 3.949 & 3.962 \\ \text { Recalculated mole percent } & & & & \\ \mathrm{Ab} & 43.82 & 42.45 & 45.76 & 45.91 & 43.95 \\ \mathrm{Aa} & 1.08 & 0.96 & 0.64 & 0.56 & 0.46 \\ \mathrm{Or} & 55.10 & 56.59 & 53.59 & 53.52 & 55.58\end{array}$


MICROPROBE ANALYSES OF PLAGIOCLASE FELDSPARS - PORPHYRIIIC RHYOLITE

\begin{tabular}{|c|c|c|c|c|c|}
\hline Sample No. & $19 \mathrm{C}$ & $31 \mathrm{~A}$ & $31 \mathrm{~B}$ & $31 \mathrm{C}$ & $31 E$ \\
\hline $\mathrm{S}_{10}$ & 64.91 & 66.72 & 67.61 & 67.28 & 68.08 \\
\hline $\mathrm{IHO}_{3}$ & n.d. & n.d. & n.d. & II.d. & n.d. \\
\hline $\mathrm{Al}_{2} \mathrm{O}_{3}$ & 20.89 & 20.10 & 20.64 & 20.38 & 20.50 \\
\hline $\mathrm{Fe}_{2} \mathrm{O}_{3}$ & 0.03 & n.d. & n.d. & n.d. & n.d. \\
\hline Mno & n.d. & n.d. & n.d. & n.d. & n.d. \\
\hline $\mathrm{MgO}$ & n.d. & n.d. & n.d. & n.d. & n.d! \\
\hline $\mathrm{CaO}$ & 1.50 & 1.59 & 1.56 & 1.48 & 1.53 \\
\hline $\mathrm{Na}_{2} \mathrm{O}$ & 9.40 & 9.25 & 9.42 & 9.44 & 9.58 \\
\hline $\mathrm{R}_{2} \mathrm{O}$ & 1.50 & 1.81 & 1.97 & 1.92 & 1.88 \\
\hline $\mathrm{BaO}$ & n.d. & n.d. & n.d. & 0.04 & 0.04 \\
\hline Total & $98.24 \%$ & $99.47 \%$ & $101.20 \%$ & $100.53 \%$ & $101.62 \%$ \\
\hline
\end{tabular}

Number of atoms on the basts of 32 oxygens

$\begin{array}{lrrrrr}\mathrm{S1} & 11.6385 & 11.8083 & 11.7734 & 11.7926 & 11.8031 \\ \mathrm{Al} & 4.4154 & 4.1938 & 4.2354 & 4.2103 & 4.1892 \\ \mathrm{Fe}^{+3} & 0.0039 & & & & \\ \mathrm{Ti} & & & & & \\ \mathrm{Mn} & & & & & \\ \mathrm{Yg} & & & & & \\ \mathrm{Ca} & 0.2878 & 0.3013 & 0.2913 & 0.2779 & 0.2848 \\ \mathrm{Na} & 3.3693 & 3.1748 & 3.1802 & 3.2090 & 3.2212 \\ \mathrm{~K} & 0.3431 & 0.4080 & 0.4373 & 0.4283 & 0.4152 \\ \mathrm{Ba} & & & & 0.0028 & 0.0069\end{array}$

For the formula $x_{4} z_{16}{ }^{\circ} 32$, where $x=\mathrm{Ca}, \mathrm{Na}, \mathrm{K}$ and $z=\mathrm{S} 1, \mathrm{AI}$

$\begin{array}{rrrrrr}z & 16.0539 & 16.0021 & 16.0088 & 16.0029 & 15.3923 \\ X & 3.9002 & 3.8841 & 3.9088 & 3.9152 & 3.9212\end{array}$

Recalculated mole percent

$\begin{array}{rrrrrr}\text { Ab } & 83.82 & 81.74 & 81.36 & 81.96 & 82.15 \\ \text { An } & 7.38 & 7.76 & 7.45 & 7.10 & 7.26 \\ \text { Or } & 8.80 & 10.50 & 11.19 & 10.94 & 10.59\end{array}$


MICROPROBE ANALYSES OF PLAGIOCLASE FELDSPARS - PORPHYRITIC RHYOLITE

\begin{tabular}{|c|c|c|c|c|c|}
\hline Sample No. & $31 A^{\prime}$ & $31 c^{\prime}$ & $35 B$ & $35 B B$ & $35 \mathrm{C} 1$ \\
\hline $\mathrm{SIO}_{2}$ & 66.46 & 66.01 & $65.58^{\circ}$ & 66.64 & 66.38 \\
\hline $\mathrm{IIO}_{2}$ & 0.00 & 0.00 & 0.00 & 0.05 & 0.00 \\
\hline $\mathrm{Al}_{2} \mathrm{O}_{3}$ & 21.39 & $20.96^{\circ}$ & 20.87 & 20.70 & 20.30 \\
\hline $\mathrm{Fe}_{2} \mathrm{O}_{3}$ & 0.07 & 0.07 & 0.07 & 0.13 & 0.03 \\
\hline Yno & 0.00 & 0.02 & 0.00 & 0.00 & 0.00 \\
\hline $\mathrm{MgO}$ & 0.00 & 0.00 & 0.05 & 0.01 & 0.01 \\
\hline $\mathrm{CaO}$ & 1.78 & 1.56 & 1.93 & 1.78 & 1.58 \\
\hline $\mathrm{Na}_{2} \mathrm{O}$ & 9.25 & 9.05 & 9.36 & 9.18 & 9.31 \\
\hline $\mathrm{K}_{2} \mathrm{O}$ & 1.77 & 1.95 & 1.70 & 1.77 & 2.04 \\
\hline Total & $100.98 \%$ & $99.63 \%$ & $99.56 \%$ & $100.08 \%$ & $100.15 \%$ \\
\hline \multicolumn{6}{|c|}{ Number of acoms on the basis of 32 oxygens } \\
\hline Si & 11.6422 & 11.6796 & 11.6308 & 11.7036 & 11.6970 \\
\hline A1 & 4.4031 & 4.3706 & 4.3614 & 4.2977 & 4.3196 \\
\hline $\mathrm{Fe}^{+3}$ & 0.0093 & 0.0089 & 0.0095 & 0.0177 & 0.0041 \\
\hline I1 & 0.0000 & 0.0000 & 0.0005 & 0.0071 & 0.0000 \\
\hline Mn & 0.0000 & 0.0037 & 0.0000 & 0.0000 & 0.0000 \\
\hline $\mathrm{Mg}$ & 0.0000 & 0.0000 & 0.0100 & 0.0020 & 0.0025 \\
\hline $\mathrm{Ca}$ & 0.3324 & 0.2955 & 0.3669 & 0.3359 & 0.2983 \\
\hline $\mathrm{Na}$ & 3.1345 & 3.1035 & 3.2174 & 3.1355 & 3.1795 \\
\hline $\mathrm{K}$ & 0.3939 & 0.4404 & 0.3856 & 0.3986 & 0.4591 \\
\hline
\end{tabular}

For the formula $X_{4}{ }^{2} 16^{\circ}{ }_{32}$, where $X=\mathrm{Ca}, \mathrm{Na}, \mathrm{K}$ and $\mathrm{Z}=\mathrm{S1}, \mathrm{Al}$

$\begin{array}{lrrrrr}\mathrm{Z} & 16.0453 & 16.0402 & 15.9922 & 16.0013 & 16.0166 \\ \mathrm{X} & 3.821 & 3.839 & 3.970 & 3.870 & 3.937 \\ \text { Recalculated mole percene } & & & & & \\ \mathrm{Ab} & 81.82 & 80.83 & 81.04 & 81.02 & 80.76 \\ \mathrm{An} & 7.90 & 7.00 & 9.24 & 8.68 & 7.58 \\ \mathrm{Or} & 10.28 & 11.47 & 9.71 & 10.30 & 11.66\end{array}$




\begin{tabular}{|c|c|c|c|c|}
\hline Sample No. & $35 \mathrm{C} 2$ & 35D & $35 E$ & 3SEE \\
\hline $\mathrm{S} \mathrm{O}_{2}$ & 65.26 & 65.28 & 66.16 & 65.38 \\
\hline $\mathrm{IIO}_{2}$ & 0.02 & 0.04 & 0.06 & 0.02 \\
\hline $\mathrm{Al}_{2} \mathrm{O}_{3}$ & 20.95 & 20.96 & 20.42 & 20.88 \\
\hline $\mathrm{Fe}_{2} \mathrm{O}_{3}$ & 0.21 & 0.18 & 0.11 & 0.11 \\
\hline Yno & 0.00 & 0.01 & 0.01 & 0.01 \\
\hline $\mathrm{MgO}$ & 0.00 & 0.03 & 0.00 & 0.02 \\
\hline $\mathrm{CaO}$ & 2.01 & 1.67 & 1.62 & 1.66 \\
\hline $\mathrm{Na}_{2} \mathrm{O}$ & 9.28 & 9.40 & 9.42 & 9.15 \\
\hline $\mathrm{K}_{2} \mathrm{O}$ & 1.85 & 1.93 & 2.10 & 2.03 \\
\hline Total & $99.57 \%$ & $99.49 \%$ & $99.90 \%$ & $99.26 \%$ \\
\hline
\end{tabular}

Number of atoms on the basis of 32 oxygens

$\begin{array}{lllll}\mathrm{SL} & 11.3930 & 11.0013 & 11.7068 & 11.6 \mathrm{Jb1} \\ \mathrm{Al} & 4.3857 & 4.0680 & 4.2588 & 4.3790 \\ \mathrm{Fe}^{+3} & 0.0274 & 0.0244 & 0.0124 & 0.0143 \\ \mathrm{TI} & 0.0022 & 0.0055 & 0.0077 & 0.0027 \\ \mathrm{Mn} & 0.0000 & 0.0014 & 0.0022 & 0.0015 \\ \mathrm{Mg} & 0.0010 & 0.0091 & 0.0000 & 0.0050 \\ \mathrm{Ca} & 0.3819 & 0.3136 & 0.3065 & 0.3163 \\ \mathrm{Na} & 3.1949 & 3.2382 & 3.2303 & 3.1592 \\ \mathrm{~K} & 0.4187 & 0.4393 & 0.4744 & 0.4599\end{array}$

For the tormula $\mathrm{X}_{4} \mathrm{z}_{16} \mathrm{O}_{32^{\prime}}$, where $\mathrm{X}=\mathrm{Ca}, \mathrm{Ma}, \mathrm{K}$ and $z-51, \mathrm{Al}$

$\begin{array}{ccccc}7 & 15.9787 & 15.9788 & 15.3656 & 16.0151 \\ \times & 3.996 & 3.992 & 4.011 & 3.934\end{array}$

Recalculated nole percent

$\begin{array}{rrrrr}\text { Ab } & 79.96 & 81.12 & 80.53 & 80.27 \\ \text { An } & 9.56 & 7.98 & 7.64 & 8.04 \\ \text { Or } & 10.48 & 10.90 & 11.83 & 11.69\end{array}$


MICROPROBE ANALYSES OF FELDSPARS OF A MAFIC INCLUSION

IN IEE PORPHYRITIC RHYOLITE

\begin{tabular}{|c|c|c|c|c|c|}
\hline Sample No. & $67 \mathrm{~A}$ & $67 B$ & $67 C$ & 670 & 67E \\
\hline $\mathrm{S}_{2} \mathrm{O}_{2}$ & 58.86 & 58.02 & 59.04 & 58.62 & 59.56 \\
\hline $\mathrm{TIO}_{2}$ & 0.05 & 0.00 & 0.00 & 0.03 & 0.01 \\
\hline $\mathrm{Al}_{2} \mathrm{O}_{3}$ & 25.15 & 25.59 & 25.20 & 25.57 & 24.86 \\
\hline $\mathrm{Fe}_{2} \mathrm{O}_{3}$ & 0.27 & 0.37 & 0.34 & 0.44 & 0.38 \\
\hline $\operatorname{Mno}$ & 0.03 & 0.00 & 0.00 & 0.00 & 0.00 \\
\hline $\mathrm{M} 80$ & 0.02 & 0.01 & 0.00 & 0.05 & 0.00 \\
\hline $\mathrm{CaO}$ & 6.29 & 6.99 & 6.91 & 6.97 & 6.42 \\
\hline $\mathrm{Na}_{2} \mathrm{O}$ & 6.37 & 6.32 & 6.53 & 5.46 & 0.68. \\
\hline $\mathrm{K}_{2} \mathrm{O}$ & 2.15 & 1.78 & 1.86 & 1.79 & 2.07 \\
\hline Total & $99.20 \%$ & $99.07 \%$ & $99.38 \%$ & $99.94 \%$ & $99.98 \%$ \\
\hline
\end{tabular}

Number of atoms on the basis of 32 oxygens

$\begin{array}{lrrrrr}\mathrm{S1} & 10.6472 & 10.5216 & 10.6188 & 10.5417 & 10.6967 \\ \mathrm{AI} & 5.3620 & 5.4690 & 5.3405 & 5.4196 & 5.2611 \\ \mathrm{Fe} & 0.0364 & 0.0510 & 0.0458 & 0.0597 & 0.0512 \\ \mathrm{II} & 0.0062 & 0.0005 & 0.0000 & 0.0039 & 0.0011 \\ \mathrm{Mn} & 0.0045 & 0.0000 & 0.0000 & 0.0000 & 0.0000 \\ \mathrm{Mg} & 0.0061 & 0.0015 & 0.0000 & 0.0142 & 0.0000 \\ \mathrm{Ca} & 1.2198 & 1.3571 & 1.3306 & 1.3437 & 1.2348 \\ \mathrm{Na} & 2.2335 & 2.2215 & 2.2771 & 2.2527 & 2.3274 \\ \mathrm{~K} & 0.4957 & 0.4116 & 0.4271 & 0.4106 & 0.4740\end{array}$

For the formula $x_{4} z_{16^{\circ}}{ }_{32}$, where $X=C a, N a, K$ and $Z=S 1, A I$

$\begin{array}{lrrrrr}Z & 16.0092 & 15.9906 & 15.9593 & 15.9513 & 15.9578 \\ X & 3.9490 & 3.9902 & 4.0348 & 4.0070 & 4.0362 \\ \text { Recalculated mole percent } & & & & \\ \text { Ab } & 30.89 & .34 .01 & 32.98 & 33.53 & 30.59 \\ \text { An } & 56.56 & 35.67 & 56.44 & 56.22 & 57.66 \\ \text { Or } & 12.35 & 10.32 & 10.59 & 10.25 & 11.74\end{array}$


Appendix 3. Lithologic key for the geochemically analyzed samples. 


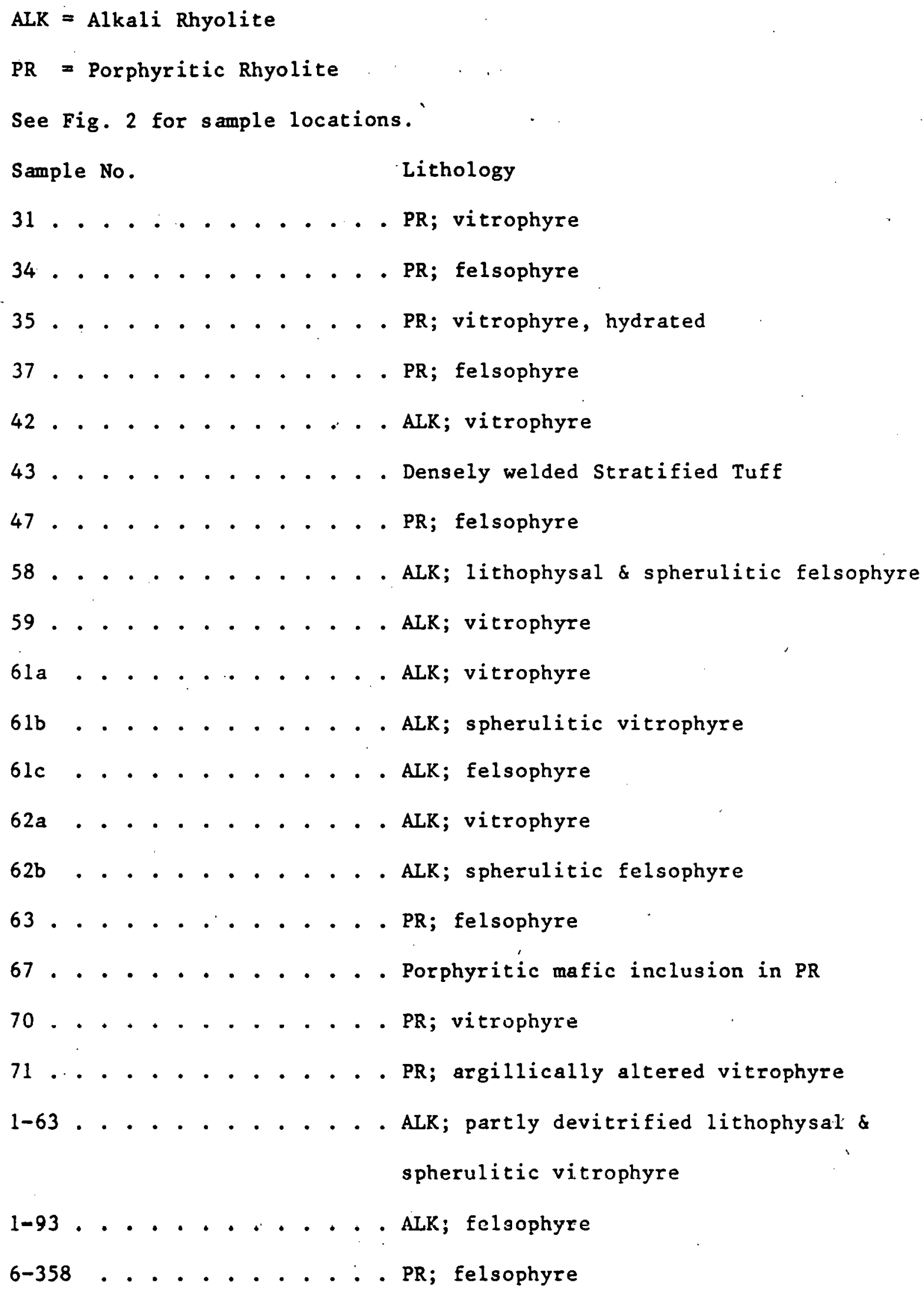


358

$-177-$

Sample No.

Lithology

8-938 .......... ALK; lithophysal felsophyre

18-113.......... . PR; felsophyre

26-112 . . . . . . . . PR; felsophyre

29-124 . . . . . . . . ALK; partly devitrified lithophysal \& spherulitic vitrophyre

29-206 . . . . . . . ALK; perlitic vitrophyre 
Appendix 4. Whole rock major element analyses on an ignited basis and fluorine-free normative computations of the Porphyritic Rhyolite.

$\mathrm{SiO}_{2}, \mathrm{TiO}_{2}, \mathrm{Al}_{2} \mathrm{O}_{3}, \mathrm{Fe}_{2} \mathrm{O}_{3}, \mathrm{MnO}, \mathrm{MgO}, \mathrm{CaO}, \mathrm{P}_{2} \mathrm{O}_{5}$

Analyst - J. Bikun

Phillips Model PW 1410 XRF, Arizona State University, Tempe, Arizona

$\mathrm{Na}_{2} \mathrm{O}, \mathrm{K}_{2} \mathrm{O}$

Analyst - J. Bikun

Varian Techtron Model 1250 AA, Arizona State University, Tempe, Arizona

F

Analysts - J. Bikun, E. Christiansen

Coleman Specific Ion Probe, Arizona State University, Tempe, Arizona

Analyst - Skyline Labs, Tucson, Ariz̄ona

Specific Ion Probe

Note: For normative computations, ratio of Feo to total Fe used is 0.52 (from Turley and others, 1979).

(n.d. - not determined) 


\begin{tabular}{|c|c|c|c|c|c|c|c|c|c|c|c|c|}
\hline Sample No. & 31 & 34 & 35 & 37 & 47 & 63 & 67 & 70 & 71 & $6-358$ & $18-113$ & $26-112$ \\
\hline $\mathrm{SiO}_{2}$ & 73.13 & 74.73 & 73.86 & $75.20^{\circ}$ & 7.4 .49 & 73.68 & 65.37 & 72.18 & 73.73 & 74.04 & 74.35 & 73.49 \\
\hline $\mathrm{THO}_{2}^{2}$ & 0.00 & 0.03 & 0.06 & $0.0 ?$ & 0.05 & 0.04 & 0.94 & 0.04 & 0.06 & 0.06 & 0.06 & 0.03 \\
\hline $\mathrm{Al}_{2} \mathrm{O}_{3}$ & 13.10 & 13.20 & 13.11 & 12.7 & 14.42 & 13.83 & 14.62 & 13.88 & 13.32 & 13.52 & 13.37 & 13.99 \\
\hline $\mathrm{Fe}_{2} \mathrm{O}_{3}$ & 1.43 & 1.5: & 1.43 & $1.0 \mathrm{~L}$ & 0.81 & 1.17 & 6.35 & 1.19 & 1.33 & 1.63 & 1.48 & 1.19 \\
\hline $\operatorname{MnO}$ & 0.01 & $0.0 i$ & 0.06 & $0.0 \mathrm{~A}$ & 0.02 & a. 05 & 0.09 & 0.06 & 0.05 & 0.07 & 0.06 & 0.06 \\
\hline $\mathrm{MgO}$ & 0.05 & 0.01 & 0.08 & $0.0^{\prime \prime}$ & 0.09 & a. 21 & 0.36 & 0.06 & 0.07 & 0.23 & 0.11 & 0.14 \\
\hline CuO & 0.6 .1 & 0.60 & 1.27 & 0.70 & 0.14 & 0.45 & 2.87 & 0.58 & 0.70 & 0.43 & 0.59 & 0.63 \\
\hline $\mathrm{Na}_{2} \mathrm{O}^{\mathrm{a}}$ & 4.02 & 3.76 & 4.33 & 3.85 & 2.63 & 3.83 & 3.15 & 4.90 & 4.39 & 3.92 & 4.01 & 3.94 \\
\hline$k_{2}{ }^{0}$ & 4.59 & 4.8 & 3.65 & $4.8 \%$ & 5.95 & 4.91 & 4.95 & 4.98 & 4.74 & 4.88 & 4.83 & 4.85 \\
\hline$P_{2}{ }^{O_{5}}$ & $0 . c 0$ & 0.00 & 0.00 & 0.00 & 0.00 & 0.00 & 0.00 & 0.01 & 0.01 & 0.00 & 0.00 & 0.00 \\
\hline 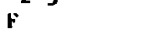 & O.E: & 0.60 & 1.80 & n.d & n.d. & 0.42 & n.d. & 1.50 & 0.88 & 0.65 & n.d. & n.d. \\
\hline Sum & $98.6:$ & 99.59 & 99.05 & 98.6. & 90.59 & 9 a. 59 & 98.85 & 99.38 & 99.28 & 99.43 & 98.86 & 98.32 \\
\hline$-(1)=r$ & 0.34 & 0.20 & 0.51 & - & - & 0.18 & - & 0.63 & 0.37 & 0.27 & - & - \\
\hline Tocal & 98.2 .2 & 99.3 .2 & $98.54 x$ & 98.6 .8 & $90.59 \%$ & $98.41 \%$ & $98.85 \%$ & $98.75 x$ & $98.91 x$ & $99.16 x$ & $98.86 x$ & 98.327 \\
\hline l.o.t. & 2.96 & 0.50 & 3.55 & 2.5: & 1.43 & 0.91 & 2.30 & 3.013 & 2.98 & 0.77 & 0.57 & 0.70 \\
\hline \multicolumn{13}{|c|}{ Huorine free CIPW roma } \\
\hline or & 29.49 & $28.4:$ & 21.57 & 28.7 & 3.5 .16 & 29.02 & 29.25 & 29.43 & 28.01 & 28.84 & 28.54 & 28.66 \\
\hline $\mathbf{a b}$ & 34.01 & $31.8 !$ & 36.64 & $32.5 \varepsilon$ & 22.25 & 32.41 & 26.65 & 41.45 & 37.15 & 33.17 & 33.93 & 33.34 \\
\hline an & 3.05 & 2.98 & 5.56 & $3.0:$ & 3.69 & 2.23 & 11.13 & 1.11 & 2.64 & 2.13 & 2.93 & 3.13 \\
\hline 9 & 29.15. & 32.81 & 31.72 & $32.5 \equiv$ & 35.86 & 31.08 & 21.59 & 23.41 & 28.37 & 30.95 & 30.80 & 30.18 \\
\hline liy & $0.8 \times$ & $0.8:$ & 0.54 & 0.45 & 3.53 & 1.09 & 1.54 & 0.01 & 0.44 & 1.36 & 0.97 & 0.96 \\
\hline di & 0.00 & 0.00 & 0.64 & 0.37 & 1.00 & 0.00 & 1.80 & 1.42 & 0.66 & 0.00 & 0.00 & 0.00 \\
\hline ap & 0.05 & 0.06 & 0.00 & $0.0 C$ & 3.00 & 0.00 & 0.35 & 0.02 & 0.02 & 0.00 & 0.00 & 0.00 \\
\hline 11 & 0.11 & 0.11 & 0.11 & $0.1:$ & 0.09 & 0.08 & 1.79 & 0.08 & 0.11 & 0.11 & 0.11 & 0.06 \\
\hline c & 0.00 & 0.81 & 0.00 & $0.0 \mathrm{C}$ & 8.40 & 1.40 & 0.00 & 0.00 & 0.00 & 1.01 & 0.47 & 1.11 \\
\hline dut & 1.00 & $1.0 \epsilon$ & 1.00 & $0.7 \mathrm{C}$ & ग. 56 & 081 & 4.42 & 0.81 & 0.93 & 1.13 & 1.03 & 0.83 \\
\hline
\end{tabular}

-lutal Fe as $\mathrm{Fe}_{2} \mathrm{O}_{3}$ 
Appendix 5. Whole rock major element analyses on an ignited basis and fluorine-free normative computations of the Alkali Rhyolite.

$\mathrm{SiO}_{2}, \mathrm{TiO}_{2}, \mathrm{Al}_{2} \mathrm{O}_{3}, \mathrm{Fe}_{2} \mathrm{O}_{3}, \mathrm{MnO}, \mathrm{MgO}, \mathrm{CaO}, \mathrm{P}_{2} \mathrm{O}_{5}$

Analyst - J. Bikun

Phillips Model PW 1410 XRF, Arizona State University, Tempe, Arizona

$\mathrm{Na}_{2} \mathrm{O}, \mathrm{R}_{2} \mathrm{O}$

Analyst - J. Bikun

Varian Techtron Model 1250 AA, Arizona State University, Tempe, Arizona

F

Analysts - J. Bikun, E. Christiansen

Coleman Specific Ion Probe, Arizona State University, Tempe, Arizona

Analyst - Skyline Labs, Tucson, Arizona

Specific Ion Probe

Note: For normative computations, ratio of Feo to total Fe used is 0.52 (from Turley and others, 1979).

(n.d. - not determined) 


\begin{tabular}{|c|c|c|c|c|c|c|c|c|c|c|c|c|c|c|}
\hline Sample No. & 42 & 43 & 38 & 59 & 612 & $61 \mathrm{~b}$. & $61 c$ & $62 a$ & $62 \mathrm{~b}$ & $1-63$ & $1-93$ & $8-938$ & $29-124$ & $29-206$ \\
\hline $\mathrm{SiO}_{2}$ & 75.93 & 75.93 & 25.83 & 76.60 & 7498 & 74.22 & $7: .13$ & 26.11 & 75.41 & 75.46 & $i 5.89$ & 75.82 & 75.86 & 76.20 \\
\hline $\mathrm{THO}_{2}$ & C. 09 & 0.16 & 0.08 & 0.07 & 0.28 & 0.28 & 3.30 & 0.14 & 0.14 & $0.10^{\circ}$ & 0.07 & 0.08 & 0.07 & 0.07 \\
\hline $\mathrm{Al}_{2} \mathrm{O}_{3}$ & 12.86 & 12.70 & 12.90 & 12.79 & 13. 12 & 13.14 & 13.82 & 12.43 & 12.49 & 12.74 & 12.77 & 12.62 & 12.98 & 12.66 \\
\hline $\mathrm{Fe}_{2} \mathrm{O}_{3}{ }^{\star}$ & 1.09 & 1.17 & 0.99 & 0.98 & 1.26 & 1.25 & 1.35 & 1.04 & 1.00 & 1.02 & 1.61 & 0.93 & 1.00 & 0.99 \\
\hline $\mathrm{MnO}$ & 0.08 & 0.06 & 0.05 & 0.06 & 0.04 & 0.06 & 3.08 & 0.06 & 0.05 & 0.06 & 0.08 & 0.07 & 0.07 & 0.07 \\
\hline $\mathrm{MgO}$ & a. 09 & 0.13 & 0.17 & 0.06 & 0.19 & 0.26 & .2 .21 & 0.12 & 0.30 & 0.14 & 0.13 & 0.13 & 0.18 & 0.05 \\
\hline Cal & 0.74 & 0.74 & 0.99 & 0.67 & 0.82 & 1.06 & .8 .85 & 0.76 & 1.97 & 0.46 & 0.39 & 0.69 & 0.72 & 0.72 \\
\hline $\mathrm{Na}_{2}, \mathrm{O}$ & 4.11 & 3.45 & 4.12 & 3.98 & 3.48 & 3.43 & 3.52 & 3.35. & 3.58 & 4.11 & 3.76 & 3.92 & 3.65 & 3.74 \\
\hline$K_{2}, 0$ & 4.69 & 5.32 & 4.82 & 4.62 & 5.51 & 5.46 & 3. $5 \mathrm{e}$ & 5.40 & 5.15 & 5.02 & 4.83 & 4.72 & 4.71 & 4.80 \\
\hline $5,0_{5}$ & 0.00 & 0.00 & 0.00 & 0.00 & 0.02 & 0.02 & 0.01 & 0.00 & 0.00 & 0.00 & 0.00 & 0.00 & 0.00 & 0.00 \\
\hline$v^{2}$ & n.d. & 0.25 & 0.12 & 0.35 & 0.20 & n... & 0.15 & 0.16 & n.d. & n.d. & n.d. & 0.30 & n.d. & 0.32 \\
\hline Sua & 99.68 & 99.93 & 100.07 & 100.18 & 99.90 & 99.18 & $9-7.9 \varepsilon$ & 99.57 & 100.09 & 99.11 & $\$ 9.53$ & 99.28 & 99.24 & 99.65 \\
\hline$-0=F$ & - & 0.11 & 0.05 & 0.15 & 0.08 & - & 0.06 & 0.07 & - & - & - & 0.13 & - & 0.13 \\
\hline Tulal & $99.68 x$ & $99.82 \pi$ & $100.02 x$ & $100.03 x$ & $99.82 x$ & $99.18 \%$ & $98.9 \% 7$ & $99.50 \%$ & $100.09 \%$ & $99.11 x$ & $99.53 x$ & $99.15 \%$ & $99.24 x$ & $99.52 \%$ \\
\hline L.O.I. & 3.11 & 2.66 & 0.79 & 3.34 & 2.97 & 2.80 & $0.1 i$ & 2.83 & 1.66 & 0.16 & 0.33 & 0.34 & 2.16 & 2.84 \\
\hline \multicolumn{15}{|c|}{ Fluorine free CIPid norms } \\
\hline or & 27.72 & 31.44 & 28.48 & 27.30 & 32.56 & 32.27 & 32.86 & 31.91 & 30.43 & 29.67 & 26.54 & 27.89 & 27.83 & 28.54 \\
\hline$a b$ & 34.78 & 29.19 & 34.86 & 33.68 & 29.45 & 29.6. - & $29.7 E$ & 28.35 & 30.29 & 34.78 & 31.81 & 33.17 & 30.88 & 31.65 \\
\hline all & 2.79 & 3.46 & 2.47 & 3.32 & 3.91 & $4 . \Xi 3$ & 1.15 & 2.93 & 2.80 & 1.49 & 1.93 & 2.90 & 3.57 & 3.49 \\
\hline 9 & 32.32 & 33.62 & 31.39 & 34.04 & 31.59 & 30.54 & 30.15 & 34.17 & 31.57 & 31.13 & 54.16 & 33.21 & 34.58 & 34.15 \\
\hline hy & 0.35 & 0.62 & 0.00 & 0.60 & 0.66 & 0.57 & $0.7 t$ & 0.31 & {$[1.7600]$} & 0.44 & 8.10 & 0.53 & 0.93 & 0.56 \\
\hline di & 0.75 & 0.34 & 1.70 & 0.00 & 0.03 & 0.15 & $0.0 r$ & 0.70 & 2.22 & 0.66 & 0.00 & 0.44 & 0.00 & 0.07 \\
\hline ap & 0.00 & 0.00 & 0.00 & 0.00 & 0.05 & 0.65 & 0.02 & 0.00 & 0.00 & 0.00 & 0.00 & 0.00 & 0.00 & 0.00 \\
\hline 11 & 0.11 & 0.30 & 0.15 & 0.13 & 0.53 & 0.53 & 0.57 & 0.27 & 0.27 & 0.19 & 0.13 & 0.15 & 0.13 & 0.13 \\
\hline$c$ & 0.00 & 0.00 & 0.00 & 0.02 & 0.00 & o.co & 0.45 & 0.00 & $0 . n 0$ & 0.00 & 0.65 & 0.00 & 0.57 & 0.00 \\
\hline mc & 0.76 & 0.81 & 0.69 & 0.68 & 0.88 & 0.87 & 0.94 & 0.72 & 0.70 & 0.71 & 1.12 & 0.65 & 0.70 & 0.69 \\
\hline
\end{tabular}


Appendix 6. Normative computations making use of available fluorine determinations.

Note: For normative computations, ratio of FeO to total Fe used is 0.52 (from Turley and others, 1979). 


\begin{tabular}{|c|c|c|c|c|c|c|c|c|}
\hline $\begin{array}{l}\text { Sampla Mo. } \\
\text { CIPW norms }\end{array}$ & 31 & 34 & 35 & 63 & 70 & 71 & $6-358$ & \\
\hline or & 29.49 & 28.42 & 21.57 & $29.0 \bar{z}$ & 29.43 & 28.01 & 28.84 & \\
\hline ab & \pm 8.54 & 28.32 & 31.95 & 30.82 & 26.07 & 31.44 & 28.22 & \\
\hline an & 0.00 & 0.00 & 0.00 & 0.00 & 0.00 & 0.00 & 0.00 & \\
\hline $\mathbf{q}$ & 34.22 & 36.50 & 37.50 & 33.14 & 34.84 & 33.60 & 35.27 & \\
\hline by & 0.84 & 0.85 & 0.87 & $1.0 \leq$ & 0.75 & 0.78 & 1.36 & \\
\hline$d t$ & 0.00 & 0.00 & 0.00 & 0.00 & 0.00 & 0.00 & 0.00 & \\
\hline up & 0.00 & 0.00 & 0.00 & 0.00 & 0.02 & 0.02 & 0.00 & \\
\hline 11 & 0.11 & 0.11 & 0.11 & $0.0 \mathrm{~b}$ & 0.08 & 0.11 & 0.11 & \\
\hline c & 2.24 & 2.58 & 2.95 & $2.5:$ & 3.42 & 2.08 & 2.75 & \\
\hline inc & 1.03 & 1.06 & 1.00 & 0.81 & 0.83 & 0.93 & 1.13 & \\
\hline fr & 1.66 & 1.36 & 2.47 & 0.84 & 3.08 & 1.81 & 1.34 & \\
\hline ne & 1.11 & 0.71 & 0.95 & $0.3=$ & 3.11 & 1.15 & 1.00 & \\
\hline$c c$ & -1.04 & -0.67 & -0.89 & -0.30 & -2.94 & -1.09 & -0.94 & \\
\hline $\begin{array}{l}\text { Sadple No. } \\
\text { CIPU worms }\end{array}$ & 43 & 58 & 59 & 610 & $61 \mathrm{c}$ & $62 a$ & $3-938$ & $29-206$ \\
\hline or & 31.44 & 28.48 & 27.30 & $32.5 E$ & 32.86 & 31.91 & 27.89 & 28.54 \\
\hline ab & 29.19 & 34.86 & 33.68 & $29.4 \mathrm{c}$ & 29.78 & 28.35 & 33.17 & 31.65 \\
\hline an & 1.84 & 2.47 & 0.76 & $2.4 \mathrm{E}$ & 3.06 & 2.60 & 1.23 & 1.23 \\
\hline 9 & 14.36 & 31.58 & 35.15 & 32.21 & 30.66 & 34.50 & 34.04 & 35.14 \\
\hline hy & 0.71 & 0.20 & 0.60 & $0.6:$ & 0.76 & 0.66 & 0.75 & 0.60 \\
\hline di & 0.00 & 1.29 & 0.00 & 0.00 & 0.00 & 0.00 & 0.00 & 0.00 \\
\hline ap & 0.00 & 0.00 & 0.00 & 0.05 & 0.02 & 0.00 & 0.00 & 0.00 \\
\hline 11 & 0.30 & 0.15 & 0.13 & 0.53 & 0.57 & 0.27 & 0.15 & 0.13 \\
\hline c & 0.59 & 0.00 & 0.96 & 0.52 & 0.89 & 0.12 & 0.61 & 0.83 \\
\hline $\mathrm{mr}$ & 0.81 & 0.69 & 0.68 & 0.84 & 0.94 & 0.72 & 0.65 & 0.69 \\
\hline fr & 0.51 & 0.25 & 0.72 & $0.4:$ & 0.31 & 0.33 & 0.62 & 0.66 \\
\hline nc: & 0.00 & 0.00 & 0.00 & 0.00 & 0.00 & 0.00 & 0.00 & 0.00 \\
\hline$\bullet c$ & 0.00 & 0.00 & 0.00 & 0.00 & 0.00 & 0.00 & 0.00 & 0.00 \\
\hline
\end{tabular}


Appendix 7. Whole rock minor element analyses of the Porphyritic Rhyolite.

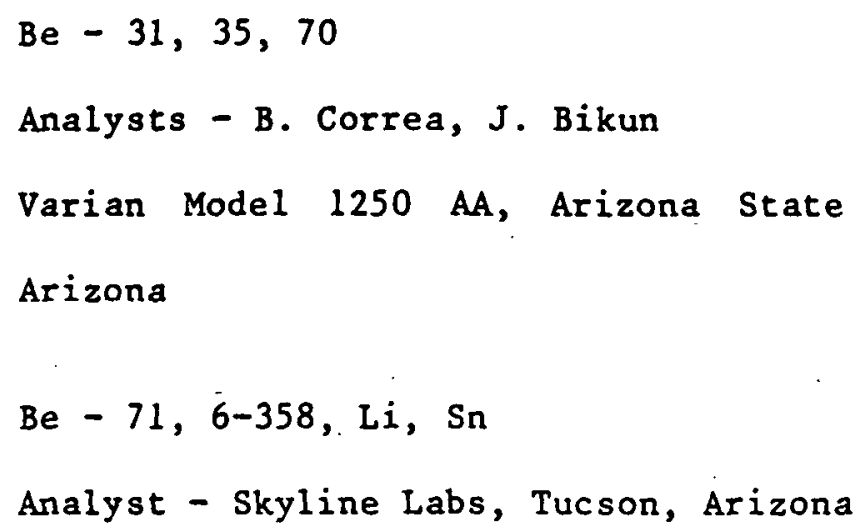




\begin{tabular}{|c|c|c|c|c|c|c|c|c|c|}
\hline Sample Ho. & 31 & 35 & 47 & 63 & 67 & 70 & 7.1 & $6-358$ & $18-113$ \\
\hline Be & $54 \mathrm{ppm}$ & 52 & & & & 82 & 65 & 10 & \\
\hline c1 & & 1680 & & & & 1060 & & & \\
\hline 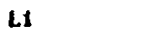 & & 80 & & & & 100 & & 145 & \\
\hline Bb & 972 & 1058 & & & & & & & \\
\hline Sn & & & & & & 30 & & & \\
\hline Sr & $=5$ & $\Rightarrow 5$ & & & & & & & \\
\hline u & & 38 & 13 & 18 & 14 & & & 17 & 13 \\
\hline \multicolumn{10}{|c|}{ I.M.A.A. Dara } \\
\hline Sc & 2.60 & 2.71 & & & & & & & \\
\hline $2 x$ & 710 & $8<0$ & & & & & & & \\
\hline Hf & 6.2 & 7.1 & & & & & & & \\
\hline $\mathbf{T a}$ & 25.8 & 25.0 & & & & & & & \\
\hline Th & 63.8 & 65.2 & & & & & & & \\
\hline U & 36.2 & JE.1 & & & & & & & \\
\hline $\mathrm{Ba}$ & 305 & 324 & & & & & & & \\
\hline $\mathbf{R b}$ & 932 & 1011 & & & & & & & \\
\hline Cs & 54.9 & 58.4 & & & & & & & \\
\hline La & 59.6 & 38.6 & & & & & & & \\
\hline $\mathrm{Ce}$ & 144 & 137 & & & & & & & \\
\hline Nd & 52 & St: & & & & & & & \\
\hline Sm & 13.54 & 17.8 & & & & & & & \\
\hline E.4 & 3.149 & 0.044 & & & & & & & \\
\hline nt & 3.31 & 3.41 & & & & & & & \\
\hline YL & 15.6 & 15.7 & & & & & & & \\
\hline I.u & 2.53 & 2.63 & & & & . & & & \\
\hline l.a/ $/ Y b *$ & 2.52 & 2.76 & & & & & & & \\
\hline
\end{tabular}


Appendix 8. Whole rock minor element analyses of the Alkali Rhyolite

Be, Li, Sn

Analyst - Skyline Labs, Tucson, Arizona

AA

$\mathrm{Rb}, \mathrm{Sr}$

Analyst - CONOCO, Inc.

XRF

U

Analyst - G. Goles

Delayed Neutron Activation, University of Oregon, Corvallis, Oregon

I.N.A.A. Data

Analyst - G. Goles, University of Oregon, Corvallis,

Oregon

(n.d. - not determined) 


\begin{tabular}{|c|c|c|c|c|c|c|c|c|c|c|c|c|c|c|}
\hline Sauple No. & 42 & 43 & 58 & 59 & $61 \mathrm{a}$ & 6111 & the & $62 a$ & $62 \mathrm{~b}$ & $1-63$ & $1-93$ & 8-938 & $29-124$ & $29-206$ \\
\hline Be & & 0 & 7 & 7 & 2 & & & 6 & & & & 9 & & 7 \\
\hline $\mathbf{L}$ & & & 80 & 30 & 20 & & & 40 & & & & 80 & & 60 \\
\hline RL & & & & & & & & & & & & & & 433 \\
\hline Sn & & & & & 2 & & & & & & & & & \\
\hline $\mathbf{s r}$ & & & & & & & & & & & & & & $=5$ \\
\hline u & & & 18 & $2 \pi$ & & 6 & 6 & & 15 & & 24 & 13 & 18 & \\
\hline I.N.A.A. Da & & & & & & & & - & & & & & & \\
\hline sc & 2.15 & & & & 2.71 & & & 1.787 & & & & & & 1.71 \\
\hline $2 \mathbf{r}$ & 610 & & & & n.d. & & & 570 & & & & & & 490 \\
\hline uf & 6.0 & & & & 7.9 & & & 5.51 & & & & & & 4.9 \\
\hline $\mathrm{Ta}$ & 6.35 & & & & 2.27 & & & 4.46 & & & & & & 5.45 \\
\hline Th & 56.0 & & & & 24.6 & & & 59.9 & & & & & & 46.9 \\
\hline u & 25.0 & & & & 5.6 & & & a.d. & & & & & & 19.2 \\
\hline Ha & 228 & & & & 44: & & & 116 & & & & & & 190 \\
\hline RL & 549 & & & & $18 \epsilon$ & & & 377 & & & & & & 430 \\
\hline co & 14.14 & & & & 2.47 & & & 7.43 & & & & & & 9.68 \\
\hline L & 25.5 & & & & 73.1 & & & n.d. & & & & & & 18.0 \\
\hline ce & 64 & & & & 132 & & & 128.9 & & & & & & 53.1 \\
\hline Nu & 31 & & & & 62.6 & & & 34.6 & & & & & & 31 \\
\hline Sw & 4.95 & & & & 8.75 & & & n.u. & & & & & & 7.49 \\
\hline Eu & 0.059 & & & & 1.22 & & & 0.211 & & & & & & 0.065 \\
\hline$T b$ & 0.79 & & & & 1.29 & & & 1.17 & & & & & & 1.92 \\
\hline Yb & 7.9 & & & & 4.0 & & & 9.9 & & & & & & 9.6 \\
\hline Lu & 1.55 & & & & 0.53 & & & 0.901 & & & & & & 1.70 \\
\hline $\mathrm{La} / \mathrm{Yb} *$ & 2.13 & & & & 12.1 & & & 3.37 & & & & & & 1.24 \\
\hline
\end{tabular}


Appendix 9. Beryllium, fluorine, and uranium mineralization mass balance calculations for the Beryllium Tuff. 
A case study of beryllium mineralization mass balance in drill hole no. 6 .

The problem to be addressed is whether there is a sufficient difference in concentration of beryllium between crystalline and glassy Porphyritic Rhyolite to account for the beryllium mineralization in the upper part of the underlying Beryllium Tuff. A one-dimensional model of mass transfer in a vertical column $1 \mathrm{~m}$ in radius will be considered. From the difference in the mean beryllium content of the glassy and crystalline Porphyritic Rhyolite, assume a 51 ppm beryllium loss upon crystallization of the Porphyritic Rhyolite lava. The density of the Porphyritic Rhyolite can be taken to be $2.4(p)$, and the density of the Beryllium Tuff can be taken to be 1.5. In drill hole no. 6 , the Porphyritic Khyolite is $18 \mathrm{~b}$ m thick, the Beryllium Tuff is $56 \mathrm{~m}$ thick, and beryllium mineralization is restricted to the top $12.5 \mathrm{~m}$ of the tuff (Fige, 4 and 37 ).

The amount of beryllium which can be derived from a cylinder 1 m in radius and $185 \mathrm{~m}$ in length consisting of crystalline Porphyritic Rhyolite is:

$$
M(\mathrm{~kg})=V\left(\mathrm{~m}^{3}\right) \cdot 1000 \mathrm{~kg} / \mathrm{m}^{3} \cdot \rho \cdot \mathrm{C}
$$

where $M$ is maso, $V$ is the volume of the cylinder ( $\left.=\pi{ }^{2}{ }_{\mathrm{l}}\right)$, $p$ is density, and $\mathrm{C}$ is the concentration change of beryllium.

Therefore:

$$
\begin{aligned}
M & =(1 \mathrm{~m})^{2} \cdot 185 \mathrm{~m} \cdot \pi \cdot 1000 \mathrm{~kg} / \mathrm{m}^{3} \cdot 2.4 \cdot\left(5.1 \times 10^{-5}\right) \\
& =71 \mathrm{~kg} \text { of beryllium lost upon crystallization. }
\end{aligned}
$$


Three contiguous core intervals were assayed for beryllium from the 12.5 $m$ of mineralized tuff, and their lengths and average grades from top to bottom are:

$$
\begin{aligned}
& \text { 1.) } 2.2 \mathrm{~m} \mathrm{;} 1563 \mathrm{ppm} \\
& \text { 2.) } 3.0 \mathrm{~m} \mathrm{;} 2919 \mathrm{ppm} \\
& \text { 3.) } 7.3 \mathrm{~m} ; 300 \mathrm{ppm}
\end{aligned}
$$

The concentration of beryllium in the lower unaltered section of the tuff in the drill core is $25 \mathrm{ppm}$, and this value can be considered as the background or primary beryllium concentration of the mineralized tuff. The amount of beryllium added to $12.5 \mathrm{~m}$ of mineralized tuff will be its concentration above the background. The mass of beryllium added to the mineralized portion of the tuff will be the sum of the amounts added to each assayed core interval. This calculation will be analogous to the preceding one used in determining the mass of beryllium lost from a $l$ m radius cylinder in the Porphyritic Rhyolite. So the mass added to a 1 m radius vertical column in the mineralized Beryllium Tuff is the sum of :

$$
\text { 1.) } \begin{aligned}
M & =(1 \mathrm{~m})^{2} \cdot 2.2 \mathrm{~m} \cdot \pi \cdot 1000 \mathrm{~kg} / \mathrm{m}^{3} \cdot 1.5 \cdot\left(1.538 \times 10^{-3}\right) \\
& =15.9 \mathrm{~kg} \\
2 .) M & =(1 \mathrm{~m})^{2} \cdot 3.0 \mathrm{~m} \cdot \pi \cdot 1000 \mathrm{~kg} / \mathrm{m}^{3} \cdot 1.5 \cdot\left(2.894 \times 10^{-3}\right) \\
& =40.9 \mathrm{~kg} \\
3 .) \mathrm{M} & =(1 \mathrm{~m})^{2} \cdot 7.3 \mathrm{~m} \cdot \pi \cdot 1000 \mathrm{~kg} / \mathrm{m}^{3} \cdot 1.5 \cdot\left(2.75 \times 10^{-4}\right) \\
& =9.5 \mathrm{~kg}
\end{aligned}
$$

Total M $=66 \mathrm{~kg}$ of beryllium added upon mineralization.

Thus, sufficient beryllium is lost by the Porphyritic Rhyolite to mineralize the upper part of the Beryllium Tuff. 
A case study of fluorine mineralization mass balance in drill hole no. 6 .

The problem to be addressed is whether there is a sufficient difference in concentration of fluorine between crystalline and glassy Porphyritic Rhyolite to account for the fluorine mineralization in the upper part of the underlying Beryllium Tuff. A one-dimensional model of mass transter in a vertical columin 1 in 1 in radius will be consldered. From the difference in the mean fluorine content of the glassy and crystalline' Porphyritic Rhyolite, assume a 0.58 percent fluorine loss upon crystallization of the Porphyritic Rhyolite lava. The density of the Porphyritic Rhyolite can be taken to be $2.4(\rho)$, and the density of the Beryllium Tuff can be taken to be 1.5. In drill hole no. 6 , the Porphyritic Rhyolite is $185 \mathrm{~m}$ thick, the Beryllium Tuff is $56 \mathrm{~m} \mathrm{thick,}$ and fluorine mineralization is restricted to the top $17.7 \mathrm{~m}$ of the tuff (Figs. 4 and 38 ).

The amount of fluorine which can be derived from a cylinder 1 m in radius and $185 \mathrm{~m}$ in length consisting of crystalline Porphyritic Rhyolite is:

$$
M(\mathrm{~kg})=V\left(\mathrm{~m}^{3}\right) \cdot 1000 \mathrm{~kg} / \mathrm{m}^{3} \cdot \rho \cdot C
$$

where $M$ is mass, $V$ is the volume of the cylinder $\left(v=\pi r^{2} h\right), \rho$ is density, and $C$ is the concentration change of fluorine.

Therefore:

$$
\begin{aligned}
M & =(1 \mathrm{~m})^{2} \cdot 185 \mathrm{~m} \cdot \pi \cdot 1000 \mathrm{~kg} / \mathrm{m}^{3} \cdot 2.4 \cdot\left(5.8 \mathrm{x}^{1} 10^{-3}\right) \\
& =809 \mathrm{~kg} \text { of fluorine lost upon crystallization. }
\end{aligned}
$$


Four contiguous core intervals were assayed for fluorine from the $17.7 \mathrm{~m}$ of mineralized tuff, and their lengths and average grades from top to bottom are:

1.) 2.2 m ; 0.6488 percent

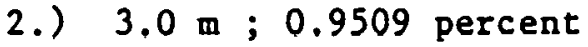

3.) $7.3 \mathrm{~m} ; 1.0466$ percent

4.) $5.2 \mathrm{~m} ; 0.5408$ percent

The concentration of fluorine in the lower unaltered section of the tuff in the drill core is 0.4263 percent, and this value can be considered as the background or primary fluorine concentration of the mineralized tuff. The amount of fluorine added to $17.7 \mathrm{~m}$ of mineralized tuff will be its concentration above the background., The mass of fluorine added to the mineralized portion of the tuff will be the sum of the amounts added to each assayed core interval. This calculation will be analogous to the preceding one used in determining the mass of fluorine lost from a 1 m radius cylinder in the Porphyritic Rhyolite. So the mass added to a 1 m radius vertical column in the mineralized Beryllium Tuff is the sum of :

$$
\text { 1.) } \begin{aligned}
M & =(1 \mathrm{~m})^{2} \cdot 2.2 \mathrm{~m} \cdot \pi \cdot 1000 \mathrm{~kg} / \mathrm{m}^{3} \cdot 1.5 \cdot\left(2.225 \times 10^{-3}\right) \\
& =23.1 \mathrm{~kg} \\
2 .) M & =(1 \mathrm{~m})^{2} \cdot 3.0 \mathrm{~m} \cdots \pi \cdot 1000 \mathrm{~kg} / \mathrm{m}^{3} \cdot 1.5 \cdot\left(5.246 \times 10^{-3}\right) \\
& =74.2 \mathrm{~kg} \\
3 .) M & =(1 \mathrm{~m})^{2} \cdot 7.3 \mathrm{~m} \cdot \pi \cdot 1000 \mathrm{~kg} / \mathrm{m}^{3} \cdot 1.5 \cdot\left(6.203 \times 10^{-3}\right) \\
& =180 \mathrm{~kg} \\
4 .) M & =(1 \mathrm{~min})^{2} \cdot 7.3 \mathrm{~m} \cdot \pi \cdot 1000 \mathrm{~kg} / \mathrm{m}^{3} \cdot 1.5 \cdot\left(1.145 \times 10^{-3}\right) \\
& =28.1 \mathrm{~kg}
\end{aligned}
$$


Total $M=306 \mathrm{~kg}$ of fluorine added upon mineralization.

Thus, sufficient fluorine is lost by the Porphyritic Rhyolite to mineralize the upper part of the Beryllium Tuff. 
A case study of uranium mineralization mass balance in drill hole no. 6 .

The problem to be addressed is whether there is a sufficient difference in concentration of uranium between crystalline and glassy Porphyritic Rhyolite to account for the uranium mineralization in the upper part of the underlying Beryllium Tuff. A one-dimensional model of mass transfer in a vertical column $1 \mathrm{~m}$ in radius will be considered. From the difference in the mean uranium content of the glassy and crystalline Porphyritic Rhyolite, assume a 23 ppm fluorine loss upon crystallization of the Porphyritic Rhyolite lava. The density of the Porphyritic Rhyolite can be taken to be $2.4(\rho)$, and the density of the Beryllium Tuff can be taken to be 1.5. In drill hole no. 6 , the Porphyritic Rhyolite is $185 \mathrm{~m}$ thick, the Beryllium Tuff is 56 m thick, and uranium mineralization is restricted to the top 12.5 .m of the tuff (Figs. 4 and 39.).

The amount of uranium which can be derived from a cylinder $1 \mathrm{~m}$ in radius and $185 \mathrm{~m}$ in length consisting of crystalline Porphyritic Rhyolite is:

$$
M(\mathrm{~kg})=V\left(\mathrm{~m}^{3}\right) \cdot 1000 \mathrm{~kg} / \mathrm{m}^{3} \cdot \rho \cdot \mathrm{C}
$$

where $M$ is mass, $V$ is the volume of the cylinder $\left(v=\pi r^{2} h\right), \rho$ is density, and $C$ is the concentration change of uranium.

Therefore:

$$
\begin{aligned}
M & =(1 \mathrm{~m})^{2} \cdot 185 \mathrm{~m} \cdot \pi \cdot 1000 \mathrm{~kg} / \mathrm{m}^{3} \cdot 2.4 \cdot\left(23 \times 10^{-5}\right) \\
& =32 \mathrm{~kg} \text { of uranium lost upon crystallization. }
\end{aligned}
$$


Three contiguous core intervals were assayed for uranium from the 12.5 $m$ of mineralized tuff, and their lengths and average grades from top to bottom are:

$$
\begin{aligned}
& \text { 1.) } 2.2 \mathrm{~m} ; 83 \mathrm{ppm} \\
& \text { 2.) } 3.0 \mathrm{~m} ; 92 \mathrm{ppm} \\
& 3 .) 7.3 \mathrm{~m} ; 47 \mathrm{ppm}
\end{aligned}
$$

The concentration of uranium in the lower unaltered section of the tuff in the drill core is $11 \mathrm{ppm}$, and this value can be considered as the background or primary uranium concentration of the mineralized tuff. The amount of uranium added to $12.5 \mathrm{~m}$ of mineralized tuff will be its concentration above the background. The mass of uranium added to the mineralized portion of the tuff will be the sum of the amounts added to each assayed core interval. This calculation will be analogous to the preceding one used in determining the mass of uranium lost from a 1 m radius cylinder in the Porphyritic Rhyolite. So the mass added to a 1 m radius vertical column in the mineralized Beryllium Tuff is the sum of :

$$
\begin{aligned}
1 .) M & =(1 \mathrm{~m})^{2} \cdot 2.2 \mathrm{~m} \cdot \pi \cdot 1000 \mathrm{~kg} / \mathrm{m}^{3} \cdot 1.5 \cdot\left(7.2 \times 10^{-5}\right) \\
& =0.75 \mathrm{~kg} \\
2 .) M & =(1 \mathrm{~m})^{2} \cdot 3.0 \mathrm{~m} \cdot \pi \cdot 1000 \mathrm{~kg} / \mathrm{m}^{3} \cdot 1.5 \cdot\left(8.1 \times 10^{-5}\right) \\
& =1.15 \mathrm{~kg} \\
3 .) M & =(1 \mathrm{~m})^{2} \cdot 7.3 \mathrm{~m} \cdot \pi \cdot 1000 \mathrm{~kg} / \mathrm{m}^{3} \cdot 1.5 \cdot\left(4.7 \times 10^{-5}\right) \\
& =1.62 \mathrm{~kg}
\end{aligned}
$$

Total $M=3.51 \mathrm{~kg}$ of uranium added upon mineralization. Thus, sufficient uranium is lost by the Porphyritic Rhyolite to mineralize the upper part of the Beryllium Tuff. 


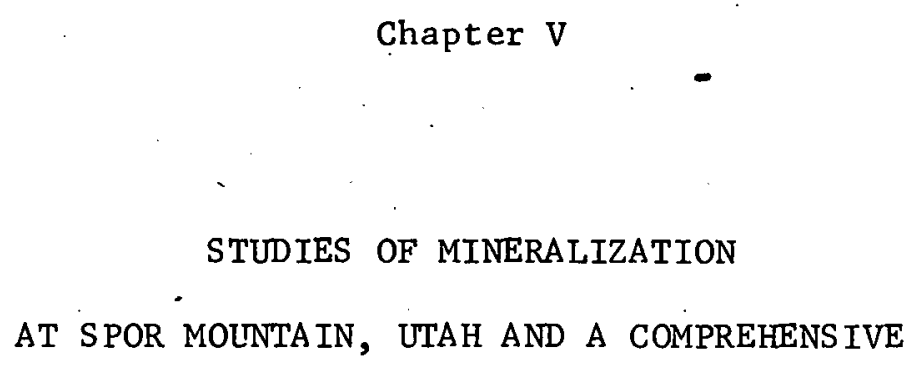

SPOR MOUNTAIN BIBLIOGRAPHY

$$
\text { by }
$$

Barbara A. Murphy 
Autoradiographs of fluorite nodules from the Roadside Pit at Spor Mountain, Utah indicate that uranium is disseminated in fluorite and opal and not located in separate U-rich minerals. Autoradiographs of the Porphyritic Rhyolite Member of the Spor Mountain Formation, the Topaz Mountain Rhyolite, and Iithophysal rhyolite from the Wah Wah Mountains revealed a random distribution of point sources for uranium. In the Porphyritic Rhyolite several of the point sources were tentatively correlated to altered oxides (hematite?).

The fine-grained nature of fluorite and silica in the Beryllium Tuff at Spor Mountain and fluid inclusion homogenization temperatures of $143^{\circ} \mathrm{C}$ for fluorite plus $162^{\circ} \mathrm{C}$ and $165^{\circ} \mathrm{C}$ for quartz indicate that tuff alteration was a relatively low temperature process. An inclusion in calcite homogenized at $290-310^{\circ} \mathrm{C}$ and suggests that deposition of calcite may have resulted from heating of circulating ground water by the overlying rhyolite flows.

Pumices from the Stratified Tuff and the Beryllium Tuff at Spor Mountain show a remarkable similarity to pumices from an ash flow unit of the Bishop Tuff in that the non-welded numices are light-colored and randomly-oriented, while the welded numices were flattened and aligned to form black glass lenticles called fiamme. Significant differences are that devitrification of pumices in the Bishop Tuft but not the Stratified or Beryllium Tuff has occurred and welding has occurred in the Bishop Tuff and Stratified Tuff but not the Beryllium Tuff. Alteration of part of the Beryllium Tuff has completely destroyed the tubular structure of the pumices within the altered zone.

Bertrandite recovered from the dissolution of fluorite nodules revealed no obvious crystallographic form even in high magnification SEM photographs. Fluorite from a nodule also revealed no distinct crystallographic form. However, fluorite from the fluorite pipe at the Bell Hill Mine crystallizes as cubes and cubes modified by octahedra(?). 


\section{INTRODUCTION}

A large variety of deposits in the Spor Mountain District have been studied and this has led to an enormous volume of literature. Detailed work has been done on the fluorspar deposits (Staatz and Osterwald, 1959), the beryllium deposits (Williams, 1963; Park, 1968; Lindsey, 1975; Lindsey, 1977), the general geology (Staatz and Carr, 1964; Lindsey, 1979), the volcanic geology (Erickson, 1963; Lindsey et a1., 1975; Shawe, 1972; Turley et al., 1979), the uranium potential (Lindsey, 1979; Lindsey, 1980; this report), the gem quality topaz (A11ing, 1887; Holfert, 1978) and other gemstones and unusual minerals of the district (Montgomery, 1934; Pabst, 1938; Nassau and Wood, 1968; Ream, 1979).

This report contains the results of detailed studies of the fluorspar deposits, the beryllium deposits and the volcanic rocks. In particular, it describes attempts to determine: (1) the location of uranium in the alkali.rhyolites and fluorite nodules of the Beryllium Tuff, (2) the temperature of formation of the Beryllium Tuff, (3) the morphology of pumices from the Beryllium Tuff and the tuff of the Topaz Mountain Rhyolite, and (4) the crystallographic habit of fluorite from the Bell Hill Mine, and of fluorite and bertrandite from the Beryllium Tuff at the Roadside Pit.

REVIEW OF WORK ON ALTERATION OF THE BERYLLIUM TUFF

The most comprehensive and detailed study of the alteration of the tuffs in the Spor Mountain District is Lindsey et a1. (1973b). It was not known until after the publication of Lindsey (1977) that the unmineralized or Stratified Tuff, centered in the Thomas Range, and the mineralized or Beryllium Tuff, southwest of Snor Mountain, are distinct. Instead, both were assumed to be associated with the Tonaz Mountain Rhyolite. The discussion of the alteration process by Lindsey et al. (1973b) plus the work on geochemical halos in Lindsey (1975) are largely invalid since they are based on this assumption. The mineralogical descriptions in these studies are nevertheless still valid. The mineralization was likewise thought to 
have occurred during or shortly after the emplacement of the Topaz Mountain Rhyolite which was dated at 6-7 m.y. (Lindsey et al., 1973b). Given the $21 \mathrm{~m} . \mathrm{y}$. date of the Porphyritic Rhyolite (Lindsey, 1977) the mineralization is now thought to have taken place between 7 and $21 \mathrm{m.y}$. ago (Lindsey, 1979, p. 62).

Two facies of the tuff of the Topaz Mountain Rhyolite (unmineralized tuff, in the article) were described in Lindsey et al. (1973b): vitric and zeolitic. The vitric tuffs consist mainly of fresh glassy pumice, a few percent of pyrogenic crystals (quartz, sanidine, plagioclase, biotite and traces of magnetite, ilmenite, topaz, sphene, and zircon), and volcanic rock fragments with a matrix of undeformed glass shards and pumice. Diagenetic alteration which resulted in the formation of the zeolitic tuff almost completely destroyed the glass and vesicular pumice leaving only relict pumice vesicles. The matrix is composed almost entirely of very small grains of clinoptilolite. Later work established a feldspathic facies (Lindsey, 1975). This facies indicates a more advanced stage of diagenesis. It contains potassium feldspar, quartz and $\alpha$-cristobalite of diagenetic origin. The vitric tuff occurs around the margins of the Thomas Range while both the zeolitic and feldspathic facies occur towards the center of the range.

'The Beryllium Tuff (mineralized tuff) contains about two or more times the content of $\mathrm{Cs}, \mathrm{Li}, \mathrm{Rb}, \mathrm{T} 1$, eU, B, Be, Ga, La, Mn, $\mathrm{Nb}, \mathrm{Sc}, \mathrm{Sn}, \mathrm{Y}$ and $\mathrm{Zn}$ over the unmineralized tuff. It has two facies: argillic and feldspathic. The argillic alteration of the tuff was incomplete, with fresh fragments of glassy pumice, volcanic rocks and carbonate rocks remaining. Up to $80 \%$ of this facies can contain dioctahedral montmorillonoid (or dioctahedral smectite). Other constituents are $1-5 \%$ fluorite, up to $20 \%$ feldspar, and minor amounts of dolomite, calcite, clinoptilolite, pumice and volcanic rock fragments. The dolomite clasts have undergone a wide range of alteration and may be leached to calcite or replaced by quartz, opal, fluorite, and clay.

The feldspathic tuff is believed to represent a more advance stage of alteration. It contains $20+\%$ potassium feldspar, 10-30\% $\alpha$-cristobalite (not in all tuff 
samples), up to $40 \%$ montmorillonoid clay, $1-8 \%$ fluorite with some glass, clinoptilolite, and calcite. The dolomite clasts have been replaced by clay, fluorite and manganese oxides or quartz, opal and purple fluorite. The matrix consists of clay, potassium feldspar, which repleces glass, zeolites and clay of the argillic tuff, cristobalite, which occurs as spherulites and fibrous masses with potassium feldspar, sericite and fine-grained anhedral fluorite. The clinoptilolite of the argillic and feldspathic facies is thought to result from diagenesis (Lindsey, 1979). The alteration of the unit has been complicated by a hydrothermal imprint placed on a diagenetic one.

The alteration pattern of the Roadside deposit was studied in detail. Two zones of feldspathic alteration occur. The upper zone, which is the top $18 \mathrm{~m}$ of the unit, coincides with extensive alteration of the dolomite clasts and the greatest amount of Be mineralization. The lower zone, which occurs at the bottom $9 \mathrm{~m}$ of the unit, has no Be concentration or dolomite alteration. These characteristics make it very similar to the feldspathic facies of the tuff of the Topaz Mountain Rhyolite. It is thought that perhaps part of this zone has a diagenetic origin (Lindsey, 1977). $\because \quad$ The center section has been argillized. The lower half of the facies contains dolomite clasts and the upper part contains calcite clasts. Dedolomitization of the clasts possibly is the result of heating from the overlying porphyritic rhyolite flow. This produced calcite and released $\mathrm{Mg}$ which was taken to form a $\mathrm{Li}-$ bearing trioctahedral montmorillonoid which is also most abundant in this zone. There are two types of altered nodules in the tuff, calcite-silica-fluorite and clay-fluorite-manganese oxide. The calcite-silica-fluorite nodules occur in both zones of alteration. The minerals are all fine-grained, the fluorite ranges from purple to colorless and the alteration sequence ideally occurs as follows: calcite-quartz-opal-tluorite. I'he filuorite- and opal-rich zones concentrate $\overline{\mathrm{L}} \mathrm{i}$, $\mathrm{U}$, $\mathrm{Be}, \mathrm{Pb}$, and $\mathrm{Zn}$. $\mathrm{Mn}$ is concentrated in the calcite zone and Mo and $\mathrm{Cu}$ are concen:rated in the quartz zone. 
The clay-fluorite-manganese oxide nodules occur locally in the zone of feldspathic alteration. These nodules have no ideal alteration sequence. Fluorite or clay can be at the core or rim. However, whenever manganese oxides occur they form fracture fillings or rims of the nodules. A high concentration of Be, Li, $\mathrm{Mg}$, and $\mathrm{Zn}$ occur both in the fluorite and clay which can be a dioctahedral or trioctahedral montmorillono1d.

Lindsey et al. (1973b) felt that these zones of argillic and feldspathic alteration were the result of hydrothermal alteration. F-bearing solutions were derived from the magma that formed the topaz rhyolite. These solutions transported $\mathrm{Be}, \mathrm{Mn}$, and $\mathrm{U}$ as fluoride complexes, using fractures and faults as conduits. At the surface where pressure and temperature of the solutions dropped they reacted with the porous tuff to form the alteration facies and Be deposits. Lindsey (1978) later felt that the hydrothermal solutions could have leached the buried pluton which formed from the magma to get their lithophile elements.

\section{AUTORADIOGRAPHY}

In this study six samples were chosen and run in two sets. The first contained three nodules from the Roadside Pit which were provided by David t.indsey of the U. S. Geological Survey. The second set contained samples of the Porphyritic Rhyolite Member of the Spor Mountain Formation, the lithophysal Topaz Mountain Rhyolite and the lithophysal rhyolite of the Wah Wah Mountains. The samples were sawed in two and one of the cut"surfaces was polished to an even surface. The' first set was placed on Tri-X pan professional film and developed with Microdol-X. The second set was placed on Royal X film and developed in an HC110 stock solution (all products were made by Kodak). A "fast" film and developer were used on the second set to enhance the exposures occurring from the radioactive decay of $U$.

Lindsey et al. (1973a) had already done mineralogical and chemical work on the nodules provided $(\mathrm{N}-22, \mathrm{~N}-24, \mathrm{~N}-34)$. The nodules consist of varying amounts of fluorite and opal. $\mathrm{N}-22$ and $\mathrm{N}-34$ contain approximately equal portions while 
N-24 is predominantly fluorite. Each nodule was separated into zones on the basis of concentric or nearly concentric color bands. A spectrographic analysis for $U$ was performed on each zone in the nodule.

For N-22 the highest exposure occurred in the center of the nodule which coicides with the largest amount of $U$ (1500 ppm). A moderate amount of exposure occurred in the middle (500-1500 ppm). Little or no exposure occurred at the rim (1000 ppm). In N-24 the rim and the core had $500 \mathrm{ppm} U$ and the middle section contained 1500 ppm U but no exposure differences could be seen. Why exposure differences could be seen for $\mathrm{N}-22$ and not $\mathrm{N}-24$ is not known. N-34 did have several small exposure patches in the center and up to $4 \mathrm{~mm}$ from the rim. Lindsey et a1. (1973a) detected no $U$ in this sample so perhaps there is another source of radiation such as Th or perhaps only the decay products of $U$ were left after leaching. The exposure of all three nodules was an erratic cloud which suggests a dissemination of $\mathrm{U}$ in the fluorite and opal, not discrete U-rich minerals.

The second set was studied to determine the U concentration in 1ithophysal versus porphyritic rhyolite. A theory had been proposed that no secondary enrichment of U from the Topaz Mountain Rhyolite occurred because the lithophysae, formed by late-stage vapor phase crystallization, had locked in the U and other lithophile elements (Sheridan, personal communication, 1979). Therefore one would expect a concentration of $U$ in the $U$ ithophysae rather than randomly disseminated in the rhyolite. However, no concentration of $U$ was seen. Both 1ithophysal rhyolites and the Porphyritic Rhyolite showed a random distribution of point sources of U. A few of the point sources in the Porphyritic Rhyolite may be correlated to altered oxides (hematite (?)), a site found to concentrate U during alteration (Zielinski, 1978). The point sources of all three samples showed variation in amount of exposure which indicated a variation in the concentration of $U$ at each site.

To summarize, the autoradiographs of the fluorite nodules indicate that the $\mathrm{J}$ was disseminated in zones in the nodules and not located in discrete U-rich 
minerals. Uranium in both the Porphyritic Rhyolite and lithophysal rhyolites was randomly distributed, probably in U-rich nhases as indicated by the correspondence between $U$ exnosure and altered oxides in the Porphyritic Rhyolite.

\section{FLUID INCLUSIONS}

A reconnaissance study of fluid inclusions was conducted during December, 1979 at the Laboratory of Economic Geology of the University of Arizona. A Mode1 I heating-freezing stage, sold by SGE (Sigma Gamma Epsilon), the student geosciences honorary at the University of Arizona, was used. The procedure outlined in the handbook accompanying the stage was used.

Various materials from the Spor Mountain District were prepared for study: clear, black and matrix topaz from lithophysae in the Topaz Mountain Rhyolite; quartz and fluorite from a thin, atypical, vuggy vein of opal-fluorite-quartz which crosscuts the Beryllium Tuff Member of the Spor Mountain Formation at the Fluoro Pit; fluorite from the Bell Hill Mine; and opal from the Joy and Beryllium Tuff (see map in Bikun, this report, Fig. 27).

The topaz, quartz, and calcite yielded thousands of secondary inclusions. No primary inclusions were found in the clear or black topaz. The opal shattered too easily for thick sections to be made so no fluid inclusion study was undertaken. Oxygen and hydrogen isotope work (Henry, 1978) on opal of the Joy Tuff and opal from the tuff of the Tonaz Mountain Rhyolite gave a temperature of formation range of $6-101^{\circ} \mathrm{C}$ depending on which method of temperature calculation was used. Another factor that indicates a low temperature origin for opal in the Spor Mountain District is the opal's association with clinoptilolite, montmorillonite and hydrated but nondevitrified glass. In geothermal provinces alteration leaves little glass untouched and the clinoptilolite and montmorillonite are limited to the coolest zones of the alteration (Henry, 1978, p. (IX) 14).

No primary inclusions were found in the fluorite of Bell Hill due to its fine grain size (also true of fluorite in the nodules of the Beryllium Tuff). If any 
fluid was trapped in the crystals these inclusions would be too small to work with. In the western United States commercial fluorite deposits and fluorite gangue of Tertiary age (6-32 m.y. old) are found in a horseshoe-shaped area which surrounds the Colorado Plateau. This belt is associated with alkali granites or rhyolites, normal Basin and Range faulting, and a high heat flow (Shawe, 1979).

The majority of these deposits are considered epithermal (Nash and Worl, 1971). Two examples follow. In the Northgate District, Jackson County, Colorado, the fluorspar deposits occur mostly in Precambrian basement but a few veins occur in sediments of Tertiary age (Van Alstine, 1947). The fluorspar had four clusters of homogenization temperatures near $113^{\circ} \mathrm{C}, 144^{\circ} \mathrm{C}, 160^{\circ} \mathrm{C}$, and $177^{\circ} \mathrm{C}$. The inclusions had a salinity of 0.2 weight \% equivalent $\mathrm{NaCl}$ (Nash and Worl, 1971).

Fluid inclusion studies of fluorite gangue associated with $\mathrm{Pb}-\mathrm{Zn}-\mathrm{Ag}$ replacement bodies and fissure fillings have been undertaken in the southwestern Star Range, Beaver County, Utah. The mineralization is associated with the intrusion of Tertiary granite into sedimentary rocks. The fluid inclusions had a homogenization temperature range of $135-205^{\circ} \mathrm{C}$ with $70 \%$ of the temperatures between $161-190^{\circ} \mathrm{C}$ (Su, 1976).

Not all of the fluorspar deposits in the province are epithermal. Inclusions in quartz associated with the fluorspar deposits in the Jamestown District, Boulder County, Colorado have filling temperatures of $250-375^{\circ} \mathrm{C}$ with salinities of $20-30$ weight $\%$ equivalent $\mathrm{NaCl}$. These denser fluids are in close association with alkalic intrusives (Nash and Cunningham, 1973).

Work on fluorite deposits in Japan, Korea, and Russia indicates a low pressure and temperature environment (the bulk of the mineralization occurring from $110^{\circ} \mathrm{C}$ to $180^{\circ} \mathrm{C}$ ) making them epitherma 1 (Arkhipchuk, 1968; Benesova and Cadek, 1969; Enjyoji and Miyazawa, 1969; Karpov, 1970; De Groodt, 1973; Puzanov, 1973; Chi, 1975; Arkhipchuk, 1976; Borodin et al., 1976; Faiziyev, 1976; Imai, 1976; Rogers, 1976).

The fluids that deposited the commercial fluorite deposits and fluorite nodules in the tuff of the Spor Mountain District could be magmatic-hydrothermal or 
circulating ground water which is heated by the rhyolite flows. An example of the latter formed the barite-fluorite-galena deposits associated with the Rio Grande Rift in south-central New Mexico. It is believed to have formed by ground water circulation through evaporites and carbonates to form a high halide and sulfate solution which was heated to $150-200^{\circ} \mathrm{C}$ by mid-Tertiary near-surface dikes and sills (Beane, 1974). Salinities of fluid inclusions from fluorite deposits related to rhyolites range from 0.2 weight \% equivalent NaCl (Van Alstine, 1969) to 10-15 weight \% equivalent NaC1 (Kessler, 1975).

l'hree primary inclusions were found in the topaz. The inclusions would not treeze which prevented determination of the salinity of the fluid. The same difficulty was encountered for the inclusions found in quartz and fluorite. Tt is believed that fluid inside small inclusions has trouble nucleating which prevents ice formation (Enjyoji, 1972) and this may be the problem for these inclusions. During homogenization of the topaz inclusions a nearby cleavage plane expanded causing decrepitation of the inclusions between $80-110^{\circ} \mathrm{C}$. Work done on homogenizing glass inclusions in "ongonite", a Russian topaz-bearing quartz keratophyre (a F-enriched silicic rock similar to the Topaz Mountain Rhyolite), gave a temperature of homogenization at $920-1030^{\circ} \mathrm{C}$ (Naumov et al., 1971).

Quartz from the veinlet in the Fluoro Pit yielded the most primaries. The fluid inclusions contained no daughter minerals or identifiable liquid $\mathrm{CO}_{2}$ (this is also true for a 1 the primary tiluid inclusions studied). Some of the inclusions were too small to work with and others were lost when they were removed from the remainder of the thick section enabling only one inclusion to be measured. On two runs this inclusion had homogenization temperatures of $162^{\circ} \mathrm{C}$ and $165^{\circ} \mathrm{C}$.

Primary inclusions in fluorite from the veinlet and calcite from a nodule were very few. The single usable inclusion in the purple fluorite twice attained a homogenization temperature of $143^{\circ} \mathrm{C}$. A primary inclusion in the calcite homogenized between $290-310^{\circ} \mathrm{C}$. Precise measurements could not be attained because a residue of Canada balsam on the thick section clouded and intermittently obscured 
the view of the inclusion. The Canada balsam could not be removed for a second run.

The size of bertrandite crystals, $<5 \mu \mathrm{m}$ (Montoya et al., 1962), prevented any fluid inclusion study. Crystallization of bertrandite in pegmatites has occurred at temperatures as low as $140-165^{\circ} \mathrm{C}$ (Khitarov, 1973) and $130-160^{\circ} \mathrm{C}$ (Remeshilo, 1974). The crystallization of bertrandite in the Beryllium Tuff at these temperatures is compatible with temperatures obtained from quartz and fluorite., ,

The data collected is preliminary only. Lack of primary inclusions and their small size prevented a statistical study. The homogenization temperatures of quartz and fluorite suggest that the alteration of the Beryllium Tuff occurred at low temperatures. The fine grain size of the fluorite, quartz and bertrandite is characteristic of low temperature conditions which also favors slow reactions and long persistence of metastable forms (Krauskopf, 1977). Only more measurements, Iff possible, will tell the precise range of alteration temperatures for the deposits. The calcite temperature appears anomalously high but it could be the result of heating of circulating ground water by the overlying rhyolite flows. Leakage of the calcite primary inclusions may have occurred but it is not likely (Roedder and Skinner, 1968).

SCANNING ELECTRON MICROSCOPY

\section{Introduction}

The scanning electron microscope (SEM) was used to investigate a variety of materials. The character of pumices and shards from the Bishop Tuff ash flows and air fall (rhyolitic composition), California-Nevada, was studied and compared. with pumices from the Beryllium Tuff Member of the Spor Mountain Formation and the tuff of the Topaz Mountain Rhyolite (Stratified Tuff) in an attempt to determine the origin of formation of these tuffs. Bertrandite residue from fluorite nodules from the Roadside Pit at Spor Mountain was studied to determine the morphology of the beryllium silicate. Fluorite from the fluorspar pipe at the Bell 
Hill Mine and from a nodule in the Blue Chalk Pit was studied to determine if there were any differences in crystal habit.

Review of theory on pumices and shards

As magma nears the surface gas bubbles nucleate from the melt and grow to form bubbles. Surface tension within the magma will spontaneously shrink bubbles with less than a critical radius while larger ones will grow (Murase and McBirney, 1973). According to Sparks (1978) the bubble growth stops before the magma is extruded. When the magma is extruded explosively, the bubbles are stretched and distorted into long or tubular vesicles and the magma is torn apart and quickly chilled to form a frothy glass. Vesicle walls in the pumice may break off to form straight or slightly curved glass shards. The pumice and shards may be deposited within an air fall or an ash flow.

After emplacement of the ash flow, compaction and welding occur if the temperature is high enough. High temperature devitrification and vapor phase crystallization will most likely occur in a thick unit that will cool slowly. A thin unit cools quickly, inhibiting high temperature devitrification and vapor phase crystallization. Welding and compaction may flatten or completely homogenize the pumice leaving little or no evidence of vesicles (Schmincke, 1974). These processes will modify the initial pumice form resulting in a variation of pumice morphology. Shards, being the walls of tubular chambers in the pumice, undergo the same flattening processes as the pumices.

Pumice and glass shards will devitrify with time but the initial slow cooling of a thick, hot, ash flow sheet may cause the glass to devitrify sooner. A common devitrification product is spherulites, a radiating growth of acicular crystals which form spheroids. The acicular fibers are usually composed of alkali feldspar, cristobalite or plagioclase (Lofgren, 1971b). Basic requirements for spherulitic crystallization are a viscous melt, slow crystallization, formation of a thin layer of the low temperature component at the liquid-crystal interface and 
the nucleation of nearly parallel fibers at disorder sites on the sides of existing fibers. Detailed information on the formation of spherulites may be found in Keith and Padden (1963) and Lofgren (1971b). The fibers grow into sheaves, then a bowtie shape and ultimately a spherical bundle (Morse and Donnay, 1936; Fig. 1): Sheaves were a more common product in the devitrification of rhyolitic glass than complete spherulites (Lofgren, 1968). Spherulites may grow over large areas of the tuff sheet cutting across shards and pumice. They may (Ross and Smith, 1960; their figs. 63 and 64) or may not (Ross and Smith, 1960; their figs. 69 and 70) completely destroy the texture of the ash flow tuff.

Another common devitrification product in ash flow tuffs is axiolites, a group of parallel fibers which grow in both directions from a 1 ine. Shards commonly devitrify in this manner leaving the outline of the shard intact (Ross and Smith, 1960; their figs. 71-74).

Lofgren (1971a) observed other devitrification products besides axiolites and spherulites in his experiments on the devitrification of rhyolite. Perhaps these textures may be found in a densely welded rhyolitic ash flow sheet that has devitrified. These textures include: granophyric--quartz enclosed within feldspar spherulites; miarolitic cavity--cavity usually lined with quartz that forms by volume change due to crystallization; and micropoikilitic quartz--feldspar spherulites enclosed in quartz.

In Schmincke's (1974) study of peralkaline silicic welded ash flow tuffs it was noted that if no devitrification occurs in a highly welded zone, the gas trapped in the pumice vesicles is redissolved in the glass when the pumice collapses during welding. The pumlce later undergoes secondary vesiculation which forms spherical vesicles. These vesicles may form by other than the above-mentioned postdepositional emplacement. Primary vesicles may have survived compaction and welding if the emplacement temperature was relatively cold. That is, "... if gas pressure in a spherical bubble equalled load pressure, the bubble might not collapse Juring welding" (Schmincke, 1974, p. 618). The characteristic that distinguishes 

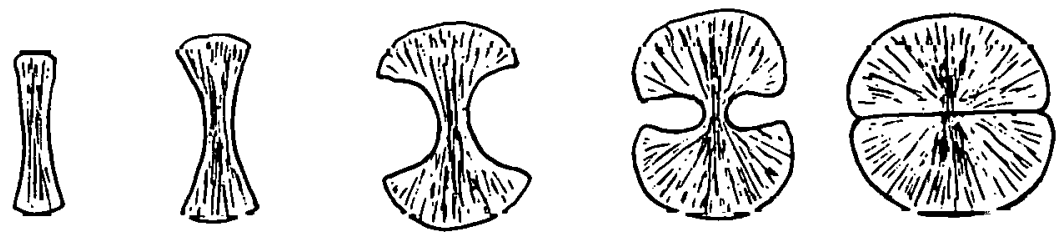

Fig. 1. Various stages of growth in spherulites (modified from Morse and Donnay, 1936, p. 397) 
secondary from primary bubbles is that secondary spherical bubbles will cut across the collapsed pumice tubes and there will be little or no devitrification around the bubbles (Schmincke, 1974). These secondary spherical bubbles may be the precursor of lithophysae (Sheridan, personal communication, 1979).

Procedure

The pumices and fluorite were taken directly from bulk samples of ash flows and nodules and fluorite pipes respectively. Dissolution of the fluorite nodules was done with acidified $\mathrm{AlCl}_{3}$ according to the method of Steven et a1. (1962). A11 samples were placed on aluminum specimen mounts with double-stick tape. The specimen mounts were coated with a thin layer of Au-Pd which provides a conductive path for electrons from the surface to the ground. This prevents a buildup of electronic charge on the sample. The SEM is an International Scientific Instrument (ISI) Super III Model.

Pumices and shards of the Spor Mountain District

a) Pumices of the Beryllium Tuff

Due to alteration, pumices from the Beryllium Tuff Member of the Spor Mountain Formation were difficult to characterize. No glassy pumices were seen in the outcrop but the altered pumices in outcrops at various claims showed random orientation and no flattening which indicates that welding has not taken place. Some randomly-oriented brown, glassy pumices were obtained from drill hole No. 18. These pumices of sample TRSM 18-571 are similar to pumices in the Bishop Tuff ash flow with a tube diameter of $10.3 \mu \mathrm{m}$ and a wall thickness of $5.0 \mu \mathrm{m}$ (Fig. 2). Altered pumices in sample TRSM 6-897 revealed an amorphous character. The vesicles were destroyed when replaced by montmorillonite (Fig. 3).

b) Pumices of the Stratified Tuff

Pumices studied from the Stratified Tuff of the Topaz Mountain Rhyolite include glassy, non-welded (TRSM 1-142, TRSM 1-315) and glassy welded (TRSM 43) samples. Although the Stratified Tuff is partly consolidated it has not undergone 


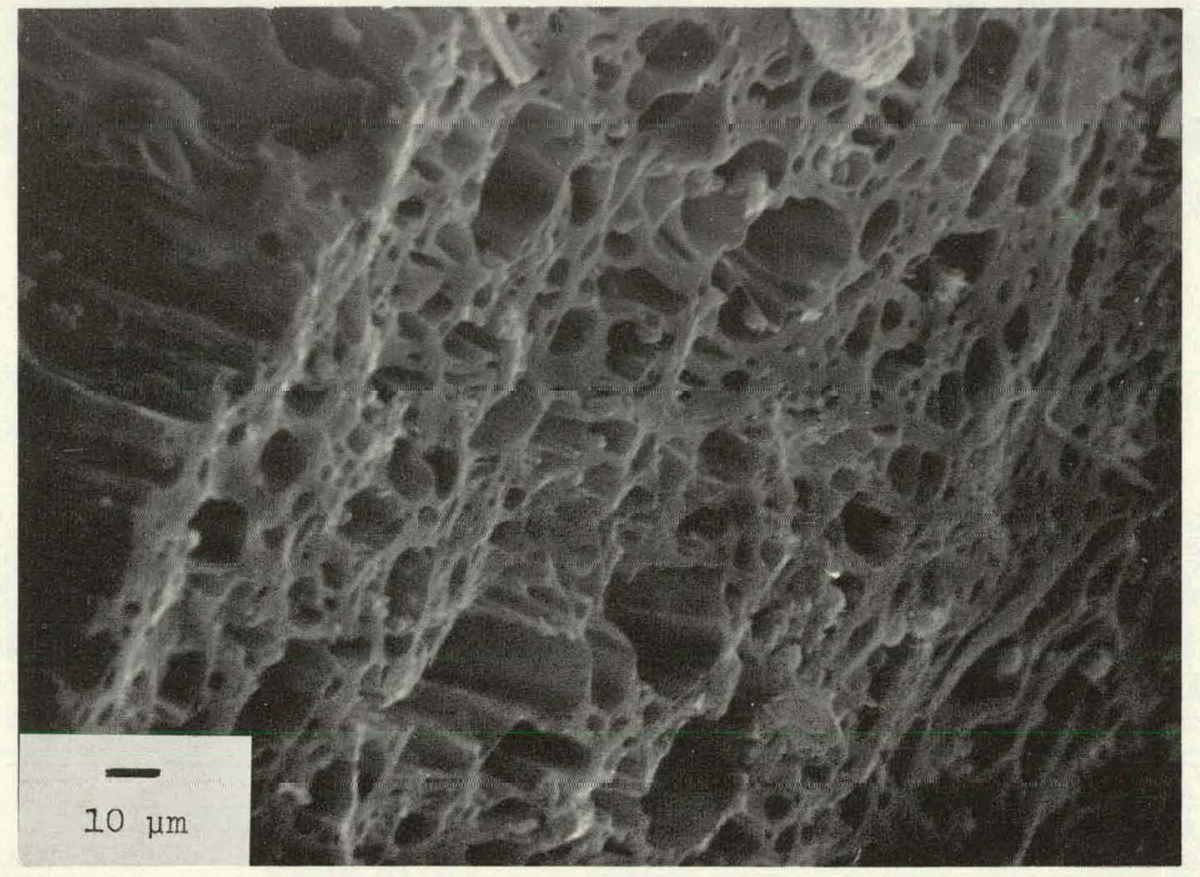

Fig. 2. Sample TRSM 18-571, grain 1: Tubular vesicles in pumice from an ash flow deposit of the Beryllium Tuff.

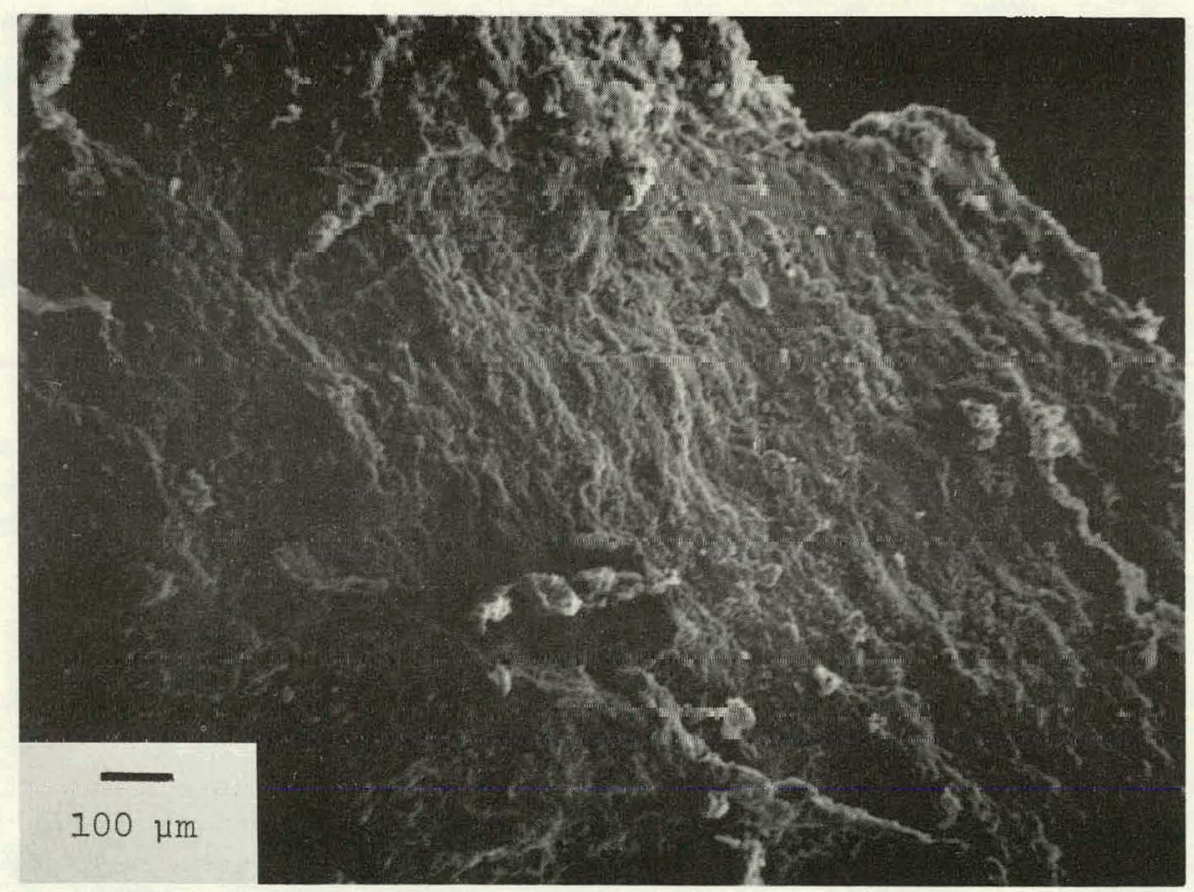

Fig. 3. Sample TRSM 6-897, grain 2: Amorphous shape of pumice from an ash flow deposit of the Beryllium Tuff. Due to alteration and replacement by montmorillonite. 
much alteration so the pumice samples are fresh-looking. Nowhere was the tuff seen to be devitrified but it has welded at some locations. Most of the pumices studied in this and the last section have been obtained from ash flow tuffs in drill core samples provided by Bendix Field Engineering Corporation (Morrison, 1979). The samples are labeled with two numbers. The first refers to the number of the drill hole. The second refers to the depth of the sample in the drill hole. Most of the pumices studied were a light gray or light brown glass that was non-welded to slightly welded and had random orientations (similar to pumices in a non-welded ash flow of the Bishop Tuff). For TRSM 1-142 and 1-315 (Figs. 4 and 5) the tubes averaged $14.7 \mu \mathrm{m}$ in diameter. with an average wal1 thickness of $8.5 \mu \mathrm{m}$. No mud or debris was seen to fill the tubes as may be expected if these pumices had survived transport in a volcanic mudflow (Schmincke, 1967).

A fiamme from the densely welded ash flow (TRSM 44, figs. 6 and 7) of the measured section of the Stratified Tuff near Wildhorse Springs (see Bikun, this report) contained no secondary vesicles (which are believed to be the result of secondary vesiculation and seen in pumices from densely welded ash flows of the Bishop Tuff). The Topaz Mountain Rhyolite and the associated tuff is $6-7 \mathrm{~m} \cdot \mathrm{y}$. old (Lindsey et a1., 1975) and the pumices appear fresh. However, the curled layer of Figure 7 suggests one of two ideas. The pumices may have undergone chemical attack and formed solution crevasses similar to those formed on quartz grains in tropical environments (Krinsley and Doornkamp, 1973; their figs. 97 and 98). Or it could be a surface skin of hydrated material (Moore, 1966) which is peeling off. The latter explanation seems more likely since a thin section of this welded tuff reveals abundant perlitic cracks in the fiammes.

The study of these pumices has shown that barring alteration (as in the Bery1lium Tuff), numices from both the Beryllium Tuff and the Stratified Tuff have a morphology similar to pumices from ash flows of the Bishop Tuff (data omitted here). A noticeable difference is that whereas the Bishop Tuff has undergone both devitrification and welding the Beryllium Tuff has appeared to have undergone neither and the Stratified Tuff has undergone only welding. 


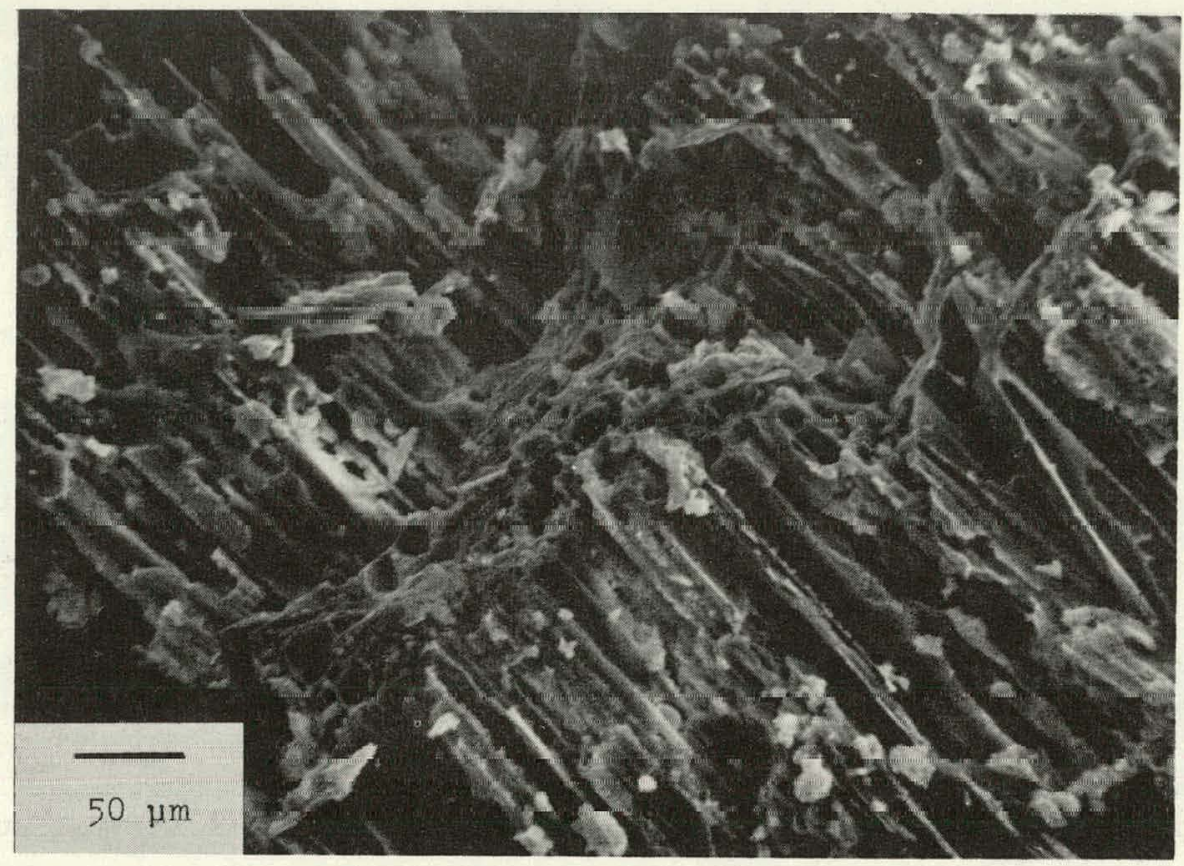

Fig. 4. Sample TRSM 1-142, grain 2: Tubular vesicles in pumice from a glassy, non-welded ash flow deposit of the Stratified Tuff.

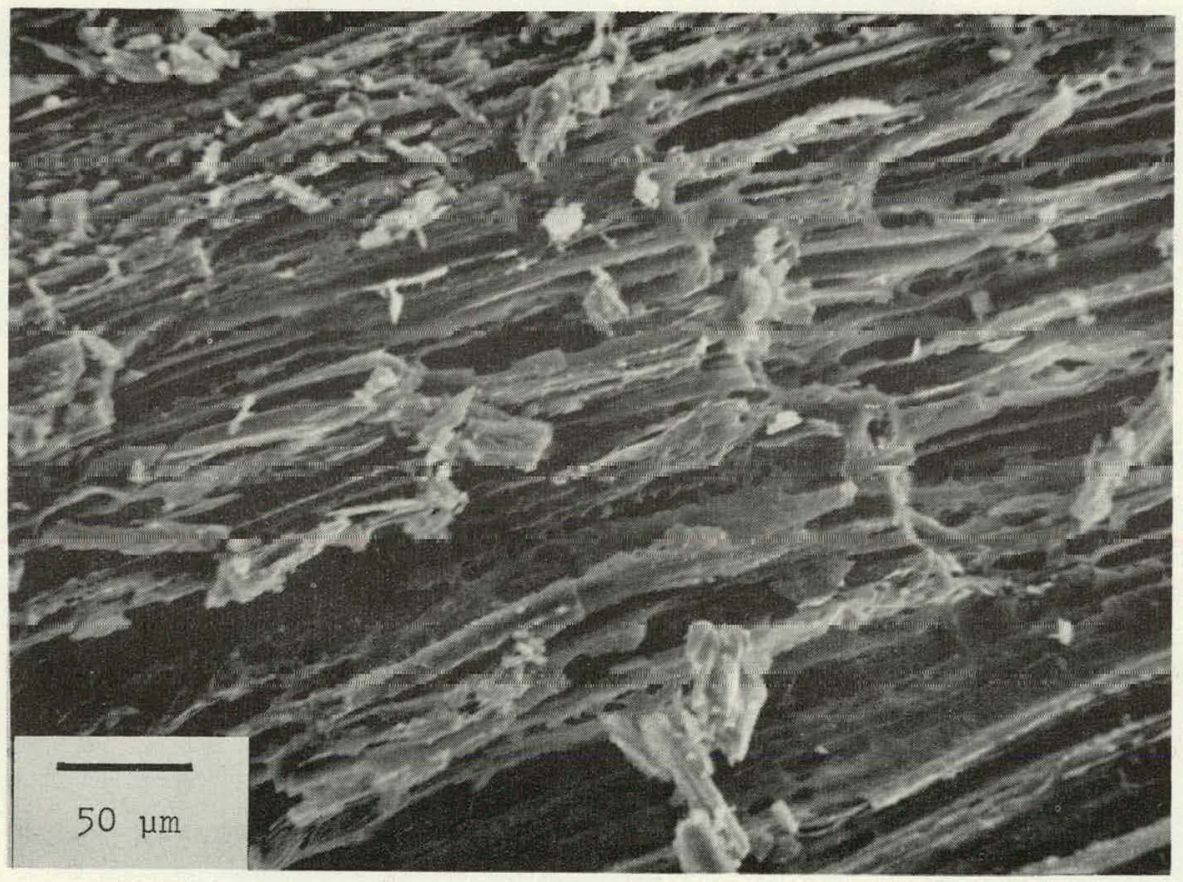

Fig. 5. Sample TRSM 1-315, grain 1: Tubular vesicles in pumice from a glassy, non-welded ash flow deposit of the Stratified Tuff. 


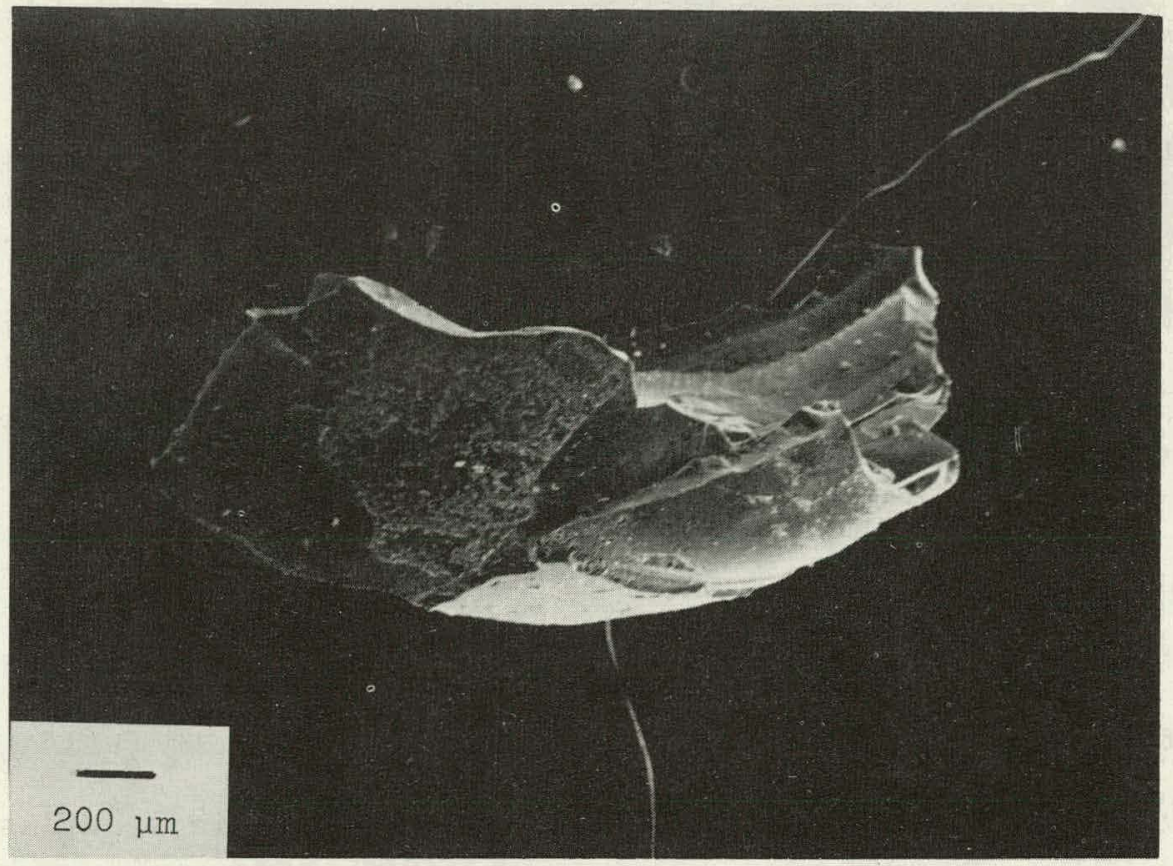

Fig. 6. Sample TRSM 44, grain 2: Fragment of fiamme from a densely welded ash flow of the Stratified Tuff, near Wildhorse Springs.

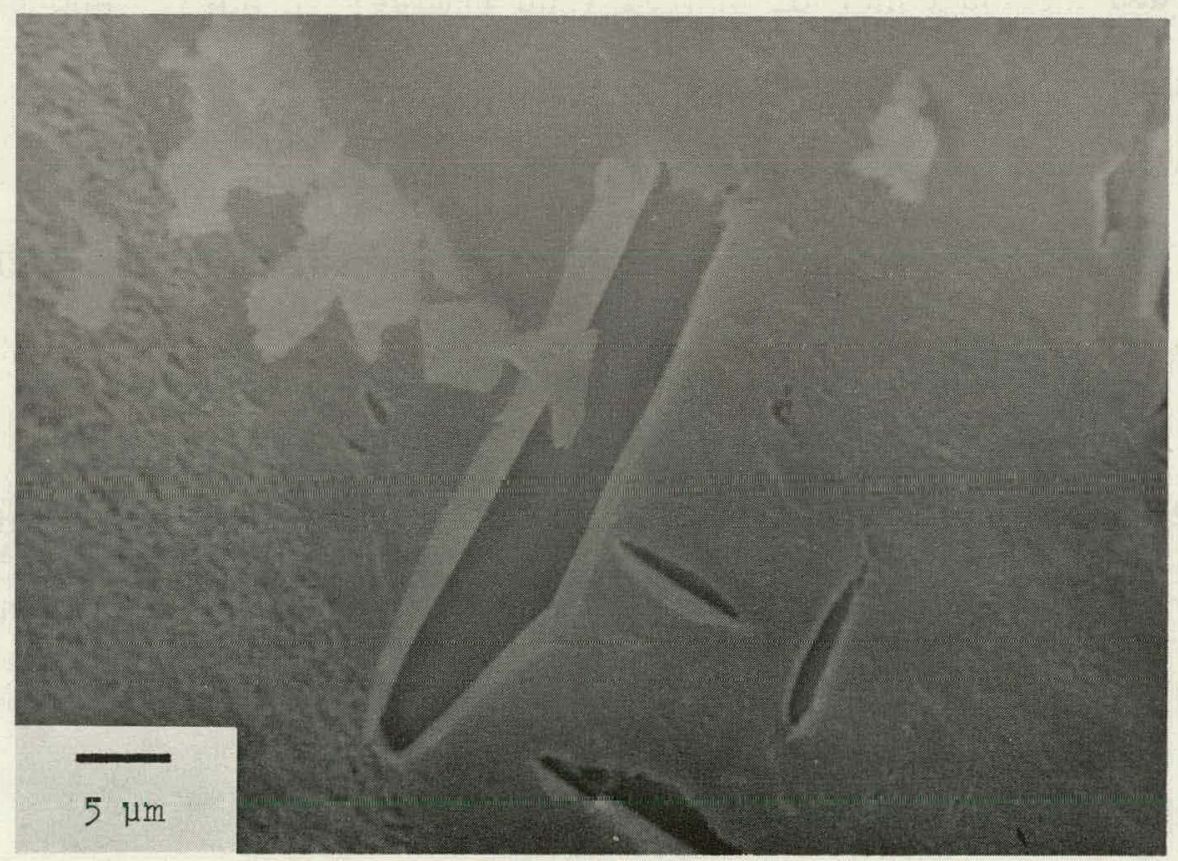

Fig. 7. Sample TRSM 44, grain 4: Curled layer on fiamme from a densely welded ash flow of the Stratified Tuff. 
c) Shards of the Beryllium and Stratified Tuffs

Shards are an integral constituent of ash flow and air fall deposits. The consolidated condition of the Beryllium Tuff and the Stratified Tuff made it impossible to extract individual shards for study. Broken surfaces of both tuffs were examined under the SEM but no shards were found. However, shards from the $0.063 \mathrm{~mm}$ size fraction of the Bishop Tuff air fall and ash flow deposits were studied and found to be delicate and angular. It is believed that these rhyolitic shards should be a good representation of shards in the Beryllium and Stratified Tuffs since these are believed to be mainly the deposits of pyroclastic flows with minor air fall and byroclastic surges (see Bikun, this report). A preliminary study of thin sections of both the Beryllium Tuff and Stratified Tuff reveal angular shards in the matrix which appears to back up the above assumption.

On the basis of crude stratification, poor sorting and a heterogeneous mixing of materials Lindsey (1977) postulated that mudflows were the dominant constituent of the Beryllium Tuff and a minor constituent of the Stratified Tuff (Lindsey, 1979) and reported an abundance of shards (and pumice) in both. However, Schmincke's (1967) study of the volcanic mudflows (which moved as an inertia type flow) of the Ellensburg Formation revealed little or no shards and pumice. Perhaps mudflows may move by other mechanisms which allow the survival of these glass particles. Further work is required on characterizing and quantifying the shard and pumice morphology not only in volcanic mudflows but other volcanic deposits such as air fall tuffs, ash flow tuffs, water-laid tuffs, and pyroclastic surges. This would provide a way to identify the origin of consolidated volcanic deposits which cannot undergo particle-size analysis (Sheridan, 1971).

\section{Spor Mountain Mineralization}

Bertrandite was discovered practically simultaneously by Staatz and Griffitts (1961) and Montoya et al. (1962) to be the beryllium-bearing mineral in the mineralized tuff. The beryllium is believed to be carried as a complex fluoride ion 
in a F-rich solution. The removal of large amounts of $F$ to form fluorite would break down the complex ions allowing bertrandite to form (Staatz and Griffitts, 1961, p. 949). It is not surprising that beryllium is found in high concentrations in the fluorite nodules and this makes them a good choice for bertrandite study. Microscopic examination of bertrandite separated from fluorite nodules revealed individual grains of bertrandite less than $5 \mu \mathrm{m}$ in diameter which formed aggregates up to $124 \mu \mathrm{m}$ in diameter. The grains showed a weak birefringence and an index of refraction from 1.54-1.58 (Montoya et al., 1962).

The crystal habit of bertrandite had yet to be described. To attempt this, two fluorite nodules, one from the Roadside Pit (BSM 9 - provided by David Lindsey) and one from the Blue Chalk Pit (BSM 10), were placed in boiling, acidified $\mathrm{Al}_{3} \mathrm{Cl}_{3}$, which dissolves fluorite but leaves the silicate minerals untouched, according to the method of Stevens et a1. (1962). The residues were analyzed by the DebyeScherrer powder camera and each contained bertrandite. Under the SEM no crysta1 habit could be distinguished in either sample (Fig. 8).

Until this study, very few fluorite crystals had been seen in the fluorspar and those crystals (cubes, 1 to $2 \mathrm{~mm}$ across) were reported from the Hilltop property and Dell No. 5 claim (Staatz and Carr, 1964, p..133). Under the SEM, fluorite from the Bell Hill Mine (BSM 4) consists of crystals approximately $7.4 \mu \mathrm{m}$ in diameter. Figures 9 and 10 reveal cubes and cubes modified by octahedra (?) respectively. These minute crystals form a boxlike framework on a microscale (Fig. 11). Large-scale open boxworks in ore of the fluorspar pipes have been reported by Staatz and Osterwald (1959, p. 61). The cubic habit of cryptocrystalline fluorite from a fluorspar pipe is in contrast to the crystal habit of cryptocrystalline fluorite from a nodule. Fluorite from the Blue Chalk Pit had an amorphous shape like the bertrandite residue (Fig. 12).

\section{ACKNOWLEDGEMENTS}

My thanks to James Bikun, Donald Burt, Eric Christiansen, Brian Correa, Steve Self, and Michael Sheridan for their ideas and time in helping me with this project. I would also like to thank Bill Knoche for his photographic expertise and the personnel of the Fluid Inclusion Laboratory at the University of Arizona. 


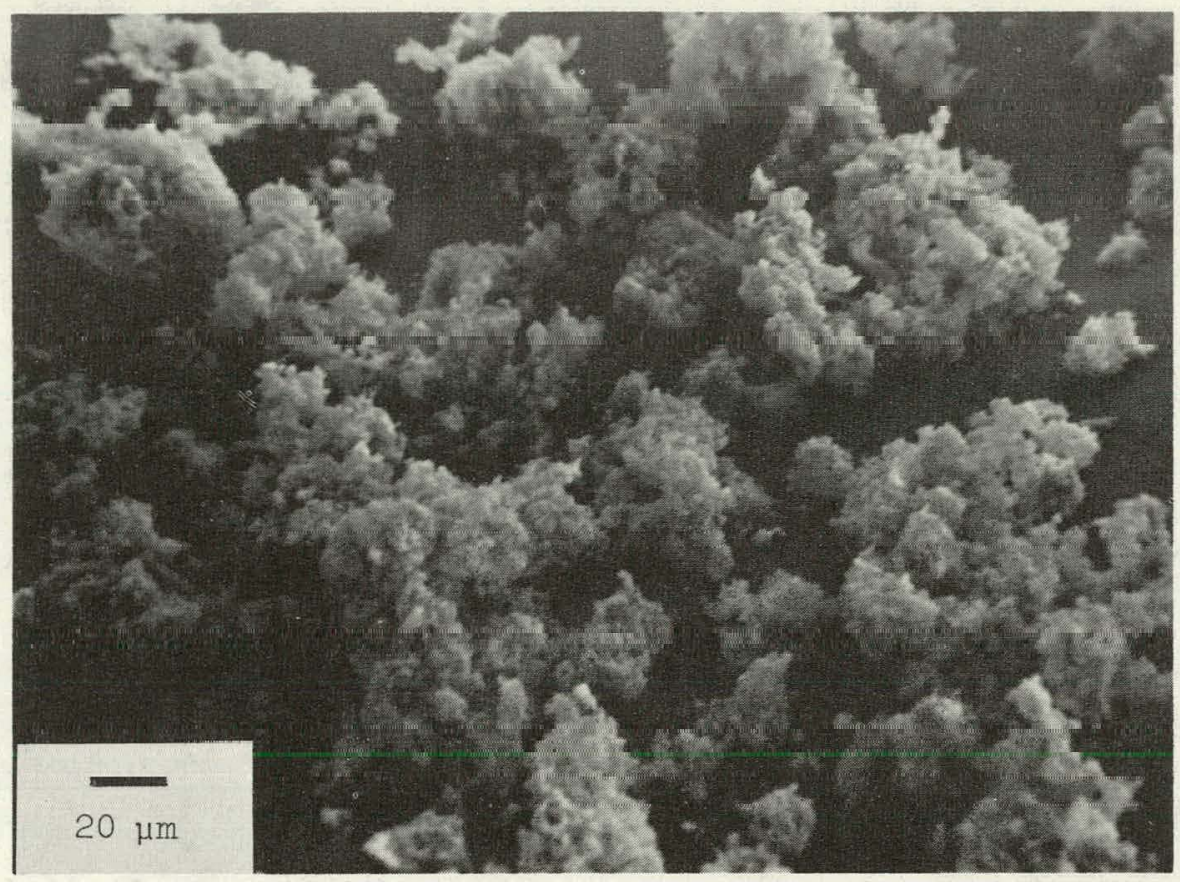

Fig. 8. Sample BSM 10, grain 2: Amorphous shape of bertrandite from fluorite nodule, Blue Chalk claim.

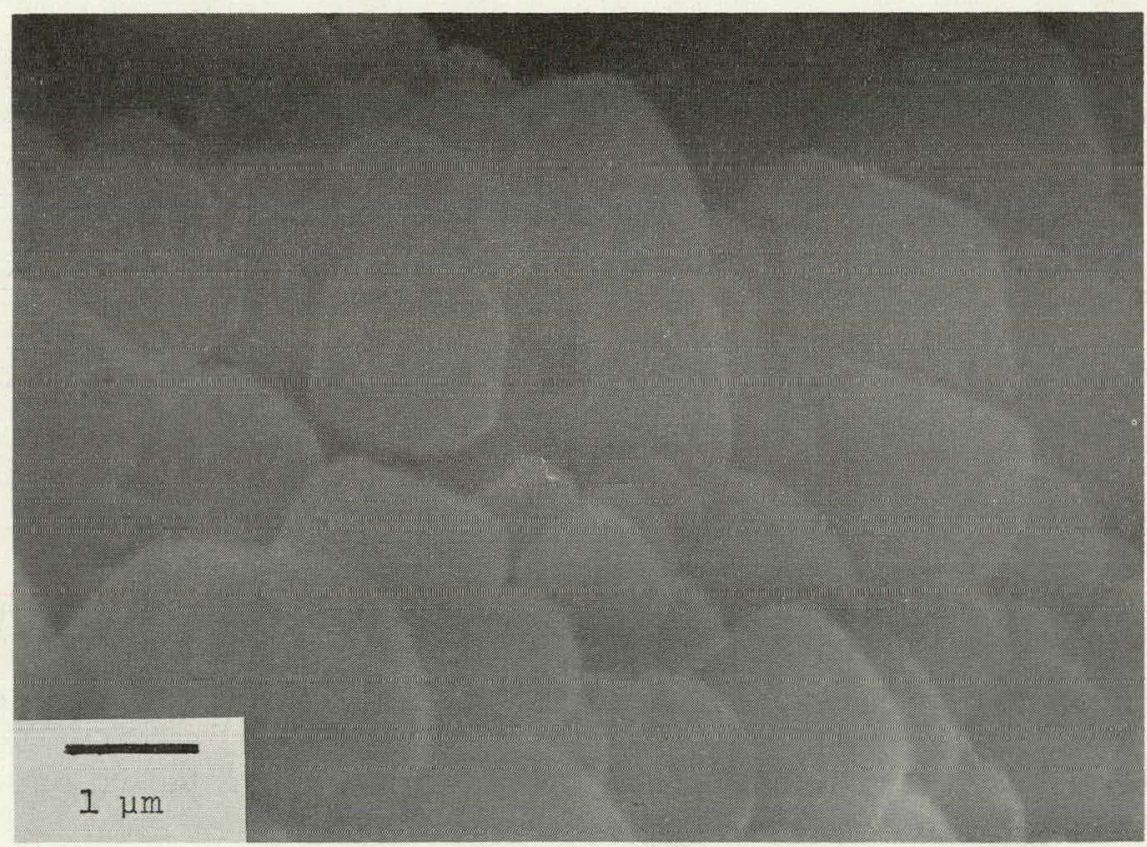

Fig. 9. Sample BSM 4, grain 2: Cubic habit of fluorite, Bell Hill Mine. 


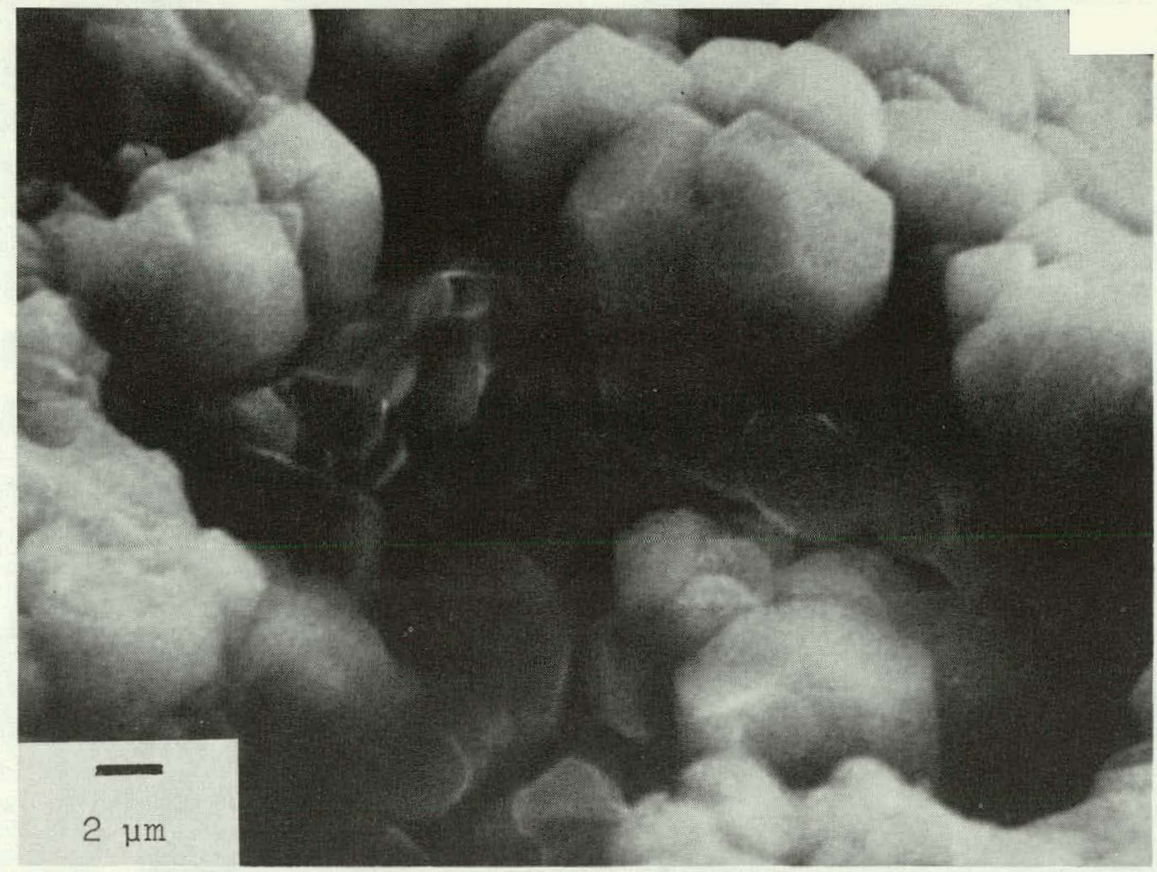

Fig. 10. Sample BSM 4, grain 1: Fluorite cubes modified by octahedra (?), Bell Hill Mine.

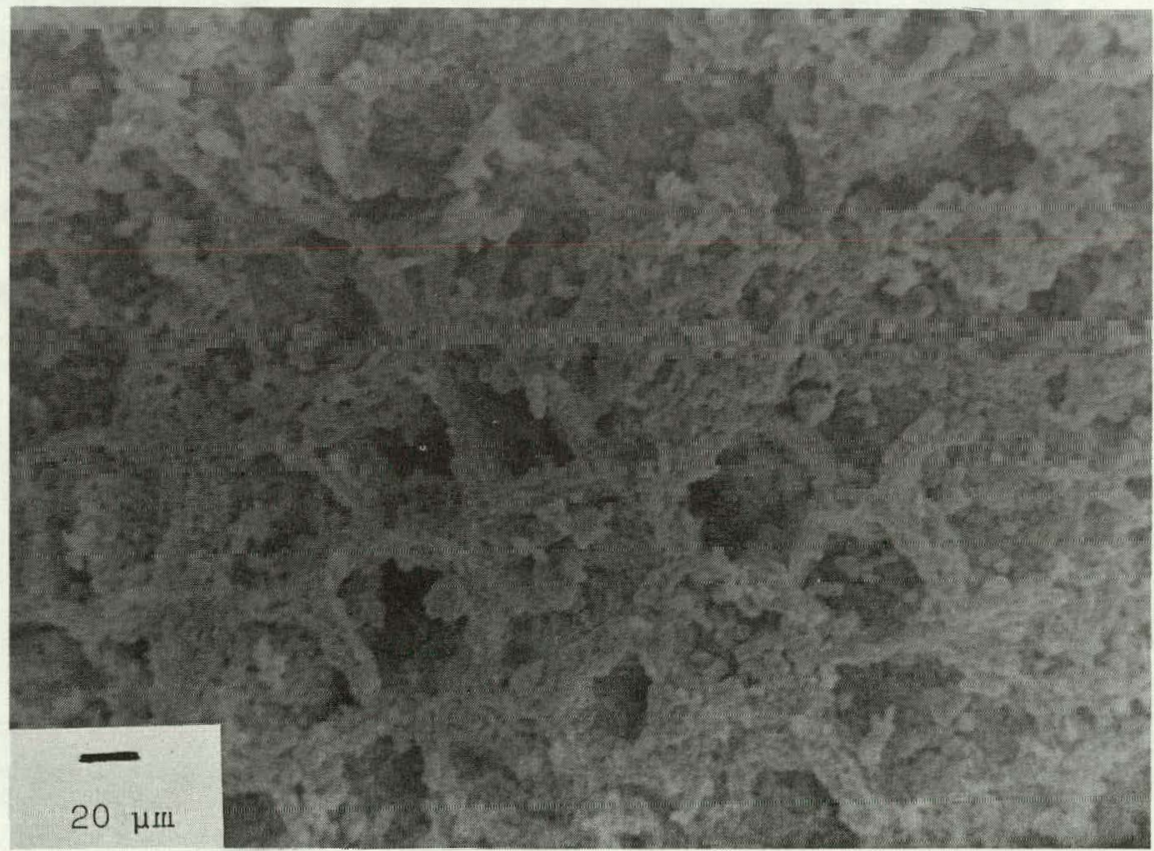

Fig. 11. Sample BSM 4, grain 2: Open boxwork of fluorite, Be11 Hil1 Mine. 


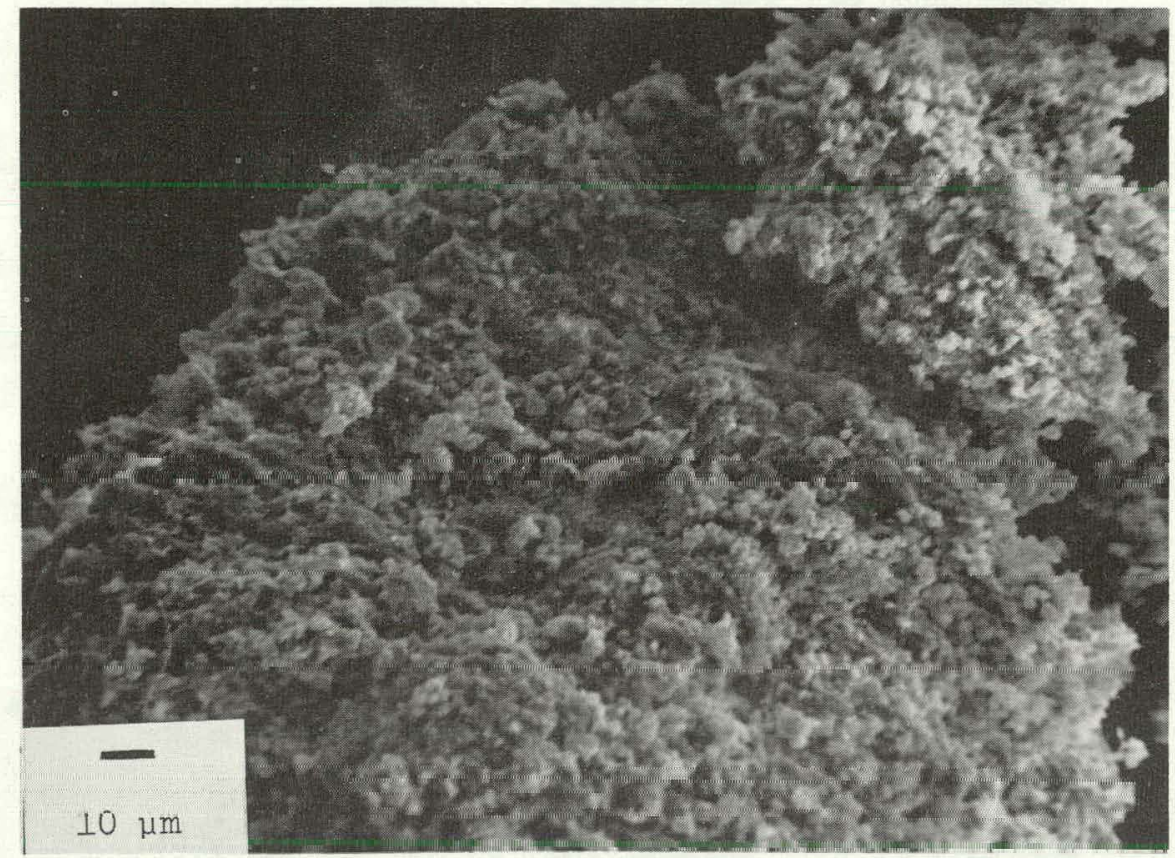

F'ig. 12. Sample BSM 11, grain 1: Amorphous shape ol fluorite, Blue Chalk claim. 


\section{REFERENCES CITED}

Alling, A.N., 1887, On the topaz from the Thomas Range, Utah: American Journal of Science, 3rd Series, 33, p. 146-147.

Arkhipchuk, R.Z., Loval'skiy, F.I., Lokerman, A.A., and Rosikhina, A.I., 1968, Mineralothermometric characteristics and temperature zonation of fluorite deposits in the Kuray orefield, Western Transbaykal'ye (abstr.): Roedder, E. (ed.), Conference on Ore-Forming Fluid Inclusions (COFFI), v. 1, p. 20.

Arkhipchuk, R.Z., 1976, Thermobarogeochemical criteria of depth of formation of fluorite deposits from Transbaikal'ye (abstr.): COFFI, v. 9, p. 6.

Beane, R.E., 1974, Barite-fluorite-galena deposits in south-central New Mexico: a product of shallow intrusions, groundwater, and epicontinental sediments (abstr.): Economic Geology, v. 69, p. 11.76.

Benesova, Z., and Cadek, J., 1969, Temperature of homogenization of inclusions in fluorite deposits of Czechoslovakia (abstr.): COFFI, v. 2, p. 13 .

Borodin, V.A., Brovchuk, I.F., Ingobatov, A.P., and Koplus, A.V., 1976, Conditions of formation of fluorite deposits (abstr.): COFFI, v. 9, p. 18.

Chi, J.M., 1975, A study on the genesis of fluorite deposits of South Korea (abstr.): COFFI, v. 8, p. 38-39.

De Groodt, J.H., Jr., 1973, Determination of temperature of fluorite formation by fluid inclusion thermometry, central Tennessee (abstr.): COFFI, v. 6, p. 33.

Enjyoji, M., and Miyazawa, T., 1969, Formation and temperatures of the fluorite deposits in Japan and Korea (abstr.): COFFI, v. 2, p. 40.

Enjyoji, M., 1972, Studies on fluid inclusions as the media of the ore formation (abstr.): COFFI, v. 5, p. 32 .

Erickson, M.P., 1963, Volcanic geology of western Juab County, Utah: in Sharp, B.J., and Williams, N.C., eds., Beryllium and uranium mineralization in western Juab County, Utah, Utah Geologica1 Society Guidebook, n. 17, p. 23-35.

Faiziyev, A.R., 1976, Conditions of formation of fluorite in Central Kazakhstan (abstr.): COFFI, v. 9, p. 40.

Henry, C.D., 1978, Origin of uraniferous opal: in Henry, C.D., and Walton,. A. ., eds., Formation of uranium ores by diagenes is of volcanic sediments, U.S. Department of Energy, G.IBX-22(79), p. (IX) 1-(IX) 20 .

Holfert, J., 1978, A field guide to topaz and associated minerals of Topaz Mountain, Utah: Privately Published, Bountiful, Utah, 66p.

Imai, N., 1976, Genesis of the fluorspar deposits of the Igashima mine, Niigata Prefecture, Japan (abstr.): COFFI, v. 3, p. 29.

Karpov, G.A., 1970, Recent fluorite in core sample from Bolshe-Bannoe deposit of hydrothermal waters, Kanchatka (abstr.): COFFI, v. 3, p. 29. 
Keith, H.D., and Padden, F.J., Jr., 1963, A phenomenological theory of spherulitic crystallization: Journal of Applied Physics, v. 34, n. 8, p. 2409-2421.

Kessler, S.E., 1975, Geochemistry of fluorite deposits, northern Coahuila, Mexico (abstr.): Geological Society of America, Abstracts with Program, v. 7, p. 1145.

Khitarov, D.N., 1973, Physico-chemical peculiarities of beryllium ore formation in carbonate rocks as indicated by data of investigation of gas-liquid inclusions in minerals (abstr.): COFFI, v. 6, p. 77.

Krauskopf, K.B., 1977, Conditions of crystallization in surface and near-surface environments (abstr.): in Crystal growth and habit (anonymous), Mineralogical Society of America, Third Mineralogical Society of America - Friends of Mineralogy Symposium, p. 2 .

Krinsley, D.H., and Doornkamp, J.C., 1973, Atlas of quartz sand surface textures: Cambridge University. Press, 91p.

Lindsey, D.A., Bradley, L.A., Gardner, J., and Merritt, V., 1973a, Mineralogical. and chemical data for alteration studies, Spor Mountain beryllium deposits, Juab County, Utah: U.S. Geological Survey Report PB-220-552, 24p., available. only from U.S. Department of Commerce National Technical Information Service, Springfield, VA, 22151.

Lindsey, D.A., Ganow, H., and Mountioy, W., 1973b. Hydrothermal alteration associated with beryllium deposits at Spor Mountain, Utah: U.S. Geological Survey, Professional Paper 818A, 20p.

Lindsey, D.A., 1975, Mineralization halos and diagenesis in water-laid tuff of the 'l'homas Kange, Utah: U.S. Geological Survey, Professional Paper 818B, 19p.

Lindsey, D.A., Naeser, C.W., and Shawe, D.R., 1975, Age of volcanism, intrusion, and mineralization in the Thomas Range, Keg Mountain, and Desert Mountain, western Utah: U.S. Geological Survey, Journal of Research, v. 3, n. 5, p. 597-604.

Lindsey, D.A., 1977, Epithermal beryllium deposits in water-laid tuff, western Utah: Economic Geology, v. 72, n. 2, p. 219-232.

Lindsey, D.A., 1978, Geology of volcanic rocks and mineral deposits in southern Thomas Range, Utah: A brief summary: Brigham Young University Geology Studies, v. 25, part 1, p. 25-31.

Lindsey, D.A., 1979, Preliminary report on Tertiary volcanism and uranium mineralization in the Thomas Range and Drum Mountains, Juab County, Utah: U.S. Geological Survey, Open File Report 79-1076, 10lp.

Lindsey, D.A., 1980, Volcanism and uranium mineralization at Spor Mountain Utah: in Energy exploration in the $80^{\prime} \mathrm{s}$, American Association of Petroleum Geologists, Southwest Section, Annual Meeting, E1 Paso, p. 43.

Lofgren, G.E., 1968, Experimental devitrification of rhyolite glass: Ph.D. thes is, Stanford University, $99 p$.

Lofgren, G.E., 1971a, Experimentally produced devitrification textures in natural rhyolitic glass: Geological Society of America Bulletin, v. 82, p. 111-124. 
Lofgren, G.E., 1971b, Spherulitic textures in glassy and crystalline rocks: Journa1 of Geophysical Research, v. 76, n. 23, p. 5635-5648.

Montgomery, A., 1934, A recent find of bixbyite and associated minerals in the Thomas Range, Utah: American Mineralogist, v. 19, p. 82-87.

Montoya, J.W., Havers, R., and Bridges, D.W., 1962, Beryllium-bearing tuff from Spor Mountain, Utah: Its chemical, mineralogical, and physical properties: U.S. Bureau of Mines, Report of Investigations $6084,15 p$.

Moore, J.G., 1966, Rate of palagonitization of submarine basalt adjacent to Hawaii: U.S. Geological Survey, Professional Paper 550-D, P. D163-D171.

Morrison, B.C., 1979, A summary geologic report on the Spor Mountain drilling project in Juab County, Utah (preliminary): U.S. Department of Energy, GJBX $-19(80), 211 p$.

Morse, H.W., and Donnay, J.D.H., 1936, Optics and structure of three-dimensional spherulites: American Mineralogist, v. 21, n. 7, p. 391-426.

Murase, T., and McBirney, A.R., 1973, Properties of some common igneous rocks at high temperatures: Geological Society of America Bulletin, v. 84, p. 35633592 .

Nash, J.T., and Work, R.G., 1971, Inclusions in western fluorite deposits (abstr.): U.S. Geological Survey, Professional Paper 750-A, p. A5.

Nash, J.T., and Cunningham, C.G., Jr., 1973, Fluid inclusion studies of fluorspar and gold deposits, Jamestown District, Colorado: Economic Geology, v. 68, n. 8 , p. 1247-1262.

Nassau, K., and Wood, D.L., 1968, An examination of red beryl from Utah: American Mineralogist, v. 53, n. 5-6, p. 801-806.

Naumov, V.B., Kovalenko, V.I., Kuzmin, M.I., Vladlykin, N.V., and Ivanova, G.I., 1971, Thermometric investigation of melting inclusions in topaz-bearing quartz keratophyre (ongonites): Doklady Akademiia Nauk SSSR, v. 199, n. 3; p. 681-683.

Pabst, A., 1938, Orientation of bixbyite on topaz: American Mineralogists, v. 23, p. $342-347$.

Park, G.M., 1968, Some geochemical and geochronologic studies of the beryllium deposits in western Utah: Unpublished M.S. thesis, University of Utah, $105 p$.

Puzanov, L.S., 1973, On regional differences in the temperatures of the origin of industrial types of flunrite ores (abstr.): COFFT, v. 7, p. 176.

Ream, L.R., 1979, The Thomas Range, Wah Wah Mountains, and vicinity, western Utah: Mineralogical Record, v. 10, n. 5, p. 261-278.

Remeshilo, B.G., 1974, Typomorphic peculiarities of beryllium minerals from zanorysh pegmatites of Volhyn, paragenetic with quartz (abstr.): COFFI, v. 7, p. 181.

Rnedder, E., and Skinner, B.J., 1968, Experimental evidence that fluid inclusions do not leak: Economic Geology, v. 63, n. 7, p. 715-730.

Rogers, P.J., 1976, Preliminary fluid inclusion studies on fluorite from the Derbyshire orefield (abstr.): DOFFI, v. 9, p. 117. 
Ross, C.S., and Smith, R.L., 1960, Ash-flow tuffs: Their origin, geologic relations, and identification: U.S. Geological Survey, Professional Paper 366, 81p.

Schmincke, H.-U., 1967, Graded lahars in the type sections of the Ellensburg formation, south-central Washington: Journal of Sedimentary Petrology, v. 37, n. 2 , p. 438-448.

Schmincke, H.-U., 1974, Volcanological aspects of peralkaline silicic welded ash- flow tuffs: Bulletin Volcanologique, v. 38, n. 3, p. 594-636.

Shawe, D.R., 1972, Reconnaissance geology and mineral potential of Thomas, Keg, and Desert Calderas, central Juab County, Utah: U.S. Geological Survey, Professional Paper 800-B, p. B66-B77.

Shawe, D.R., 1979, Distribution and diagenesis of flunrite deposits in the western United States and their significance to metallogeny (a comment): Geology, v. 7, n. 3, p. 115-117.

Sheridan, M.F., 1971, Particle-size characteristics of pyroclastic tuffs: Journal of Geophysical Research, v. 76, p. 5627-5634.

Sparks, R.S.J., 1978, The dynamics of bubble formation and growth in magmas: a review and analysis: Journal of Volcanological and Geothermal Research, v. 3, n. $1-2$, p. $1-37$.

Staatz, M.H., and Osterwald, F.W., 1959, Geology of the fluorspar district, Juab County, Utah: U.S. Geological Survey, Bulletin 1069, 97p.

Staatz, M.H., and Griffitts, W.R., 1961, Beryllium-bearing tuff in the Thomas Range, Juab County, Utah: Economic Geology, v. 56, p. 941-950.

Staatz, M.H., and Carr, W.J., 1964, Geology and mineral deposits of the Thomas and Dugway Ranges, Juab and Tooele Counties, Utah: U.S. Geological Survey, Professional Paper 415, 188p.

Stevens, R.E., Sainsbury, C.L., and Bettiga, A.C., 1962, Dissolving fluorite with solutions of aluminum salts: U.S. Geological Survey, Professional Paper 450-C, p. C98-C 99 .

Su, B.-C., 1976, Fluid inclusion geothermometry of fluorite, Star Range, Utah: Unpublished M.S. thesis, University of Utah.

Turley, C.H., Nash, W.P., and Brown, F.H., 1979, Petrology and geochronology of late Tertiary and Quaternary volcanic rocks in the easternmargin of the Basin and Range Province, Utah: U.S. Geological Survey, Contract 14-08-0001-G343, Final Report, v. 1, 78p.

Van Alstine, R.E., 1947, Fluorspar investigations: in Vanderwilt, J.W., ed., Mineral resources of Colorado, State of Colorado, Mineral Resources Board, Denver, p. 457-465.

Van Alstine, R.E., 1969, Geology and mineral deposits of the Poncha Springs northeast quadrangle, Chaffe County, Colorado: U.S. Geological Survey, Professional Paper 626, 52p. 
Williams, N.C., 1963, Beryllium deposits, Spor Mountain, Utah: in Sharp, B.J., and Williams, N.C., eds., Beryllium and uranium mineralization in western Juab County, Utah, Ütah Geological. Society Guidebook, n. 17, p. 36-59.

Zielinski, R.A., 1978, Uranium abundances and distribution in associated glassy and crystalline rhyolites of the western United States: Geological Society of America Bulletin, v. 89, p. 409-414.

NOTE: COFFI = Fluid Inclusion Research, Proceedings of Conference on Ore-Forming Fluid Inclusions 
COMPREHENSIVE SPOR MOUNTAIN BIBLIOGRAPHY

Alling, A.N., 1887, On the topaz from the Thomas Range, Utah: American Journal of Science, 3rd Series, 33, p. 146-147.

Bikun, J.V., 1980, Fluorine and lithophile element mineralization at Spor Mountain, Utah: unpub. M.S. thesis, Arizona State University, Tempe, Arizona, 195p.

Bowyer, B., 1963, Yellow Chief uranium mine, Juab County, Utah: in Sharp, B.J., and Williams, N.C., eds., Beryllium and uranium mineralization in western Juab County, Utah, Utah Geological Snriety Fuidebook, n. 17, p. 15-22.

Brock, D. and Brock, R., 1954, Utah's Topaz Mountain: Gems and Minerals, n. 202, p. 40-41.

Bullock, K.C., 1976, Fluorite occurrences in Utah: Utah Geological and Mineral Survey, Bulletin 110, 89p.

Cadigan, R.A., Nash, J.T., Zech, R.S., Wallace, H.R., Hills, F.A., and Robinson, K., 1979, Evaluation of the potential for uranium and other mineral resources of the Deep Creek Mountains withdrawal area, Juab County, Utah: U.S. Geological Survey Open File Report, 79-1.304.

Coats, R.R., Barnett, P.R., and Conklin, N.M., 1962, Distribution of beryllium in unaltered silicic volcanic rocks of the western conterminous United States: Economic Geology, v. 57, p. 963-968.

Coats, R.R., Goss, W.D., and Rader, L.F., 1963, Distribution of fluorine in unaltered sllicic volcanic rocks of the western conterminous United States: Economic Geology, v. 58, n. 6, p. 941-951.

Cohenour, R.E., 1959, Sheeprock Mountains, Tooele and Juab Counties, Precambrian and Paleozoic stratigraphy, igneous rocks, structure, geomorphology and economic geology: Utah Geological and Mineral Survey, Bulletin 63 .

Cohenour, R.E., 1963, Beryllium and associated mineralization in the Sheeprock Mounlails: In Sharp, B.J., and W1lliams, N.C., eds., Beryllium and uranium mineralization in western Juab County, Utah, Utah Geological Society Guidebook 17, p. 8-13.

Costain, J.K. and Wright, P.M., 1973, Heat flow at Spor Mountain, Jordan Valley, Bingham, and LaSal, Utah: Journal of Geophysical Research, v. 78, n. 35, p. $8687-8698$.

Crittenden, M.D., Jr., Straczek, J.A., and Roberts, R.J., 1961, Manganese deposits in the Drum Mountains, Juab and Millard Counties, Utah: U.S. Geological Survey, Bulletin 1082-H, p. 493-544. 
Cross, W., 1886, On the occurrence of topaz and garnet in lithophyses of rhyolite: American Journal of Science, 3rd Series, v. 31, p. 432-438.

Darling, R. and Chapman, D.S., 1979, Heat flow in western Utah: Geological Society of America, Abstracts with Programs, v. 11, n. 6, p. 269.

Davis, L.J., 1978, Spor Mountain beryllium district, Juab County, Utah: in Shawe, D.R., ed., Guidebook to the mineral deposits of the central Great Basin, Nevada Bureau of Mines and Geology, Report 32, p. 62-64.

Englemann, H., 1863, Topaz in Utah: Academy of Science of St. Louis, Transactions 2, p. 114 .

Erickson, M.P., 1963, Volcanic geology of western Juab County, Utah: in Sharp, B.J., and Williams, N.C., eds., Beryllium and uranium mineralization in western Juab County, Utah, Utah Geological Society Guidebook, n. 17, p. 23-35.

Files, F.G., 1978, Uranium in volcanic environments in the Great Basin: U.S. Department of Energy, GJBX-98(78), 20p.

Fitch, C.A., Jr., Quigley, J.E., and Barker, C.S., 1949, Utah's new mining district (Topaz Mountain): Engineering and Mining Journal, v. 150, p. 63-66.

Frondel, C., 1970, Scandium-rich minerals from rhyolite in the Thomas Range, Utah: American Mineralogist, v. 55, n. 5-6, p. 1058-1060.

Glanzman, R.K. and Meier, A.L., 1979, Preliminary report on samples collected during lithium reconnaissance studies in Utah and Idaho: U.S. Geological Survey Open File Report 79-279, 52 p.

Glanzman, R.K., Rytuba, J.J. and Otton, J.K., 1979, Lithium and boron association with uranium mineralization: Geological Society of America, Abstracts with Programs, v. 11, n. 7, p. 433.

Griffitts, W.R., 1959, Non-pegmatitic deposits of beryllium in the Unfted States: Mining Engineering, v. 11, n. 12, p. 1227.

Griffitts, W.R., 1963, Geochemical features of mineralized tuff at Spor Mountain, Utah: Mining Engineering, v. 15, n. 8, p. 54.

Griffitts, W.R., 1964, Beryllium: Utah Geological and Mineral Survey, Bulletin 73, p. 71-75.

Griffitts, W.R. and Rader, L.F., Jr., 1963, Beryllium and fluorine in mineralized tuff, Spor Mountain, Juab County, Utah: U.S. Geological Survey, Professional Paper 475-B, p. B16-B17.

Henry, C.D. and Walton, A.W., 1978, Formation of uranium ores by diagenesis of volcanic sediments: U.S. Department of Energy, GJBX$22(79), 444 \mathrm{p}$. 
Hillebrand, W.F., 1905, Red beryl from Utah: American Journal of Science, v. 4, n. 19, p. 330-331.

Hintze, L.F., 1980, Preliminary geologic map of the Fish Springs NW and Fish Springs SW quadrangles, Juab and Tooele Counties, Utah: U.S. Geological Survey Miscellaneous Field Investigations Map MF-1148, $1: 24,000$.

Hogg, N.C., 1972, Shoshonitic lavas in west-central Utah: Brigham Young University Geology Studies, v. 19, part 2, p. 133-184.

Holfert, J., 1978, A field guide to topaz and associated minerals of Topaz Momntain, IItah: Prfvately Puhtished, Bountiful, Utah, 66p.

Jones, A.J., 1895, Topaz crystals of Thomas Mountains, Utah: Iowa Academy of Science, Proceedings, v. 2, p. 175-177.

Leedom, S.H., 1974, Little Drum Mountains, an early Tertiary shoshonitic volcanic center in Millard County, Utah: Brigham Young University Geology Studies, v. 21, part 1, p. 73-108.

Leedom, S.H. and Mitchell, T.P., 1978, Preliminary study of favorability for uranium resources in Juab County, Utah: U.S. Department of Energy, GJBX-23(78), 27p.

Lindsey, D.A., 1975a, Mineralization halos and diagenesis in water-laid tuff of the Thomas Range, Utah: U.S. Geological Survey, Professional Paper 818B, p. B1-B19.

Lindsey, D.A., 1975l, The effect of sedimentacton and diagenesis on trace element compoeition of the watcr laid tuff in the Keg Munntain aited, Utah: U.S. Geological Survey, Professional Paper 818C, p. C1-C35.

Lindsey, D.A., 1977, Epithermal beryllium deposits in water-laid tuff, western Utah: Economic Geology, v. 72, n. 2, p. 219-232.

Lindsey, D.A., 1978a, Geology of volcanic rocks and mineral deposits in. the southern Thomas Range, Utah: A brief summary: Brigham Young University Geology Studies, v. 25, part 1, p. 25-31.

LIndsey, D.A., 1978b, Geology of the Yellow Chief Mine, Thumas Range, Juab County, Utah: in Shawe, D,R., ed., Guidebook to the mineral deposits of the central Great Basin, Nevada Bureau of Mines and Geology Report 32, p. 65-68.

Lindsey, D.A., 1979a, Preliminary report on Tertiary volcanism and uranium mineralization in the Thomas Range and Drum Mountains, Juab County, Utah: U.S. Geological Survey, Open File Report 79-1076, 101p.

Lindsey, D.A., 1979b, Geologic map and cross-sections of Tertiary rocks in the Thomas Range and Northern Drum Mountains, Juab County, Utah: U.S. Geological Survey, M1scellaneous Investigations Map I-1176, $1: 62,500$. 
Lindsey, D.A., 1979c, Fluorine, beryllium, and uranium mineralization in the Thomas Range, western Utah: Geological Society of America, Abstracts with Programs, v, 11, n. 7, p. 466-467.

Lindsey, D.A., 1980, Volcanism and uranium mineralization at Spor Mountain, Utah: in Energy exploration in the $80^{\prime} \mathrm{s}$, American Association of Petroleum Geologists, Southwest Section, Annual Meeting, El Paso, Program, p. 43.

Lindsey, D.A., Ganow, H.', and Mountjoy, W., 1973, Hydrothermal alteration associated with beryllium deposits at Spor Mountain, Utah: U.S. Geological Survey, Professional Paper 818A, p. A1-A20.

Lindsey, D.A., Naeser, C.W., and Shawe, D.R., 1975, Age of volcanism, intrusion, and mineralization in the Thomas Range, Keg Mountain, and Desert Mountain, western Utah: U.S. Geological Survey, Journal of Research, v. 3, n. 5, p. 597-604.

Ludwig, K.R., Lindsey, D.A., and Zielinski, R.A., 1979, U-Pb isotope dates of uraniferous opals associated with beryllium-fluorine-uranium mineralization, Spor Mountain, Utah: Geological Society of America, Abstracts with Programs, v. 11, n. 7, p. 469.

Ludwig, K.R., Lindsey, D.A., Zielinski, R.A., and Simmons, K.R., 1980, $\mathrm{U}-\mathrm{Pb}$ ages of uraniferous opals and implications for the history of beryllium, fluorine, and uranium mineralization at Spor Mountain, Utah: Earth and Planetary Science Letters, v. 46, p. 211-232.

McAnulty, W.N., and Levinson, A.A., 1964, Rare alkali and beryllium mineralization in volcanic tuffs, Honeycomb Hills, Juab County, Utah: Economic Geology, v. 59, n. 5, p. 768-774.

Meeves, H.C., 1966, Nonpegmatitic beryllium occurrences in Arizona, Colorado, New Mexico, Utah and four adjacent states: U.S. Bureau of Mines, Report of Investigations $6828,68 \mathrm{p}$.

Meeves, H.C., Harrer, C.M., Salsbury, M.H., Konselman, A.S., and Shannon, S.S., Jr., 1966, Reconnaissance of beryllium-bearing pegmatite deposits in six Western States, Arizona, Colorado, New Mexico, South Dakota, Utah and Wyoming: U.S. Bureau of Mines, Information Circular 8298.

Montgomery, A., 1934, A recent find of bixbyite and associated minerals in the Thomas Range, Utah: American Mineralogist, v. 19, D. 82-87.

Montoya, J.W., Havens, R. and Bridges, D.W., 1962, Beryllium-bearing tuff from Spor Mountain, Utah: its chemical, mineralogical, and physical properties: U.S. Bureau of Mines, Report of Investigations $6084,15 p$.

Montoya, J.W., Baur, G.S., and Wilson, S.R., 1964, Mineralogical investigation of beryllium-bearing tuff, Honeycomb Hills Juab County, Utah:

U.S. Bureau of Mines, Report of Investigations $6408,11 \mathrm{p}$. 
Moore, W.J., and Sorensen, M.L., 1978, Metamorphic rocks of the Granite Peak area, Tooele County, Utah: Geological Society of America, Abstracts with Programs, v. 10, n. 5, p. 234.

Moore, W.J. and Sorensen, M.L., 1979, Geologic map of the Tooele $1^{\circ}$ by $2^{\circ}$ quadrangle, Utah: U.S. Geological Survey Miscellaneous Investigations Map I-1132, 1:250,000.

Morris, H.T., 1978, Preliminary geologic map of Delta $2^{\circ}$ west-central Utah: U.S. Geological Survey, Open File Report 78-705, 9p.

Morr1son, B.C., 1980, A summary of geologic report on the Spor Mountain drilling project in Juab County. Utah; Ū.S. Department of Energy, GJBX-19(80), 211 p.

Nash, W.P., 'lurley, C., Yetersen, J. and Brown, F.H., 1978, Volcanism and the regional assessment of geothermal potential in west-central Utah: in Geothermal energy; a novelty becomes a resource; Transactions, v. 2, section 2, p. 475-477.

Nassau, K, and Wood, D.L., 1968, An examination of red bery1 from Utah: American Mineralogist, v. 53, n. 5-6, p. 801-806.

Newe11, R.A., 1971, Geology and geochemistry of the northern Drum Mountains, Juab County, Utah: Unpublished M.S, thesis, Colorado School of Mines, $115 p$.

Newe11, R.A., 1974, Beryllium, copper, fluorite, and manganese mineralization related to a recently identified Valies-type caldera, Juab County, Utah: Ceological Society of America, Abstracts with Programs, v. 6, il. 3, p. 227.

O'Neil, J.R. and Bailey, G.B., 1979, Stable isotope investigation of goldbearing jasperoid in the central Drum Mountains, Utah: Economic Geology, v. 74, n. 4, p. 852-859.

Outerbridge, W.F., Staatz, M.H., Meyrowitz, R. and Pommer, A.M., 1960, Weeksite, a new uranium silicate from the Thomas Range, Juab County, Utah: American Mineralogist, v. 45, p. 39-52.

Pabst, A., 1938, Orientation of bixbyite on topaz: American Mineralogist, v. 23, p. 342-347.

Palache, C., 1934, Minerals from Topaz Mountain, Utah: American Mineralogist, v. 19 , n. 1 , p. 14-15.

Park, G.M., 1968, Some geochemical and geochronologic studies of the beryllium deposits in western Utah: Unpublished M.S. thesis, University of Utah, 105p.

Park, G.M., 1971, Volcanics, Thomas Range, in Radioactive and isotopic age determinations of Utah rocks: Utah Geological and Mineral Survey, Bulletin 81 . 
Patton, H.B., 1908, Topaz-bearing rhyolite of the Thomas Range, Utah: Geological Society of America, Bulletin 19, p. 177-192.

Penfield, S.L. and Foote, H.W., 1897, On bixbyite, a new mineral, and notes on the associated topaz: American Journal of Science, 4th Series, v. 4, p. 105-108.

Pierce, C.R., 1974, Geology of the sourthern part of the Little Drum Mountains, Utah: Brigham Young University Geology Studies, v. 21, part 1, p. 109129.

Ream, L.R., 1979, The Thomas Range, Wah Wah Mountains, and vicinity, western Utah: Mineralogical Record, v. 10, n. 5, p. 261-278.

Rees, D.C., Erickson, M.P. and Whelan; J.A., 1973, Geology and diatremes of Desert Mountain, Utah: Utah Geological and Mineral Survey, Special Study $42,12 \mathrm{p}$.

Saunders, D.F., 1979, Characterization of uraniferous geochemical provinces by aerial gamma-ray spectrometry: Mining Engineering, v. $31, \mathrm{n} .12$, p. $1715-1722$.

Schmetzer, K., Bank, H. and Berdesinki, W., 1974, Eine seltene rote Varietat der Mineralart Beryl1 (fruher Bixbit genannt): Deutsche Gemmologische Gesselschaft, Zeitschrift, v. 23, p. 139-141.

Sharp, B.J., 1963, Uranium in fluorite, Spor Mountain, Utah: in Sharp, B.J. and Williams, N.C. eds., Beryllium and urantum mineralization in western Juab County, Utah, Utah Geological Society Guidebook, n. 17, p. 14,

Shawe, D.R., 1964, A late Tertiary low-angle fault in western Juab County, Utah: U.S. Geological Sruvey, Professional Paper 501-B, p. B13-B15.

Shawe, D.R., Mountjoy, W. and Duke, W. 1964, Lithium associated with beryllium in rhyolitic tuff at Spor Mountain, western Juab County, Utah: U.S. Geological Survey, Professional Paper 501-C, p. C86-C37.

Shawe, D.R., 1966, Arizona-New Mexico and Nevada-Utah beryllium belts: U.S. Geologica1 Survey, Professional Paper 550-C, p. C206-C213.

Shawe, D.R., 1968, Geolngy of the Spor Mountain beryllium district, Utah: in RIdge, J.D., ed., Ore deposits in the United States, 1933-1967, American Institute of Mining Engineers, New York, v. 2, p, 1148-1161,

Shawe, D.R., 1972, Reconnaissance geology and mineral potential of Thomas, Keg, and Desert Calderas, central Juab County, Utah: U.S. Geological Survey, Professional Paper 800-B, p. B66-B77.

Shawe, D.R., ed., 1976, Geology and resnurres of fluorine in the United States: U.S. Geological Survey, Professional Paper 933, 99p.

Shawe, D.R. and Stewart, J.H., 1976, Ore deposits as related to tectonics, Nevada and Utah: Transactions, Society of Mining Engineers, American Institute of Mining Engineers Meeting, Las Vegas, p. 225-232. 
Smith, C.H., Woo, C.C. and Dickerson, B.F., 3rd, 1961, New beryllium developments: Mining Engineering, v. 13, n. 11, p. 1251.

Staatz, M.H., and Osterwald, F.W., 1956, Uranium in the fluorspar deposits of the Thomas Range, Utah: U.S. Geological Survey, Professional Paper 300 , p. 131-136.

Staatz, M.H. and Osterwald, F.W., 1959, Geology of the Thomas Range fluor-. spar district, Juab County, Utah: U.S. Geological Survey Bulletin 1069. 97p.

Staatz, M.H. and Griffitts, W.R., 1961, Beryllium-bearing tuff in the Thomas Range, Juab County, Utah: Economic. Geology, v. 56, p. 941-950.

Staatz, M.H., 1963, Geology of the beryllium deposits in the Thomas Range, Juab County, Utah: U.S. Geological Survey, Bulletin 1142-M, 36p.

Staatz, M.H. and Carr, W.J., 1964, Geology and mineral deposits of the Thomas and Dugway Ranges, Juab and Tooele Counties, Utah: U.S. Geological Survey, Professional Paper 415, 188 p.

Starkey, H.C. and Mountjoy, W., 1973, Identification of a lithium-bearing smectite from Spor Mountain, Utah: U.S. Geological Survey, Journal of Research, v. 1, n. 4, p. 415-419.

Staub, A.M., 19\%5, Geology of the Picture Rock Hills quadrangle, southwestern Keg Mounta1ns, Juab County, Utah: Unpublished M.S. thesis, University of Utah, $87 \mathrm{p}$.

Stewart, J.H., Moore, W.J. and Zietz, T., 1977, Fast-iest pattorns of Cenozolc igneous rocks, aeromagnetic anomalies, and mineral deposits, Nevada and Utah: Geologica1 Society of America, Bulletin 88, p. 67-77.

Stowe, C.H., 1979, Rockhound guide to mineral and fossil localities in ULah: Utah Geological and Mineral Survey, Circular 63, 79p.

Texas Instruments, Inc., 1977, Aerial gamma-ray and magnetic survey of the Delta area, Utah: U.3. Department of Energy, GJBX-18(7\%).

Thurston, W.R., Staatz, M.H., Cox, D.C. and others, 1954, Fluorspar deposits of Utah: II.S. Fenlngical Survey, Bulletin 10n5, 53p.

Turley, C.H., Nash, W.P. and Brown, F.H., 1979, Petrology and geochronology of late Tertiary and Quaternary volcanic rocks in the eastern margin of the Basin and Range Province, Utah: U.S. Geological Survey, Contract 14-08-0001-G343, Final Report, v. 1, 78p.

Turley, C.H., Nash, W.P., 1980, Volcanism in western Juab and Millard Counties, Utah: Utah Geological and Mineral Survey Special Studies 52, Part I, p. 1-33. 
Waters, D.N., Burton, J.M., Clements, M., Lovesey, R.J: and Morris, D.F.C., 1965, The occurrence of beryllium in fluorite: Geochimica et Cosmochimica Acta, v. 29, p. 1293-1302.

Weight, H.O., 1947, Field day for topaz collectors, (Thomas Mountain, Utah): Desert Magazine, v. 10, n. 12, p. 19-24.

Williams, N.C., 1954, Nonpegmatite beryl occurrence, Sheeprock Moutains, Utah: Geological Socfety of America, Bulletin 65, n. 12, part 2, p. 1388 .

W111 lams, N.C. 1963, Beryllium deposits, Spor Mountain, Utah: in Sharp, B.J., and Williams, N.C., eds., Beryllium and uranium mineralization in western Juab County, Utah, Utah Geological Society Guidebook, n. 17, p. 36-59.

Zielinsk1, R.A., Ludwig, K.R. and Lindsey, D.A., 1977, Uranium-lead apparent ages of uraniferous secondary silica as a guide for describing urantum mobility: U.S. Geological Survey, Circular 753, p. 39-40.

Zielinski, R.A., Lindsey, D.A. and Rosho1t, J.N., 1980, The distribution and mobility of uranium in glassy and zeolitized tuff, Keg Mountain area, Utah, U.S.A.: Chemical Geology, v. 29, p. 139-162. 


\section{Chapter VI}

\section{URANIUM MINERALIZATION ASSOCIATED WITH}

\section{FLUORINE-RICH RHYOLITES IN SOUTHWESTERN UTAH}

by

Eric H: Christianeen 


\section{ABSTRACT}

Several small uranium deposits in southwestern Utah are associated with a distinctive Miocene period of fluorine-rich rhyolitic volcanism. The rhyolitic lavas contain high concentrations of $U(\sim 20 \mathrm{ppm})$ and other 1,ithophile elements and often contain topaz in lithophysae or in the groundmass. This period of volcanism is distinct from an earlier 0ligocene period of calc-alkalic magmatism and caldera formation. Uranium and fluorite deposits near the Staats Mine, Wah Wah Mountains, occur within tuffs beneath a topaz rhyolite lava flow and alng the hrerriated margins of an intrusive phase of the body. No uranium concentrations were found associated with the rhyolite lavas and tuffs near Four Mile Wash, also in the Wah Wah Mountains, in spite of their high $U$ content and overall chemical similarity to the lavas at the Staats Mine. The lack of reactive carbonate clasts within the tuffs at Four Mile Wash and the apparent lack of any hydrothermal alteration of the lava are consistent with its barren state. Other localities in the southeastern Great Basin experienced rhyolitic volcanism similar to that at the Staats Mine but mostly did not experience the special conditions in their emplacement, cooling and alteration histories necessary to generate notable uranium concentrations within or near the volcanic rocks. Devitrification and/or groundwater leaching has released significant quantities of uranium from the rhyolitic rocks and some may have been concentrated in sedimentary deposits within the adjacent valleys. 


\section{INTRODUCTION AND SCOPE}

Uranium mineralization occurs associated with several small bodies of rhyolite in the Basin and Range province of southwestern Utah. (Fig. 1). Sma11 quantities of uranium ore have been produced from a number of mines in the region and several major companies are conducting exploration programs in the area. Fluorite deposits occur throughout the same region of southwestern Utah and, although other fluorite occurences are related to uranium-rich rhyolitic lavas and tuffs. These distinctive rhyolites are themselves rich in F (>3000 ppm) and other lithophile elements and often contain topaz in lithophysae or groundmass.

In an attempt to identify the factors that may lead to the presence or absence of economic mineralization, both mineralized and "barren" rhyolites from the Wah Wah Mountains were studied. The only producing uranium mine within the region is the Holly Claim near the Staats Mine in the southern part of the range (Fig. 1). The mineralization occurs in tuffs beneath a small topaz rhyolite lava flow. A similar rhyolite dome complex, with no known uranium deposits, from the Four Mile Wash area $13 \mathrm{~km}$ south of the Holly Claim was studied for comparison. In addition several rhyolite occurrences and fluorite deposits along the "Blue Ribbon lineament" of Rowley et al. (1978a) were examined to assess the relationship of this feature to uranium mineralization in the region.

This report is based on a combination of field and laboratory studies conducted in 1979 and 1980. My initial visit to the Staats Mine area was in the company of M. F. Sheridan and D. M. Burt in May 1979, who pointed out many critical features. Three weeks were spent in the region during July and August mapping the areas around the Staats Mine and Four Mile Wash. Approximately 75 samples of fresh and altered rocks were collected and thin sections of 55 samples were studied. Whole rock chemical analyses of 18 fresh samples were performed using X-ray fluorescence and atomic absorption techniques at Arizona State University. Uranium concentrations for 5 samples were determined by neutron activation and delayed neutron analysis at the 
Fig. 1. Index map of southwestern Utah and adjacent areas in Nevada, showing the location and approximate extent of Miocene rhyolites and intrusive rocks with various ages discussed in this paper. After M. G. Best (unpublished manuscript) and Keith (1980). 
Center for Volcanology, University of Oregon. Potassium, uranium and thorium con- . centrations were determined for another 55 samples by gamma ray spectroscopy (grs) at the University of Texas, E1 Paso.

\section{GEOLOGIC SETTING}

Southwestern Utah lies along the eastern margin of the Basin and Range physiographic province and shares most of its geologic features and history with the rest of the Great Basin, including the Spor Mountain area (Bikun, this report) which lies about $200 \mathrm{~km}$ to the north.

During the Paleozoic and Mesozoic Eras shallow marine and continental sediments accumulated on what was probably a continental margin produced by Precambrian rifting (Stewart, 1972). Late Mesozoic and early Tertiary orogenisis (the Sevier and Laramide orogenies) produced large, low angle thrust sheets that juxtapose a series of carbonate-dominated sediments of late Precambrian to Silurian age over Mesozoic continental deposits (Miller, 1966). Locally, lower Tertiary fluvial and lacustrine sediments veneer this sequence.

Approximately $30 \mathrm{~m} . \mathrm{y}$. ago, the southern Great Basin experienced explosive volcanism over a bṛoad area. The resulting vnlranic rocke lic unconformably uver the eroded remnants of the thrust-faulted terrain. Although the composition of the initial volcanic products is fairy silicic (Conrad, 1.969; Bushman, 1973; Campbell, 1978), the largest volumes are represented by dacitic ash-flow tuffs and andesitic lavas. The most extensive units erupted during this oligocene volcanism are included in the Needles Range Formation (Mackin, 1960; Cook, 1965; Best et a1., 1973). One of the three reglonal sheets (the Wah Wah Springs Tuff Member) outcrops over an area of almost $40,000 \mathrm{~km}^{2}$ and its enuption volume is estimated at nearly 4,000 $\mathrm{km}$ (Shuey et a1., 1976). The Needles Range Formation has been dated by K-Ar methods as 29.7 $\pm 0.9 \mathrm{m.y.} \mathrm{old} \mathrm{(Armstrong,} \mathrm{1970;} \mathrm{Fleck} \mathrm{et} \mathrm{al.,} \mathrm{1975),} \mathrm{and} \mathrm{provides} \mathrm{a} \mathrm{prominent} \mathrm{strati-}$ graphic marker throughout much of the eastern Great Basin and western Colorado 
Plateaus. Typically, large collapse-type calderas were produced as a result of these eruptions. The Indian Peak cauldron, partially exposed within the Needle Range, is the source for several members of the Needles Range Formation (Best et al., 1979). Contemporaneously with the ash-flow magmatism, composite volcanic piles were built in the Black Mountains and other nearby areas (Rowley, 1978). Another prominent marker unit within the 01igocene sequence is the Isom Formation (Williams, 1967; Mackin, 1960). It is a distinctive, crystal-poor tuff with secondary flowage features and abundant vapor-phase crystallization. It has been dated at 25-26 m.y. (Armstrong, 1970; Fleck, et al., 1975). Overlying the Isom Formation is a hetrogeneous assemblage of rhyolitic tuffs and trachyandesite lava flows in several of the mountain:ranges (Keith, 1980).

Associated with this intermediate to silicic (generally calc-alkalic) vollcanism are several small intrusions that range in composition from monzonite to granodiorite (Fig. 1). They are scattered throughout the area from the Stateline District to Milford. Several are minexalized; hydrothermal, metasomatic and disseminated $\mathrm{Cu}$, $\mathrm{Ag}, \mathrm{Pb}$ and $\mathrm{Zn}$ mineralizations are typical (Lemmon, et al., 1973). Hydrothermal fluorite deposits (Bullock, 1976) surround a small granodiorite intrusion in the Needle Range that may be the resurgent core of the Indian Peak: Cauldron (Grant, et al., 1976). These deposits have accounted for most of the fluorite production in the region. However, they are not uraniferous.

A "porphyry" molybdenum ore body was recently discovered near Pine Grove in the central Wah Wah Mountains (Wa11 Street Journal, 8 January, 1978; Keith, 1980). The mineralization occurs within a garnet-bearing rhyolite porphyry that appears to have explosively vented to the surface during its evolution. The placement of this rhyolitic $\left(\sim 76 \% \mathrm{SiO}_{2}\right)$ intrusion within either the calcalkalic sequence just described or the following rhyolitic suite is problematic 
because of its age (23-25 m.y.; Keith, 1980).

The nature of volcanism in southwestern Utah changed abruptly after about 23 m.y. ago. The predominant volcanic rocks of this epoch are trachyandesite lavas and rhyolites. Best (unpub. ms.) has obtained a $\mathrm{K}$-Ar age of $23 \mathrm{~m} \cdot \mathrm{y}$. on a trachyandesite from the Wah Wah Mountains. The rhyolites were emplaced as subvolcanic intrusions, smal1, domes or short flows. The youngest flows in this sequence genreally lie unconformably on tilted faultblocks of the older ash-flows and are commonly high in silica $(>75 \%)$. Similar rhyolitic volcanism occured contemporaneously in the Marysvale region (Carmony, 1977; Wender and Nash, 1978; Rowley, et al., 1979) and at Spor Mountain (Lindsey, 1979; Bíkun, this report). At Spor Mountain and in the Wah Wah Mountains-Needle Range region the high-silica rhyolites are generally rich in fluorine (>5000 ppm in many cases) and topaz, fluorite, bixbyite and garnet occur in lithophysae or in the groundmass of crystalline lavas. Associated with the silicic volcanism are small deposits of lithophile elements, notably uranium and fluorite (and beryllium at Spor Mountain). Some alunitic alteration (K-Ar age $15.5 \mathrm{~m} . \mathrm{y}$. , M.G. Best, unpub. ms.) is also associated with rhyolitic volcanism, as we11 as iron (Blawn Mouncain) and mercury (south of the Tetons). All of thesc occurrences are in the Wah Wah Mountains.

This period of apparently bimodal volcanism was approximately contemporaneous with the inception of basin and range faulting in the region -- 21-22 m.y. ago (Rowley et al., 1978a) -- if the ages of the Staats Mines intrusion, $20 \mathrm{~m} . \mathrm{y}$. (Rowley, et al., 1978b), two intrusions in the Stateline District, 17 and $21 \mathrm{m.y}$. (Keith, 1980) and four lavas from the Wah Wah Mountains $\left(21.5-23 \mathrm{~m} \cdot \mathrm{y}_{\bullet}\right)$ are representative. Although rhyolitic volcanism has continued to the present, basaltic volcanism has become volumetrically more important throughout the Great Basin and has become increasingly conentrated along the margins of the Basin and Range province (Best and Hamblin, 1978). 
THE STAATS MINE AREA, WAH WAH MOUNTAINS

The Staats, or Monarch, Mine in the southern Wah Wah Mountains has been a minor producer of uranium and fluorite since at least the mid-1950's (Thurston et al., 1954). Other nearby mines (Daisy, Producer and Holly) have periodically produced ore. The mines are centered around a small ( $1 \mathrm{~km}$ by.2 km ) intrusive-extrusive body of topaz-bearing rhyolite. Thurston et al. (1954), Whelan (1965), Bullock (1976) described the igneous body as a rhyolite-porphyry complex that was intruded by an igneous breccia that hosts the mineralization in some locations. Remapping of the area indicated.that only part of the outcrop is intrusive, and the mineralized "mylonized breccia" described by Whelan is an altered lithic-rich tuff. The map is shown in Figure 2.

Geology

Only four significant geologic units were mapped in this area--a sequence of undifferentiated Paleozoic sedimentary rocks, a Tertiary andesite, the rhyolite of Staats Mine and the tuff of Holly Claim.

Sedimentary rocks. The sedimentary rocks around the outcrop are not differentiated on the map. Miller (1966) and Lindsey and Osmonson (1978) have described these rocks. Briefly they consist of Ordovician to Mississippian quartzites and massive dolomites that are part of an allochthonous thrust sheet. Bodies of jasperiod occur within the dolomites and the carbonates are variably altered to clays or silicified near the rhyolite.

Tertiary andesite. Two small outcrops of brown aphanitic andesite unconformably overlie the dolomites along the southwest margin of the northern lobe of the rhyolitic mass. The lava is non-vesicular, flow-banded and weathers to decimeter sized slabs. Apparently, these outcrops are remnants of a lava flow that partially filled gullies in the underlying dolomite. In hand sample, they resemble other andesitic lavas that were extruded both before and after the eruption of the Needles Range Formation. They probably correlate with the andesite member of the pre-Needles Range, 


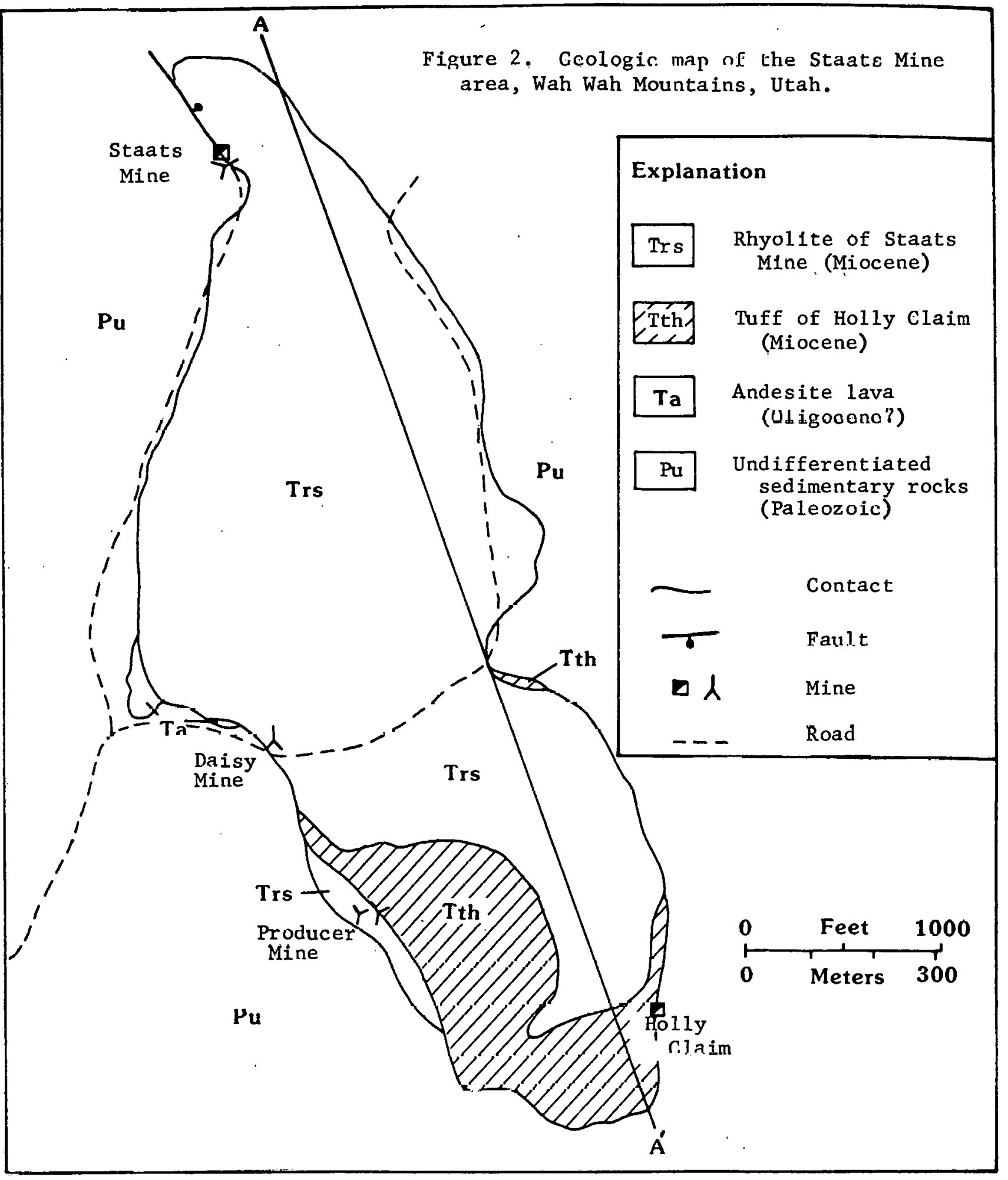


Escalante Desert Formation which is exposed about a mile to the southwest (Best and Keith, 1979).

Tuff of Holly Claim. Ringing the southern lobe of the rhyolite is a lithicrich tuff composed of interlayered pyroclastic surge and pyroclastic flow deposits. Locally the lithic inclusions exceed $10 \mathrm{~cm}$ in diameter, and the rock could be called a pyroclastic breccia. The tuff has been extensively altered and original glassy material is dominantly clay minerals. Lithic inclusions are predominantly carbonate fragments from the underlying country rock, but clasts of volcanic rocks comprise approximately $25 \%$ of the inclusions. Represented in the volcanic inclusions are several members of the Needles Range Formation (dominantly the Wah Wah Springs Tuff) and an andesitic lava, similar to that exposed along the margins of the rhyolite. The tuff unconformably overlies the carbonate rocks at the extreme southern tip of its outcrop area and is conformably overlain by rhyolite lava. The informal desig-. nation of this unit is taken from the name of an open cut in the tuff near its southeast margin where exposures are best (Fig. 2). Some uranium ore has been shipped from this location. The unit is interpreted to be the remnant of a tuff ring emplaced during the initial venting of the upper portion of a rhyolitic magma chamber. The tuff of the Holly Claim is similar to and correlative with the tuff member of the Blawn Wash Formation (Best and Keith, 1979).

The rhyolite of Staats Mine. The dominant rock within the igneous complex is a dense, grey porphyritic rhyolite. Contacts with the other units are often obscure, but sharp intrusive contacts are well-exposed in several bulldozer cuts along its northern margin. To the south the rhyolite overlies andesitic lava or the tuff of Holly claim and in these localities is clearly extrusive. The rhyolite crops out over an area of slightly less than $2 \mathrm{~km}^{2}$. The name is derived from the Staats Mine, located along the western margin of the outcrop. An age of $20.2 \mathrm{~m} \cdot \mathrm{y}$. was obtained on sanidine from the rhyolite by K-Ar methods (Rowley and others, $1978 \mathrm{~b}$ ). Miarolitic cavities and flow banding are common within the rhyolite mass. Along its eastern margin columnar joints are prominent. Both Miller (1966) and Whelan (1965) 
speculated that the northern lobe is a sill from a stock represented by the southern lobe. Although the northern lobe may be sill-like in places, the extreme northern part has sharp, vertical contacts with the sediments and the presence of the tuff around the southern lobe demonstrates the extrusive nature of the complex. Best and Keith (1979) have included the rhyolite within their rhyolite member of the Tetons, but because of its strongly porphyritic nature, it is probably more similar to their rhyolite member of Pink Knolls.

Petrographically, the rhyolite consists of euhedral smoky quartz and feldspar phenocryses several millimeters in length set in a felty groundmass ( $275 \%$ of the rock) of alkali feldspar and silica minerals. The modal mineralogy is summarized in Table 2. Trace constiuents include phenocrysts of biotite, Fe-Ti oxides and magmatic fluorite. Topaz occurs within the groundmass as a vapor phase mineral. The biotites are generally altered to assemblages of oxides minerals and most of the feldspar phenocrysts are turbid. Fresh feldspar compositions analyzed by electron microprobe (Christiansen et al., this report) plot in two fairly tight fields near Or55 and Ab87. Using Stormer's (1975) two-feldspar geothermometer a temperature of $650^{\circ} \mathrm{C}$ was obtained. This is a fairly low temperature but is consistent with temperatures obtained by Bikun (this report) and Turley et al. (1979) for similar fluorine-rich rhyolites from near the Thomas Range. Chemically the rhyolite is subalkaline and peraluminous (Table 1, analysis 1). The rhyolite is high in silica, alkalies and $\mathrm{Rb}$ and $10 \mathrm{w}$ in $\mathrm{TiO}_{2}$, features typical of topaz rhyolites. The fluorine concentration is over 0.50 wt.\% and the Ucontent is $14 \mathrm{ppm}$ (Table 5). In view of the slightly altered nature of the phenncrysts, and the mobility of $F$ and $U$ (Zielinski et al., 1977) these probably do not represent magmatic values. Almost certainly the U-content of the rhyolite was reduced by post-consolidation alteration. -Glassy topaz rhyolites generally contain 20 ppm uranium (Table 5).

Eruption and Emplacèment

Studies of the emplacement of viscous rhyolite domes and flows have shown that 
Table 1: Chemical analyses of rhyolites from southwestern Utah.

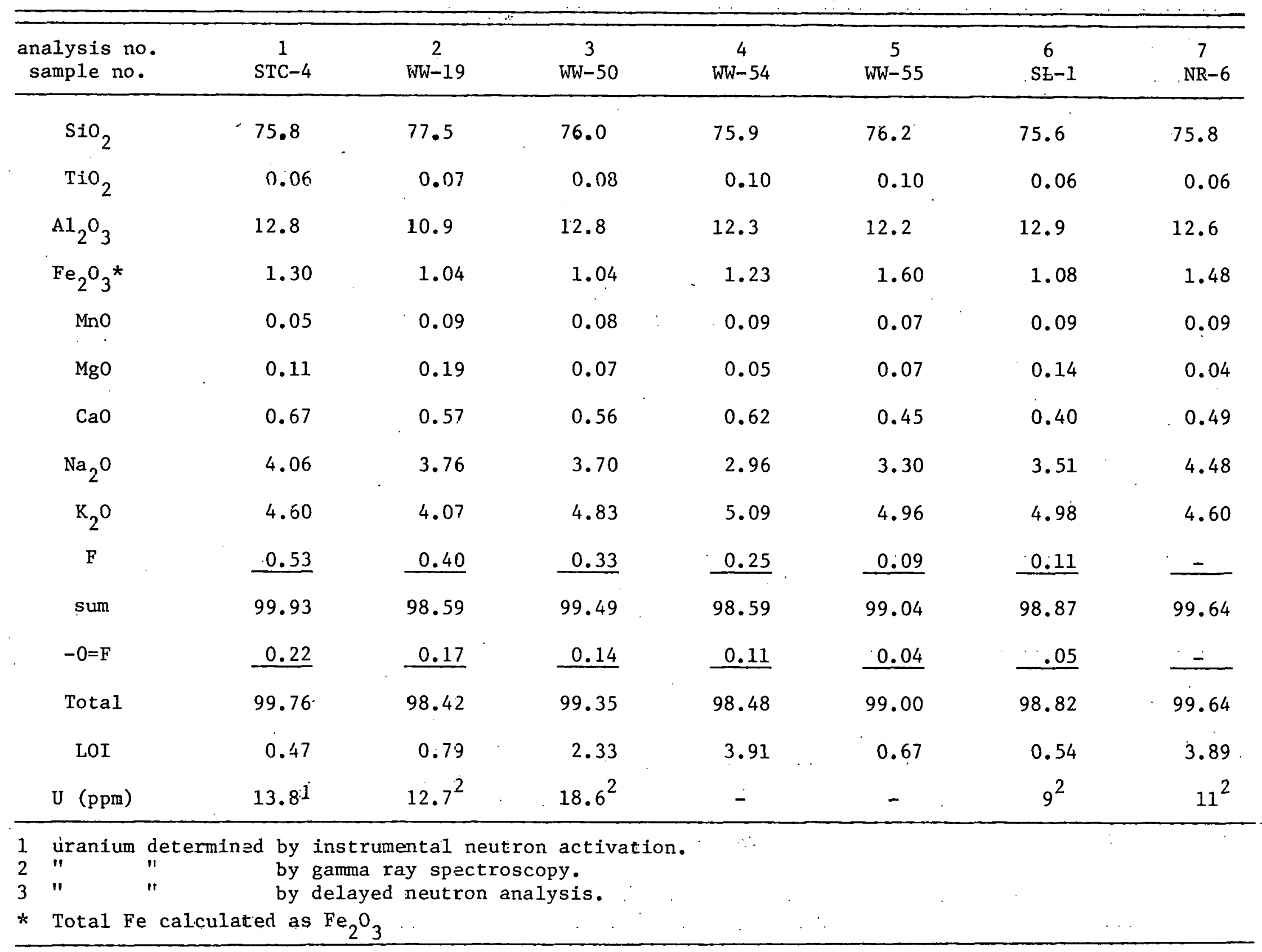


Table 1. continued.

\begin{tabular}{|c|c|c|c|c|c|c|c|}
\hline $\begin{array}{c}\text { analysis nc. } \\
\text { sample no. }\end{array}$ & $\begin{array}{c}8 \\
\mathrm{NR}-2\end{array}$ & $\begin{array}{c}9 \\
N R-9\end{array}$ & $\begin{array}{c}11 \\
W W-6 b\end{array}$ & $\begin{array}{c}11 \\
W W-7\end{array}$ & $\begin{array}{c}12 \\
W N-8\end{array}$ & $\begin{array}{c}13 \\
W W-9\end{array}$ & $\begin{array}{c}14 \\
W W-10\end{array}$ \\
\hline $\mathrm{SiO}_{2}$ & 77.3 & 77.1 & 77.7 & 77.1 & 76.5 & 76.8 & 77.3 \\
\hline $\mathrm{TiO}_{2}$ & 0.18 & 0.13 & 0.16 & 0.06 & 0.06 & 0.11 & 0.10 \\
\hline $\mathrm{Al}_{2} \mathrm{O}_{3}$ & 12.7 & $\$ 2.5$ & 12.2 & 12.6 & 12.6 & 12.3 & 12.2 \\
\hline $\mathrm{Fe}_{2} \mathrm{O}_{3}^{*}$ & 1.33 & 1.03 & 1.09 & 0.93 & 1.00 & 1.16 & 1.19 \\
\hline Mno & 0.37 & 0.04 & 0.05 & 0.06 & 0.09 & 0.09 & 0.08 \\
\hline $\mathrm{MgO}$ & 0.20 & 0.12 & 0.15 & 0.10 & 0.07 & 0.10 & 0.06 \\
\hline $\mathrm{CaO}$ & 0.49 & $0.9^{-}$ & 0.63 & 0.17 & 0.66 & 0.91 & 0.45 \\
\hline $\mathrm{Na}_{2} \mathrm{O}$ & 2.79 & $1.9^{-}$ & 3.20 & 3.42 & 3.95 & 4.21 & 3.63 \\
\hline $\mathrm{K}_{2} \mathrm{O}$ & 5.12 & 5.79 & 5.00 & 5.25 & 4.57 & 3.25 & $4.57^{\circ}$ \\
\hline F & - & - & - & - & - & 0.50 & - \\
\hline sum & 09.88 & 99.53 & 100.18 & 99.69 & 99.49 & 99.33 & 99.58 \\
\hline$-0=F$ & - & - & $=$ & - & - & 0.21 & - \\
\hline Total & 5.9 .88 & $99.5 E$ & 100.18 & 99.69 & 99.49 & 99.12 & 99.58 \\
\hline LOI & 2.99 & 3.37 & 2.54 & 0.72 & 4.35 & 4.36 & 0.45 \\
\hline $\mathrm{U}$ & $9.6^{2}$ & $6.5^{2}$ & $19.6^{3}$ & - & $20.6^{3}$ & $20.2^{2}$ & $13.8^{3}$ \\
\hline
\end{tabular}


Table 1. continued.

\begin{tabular}{|c|c|c|c|c|}
\hline $\begin{array}{c}\text { analysis no. } \\
\text { sample no. }\end{array}$ & $\begin{array}{c}15 \\
W W-41\end{array}$ & $\begin{array}{c}16 \\
\text { WW-11 }\end{array}$ & $\begin{array}{c}17 \\
\text { SH-1 }\end{array}$ & $\begin{array}{c}18 \\
\mathrm{SH}-3\end{array}$ \\
\hline $\mathrm{SiO}_{2}$ & 75.8 & 75.1 & 77.5 & 73.7 \\
\hline $\mathrm{TiO}_{2}$ & 0.05 & 0.09 & 0.22 & 0.13 \\
\hline $\mathrm{Al}_{2} \mathrm{O}_{3}$ & 12.9 & 13.0 & 11.0 & 12.2 \\
\hline $\mathrm{Fe}_{2} \mathrm{O}_{3} *$ & 1.26 & 1.34 & 1.69 & 1.65 \\
\hline Mno & 0.12 & 0.11 & 0.02 & 0.06 \\
\hline $\mathrm{MgO}$ & 0.04 & 0.17 & 0.24 & 0.13 \\
\hline $\mathrm{CaO}$ & 0.62 & 0.91 & 0.26 & 3.08 \\
\hline $\mathrm{Na}_{2} \mathrm{O}$ & 3.84 & 3.80 & 3.02 & 3.40 \\
\hline $\mathrm{K}_{2} \mathrm{O}$ & 4.80 & 4.90 & 5.25 & 5.12 \\
\hline$F$ & 0.45 & - & .0 .06 & 0.14 \\
\hline sum & 100.05 & 99.42 & 99.26 & 99.61 \\
\hline$-0=F$ & 0.19 & - & 0.03 & 0.06 \\
\hline Total & 99.86 & 99.42 & 99.23 & 99.55 \\
\hline LOI & 3.26 & 0.82 & 0.13 & 1.12 \\
\hline $\mathrm{U}(\mathrm{ppm})$ & $\begin{array}{l}21.3^{1} \\
21.5^{2}\end{array}$ & - & $5.6^{2}$ & $7.5^{2}$ \\
\hline
\end{tabular}


Tajle 2. Moial composition of volcanic rocks from southwestern Utah.

\begin{tabular}{|c|c|c|c|c|c|c|c|c|c|c|c|}
\hline area & sample no. & matrix & guartz & sanidine & plagioclase & biot & fluorite & topaz. & opaques & & others \\
\hline \multirow{2}{*}{$\begin{array}{l}\text { Staats } \\
\text { Mine }\end{array}$} & STC-4 & 73.2 & 7.4 & 10.5 & 7.7 & 0.2 & 0.6 & 0.4 & $\operatorname{Tr}$ & & -- \\
\hline & $W W-2$ & 72.0 & 10.0 & $1 \dot{4} .0$ & 2.0 & $\operatorname{Tr}$ & -- & $\operatorname{Tr}$ & Tr. & & -- \\
\hline \multirow{3}{*}{$\begin{array}{l}\text { Four Mile } \\
\text { Wash }\end{array}$} & WW-19 & 86.6 & 2.2 & 6.8 & 2.8 & $-\frac{-}{6}$ & -- & 1.4 & 0.2 & & zircon \\
\hline & $W W-50$ & 75.2 & 0.2 & . 1.2 & 6.0 & $\mathrm{Tr}$ & -- & 1.0 & 0.4 & & -- \\
\hline & $W W-54$ & 92.0 & 3.6 & 2.8 & 1.4 & -- & -- & $\mathrm{Tr}$ & 0.2 & & -- \\
\hline $\begin{array}{l}\text { Cottonwood } \\
\text { Wash }\end{array}$ & $N R-6$ & 74.4 & $6 . \epsilon$ & 8.8 & 2.6 & 0.8 & 0.4 & -- & -- & & -- \\
\hline \multirow{2}{*}{$\begin{array}{l}\text { Commissary } \\
\text { Creek }\end{array}$} & $\mathrm{NR}-2$ & 35.6 & 0.6 & $\varepsilon .0$ & 4.6 & 1.0 & -- & -- & 0.2 & & -- \\
\hline & NR-9 & 70.2 & 7.2 & $1 \bar{\pi} .2$ & 4.6 & 0.2 & -- & -- & 0.6 & & -- \\
\hline \multirow[t]{2}{*}{ The Tetons } & WW-7 & 97.4 & 0.8 & 1.4 & 0.4 & -- & -- & -- & -- & & -- \\
\hline & WW-8 & 96.0 & -- & 2.6 & 1.4 & -- & -- & -- & -- & & -- \\
\hline \multirow{3}{*}{$\begin{array}{l}\text { Broken } \\
\text { Ridge }\end{array}$} & $W W-9$ & 98.2 & 0.8 & 0.8 & 0.2 & -- & -- & -- & -- & & -- \\
\hline & WW-10 & 84.8 & 1.6 & 1.0 & -- & -- & $--(1 i$ & ophysa 1 & minerals & 13.2) & ) -- \\
\hline & $W W-1 I$ & 71.4 & 6.4 & 5.4 & 1.4 & -- & -- & -- & 0.2 & - & -- \\
\hline Dead Horse & $\mathrm{SH}-1$ & $7 \mathrm{C}$ & 12 & 15 & 1 & 1.5 & -- & -- & 0.8 & & $\mathrm{hb}$ \\
\hline
\end{tabular}

Note. Values are in volume percent. $\operatorname{Tr} .=t r a c e$ 
many are emplaced within or óriginate from a tuff ring produced by a variety of pyroclastic processes (fall, surge, flow) during the initial explosive venting of the magma (Sheridan and Updike, 1975; Christiansen and Lipman, 1966; Heiken, 1978). The tuff ring commonly consists of a mixture of juvenile rhyolitic material, generally pumice-rich, and accidental lithic fragments derived from the rocks overlying the site of explosion. These eruptions can occur when the rising magma comes in contact with ground water or when the magma becomes saturated with volatiles that exsolve explosively upon pressure release.

The rhyolite of the Staats Mine appears to have been emplaced in a similar fashion. Lithic inclusions within the tuff of Holly Claim include those rock types through which the rhyolite would have vented, namely carbonates and intermediate composition volcanic rocks. The eruption of the tuff of Holly Claim was followed by the emplacement of a viscous rhyolite dome; along its western margin, a lobe of rhyolitic lava must have extended over the tuff ring. The northern, intrusive lobe of the rhyolite of Staats Mine may have been emplaced as a sill, as suggested by Whelan (1965) and Miller (1966), but the near vertical contacts along its margin make this interpretation less tenable. Alternatively, the northern lobe may represent the main mass of the rhyolite intrusion with its pyroclastic blanket and extrusive lava rover stripped away hy erosion. This interpretation, shown in, Fig. 3, requires that considerable topographic relief existed at the time of eruption and suggests that the tuff of Holly Claim was deposited in a paleo-valley and preserved by its lava cover.

\section{Mineralization}

Staats Mine. The ore deposits at the Staats Mine have received previous attention from Thurston et al. (1954), Whelan (1965), Bullock (1976) and Lindsey and Osmonson (1978). Fluorite (and uranium) mineralization is confined to a narrow breccia zone that occurs along the margin of the intrusive portion of the rhyolite. A shaft and an adit penetrate into this breccia zone near the northwest corner of the rhyolite. The breccia was produced by intrusion of the rhyolite plug so that transi- 
Figure 3. Geologic cross-secticn of the rhyolite dome and lava flow near the Staats Mine, Wah Wah Mountains, Utah.

\section{Feet A}

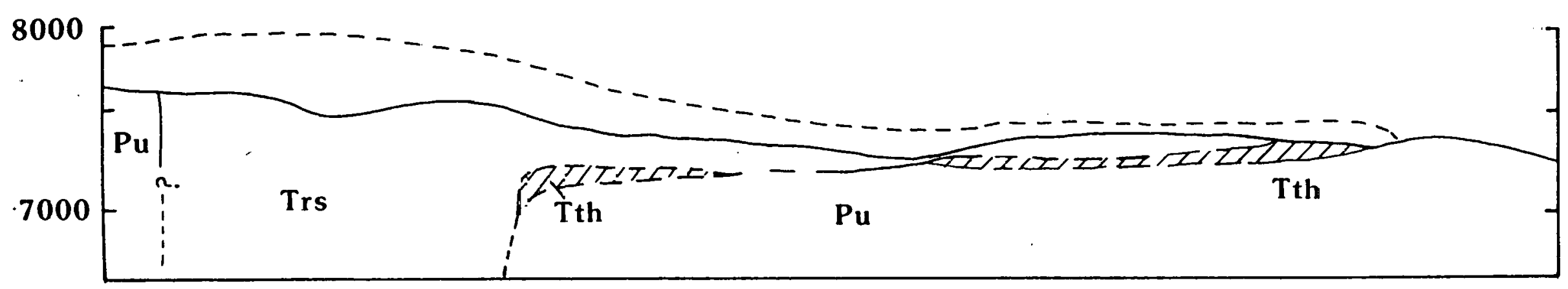


tions from unaltered carbonate country rock, brecciated dolomite, altered and brecciated dolomite and rhyolite to altered rhyolite are common. The mineralized zone is marked by pervasive alteration to clays (Lindsey and Osmonson, 1978, identified kaolinite, montmorillonite and illite), fluorite stringers, calcite and quartz. Pyrite and hematite are also present within the ore zone. Purple fluorite occurs within the breccia as pods or lenses, that extend vertically, parallel to the margin of the instrusion, for approximately $10 \mathrm{~m}$ in the shaft (Thurston et a1., 1954). Fluorite mineralization does not extend into the unbrecciated country rocks. In places the contact zone is faulted and mineralization ends abruptly at the fault plane, with fluorite replacements extending into the altered rhyolite.

Uranium concentrations, as indicated by testing with a scintillometer, are intimately related to the fluorite, but white, altered rhyolite with no apparent fluorite yields the highest counts, $2140 \mu \mathrm{r} / \mathrm{hr}$ (Table 3 ). However all of the contact zone is more radioactive than either the country rock or the main rhyolite mass. Uraninite, autunite and uranophane have been identified in the fluorite breccia near the Staats Mine (Whelan, 1965).

The field relations around the Staats Mine suggest that Ca+t-bearing fluids (from the carbonate country rock) were transported into or along the brecciated margin of the cooling rhyolite after its intrusion. Reactions between the fluorine-rich rhyolite or a F-rich fluid separated from the rhyolite and Ca-rich aqueous fluids precipitated fluorite, trapping uranium in the process as much of the uranium was probably being carried by fluorine complexes within the magma (cf. Burt and Sheridan, 1980). High temperature devitrification of glassy rhyolite leads to the loss of both $\mathrm{U}$ and F (Zielinski et a1., 1977). Presumably such processes had already released these elements and placed them in a form that would be highly susceptible to fluid transport and redeposition along the porous brecciated contacts. Lower pressure and temperature encountered by rising fluids also favors the disassociation of F-complexes (Bailey, 1977). All of these factors probably played a role in the deposition of fluorite and concentration of uranium at the sediment-rhyolite contact. 
Table 3. Radioactivity of rock units in the Staats. Mine area, Wah Wah Mountains, Utah

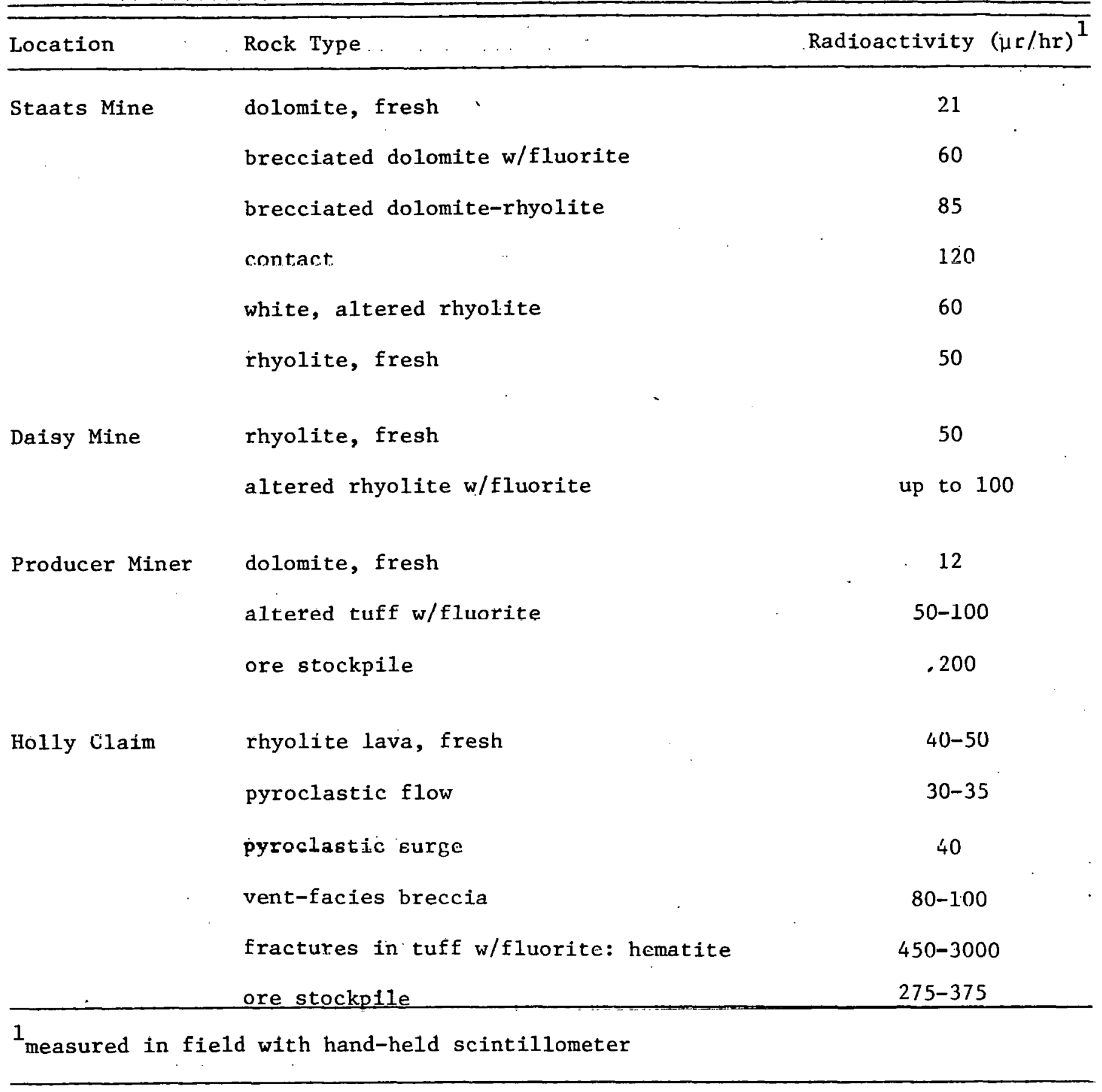


The Daisy Mine. . The Daisy Mine lies about one kilometer south of the Staats Mine along the brecciated margin of the rhyolite of Staats Mine. Fluorite and uranium ore were shipped from the mine (Bullock, 1976). The mineralization is similar to that at the Staats Mine and consists of lenses and pods of green to purple uraniferous fluorite. Uraninite occurs in the more intensely alterëd parts cf the mine.

The Holly Claim. Near the southeast corner of the rhyolite complex a short cut and a vertical shaft at its northern end were constructed on the Holly Claim (owned by Lavar Hollingshead of Ely, Nevada). The mine is located in a strongly altered tuff. The tuff, as exposed in the walls of the cut, consists of a lower vent: breccia about $1 \mathrm{~m}$ thick, with large 1ithic inclusions, overlain by a finer-grained, distinctly laminated ash flow. Faulting that may have accompanied the eruption, has dropped the vent breccia below the floor of the cut on the north, toward the probable location of the vent. Calcite and clay are abundant and have replaced most of the originally pumiceous materials. Uraniferous fluorite occurs as fissure-fillings and as purple rims around some of the abundant carbonate lithic fragments. Testing with a scintillometer showed that the coarse vent facies are more radioactive $(80-100 \mu \mathrm{r} /$ $\mathrm{hr}$ ) than the overlying pyroclastic flow $(30-35 \mu \mathrm{r} / \mathrm{hr})$ or the rhyolite lava $(50 \mu \mathrm{r} / \mathrm{hr})$. However, fluorite-and quartz-lined fractures, stained with hematite, within the ash flow yield readings ranging from 450 to $3000 \mu \mathrm{r} / \mathrm{hr}$. Table 3 compares the radioactivity of various lithologies surrounding the rhyolite of Stats Mine.

Mineralization of the tuff of Holly Claim probably proceded in a manner similar to that proposed by Burt and Sheridan (1980; this report). Several elements of this model were derived from an examination of this area. It was suggested that heat from a rhyolite dome or flow could set up near-surface water circulation into and uf the volcanic vent and out through underlying tuffs. This flow pattern is determined by the porosity and permeability of the brecciated contact zone and the 1ithic-rich tuffs. Some ore deposition probably occurred during this type of fairly low temperature alteration of the glassy tuff to clays, calcite, fluorite and iron oxides. All of the 
ore elements could easily be derived from the cooling rhyolite and redistributed within the tuff with its reactive lithic fragments. The continued percolation of even lower temperature ground water through the vent complex presumably has further modified the ore distribution.

THE FOUR MILE WASH AREA, WAH WAH MOUNTAINS

Another small rhyolite dome occurs on the east side of Four Mile Wash, approximately $13 \mathrm{~km}$ due south of the rhyolite of the Staats Mine. The dome is nearly circular in plan with a diameter of $1.8 \mathrm{~km}$. Although the complex is structurally and chemically similar to that of the Staats Mine, no uranium has been reported from it. One of the purposes of this study was to determine the reasons for its barren state.

Geology

The geology of the area: is shown in Figure 4. Five 1ithologic units were mapped in the field.

Sedimentary rocks. The entire east side of the area is underlain by Paleozoic carbonate sediments. Near the rhyolite the rocks consist of a mottled grey dolomite. No alteration of the sediments is apparent near the rhynlite contact.

Older Tertiary volcanic rocks. For the sake of simplicity a diverse group of tuffs and lavas that are older than the rhyolite dome are grouped together as older Tertiary volcanic rocks. Most of this unit consists of the Lund Tuff Member of the Needles Range Formation. To the north and south flow-banded andesitic lavas crop out that probably correlate with the hornblende andesite mapped by Best (1979). Occasional exposures of a white crystal-rich ash-flow tuff occur near the margins of the rhyolite. This is probably the Bauers Tuff Member of the Condor Canyon Formation (22 m.y. old, Feck et al., 1975). Although the contact is poorly exposed these volcanics probably cover the Paleozoic sedimentary rocks and may have an aggregate thickness of several hundred meters. 


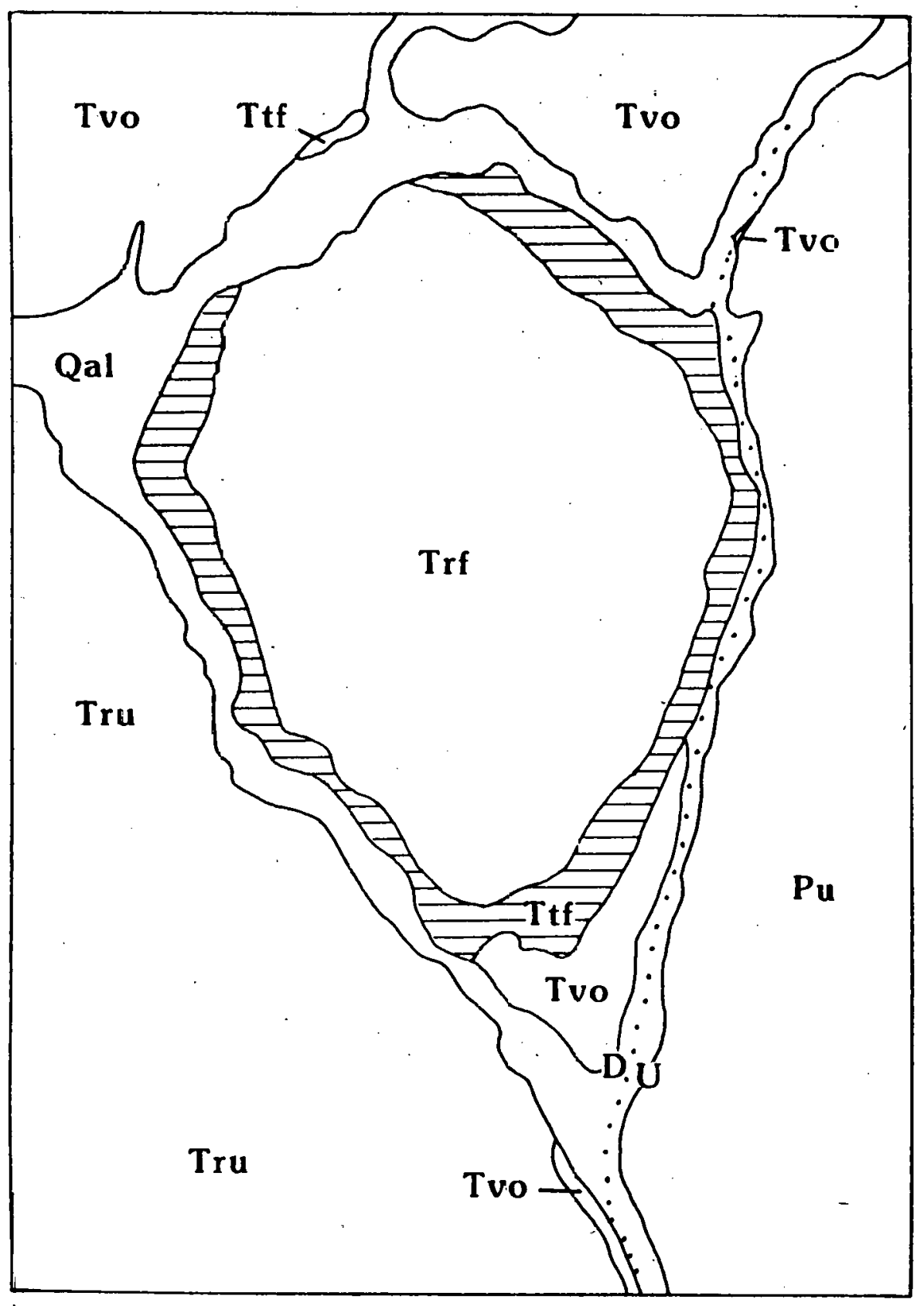

Figure 4. Simplified geologic map of the Four Mile Wash area, Wah Wah Mountains, Utah.

\section{Explanation}

Tru Undifferentiated rhyolite lava and tuff (Miocene)

Trf Rhyolite of Four Mile Wash (Miocene)

ETtf- Tuff of Four Mile Wash (Miocene)

Tuo Undifferentiated older volcanic rocks (Miocene-01igocene)

Undifferentiated sedimentary
rocks. (Paleozoic)

- Contact

- ... Fault, dotted where concealed

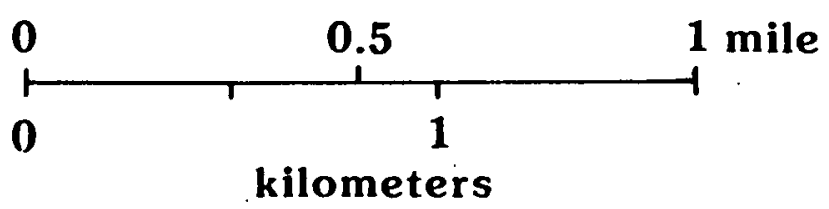


Tuff of Four Mile Wash. Resting unconformably on the older volcanic rocks is a white unwelded tuff. The tuff consists of a variety of pyroclastic deposits, including pyroclastic fall, pyroclastic flow and pyroclastic surge. Stream gullies expose sections $4 \mathrm{~m}$ thick that consist dominantly of massive and sandwave facies pyroclastic surge typical of tuff units beneath rhyolite domes elsewhere. Alternating beds are lithic rich. All of the components of the older volcanic section are represented in the lithic suite, but no carbonate or sedimentary inclusions are present. Glassy crystal-rich inclusions of rhyolitic composition reach $20-30 \mathrm{~cm}$ across. These inclusions, probably represent quenched samples of the rhyolitic magma ejected during eruption as bombs. The total thickness of the tuff is probably about $10 \mathrm{~m}$ on the east side of the dome, although the base may not be exposed. Much of the pumice within the tuff is still fresh and unaltered although in places alteration to zeolites has occurred.

Rhyolite of Four Mile Wash. A dense pink porphyritic rhyolite conformably overlies the pyroclastic unit. Black vitrophyre lenses in a devitrified matrix occur near the base of the unit and are overlain by a thick section of 1ithophysal rhyolite. Steeply-d1pping, flow-banded green vitrophyre bands occur near the top and are capped by a dense, pink devitrified rhyolite lava. The rhyolite of Four Mile Wash is consistently phenocryst-poor, ranging from 75 - 92\% matrix, either glass or its devitriflcation produces. The modal mineralogy of three samples is summarized in Table 2 . Sanidine is the dominant phenocryst and occurs along with quartz and plagioclase. Trace amounts of biotite, topaz, Fe-Ti oxides and zircon are also present. The feldspars are fresh and unaltered. Fluorite, topaz, quartz and alkali feldspars also occur in lithophysae. Analyses of four samples from various facies within the dome are presented in 'lable 1 , analyses 2-5. The glassy sample, analysis 3 , probably represents the magma composition. It is a high-silica subalkaline rhyolite, similar in many respects to the rhyolite of the Staats Mine. The glass contains 19 ppm U (gamma ray spectroscopy -grs) and 3300 ppm F. Apparently, spherulitic devitrification released uranium, as the devitrified sample contains only $13 \mathrm{ppm} U$ (grs) but trapped 
F. The lithophysal section is depleted in fluorine (920 ppm), with only about $25 \%$ as much as fresh glass. Unfortunately, the results of the U-analysis for the lithophysal rocks were not returned.

Undifferentiated rhyolite. The southwestern part of the map area is covered by a thick sequence of topaz-bearing rhyolitic lavas and underlying tuffs. They are part of a rhyolite dome complex at Broken Ridge and Mountain Spring Peak discussed below. Although they are chemically similar to the lavas on the west side of the Wash, they can be distinguished by their crystal-rich nature. No lavas from this complex were found beneath the dome of Four Mile Wash, so they are probably younger. All of these rhyolites belong to the Miocene rhyolite of Broken Ridge as mapped by Best (1979).

\section{Eruption and Emplacement}

The empiacement of the rhyolite dome complex at Four Mile Wash was similar in many respects to that of the Staats Mine. Emplacement consisted of three main «stages: a.) initial explosions and vent-clearing above a shallow rhyolite magma $\therefore$ leading to the deposition of a lithic-rich apon of tuffs (or breccias) around the vent; b.) formation of a tuff ring through the buildup of pyroclastic surge deposits and short ash flows; and c.) eruption of a viscous rhyolite dome inside and above the tuff ring. No intrusive equivalent of the Four Mile Wash rhyolite is exposed as at the Staats Mine. The alteration of the tuff is much wess advance indicating that any fluid circulation was limited and ineffective.

\section{Mineralization}

No known uranium deposits occur within or near the rhyolite dome complex at Four Mile Wash, although the rhyolites are chemically similar to those at the Staats Mine (compare analyses 1 and 2 or 3, Table 1). Although the high magmatic concentration of $\mathrm{U}$ and $\mathrm{F}$ is probably important to the formation of ore deposits, they are not sufficient by themselves. Other processes operating during the eruption, emplacement 
and cooling of the rhyolite must be responsible for ore deposition. While the glassy sample from Four Mile Wash has a uranium content of $19 \mathrm{ppm}$, a devitrified sample contains $13 \mathrm{ppm}$-- about the same as the devitrivied samples from the Staats Mine. This suggests that while $U$ (and possibly $F$ ) was lost during devitrification. and cooling of both rhyolites (Zielinski, et al., 1977), the uranium at the Staats Mine was selectively concentrated within the ore-bearing tuffs and brecciated margins of the intrusions, and lost to the environment at Four Mile Wash. Scintillometer surveys indicate that the tuff immediately below the lava is slightly more radioactive (35$40 \mu \mathrm{r} / \mathrm{hr}$ ) than the rhyolite at Four Mile Wash, suggesting that small quantities of U may have been trapped by the tuff.

Other important differences between the two areas include the unaltered state of the feldspars and the absence of carbonate lithic fragments within the tuff of Four Mile Wash. Presumably the lack of feldspar alteration indicates the absence of "hydrothermal" alteration at Four Mile Wash. Much of the uranium released by devitrification of the overlying rhyolite, probably moving as halogen complexes, could not be trapped within the tuff because of the lack of localizing carhnnate clasts. Minor opal-lined fractures and zeolite replacements may explain the slight excess radioactivity of the tuff of Four Mile Wash.

OTHER LOCALITIES - THE BLUE RIBBON LINEAMENT,

Shawe and stewart (1976) and Stewart et al. (1977) identified an east-trending belt of Tertiary magmatism and tectonism called the Pioche-Marysvale belt that extends across the southwestern part of Utah. It takes its name from the endpoints of the belt in Nevada and Utah. A prominent aeromagnetic high coincides with it and deposits of gold, silver, lead, zinc, fluorite, uranium and alunite occur along it. Rowley et al. (1978b) proposed that another more restricted belt, the Blue Ribbon lineament, can be identified as part of the Pioche-Marysvale belt. It is marked by volcanic centers, hotsprings and mineral deposits, including the Staats Mine and the Four Mile Wash area. In an effort to assess the role this feature may have played 
Table 4. Radioactivity of rock units from southwestern Utah.

\begin{tabular}{|c|c|c|}
\hline Location & Rock Type & Radioactivity $(\dot{\mu r} / \mathrm{hr})^{1}$ \\
\hline \multirow{2}{*}{$\begin{array}{l}\text { Four Mile Wash, } \\
\text { Wah Wah Mountains* }\end{array}$} & rhyolite lava & 40 \\
\hline & $\begin{array}{l}\text { unwelded tuff } \\
\text { (zeolites \& opal) }\end{array}$ & $35-40$ \\
\hline \multirow{2}{*}{$\begin{array}{l}\text { Stateline district, } \\
\text { White Rock Mountains* }\end{array}$} & rhyolite lavà & 50 \\
\hline & $\begin{array}{l}\text { unwelded tuff } \\
\text { (quartz \& Fe-Mn oxides) }\end{array}$ & 60 \\
\hline \multirow{2}{*}{$\begin{array}{l}\text { Cottonwood Wash, } \\
\text { Needle Range }(*)\end{array}$} & rhyolite lava & $40-50$ \\
\hline & $\begin{array}{l}\text { unwelded tuff } \\
\text { (clay \& mafic inclusions) }\end{array}$ & $35-40$ \\
\hline $\begin{array}{l}\text { Commissary Creek, } \\
\text { Needle Range }\end{array}$ & $\begin{array}{l}\text { welded rhyolitic } \\
\text { ash-flow tuff }\end{array}$ & $<30$ \\
\hline \multirow{2}{*}{$\begin{array}{l}\text { Cougar Spar Mine } \\
\text { areą, Nepd1,e Range }\end{array}$} & coarse-grained fluorite & $<10$ \\
\hline & Needles Range Formation & 20 \\
\hline \multirow{2}{*}{$\begin{array}{l}\text { The Tetons, Wah Wah } \\
\text { Mountains* }\end{array}$} & rhyolite lava & $40-60$ \\
\hline & unwelded tuff & 55 \\
\hline \multirow{4}{*}{$\begin{array}{l}\text { Broken Ridge, Wah } \\
\text { Wah Mountains* }\end{array}$} & spherulitic rhyolite lava & $40-50$ \\
\hline & lithophysal rhyolite lava & $70-80$ \\
\hline & $\begin{array}{l}\text { ùnwelded tuff (immediately } \\
\text { beneath lava-tuff contact) }\end{array}$ & $60-70$ \\
\hline & $\begin{array}{l}\text { unwelded tuff (far from } \\
\text { lava-tuff contact) }\end{array}$ & 50 \\
\hline $\begin{array}{l}\text { Dead Horse Reservoir, } \\
\text { Shauntie Hills }\end{array}$ & rhyolite dome or intrusion & $<30$ \\
\hline \multirow{2}{*}{$\begin{array}{l}\text { Thermo Hot Springs } \\
\text { Escalante Desert }\end{array}$} & rhyolite lava & $<30$ \\
\hline & sinter mounds & $24-26$ \\
\hline
\end{tabular}

*topaz-bearing rhyolite.

(*) lithophile element-rich, but no topaz reported.

1 determined in field with hand-held scintillometer. 
Table 5. Whole rock uranium and thorium content of volcanic :rocks from southwestern Utah

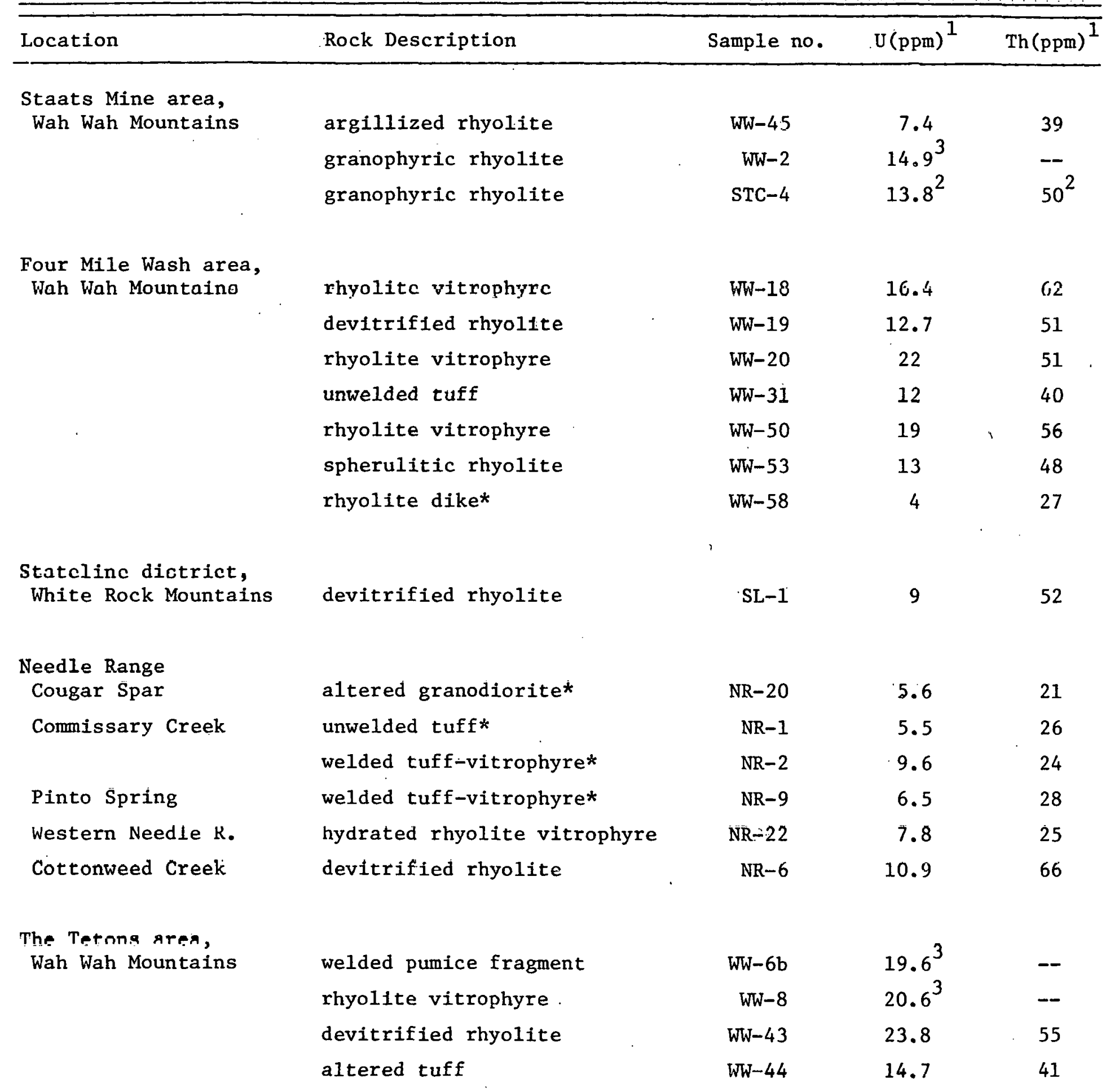


Table 5. continued

\begin{tabular}{|c|c|c|c|c|}
\hline socation & Rock Description. & Sample no. &.$U(p p m)^{1}$ & $\operatorname{Th}(p p m)^{1}$ \\
\hline \multirow[t]{7}{*}{$\begin{array}{l}\text { Broken Ridge, } \\
\text { Wah Wah Mountains }\end{array}$} & rhyolite vitrophyre & WW-9 & $20.2^{2}$ & $54^{2}$ \\
\hline & lithophysal rhyolite. & WW-10 & $13.8^{3}$ & -- \\
\hline & rhyolite vitrophyre & $W W-41$ & $21 \cdot 3^{2}$ & 64 \\
\hline & " " " & " " & 21.5 & 61 \\
\hline & rhyolite vitrophyre & WW-17 & 18.5 & 53 \\
\hline & unwelded tuff & WW-33 & 7.2 & 32 \\
\hline & spherulitic rhyolite & $W W-40$ & 17.1 & 67 \\
\hline $\begin{array}{l}\text { Dead Horse Reservoir, } \\
\text { Shauntie Hills }\end{array}$ & devitrified rhyolite* & $\mathrm{SH}-1$ & 5.6 & 26 \\
\hline \multirow[t]{2}{*}{$\begin{array}{c}\text { Thermo Hot Springs, } \\
\text { Escalante Desert }\end{array}$} & sinter* & $\mathrm{SH}-2$ & 32.9 & 5 \\
\hline & devitrified rhyolite* & $\mathrm{SH}-3$ & 7.5 & 20 \\
\hline \multicolumn{5}{|l|}{ ũhers } \\
\hline \multirow[t]{3}{*}{ Wah Wah Mountains } & tuff of Pine Grove* & WW- 56 & 7.4 & 21 \\
\hline & dike near Pine Grove* & $W W-59$ & 12.0 & 18 \\
\hline & beryl-bearing rhyolite & $W W-27$ & 12.3 & 44 \\
\hline . & diorite* & $W W-29$ & 3.3 & 11 \\
\hline
\end{tabular}

1 determined by gamma ray spectroscopy

2 determincd by instrumental neutron activation analysis

3 determined by delayed neutron analysis

* unrelated to lithophile element enriched rhyolites 
in uranium mineralization, several localities along its western reaches within Utah's Great Basin were examined. These included localities where known uranium and fluorine mineralization occur and exposures of possible topaz-bearing rhyolites. The geology of each area is briefly described in the following sections.

\section{Stateline District, White Rock Mountains, Utah and Nevada}

Along the westward projection of the Blue Ribbon lineament at the Utah-Nevada border, lies an area with Miocene rhyolites not mentinned by Rowley et al. (1978b). An older $\left(>21 \mathrm{~m} \cdot \mathrm{y}_{\bullet}\right)$ series of rhyodacitic composition volcanic and intrusive rocks are the hosts for epithermal Au-Ag veins in the Stateline mining district (Keith, 1980). Topaz- and fluorite-bearing rhyolit.es nverlie them in the Johnny Canyon ared of the White Rock Mountains (Fig. 1). Tuffaceous units underlie the rhyolitic lavas and are probably cogenetic. Locally the tuffs have a slightly higher radioactivity than the lavas as measured with a scintillometer ( $60 \mu \mathrm{r} / \mathrm{hr}$ versus $50 \mu \mathrm{r} / \mathrm{hr} ; \mathrm{Table} 4)$. Fractures within the lavas, laced with quartz crystals up to $3 \mathrm{~cm}$ long and Fe-Mn oxides, also show approximately the same level of radioactivity as the tuffs, Keith (1980) suggests that these small uranium anomalies were derived by epi thermal leaching of topaz rhyolites. Convection was driven by younger rhyolitic intrusions and deposited an association of Fe-Mn oxides or clays within the fractures and tuffs.

The rhyolite in Johnny Canyon is pink, crystal-poor and generally lithophysal. The chemistry of one sample is presented in Table 3, analysis 6. The rhyolite is similar to those in the Wah Wah Mountains, with low $\mathrm{TiO}_{2}(0.05 \mathrm{wt} \%$ ) and fairly high MnO (0.08 wt \%). Its uranium content ( 9 ppm-grs) is low compared with other topaz rhyolites, possibly as a result of devitrification and formation of lithophysae or leaching, but its high content of $\mathrm{Th}, \mathrm{Be}$, and $\mathrm{Li}$ suggest that it is part of the same lithophile-rich series as those in the Wah Wah Mountains.

\section{Cottonwood Wash, Needle Range}

Several outcrops of rhyolitic lavas and tuffs occur in the southernmost Needle 
Range to the east of the White Rock Mountains (Fig. 1). Two hills of rhyolite lava occur on the east side of the range near Cottonwood Wash, in T.30 S.,. R.18. W. sec. 22 and 23 and cover about $2 \mathrm{~km}^{2}$. The lava is porphyritic with obvious phenocrysts of quartz, feldspar and biotite. A modal analysis appears in Table 2. Only in a few exposures is the rock vuggy--normally it is a dense pink lava with little flow banding. No topaz was found. The southernmost hill, in section 22, is underlain by a "lithic"-rich tuff that has been partially altered to clay minerals. The inclusions are almost entirely extremely fine-grained, red volcanic rocks. Although exposure of the tuff is poor, some of the inclusions appear to have been molten at the time of incorporation into the rhyolitic tuff. One inclusion has a fine-grained margin (interpreted as a quench texture) with a more coarsely crystalline interior. This texture and the incorporation of inclusions in the tuff may be the result of mixing of two magmas-a hotter "mafic" magma injected into a crystallizing rhyolite and may demonstrate the bimodal character of the volcanism. No chemical analyses of these inclusions were performed because they are extensively altered. There are no exposures of rocks similar to the inclusions nearby. This situation appears to be similar tc the inferred eruption of the Spor Mountain magma chamber. The rhyolite there also has mafic inclusions that may be melt blebs (M.F. Sheridan, personal communication, 1979).

Unlike the other rhyolitic complexes studied, the tuff at Cottonwood Wash is not systematically more radioactive than the lava. Scintillation counter surveys show the rhyolite counts 40-50 $\mu \mathrm{r} / \mathrm{hr}$ and the tuff 35-40 $\mu \mathrm{r} / \mathrm{hr}$ (Table 4).

Chemically the rhyolite is similar to other F-rich rhyolites (Table 1, analysis 7). It is low in $\mathrm{TiO}_{2}$ and high in $\mathrm{SiO}_{2}$, alkalies and MnO. Its uranium and thorium contents are similar to those of other devitrified samples of topaz rhyolite ('lable 5). However, Grant and Best (1979) have included the rhyolite of Cottonwood Wash in their rhyolite of Pinto Spring (discussed in the next section) which is a rhyolitic ash-flow tuff with much lower Th values ( 26 vs $66 \mathrm{ppm}$ ). The two rhyolites are probably unrelated. 
Commissary Creek Area, Needle Range

Several outcrops of a tilted section of a rhyolitic ash-flow tuff occur along Commissary Creek in R.18.W., T.30 S., Pinto Spring quadrangle. The tuff is densely welded near its base and contains abundant broken phenocrysts of sanidine and plagioclase. Quartz and biotite occur in smaller amounts (Table 2). This rhyolite is chemically distinct from F-rich rhyolites in that $\mathrm{TiO}_{2}$ is greater than 0.1 wt\% and $\mathrm{K}_{2} \mathrm{O}$ is greater than $5 \mathrm{wt. \%}$ (Tuble 3, analysis 8 ). Generally topaz rhyolites have values somewhat lower than this. As noted above Th is much lower than in topaz rhyolitea and $U$ is only about 8 ppm (grs) even in glassy samples. The emplacement of the magma as a thick ash flow is atypical of the dome-related lavas associated with topaz rhyolites. The rhyolitic ash flow at Commissary Creek is indistinguishable from the rhyolite of Pinto Springs at its type locality about $6 \mathrm{~km}$ south (Grant and Best, 1979), Table 1, analysis 9, and is probably older than the topaz rhyolites of the region sincc it has bèen tilted by faulting.

No uranium anomalies were found; a scintillation counter survey revealed counts of less than $30 \mu \mathrm{r} / \mathrm{hr}$, slightly less than for normal topaz-bearing lavas (Table 4).

\section{Cougar Spar Mine Area, Needle Range}

The southern part of the Needle Range hosts several fluorite deposits; none of them are uraniferous. These deposits are presumably associated with the older caldera magmatism and are contemporaneous with chalcophile mineralization in the Needle Range and elsewhere. Most of the fluorite deposits in the Needle Range arp spatially associated with a granodiorite intrusion near the Cougar Spar Mine (Fig. 1), the main producer of fluorite in the area. The fluorite is coarse-grained, generally green or pale purple; and occurs in veins or within breccia along faults cutting intermedlate composition ash flows and lavas. This portion of the Needle Range is within the Indian Peak cauldron which is the source of at least one of the units of the $29 \pm 1 \mathrm{~m} . \mathrm{y}$ old Needles Range Formation (Best et al., 1979; Grant and Best, 1979). The intrusion is mapped as the intrusive phase of the Wah Wah Springs Tuff. The fluorite deposits are 
probably the result of the waning stages of igneous activity, possibly related to resurgence of the caldera. In any case, the fluorite mineralization is apparently unrelated to rhyolitic volcanism and is non-uraniferous (Table 4 and 5). Thurston and others (1954) and Bullock (1976) give detailed descriptions of several deposits, including the JB Mine, Utah Mine, Cougar Spar Mine and the Noonday Mine.

The Tetons, Wah Wah Mountains

In addition to the Staats Mine and the Four Mile Wash areas there are several other topaz-bearing rhyolites along the trend of the Blue Ribbon lineament. Several low hills $2-3 \mathrm{~km}$ south and southeast of the rhyolite of the Staats Mine are underlain by topaz rhyolite. The most prominent hills, in T.30S. R.18W., are called The Tetons. Modal analyses of these lavas are presented in Table 2. The rhyolite is weakly porphyritic with small phenocrysts of quartz and feldspar in a devitrified or glassy groundmass. Topaz, fluorite and garnet occur in lithophysae near the crest of the Tetons. The rhyolite lava is underlain by a partially fused tuff (terminology of Christiansen and Lipman, 1966). Deformed pumice lapilli are black and vitreous and set in a matrix of brown devitrified glass. The Tetons are probably the eruptive renter for the rhyolite lavas nearby.

The whole rock uranium content of a vitrophyre from these lavas is 1.5 times that of the Staats rhyolite (20-21 ppm; Table 5) a further indication that the mineralized rhyolite was depleted to form the uranium deposits. No uranium deposits are known from The Tetons area. The rhyolite overlies older ash flows of the Escalante Desert Formation and few carbonate clasts occur within the tuff. Scintillometer surveys show that the tuff is slightly more radioactive than the overlying lava (55 vs. 40-60 $\mu \mathrm{r} / \mathrm{hr}$; Table 4).

The rhyolites are chemically similar to other topaz rhyolites ('rable 1, analyses $10,11,12)$. However sample WW-6b, a pumice separated from the basal tuff, contains an anomalous $\mathrm{TiO}_{2}$ content $(0.16 \mathrm{wt} . \%)$ and high $\mathrm{SiO}_{2}$ content (78\%). 


\section{Broken Ridge, Wah Wah Mountains}

A large mass of coalescing topaz rhyolite tuffs, lava flows and domes forms series of hills south and west of the Four Mile Wash area. The volcanics, centered around Broken Ridge, cover an area of approximately $40 \mathrm{~km}^{2}$ and represent the eruptive products of several vents. Although no samples have been dated, they are probably Miocene in age based on local stratigraphic relations (Best, 1979). They unconformably overlie faulted and tilted units of the Needles Range Formation.

Modal analyses of some samples are presented in Table 2. The rhyolites are phenocryst poor ( $<10 \%$ by volume) and have little or no biotite. Topaz crystals, some severa1 centineters long, are common in lithophysae. The 1ithophysae are extremely delicate; some have 10 or more concentric shells. Other 1ithophysal minerals include quartz, sanidine, fluorite and hematite. Opal, with fluorite encrustations, occurs along some fractures.

The lavas are chemically similar to those exposed at The Tetons (Table 1, analyses 13-16). The fluorine content of a glassy sample (WW-9) is $0.50 \mathrm{wt} \%$. Bubidium, cesium, lithium and other lithophile elements are high as well, (Christiansen et al., this report). The whole rock uranium content of the glasses is about $20 \mathrm{ppm}$ (INAA and grs). A lithophysal sample (WW-10) collected from the same outcrop as one of the vitrophyres has a uranium content of only $14 \mathrm{ppm}$ (grs) consistent with the observation elsewhere that devitriflcation (including the formation of lithophysae) releases uranium. However from scintillometer surveys (Table 4) lithophysal zones appear to be more radioactive (70-80 $\mathrm{\mu r} / \mathrm{hr})$ than vitrophyres or rhyolites with spherulitic devitrification (40-50 $\mu r / h r)$. This contradictory result" may be caused by the deposition of uraniferous opal or fluorite in the porous lithophysal zones that were not sampled for the fresh rock analyses. Yorous pyroclastic surg deposits immedfately beneath the rhyolite lavas are also more radioactive $(60-70 \mu \mathrm{r} / \mathrm{hr})$, while those several meters lower in the section gave counts of $50 \mu \mathrm{r} / \mathrm{hr}$. The radioactive anomalies immedately beneath lava are common and may be the result of trapping of uranium released during devitrification of the overlying lava. 


\section{Dead Horse Reservoir, Shauntie Hills}

Erickson and Dasch (1963) mapped two small plugs of rhyolite in the southern Shauntie Hills. One, near Dead Horse Reservoir, yielded a K-Ar date on sanidine of $11.6 \pm 0.4 \mathrm{~m} . \mathrm{y}$. (Rowley et al., 1978a). The rhyolite is porphyritic and mostly devitrified, although some intensely hydrated glass is present. Phenocrysts include quartz, feldspar and biotite (Table 2). No topaz occurs in the groundmass.

The chemical composition of this younger rhyolite is slightly different from the topaz-bearing group (Table 1). Although it is a high-silica rhyolite, its alumina content is only about $11 \%$ - less than that of any of the other rhyolites analyzed from this region. Iron and potassium are high relative to topaz rhyolites and it has a very high $\mathrm{TiO}_{2}$ content $(>0.20 \mathrm{wt. \%})$. Its trace element chemistry is also distinct: fluorine <0.1 wt.\%, 6 ppm uranium (grs) and 26 ppm thorium (grs). These characteristics demonstrate its dissimilarity to the older topaz rhyolites.

The plug is only about $0.5 \mathrm{~km}$ in diameter and no cogenetic tuff occurs beneath

$\because$ it. The body may not have vented to the surface, but contact relations with the surrounding intermediate volcanics, mapped by Rowley (1978) as the volcanic rocks of Shauntie Hi1.1s, are not clear. Most of the older volcanics are propylitically altered; some silification is present near the plug.

Scintillometer readings over the rhyolite did not exceed $30 \mu \mathrm{r} / \mathrm{hr}$ (Table 4), considerably lower than those of the older topaz rhyolite of the Staats Mine and others in the Needle and Wah Wah Ranges. Alteration zones within the older volcanics show no sign of anomalous uranium content.

\section{Thermo Hot Springs}

About $9 \mathrm{~km}$ southeast of Dead Horse Reservoir another small rhyolite body protrudes above the alluvium of the Escalante Desert. It has been called the rhyolite of Thermo Hot Springs (Rowley et al., 1978b), after the springs located $3.5 \mathrm{~km} \mathrm{to}$ the west. It has a $\mathrm{K}-\mathrm{Ar}$ date of $10.3 \pm 0.4 \mathrm{~m} \cdot \mathrm{y}$. (Rowley et al., 197.8b), younger 
than the probable age of the other rhyolites described here. The rhyolite is crystal-poor, with only about $2 \%$ by volume of quartz, feldspars and hornblende. A spherulitic vitrophyre crops out on the west side. As at the rhyolite of Dead Horse Reservoir, no tuff could be found beneath it.

The devitrified sample analysed (Table 3, analysis 18) is distinctive from topaz rhyolites. It is lower in $\mathrm{SiO}_{2}$ and $\mathrm{Al}_{2} \mathrm{O}_{3}$ and distinctly higher in iron and calcium than topaz-bearing rocks. Although its fluorine content is near that of some topaz rhyolites (1400 ppm vs. $1000-10,000 \mathrm{ppm})$ both its U (7 ppm - grs) and Th (20 ppm - grs) contents are unlike those of the topaz rhyolites. A scintlllometer survey revealed no readings greater than $30 \mu \mathrm{r} / \mathrm{hr}$ (Table 4 ).

A scintillometer survey over the sinter mounds and pools at Thermo Hot Springs revealed no anomalies (Table 4). Radioactivity ranged from 24-26 $\mu \mathrm{r} / \mathrm{hr}$. The springs are aligned on a $3 \mathrm{~m}$ high, north-trending ridge composed of sinter and alluvium and are probably unrelated to the volcanism that produced the rhyolites.

\section{SUMMARY AND CONCLUSIONS}

Several small uranium deposits occur near fluorine- and uranium-rich rhyolitic volcanic rocks in southwestern Utah. Characteristically the deposits occur along the contacts of rhyolite intruded into carbonate rocks (i.e. the Stats Mine) or in 1ithic-rich pyroclastic deposits beneath rhyolite domes and lava flows (i.e. the Holly Cla1ni and small concentrations under most other domes). Presumably U (and F) are reledsed frum the volcanic rocks by devitrification or leaching and then locally reconcentrated in favorable environments. The uranium occurrences are related to a mid-Tertiary episode of bimodal, trachyandesite and topaz rhyolite magmatism that is distincl frum earlier caldera-related, calc-alkalic volcanism. The intrusion and solidification of Oligocene stocks (i.e. the Cougar Spar area) resulted in hydrothermal fluorite deposits that have no appreciable uranium. Younger rhyolite domes and flows in southwestern Utah, such as those at Dead Horse Reservoir or Thermo Hot Springs, are not extremely enriched in lithophile elements and uranium deposits 
associated with them are unlikely.

The relationship of the Blue Ribbon lineament to uranium mineralization seems to have been secondary. Although rhyolitic volcanism was common along its length, it appears that a specific magma composition and special conditions for emplacement and cooling were necessary for uranium mineralization. The Miocene age of mineralized rhyolites, their fluorine - and uranium-rich character, the emplacement of carbonaterich pyroclastic deposits beneath them (or their intrusion into carbonate rocks) and the subsequent passage of fluids through porous breccias or tuffs are the principle features which these small uranium deposits have in common (cf. Burt and Sheridan, 1980; this report). Even topaz rhyolites, with high concentrations of $U$ and $F$, that have not experienced these special emplacement and cooling histories are not associated with economic uranium deposits.

Topaz rhyolites, like those exposed across the southern part of the Needle Range and Wah Wah Mountains, may be good source rocks for sedimentary uranium deposits because of their high magmatic concentrations of uranium. The average $U$ content of nine gadssy samples of topaz rhyolite from southwestern Utah is 19.9 ppm. The average $U$ content of nine devitrified samples collected from the same units is 14.2 ppm (13.4 ppm if two argillically altered samples are included); the average $U$ content of three tuff samples is $11.3 \mathrm{ppm}$. Topaz rhyolite lavas and tuffs cover at least $75 \mathrm{~km}^{2}$ in the region so a reasonable estimate of their volume may be around $25 \mathrm{~km}^{3}$. If the entire volume lost $5.7 \mathrm{ppm}(19.9-14.2 \mathrm{ppm})$, approximately $3.7 \times 10^{8} \mathrm{~kg}$ of uranium would have been released (assuming a rock density of $2.6 \mathrm{gm} / \mathrm{cm}^{3}$ ). Certalnly, some of this uranium escaped into the atmosphere during early high-temperature devitrification of glass but some may have entered the hydrologic system by leaching or during weathering. A portion of this may have been deposited in reducing environments within the valley-fill sediments of the Escalante Desert to the south or Pine Valley to the north between the Wah Wah and Needle Ranges. Cunningham et al. (1980) have discussed the possibility of a similar situation near the Marysvale volcanic field. 
Table 6. Descriptions and locations of samples

\begin{tabular}{|c|c|c|}
\hline Sample no. & Description & Locațion \\
\hline$W W-2$ & devitrified rhyolite, feldpars altered & NW $\frac{1}{4}$ sec. 31, T. 29S., R. $15 \mathrm{~W}$. \\
\hline$W \cdot J-6 b$ & welded pumice fragment & NE $\frac{1}{4} \mathrm{sec} .7$, T. 30S., R. $15 \mathrm{~W}$. \\
\hline WW-7 & devitrified rhyolite & SW $\frac{1}{4} \sec .12$, T. $306,$, R. $16 \mathrm{~W}$. \\
\hline WW-8 & rhyolite vitrophyre & SE $\frac{1}{4} \mathrm{sec} .12$, T. 30S., R. $16 \mathrm{~W}$. \\
\hline$W W-9$ & rhyolite vitropliyre & SW $\frac{1}{4}$ sec. 2, T. $32 S_{.}, R_{0} 16 \mathrm{~W}$. \\
\hline WW-10 & lithophysal shyolite & SW $\frac{1}{2}$ sec. $2, T .32 \mathrm{~S} ., \mathrm{R}, 16 \mathrm{~W}$. \\
\hline WW-11 & lithophysal rhyolite & $\mathrm{NE} \frac{1}{4} \mathrm{sec} \cdot 33, \mathrm{~T} \cdot 31 \mathrm{~s}, \mathrm{R}, 16 \mathrm{~W}$. \\
\hline WW-17 & rhyolite vitrophyre & SW $1 \frac{1}{4}$ sec. $35, T, 31 S .$, R. 16W. \\
\hline WW-18 & devitrified rhyolile & NW $\frac{1}{4}$ scc. 13, T. $31 \mathrm{~s} .$, R. $16 \mathrm{~W}$. \\
\hline WW-19 & devitrified rhyolite & NE $\frac{1}{4}$ sec. 13, T. $31 \mathrm{~S} .$, R. $16 \mathrm{~W}$. \\
\hline WW-20 & rhyolite vitrophyre & $\mathrm{NE} \frac{1}{4} \mathrm{sec} .19, \mathrm{~T} .31 \mathrm{~S} .$, R. $15 \mathrm{~W}$. \\
\hline$W W-27$ & bery1-bearing rhyolite & NW $\frac{1}{4}$ sec. 29, T. $29 \mathrm{~S} .$, R. $14 \mathrm{~W}$. \\
\hline$W W-29$ & diorite & Wah Wah Pass \\
\hline$W W-31$ & unwelded tuff & SW $\frac{1}{4}$ sec. $7, T \cdot 31 \mathrm{~S} .$, R. $15 \mathrm{~W}$. \\
\hline WW-33 & unwelded tuff & SW $\frac{1}{4} \mathrm{sec} .35$, T. $31 \mathrm{~S} .$, R. $16 \mathrm{~W}$. \\
\hline$W W-40$ & spherulitic rhyolite & sec. 2 , T. $32 \mathrm{~S} ., \mathrm{R}, 16 \mathrm{~W}$. \\
\hline$W W-41$ & rhyolite vitrophyre & sec, $2, T, 32 \mathrm{~S},, \mathrm{R}, 16 \mathrm{~W}$ \\
\hline$W W-43$ & devitrified rhyolito & $3 E \frac{1}{1 / 4}$ sec. 16, T. $305 .$, R. $16 \mathrm{~W}$. \\
\hline$W W-44$ & unwelded tuff, argillized & SW $\frac{1}{4}$ sec. 15, T. 30S, R. RW. \\
\hline WW -45 & argillized rhyolite & NW $\frac{1}{4} \sec .31, T .29 \mathrm{~S}$, R. $15 \mathrm{~W}$. \\
\hline WW- 50 & rhyolite vitrophyre & SW $\frac{1}{4}$ sec. 13, T. 31 S., R. $16 W$ \\
\hline WW-53 & spherulitic rhyolite & $\mathrm{NW} \frac{1}{4} \mathrm{sec}, 18, \mathrm{~T}, 31 \mathrm{~s}, \mathrm{R}, 15 \mathrm{~W}$ \\
\hline WW-54 & green rhyolite vitrophyre & $" 1 "$ \\
\hline WW-55 & 1ithophysal rhyolite & $"$ \\
\hline$W W-56$ & fused tuff of Pine Grove & NE $\frac{1}{4}$ sec. $36, T .28 \mathrm{~S}, R_{0} 15 \mathrm{~W}$ \\
\hline$W i v-58$ & rhyolite dike & NE $\frac{1}{4}$ sec. 7, T. 31S., R. $15 \mathrm{~W}$. \\
\hline
\end{tabular}


able 6 . continued

\begin{tabular}{cll}
\hline Sample no. & Description & Location \\
\hline STC-4 & devitrified rhyolite, feldspars altered & NW $\frac{1}{4}$ sec. 6, T. 30S., R. 15W. \\
SH-1 & devitrified rhyolite & S $\frac{1}{2}$ sec. 31, T. 29 S., R. 12 W. \\
SH-2 & devitrified rhyolite & NE $\frac{1}{4}$ sec. 26, T. 30 S., R. 12 W. \\
SH-3 & devitrified rhyolite & " \\
SL-1 & devitrified rhyolite & N $\frac{1}{2}$ sec. 35, T. 32S., R. 20W. \\
NR-1 & unwelded tuff & W $\frac{1}{2}$ sec. 12, T. 30S., R. $18 \mathrm{~W}$. \\
NR-2 & welded tuff, vitrophyre & W $\frac{1}{2}$ sec. 12, T. 30S., R. 18W. \\
NR-6 & devitrified rhyolite & SE $\frac{1}{4}$ sec. 22, T. 30S., R. 18W. \\
NR-9 & welded tuff, vitrophyre & NE $\frac{1}{4}$ sec. 2, T. 31S., R. 18W. \\
NR-20 & altered granodiorite & NE $\frac{1}{4}$ sec. 9, T. 30S., R. 18W. \\
NR-22 & green rhyolite vitrophyre & SW $\frac{1}{4}$ sec. 5, T. 30S., R. 18W.
\end{tabular}


RECOMMENDATIONS FOR FURTHER STUDY

The results of this study suggest that detailed study of the uranium and fluorite deposits near the Staats Mine could help to answer several questions regarding volcanogenic uranium deposits. The mineralogic sites of uranium in tuffs and lavas are extremely important for determing the methods of uranium release and concentration in a rhyolite dome complex. Using autoradiography these sites could be determined at the scale of a thin section, in vitrophyres, devitrified lavas (spherulitic, lithophysal and granophyric textures need to be examined) and in fresh and mineralized tuffs or lavas. Further studies using the microscope or electron microprobe could characterize the nature of these sites and provide much needed data on the release and concentration of uranium. Similar studies of samples across tuff-lava contacts could test the observation that the tuffs immediately below rhyolite lavas are slightly more radioactive. These studies could be amplified by analytical determination of mobile, lithophile element concentrations and their correlation with uranium content in glassy, devitrified and altered rocks. The role of carbonate clasts (or intermediate volcanics) as localizers of mineralization could also be studied by these techniques.

The alteration mineralogy of the tuff at the Holly Claim and the rhynlite along the intrusive contact could place some limits on the nature of the hydrothermal system that modifled elemental concentrations. The temperature and, possibly, the composition of the fluid could be limited by the mineral assemblage that resulted or by analyzing fluid inclusions.

On an even larger scale shallow drilling through the topaz rhyolite near the Staats Mine could determine if more uranium-mineralized tuff underlies the extrusive portion of the complex and would reveal the nature of mineraliztion at the lava-tuff and tuff-sediment contacts. 
Acknowledgements

I thank M.F. Sheridan and D.M. Burt for assistance and discussion regarding this project and the manuscript. I am also indebted to Myron Best for indroducing me to the geology of the area in 1976 and for much helpful advice during the course of this study. Discussions with Jeff Keith, Jim Bikun, Brian Correa and Barbara Murphy helped me to formulate some of the ideas presented here. 


\section{REFERENCES CITED}

Armstrong, R.L., 1970, Geochronology of Tertiary igneous rocks, eastern Basin and Range Province, western Utah, eastern Nevada, and vicinity, U.S.A.:

Geochimica et Cosmochimica Acta, v. 34, p. 203-232.

Bailey, J.C., 1977, Fluorine in granitic rocks and melts: A review: Chemical Geology, v. 19, p. 1-42.

Best, M.G., 1979, Geologic map of Tertiary volcanic rocks in the Mountain Spring Peak quadrangel, Iron County, Utah: U.S. Geological Survey Open-File Report 79-1610.

Best, M.G., and Hambin, W.K., 1978, Origin of the northern Basin and Range province: Implications from the geology of its eastern boundary, in Smith, R.B., and Eaton, G.P., Cenozoic tectonics and regional geophysics of the western Cordillera, Geological Society of America Memoir 152, p. 313-340.

Best, M.G., and Keith, J.D., 1979, Geologic map of Tertiary volcanic rocks in the Observational Knoll and The Tetons quadrangles, Beaver and Iron Counties, Utah: U.S. Geological Survey Open-File Report 79-1612.

Best, M.G., Grant, S.k., and Holmes, R. D., 1979, Geologic map of the Miners Cabin Wash and Buckhorn Spring quadrangles, Beaver County, Utah: U.S. Geological Survey Open-File Report 79-1612.

Best, M.G., Shuey, R.T., Caskey, C.F., and Grant, S.K., 1973, Stratigraphic relations of members of the Needles Range Formation at type localities in southwestern Utah: Geological Society of America Bulletin, v. 84, p. 3269-3278.

Bullock, K.C., 1976, Fluorite occurrences in Utah: Utah Geological and Minerad Suivey bulletin 110, $89 \mathrm{p}$.

Burt, D.M. and Sheridan, M.F., 1980, A model for the formation of uranium/1ithophile element deposits in fluorine-enriched volcanic rocks: to appear in American Association of Petroleum Geologists special publication, Iranium in Volcanic Rocks.

Bushman, A.V., 1978, Pre-Needles Range silicic volcanism, Tunnel Spring Tuff (Oligocene), west-central Utah: Brigham Young University Geology Studies, v. 20 , p. 159-190.

Campbel1, D.R., 1978, Strac1graphy of pre-Needles Range Formation ash-flow tuffe in the northern Needle Range and southern Wah Wah Mountains, Beaver County, Utah: Brigham Young University Geology Studies, v. 25, p. 31-46.

Christiansen, R.L. and Lipman, P.W., 1966, Emplacement and thermal history of a rhyolite lava flow near Fortymile Canyon, southern Nevada, Geological Soclety of American Bulletin, v. 77, p. 671-689.

Conrad, O.G., 1969, Tertiary volcanic rocks of Needles Range, western Utah: Utah Geological and Mineral Survëy', Special. Studies 29, 28 p. 
Cook, E.F., 1965, Stratigraphy of Tertiary volcanic rocks in eastern Nevada: Nevada Bureau of Mines Report 11, 61 p.

Cunningham, C.G., Steven, T.A., and Rasmussen, J.D., 1980, Volcanogenic uranium deposits associated with the Mount Belknap Volcanics, Marysvale volcanic field, west-central Utah: American Association of Petroleum Geologists, southwest section 1980, Abstracts, p. 22 .

Erickson, M.P. and Dash, E.J., 1963, Geology and hydrothermal alteration in northwestern Black Mountains and southern Shauntie Hills, Beaver and Iron Counties, Utah: Utah Geological and Mineral Survey, Special Studies 6, 32 p.

Fleck, R.J., Anderson, F.F., and Rowley, P.D., 1975, Chronology of mid-Tertiary volcanism in High Plateaus region of Utah: Geologfcal Society of America Special Paper 160, p. 53-61.

Grant, S.K. and Best, M.G., 1979, Geologic map of the Pinto Spring and part of the Atchinson Creek Quadrangles, Beaver and I.ron Counties, Utah: U.S. Geological Survey Open-File Report 79-1656.

Heiken, G., 1978, Plinian-type eruptions in the Medicine Lake Highland, California, and the nature of the underlying magma: Journal of Volcanology and Geothermal Research, v. 4, p. 375-402:

Keith, J.D., 1980, Miocene porphyry intrusions, volcanism and mineralization, southwestern Utah and eastern Nevada: M.S. thesis, University of Wisconsin, Madison, $166 \mathrm{p}$.

Lemmon, D.M., Silberman, M.L., and Kistler, R.W., 1973, Some K-Ar ages of extrusive and intrusive rocks of the San Francisco and Wah Wah Mountains, Utah: Utah Geological Association Publication 3, p. 23-26.

Lindsey, D.A., 1979, Preliminary report on Tertiary volcanism and uranium mineralization in the Thomas Range and Drum Mountains, Juab County, Utah: U.S. Geological Survey Open-File Report 79-1076.

Lindsey, D.A. and Osmonson, L.M., 1978, Mineral potential of altered rocks near Blawn Mountain, Wah Wah Range, Utah: U.S. Geological Survey Open-File Report $78-114$.

Mackin, J.H., 1960, Structural significance of Tertiary volcanic rocks in southwestern Utah: American Journal of Science, v. 258, p. 81-131.

Miller, G.M., 1966, Structure and stratigraphy of southern part of Wah Wah Mountains, southwest Utah: American Association of Petroleum Geologists Bulletin, v. 50, p. $858-900$.

Rowley, P.D., 1978, Geologic map of the Thermo 15-minute quadrange1, Beaver and Iron Counties, Utah: U.S. Geological Survey Quadrangle Map 1493.

Rowley, P.D., Anderson, J.J., Williams, P.L., and Fleck, R.J., 1978a, Age of structural differentiation between Colorado Plateaus and Basin and Range provinces in southwestern Utah: Geology, v. 6, p. 51-55.

Rowley, P.D., Lipman, P.W., Mehnert, H.H., Lindsey, D.A. and Anderson, J.J., 1978.b, Blue Ribbon lineament, an east trending structural zone within the Pioche mineral belt of southwestern Utah and eastern Nevada: Journal of Research U.S. Geological Survey, v. 6, p. 175-192. 
Rowley, P.D., Steven, T.A., Anderson, F.F., and Cunningham, C.G., 1979, Cenozoic stratigraphic and structural framework of southwestern Utah: U.S. Geologic Survey Professional Paper 1149, 22 p.

Shawe, D.R. and Stewart,.J.H., 1976, Ore deposits as related to tectonics and magmatism, Nevada and Utah: Society of Mining Engineers, AIME, Transactions, v. 260 , p. 225 231.

Sheridan, M.F. and Updike, R.G., 1975, Sugarloaf Mountain Tephra - A Pleistocene rhyolitic deposit of base-surge origin in northern Arizona: Geological Society of America Bulletin, v. 86, p. 571-581.

Shuey, R.T., Caskey, C.F., and Best, M.G., 1976, Distribtion and paleomagnetism of the Needles Range Formation, Utah and Nevada: American Journal of Science, $v$. 276 , p. 954-968.

Stewart, J.H., 1972, In1tlal deposits in the Cordilleran Geosyncline: Evidence of a Late Precambrian $(<850 \mathrm{~m} . \mathrm{y}$.$) continental separation: Geological Society of$ America Bulletin, v. 83, p. 1345-1360.

Stewart, J.H.,.Moore, W.J., and Zietz, I., 1977, East-west patterns of Cenozoic igneous rocks, aeromagnetic anomalies, and mineral deposits, Nevada and Utah: Geologica1 Society of America Bulletin, v. 88, p. 67-77.

Stormer, J.C., 1975, A practical two-feldspar geothermometer: American Mineralogist, v. 60 , p. $667-674$.

Thurston, W.R., Staatz, M.H., Cox, D.C., and others, 1954, Fluorspar of Utah: U.S. Geological Survey Bulletin 1005, 53 p.

Turley, C.H., Nash, W.P., and Brown, W.P., 1979, Petrology and geochronology of late Tertiary and Quaternary volcanic rocks in the eastern margin of the Basin and Tange Province, Utah: U.S. Department of Energy, Contract EY-76-S-07-1601, Final Repuit, UnIversicy of Ũah, v. $1,18 \mathrm{p}$.

Whelan, J.A., 1965, Hydrothermal alteration and mineralization, Staats Mine and Blawn Mountain areas, central Wah Wah Range, Beaver County, Utah: Utah Geological and Mineralogical Survey Special studies no. 12, 35 p.

Wender, L.E., and Nash, W.P., 1979, Petrology of Oligocene and early Miocene calcalkallc volcanism in the Marysvale area, Utah: Geological Society of America Bulletin, pt. 2, v. 90, p. 37-79.

Williams, P.L., 1967, Strat1graphỹ and petrography of the Quichipa Group, southwestern Utah and southeastern Nevada: Ph.D. thesis, University of Washington, Seattle, 139 p.

Zielinski, R.A., Lipman, P.W., and Millard, H.T., 1977, Minor element ahundanres in obsidian, perlite and lefsite of calc-alkalic rhyolites: American Mineralogist, v. 62 , p. 426-437. 
Chapter VII

FLUORINE AND LI'IHOPHILE ELEMENT MINERALIZATION

IN THE BLACK RANGE AND SIERRA CUCHILLO,

NEW MEXICO

by

Brian P. Correa 
The Taylor Creek Rhyolite (age $24.0 \mathrm{~m} . \mathrm{y}$. ) is a topaz rhyolite which contains cassiterite veins and is not associated with known $U$, Be, or $F$ muneralization. This rhyolite may be the ring fracture volcanics of one of two large cauldrons that are the surface expression of an underlying batholith $125 \mathrm{~km}$ in diameter. The rhyolite is composed of thick piles of flow-layered and flowbanded lava (domes) that are usually devitrified and vapor-phase altered. The rhyolite is crystal-rich $(20-40 \%)$ and contains mostly sanidine and quartz with minor biotite, hornblende, plagioclase, titanite, ferroaugite, titaniferous magnetite and zircon. Chemically, the Taylor Creek Rhyolite has high $\mathrm{SiO}_{2}(78 \%)$ and $\mathrm{K}_{2} \mathrm{O}$ and low $\mathrm{Al}_{2} \mathrm{O}_{3}, \mathrm{MnO}, \mathrm{MgO}$, and $\mathrm{CaO}$. The rhyolite contains $0.4 \% \mathrm{~F}, 10 \mathrm{ppm}$ $\mathrm{U}, 10 \mathrm{ppm} \mathrm{Be}, 20 \mathrm{ppm} \mathrm{Li}, 25 \mathrm{ppm} \mathrm{Sn}, 350 \mathrm{ppm} \mathrm{Rb}, 550 \mathrm{ppm} \mathrm{Zr}, 5 \mathrm{ppm} \mathrm{Sr}$, and low contents of $\mathrm{Sc}, \mathrm{Cr}, \mathrm{Co}, \mathrm{Ba}$, and $\mathrm{Eu}$. Heavy rare-earth element abundances are high, and the rare-earth element pattern is flat $(\mathrm{La} / \mathrm{Lu}=2.37)$ with a pronounced negative $\mathrm{Eu}$ anamoly and $\mathrm{La} / \mathrm{Ce}=1,03$. These characteristics suggest that Taylor Creek Rhyolite is the extrusive equivalent of anorogenic granites formed within stable continents, and that it was formed by partial melting of crustal material. Underlying pyroclastic deposits containing reactive foreign lithic fragments that might host $U, B e$, and $F$ mineralization are absent or concealed.

Significant $\mathrm{F}, \mathrm{Be}, \mathrm{Fe}$, and $\mathrm{W}$ mineralization occurs in skarns related to aplitic and porphyritic intrusives at Iron Mountain, northern Sierra Cuchillo, N.M., and minor Be and $U$ mineralization is present in altered fault gouge $2 \mathrm{~km}$ to the north. This mineralization appears to be older than but geochemically similar to that in the Taylor Creek Rhyolite. 


\section{THE URANIUM CONTENT OF FLUORINE-ENRICHED TAYLOR CREEK RHYOLITE \\ OF THE NORTHERN BLACK RANGE, SOUTHWESTERN NEW MEXICO}

\section{$\underline{\text { INTRODUCTION }}$}

Topaz rhyolite lava occurs in the northern Black Range, southwestern New Mexico (Fries et al., 1942; Ericksen et al., 1970; Lufkin, 1972). This rhyolite, whose major outcrops are shown on Figure 1, has been named the Taylor Creek Rhyolite (Elston et a1., 1968). As far as can be ascertained, no uranium or beryllium mineralization has been reported in the Taylor Creek Rhyolite. Nevertheless, due to the similarity between the porphyritic rhyolite lava at Spor Mountain and the Taylor Creek Rhyolite, the latter was chosen as a study area for this project.

The Taylor Creek Rhyolite is best known for the tin deposits within it, although the presence of secondary minerals (topaz, garnet, bixbyite, pseudobrookite, and fluorite) indicate the similarity to the topaz rhyolites of Utah. Other occurrences of cassiterite in rhyolites in the western United States are at Izenhood Ranch and Majuba Hi 11, Lander and Pershing Counties, Nevada (Fries, 1942; Trites and Thurston, 1958), Spor Mountain, Utah (Shawe, 1968), the Staats Mine, Wah Wah Mountains, Utah (Lindsey and Osmonson, 1978), and east of Safford, Arizona (Galbraith and Brennan, 1970). More than 1000 occurrences of tin mineralization have been reported in nineteen states of Mexico (Pan, 1974), and Smirnov (1977) reports a tin deposit in rhyolite from the U.S.S.R. Topaz is reported in the rhyolites from Nevada, Utah, and Mexico. Excluding the two occurrences from Utah (which are associated with U, F, and Be mineralization in underlying tuffs), the other tin-bearing rhyolites could be classified as a sub-type of topaz rhyolite (tin rhyolite). 


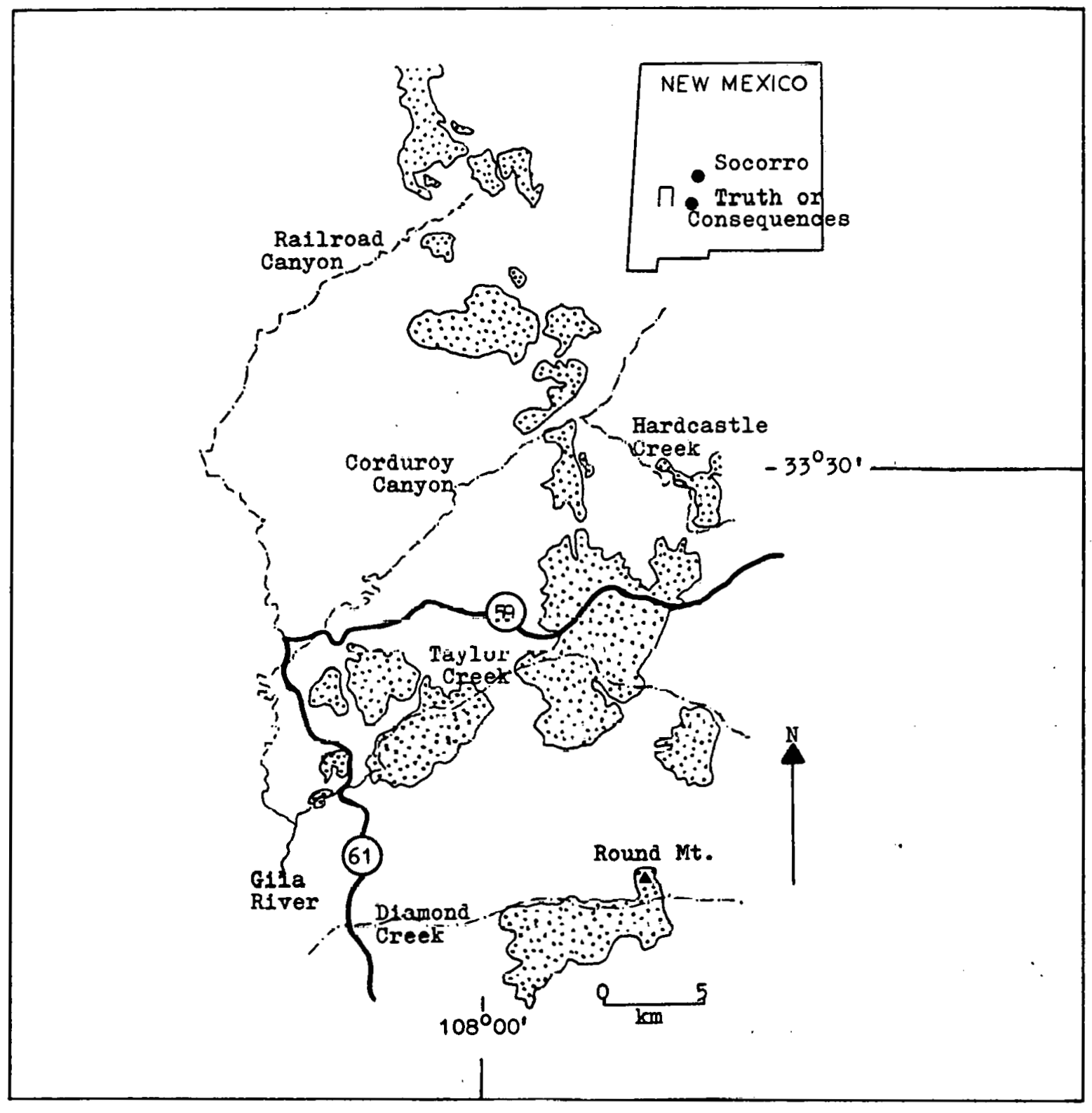

$-$

Fig. 1. Map of the major outcrops of Taylor Creek Rhyolite in the northern Black Range, southwestern New Mexico (after Lufkin, 1977). Some of the northernmost outcrops are probably the rhyolite of Indian Peaks (Fodor, 1976). 


\section{PREVIOUS WORK}

Volcanic Rocks

Felsic rocks associated with two large ash-flow tuff cauldrons and their outer ring complex belong to a distinct petrologic suite within the Mogollon Plateau volcanic field known as the Catron volcanic suite (Rhodes, 1976). The ages of rocks in this volcanic suite range from 27.3 to $24.0 \mathrm{~m} . \mathrm{y}$. years (Elston et al., 1973). The Catron volcanic suite has been assigned to the high-silica alkali rhyolite suite (32-21 m.y.) of three overlapping suites of volcanic rocks in the Mogollon-Datil field of southwestern New Mexico (E1ston et al., 1976a). Petrologic and structural data indicate the presence of a large batholith underlying the Mogollon Plateau (Rhodes, 1976).

Two types of felsic lava have been recognized in the Catron volcanic suite (Rhodes, 1976). Crystal-poor "framework lava" forms the outer ring complex, and it is interpreted as a direct derivative of the batholith beneath the Mogollon Plateau (Rhodes, 1976). Crystal-rich "cauldron lava" fills the two ash-flow tuff cauldrons and partially outlines them with domes and flows (Rhodes, 1976). "Cauldron lava" is interpreted as the product of differentiated, volatilerich shallow cupolas separated from the underlying batholith (Rhodes, 1976).

The easternmost of the two cauldrons, the Gila Cliff Dwelling Cauldron, is outlined by the Jerky Mountain Rhyolite "framework lava" and filled by the Bloodgood Canyon Rhyolite "cauldron lava" (Rhodes, 1976). The Taylor Creek Rhyolite may represent the ring-fracture "cauldron lava" of the Gila Cliff Dwellings Cauldron (Rhodes, 1976). The Taylor Creek Rhyolite has been dated at $24.0 \pm 0.5 \mathrm{~m} . \mathrm{y}$. years old (Elston et al., 1973). Considerably more detail on the Catron volcanic suite is given in Elston and Northrop (1976). 


\section{Lithophile Element Mineralization}

Lithophile element mineralization in the Taylor Creek Rhyolite is limited to tin. Cassiterite occurs in veins and 1ithophysae (Fries, 1940; Ericksen et a1., 1970; Lufkin, 1972). Molybdenum and beryllium anomalies are present in the Mogollon Plateau volcanic field but outside of the fluorine-enriched Taylor Creek Rhyolite (E1ston et al., 1976b). Fluorine, tungsten, and berylliumbearing skarns occur at Iron Mountain in the central Sierra Cuchi11o (Jahns, 1944).

\section{PRESENT INVESTIGATION}

This study includes the results of quantitative analysis of phenocrysts, major and trace element (F, U, Sn, Be, Li) whole-rock chemistry, determination of magma type and its origin, sources and controls of ore deposit.s, and the role of fluorine and pyroclastic rocks in uranium concentration. This study also includes the determination of the volcanic rock types, secondary features, eruption and emplacement history, and volcanic setting of the Taylnr Creek. Khyolite.

VOLCANIC GEOLOGY

Rock Types and Secondary Features

The Taylor Creek Rhyolite is predominantly composed of flow-layered and flow-banded lava, but ignimbrites are also present in minor amounts. Pyroclastic surge and fall deposits were not observed.

Ignimbrites exposed at Hardcastle Creek are densely welded. A vitrophyre exposed in Paramount Canyon may be an ignimbrite (Lufkin, 1972). Taylor Creek Rhyolite crops out along N.M. 78 near Indian Peaks in the northern Black Range (Fodor, 1976). At this locality, unwelded tutf was observed beneath flow-banded Taylor Creek Rhyolite lava. This tuff is not the Railroad Canyon Rhyolite. The tuff contains large blocks of porphyritic lava that have vesiculated cores and ash welded to the irregular margins of the blocks indicating the blocks were still liquid when deposited with the tuff. The sanidine phenocrysts in the 
blocks are similar (in size and number) to those in the overlying flow-banded, porphyritic Taylor Creek Rhyolite lava. The tuff may have a hydromagmatic origin.

Nearly all the Taylor Creek Rhyolite exposed in the Black Range is either devitrified or vapor-phase altered. Vitrophyres are rare. Both granophyric textures and spherulites were observed, and axiolites are present in one densely welded ignimbrite from Hardcastle Creek. Most of the Taylor Creek Rhyolite has undergone vapor-phase alteration and vapor-phase crystallization. Miarolitic cavities and lithophysae lined with quartz and other minera1s are common. Argillized, bleached zones of rhyolite containing cassiterite veins may be products of fumarolic alteration.

Eruption and Emplacement History

Exposures of Taylor Creek Rhyolite lava at Taylor Creek attain a thickness of approximately 400 feet. At one locality along Taylor Creek, the entire thickness of 400 feet constitutes a large, overturned fold that can be traced from the base to the top of the outcrop. The dome exposed at Taylor Creek is an endogenous dome. The Taylor Creek Rhyolite dome at Taylor Creek closely resembles domes formed by squeezing viscous material through a narrow aperture (Reyer, 1888; in Wi1liams, 1932). The lava did not flow great distances and retained its dome geometry. Individual cooling units are not visible, indicating that all the lava was emplaced at close to the same time. The great thickness of lava prevented rapid cooling. This conclusion is supported by the abundance of devitrified and vapor-phase altered rocks and the absence of vitrophyres.

\section{Volcanic Setting}

Exposures of Taylor Creek Rhyolite are thought to represent the ring fracture volcanics of the Gila Cliff Dwellings Cauldron, although they are 
present only along the eastern margin of the cauldron (Rhodes, 1976). Similarity in age, mineralogy, and chemical composition to the Gila Cliff Dwellings Cauldron members of the Catron volcanic suite suggests the Taylor Creek Rhyolite belongs to this suite. Whether the Taylor Creek Rhyolite represents the ring fracture volcanics of the Gila Cliff Dwellings Cauldron or a separate dome field was not determined in this study.

\section{PETROLOGY}

Mineralogy

The Taylor Creek, Bloodgood Canyon, and Jerky Mountain Rhyolite were examined petrographically and all contain sanidine, quartz, biotite, hornblende, plagioclase, sphene and oxides, although all these phases may not be present in one thin section. In addition, one sample of Taylor Creek Rhyolite (IP-2) contains ferroaugite but no biotite or amphibole. Other minerals in the Taylor Creek Rhyolite include titaniferous magnetite, zirron and fayalito (?) (Lufkin, 1972). Uxides were not identified in this study. Identical mincralogy between the Gila Cliff Dwellings Cauldron members of the Catron vnlranic suite euggests these rocks are genetically related. Biotite and hornblende, except in Bloodguud Canyon khyolite vitrophyre BR-3, are either rimmed or replaced by opaque oxides. Embayed quartz and sanidine phenocrysts are present in all three rhyolites. Glomeroporphyritic textures are common in the Taylor Creek Rhyntite and Iess common in the Bloodgood Canyon and Jerky Mountain Rhyolite, Graphic texture was observed in a few samples, including the Jerky Mountain Rhyolite; this observation is in disagreement with a previous investigation (Rhodes, 1976).

A sample of Taylor Creek Rhyolite (IP-2) from the northern Black Range near Indian Peaks was chosen for electron microprobe analysis of phenocrysts (Table 1). This sample of Taylor Creek Rhyolite is atypical because it contains pyroxene but no biotite or amphibole. Sanidine phenocrysts have nearly equal molecular percentages of orthoclase and albite, and the anorthite 


$$
\therefore \quad \text { Table } 1
$$

Chemical composition and structural formula of sanidine and pyroxene phenocrysts in Taylor Creek Rhyolite; sample IP-2.

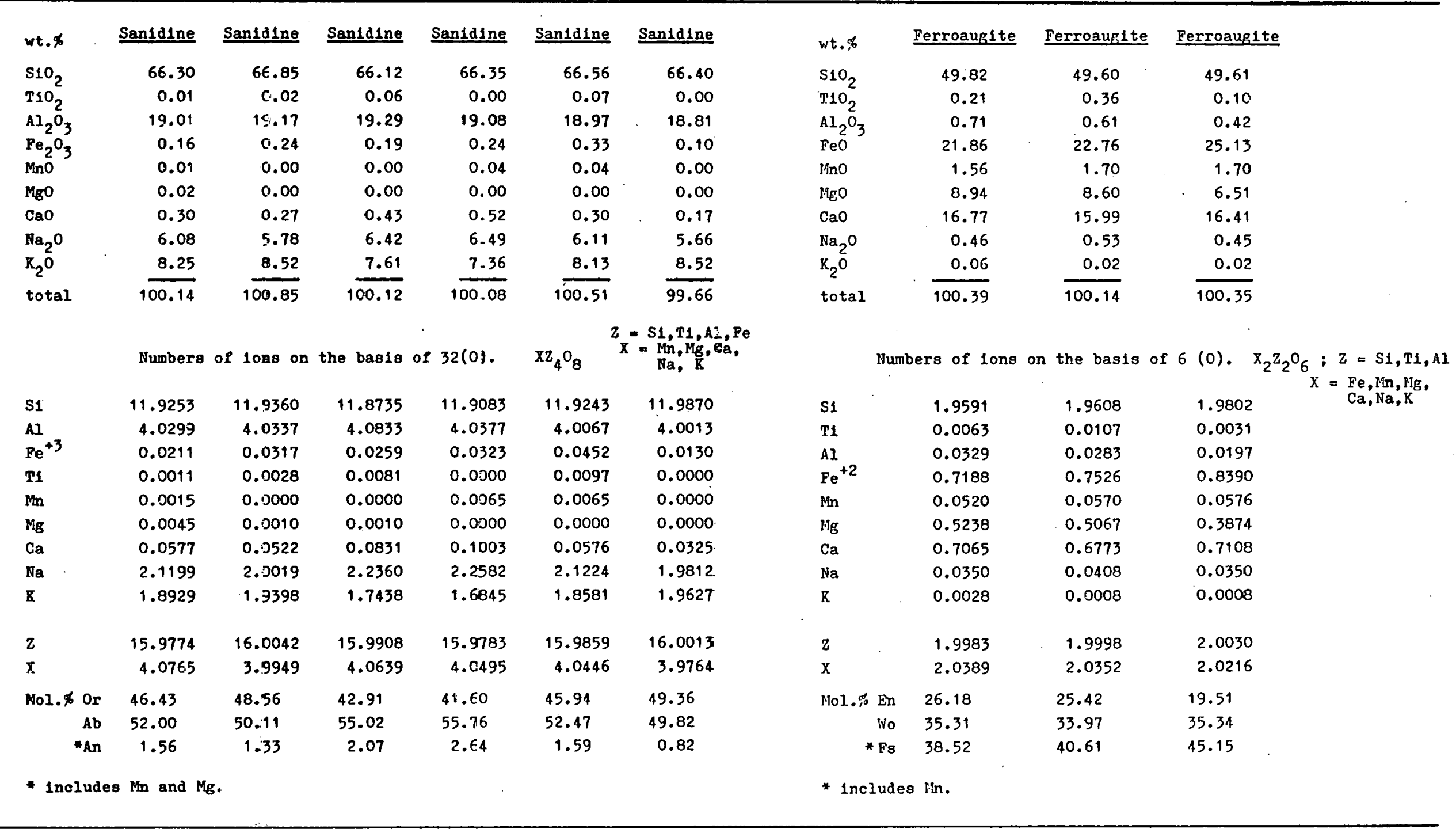

Analyses by B. Correa using ARL SEMQ electron microprobe with Tracor Northern authomation (NS-880, TN-1310) and Bence-Albee matrix correction program. Beam diameter of 25 microns, sample current of $20 \mathrm{nA}$ at $15 \mathrm{kV}$. 
component does not exceed 3\% (Table 1, Fig. 2). The pyroxenes are ferroaugite, and they contain up to 1.70 wt.\% Mn0 (Table 1, Fig. 2a).

\section{Chemistry}

Nine samples of the Gila Cliff Dwellings Cauldron members of the Catron volcanic suite (Table 2, Appendix 1) were analyzed for major elements (Table 3, first 9 analyses). Relative to typical orogenic rhyolites, all members of the suite contain low $\mathrm{Al}_{2} \mathrm{O}_{3}$, MnO, MgO, and $\mathrm{CaO}$ and high $\mathrm{SiO}_{2}$ and $\mathrm{K}_{2} \mathrm{O}$. The Taylor Creek Rhyolite is characterized by higher $\mathrm{SiO}_{2}$ and lower $\mathrm{Na}_{2} \mathrm{O}$ and $\mathrm{K}_{2} \mathrm{O}$ (Figs. $3,4,5$ ). Total alkalis exceed $\mathrm{Fe} 0$ and MgO for all samples (Fig. 6). Some of the variability between samples of Taylor Creek Rhyolite may be due to different amounts and types of phenocrysts, groundmass, and secondary features. Sample IP-2, for example, owes its high $\mathrm{SiO}_{2}$ content in part to microscopic opal veins within the otherwise fresh lava. No samples of Taylor Creek Rhyolite that had undergone visible vaporphase alteration were analyzed.

Nine samples of the Gila Cliff Dwellings Cauldron members of the Catron volcanic suite werc analyzed for $\mathrm{Be}, \mathrm{Li}$, and $\mathrm{Sn}$ (Table 4,7 of the 9 above plus BR-19 and IP-1). Lithophysal, topaz-bearing Taylor Creek Rhyolite (BR-19) contains the highest amounts of $\mathrm{Be}, \mathrm{Li}$ and $\mathrm{Sn}$. Taylor Creek Rhyolite vitrophyre (HC-8). contains the second highest Li. Densely welded ignimbrites of Taylor Creek Rhyolite (HC-3 and BR-28) contain high Be and Li.

Vitrophyres of the Bloodgood Canyon (BR-3) and Taylor Creek Rhyolite (HC-8) "cauldron lava" of the Gila Cliff Dwellings Cauldron were analyzed for fluorine (Table 4). The fluorine content of the Taylor Creek Rhyolite is nearly four times that of the Bloodgood Canyon Rhyolite. The major differences between the two "cauldron lavas" of the Gila Cliff Dwellings Cauldron are that the Taylor Creek Rhyolite is higher in $\mathrm{SiO}_{2}$ and fluorine and the Bloodgood Canyon Rhyolite is higher in $\mathrm{K}_{2} \mathrm{O}$ and $\mathrm{Na}_{2} \mathrm{O}$. 


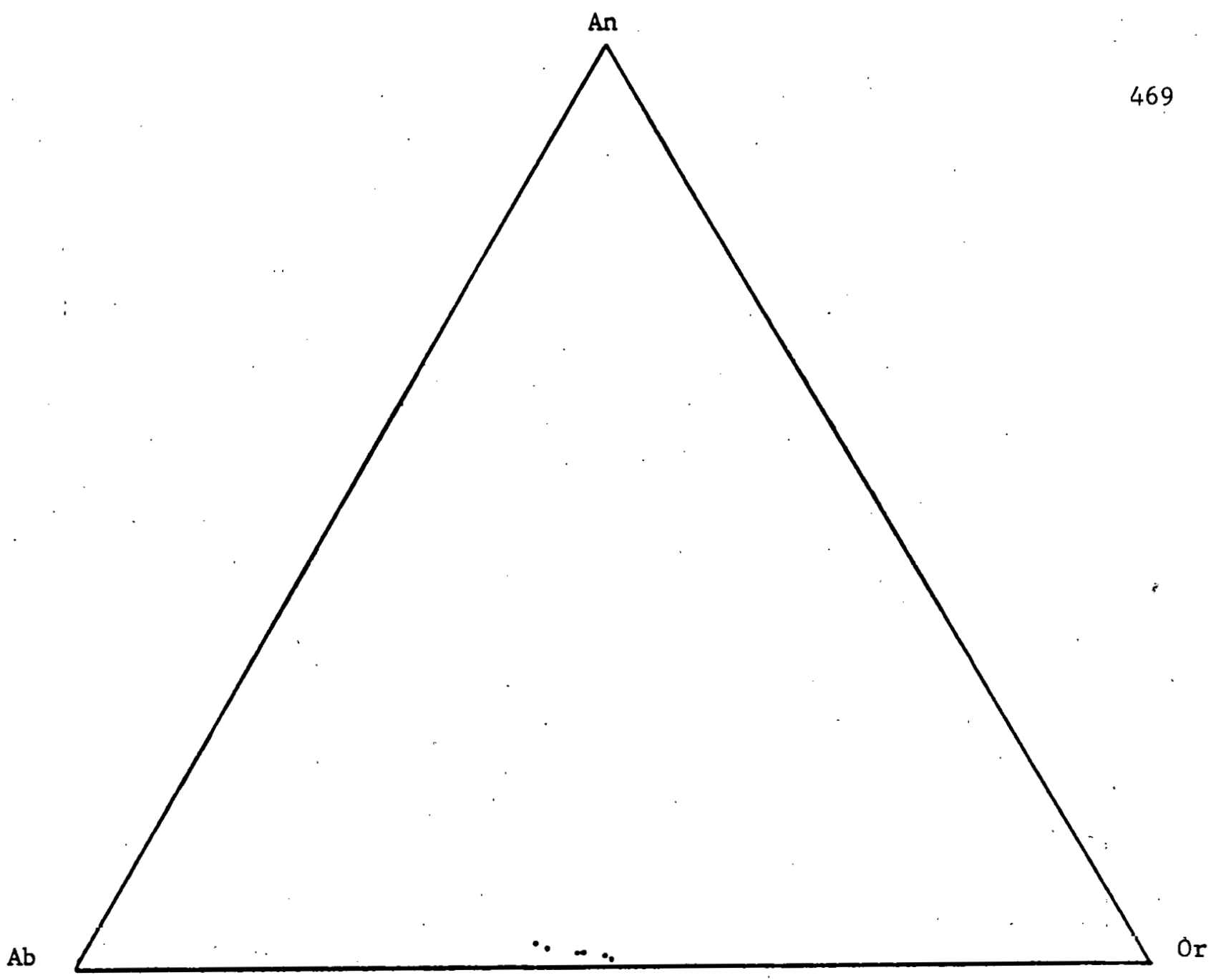

Fig: 2. Composition of sanidine as molecular proportions of anorthite $(\mathrm{An})$, albite $(\mathrm{Ab})$, and orthoclase (Or).

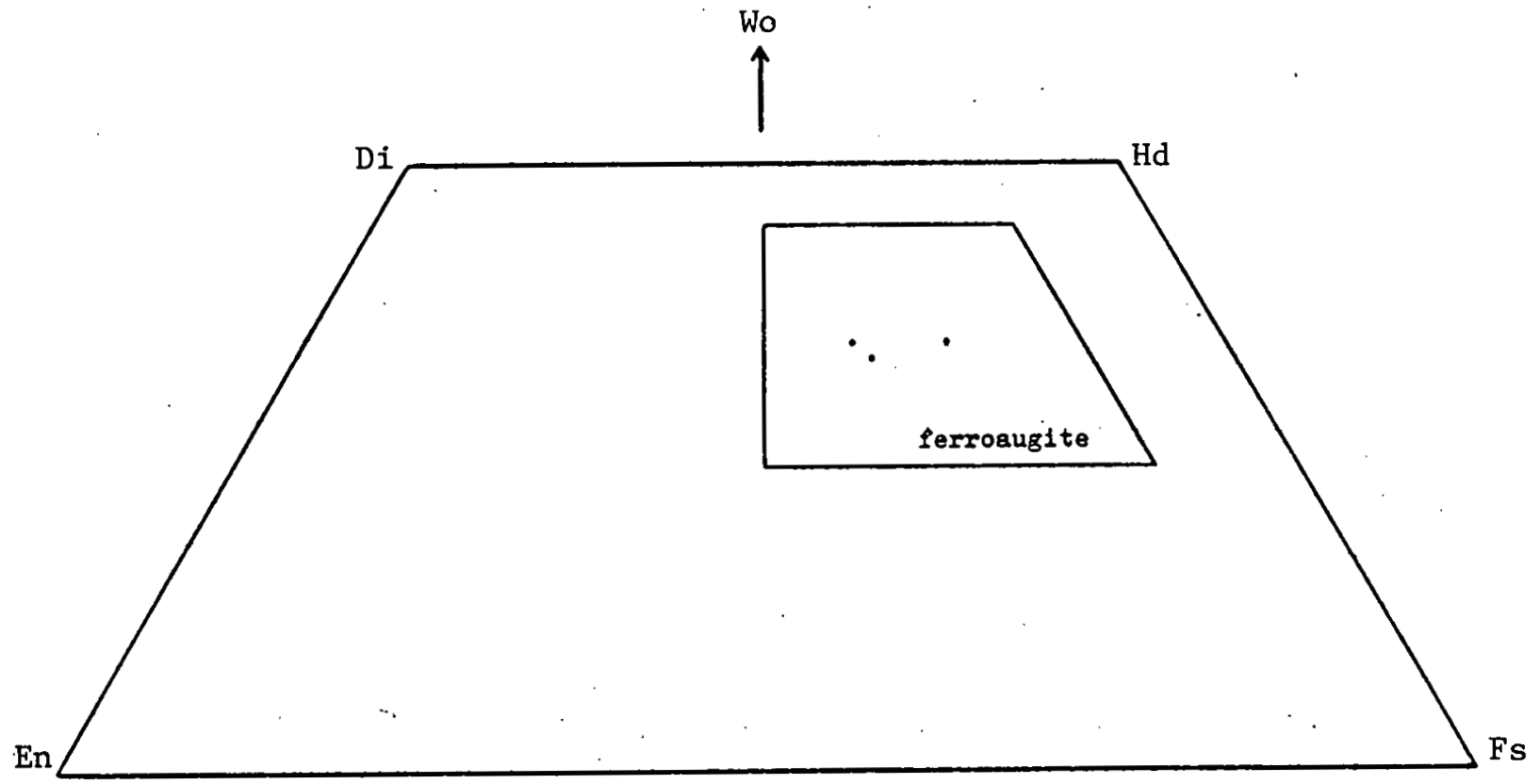

Fig. 2a. Composition of pyroxene as molecular proportions of enstatite (En); ferrosilite (Fs), and wollastonite (Wo). 


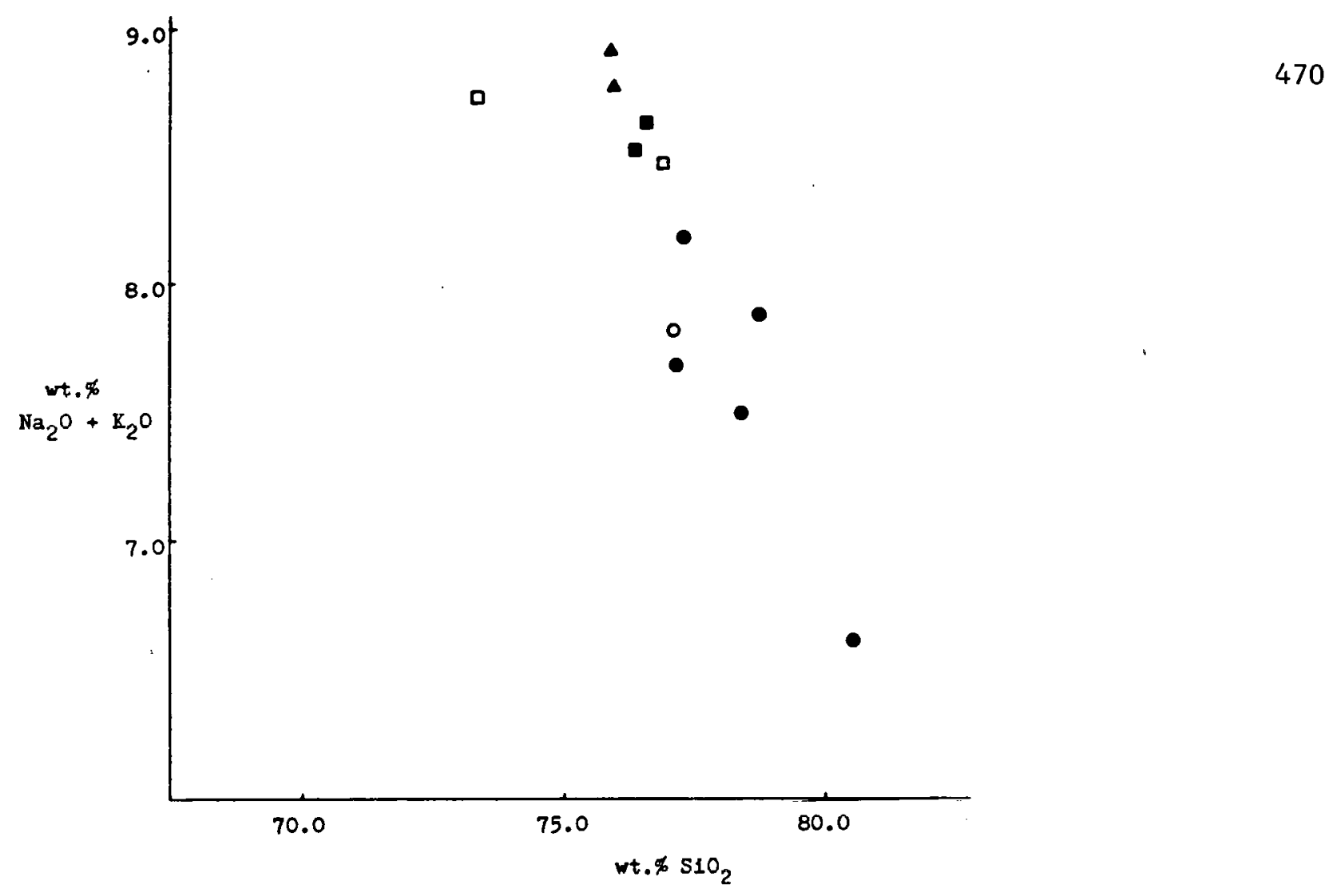

Fig. 3. Plot of weight percent $\mathrm{Na}_{2} \mathrm{O}+\mathrm{K}_{2} \mathrm{O}$ versus weight percent $\mathrm{SiO}_{2}$ of rocks from New Mexico.

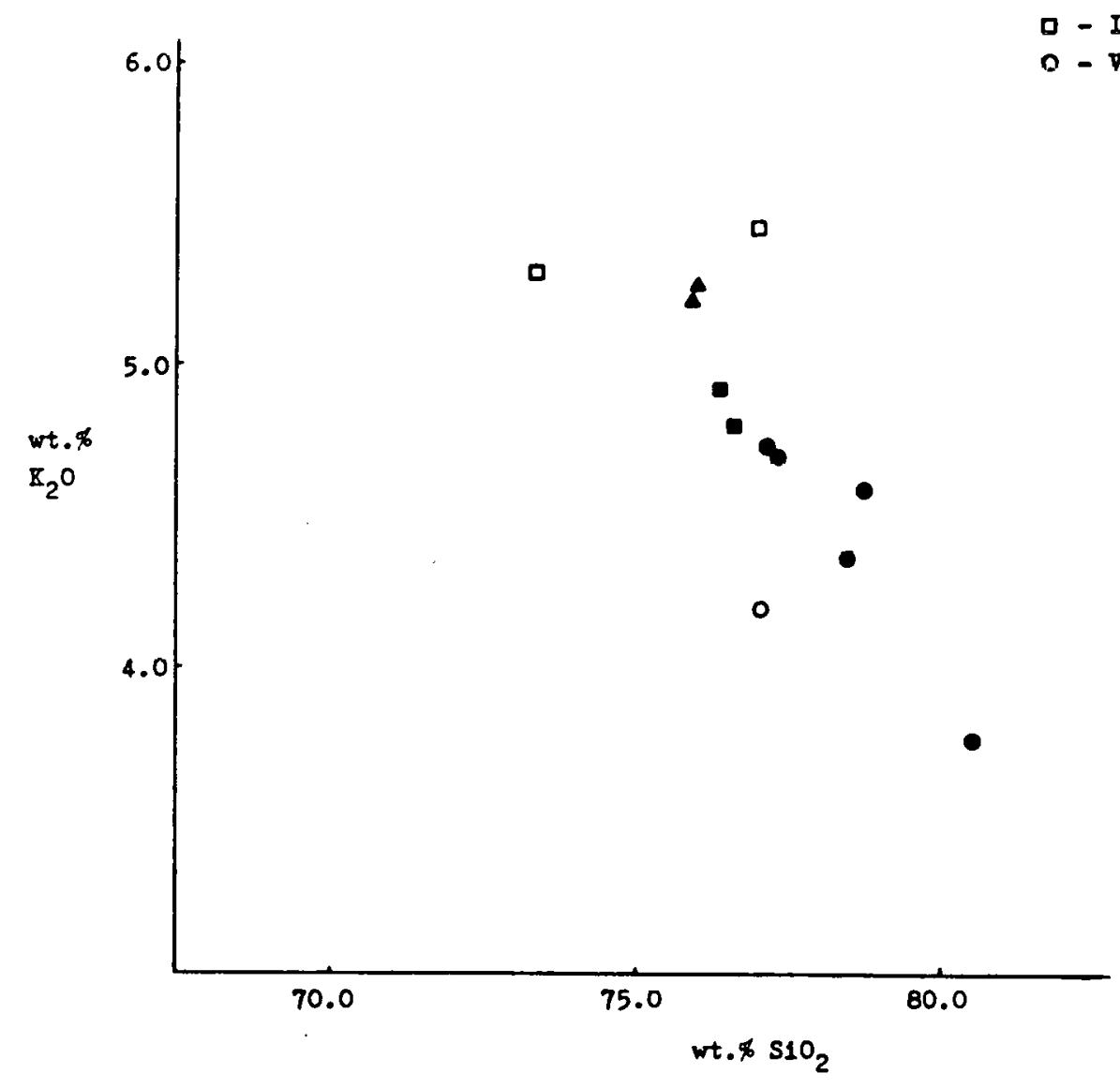

- Jerky Mounta1n Rhyolite

- Bloodgood Canyon Rhyolite

- Tuylar Creek Khyolite

D - Iron Mountaln aplite and rhyolite porphyry

- V1oko Poall Rhyol1te

Fig. 4. Plot of weight percent $\mathrm{K}_{2} 0$ versus weight percent $\mathrm{SiO}_{2}$ of rocks from New Mexico. 


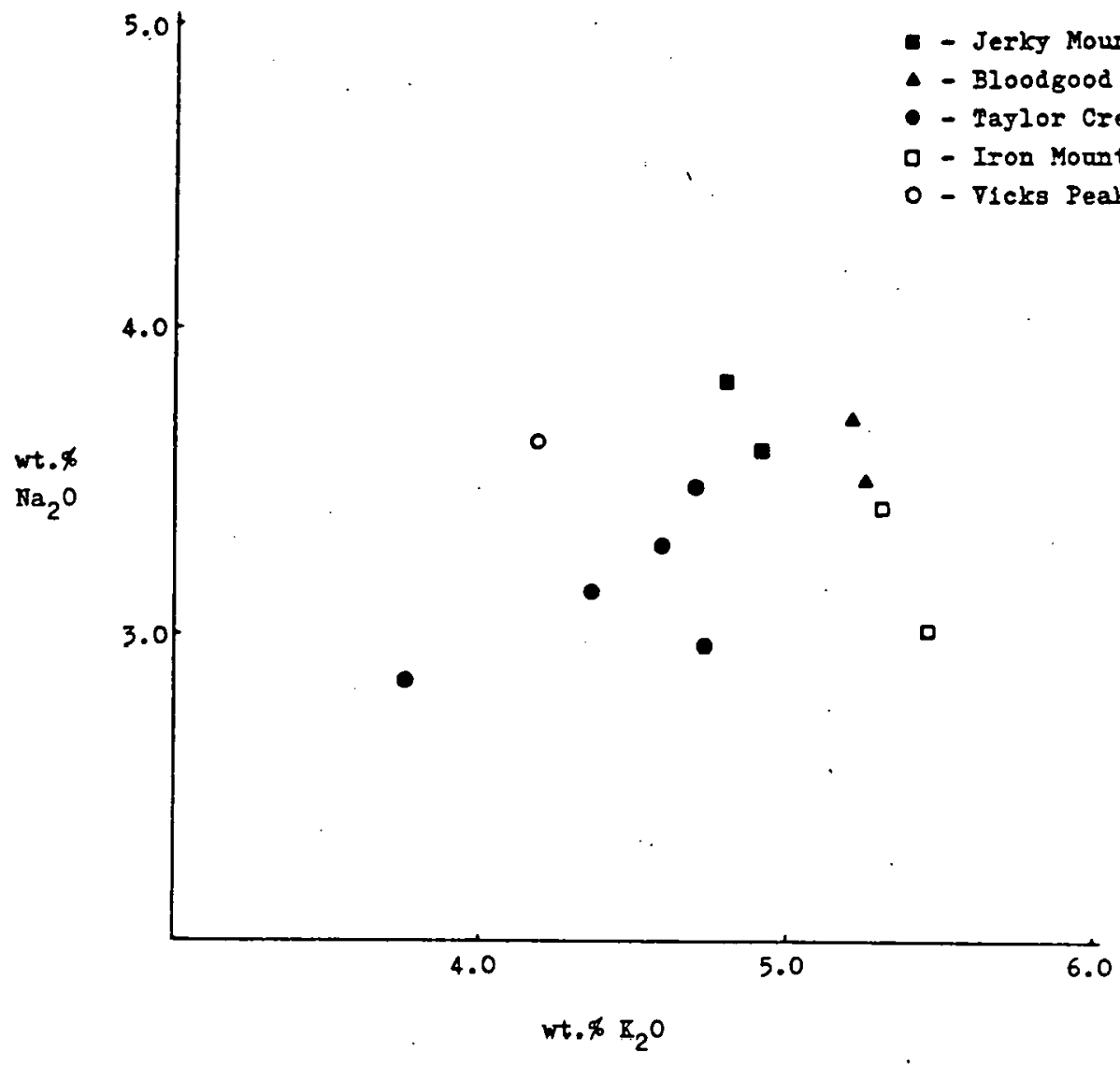

Fig. 5. Plot of weight percent $\mathrm{Na}_{2} \mathrm{O}$ versus weight percent $\mathrm{K}_{2} \mathrm{O}$ of rocks from New Mexico.

D, $\mathrm{Be}, \mathrm{II}$

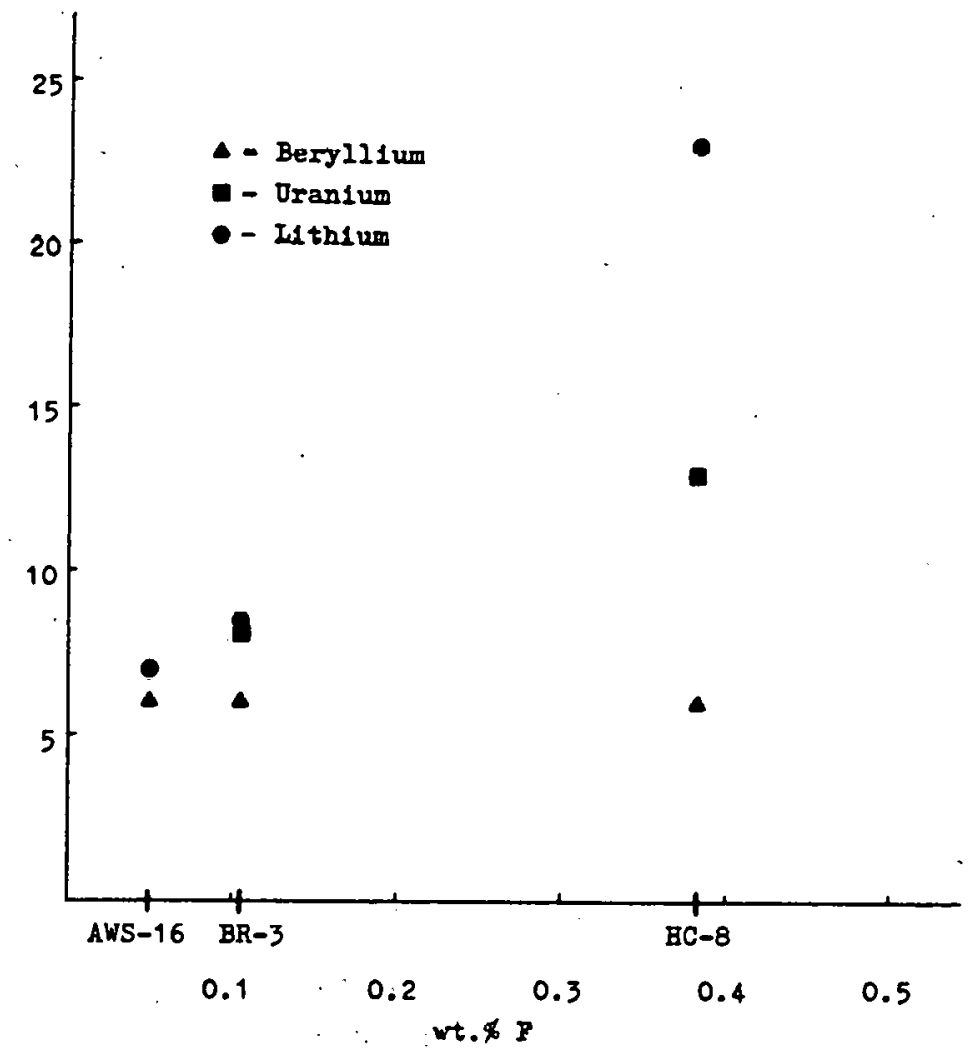

Fig. 8. Plot of parts per million uranium, beryllium, and lithium versus weight percent fluorine of vitrophyres from New Mexico. 


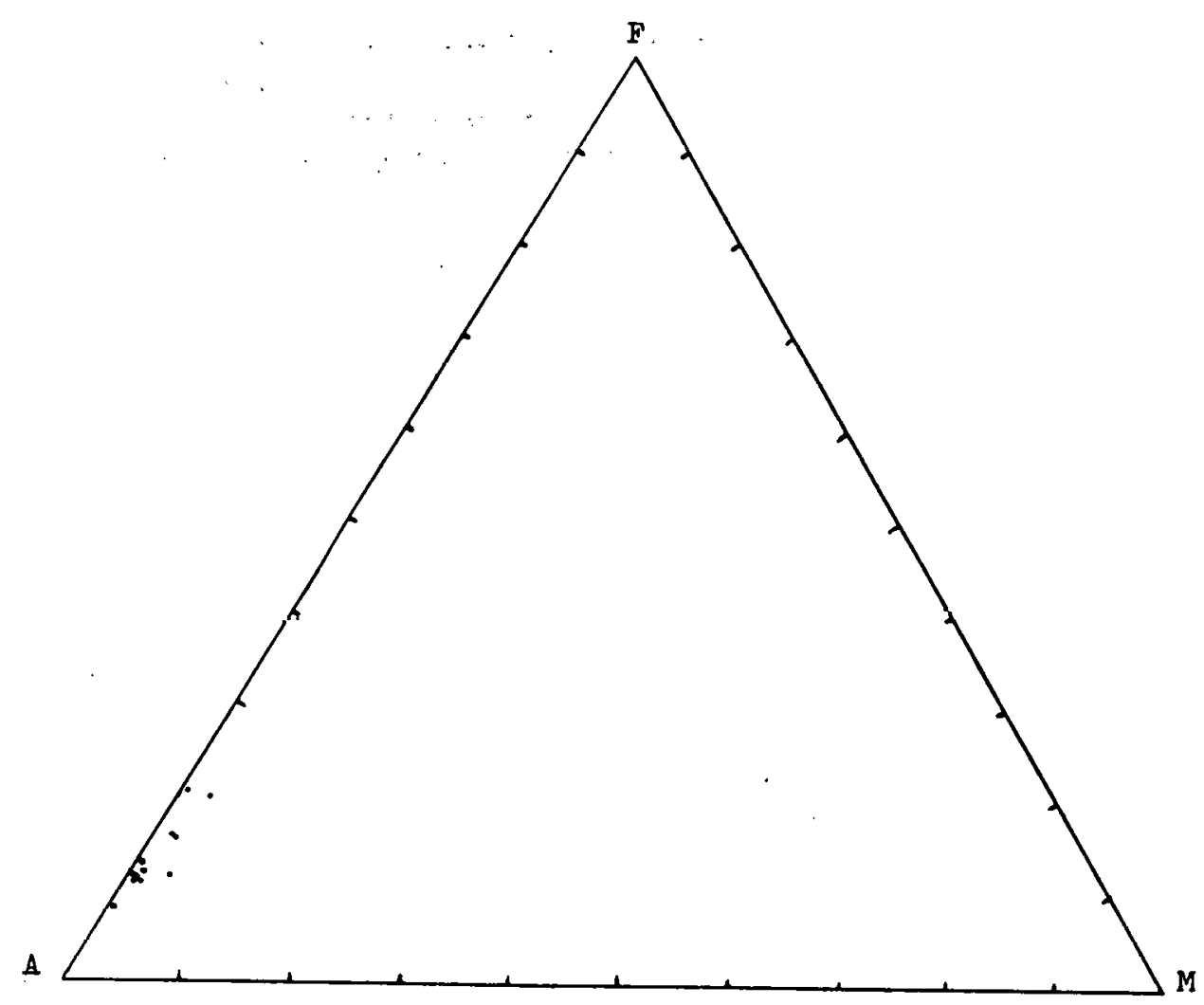

Fig. 6. Composition of rocks from New Mexico as weight proportion of oxides $\left(\mathrm{A}=\mathrm{Na}_{2} \mathrm{O}+\mathrm{K}_{2} \mathrm{O} ; \mathrm{F}=\right.$ total $\mathrm{Fe}$ as $\mathrm{Fe} 0 ; \mathrm{M}=\mathrm{MgO}$ ).

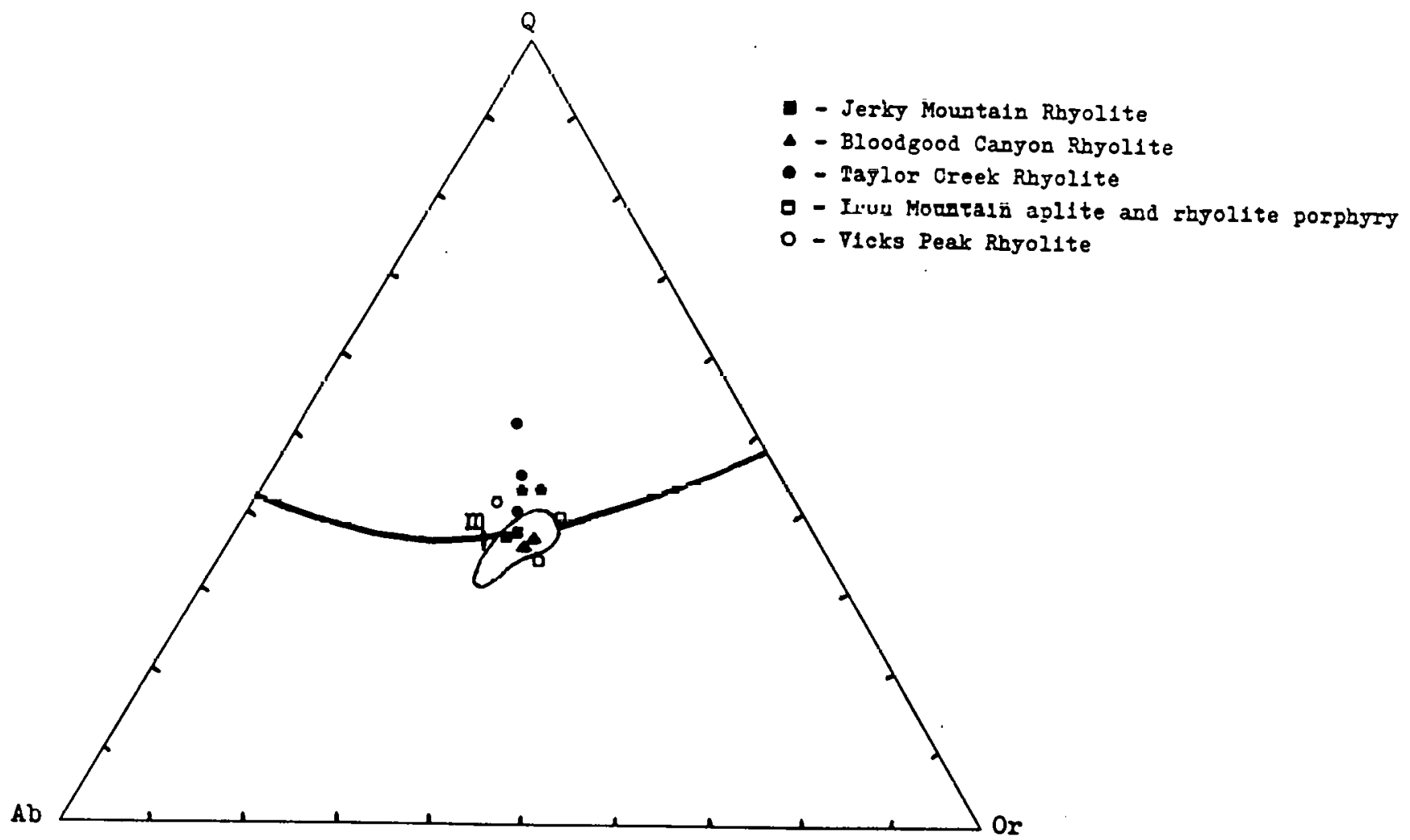

Fig. 7. Plot of normative $Q$, or, ab of rocks from New Mexico. Curve is for the water-saturated liquid in equilbrium with quartz and alkali feldspar at 1000 bars confining pressure. Isobaric minimum is labeled m. Analyzed granites concentrate in the circled area (after Carmichael et al., 1974; from Tuttle and Bowen, 1958). 
Table 2

Description of analyzed samples from New Mexico.

\begin{tabular}{|c|c|}
\hline sample & sample description \\
\hline $\mathrm{BR}-1$ & miarolitic, flow-banded Jerky Mountain Rhyolite lava \\
\hline $\mathrm{BR}-2$ & spherulftic, flow-banded Jerky Mountain Rhyolite lava \\
\hline $\mathrm{BR}-3$ & hydrated vitrophyre of Bloodgood Canyon Rhyolite \\
\hline $\mathrm{BR}-3 \mathrm{a}$ & devitrified Bloodgood Canyon Rhyolite; incipiently welded \\
\hline$B R-16$ & devitrified Taylor Creek Rhyolite lava \\
\hline $\mathrm{BR}-28$ & $\begin{array}{l}\text { partly devitrified Taylor Creek Rhyolite; } \\
\text { densely welded Ignimbrite }\end{array}$ \\
\hline $\mathrm{HC}-3$ & $\begin{array}{l}\text { partly devitrified Taylor Creek Rhyolite; } \\
\text { densely welded ignimbrite }\end{array}$ \\
\hline HC-8 & hydrated vitrophyre of Taylor Creek Rhyolite \\
\hline IP-2. & $\begin{array}{l}\text { partly devitrified Taylor Creek Rhyolite; block in } \\
\text { Ignimbrite underlying flow-banded lava(IP-1) }\end{array}$ \\
\hline BR-29 & aplite of Iron Mountain \\
\hline $\mathrm{BR}-30$ & rhyolite porphyry of Iron Mountain \\
\hline AWS-16 & hydrated vitrophyre of Vicks Peak Rhyolite \\
\hline AWS-11 & altered, densely welded V1cks Peak Rhyolite \\
\hline AWS-15 & altered rhyolite of Alum Spring \\
\hline $\mathrm{HC}-7$ & silicified Iaylor Creek Rhyulite \\
\hline $\mathrm{BR}-19$ & 11thophysal, topaz-bearing Taylor Creek Rhyolite lava \\
\hline IP-1 & $\begin{array}{l}\text { devitrified and vapor-phase altered Taylor Creek } \\
\text { Rhyolite lava overlying Ignimbrite containing IP-2 }\end{array}$ \\
\hline AWS-9 & altered fault gouge containing $B e$ and $U$ mineralization \\
\hline
\end{tabular}


Chemical ccmpositiors and CIPW norms of rocks from the Catron volcanic stite: Iror Mountain, and the northern Sierra Cuchillo.

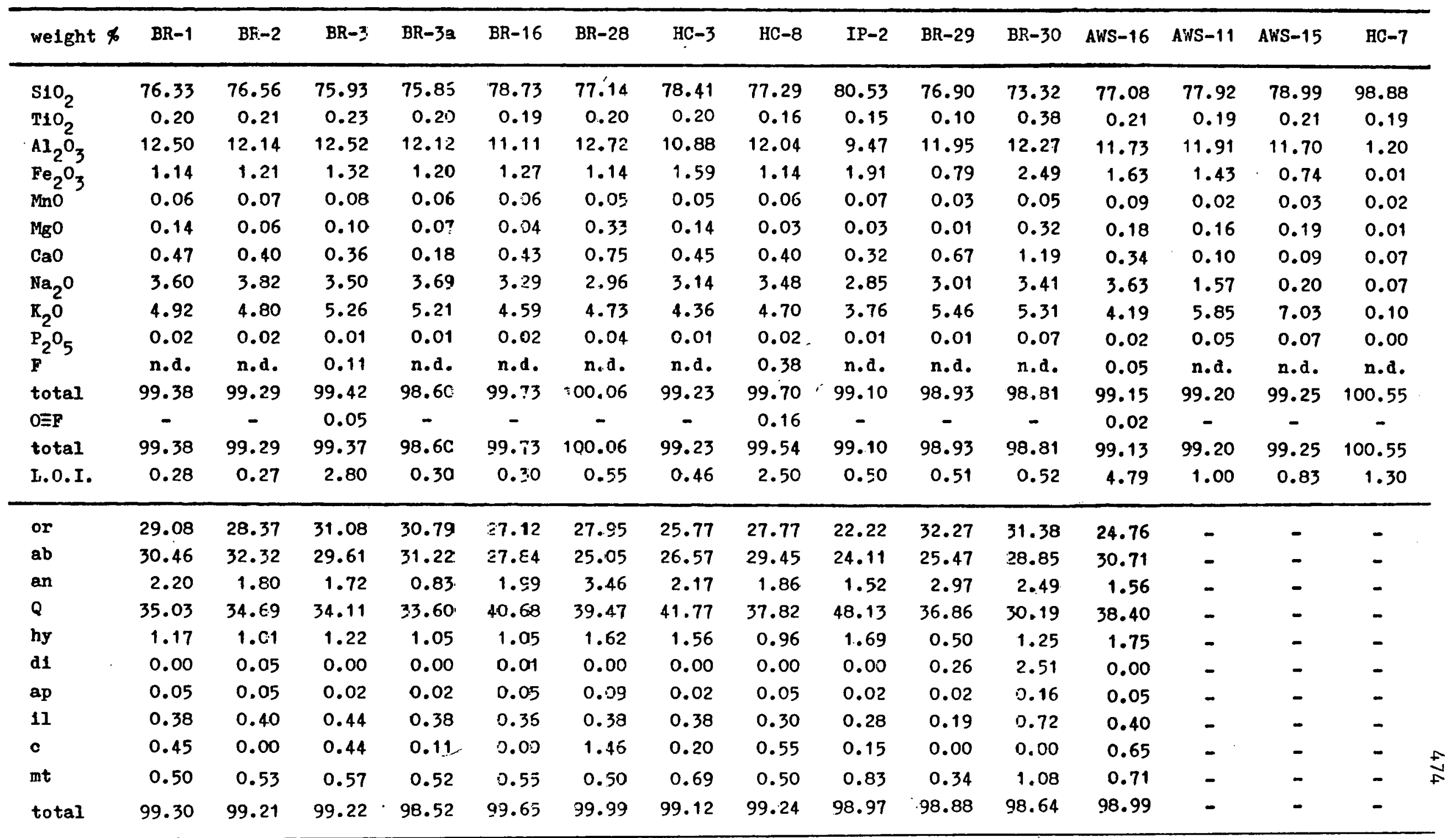

Chemical compositions determined by $\mathrm{X}$-ray fluorescerce spectroscopy (Phillips $\mathrm{PW}-141 \mathrm{~d}$ ), except $\mathrm{Na2} 0$ and MgO by atomic absorbtion spectrophotometry (Varian Techtron 1250) : analyst B. Correa. For CIPN norms $\mathrm{Fe} /$ total Fe as FeO $=0.70$. 
Table 4

Trace element content of rocks from New Mexico.

\begin{tabular}{lccccc}
\hline sample & ppm 0 & ppm Be & ppm Li & ppm Sn & ppm $F$ \\
\hline BR-1 & n.d. & 5 & 11 & 25 & n.d. \\
BR-2 & 6.6. & 5 & 13 & 25 & n.d. \\
BR-3 & 8.1 & 6 & 8 & 25 & 1060 \\
BR-3a & n.d. & n.d. & n.d. & n.d. & n.d. \\
BR-16 & n.d. & n.d. & n.d. & n.d. & n.d. \\
BR-28 & 8.6 & 10 & 15 & 25 & n.d. \\
HC-3 & 7.5 & 10 & 15 & 25 & n.d. \\
HC-8 & 12.9 & 6 & 23 & 25 & 3820 \\
IP-2 & 30.2 & 4 & 7 & 10 & n.d. \\
BR-29 & n.d. & 19 & 13 & 10 & n.d. \\
BR-30 & 1.7 & 13 & 5 & 25 & n.d. \\
AWS-16 & n.d. & 6 & 7 & 10 & 50o \\
AWS-11 & 9.7 & 7 & 8 & 25 & n.d. \\
AWS-15 & n.d. & n.d. & n.d. & n.d. & n.d. \\
HC-7 & n.d. & 8 & 6 & 10 & n.d. \\
BR-19 & 7.4 & 12 & 50 & 50 & n.d. \\
IP-1 & 9.4 & n.d. & n.d. & n.d. & n.d. \\
AWS-9 & 78.0 & 30 & 90 & 100 & n.d. \\
\hline
\end{tabular}

Uranium determined by delayed neutron activation analysis. Beryllium, lithium, and tin determined by atomic absorbtion spectrophotometry on Varlan Techtron Model 1250. National Institute for Metallurgy(South Africa) rook standard NIM-G was used as a matrix and doped to appropriate concentrations to cover the range of unknowns. NIM-G was used because of its similarity in major element composition to the unknowns and its low concentration of $\mathrm{Be}, \mathrm{II}$, and Sn. U.S.G.S. standard $\mathrm{G}-2$ was also used for the beryllium analysis. n.d. = not determined. 
The trace element content of Taylor Creek Rhyolite vitrophyre (HC-8) shows that it is depleted in $\mathrm{Sc}, \mathrm{Cr}$, Co, and $\mathrm{Ba}$ compared to the average granite (Table 5). Taylor Creek Rhyolite is enriched in $\mathrm{Zr}, \mathrm{Hf}, \mathrm{Th}, \mathrm{U}, \mathrm{Rb}$, Cs, and especially $\mathrm{Yb}$ over the average granite. The Taylor Creek Rhyolite and average granite have approximately the same amounts of La and Ta. The rare-earth element distribution pattern normalized to that of chondrites (Fig. 9) shows a pronounced negative Eu anamoly. Heavy rare-earth element abundances are high and $\mathrm{La} / \mathrm{Lu} \mathrm{(2.37)}$ is low compared to the Bishop Tuff and other highly differentiated, subalkaline ash-flow tuffs and lavas (Hildreth, 1979; Noble et al., 1979). Some highly differentiated peralkaline glasses exceed Taylor Creek Rhyolite in heavy rare-earth element content, but most peralkaline glasses have two to six times higher $\mathrm{La} / \mathrm{Lu}$ (Noble et al., 1979). One aspect of the rareearth element distribution of Taylor Creek Rhyolite (Fig. 9) which is different from other highly differentiated subalkaline and peralkaline volcanic rocks is luw La/Ce $(1.03)$.

\section{Petrogenesis}

In terms of normative $q z, a b$, and or, the Gila Cliff Dwellings Cauldron members of the Catron volcanic suite plot near the boundary curve between the quartz and alkali feldspar fields in the water-saturated system $\mathrm{NaAlSi}_{30} \mathrm{O}_{8}-\mathrm{KAlSi}_{3} \mathrm{O}_{8}-$ $\mathrm{SiO}_{2}$ in the range of 500 to 3000 bars confining pressure (Fig. 7). Bloodgood Canyon and Jerky Mountain Rhyolite plot within the area where analyzed granites plot, and the Taylor Creek Rhyolite plots more toward the quartz apex (Fig. 7). The extreme quartz-rich sample (IP-2) does not represent a true composition because of microscopic opal veins in that sample. Although the Gila Cliff Dwellings Cauldron members of the Catron volcanic suite are similar in normative $q z, a b$, and or to analyzed granites, the trace element content of Taylor Creek Rhyolite is much different (Table 5). Taylor Creek Rhyolit, is similar to peralkaline rhyolites in its content of $\mathrm{Sc}, \mathrm{Co}, \mathrm{Cr}, \mathrm{Th}, \mathrm{Yb}$, and $\mathrm{Lu}$, but it is slightly lower in $\mathrm{Zr}, \mathrm{Hf}, \mathrm{Ta}, \mathrm{La}, \mathrm{Ce}, \mathrm{Nd}, \mathrm{Sm}, \mathrm{Eu}$, and $\mathrm{Tb}$ and slightly 
Table 5

Trace element content of Taylor Creek Rhyolite vitrophyre(HC-8).

\begin{tabular}{lcc}
\hline parts per million(HC-8) & $\begin{array}{c}\text { ppm of average granite, from Taylor(1964), } \\
\text { Taylor and White(1966). }\end{array}$ \\
\hline Sc & 1.70 & 6 \\
Cr & 2.70 & 10 \\
Co & 0.42 & 2 \\
Zr & 550 & 180 \\
Hf & 7.80 & 4 \\
Ta & 3.28 & 3.5 \\
Th & 32.40 & 17 \\
U & 12.90 & 4.8 \\
Ba & 110 & 600 \\
Rb & 348 & 145 \\
Cs & 9.29 & 5 \\
La & 43 & 50 \\
Ce & 108 & n.d. \\
Na & 53 & n.d. \\
Sm & 10.55 & n.d. \\
Eu & 0.264 & n.d. \\
Tb & 2.61 & n.d. \\
Yb & 13.20 & o.18 \\
Lu & 1.84 & n.d. \\
& & \\
\hline & &
\end{tabular}

Trace element content determined by instrumental neutron activation analysis at the University of Oregon by G. Goles. 


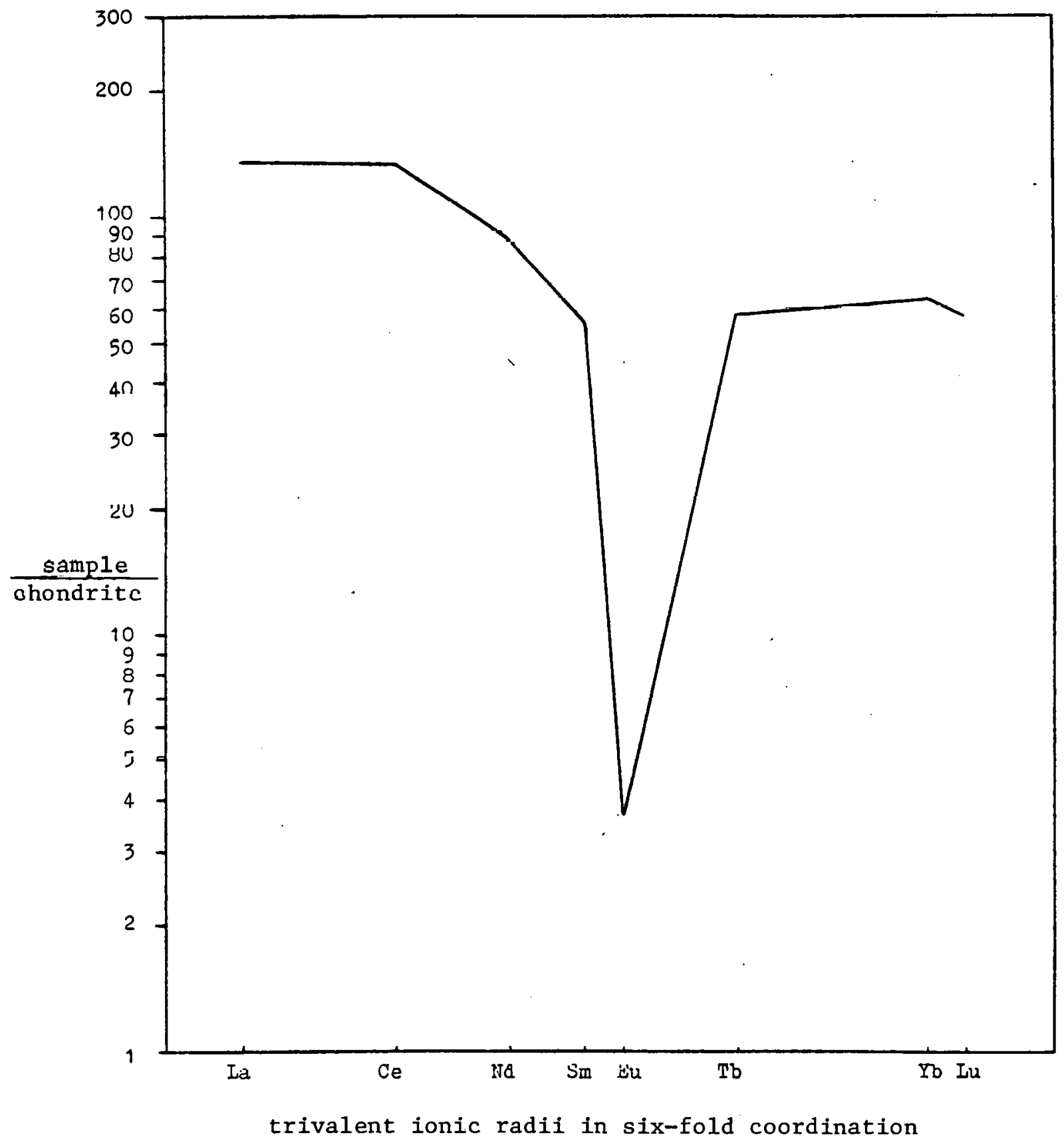

Fig. 9. Distribution of rare-earth elements in Taylor Creek rhyolite (HC-8) normalized to Leedey chondrite divided by 1.2 . Data from Masuda et al. (1973). Ionic radii from Whittaker and Muntus (1970). 
higher in $\mathrm{U}, \mathrm{Ba}$, and $\mathrm{Rb}$. Thus, Taylor Creek Rhyolite has the trace element content of highly differentiated rocks (peralkaline).

According to Elston et al. (1976a), the high-silica alkali rhyolite suite (of which the Catron volcanic suite is a member) was produced by partial melting of upper mantle and/or lower crust in response to rising isotherms, caused at least in part by emplacement of basaltic andesite and the intense period of calc-alkaline volcanism beginning $37 \mathrm{~m} . \mathrm{y}$. and $43 \mathrm{~m} . \mathrm{y}$. years ago respectively. The highsilica alkali rhyolite suite is largely confined to the Mogollon Plateau which is underlain by a composite granitic pluton $125 \mathrm{~km}$ in diameter (Elston et al., 1976a). The most mafic rock in the Catron volcanic suite is a quartz latite, so the suite must have formed at least in part by melting of the felsic fraction of the lower, crust. Initial ${ }^{87} \mathrm{Sr} /{ }^{86} \mathrm{Sr}$ are in the range of 0.7100 to 0.7300 for high $\mathrm{Rb}(270$ and $221 \mathrm{ppm})$, low $\mathrm{Sr}(6.2$ and $4.7 \mathrm{ppm})$ rocks of the high-silica alkali rhyolite suite (Bikerman, 1976). Preliminary initial ${ }^{87} \mathrm{Sr} /{ }^{86} \mathrm{Sr}$ determinations for Taylor Creek Rhyolite gave a $\mathrm{Rb}$ content of $350 \mathrm{ppm}$, a $\mathrm{Sr}$ content of less than $5 \mathrm{ppm}$ and an initial ${ }^{87} \mathrm{Sr} /{ }^{86} \mathrm{Sr}$ of 1 ess than 0.7520 . Therefore, incorporation of crustal material may have played a significant role in forming the high-silica alkali rhyolite suite. The narrow range of bulk composition in the Gila Cliff Dwellings Cauldron members of the Catron volcanic suite suggests the composition of the batholith was at or near the isobaric minimum in the water-saturated system $\mathrm{NaAlSi}_{3} \mathrm{O}_{8}-$ $\mathrm{KAlSi}_{3} \mathrm{O}_{8}-\mathrm{SiO}_{2}$ to begin with. Of the two "cauldron lavas" of the Gila Cliff

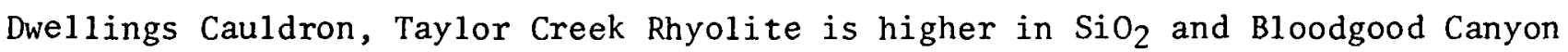
Rhyolite is higher in $\mathrm{K}_{2} \mathrm{O}$ and $\mathrm{K}_{2} \mathrm{O}+\mathrm{Na}_{2} \mathrm{O}$. This may reflect continued differentiation of the "cauldron lava" magma after eruption of the Bloodgood Canyon Rhyolite by alkali feldspar fractionation and/or thermogravitational diffusion (Hildreth, 1979). Fractional crystallization of sanidine would increase $\mathrm{SiO}_{2}$ and decrease $\mathrm{K}_{2} \mathrm{O}$, $\mathrm{Na}_{2} \mathrm{O}$, and $\mathrm{Al}_{2} \mathrm{O}_{3}$ in the magma. Fractional crystallization alone does not account for the differences in the content of F, U, and Li between Bloodgood Canyon Rhyolite vitrophyre (BR-3) and Taylor Creek Rhyolite vitrophyre (HC-8) (Table 4). A large percent of the magma would have to crysta1- 
lize to create the increase in $\mathrm{F}, \mathrm{U}$, and $\mathrm{Li}$ in Taylor Creek Rhyolite. Thus, thermogravitational diffusion may explain the increase in these elements in Taylor Creek Rhyolite. The pronounced negative Eu anamoly in Taylor Creek Rhyolite (Fig. 9) indicates that feldspar fractionation operated at some time before or during the generation of Taylor Creek Rhyolite.

The Gila Cliff Dwellings Cauldron members of the Catron volcanic suite are chemically very similar to the A-type (anorogenic) granites of Loiselle and Wones (1979). Their A-type granites are mildly alkaline, have low CaO and $\mathrm{Al}_{2} \mathrm{O}_{3}$ contents, high $\mathrm{Fe} / \mathrm{Fe}+\mathrm{Mg}$, high $\mathrm{K}_{2} \mathrm{O} / \mathrm{Na}_{2} \mathrm{O}$ and absolute $\mathrm{K}_{2} \mathrm{O}$ content. A-type grạnites are high in fluorine, enriched in incompatible trace elements (REE except $\mathrm{Eu} ; \mathrm{Zr}, \mathrm{Nb}, \mathrm{Ta}$ ) and low in $\mathrm{Co}, \mathrm{Sc}, \mathrm{Cr}, \mathrm{Ni}, \mathrm{Ba}, \mathrm{Sr}$, and $\mathrm{Eu}$ (Loiselle and Wones, 1979). A-type granites are produced by interaction of alkali basalt and granulite facies lower crust or fractionation from alkali basalt without crustal interaction (Loiselle and Wones, 1979). The high initial ${ }^{87} \mathrm{Sr} /{ }^{86} \mathrm{Sr}$ of the high-silica alkali rhyolite suite indicates a considerable crustal component. A-type granites with high initial ${ }^{87} \mathrm{Sr} /{ }^{86} \mathrm{Sr}$ form within stable continents, and those with low initial ${ }^{87} \mathrm{Sr} /{ }^{86} \mathrm{Sr}$ form along rift zones (Loiselle and Wones, 1979 ).

TIN DEPOSITS IN THE TAYLOR CREEK RHYOLITE

Review of Previous Studies

Previous investigation of the tin mineralization in the Taylor Creek Rhyolite has produced considerable data on the nature of the deposits (Lufkin, 1972). Coarsely crystalline cassiterite, wood tin, hematite, quartz, cryptocrystalline silica, bixbyite, pseudobrookite, alkali feldspar, topaz, and monazite occur in discontinuous veins in the rhyolite (Lufkin, 1972). The structure of the veins has been interpreted as a tensional feature developed after flowage of the rhyolite ceased (Lufkin, 1972). The veins were deposited from a gas phase released from volatile and tin-rich layers within the cooling rhyolite domes (Lufkin, 1972). Based on the composition of coexisting cassiterite, 
bixbyite and pseudobrookite in lithophysae, a temperature of $600^{\circ} \mathrm{C}$ or higher was assigned to the formation of the tin veins (Lufkin, 1972).

\section{Present Investigation}

This study is in agreement with previous investigations on the structure of the veins. It is doubtful, though, that volatile and tin-rich layers large enough to produce the tin veins could exist as distinct layers within the rhyolite domes. Zones of miarolitic cavities and lithophysae containing cassiterite are present, but the amount of tin in these zones is much less than in the veins and only represents the tin content of the lava. The tin is interpreted as being derived from the rhyolite, but not from volatile and tinrich layers within the domes. This origin of the mineralizing solutions is supported by the discontinuity of the tin veins and the absence of tin veins at depth. To what depth the argillized and bleached zones containing the tin veins occur is not known. Studies of the Dzhalinda deposit, U.S.S.R. have shown that tin veins occur in quartz metasomatites confined to the nearsurface facies of the quartz porphyry extrusion (Smirnov, 1977). The depth of the ore-bearing metasomatites does not exceed 35 meters, and hydrothermal alteration is absent at 50 meters from the surface (Smirnov, 1977). Wood-tin and cherl-like yuartz replace the cataclased and altcred quartz porphyries along discontinuous zones (Smirnov, 1977). The Dzhalinda deposit may be an analog to the tin deposits in the Taylor Creek Rhyolite. If fumarolic gases produced by devitrification of the rhyolite carried tin towards the surface and deposited it along fractures, this would result in alteration only near the surface and the absence of tin veins at depth. Studies of fumarolic mounds and ridges have shown that alteration is not produced at great depths or distances away from the mounds (Sheridan, 1970). The temperature of formation deduced for the Black Range tin deposits must be considered as a maximum only. 'The 
temperature of $600^{\circ} \mathrm{C}$ is actually just the temperature of vapor-phase crystallization in the lithophysae. Such a temperature for vapor-phase crystallization and lithophysae growth is reasonable because at any lower temperature the strength of the lava would prohibit growth of a vesicle. If a model of fumarolic deposition is assumed, a range of temperatures from the extrusion temperature of the rhyolite to $25^{\circ} \mathrm{C}$ would be expected. The abundance of wood-tin and cryptocrystalline silica in the tin veins suggests a much lower temperature for formation of the tin veins. The Mexican tin deposits formed at lower than $150^{\circ} \mathrm{C}$, indicating much of the tin is deposited at low temperatures (Pan, 1974). URANIUM CONTENT OF TAYLOR CREEK RHYOLITE AND THE ROLE OF INITIAL ERUPTIVE PRODUCTS AND FOREIGN LITHICS IN. URANIUM MINERALIZATION

The uranium content of Taylor Creek Rhyolite ranges from $7.4 \mathrm{ppm}$ to 30.2 ppm (Table 4). Lithophysal, topaz-bearing Taylor Creek Rhyolite lava (BR-19) has the lowest uranium content $(7.4 \mathrm{ppm})$, and a block in tuff underlying flowbanded Taylor Creek Rhyolite lava near Indian Peaks (IP-2) has the highest uranium content (30.2 ppm). This block, although only slightly devitrified, contains microscopic veins of opal which probably carry part of the uranium. Taylor Creek Rhyolite vitrophyre (HC-8) has the highest uranium content ( $12.9 \mathrm{ppm})$ besides IP-2. Densely welded ignimbrites (HC-3 and BR-28) contain no more uranium than flow-banded lavas (BR-19 and IP-1) eventhough the ignimbrites are only partly devitrified and the lavas are vapor-phase altered.

Most of the Taylor Creek Rhyolite is large, thick piles of devitrified and vapor-phase altered lava similar to the Topaz Mt. Rhyolite of the Thomas Range, Utah (Lindsey, 1979). Aprons of tuff produced by hydromagmatic or magmatic eruptions when the Taylor Creek Rhyolite initially vented to the surface are not visible at most outcrops. These tuffs, if present, are probably covered by the 1 arge domes which followed any initial explosive activity. These tuffs 
would be the most probable hosts for uranium mineralization due to their permeability and the presence of reactive, foreign lithic fragments as at Spor Mt., Utah (Bikun, this voiume). Near Indian Peaks, in the northern Black Range, is the only outcrop of Taylor Creek Rhyolite lava underlain by tuff observed during this study. Large blocks (15 cm in diameter) of Taylor Creek Rhyolite are present in the tuff. This outcrop is interpreted as a small tuff ring filled and covered by a flow-banded dome from the same vent. The radioactivity of the tuff is two times that of the overlying lava. The overlying lava (IP-1) contains $9.4 \mathrm{ppm}$ uranium, and a block of Taylor Creek Rhyolite (IP-2) (containing microscopic opal veins) in the tuff has $30.2 \mathrm{ppm}$ uranium. Thus, uranium was concentrated in the tuff underlying the lava by meteoric-hydrothermal convection through the tuff or groundwater leaching of the lava. This outcrop of Taylor Creek Rhyolite is analogous to uranium mineralization in tuffs beneath lava at Spor Mt., Utah (Bikun, this volume) although no fluorite-mineralized, carbonate lithic fragments are present at this outcrop and the uranium content is much lower.

The dependence of uranium content and uranium mineralization on the fluorine content of Taylor Creek Rhyolite is somewhat obscure. The only outcrop of Taylor Creek Rhyolite containing macroscopic topaz (BR-19) is the lowest in uranium content $(7.4 \mathrm{ppm})$. This vapor-phase altered rock may have lost much of its uranium by leaching. Comparing Bloodgood Canyon Rhyolite (BR-3) and Taylor Creek Rhyolite (HC-8) "cauldron lava" vitrophyres shows that uranium increases with increasing fluorine, although the increase in uranium content is small (Fig. 8). Lithium shows a stronger correlation with fluorine content (Fig. 8). CONCLUSION

The Taylor Creek Rhyolite represents a sub-type of topaz rhyolite characterized by cassiterite veins in the upper parts of the lavas and a relatively 
lower content of $U, \mathrm{Be}$, and F. Cassiterite occurs in topaz rhyolites at Spor Mt. and the Wah Wah Mts., Utah, but tin in these occurrences is subordinate to the $\mathrm{Be}, \mathrm{U}$, and $\mathrm{F}$ mineralization. In addition to the lower content of uranium and fluorine in the Taylor Creek Rhyolite, the lack of uranium and fluorine mineralization associated with the Taylor Creek Rhyolite is due to the absence or concealment of pyroclastic deposits (especially hydromagmatic deposits - explosion breccias, surges, airfall) which commonly underly the capping lavas. These deposits not only provide the permeability for meteorichydrotherma 1 convection through the vent area, but also may contain reactive foreign lithic fragments (Ca-rich) which become the focal points of uranium and fluorine mineralization as at Spor Mountain, Utah (Bikun, this volume). Considerable uranium and fluorine probably were leached from the lavas but were lost due to lack of a suitable environment for deposition. Pyroclastic deposits, thick and extensive enough to host economic uranium mineralization, may we11 exist beneath the large piles of Taylor Creek Rhyolite lava, but their existence and possible content of reactive lithic fragments remains to be verified.

There is a possibility that economic tin deposits might exist in addition to those in the upper parts of the Taylor Creek Rhyolite. Shallow, intrusive bodies of Taylor Creek Rhyolite may host low-temperature hydrothermal tin deposits of the Mexican-type (Pan, 1974). At moderate depth, there may be high-temperature hydrothermal tin deposits, especially greisens, associated with granitic bodies as in Cormwa11, England (Hosking, 1969) and the Seward Peninsula, Alaska (Sainsbury, 1969). Mexican-type tin deposits are more likely to be discovered because of the shallow level of erosion in the Black Range. 
URANIUM AND BERYLLIUM MINERALIZATION NEAR APACHE WARM SPRINGS, NORTHERN SIERRA CUCHILLO, NEW MEXICO

\section{ECONOMIC GEOLOGY}

One mile north of the Iron Mountain district in the northern Sierra Cuchi110, New Mexico, uranium and beryllium mineralization occurs in fault gouge. Previous investigation has identified the beryllium-bearing mineral as bertrandite (Hillard, 1969). The high uranium content of the fault gouges (78 ppm: AWS-9) has not been reported previously (Table 4). Numerous faults have juxtaposed blocks of densely welded, rhyolitic ignimbrite and andesite lava. This rhyolite is probably the Vicks Peak Rhyolite (Maldonado, 1974). In the fault gouge between the rhyolite and andesite, anomalous concentrations of beryllium (up to $2.50 \mathrm{wt} . \% \mathrm{BeO}$ ) are present (Hillard, 1969). In the immediate vicinity of the beryllium mineralization, kaolinite, alunite, montmorillonite and silica alteration is present (lillard, 1969). Beryllium mineralization is confined to areas of montmorillonite alteration (Hillard, 1969).

To determine whether the beryllium content of the fault gouge (AWS-9) could be derived by mobilizing primary beryllium out of fresh rhyolite into the fault gouge, samples of vitrophyre (AWS-16) and altered rhyolite (AWS-11) near the beryllium mineralization were analyzed for beryllium (Table 4). The lack of difference in beryllium content between the vitrophyre and altered rhyolite implies that beryllium was introduced from a foreign source.

Other mineralization is present near the vicinity of the beryllium and uranium mineralization. Fluorite, calcite and quartz veins contain $\mathrm{Cu}, \mathrm{Fe}$, and $\mathrm{Pb}$ sulfides. A quartz monzonite intrusive body exposed nearby may be the source of the mineralizing solutions which deposited the sulfides. Cooler hydrothermal solutions may have deposited the uranium and beryllium at greater distances 
away from the intrusive. A thin coating of fluorite along a fracture was found on altered rhyolite adjacent to the Be mineralization.

CHEMISTRY OF THE VOLCANIC ROCKS

A hydrated vitrophyre (AWS-16) and altered sample of Vicks Peak Rhyolite (AWS-11) were analyzed for major elements (Table 3). Alteration has destroyed the original chemistry of AWS-11. The analysis of vitrophyre AWS-16 has interesting implications. Supposedly, Vicks Peak Rhyolite was empted from the Nogal Canyon Cauldron in the southern San Mateo Mountains and deposited in the northern Sierra Cuchillo (Maldonado, 1974). Vicks Peak Rhyolite is reported as the oldest member of the high-silica alkali rhyolite suite $(32-21 \mathrm{~m} . \mathrm{y}$.$) of$ three overlapping suites of volcanic rocks in the Mogollon-Datil field of southwestern New Mexico (Elston et al., 1976a). In terms of normative $q z$, $a b$, and or, the Vicks Peak Rhyolite is similar to the Gila Cliff Dwellings Cauldron members of the Catron volcanic suite (Fig. 7). Vjcks Peak Rhynlitee (AWS-16) contains high $\mathrm{SiO}_{2}$, but the $\mathrm{K}_{2} \mathrm{O}$ content is much lower than members of the Catron volcanic suite (Fig. 4) and $\mathrm{Na}_{2} \mathrm{O}$ is relatively high (Fig. 5). The initial ${ }^{87} \mathrm{Sr} /{ }^{86} \mathrm{Sr}$ ratio of Vicks Peak Rhyolite (Appendix II) is characteristic of the calc-aikalic andesite to rhyolite suite of the Mogollon-Datil field (Elston et a1., 1976a). Thus, Vicks Peak Rhyolite may not be the oldest member of the high-silica alkali rhyolite suite, because it may not belong to this suite.

A sample of the rhyolite of Alum Spring (AWS-15) was also analyzed for major elements (Table 3) because of its similarity to porphyritic intrusives at Iron Mountain, but the sample was too altered for any petrologic interpretations.

VOLCANOLOGY

Vicks Peak Rhyolite exposed in the northern Sierra Cuchillo was erupted from the Nogal Canyon Cauldron in the southern San Mateo Mountains (Maldonado, 1974; Elston et al., 1976a). The thickness of densely welded ignimbrite of 
Vicks Peak Rhyolite in the northern Sierra Cuchillo and the presence of mesobreccia interbedded with the ignimbrite suggest that a collapse-feature may exist north of Alamosa Creek in the extreme northern Sierra Cuchi11o. The presence of such a feature was not determined in this study. 
BEHAVIOR OF URANIUM AND FLUORINE AT IRON MOUNTAIN, CENTRAL

1 SIERRA CUCHILLO, NEW MEXICO

To investigate the behavior of uranium and fluorine in a high temperature, subvolcanic environment, the fluorine, beryllium, and tungsten-bearing.skarns at Iron Mountain were chosen as a field site. The beryllium, fluorine and tungsten-bearing minerals are helvite, fluorite, scheelite and powellite (Jahns, 1944),

Major element analyses (Table 3) of aplite (BR-29) and rhyolite porphyry $(\mathrm{BR}-30)$ show the intrusives to be high in $\mathrm{K}_{2} \mathrm{O}$ and low in $\mathrm{Na}_{2} \mathrm{O}$ (Fig. 3, 4, and 5). The whole rock chemistry is similar to members of the Catron volcanic suite (Fig. 7). A biotite from Iron Mountain gave a K-Ar age of $29.2 \pm 1.1$ m.y. (Chapin et al., 1978). Thus, the intrusives at Iron Mountain are older than the Catron volcanic suite and are probably one of the oldest members of the high-silica alkali rhyolite suite (especially if Vicks Peak Rhyolite does not belong to the high-silica alkali rhyolite suite). Trace element analyses show the rhyolite porphyry (BR-30) to be enriched in Be and low in U (Table 4).

Surveys with a scintillometer indicate intrusive rocks are more radioactive than skarn. Fluorite-rich samples of skarn did not exceed intrusive rocks in radioactivity. Skarn is more radioactive than unaltered marble, however. Higher radioactivity of the intrusive rocks may be due to $T$ h and $K$. With such limited data, it cannot be stated whether or not uranium migrated with fluorine out of the rhyolite and into the skarn. 
489

ACKNOWLEDGMENTS

Special thanks are owed to D. M. Burt for a critical review of the maniscript and to J. Bikun and E. Christiansen for helpful discussions. The author is grateful to R. Satin for help with atomic absorbtion spectrophotometry and A. Yates for help with $\mathrm{x}$-ray fluorescence spectroscopy. Electron microprobe analyses made possible by $M$. Drake and $T$. Testa of the University of Arizona. Uranium by delayed neutron activation and trace element analyses by I.N.A.A. were performed by G. Coles of the University of Oregon. Preliminary Sr-isotope data were provided by Conoc 0 , Inc.

0

政 


\section{REFERENCES CITED}

Bikerman, M., 1976, Initial $\mathrm{Sr} 87 / \mathrm{Sr}^{86}$ ratios and $\mathrm{K}-\mathrm{Ar}$ dates of some volcanic rocks from Catron County; New Mexico: Geological Society of America, Abstracts with Programs, v. 8, p. 569.

Carmichae1, I. S. E., Turner, F. J., and Verhoogen, J., 1974, Igneous Petrology: McGraw-Hi 11, New York, p. 230.

Chapin, C. E., Jahns, R. H., Chamberlin, R. M., and Osburn, G. R., 1978, First day road $\log$ from Socorro to Truth or Consequences via Magdalena and Winston, in Field Guide to Selected Cauldrons and Mining Districts of the Datil-Mogollon Volcanic Field New Mexico: New Mexico Geological Society Special Publication No. 7, p. 17.

Elston, W. E., Coney, P. J., and Rhodes, R. C., 1968, A progress report on the Mogolion Plateau volcanic province, southwestern New Mexico: Colorado School of Mines Quarterly, v. 63, p. 261-287.

E1ston, W. E., Damon, P. E., Coney, P. J., Rhodes, R. C., Smith, E. I., and Bikerman, Michae1, 1973, Textiary volcani.c rocks, Mogollon-Datil province, New Mexico, and surrounding region: K-Ar dates, patterns of eruption, and periods of mineralization: Geological Society of America Bulletin, v. 84 , p. 2259-2273.

Elston, W. E., Rhodes, R. C., Coney, P. J., and Dea1, E. G., 1976a, Progress report on the Mogollon Plateau volcanic field, southwestern New Mexico, No. 3 - Surface expression of a pluton, in Cenozoic Volcanism in Southwestern New Mexico: New Mexico Geological Society Special Publication No. 5, p. 3-28.

E1stoin, W. E., Rhodes, R. C., and Erb, E. E., 1976b, Control of mineralization by Mid-Tertiary volcanic centers, southwestern New Mexico, in Cenozoic Volcanism in Southwestern New Mexico: New Mexico Geological Society Special Publication No. 5, p. 127.

Elston, W. E. and Northrop, S. A., eds., 1976, Cenozoic Volcanism in Snuthwestern New Mexico: New Mexico Geological Society Special Publication No. $5,151 \mathrm{p}$.

Ericksen, G. E., Wedow, Helmuth, Jr., Eaton, G. P., and Leland, G. R., 1970, Mineral resources of the $B$ lack Range Primitive Area, Grant, Sierra, and Catron lounties, New Mexico: U.S. Geological Survey Bulletin 131.9-E, $162 \mathrm{p}$.

Fodor, R. V., 1976, Volcanic geology of the northern Black Range, New Mexico, in Cenozoic Volcanism in Southwestern New Mexico: New Mexico Seological Society Special Publication No. 5, p. 68-70.

Fries, C., Jr., 1940, Tin deposits of the Black Range, Catron and Sierra Counties, New Mexico, a preliminary report: U.S. Geological Survey Bulletin 922-M, p. 355-370.

Fries, C., Jr., 1942, Tin deposits of North Lander County, Nevada: U.S. Geological Survey Bulletin 931-L, p. 279-294. 
Fries, C., Jr., Schaller, W. I'., and Glass, J. J., 1942, Bixbyite and pseudobrookite from the tin-bearing rhyolite of the Black Range, New Mexico: American Mineralogist, v. 27, no. 4, p. 305-322.

Galbraith, F. W., and Brennan, D. J., 1970, Minerals of Arizona; Arizona Bureau of Mines Bulletin 181, $116 \mathrm{p}$.

Hildreth, W., 1979, The Bishop Tuff: evidence for the origin of compositional zonation in silicic magma chambers: Geological Society of America Special Paper 180, p. 43-75.

Hillard, P. D., 1969, Geology of beryllium mineralization near Apache Warm Springs, Socorro County, New Mexico: New Mexico Bureau of Mines and Mineral Resources Circular 103, 16 p.

Hosking, K. F. G., 1969, The nature of the primary tin ores of the south-west of England, in A second technical conference on tin, Bangkok, 1969: London, Internationa $\overline{1}$ Tin Council, v. 3, p. 1157-1244.

Jahns, R. H., 1944, Beryllium and tungsten deposit of the Iron Mountain district, Sierra and Socorro Counties, New Mexico: U.S. Geological Survey. Bulletin 945-C, p. 45-79.

Lindsey, D. A., 1979, Preliminary report on Tertiary volcanism and uranium mineralization in the Thomas Range and northern Drum Mts.; Juab County, Utah: U.S. Geological Survey open-file report $79-1076,100$. p.

Lindsey, D. A., and Osmonson, L. M., 1978, Minera1 potential of altered rocks near Blawn Mountain, Wah Wah Range, Utah: U.S. Geological Survey open-file

i report $78-114,17 \mathrm{p}$.

Loiselle, M. C., and Wones, D. R., 1979, Characteristics and origin of anorogenic granites (abs.): Geological Society of America Abstracts with Programs, v. 11 , no. 7, p. 468 .

Lufkin, J. L., 1972, Tin mineralization within rhyolite flow-domes, B1ack Range, New Mexico (Ph.D. dissert.); Stanford University, $148 \mathrm{p}$ :

Maldonado, Florian, 1974, Geology of the northern part of the Sierra Cuchillo, Socorro and Sierra Counties, New Mexico (M.S. thesis): Albuquerque, University of New Mexico, $59 \mathrm{p}$.

Masuda, A., Nakamura, N., and Tanaka, T., 1973, Fine structures of mutually normalized rare-earth patterms of chondrites: Geochimica et Cosmochimica Acta, v. 37, p. 239-248.

Noble, D. C., Rigot, W. L., and Bowman, H. R., 1979, Rare-earth-element content of some highly differentiated ash-flow tuffs and lavas: Geological Society of America Special Paper 180, p. 77-85.

Pan, Yuh-Shyi, 1974, The genesis of the Mexican-type tin deposits in acidic volcanics. (Ph.D. dissert.): Columbia University, $286 \mathrm{p}$.

Rhodes, R. C., 1976, Petrologic framework of the Mogollon Plaetau volcanic ring complex, New Mexico - Surface expression of a major batholith; in Cenozoic Volcanism in Southwestern New Mexico: New Mexico Geological Society Special Publication No. 5, p. 103-112. 
Sainsbury, C. L., 1969, Geology and ore deposits of the central York Mts., western Seward Peninsula, Alaska: U.S. Geological Survey Bulletin 1287, $101 \mathrm{p}$.

Shawe, D. R., 1968, Geology of the Spor Mountain beryllium district, Utah, in Ridge, J. D., ed., Ore deposits of the United States: American Institute of Mining Engineers, New York, v. 2, p. 1148-1162.

Sheridan, M. F., 1970, Fumarolic mounds and ridges of the Bishop Tuff, California: Geological Society of America Bulletin, v. 81, p. 851-868.

Smirnov, V. I., ed., 1977, The Dzhalinda deposit, in Ore Deposits of the U.S.S.R.: Pitman Publishing, San Francisco, V. III, p. 286-287.

Taylor, S. R., 1964, Abundance of chemical elements in the continental crust new table: Geochimica et Cosmochimica Acta, v. 28, p. 1273-1285.

Taylor, S. R., and White, A. J. R., 1966, Trace element abundances in andesites: Bulletin Volcanologique, v. 29, p. 177-194.

Trites, A. F., and Thurston, R. H., 1958, Geology of Majuba Hi11, Pershing County, Nevada: U.S. Geolngic.al Survey Bulletin 1046-I, p. 183-203.

Tuttle, O. F., and Bowen, N. L., 1958, Origin of granite in the light of experimental studies in the system NaA1Si ${ }_{3} \mathrm{O}_{8}-\mathrm{KAlSi}_{3} \mathrm{O}_{8}-\mathrm{SiO}_{2}-\mathrm{H}_{2} \mathrm{O}$ : Geological Society of America Memoir, no. 74, $153 \mathrm{p}$.

Whittaker, E. J. W., and Muntus, R., 1970, Ionic radii for use in geochemistry: Geochimica et Cosmochimica Act.a, v. 34, p. 145-156.

Williams, Howel, 1932, The history and character of volcanic domes: University of California, Department of Geolngisal Srienres Rulletin, v. $31, \mathrm{p}$ : 51.146. 


\section{Appendix I}

Estimated phenocryst content and location of samples analyzed from New Mexico.

\begin{tabular}{lcll}
\hline sample & \% phenocrysts & \multicolumn{2}{c}{ sample location } \\
\hline BR-1 & 10 & R.11W.,T.14S. & along N.M. 61 at Rocky Canyon \\
BR-2 & 10 & R.11W.,T.14S. & along N.M. 61. at Rocky Canyon \\
BR-3 & 25 & R.11W.,T.14S. & along N.M. 61 at Rocky Canyon \\
BR-3a & 20 & R.11W.,T.14S. & along N.M. 61 at Rocky Canyon \\
BR-16 & 30 & R.10W.,T.9S. & Hardcastle Creek \\
BR-28 & 40 & R.10W.,T.9S. & Hardcastle Creek \\
HC-3 & 25 & R.10W.,T.9S. & Hardcastle Creek \\
HC-8 & 20 & R.10W.,T.9S. & Hardcastle Creek \\
IP-2 & 15 & R.11W.,T.8S. & along N.M. 78 near. Indian Peaki. \\
BR-29 & 100 & R.8W.,T.9S. & Iron Mountain \\
BR-30 & 50 & R.8W.,T.9S. & Iron Mountain \\
AWS-16 & 1 & R.7W.,T.9S. & east of Mionticello. Box Canyon \\
AWS-11 & 1 & R.7W.,T.9S. & south of Monticello Box Canyon \\
AWS-15 & 20 & R.7W.,T.9S. & southeast of Monticello Box \\
HC-7 & 20 & R.10W.,T.9S. Hardcastle Creek \\
BR-19 & 25 & R.10W.,T.11S. & Round Mountain \\
IP-1 & 20 & R.11W.,T.8S. & along N.M. 78 near Indian Peaks \\
AWS-9 & -- & R.7W.,T.9S. & south of Monticello Box Canyon
\end{tabular}


Appendix II

Sr ISOTOPE COMPOSITION OF VICKS PEAK RHYOLITE(AWS-16)

\begin{tabular}{|c|c|c|c|c|c|}
\hline $\begin{array}{l}\text { present day } \\
{ }^{87} \mathrm{Sr} /{ }^{86} \mathrm{Sr}\end{array}$ & $\mathrm{Rb}$ ppm & Sr ppm & $\begin{array}{l}\text { Assumed } \\
\text { Age, m.J. }\end{array}$ & ${ }^{87} \mathrm{Rb} /{ }^{86} \mathrm{Sr}$ & $\left({ }^{87} \mathrm{Sr} / /^{86} \mathrm{Sr}\right)_{0}$ \\
\hline \multirow[t]{2}{*}{$0.72226 \pm 0.00005$} & $295 \pm 5$ & $32 \pm 1.1$ & 30 & 36 & $0.7070 \pm 0.0008$ \\
\hline & & & 32 & 36 & $0.7060 \pm 0.0008$ \\
\hline \multicolumn{6}{|c|}{$\begin{array}{l}\text { * normalized to }{ }^{86} \mathrm{Sr} /{ }^{88} \mathrm{Sr}=0.11940 ; \mathrm{NBS}^{8} 87 \mathrm{SrCO}_{3} \text { standard, } \\
{ }^{87} \mathrm{Sr} /{ }^{86} \mathrm{Sr}=0.71040 \pm 0.00003, N=5\end{array}$} \\
\hline
\end{tabular}

Analysis by I. Jones, Conoco Inc.. 